Федеральное

государственное

бюджетное

учреждение

науки

Институт

мировой

Российской

том 2 \#3

академии наук

2017

литературы

имени

А.М. Горького

Москва
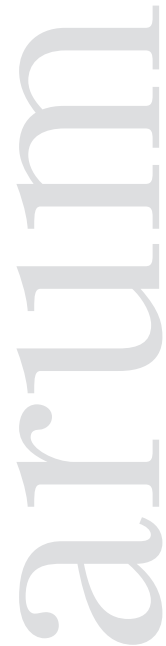

Studia Litterarum

Литературные исследования

Научный журнал

Издается с 2016 года 
Studia Litterarum:

Науч. журн. - 2017.

-T. 2, № 3. - M.:

ИМЛИ РАН, 2017.

$-400 \mathrm{c}$.

Academic journal. - 2017 .

- Vol. 2, no 3. - Moscow,

IWL RAS Publ., 20I7.

$-400 \mathrm{p}$.
Журнал

зарегистрирован

в Федеральной службе

по надзору

в сфере связи и массовых

коммуникаций

Свидетельство

о регистрации

ПИ № ФС $77-66625$

от 27 июля 2016 г.

Подписной индекс

по каталогу «Роспечать»

80538

ISSN 2500-4247 (Print)

ISSN 254I-8564 (Online)

Адрес редакиии:

І2І069 г. Москва,

ул. Поварская, д. 25 а

Телефон:

+7 (495) 690-50-30

E-mail: stud-lit@mail.ru

www.studlit.ru
The journal

is registered

at the Federal Service

for Supervision

of Media and

Mass Communications

Registration Certificate

PE № FS $77-66625$,

July 27, 2016

Subscription index in the catalogue "Rospechat" 80538

ISSN 2500-4247 (Print)

ISSN 254I-8564 (Online)

Address of the Editorial

Department:

Povarskaya 25 a,

I2I069 Moscow

Phone:

+7 (495) 690-50-30

E-mail: stud-lit@mail.ru

www.studlit.ru 
Federal State

Budget

Institution

of Science

A.M. Gorky

of the Russian

vol 2 \#3

Institute

Academy

2017

of World

of Sciences

Literature

Moscow

Studia Litterarum

Literary Studies

Academic journal

Published since 2016 
Главный редактор

А.Б. Куделин (ИМЛИ РАН, Москва, Россия)

Заместитель главного редактора

О.А. Туфанова (ИМЛИ РАН, Москва, Россия)

Ответственный секретарь

Редакторы

М.В. Каплун (ИМЛИ РАН, Москва, Россия)

А.В. Голубков, А.П. Уракова (ИМЛИ РАН, Москва, Россия)

\section{МЕЖДУНАРОДНЫЙ РЕДАКЦИОННЫЙ СОВЕТ}

Д.П. Бак (Государственный литературный музей, Москва, Россия), Т.М. Горяева (Российский государственный архив литературы и искусства, Москва, Россия), Р. Джулиани (Университет Ла Сапиенца, Рим, Италия), Л.И. Ливак (Торонтский Университет, Торонто, Канада), Э. Лэрд (Университет Браун, Провиденс, США), Д. Ота (Кумамото Гакуэн Университет, Кумамото, Япония), Ф.Б. Поляков (Институт славистики Венского университета, Вена, Австрия), Р.М. Распопович (Исторический институт Университета Черногории, Подгорица, Черногория), Д.Рицци (Университет Ка Фоскари, Венеция, Италия), И.В. Силантьев (Институт филологии СО РАН, Новосибирск, Россия), Г. Тиханов (Лондонский университет королевы Марии, Лондон, Великобритания), Л.С. Флейшман (Стэнфордский университет, Стэнфорд, США), М. Цимборска-Лебода (Университет Марии Кюри-Склодовской в Люблине, Люблин, Польша)

\section{РЕДАКЦИОННАЯ КОЛЛЕГИЯ}

М.Л. Андреев (ИМЛИ РАН, Москва, Россия), С. Гардзонио (Пизанский университет, Пиза, Италия), Б.Ф. Егоров (Санкт-Петербургский институт истории РАН, Санкт-Петербург, Россия), Ж.-Ф. Жаккар (Женевский университет, Женева, Швейцария), Вяч. Вс. Иванов (Институт мировой культуры МГУ, Институт Русская Антропологическая Школа РГГУ, Москва, Россия), Н.В. Корниенко (ИМЛИ РАН, Москва, Россия), О.А. Коростелев (ИМЛИ РАН, Москва, Россия), А.Ф. Кофман (ИМЛИ РАН, Москва, Россия), А.В. Лавров (Институт русской литературы (Пушкинский Дом) РАН, Санкт-Петербург, Россия), Д.С. Московская (ИМЛИ РАН, Москва, Россия), В.В. Полонский (ИМЛИ РАН, Москва, Россия), А.Ф. Строев (Университет Новая Сорбонна - Париж 3, Париж, Франция), А.Л. Топорков (ИМЛИ РАН, Москва, Россия), М. Шруба (Рурский университет, Бохум, Германия)

Адрес редакции: г21069 г. Москва, ул. Поварская, д. 25 а

Телефон: +7 (495) 690-50-30

E-mail: stud-lit@mail.ru

Сайт: www.studlit.ru 
Editor-in-Chief

Alexander B. Kudelin (A.M. Gorky Institute of World Literature of the Russian

Academy of Sciences, Moscow, Russia)

Deputy Editor-in-Chief

Olga A.Tufanova (A.M. Gorky Institute of World Literature of the Russian Academy

of Sciences, Moscow, Russia)

Managing Editor

Marianna V. Kaplun (A.M. Gorky Institute of World Literature of the Russian Academy of Sciences, Moscow, Russia)

Editors Andrei V. Golubkov (A.M. Gorky Institute of World Literature of the Russian Academy of Sciences, Moscow, Russia), Alexandra P. Urakova (A.M. Gorky Institute of World Literature of the Russian Academy of Sciences, Moscow, Russia)

\section{INTERNATIONAL EDITORIAL COUNCIL}

Dmitry P. Bak (State Literary Museum, Moscow, Russia), Tatiana M. Goryaeva (Russian State Archive of Literature and Art, Moscow, Russia), Rita Giuliani (Sapienza University, Rome, Italy), Leonid I. Livak (University of Toronto, Toronto, Canada), Andrew Laird (Brown University, Providence, USA), Jotaro Ohta (Kumamoto Gakuen University, Kumamoto, Japan), Fedor B. Poljakov (Institute for Slavistics, University of Vienna, Vienna, Austria), Radoslav M. Raspopovic (University of Montenegro, Historical Institute of the University of Montenegro, Podgorica, Montenegro), Daniela Rizzi (Ca' Foscari University, Venice, Italy), Igor V. Silantiev (Institute of Philology of Siberian Branch of the Russian Academy of Sciences, Novosibirsk, Russia), Galin Tihanov (Queen Mary University of London, London, Great Britain), Lazar S. Fleishman (Stanford University, Stanford, USA), Maria Cymborska-Leboda (Maria Curie-Skłodowska Universtity in Lublin, Lublin, Poland)

\section{EDITORIAL BOARD}

Mikhail L. Andreev (A.M. Gorky Institute of World Literature of the Russian Academy of Sciences, Moscow, Russia), Stefano Garzonio (University of Pisa, Pisa, Italy), Boris F. Egorov (Saint Petersburg Institute of History of the Russian Academy of Sciences, Saint Petersburg, Russia), Jean-Philippe Jaccard (University of Geneva, Geneva, Switzerland), Vyacheslav V. Ivanov (Institute of World Culture of Moscow State Lomonosov University, Institute Russian Anthropological School of the Russian State University for the Humanities, Moscow, Russia), Natalya V. Kornienko (A.M. Gorky Institute of World Literature of the Russian Academy of Sciences, Moscow, Russia), Oleg A. Korostelev (A.M. Gorky Institute of World Literature of the Russian Academy of Sciences, Moscow, Russia), Andrey F. Kofman (A.M. Gorky Institute of World Literature of the Russian Academy of Sciences, Moscow, Russia), Alexander V. Lavrov (Institute of Russian Literature (Pushkinsky Dom) of the Russian Academy of Sciences, Saint Petersburg, Russia), Darya S. Moskovskaya (A.M. Gorky Institute of World Literature of the Russian Academy of Sciences, Moscow, Russia), Vadim V. Polonsky (A.M. Gorky Institute of World Literature of the Russian Academy of Sciences, Moscow, Russia), Alexander F. Stroev (New Sorbonne University - Paris 3, Paris, France), Andrey L. Toporkov (A.M. Gorky Institute of World Literature of the Russian Academy of Sciences, Moscow, Russia), Manfred Schruba (Ruhr University, Bochum, Germany) 
Теория литературы

го Маликова М.Э. К описанию ‘филологического перевода’ в І930-е гг.: А.А. Франковский переводчик английского романа XVIII в.

46 Кудрявцева T.В. Литературный процесс в Германии на рубеже XIX-XX вв.:

взаимодействие художественных течений

Мировая литература

74 Красавченко Т.Н. «А будущее таилось в прошедшем»: о механизме движения поэзии британского модернизма от Т.С. Элиота к Теду Хьюзу

82 Андреев М.Л. «Героические комедии» Корнеля

94 Халтрин-Халтурина Е.В. Два жениха

и два сонета: о поэтических формах в «Ромео и Джульетте»

II8 Толмачёв В.М. О символизме Томаса Манна I38 Голубцова А.В. А.С. Пушкин в итальянской драматургии XIX в.

Русская литература

I50 Калавски Ж. Главы из пушкинского романа. «Последний текст» и «Шпага щекотливого дворянина» Андрея Битова - культовые механизмы и поэтика текста

I66 Стеценко E.A. Марк Твен в русской дореволюционной периодической печати. Часть вторая

I90 Ljunggren M. The Dutch Connection: Johanna van der Meulen's Contribution to Russian Symbolism

204 Игнатьева (Оганисьян) М.Ю. Расин и Мандельштам

220 Московская Д.С. Шекспир и борьба за встречный промфинплан, или как сделано «Высокое напряжение» 
236 Федоров М.Л. Путешествие в Древнюю Русь и обратно. «Богатыри» Демьяна Бедного

Литература народов России и Ближнего зарубежья 252 Барабаш Ю.Я. «Псалмы Давида» Тараса Шевченко: от сакрального текста к поэтическому «тексту» (опыт системно-компаративного анализа)

Фольклористика

274 Самоделова Е.А. «Молитва архангелу Михаилу» и «Сон Богородицы» в записях П.Г. Богатырева (по архивным источникам)

Текстология. Источниковедение. Публикации 300 Резвый В.А. «Фальсификация Шекспира»: неизданная статья Георгия Шенгели о переводах Бориса Пастернака

334 Скороходов М.В. Иллюстративные материалы в биографических исследованиях (из опыта подготовки «Летописи жизни и творчества С.А. Есенина»)

Рецеензии

346 Николеску T. «Opus magnum» Ивана Верча

Научная жизнь

370 Закружная 3.С. Круглый стол «Историография Гражданской войны в России в памятниках литературы, эго-документах и публицистике»

382 Серегина С.А. Отчет о научной конференции «"Вечные” сюжеты и образы в литературе и искусстве русского модернизма: Итоги и перспективы проекта РНФ» (І6-І7 ноября 2016 г., ИМЛИ РАН) 
Literary Theory

Io Maria E. Malikova. Towards the Description of "Philological Translation" in the I930-s: Adrian

A. Frankovsky as Translator of the $18^{\text {th }}$ Century English Novel

46 Tamara V. Kudryavtseva. Literary Process in Germany at the Turn of the $19^{\text {th }}$ and $2 \mathrm{O}^{\text {th }}$ Centuries: Interaction of Literary Trends

World Literature

74 Tatiana N. Krasavchenko. "And time future contained in time past": British Modernist Poetry from T.S. Eliot to Ted Hughes

82 Mikhail L. Andreev. Corneille's Heroic Comedies

94 Elena V. Haltrin-Khalturina. Two Wooers and their Sonnets: On Poetic Forms in Romeo and Juliet

II8 Vasily M. Tolmatchoff. On the Symbolism of Thomas Mann

I38 Anastasia V. Golubtsova. Alexander Pushkin in the $19^{\text {th }}$ Century Italian Drama

Russian Literature

I50 Zsófia Kalavszky. Chapter from Pushkin's Novel. Cultic Mechanisms and Textual Poetics of "The Last Text" and "The Sword of the Sensitive Nobleman" by Andrey Bitov

I66 Ekaterina A. Stetsenko. Mark Twain in the Russian Pre-Revolutionary Periodical. Part 2

I90 Magnus Ljunggren. The Dutch Connection: Johanna van der Meulen's Contribution to Russian Symbolism

204 Maria Yu. Ignatieva (Oganisyan). Racine and Mandelstam

220 Darya S. Moskovskaya. Shakespeare and the Fight for Promfinplan, or How High Voltage is Made 
236 Maksim L. Fyodorov. A Journey to the Old Russia and Back. Bogatyry by Demian Bedny

Literature of the Peoples of Russia and Neighboring Countries 252 Yuri Y. Barabash. David's Psalms by Taras

Shevchenko: From the Sacred Text to the Poetical Text

\section{Folklore Studies}

274 Elena A. Samodelova. "Prayer to the Archangel Michael" and "The Dream of Our Lady" in the Records of Petr G. Bogatirev (On the Archival Materials)

Textology. Materials

300 Vladislav A. Rezvy. "Falsification of Shakespeare": Georgy Shengeli's Unpublished Article on Boris Pasternak's Translations

334 Maxim V. Skorokhodov. Illustrations in Biographical Studies: Sharing Experience of Preparing The Chronicle of Life and Work of Sergey Esenin

Reviews

346 Tatiana Nicolescu. "Opus magnum" by Ivan Verch Academic Life

370 Zoya S. Zakruzhnaya. Round Table "Istoriography of Russian Civil War in Literature, Ego-Documents and Criticism"

382 Svetlana A. Serjogina. Conference "'Eternal' Plots and Images in Literature and Art of Russian Modernism (November I6-I7, IWL RAS) 
УДК 82.09

ББК $83(2 \mathrm{Poc}=$ Рус $)+83$

$+83.3(4$ Вел $) 5 \mathrm{I}$
К ОПИСАНИЮ «ФИЛОЛОГИЧЕСКОГО ПЕРЕВОДА» В 1930-Е ГГ.:

А.А. ФРАНКОВСКИЙ - ПЕРЕВОДЧИК

АНГЛИЙСКОГО РОМАНА ХVIII В.

(C) 2017 г. М.Э. Маликова

Институт русской литературы

(Пушкинский Дом) Российской академии наук, Санкт-Петербург, Россия

Дата поступления статьи: г2 апреля 2017 г.

Дата публикации: 25 сентября 2017 г.

DOI: IO.22455/250O-4247-20I7-2-3-IO-45

Аннотация: В первой части статьи описывается явление «филологического перевода» в советской культуре г930-х гг. и, в частности, переводы А.А. Франковским английского романа XVIII в. Несмотря на то что в советской культуре с ее доминирующим марксистским дискурсом «идеалистические» философско-эстетические основания филологического перевода не могли быть описаны ни в рецензиях критиков, ни в переводческих паратекстах, они были хорошо известны переводчикам - выходцам из университетской философско-филологической среды, к которым принадлежал и Франковский, и были представлены в эти годы в нескольких важных историко-теоретических работах о переводе университетских профессоров Ф.Д. Батюшкова, М.П. Алексеева, А.М. Финкеля. Во второй части статьи на материале сохранившихся в архиве Франковского (РО ИРЛИ. Ф. І32) черновиков демонстрируется его индивидуальная ориентация в русле филологического перевода. Отмечается установка переводчика на буквальное воссоздание по-русски английского синтаксиса и в целом конструирование интеллектуального, рационального, «европейского» прозаического русского языка. Также отмечаются разительные параллели между интересом Франковского к юмору как доминанте раннего английского романа и к передаче несобственно-прямой речи, как она была проанализирована в немецкой философско-лингвистической школе Карла Фосслера, с аналогичными интересами М.M. Бахтина этих лет, что создает актуальный культурный контекст для переводов Франковского, не замеченный современниками.

ключевые слова: филологический перевод, советская культура г930-х гг., актуальность переводов классики.

Информация об авторе: Мария Эммануиловна Маликова - кандидат филологических наук, старший научный сотрудник, Институт русской литературы (Пушкинский Дом) Российской академии наук, наб. Макарова, д. 4, І99034 г. Санкт-Петербург, Россия.

E-mail: maria.e.malikova@gmail.com 


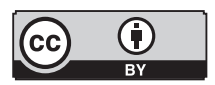

This is an open access article distributed under the Creative Commons Attribution 4.0 International (CC BY 4.O)

\section{TOWARDS THE DESCRIPTION OF} "PHILOLOGICAL TRANSLATION"

IN THE 1930s: ADRIAN A. FRANKOVSKY

AS TRANSLATOR OF THE $18^{\text {th }}$ CENTURY

ENGLISH NOVEL

(C) 20I7. M.E. Malikova

Institute of Russian Literature (Pushkin House)

of the Russian Academy of Sciences,

St. Petersburg, Russia

Received April I2, 2017

Date of publication: September 25, 2017

Abstract: The first part of the article describes the phenomenon of "philological translation" in the Soviet culture of the 1930 s and, in particular, translations of the $18^{\text {th }}$ century English novels by Adrian A. Frankovsky. Within the Soviet culture with its dominating Marxist discourse, "idealistic" philosophical-aesthetic foundations of philological translation were absent from critical reviews or translators' paratexts. However, these concepts were well familiar to translators from the university philosophical and philological habitus, to which Frankovsky also belonged, and were presented in a number of theoretical and historical works on translation authored by such university professors as Fyodor D. Batyushkov, Mikhail P. Alexeev, and Alexander M. Finkel'. Their brief overview allows to trace the origins of Frankovsky's concept of translation. The second part of the article is based on the draft materials preserved in Frankovsky's archive (Manuscript Department of Pushkin House, Fund I32). Their analysis allows to demonstrate Frankovsky's individual orientation within the field of philological translation. Frankovsky was focused on literal reproduction of the foreign syntax in the Russian language and thus endeavored to construct a more intellectual, rational, "European” Russian language. There are also striking parallels between Frankovsky's interest in humor as the dominant of the early English novel and his conveyance of indirect speech (as it was analyzed within German linguistic school of Carl Vossler) with similar interests of Mikhail M. Bakhtin at the same time. This allows us to place Frankovsky's translations within the cultural context that remained unnoticed by his contemporaries.

Keywords: philological translation, Soviet culture of the I930s, actuality of translating classics

Information about the author: Maria E. Malikova, $\mathrm{PhD}$ in Philology, Senior Researcher, Institute of Russian Literature (Pushkin House) of the Russian Academy of Sciences, Makarova embankment 4, 199034 St. Petersburg, Russia.

E-mail: maria.e.malikova@gmail.com 
Ленинградский переводчик Адриан Антонович Франковский (I888I942) известен прежде всего как создатель «русского Пруста» - выполненных им в середине г920-x - I930-х гг. переводов романов из эпопеи «В поисках за утраченным временем», отличающихся от позднейших советских переводов Н.М. Любимова тем, что в них «слышна была умная речь автора <...>. Интонация сухого, резкого, острого ума была даже усилена по сравнению с оригиналом <...>. Это был перевод во всех смыслах слова современный» [I4]. Созданный Франковским в г930-е гг. до сих пор дефинитивный «русский Стерн» - переводы «Сентиментального путешествия» и «Тристрама Шенди» - вышел позже, в неудачное время (соответственно, в І940 и І949 гг.), что помешало ему сыграть роль в «целевой культуре перевода». И едва было отмечено в целом историко-филологическое значение делавшихся Франковским на протяжении десяти лет переводов классического английского романа XVIII в., которые он неизменно сопровождал фундаментальными предисловиями и комментариями, а также специфика сконструированной переводчиком для его адекватной передачи русской дикции. Помимо Стерна, над которым Франковский начал работать в конце г934 г., им были радикально отредактированы для издательства «Academia» и в значительной степени доработаны (переведены выпущенные ранее по цензурным и эдиционным причинам эпизоды), а также снабжены примечаниями и исследовательскими преамбулами «От редактора» два старых русских перевода классики раннего английского романа - «Путешествия в некоторые отдаленные страны Лемюэля Гулливера» Дж. Свифта (г28; 2-е изд. - І930; пер. П. Кончаловского и В. Яковенко впервые опубл. в І889 г.) и «Ро- 
бинзона Крузо» Д. Дефо (г929; пер. М.А. Шишмаревой и 3.Н. Журавской впервые опубл. в 1902 г.); после чего, также в «Academia», вышли его оригинальные переводы памфлетов Свифта «Сказка бочки» и «Рассуждение о механическом действии духа» (I93I) и романа Дефо «Молль Флендерс» (1932). Перевод «Сентиментального путешествия» Стерна, а также его воспоминаний, писем и дневника Франковский сделал в 1934-I935 гг. (опубл. в г940 г.), «Тристрама Шенди» в І937-г940 гг. (опубл. в 1949 г., через семь лет после смерти переводчика). Наконец, в те же годы Франковский работал над творчеством еще одного значительного английского романиста-новатора XVIII в., Генри Филдинга - в первой половине I930-х он перевел «Историю Тома Джонса, найденыша», которая вышла в «Academia» в I935 г. (но без фундаментального историко-литературного предисловия переводчика, сохранившегося в его архиве $)$; а в 1938-г939 гг. начал перевод более раннего романа Филдинга, «Джозеф Эндрюс», из которого, вероятно, успел подготовить только «Предисловие автора». В связи со своими занятиями Филдингом, не только романистом, но и драматургом, Франковский в I940 г. совместно с Д.М. Горфинкелем по договору с издательством «Искусство» (вероятно, для серии «Библиотека мировой драматургии») перевел две английские пьесы XVIII в. - «Джон Буль, или Камин англичанина» Джорджа Колмена Младшего и «Хитрый план щеголей» Джорджа Фаркуара, - оставшиеся неоплаченными и неопубликованными.

Франковский занимался английской прозой XVIII в. в перспективе ее «филологического перевода», восходящего к традиции, прежде всего немецкой, переводов античной классики и литературного канона нового времени. Филологический перевод не равен буквальному, хотя на первый взгляд они могут казаться одним и тем же (ср.: [II]). Сущность этого тонкого отличия описана Гёте в примечании «Перевод» к «Западно-восточному дивану» (которое Вальтер Беньямин назвал одним из лучших высказываний о теории перевода [8, с. 268]): высшая, самая совершенная форма перевода, который тождественен подлиннику и при этом значительно обогащает литературные возможности родного языка «риторическими,

I РО ИРЛИ. Ф. І32. О фонде Франковского, поступившем в Пушкинский Дом сразу после смерти переводчика в блокадном Ленинграде в г942 г., см.: [23]. 
ритмическими, метрическими выгодами», в своем завершении смыкается с первоначальной формой перевода - простым прозаическим подстрочником. «По мере того, как перевод стремится отождествиться с подлинником, он все больше сближается с подстрочником и крайне облегчает понимание оригинала, так что подводит нас к основному тексту, можно даже сказать - подгоняет нас к нему <...>» [13, с. 326-329]. В «филологическом переводе», как и в буквальном, каждое слово и синтаксис по возможности точно соответствуют словам и синтаксической организации подлинника; его задача, как и задача подстрочника, - передать смысл подлинника, однако эта точность принципиально более фундаментальная в отношении исторического понимания оригинала и, как следствие, актуальная в отношении отечественной дикции.

«Филологический перевод» не сводится также и к исторической точности, достигаемой культурной археологией значений слов и реалий подлинника и находящей свое наглядное выражение как собственно в историко-литературной адекватности перевода, так и в фундаментальных комментариях и предисловиях к нему переводчика/редактора (часто столь обширных, что они могут быть опубликованы лишь частично, как примечания М.Л. Лозинского к «Божественной комедии», или требуют отдельного тома, как комментарий Г.Г. Шпета к «Посмертным запискам Пиквикского клуба»). Историческая точность составляет важную часть филологического перевода, однако ограниченный только ею он представлял бы лишь мертвый «фиктивный слепок» оригинала [I5, с. 376]. «Филологический перевод» классики есть задача по своей сути живая, актуальная для принимающей культуры, как в силу природы самого классического памятника, способного к вечному обновлению, так и благодаря позиции переводчика, обращающегося к этому произведению из той точки современности, где старые переводы стали по каким-то причинам неприемлемы и возникла потребность в новых.

Как высочайшая историко-литературная точность, так и актуальность переводов Франковского из Стерна для отечественной культуры были отмечены в немногочисленных, но существенных откликах современников, появившихся сразу по выходе в г940 г. «Сентиментального путешествия». Рецензенты единодушно формулировали то парадоксальное обстоятельство, что «в сущности до настоящего времени мы совершенно 
не знали» многократно переводившегося на русский «одного из величайших писателей Запада, могущественно влиявшего на нашу словесность (начиная от Радищева и кончая Толстым)» [43]. Об этом писал не только процитированный К.И. Чуковский, который подчеркнуто не упомянул о влиянии Стерна в интерпретации В.Б. Шкловского на русскую прозу I920-х гг., но и «невероятнейший», по словам Шкловского, Петр Сторицын (Стерн Франковского - «текстуально точный, без отсебятин, не руссифицированный, с правильно переданными интонациями и стилевыми особенностями. <..> мы можем сказать, что Стерн впервые переведен на русский язык» [33, с. I5I], подробнее см.: [9]), и Б.М. Эйхенбаум, слова которого: этот перевод «впервые раскрывает русскому читателю все намеки и тонкий смысл стерновских рассуждений и передает всю прелесть, все изящество стерновского стиля» [48, с. 3I5] - перекликаются со словами его старого товарища по ОПОЯЗу, заметившего, в связи со Стерном, что в судьбе литературного произведения могут происходить «перевороты», когда оно в восприятии нового поколения читателей «как бы пишется заново» [45, с. г99]. Однако переводы Франковского, способные, казалось бы, по своим качествам совершить новый «переворот» в русской судьбе Стерна, актуализировать его в отечественной культуре, такой роли не сыграли: дальнейшего осмысления сделанного в этих переводах, которые А.А. Елистратова позже назвала «настоящим подвигом научного исследования и художественного воссоздания оригинала» [I7, с. 656], не последовало, и на вышедший в г949 г. перевод «Тристрама Шенди» нам не удалось обнаружить ни одного печатного отклика - что вполне объясняется разгаром «борьбы с космополитизмом», «буквалистическим переводом» [I] и «схоластической шпетовщиной»².

2 Выражение из установочной речи И.А. Кашкина на заседании Секции переводчиков Союза Советских писателей ІІ марта І948 г. (РГАЛИ. Ф. 2854. Оп. І. Д. ІІ6. Л. Іо, цит. по: [56, с. 32]). У Шпета и Франковского базовые презумпции «филологического перевода» были, вероятно, общие (хотя Шпет, с его «сверхфилологической» точностью и комментариями объемом в отдельный том, конечно, представлял собой крайнюю позицию); именно Шпет в 1932 г. начал переводить Стерна для «Academia» и не возражал против передачи части работы Франковскому (см.: [9; 45, с. 269, 260]); переведенные им к 1934 г. части «Тристрама Шенди» (Кн. І, гл. І-25, Кн. ІІ, гл. І-2) хранятся в: ОР РГБ. Ф. 7І8. К. І2. Ед. хр. 5; Франковский знал о шпетовском переводе, но текста его, вероятно, не видел. 
Задача настоящей статьи - выявить некоторые основания представлений Франковского о «филологическом переводе» на материале его работы с английской прозой XVIII в. и поставить их в контекст советского филологического перевода I930-х гг. Последнее представляется необходимым потому, что Франковский сам не делал никаких мета-высказываний о переводе ни в переводческих / редакторских паратекстах, ни в критических статьях (которых не писал), ни в переписке, поэтому для понимания его представления о «задаче переводчика» важно выявление релевантного культурного контекста.

В советской истории литературы проблематика и само понятие «филологического перевода» периодически упоминались на протяжении I920-X - I930-х гг., главным образом не в более заметных и влиятельных в литературном поле критически-прескриптивных статьях и рецензиях, а в работах представителей традиционной университетской науки, а сам этот тип перевода реализовывался в продукции издававших мировую классику издательств М. и С. Сабашниковых, потом «Academia», после закрытия последнего в конце I930-х гг. - Гослитиздата (ведущие ленинградские мастера «филологического перевода» А.А. Смирнов, М.Л. Лозинский, Б.А. Кржевский, А.А. Франковский и др. были институционально связаны как с университетской наукой, так и с издательством «Academia»). Однако в советской литературе І930-х гг., эпохи расцвета «филологического перевода», не могли обсуждаться его - «идеалистические» и «буржуазные», с точки зрения оккупировавшей весь критический дискурс марксистской доксы философско-эстетические основания. То, что в конечном счете здесь не был осмыслен и усвоен тот «русский европейский» язык, который создали в те годы переводчики-филологи в до сих непревзойденных русских переводах европейской классики, как «Божественная комедия» Данте и «Гамлет» Шекспира в переводе М.Л. Лозинского, «Сентиментальное путешествие»

3 Несмотря на то что Франковский хранил полученные им письма, начиная со своего переезда в Петербург в I906 г., эпистолярии в его архиве крайне мало, а те несколько посланий, что он получил от коллег (Б.А. Грифцова, И.А. Кашкина, М.А. Кузмина, К.И. Чуковского; от последних трех по одному письму, от Грифцова - три; см. также письма Франковского Грифцову г927-І938 гг. в: РГАЛИ. Ф. 2І17. Оп. І. № 7), ценивших его переводы, носят сугубо деловой характер и написаны в уважительном, но сухом тоне. Исключение составляют несколько писем испаниста Б.А. Кржевского г9І6-г934 гг., с которым Франковского связывали близкие дружеские отношения. 
Стерна в переводе А.А. Франковского, «Дон Кихот» Сервантеса в переводе под редакцией Б.А. Кржевского и А.А. Смирнова и проч., целого ряда произведений античной и восточной литератур, связано с отсутствием в печатной советской культуре І930-х гг. адекватного критического дискурса для его описания, место которого заняли редукционистская историко-литературная периодизация и соответствующее деление писателей на «буржуазных», «реакционных», «реалистов» и проч.4, оценочное и вульгарно осовременивающее «классовое» прочтение памятников прошлого зии критиков, но и фундаментальные предисловия и комментарии самих переводчиков и редакторов, являющиеся неотъемлемой частью «филологических переводов», хотя до собственно вульгарно социологических объяснений почти не опускались, были сведены к обзору существующей литературы, главным образом иностранной, очерку истории русских переводов и культурологическому пояснению реалий. Скромный технический статус паратекстов от переводчика / редактора перевода позволял им сохранять идеологическую нейтральность, однако при условии сугубо объективного компилятивного историко-литературного характера.

Таким образом, философско-эстетические основания сделанных в I930-е гг. переводов классики и их актуальность для отечественной культуры остались невыявленными - при этом можно уверенно предположить,

4 Ср.: Пруст - «энциклопедия буржуазного паразитизма» [І2, с. I54]; Филдинг - «буржуазный моралист, вступает <...> в борьбу с Филдингом-реалистом» [16, с. 55]; «Свифт воплотил в себе весь пессимизм, всю злобу, всю безнадежность старых разбитых классов, оттеняемых капиталом и новой обуржуазившейся аристократией. С цинизмом отчаяния он изображал нового буржуазного человека <...>. Дефо стоит по другую сторону правящей аристократии. Он сын поднимающейся плебейской буржуазии - плебей, хотя еще и не демократ. <...> Из принципиального защитника своего класса он сделался агентом аристократических политиков. Его художественные произведения лишены четкой политической направленности. Он не судит, не учит - он информирует и развлекает. Своей социальной “скромностью” он типичен для буржуазной массы своего времени» [24, c. IX-X].

5 Ср.: «Современный советский читатель доскажет за автора выводы, каких он, вследствие своей исторической и классовой ограниченности, не сделал <...» [33, с. 34]; «Начиная с Теккерея, английская буржуазная критика делает не одно усилие, чтобы похоронить истинное реалистическое значение Филдинга, которое становится ей все более не по плечу. Поэтому особенно своевременно (издание «Истории Тома Джонса». - М.M.) у нас в стране, массовый читатель которой сумеет оценить по достоинству смелость, бодрость и жизнерадостность творчества великого английского романиста» [I6, с. 57]; «Робинзон - несомненно самая бодрая книга во всей буржуазной литературе. <...> Единственный наследник того, что было бодрого и здорового в Робинзоне, - строящий социализм пролетариат» $[24$, c. XVI]. 
что сами мастера «филологического перевода», вынужденно выбрав в эти годы «нишу» переводческой и редакторской деятельности, относились к задаче переводчика в первую очередь как к задаче понимания и не могли не внести в нее философские основания, поскольку все они в начале карьеры, в г9го-е - начале г920-х гг., формировались как философы, в университетской интеллектуальной среде, пропитанной неокантианскими и феноменологическими идеями. Это относится не только ко вполне очевидной в этом контексте фигуре Г.Г. Шпета, чьи радикальные переводческие и комментаторские приемы и подходы весьма вероятно вытекают из его философии слова, но и А.А. Смирнова, которого Андрей Белый, встретив в салоне Мережковских, заметил как «философа Смирнова», говорившего о Канте и имевшего собственные философские амбиции [3І, с. I7, прим. 5I]; и М.Л. Лозинского, поэта-постсимволиста, который в отношении переводческого метода придерживался более «филологического» подхода, чем филолог А.А. Смирнов [47, c. I22-I23]. Франковского знавшие его в начале г920-х гг. люди также запомнили как «ученого и философа», интересующегося современной немецкой философией [5I, с. гог] $]^{6}$ «переводчика Шпенглера» [34, с. I30]7.

6 Ранние американские исследователи творчества и биографии М.М. Бахтина К. Кларк и М. Холквист сообщают, что Франковский в начале г920-х «иногда захаживал» («was <...> occasional visitor») на бахтинский семинар в Ленинграде [55, с. Іог] - других подтверждений этому нам не удалось обнаружить, однако сама возможность близости Франковского, с его консервативными для І920-х гг. философскими интересами, к кругу Бахтина представляется вполне вероятной. Философские интересы Франковского восходят к его учебе в петербургском университете, где он был близок к профессору-неокантианцу и психологу А.И. Введенскому и позже, вероятно, входил (в 1918 г.) в Братство святой Софии Д.В. Болдырева, что позволяет предположить его знакомство с философскими текстами Болдырева (см. его вышедшую посмертно книгу «Знание и бытие» (Харбин, І935, с предисл. Н.О. Лосского)) и с его яркой религиозно-политической публицистикой петроградского периода (статьи 1915-1917 гг. в журналах «Русская мысль» и «Русская свобода»). Первый опубликованный перевод Франковского, вышедший еще в студенческие годы, - «Введение в теорию познания» немецкого философа-неокантианца Августа Мессера (г9Іо; «Einführung in die Erkenntnistheorie», I909). В І92I-I923 гг. он состоял членом и секретарем университетского Философского общества (которое возглавляли в эти годы Э.Л. Радлов и Н.О. Лосский) и участвовал в издававшемся им журнале «Мысль» (см. его очерк «Философское общество при Петроградском университете» в: Мысль. 1922. № І. С. І87-188), где опубликовал «Обзор немецкой философской литературы I9I4-I92I г.» (Там же. 1922. № 2-3); участвовал в периодическом издании Лосского и Радлова «Новые идеи в философии», где вышли его переводы статей Х. Зигварта «Основные вопросы этики» (I9I4. Сб. І4) и Р. фон Шуберт-Зольдерна «О бессознательном в сознании» (I9I4. Сб. І5).

7 Франковский был редактором выполненного коллективом авторов перевода «Заката Европы» (1923) О. Шпенглера - судя по сохранившимся в архиве переводчика 
Несмотря на то что свои представления о филологической «задаче переводчика» Франковский не эксплицировал, круг известных ему, как университетскому философу, релевантных для понимания перевода общеевропейских философско-эстетических идей вполне очевиден и был очерчен в нескольких работах по истории и теории перевода, вышедших в 1920-1930-е гг. из университетской филологической среды - Ф.Д. Батюшкова, А.М. Финкеля, М.П. Алексеева. Впервые, вероятно, в советское время филологическое понимание перевода было обозначено в двух статьях Батюшкова, добавленных в известный сборник статей Гумилева и Чуковского «Принципы перевода» (впервые: «Всемирная литература», г9г9) при его переиздании в г920 г. Несмотря на старомодный академический тон этих небольших работ, устарелость воззрений их автора на природу языка, отсутствие боевитой полемической категоричности и слабую возможность влияния, поскольку Батюшков только что умер и статьи были напечатаны в мемориальном порядке, эти тексты создают важный концептуальный противовес более известным субъективным и дидактически-прескриптивным статьям Гумилева и Чуковского и демонстрируют, что и в те годы специалист-филолог, оказавшийся перед необходимостью написать общий очерк проблемы перевода, отнюдь не чувствовал себя, в отличие от Чуковского, «одиночкой, бредущим по неведомой дороге», лишь «смутно» и «инстинктивным литературным чутьем» ощущавшим, что такое перевод [44]. Ученый имел опору в большой европейской филологической традиции, прежде всего в немецкой философской лингвистике и искусствознании - теории и практике перевода у В. фон Гумбольдта, Ф. Шлейермахера, немецких романтиков, взгляды которых, как писал в важнейшей книге по истории и теории перевода 1929 г. харьковский профессор А.М. Финкель, и сейчас «составляют основу всех рассуждений о переводе» [37, с. 62]. «Современная европейская литература, посвященная теории перевода, - как заметил в лекции, прочитанной в конце г927 г. в Саратовском университете и вышедшей в І93І г. отдельной брошюрой, снабженной обширной библиографией вопроса, другой отечественный представитель “филологического перевода”, ученый-компаративист М.П. Алексеев, - поистине необозрима», в различные исторические эпохи и часто в одну и ту же эпоху вопрос

(РО ИРЛИ. Ф. І32) текстам с редакторской правкой, он фактически заново переписал весь перевод. 
о задаче переводчика уже решался разными, зачастую находящимися в резком и явном противоречии между собою, способами [2, с. І2]. Батюшков принципиально противостоит позиции Чуковского, не называя его имени, когда говорит, что переводчика следует уподоблять не актеру (который, по Чуковскому, «преображается» в автора [4I, с. 25]), а филологу: актер в своей работе воплощения хотя и подчинен замыслу автора, но располагает разными возможностями, Отелло в исполнении разных актеров - «это все разные Отелло по канве замысла Шекспира»; переводчик же должен воспроизвести то, что дано. Актер, воплощая, имеет перед собой возможности открывать новое; переводчик, как и филолог, познает познанное» [4, с. I4-I5].

Философским горизонтом рассуждений о переводе в статьях Батюшкова служит мысль о фундаментальной невозможности перевода, о непереводимости, поэтому он утверждает противоречащую идеологии «Всемирной литературы», но принципиально важную для понимания философско-лингвистического фундамента проблемы перевода аксиому: «никакой, даже самый современный, перевод не может вполне заменить чтение художественного произведения в подлиннике» [4, с. го]. Батюшков ссылается на А.А. Потебню (писавшего, что «язык настраивает весь механизм мысли особым, так сказать, индивидуальным образом» и, следовательно, всякий перевод с одного языка на другой есть всегда «переложение своими словами», изменяющее содержание подлинника [4, с. II]; ср.: [25, с. 263-264]), который в свою очередь опирался на Гумбольдта в изложении Штейнталя. Два релевантных для практики «филологического перевода» фундаментальных подхода, следующих из этого философского основания, это - предпочтение «очуждающего» (verfremdend) перевода «доместицирующему» и соответствующая способность таких переводов обновлять национальный язык; и понимание перевода как прежде всего герменевтической процедуры, «модуса сосредоточенного понимания» [56, с. I89], акцент на природе оригинала и его автора, а не на «творческой личности» переводчика ${ }^{8}$ и не на коммуникативном аспекте перевода, т. е. фигуре современного отечественного читателя. Наиболее под-

8 С точки зрения «филологического перевода» тема «творческой личности переводчика», которая прежде всего интересует Чуковского, не является первостепенной - «индивидуальность переводчика» подчиняется автору «безусловно» [4, с. Іо] - основной вопрос: как индивидуальность автора оригинала воплощена в «стиле [его] языка» [5, с. 23]. Соответственно, задача переводчика - это задача понимания: «...вдуматься в язык писателя и выяснить себе его стиль <...» [5, c. 22]. 
робное и фундаментальное изложение философские основания взглядов на перевод получили в этот период в советской России в написанной на украинском языке книге А.М. Финкеля, профессора Харьковского университета, автора «Критического введения к Потебне» (предисловия к книге Потебни «Из лекций по теории словесности». Харьков, І930), переводчика сонетов Шекспира и одного из авторов сборника пародий «Парнас дыбом» (I925), «Теория и практика перевода» (Харьков, І929), которая, несомненно, является центральным историко-теоретическим трудом в истории советского «филологического перевода» I930-х гг. и заслуживает гораздо более подробного изложения, чем уместно в рамках настоящей статьи.

Батюшков и Финкель с их опорой на немецкую философскую традицию были современны общеевропейским поискам в теории перевода первого тридцатилетия XX в., которые в основном «восходят к немецким литературным и философским традициям, к романтизму, герменевтике и экзистенциальной феноменологии» [57, с. II]. В послевоенные годы советская теория перевода, как известно, надолго отошла от общеевропейского философского пути, приобретя характер по преимуществу идеологической критики и технического лингвистического анализа. Признаки этого вынужденного отказа теоретиков перевода г930-х гг. от философских оснований, сформировавших их интеллектуальный этос, можно различить и ранее. А.В. Федоров в книге І94I г. кается, что в своих старых работах, «не становясь в принципе на точку зрения непереводимости, все же слишком сильный упор делал на примеры несовместимости формально-языковой и художественно-смысловой передачи отдельных деталей оригинала, рассматривая их самих по себе, и из этого порой вытекали наивно-пессимистические или скептические выводы» [35, с. 4-5] и, признавая достигнутый переводчиками символистской эпохи новый уровень точности, повторяя известные слова В.Я. Брюсова из его статьи «Фиалки в тигеле» (1905) и испаниста Д.К. Петрова о том, что, учитывая заведомую невозможность, неудачу всякого перевода, способного дать лишь «неточную копию», следует, может быть, «вовсе не переводить. <...> Не лучше ли уединенному любителю поэзии взять на себя труд выучиться чужому языку, одолеть любимое произведение в подлиннике, целиком и основательно овладеть им?», замечает, что эти мысли происходят из идеалистической эстетики и недостаточной заботы об интересах читателя [35, с. І2], и противопоставляет им прин- 
ципы «оптимистического» «советского» перевода, передающего «идейное целое» подлинника. А.А. Смирнов также мотивирует отказ от идеи непереводимости тем, что в ее основании лежит «идеалистическая» точка зрения на язык [29] - тогда как его собственные литературно-эстетические воззрения, как показал Б.С. Каганович, восходили к Б. Кроче [І8], придерживавшемуся радикального взгляда на невозможность переводов [20, с. 77]. Даже А.М. Финкель в статье г939 г. апеллирует в критике непереводимости к тому несущественному обстоятельству, что сами сторонники этой «пессимистической» позиции, Гумбольдт и Потебня, дали прекрасные образцы перевода классики [38, с. 258].

И все же, несмотря на то что, как прекрасно понимали уже в г930-е гг. наиболее ориентированные на завоевание власти в поле перевода переводчики и критики, перевод является «делом большой государственной важности» [42, с. 6], в том числе и переводы классики, поскольку их периодическое «обновление» имеет остро актуальный и политический смысл «[к]аждая эпоха создает свой перевод, согласно <...> запросам своего времени» [I9, с. 2І2], власть, уделявшая в этот период преимущественное внимание переводу между русским и национальными языками народов СССР (о чем, в связи с темой перевода, в основном шла речь на Первом съезде советских писателей в I934 г.), не подверстывала еще жестко перевод классики к требованиям «социалистического реализма» и не проводила определенной идеологической линии в отношении переводчиков-филологов и «филологического перевода»9, позволяя им публично высказывать свою

9 При этом власть преследовала неофициальные объединения и студии переводчиков: в 1932 г. по делу о «контрреволюционной организации фашистских молодежных кружков и антисоветских литературных салонов» был арестован и приговорен к трехлетнему условному сроку М.Л. Лозинский. Петроградское ОГПу придумало целую схему, в центр которой был поставлен ученик Лозинского по студии перевода М.Д. Бронников, объединявший, с одной стороны, «фашистские молодежные кружки» (с такими сугубо культурными названиями, как «Бодлэровская академия», «Штроггейм клуб» и «Шекспир банджо») и «асоциальные литературные салоны»: стоящий в стороне и связанный с общим «заговором» только через фигуру Бронникова «а/с кружок Лозинского», а также «мистико-спиритуалистический кружок Наумовой В.К.», «а/с литературный салон Билибиной Т.В.» и др. (схема ОГПУ сохранилась в архиве Лозинского). В г935 г. по делу o «Немецко-фашистской организации», так называемому «Делу о Большом немецко-русском словаре», была репрессирована целая группа философов, филологов и искусствоведов круга ГАХН, много занимавшихся в г93о-е гг. переводами (М.А. Петровский, Г.Г. Шпет, А.Г. Габричевский, Б.И. Ярхо),что, в частности, повлияло на судьбу юбилейного собрания сочинений Гете. 
позицию ${ }^{\text {Iо }}$ и обсуждать разные подходы ${ }^{\text {I }}$. Последний раз «переводчики-филологи» вели почти на равных профессиональную дискуссию с «творческими» «переводчиками-поэтами», означенными сильной после Первого съезда писателей фигурой Б.Л. Пастернака и влиятельной в театральных кругах А.Д. Радловой, а также с претендовавшими на власть в литературном поле критиками К.И. Чуковским и Д.П. Святополк-Мирским, во время предвоенного обсуждения переводов для собрания сочинений Шекспира. Принцип «эквиритмии», положенный в основание нового собрания сочинений его редакторами А.А. Смирновым и Г.Г. Шпетом, маркировал приверженность определенной переводческой традиции, восходящей к переводам, в частности, из Шекспира, немецких романтиков, А. Шлегеля и Л. Тика [47, c. 728], и служил шибболетом в определении позиций спора. Этот принцип, в частности, выступал в переводе М.Л. Лозинским «Гамлета» как способ достижения «компактности словесных конструкций», «большей нагруженности понятиями каждого слова», «дисциплины словесной культуры» [40], т. е. создания более интенсивного - современного - русского языка, который, на свой лад и никак не участвуя в дискуссиях о переводе, создавал в переводах прозы и Франковский.

К переводам Франковского в высшей степени приложимо известное утверждение о том, что ту роль, какую в поэзии играет рифма и ритм, в прозе играет синтаксис. В ту эпоху Вальтер Беньямин в своей знамени-

го Так, на первом Всесоюзном совещании переводчиков в январе г936 г. наряду с сугубо политическим по своим целям, направленным на то, чтобы быть законодателем «общих принципов, обязательных для каждого нашего переводчика» [3, с. I48] пленарным докладом театрального критика И.Л. Альтмана, в собственно переводоведческом отношении крайне путаном, были безупречно профессиональные, несмотря на компромиссность, выступления А.А. Смирнова и М.Л. Лозинского, описавших основания «адекватного перевода», соединяющего передачу буквального смысла текста и «всего существенного в его словесно-звуковом оформлении, имеющего значение не только в стихах, но и в прозе» и утверждавших необходимость предварительной фундаментальной историко-литературной работы переводчика [30; 21, с. 170-189].

II Филологические переводы классики сосуществовали с переводами сокращенными (для детей и проч.) и вольными, часто одних и тех же произведений. Так, в I935 г., когда Франковский уже сделал свой перевод «Сентиментального путешествия», а Шпет перевел часть «Тристрама», в Гослитиздате вышел перевод «Сентиментального путешествия», выполненный Надеждой Вольпин - «халтурный и сумбурный. Ее стиль - не научно-художественный, а дилетантский и обывательский» [33, c. I50-I5I], а в массовой «Библиотеке Огонька» - добросовестный, но тяжелый и устаревший перевод Д.В. Аверкиева I890-х гг. в отрывках. 
той статье «Задача переводчика» (1923) обновляет идею Шлейермахера об “очуждающем” переводе, который приближает читателя переводного текста к иностранному через точный перевод, трансформирующий переводящий язык, и говорит о том, что «чистый язык» высвобождается в переводе через буквализмы, особенно в синтаксисе. Франковский еще с первых своих французских переводов, из Анри де Ренье, считает верным как можно точнее передавать своеобразие синтаксиса иностранной прозы, который «так далек от синтаксиса прозы русской» [39], принципиально расходясь в этом с показательной для противоположного направления позицией Чуковского, категорически утверждавшего, что синтаксис в переводе должен быть обязательно русский [4I, с. I5-I9], и вызывая своими новаторскими переводами Пруста резкую критику К. Локса в журнале «Печать и революция» (І927. Кн. 8): «Двухаршинные периоды, отмечающие в подлиннике сложность мысли, кажутся в русском тексте просто варварством неуча; бесконечные “который, который”, “что, что” приводят в отчаяние $<$... >.

Этому же идеалу сохранения в переводе своеобразия иностранного синтаксиса и создания большей смысловой нагруженности каждого слова Франковский следует и в своих переводах английской прозы XVIII в. Так, правя свой перевод фразы, открывающей первую главу первого тома «Тристрама Шенди»: «I wish either my father or my mother, or indeed both of them, as they were in duty both equally bound to it, had minded what they were about when they begot me <...> , Франковский движется к тому, чтобы тонкий юмор Стерна и своеобразие его словесного строя были выражены по-русски с той же языковой компактностью, что и по-английски. Первоначальный вариант перевода «уделили некоторое (исправлено на: «больше») внимания тому, что они делают» исправлен на абстрактно-интеллектуальное «поразмыслили» (ср. «minded»), в результате чего сохраняется тонкий юмористический эффект, поскольку слово «поразмыслили» относится к тому, что традиционно (но не отцом Тристрама) понимается именно как действие, а не размышление - процессу зачатия (вернее, первоначально Франковский переводит «when they begot mе» как «производили меня на свет», но потом исправляет на однословное, как в английском, «меня зачинали»): «Я бы желал, чтобы отец мой или мать, а то и оба они вместе, ведь обязанность эта лежала одинаково на них обоих, - поразмыслили 
над тем, что они делают в то время, когда они меня зачинали». Здесь мы видим стремление переводчика к словесной концентрации русской дикции, ее «англизированию». В заметке «От редактора» к переводу «Приключений Гулливера» Франковский дает характеристику стиля, аналог которому стремится создать по-русски: «...у Свифта взвешено каждое слово; живший в “золотой век” рационализма, Свифт сам был рационалистом; его рассуждения о возникновении лжи и заблуждения (в IV части) почти совпадают с рассуждениями Декарта (в четвертом Размышлении); отличительные черты слога бробдингнежцев: ясность, мужественность и гладкость, отсутствие всякой цветистости, стремление избегать нагромождения ненужных слов и разнообразия выражений, являются идеалом, которому всегда следует Свифт». Интеллектуальный, в своих основаниях философский, русский язык, который создает Франковский в своих переводах, можно назвать, воспользовавшись определением стиля игры вымышленной Прустом актрисы Берма, «умной дикцией» $[26, \text { с. 80 }]^{\text {12}}$. В том же ключе Франковский характеризует стиль Филдинга в черновой заметке к написанному им, но оставшемуся неопубликованным фундаментальному предисловию к переводу «Тома Джонса»:

Стиль Филдинга - стиль XVIII века с его рассудочностью, логической расчлененностью, периодичностью, отсутствием эмоциональной расплывчатости - переведен (А.И. Кронебергом. - M.M.) на язык гоголевской натуральной школы, в котором все эти моменты разрыхляются, смазываются, из желания избежать сухости. Между тем очень ценно передать все особенности слога Филдинга, исполненного тонкого, «интеллектуального» юмора и иронии. Конечно при этом следует отбросить всякую попытку стилизовать Филдинга под русский XVIII век; слишком велико несоответствие между тогдашней английской и русской культурой, и в слишком младенческом состоянии находился тогдашний русский «метафизический», по выражению Пушкина, язык (РО ИРЛИ. Ф. Із2).

I2 В самом переводе оригинального французского выражения «l'intelligence de la diction», приобретающего у Франковского несколько даже утрированный характер выразительного и экономного интеллектуального термина: «умная дикция» - наглядно видно отличие его манеры от аморфного бытового языка в переводе Н. Любимова: «понимание того, что хотел сказать автор». 
Франковский цитирует здесь слова Пушкина, который писал Вяземскому в I825 г.: «...русский метафизический язык находится у нас еще в диком состоянии. Дай бог ему когда-нибудь образоваться наподобие французского (ясного точного языка прозы, т. е. языка мыслей)» [28, с. г66], и хвалил друга, что тот «заступился явно за галлицизмы» [28, с. I67], - и актуализирует в советские г930-е гг. этот пафос Пушкина, размышлявшего сто лет назад о необходимости создания нового - «ясного, точного» - современного русского прозаического языка как языка «метафизического», «языка мыслей», в отечестве, где «ученость, политика и философия еще по-русски не изъяснялись; метафизического языка у нас вовсе не существует» [27, с. I4]. Пафос этот был близок Франковскому и в годы его интеллектуального формирования, когда философские антрепризы І9Іо-х - начала І920-х гг., в которых он деятельно участвовал (философское общество, философские периодические издания, издательство «Academia», созданное при университетском философском обществе и начавшее свою деятельность с издания нового собрания творений Платона), ставили своей целью синхронизировать отечественного читателя с современной философской и культурной мыслью Европы и ее языком; и в переводах Пруста, где он создал новый интеллектуальный русский язык, замешанный на философии А. Бергсона и искусствознании Г. Вёльфлина и опыте создания для них русского языкового эквивалента'ㄹ. Можно предположить, что свои переводы английской прозы XVIII в. с ее разработанной рациональной расчлененностью и интеллектуальным юмором Франковский также рассматривал как возможность обновления современного русского прозаического языка, претерпевавшего идеологическую «порчу» и примитивизацию.

\footnotetext{
I3 В начале I920-х гг. в переводе Франковского вышла новейшая работа А. Бергсона «Длительность и одновременность: (По поводу теории Эйнштейна)» (I923), а также «Я и оно» 3. Фрейда (1924); этот раннесоветский интерес к ключевым фигурам современной европейской мысли восходил к русской культуре г9Іо-х гг., когда, в частности, серия «Новые идеи в философии», в которой активно участвовал Франковский, открывалась статьей Бергсона «Философская интуиция» (I9I2. №I) и посвящала отдельный выпуск теме «Бессознательного» (в ее философском, не психоаналитическом, аспекте; 19I4. № 15). Перевод труда Г. Вёльфлина «Основные понятия теории искусств», вышедший в I930 г., Франковский сделал также в первой половине г920-х: в марте г924 г. он докладывал на заседании правления издательства «Academia» о «совершенной непригодности» предложенного ГИИИ перевода книги Вёльфлина, сделанного С.И. Чацкиной (ОР РНБ. Ф. пІ2о. № 6I. Л. 6), и уже осенью показал директору издательства А.А. Кроленко свой перевод этой книги, «который он сделал, так сказать, для себя, без заказа» (Там же. № 266. Л. 97); в архиве сохранился неопубликованный текст его предисловия к переводу.
} 
Сохранившаяся в архиве черновая рукопись начатого Франковским перевода романа Филдинга «Джозеф Эндрюс» позволяет увидеть процесс воссоздания по-русски английского синтаксиса. В самых общих чертах ход переводческой работы Франковского таков: он начинает со смыслового подстрочника, потом в процессе многослойной стилистической правки добивается, чтобы интонация перевода, без чрезмерного насилия над русским языком, воспроизводила своеобразие «рассудочного», «логического» английского синтаксиса со множеством вводных фраз, передавая их усиленной пунктуационной расчлененностью ${ }^{\mathrm{I4}}$ :

Так как рядовой английский читатель может быть иное Весьма возможно Так как может статься, что представление (рядового англичанина) о романе у рядового английского читателя может статься иное, чем нежели у автора этих томиков, и потому он, мөжет быть, ждет на рассчитывает найт развлече ние, он следовательно ждет на последующих дальнейших страницах развлечениея, которого коего там (нет) не оказывается, и даже не предполагалось, өжет быть, то не будет, пожалуй, неуместнөым предпослать несколько слов касательно этого литературного жанра, которого нас, никтө, насколько мне известно $я$ знаю я помню не прөбовал до сих пор на нашем языке никто не пробовал на нашем языке.до сих пор, насколько я знаю, на нашем языке никто не пробовал.

\section{Окончательный текст:}

Так как представление о романе у рядового английского читателя, может статься, иное, нежели у автора этих томиков, и он, следовательно, ждет развлечения, которого на дальнейших страницах не оказывается и даже не затевалось, то не будет, полагаю, неуместно предпослать несколько слов касательно литературного жанра, до сих пор, насколько я знаю, на нашем языке никем не испробованного ${ }^{15}$.

I4 Далее в цитате вписанное переводчиком над строкой выделено курсивом, зачеркнутое - соответствующим образом, скобки принадлежат Франковскому.

I5 РО ИРЛИ. Ф. г32. Ср. оригинальный текст: «As it is possible the mere English reader may have a different idea of romance from the author of these little volumes, and may consequently expect a kind of entertainment not to be found, nor which was even intended, in the following pages, it may not be improper to premise a few words concerning this kind of writing, which I do not remember to have seen hitherto attempted in our language». 
Стремление Франковского сохранять по-русски даже объем английских синтаксических оборотов наглядно видно при сравнении с этим пассажем из романа в переводе Надежды Вольпин: «соncerning this kind of writing» она переводит «о том роде словесности» [36, с. 5], а Франковский: «касательно литературного жанра» (отметим также, что здесь, как и в приведенном выше переводе обиходной фразы Пруста «l'intelligence de la diction» интеллектуальным термином «умная дикция», Франковский подвергает оригинал аналитическому современному прочтению, заменяя «this kind of writing», что действительно можно перевести, как это сделала Вольпин, довольно аморфным выражением «род словесности», четким определением «литературный жанр», поскольку именно теме нового, создаваемого Филдингом романного жанра посвящено предисловие к роману). Аналогичным образом несколько громоздкую пассивную конструкцию «which I do not remember to have seen hitherto attempted» Франковский первоначально переводит простой активной конструкцией «никто не пробовал», как это делает и Вольпин («никто <...> не пытался»), однако потом исправляет на пассивную, как в подлиннике, компенсируя синтаксическую громоздкость подлинника морфологической: «никем не испробованного».

При анализе правленых переводчиком черновиков, сохранившихся в его архиве, можно заметить также как, двигаясь к словарно точному (буквальному) переводу и далее к точному «по смыслу» (адекватному), Франковский часто возвращается в окончательном варианте к буквальной словарной точности. Так, знаменитая фраза, открывающая in medias res «Сентиментальное путешествие» Стерна: «They order, said I, this matter better in France», - относительно которой автор предоставляет читателю гадать, к чему она относится, первоначально была переведена Франковским в современном бытовом значении («order» как «to order a meal»): «Вещь эту, - сказал я, - лучше готовят во Франции». Потом исправлена на: «Во Франции, - сказал я, - это лучше устроено» - где слово «order» передано в своем основном словарном значении («I. Method, regular disposition. 2. Established process. 3. Proper state. $<\ldots>$ 5. Regularity, settled mode» и т. д. [54]). Далее этот словарно точный перевод («устроено») заменяется на «делают»: «Во Франции, - сказал я, - делают это лучше». Использованием глагола «делают» с крайне широкой сочетаемостью и семантическим полем, переводчик добивается русского смыс- 
лового эквивалента оригинального замысла Стерна, иронически оставившего читателю максимальный простор возможных интерпретаций. Однако в окончательном печатном варианте переводчик возвращается к словарно наиболее точному «устроено». Здесь мы, как кажется, видим работу «филологического перевода», как он описан в приведенной в начале нашей статьи цитате из Гете: через осмысление текста он смыкается с буквальным переводом.

Подготовительные рабочие заметки Франковского, сохранившиеся в его архиве, также указывают на направления его филологического интереса в переводе английской прозы XVIII в. Если в опубликованных предисловиях к своим переводам Франковский уделяет особенное внимание своеобразию создававшегося Дефо, Свифтом, Филдингом, Стерном романного жанра, то в подготовительных заметках его внимание смещено к другой теме, которая в паратекстах остается почти невысказанной - своеобразию английского юмора. Из забавной книжки «An Essay on the New Species of Writing founded by Mr. Fielding: With a Word or Two upon the Modern State of Criticism» (London: Printed for W. Owen, near Temple-Bar, I75I) Франковский выписывает не остроумное рассуждение ее анонимного автора об отличии новаторского, «подражающего Природе» («реалистического», говоря более поздним языком), стиля романов Филдинга от «romance», реакцией на который он явился, а «Законы», положенные Филдингом в основу романа:

I) Humour [анонимный автор книги описывает юмор Филдинга не очень внятно: «the whole humour must diffuse itself» (p. I7) - M.M. $\left.{ }^{\mathrm{I}}\right]$

2) Характеры - каждое их слово должно соответствовать лицу [«Every word they speak must be entirely consonant to the notion the author would have his readers to entertain on them. And here it may not be amiss to remark that great analogy there is between these histories and dramatic performances <...>» (p. I7)]

The style should be easy and familiar, but at the same time sprightly and entertaining... sometimes heightened to the mock-heroic, to ridicule the bombast $[<\ldots>$, which obtains so much in the romances [p. I9-20]».

I6 Здесь и далее в квадратных скобках мы приводим выпущенные Франковским фрагменты текстов, из которых он делает выписки, или цитаты из них, необходимые для лучшего понимания сделанных переводчиком для себя кратких заметок. 
Из исследования Уилбура Л. Кросса об эволюции английского романа (Cross W.L. Development of the English Novel. New York, London: McMillan, I899) Франковский также делает выписку именно о юморе Стерна: «It is a kind of humor that evokes only the gentlest emotions of pity, to be followed by the smile. It enfranchises the heart, purging it of melancholy and giving zest to the mere bagatelles of existence»; из эссе Уолтера Бейджхота «Стерн и Теккерей» (I864): «[There is even something scholar-like in his (Sterne's. - M.M.) style. It bears the indefinable traces which an exact study of words will always leave upon the use of words. $<\ldots>$ Our present novel readers do not at all care for an elaborate caricature of the scholastic learning; it is so obsolete that we do not care to have it mimicked.] Much of Tristram Shandy is a sort of antediluvian fun, in which uncouth Saurian jokes play idly in an intelligible world» [49, с. 23I-232]. Из главы о Стерне фундаментального десятитомного труда Эрнеста А. Бейкера «История английского романа» Франковский выписывает также не пассажи о пародийной романной структуре у Стерна, а о своеобразии его юмора: «Sterne’s laughter at puritanical reticence» (имеется в виду следующий пассаж: «His (Sterne’s. M.M.) favourite jests were directed at that puritanical foible, of inviolable reticence on certain subjects and everything connected with them. He loved to make the flesh creep by uttering the forbidden word, pointing an impish finger at the very thing that ought to be ignored. The exaggerated and often hypocritical reticence of the formalist was too much for his risability and he made fair game of it» [50, с. 274]), и афоризм: «what is the laughter of genius to one man is pornography to another» [50, c. 275]. Читая знаменитые лекции Уильяма Хэзлитта об английских писателях-юмористах, Франковский останавливает внимание на вступительной, «Об остроумии и юморе», в частности: «The essence of the laughable then is the incongruous, the disconnecting one idea from another, or the jostling of one feeling against another» [53, c. 4]. B книге Кэтлин М. Линч об английской комедии эпохи реставрации его привлекает изложение теории «юморов» Бена Джонсона [55, с. I5], в книге Эдмунда Госсе «Жизнь Конгрива» - определение юмора, данное этим английским драматургом XVIII в.: «[<...>] “a singular and unavoidable manner of doing or saying anything, peculiar and natural to one man only, by which his speech and actions are distinguished from those of other men”. He is inclined to deny it to women, or states, at least, that, so far as his experience goes, "if ever 
anything does appear comical or ridiculous in a woman, I think it is little more than an acquired folly". $[<\ldots>]$ only a very small selection of whimsical natures really lend themselves to dramatic development. He (Congreve) closes with a defence of English eccentricity, which is as true as it was two hundred years ago: - "There is more of humour in our English comic writers than in any other. I do not at all wonder at it, for I look upon humour to be almost of English growth; at least, it does not seem to have found such increase on any other soil. And what appears to me to be the reason of it is the great freedom, privilege, and liberty which the common people of England enjoy» [52, с. 82]. Наконец, Франковский делает пространные выписки и частью пересказывает эссе Г.К. Честертона «Юмор», представляющее собой одноименную статью из «Encyclopaedia Britannica» (І4-е изд. I929. T. XI): «A perception of the comic or incongruous of a special sort - humour is more subtle, than wit, or on the other side more vague. A deficiency of humour to search for a definition of humour. История humour влаги <...> У Бен Джонсона юмор - the ruling passion. Отсюда далее идея о преувеличении; юмор - эксцентричность. Юморист - эксцентрик, сознавший свою эксцентричность. <...> Нынче под юмором разумеют всегда сознательный юмор and generally a rather deep and delicate appreciation of the absurdities of others. Но с ним связывается, особенно в противопоставлении wit, традиция атмосферы, окружавшей старого эксцентрика. Существ[енный] элемент: сознание, что смеясь сам являешься предметом смеха. Предполагает сознание человеч[еской] слабости, тогда как wit - проявление силы человеч[еского] интеллекта. Wit орудие сатиры. Для wit оружие легко, в то время им наносимые удары сокрушительны. <...> Wit corresponds to the divine virtue of justice Humour corresponds to the human virtue of humility».

У нас нет возможности в полной мере соотнести английское стандартное, зафиксированное в новейшем издании Британской энциклопедии представление о юморе с отечественным той же эпохи, поскольку, как известно, «Литературная энциклопедия» 1929-І939 гг. до последнего тома, где была бы статья «Юмор», не дошла (а статья «Комическое» состоит из отсылки к статье «Эстетика», которая также не вышла). В советской литературе г930-х гг. социально-бытовая сатира явно преобладала над сложным интеллектуальным юмором. Тема юмора не выделена и в переводческих/редакторских паратекстах, а также в синхронических от- 
кликах на вышедшие в эти годы новейшие и заново отредактированные и откомментированные историко-филологические переводы классики европейского юмористического романа: Рабле («Гаргантюа и Пантагрюэль» / пер. В.А. Пяста под ред. и с прим. Б.А. Кржевского. Л.: Гослитиздат, г938), Боккаччо («Декамерон»/ пер. А.Н. Веселовского; вступ. статья В.Ф. Шишмарева. Л.: Academia, г927), Сервантеса («Дон Кихот» / пер. под ред. и с комм. Б.А. Кржевского и А.А. Смирнова. М.; Л.: Academia, I929, I932). В рецензиях на английские переводы Франковского, даже из Стерна, она также не является доминирующей ${ }^{17}$. Однако интерес Франковского к юмору как ключевому элементу, формировавшему жанр английского романа, имеет разительное сходство с интересом к этому же литературному аспекту М.M. Бахтина тех лет. В лекциях первой половины І920-х о современной отечественной литературе Бахтин призывает ее отказаться от «реалистического, бытового юмора Чехова» ради гоголевской линии «идеального, символического юмора, как называют его немецкие эстетики, конструктивного юмора» [6, с. 4I2] и пишет о юморе как конструктивном элементе раннего английского романа в оставшейся в рукописи книге «Слово в романе. К вопросам стилистики романа» (книга была задумана перед отъездом из Ленинграда в г930 г. и написана в Кустанайской ссылке в г930-г934 гг.). Бахтин определяет своеобразие прозаического романного языка наличием в нем внутренней разноречивости, диалогичности. Язык вообще «населен и перенаселен чужими интенциями» [7, с. 47], он состоит из разных профессиональных, социальных, поколенческих и прочих диалектов, языков. Романист «принимает разноречие и разноязычие литературного и внелитературного языка в свое произведение. На этом расслоении языка, на его разноречивости и даже разноязычии он строит свой стиль <...> [7, с. 5I]. В качестве примера разноречия, внутренней диалогичности прозаического языка как специфической особенности романного жанра Бахтин приводит английский юмористический роман Филдинга, Смоллета, Стерна, Диккенса, Теккерея, в котором «мы найдем юмористико-пародийное воспроизведе-

I7 Актуальность Стерна для отечественной литературы Сторицын и Эйхенбаум видят в сфере психологического романа - «разложении душевной жизни на противоречивые движения и страсти» [48, с. 315], умении «изобразить сложность и противоречивость мыслей, побуждений и чувств, “приливы и отливы” в настроениях, определяющих наши поступки» [33, c. I48]. 
ние почти всех слоев современного ему разговорно-письменного литературного языка. <...> Эта, обычно пародийная, стилизация жанровых, профессиональных иных слоев языка перебивается иногда прямым (обычно патетическим или сентиментально-идиллическим) авторским словом, непосредственно (без преломления) воплощающим смысловые и ценностные интенции автора. Но основою языка в юмористическом романе служит совершенно специфический модус употребления “общего языка”. $<. .>$ Автор в той или иной степени отделяет себя от этого общего языка <...>, заставляя свои интенции преломляться сквозь эту среду общего мнения (всегда поверхностного и часто лицемерного), воплощенного в языке» [7, с. 54]. У зачинателей английского юмористического романа, особенно у Стерна, эта пародийная стилизация различных слоев и жанров литературного языка, введение чужого слова в авторское, по сравнению с Диккенсом, которому Бахтин уделяет основное внимание, утрированы: «Пародийно-объектное восприятие различных разновидностей литературного языка проникает у них <...> в очень глубокие пласты самого литературно-идеологического мышления, превращаясь в пародию на логическую и экспрессивную структуру всякого идеологического <...> слова, как такового» [7, с. 6I-62]; кроме того, у «наиболее радикальных, раблезианских представителей» юмористического романа, Стерна, Сервантеса и Жан-Поля [7, с. 57], очень существенную роль в построении языка играет «литературная пародия в узком смысле»: «Литературная пародия еще более отодвигает автора от языка, еще более осложняет его отношение с литературным языком своего времени, притом на собственной территории романа. Господствующее в данную эпоху романное слово само делается объектным и становится средою преломления для новых авторских интенций. <..> Можно сказать, что важнейшие романные образцы и разновидности были созданы в процессе пародийного разрушения предшествующих романных миров» [7, с. 62-63]. Тотальную раблезианскую пародийность, черты которой можно найти у Стерна, Бахтин характеризует в духе, отличном от того, в каком выдержана его позднейшая книга о Рабле, и при этом остро актуальном в советском контексте: он отмечает пародийное отношение Рабле почти ко всем формам «идеологического», т. е. изолгавшегося, слова, словесной патетики («патетическое слово и всякое “важное слово” для него по своей природе лживы»), «дискреди- 
тирование всякой <...> “важной” серьезности <...> идеологического слова как условной и лживой, как злостно неадекватной действительности, достигает у Рабле предельной прозаической чистоты» [7, с. 65]. Фокус философского, лингвистического и идеологического, интереса Бахтина к юмору в раннем английском романе, конечно, не совпадает с содержанием историко-литературных выписок Франковского, сделанных с ясной целью понять, как английский романный и драматургический юмор той эпохи понимался его современниками и соотечественниками, однако само это совпадение преимущественного интереса к юмору в английском романе XVIII в., выделяющее Бахтина и Франковского из общего контекста, а также прописанный Бахтиным актуальный смысл интереса к юмору, пародии как разоблачению всякого «идеологического слова» создает, как представляется, значимый контекст для понимания актуального для «принимающей культуры перевода» смысла обращения Франковского в г930-е гг. к переводам Стерна и Свифта.

Не так уж важно, является ли это совпадение интересов типологическим или Франковский в самом деле «иногда захаживал» к Бахтину в Ленинграде [5I, с. Іог], или у них были общие знакомые, которые могли пересказывать Франковскому темы, обсуждавшиеся на этом неформальном семинаре. Во всяком случае, учитывая общность их философской ориентации, типологическое сходство представляется несомненным и подтверждается еще одним на первый взгляд прикладным, техническим соображением Франковского о переводе, которое он делает в заметке от 22 марта I93I г., посвященной старому переводу романа Филдинга «Приключения Тома Джонса, найденыша» А.И. Кронебергом (это подготовительная заметка к обширному предисловию переводчика к роману, оставшемуся неопубликованным и сохранившемуся в его архиве):

Язык перевода звучит для нашего времени архаически; можно опасаться даже, что некоторые места останутся непонятными для современной читающей публики. <...> Многие стилистические и синтаксические особенности подлинника в переводе пропали. В настоящее время нельзя не считаться с исследованиями английской прозы XVIII века, произведенными в последние два десятилетия преимущественно немецкими англистами. Например, функция косвенной речи и так называемой несобственной прямой 
речи в повествовательной ткани хорошо изучена в школе Фосслера. Нельзя поэтому ни ту ни другую речь механически преобразовывать в прямую, как это мы постоянно видим у переводчика. Несобственно прямая речь, в значительной степени являющаяся новшеством Филдинга, вполне свойственна русскому языку (образцы ее мы встречаем у Пушкина, у Достоевского, и других писателей), и незачем производить подобную переделку. Это все равно, как если бы обращение Мазепы к Петру (у Пушкина): «И знает бог и видит свет: он, бедный гетман, двадцать лет царю служил душою верной...» мы переделали так: «...я, бедный гетман, двадцать лет...». Это недопустимо, потому что несобственно прямая речь всегда густо окрашена авторской оценкой, у Филдинга по большей части иронией, и вкладывать эту иронию в уста самих героев значит грубо искажать перспективу. Нельзя поэтому переводить «For her part, she could not help...» «но что касается до меня, так я не могу» (стр. І2), то же на стр. І5 и т. д.

Аналогичные замечания можно высказать относительно перевода нередких у Филдинга реторических периодов и т. д.

Ровно эту цитату из «Полтавы» как «чрезвычайно характерный пример» приводит, и именно в связи с обсуждением проблемы несобственно-прямой речи в более широком контексте исследования синтаксиса и с апелляцией к школе Фосслера, В.Н. Волошинов в книге г929 г. «Марксизм и философия языка» [Iо, с. I53-I54], что связано с общим заинтересованным вниманием круга Бахтина, в отличие от тогдашнего лингвистического мейнстрима, ориентированного на Ф. де Соссюра, к философско-лингвистическому подходу «школы Фосслера» [24], в частности, к теме несобственно-прямой речи как двуголосого слова, интерференции голосов автора и героя, которая играет важную роль в бахтинской концепции диалога в вышедшей тогда же книге «Проблемы поэтики Достоевского» (I929). Разработанность синтаксических способов передачи чужой речи, в частности, несобственно-прямая речь, по Бахтину/ Волошинову, свидетельствует об аналитической работе, о развитости в национальном языке картезианского рационализма, риторики, - качеств, в русском языке исторически представленных чрезвычайно слабо [1о, с. 342-344]. Очевидно, что такое понимание несобственно-прямой речи смыкается с описанным выше пониманием Бахтиным юмора и па- 
родии в раннем английском романе как «гибридного слова» и сводится к доминантному для него интересу к внутренней диалогичности литературного слова. Акцент Франковского на адекватном русском переводе несобственно-прямой речи, т. е. создании аналитического «синтаксического шаблона» передачи чужой речи [го, с. 342-343] для русского языка, в истории которого «не было картезианского, рационалистического периода, когда разумно-самоуверенный и объективный “авторский контекст” анализировал и расчленял предметный состав чужой речи <...> [Iо, c. 342], вписывается в отмеченную нами общую тенденцию его переводов, фундированную философско-эстетическим университетским воспитанием переводчика (и, вероятно, более поздним, скорее всего опосредованным, влиянием Бахтина), создавать по-русски рефлексивную, картезианскую, интеллектуально разработанную «умную дикцию». 


\section{Список литературы}

I Азов А.Г. Поверженные буквалисты. Из истории художественного перевода в СССР в г920-г96о-е годы. М.: Высшая Школа Экономики, 2013. 21з с. Алексеев М.П. Проблема художественного перевода. Иркутск: Изд-е Иркутского ун-та, І93І. 50 с.

3 Альтман Иоганн. О художественном переводе // Литературный критик. 1936. № 5. С. $148-169$.

4 Батюшков Ф.Д. Задачи художественных переводов // Принципы художественного перевода. Статьи Ф.Д. Батюшкова, Н. Гумилева, К. Чуковского. 2-е изд., доп.

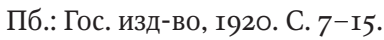

5 Батюшков Ф.Д. Язык и стиль // Принципы художественного перевода. Статьи Ф.Д. Батюшкова, Н. Гумилева, К. Чуковского. 2-е изд., доп. Пб.: Гос. изд-во, І 920. С. $16-20$. Бахтин М.M. Записи лекций по истории русской литературы // Бахтин М.M. Собр. соч.: в 7 т. М.: Русские словари, 200о. Т. 2. С. 2І3-4II. Бахтин М.М. Слово в романе // Бахтин М.М. Собр. соч.: в 7 т. М.: Языки славянских культур, 20I2. Т. 3. С. 9-339. Беньямин В. Задача переводчика. Предисловие к переводу “Tableaux Parisiens” Бодлера / пер. Е. Павлова // Бенъямин В. Учение о подобии. Медиаэстетические фрагменты. М.: РГГУ, 2012. С. 254-27і.

9 Будрин П. «Реабилитация Стерна»: Лоренс Стерн в Москве и Ленинграде I932-I94I гг. (Из истории одного издательского проекта) // Русская филология. 26. Сборник научных работ молодых филологов. Тарту, 2015. С. I7І-I82. Волошинов В.Н. Марксизм и философия языка. Основные проблемы социологического метода в науке о языке. 2-е изд. Л.: Прибой, І930. І57 с. Волчек О.Е. Литературный перевод в советской России: от автономии к идеологии вкуса // Новые русские гуманитарные исследования. 2005. № Io. URL: http:// www.nrgumis.ru/articles/I956/ (дата обращения: ог.04.2017). Гальперина Е.Л. Марсель Пруст // Литературный критик. І934. № 7-8. С. 153-I77. Гете И.В. Западно-восточный диван / изд. подг. И.С. Брагинский, А.В. Михайлов. М.: Наука, I988 (серия «Литературные памятники»). 894 с.

I4 Дашевский Г. Пропасти перевода // Коммерсант Weekend. I7 октября 2008 г. URL: http://stengazeta.net/?p=I0005373 (дата обращения: ог.04.20I7).

I5 Егунов А.Н. Гомер в русских переводах XVIII-XIX веков. М.; Л.: Наука, I964. 439 c.

I6 Елистратова А.А. Классик английского реализма [Рец. на: Филдинг Г. История Тома Джонса, найденыша / пер. А.А. Франковского. М.; Л.: Academia, I935] // Художественная литература. І935. № Іо. С. 52-6о.

Елистратова А.А. [Преамбула к примечаниям] // Стерн Л. Жизнь и мнения Тристрама Шенди, джентльмена. Сентиментальное путешествие по Франции и 
Италии / пер. с англ. М.: Худож. лит., І968. С. 655-656 («Библиотека всемирной литературы»).

I8 Каганович Б.С. А.А. Смирнов и русские переводы Шекспира г930-х годов // Laurea Lorae: Сборник памяти Ларисы Георгиевны Степановой. СПб.: НесторИстория, 201г. С. 704-727.

I9 Кашкин И.А. Мистер Пиквик и другие (Диккенс в издании «Academia») // Литературный критик. І936. № 5. С. 212-228. Кроче Б. Эстетика как наука о выражении и как общая лингвистика.

М.: Изд. М. и С. Сабашниковых, І92о. Ч. г: Теория / пер. В. [правильно: Б.] Яковенко. І7о с.

2I Багровое светило: Стихи зарубежных поэтов в переводе Михаила Лозинского / сост., автор предисл. и прим. Е. Эткинд. М.: Прогресс, 1974. 216 с.

22 Маликова М.Э. О переводчике Адриане Антоновиче Франковском по материалам его архива // Ежегодник Рукописного отдела Пушкинского дома на 2016 год. СПб.: Дмитрий Буланин, 2017. С. 37-гоо.

23 Мирский Д.П. Робинзон Крузо // Дефо Д. Робинзон Крузо. Т. I / пер. с англ. М.А. Шишмаревой и 3.Н. Журавской; под ред. А.А. Франковского. М.; Л.: Academia, I935. C. VII-XVI.

24 Попова И.Л. Книга М.М. Бахтина о Рабле в контексте идей школы Фосслера (к постановке проблемы) // Новый филологический вестник. 2005. № I. URL: http://cyberleninka.ru/article/n/kniga-m-m-bahtina-o-rable-v-kontekste-ideyshkoly-fosslera-k-postanovke-problemy (дата обращения: oг.04.20I7).

25 Потебня А.А. Эстетика и поэтика. М.: Искусство, I976. 6I4 с.

26 Пруст М. Собрание сочинений / пер. А.А. Франковского. Л.: Гос. изд-во «Худож. лит.», І936. Т. 3: В поисках за утраченным временем. Германт. 7Іо с.

27 Пушкин А.С. О предисловии г-на Лемонте к переводу басен И.А. Крылова // Пушкин А.С. Собр. соч.: в го т. М.: ГИХЛ, І962. Т. 6. С. ІІ-І5.

28 Пушкин А.С. Письмо П.А. Вяземскому, І3 июля І825 г. // Пушкин А.С. Собр. соч.: в го т. М.: ГИХЛ, І962. Т. 9. С. І66-І67.

29 Смирнов А.А. Методика литературного перевода // [Алексеев М.П., Смирнов А.А.] Перевод // Литературная энциклопедия. М.: ОГИЗ РСФСР, Советская энциклопедия, I934. T. 8. URL: http://feb-web.ru/feb/litenc/encyclop/ (дата обращения: ОI.04.20I7).

30 Смирнов А.А. О задачах и средствах художественного перевода // Литературная газета. № 2 (565). Іо января 1936. С. 2.

3I Смирнов А.А. Письма к Соне Делонэ. М.: Новое литературное обозрение, $201 \mathrm{I}$. 5 I9 c.

32 Спасский Ю. История Тома Джонса [Рец. на: Филдинг Г. История Тома Джонса, найденыша. М.; Л.: Academia, І935] // Литературное обозрение. І936. № 5 . C. $33-36$. 
Сторищын П. Реабилитированный Стерн // Литературный современник. І940. № I2. C. $148-\mathrm{I} 52$.

Тахо-Годи А.А. Жизнь и судьба: Воспоминания. М.: Молодая гвардия, 2009. 69I с. Федоров А.В. О художественном переводе. Л.: Гослитиздат, І94I. 260 с. Филдинг Генри. История приключений Джозефа Эндруса и его друга Абраама Адамса... / пер. с англ. Н. Вольпин; под ред. М.Ф. Лорие. М.: ГИХЛ, І949. 396 с. Фінкель О. Теорія й практика перекладу. Харьків, г929. Цит. по: Олександр Фінкель - забутий теоретик українського перекладознавства: Збірка вибраних праць / за ред. Л.М. Черноватого та В.І. Карабана. Вінниця: Нова книга, 2007. C. $49^{-182 .}$

38 Финкель А.M. О некоторых вопросах теории перевода // Научные записки Харьковского государственного Института иностранных языков. І939. Т. І. С. 59-82. Цит. по: Олександр Фінкель - забутий теоретик українського перекладознавства: Збірка вибраних праць / за ред. Л.М. Черноватого та В.І. Карабана. Вінниця: Нова книга, 2007. С. 227-258.

39 Франковский А.А. [Предисловие к переводу Ф.К. Сологубом романа А. де Ренье «Дважды любимая»] // Ренье А. де. Собр. соч. Л.: Academia, г926. Т. 2.

40 Чекалов И.И. Переводы «Гамлета» М. Лозинским, А. Радловой и Б. Пастернаком в оценке советской критики зо-х годов // Шекспировские чтения I990. М.: Наука, І990. С. 183-200.

Чуковский К.И. Переводы прозаические // Принципы художественного перевода. Статьи К. Чуковского и Н. Гумилева. Пб.: Всемирная литература, І9І9. С. 7-24. Чуковский К.И. Искусство перевода. М.-Л.: Academia, I936. 222 с.

43 Чуковский К. Невидимки // Литературная газета. № 63. 3 г дек. г940. С. 5 .

44 Чуковский К.И. Высокое искусство // Чуковский К.И. Собр. соч.: в 15 т. М.: Терра-Книжный клуб, 20ог. T. 3. URL: https://www.litmir.me/br/?b=I03556 (дата обращения: оІ.04.20I7).

45 Шкловский В.Б. «Евгений Онегин» (Пушкин и Стерн) // Очерки по поэтике Пушкина. Берлин: Эпоха, I923. С. I99-220. URL: http://lib.pushkinskijdom.ru/ LinkClick.aspx?fileticket=RxcFSRL_amk\%3D\&tabid=I0396 (дата обращения: OI.04.2OI7).

46 Густав Шпет: философ в культуре: документы и письма / отв. ред.-сост. Т.Г. Щедрина. М.: РОССПЭН, 2ОІ2. 675 с.

47 Густав Шпет и шекспировский круг. Письма, документы, переводы / отв. ред.-сост., предисл., коммент., археогр. работа и реконструкция Т.Г. Щедриной. М.; СПб.: Петроглиф, 2013. 760 с. («Российские Пропилеи»).

48 Эйхенбаум Б.М. [Рецензия] Стерн Л. Сентиментальное путешествие. Воспоминания. Письма. Дневник. Москва, І940 // Звезда. І940. № 8-9. С. 315-316. The Works and Life of Walter Bagehot: in Io vols. / ed. by Mrs. Russell Barrington. Vol. IV. Political and Literary Essays. Bombay, Calcutta, \& Madras: Longmans, Green \& 
Co, I9I5. URL: http://oll.libertyfund.org/titles/bagehot-the-works-and-life-of-walterbagehot-vol-4-political-literary-literary-essays (дата обращения: ог.04.20I7). Baker E.A. The History of the English Novel: in Io vols. Vol. IV. Intellectual realism: from Richardson to Sterne. London: H.F.\& G. Witherby, I936. URL: https://archive. org/stream/historyoftheengloı209ombp/historyoftheengloı209ombp_djvu.txt (дата обращения: ог.04.2017).

5I Clark Katerina, Holquist Mikhael. Mikhail Bakhtin. Cambridge, Mass.; London: Belknap Press of Harvard University Press, I984. 398 p.

52 Gosse Edmund. The Life of William Congreve. London: Walter Scott, I888. URL: https://archive.org/details/lifeofwilliamconoogossrich (дата обращения: OI.04.20I7).

53 Hazlitt William. Lectures on the English Comic Writers. New York: Wiley \& Putnam, I845. URL: https://books.google.ru/books?id=7IpFg_liEYUC\&printsec=frontcover\& $\mathrm{hl}=\mathrm{ru} \# \mathrm{v}=$ onepage \&q\&f=false (дата обращения: ог.04.20I7).

54 Johnson Samuel. A Dictionary of the English language: in 2 vols. The $6^{\text {th }}$ ed. Vol. II. London: Printed for J.F. and C. Rivington at al., I785. URL: https://archive.org/ stream/dictionaryofenglo2johnuoft\#page/n3/mode/2up (дата обращения: OI.04.20I7)

55 Lynch Kathleen $M$. The social mode of Restoration comedy. New York and London: MacMillan, I926. 242 p.

56 Steiner George. The Hermeneutic motion // The Translation Studies Reader / ed. by Lawrence Venuti. London and New York: Routledge, 2000. P. І86-г9г (впервые: Steiner George. After Babel: Aspects of language and Translation. Oxford: Oxford University Press, I975. P. 296-303).

57 Venuti Lawrence. [I900s-I930s. Introduction] // The Translation Studies Reader / ed. by Lawrence Venuti. London and New York: Routledge, 2000. P. II-I4.

58 Witt Susanna. Byron's «Don Juan» in Russia and the «Soviet school of Translation» // Translation and Interpreting Studies. 20I6. Vol. II. № I. P. 23-4I. 


\section{References}

I Azov A.G. Poverzhennye bukvalisty. Iz istorii khudozhestvennogo perevoda $v$ SSSR $v$ I920-1960-e gody [The "bukvalists" defeated. From the history of literary translation in the USSR in the I920-I960-s]. Moscow, Vysshaia Shkola Ekonomiki Publ., 2013. 213 p. (In Russ.)

Alekseev M.P. Problema khudozhestvennogo perevoda [The problem of literary translation]. Irkutsk, Izdanie Irkutskogo universiteta Publ., I93I. 5 o p. (In Russ.) Al'tman Iogann. O khudozhestvennom perevode [About literary translation]. Literaturnyi kritik, I936, no 5, pp. I48-I69. (In Russ.) Batiushkov F.D. Zadachi khudozhestvennykh perevodov [Tasks of literary translations]. Printsipy khudozhestvennogo perevoda. Stat'i F.D. Batiushkova, N. Gumileva, K. Chukovskogo, 2-e izd., dop. [Principles of literary translation. Articles by F.D. Batiushkov, N. Gumilev, K. Chukovsky, 2-nd ed., ammended]. Petersburg, Gosudarstvennoe izdatel'stvo Publ., I920, pp. 7-15. (In Russ.)

5 Batiushkov F.D. Iazyk i stil' [Language and style]. Printsipy khudozhestvennogo perevoda. Stat'i F.D. Batiushkova, N. Gumileva, K. Chukovskogo, 2-e izd., dop. [Principles of literary translation. Articles by F.D. Batiushkov, N. Gumilev, K. Chukovsky, 2-nd ed., ammended]. Petersburg, Gosudarstvennoe izdatel'stvo Publ., I920, pp. I6-20. (In Russ.)

Bakhtin M.M. Zapisi lektsii po istorii russkoi literatury [Summary of lectures on the history of Russian literature]. Bakhtin M.M. Sobr. soch.: $v 7 t$. [Collected works: in 7 vols.]. Moscow, Russkie slovari Publ., 2000, vol. 2, pp. 2I3-4II. (In Russ.)

7 Bakhtin M.M. Slovo v romane [Word in the novel]. Bakhtin M.M. Sobr. soch.: $v$ t. [Collected works: in 7 vols.]. Moscow, Iazyki slavianskikh kul'tur Publ., 20I2, vol. 3, pp. 9-339. (In Russ.)

8 Ben'iamin V. Zadacha perevodchika. Predislovie k perevodu “Tableaux Parisiens” Bodlera [The task of translator. Introduction to the translation of Baudelaire's "Tableaux Parisiens”], trans. E. Pavlova. Ben'iamin V. Uchenie o podobii. Mediaesteticheskie fragment [Treatise on similarity. Mediaesthetic fragments]. Moscow, RGGU Publ., 20I2, pp. 254-27I. (In Russ.)

9 Budrin P. «Reabilitatsiia Sterna»: Lorens Stern v Moskve i Leningrade I932I94I gg. (Iz istorii odnogo izdatel'skogo proekta) [“Rehabilitation of Sterne”: Lawrence Sterne in Moscow and Leningrad in I932-I94I (From the history of a publishing project)]. Russkaia filologiia 26. Sbornik nauchnykh rabot molodykh filologov [Russian Philology. Vol. 26. Collected works of young philologists]. Tartu, 20I5, pp. I7I-I82. (In Russ.) Voloshinov V.N. Marksizm i filosofiia iazyka. Osnovnye problemy sotsiologicheskogo metoda v nauke o iazyke, 2-e izd. [Marxism and philosophy of language. Main problems of the sociological method in the science of language, 2-nd ed.]. Leningrad, Priboi Publ., I930. I57 p. (In Russ.) 
Volchek O.E. Literaturnyi perevod v sovetskoi Rossii: ot avtonomii k ideologii vkusa [Literary translation in the Soviet Russia: from autonomy to the ideology of taste]. Novye ruskkie gumanitarnye issledovaniia, 2005, no Io. Available at: http://www.nrgumis.ru/articles/I956/ (Accessed or April 20I7). (In Russ.).

Gal'perina E.L. Marsel' Prust [Marcel Proust]. Literaturnyi kritik, I934, no 7-8, pp. I53-I77. (In Russ.)

Goethe I.-W. Zapadno-vostochnyi divan [West-East Divan], ed. I.S. Braginskii, A.V. Mikhailov. Moscow, Nauka Publ., I988. 894 p. (In Russ.)

Dashevskii G. Propasti perevoda [Abysses of translation]. Kommersant Weekend, October I7, 2008. Available at: http://stengazeta.net/?p=I0005373 (Accessed or April 20I7). (In Russ.)

Egunov A.N. Gomerv russkikh perevodakh XVIII-XIX vekov [Homer in Russian translation of the $18^{\text {th }}-2 \mathrm{O}^{\text {th }}$ centuries]. Moscow; Leningrad, Nauka Publ., I964. 439 p. (In Russ.)

Elistratova A.A. Klassik angliiskogo realizma [Classic of English realism]. Khudozhestvennaia literature, I935, no Io, pp. 52-60. (In Russ.) Elistratova A.A. [Preambula k primechaniiam] [Preface to the commentary]. Stern L. Zhizn' i mneniia Tristrama Shendi, dzhentl'mena. Sentimental'noe puteshestvie po Frantsii $i$ Italii [Sterne L. The life and opinions of Tristram Shandy, Gentleman; A sentimental journey through France and Italy], trans. Moscow, Khudozh. lit. Publ., I968, pp. 655-656. (In Russ.)

8 Kaganovich B.S. A.A. Smirnov i russkie perevody Shekspira I930-kh godov [A.A. Smirnov and Russian translations of Shakespeare of the I930s]. Laurea Lorae: Sbornik pamiati Larisy Georgievny Stepanovoi [Laurea Lorae. Collection in memory of Larissa Georgievna Stepanova]. St. Petersburg, Nestor-Istoriia Publ. 20II, pp. 704-727. (In Russ.) Kashkin I.A. Mister Pikvik i drugie (Dikkens v izdanii «Academia») [Mister Pickwick (Dickens published by “Academia”)]. Literaturnyi kritik, I936, no 5, pp. 212-228. (In Russ.)

Kroche B. Estetika kak nauka o vyrazhenii i kak obshchaia lingvistika. [Aesthetics as a study of representation and as general linguistics], trans. V. [B.] Iakovenko. Moscow, Izd. M. i S. Sabashnikovykh Publ., I920. Part I: Theory. I70 p. (In Russ.) Bagrovoe svetilo: Stikhi zarubezhnykh poetov v perevode Mikhaila Lozinskogo [Scarlet star. Poems of foreign poets translated by Mikhail Lozinsky], ed., comments and intro E. Etkind. Moscow, Progress Publ., I974. 216 p. (In Russ.) Malikova M.E. O perevodchike Adriane Antonoviche Frankovskom po materialam ego arkhiva [About translator Adrian Antonovich Frankovsky on the materials from his archive]. Ezhegodnik Rukopisnogo otdela Pushkinskogo Doma na 2or6 god [Year-book of the Pushkin House Manuscript Division]. St. Petersburg, Dmitrii Bulanin Publ., 20I7, pp. 37-IOO. (In Russ.)

Mirskii D.P. Robinzon Kruzo [Robinson Crusoe]. Defo D. Robinzon Kruzo. T. I [Defoe D. Robinson Crusoe], trans. M.A. Shishmareva i Z.N. Zhuravskaya, 
ed. A.A. Frankovsky. Moscow; Leningrad, Academia Publ., I935, pp. VII-XVI. (In Russ.)

24 Popova I.L. Kniga M.M. Bakhtina o Rable v kontekste idei shkoly Fosslera (k postanovke problemy) [M.M. Bakhtin book on Rabelais in the context of the ideas of Vossler school]. Novyi filologicheskii vestnik, 2005, no I. Available at: http://cyberleninka.ru/ article/n/kniga-m-m-bahtina-o-rable-v-kontekste-idey-shkoly-fosslera-k-postanovke-problemy (Accessed or April 20I7). (In Russ.)

25 Potebnia A.A. Estetika i poetika [Aesthetics and poetics]. Moscow, Iskusstvo Publ., I976. 6I4 p. (In Russ.)

26 Prust M. Sobranie sochinenii [Collected works], trans. A. A. Frankovskogo. Leningrad, Gosudarstvennoe izdatel'stvo "Khudozhestvennaia literature” Publ., I936. Vol. 3: $\mathrm{V}$ poiskakh za utrachennym vremenem. Germant [A la recherché de temps perdue. Le Côté de Guermantes]. 7Io p. (In Russ.)

27 Pushkin A.S. O predislovii g-na Lemonte k perevodu basen I.A. Krylova [On the introduction of Mr. Lemonte to the translation of I.A. Krylov's fables]. Pushkin A.S. Sobranie sochinenii: $v$ Io t. [Works: in Io vol.]. Moscow, GIKhL Publ., I962, vol. 6, pp. II-I5. (In Russ.)

28 Pushkin A.S. Pis'mo P.A. Viazemskomu, I3 iiulia I825 g. [A Letter to P.A. Vyazemsky, July I3, I825]. Pushkin A.S. Sobranie sochinenii: v Io t. [Works: in Io vol.]. Moscow, GIKhL Publ., I962, vol. 9, pp. I66-I67. (In Russ.)

29 Smirnov A.A. Metodika literaturnogo perevoda [Method of literary translation]. [Alekseev M.P., Smirnov A.A.] Perevod [Translation]. Literaturnaia entsiklopediia [Literary encyclopedia]. Moscow, OGIZ RSFSR, Sovetskaia entsiklopediia Publ., I934. Vol. 8. Available at: http://feb-web.ru/feb/litenc/encyclop/ (Accessed or April 20I7). (In Russ.)

30 Smirnov A.A. O zadachakh i sredstvakh khudozhestvennogo perevoda [On the tasks and means of literary translation]. Literaturnaia gazeta, Jan. IO, I936, no 2 (565), p. 2. (In Russ.)

3I Smirnov A.A. Pis'ma k Sone Delone [Letters to Sonia Delone]. Moscow, Novoe literaturnoe obozrenie, 20II. 5I9 p. (In Russ.)

32 Spasskii Iu. Istoriia Toma Dzhonsa [The story of Tom Jones]. Literaturnoe obozrenie, I936, no 5, pp. 33-36. (In Russ.)

33 Storitsyn P. Reabilitirovannyi Stern [Sterne rehabilitated]. Literaturnyi sovremennik, I940, no I2, pp. I48-I52. (In Russ.)

34 Takho-Godi A.A. Zhizn' i sud'ba: Vospominaniia [Life and destiny: Memoir]. Moscow, Molodaia gvardiia Publ., 2009. 69I p. (In Russ.)

35 Fedorov A.V. O khudozhestvennom perevode [On literary translation]. Leningrad, Goslitizdat Publ, I94I. 260 p. (In Russ.)

36 Fielding H.G. Istoriia prikliuchenii Dzhozefa Endrusa i ego druga Abraama Adamsa... [The history of the adventures of Joseph Andrews and of his friend Mr. Abraham Adams...], trans. N. Vol'pin, ed. M.F. Lorie. Moscow, GIKhL Publ., I949. 396 p. (In Russ.) 
37 Finkel' O. Teoriia i praktika perekladu [Theory and practice of translation]. Khar'kiv, 1929. Qtd in: Oleksandr Finkel' - zabutii teoretik ukraïn'kogo perekladoznavstva: Zbirka vibranikh prats' [Alexander Finkel - forgotten theorist of Ukranian translation studies. Collection of selected works], ed. L.M. Chernovatogo and V.I. Karabana. Vinnytsia, Nova kniga Publ., 2007, pp. 49-I82. (In Ukrainian)

38 Finkel' A.M. O nekotorykh voprosakh teorii perevoda [On some questions in the theory of translation]. Nauchnye zapiski Khar'kovskogo gosudarstvennogo Instituta inostrannykh iazykov [Academic notes of the Kharkov State Institute of Foreign Languages], I939, vol. I, pp. 59-82. Qtd. in: Oleksandr Finkel' - zabutii teoretik ukraïns'kogo perekladoznavstva: Zbirka vibranikh prats' [Alexander Finkel - forgotten theorist of Ukranian translation studies. Collection of selected works], ed. L.M. Chernovatogo and V.I. Karabana. Vinnytsia, Nova kniga Publ., 2007, pp. 227-258. (In Russ.)

39 Frankovskii A.A. [Predislovie k perevodu F.K. Sologubom romana A. de Ren'e "Dvazhdy liubimaia”] [Introduction to F.K. Sologub's translation of H. de Regnier's novel $L a$ Double Maitresse]. Ren'e A. de. Sobr. soch. [Collected writings]. Leningrad, Academia Publ., I926. Vol. 2. (In Russ.)

40 Chekalov I.I. Perevody "Gamleta” M. Lozinskim, A. Radlovoi i B. Pasternakom v otsenke sovetskoi kritiki 30-kh godov [Translations of "Hamlet" by M. Lozinsky, A. Radlova and B. Pasternak in evaluation of Soviet critics of the I930s]. Shekspirovskie chteniia 1990 [Shakespeare Readings I990]. Moscow, Nauka Publ., I990, pp. I83-200. (In Russ.)

4I Chukovskii K.I. Perevody prozaicheskie [Translations of prose]. Printsipy khudozhestvennogo perevoda. Stat'i K. Chukovskogo i N. Gumileva [Principles of artistic translation: essays by K. Chukovsky and N. Gumilev]. Petersburg, Vsemirnaia literature Publ., I9I9, pp. 7-24. (In Russ.)

42 Chukovskii K.I. Iskusstvo perevoda [The art of translation]. Moscow; Leningrad, Academia Publ., I936. 222 p. (In Russ.)

43 Chukovskii K. Nevidimki [The unseen]. Literaturnaia gazeta, Dec. 3I, I940, no 63, p. 5. (In Russ.)

44 Chukovskii K.I. Vysokoe iskusstvo [Sublime art]. Chukovskii K.I. Sobr. soch.: v I5t. [Collected works: in I5 vols.]. Moscow, Terra-Knizhnyi klub Publ., 200I. Vol. 3. Available at: https://www.litmir.me/br/?b=I03556 (Accessed or April 20I7). (In Russ.)

45 Shklovskii V.B. «Evgenii Onegin» (Pushkin i Stern) [“Eugene Onegine” (Pushkin and Sterne)]. Ocherki po poetike Pushkina [Essays on the poetics of Pushkin]. Berlin, Epokha Publ., I923, pp. I99-220. Available at: http://lib.pushkinskijdom.ru/LinkClick.aspx?fileticket=RxcFSRL_amk\%3D\&tabid=I0396 (Accessed I April 20I7). (In Russ.)

46 Gustav Shpet: filosof v kul'ture: dokumenty i pis'ma [Gustav Shpet: philosopher in culture: documents and letters], ed.-comp. T.G. Shchedrina. Moscow, ROSSPEN Publ., 2012. 675 p. (In Russ.). 
Gustav Shpet i shekspirovskii krug. Pis'ma, dokumenty, perevody [Gustav Shpet and the Shakespeare circle. Letters, documents, translations], ed., intro., comments, archeological reconstruction T.G. Shchedrina. Moscow, St. Petersburg, Petroglif Publ., 20I3. 760 p. (In Russ.)

48 Eikhenbaum B.M. [Retsenziia] Stern L. Sentimental'noe puteshestvie. Vospominaniia. Pis’ma. Dnevnik. Moskva, I940 [Rev. of: L. Sterne. Sentimental Journey. Memoir. Letters. Journal.], transl. by A. Frankovsky. Moscow, I940. Zvezda, I940, no 8-9, pp. 315-3I6 (In Russ.)

49 The Works and Life of Walter Bagehot: in Io vols., ed. by Mrs. Russell Barrington. Vol. IV. Political and Literary Essays. Bombay, Calcutta, \& Madras, Longmans, Green \& Co, I9I5. Available at: http://oll.libertyfund.org/titles/bagehot-the-works-and-lifeof-walter-bagehot-vol-4-political-literary-literary-essays (Accessed or April 20I7). (In English)

50 Baker E.A. The History of the English Novel: in Io vols. Vol. IV. Intellectual realism: from Richardson to Sterne. London, H.F.\& G. Witherby, I936. Available at: https://archive. org/stream/historyoftheengloı2090mbp/historyoftheengloi209ombp_djvu.txt (Accessed or April 20I7). (In English)

5I Clark Katerina, Holquist Mikhael. Mikhail Bakhtin. Cambridge, Mass., London, Belknap Press of Harvard University Press, I984. 398 p. (In English)

52 Gosse Edmund. The Life of William Congreve. London, Walter Scott, I888. Available at: https://archive.org/details/lifeofwilliamconoogossrich (Accessed or April 20I7). (In English)

53 Hazlitt William. Lectures on the English Comic Writers. New York, Wiley \& Putnam, I845. Available at: https://books.google.ru/books?id=7IpFg_liEYUC\&printsec=frontcover\&hl=ru\#v=onepage\&q\&f=false (Accessed or April 20I7). (In English)

54 Johnson Samuel. A Dictionary of the English language: in 2 vols. The $6^{\text {th }} \mathrm{ed}$. Vol. II. London, Printed for J.F. and C. Rivington at al., I785. Available at: https://archive.org/ stream/dictionaryofenglo2johnuoft\#page/n3/mode/2up (Accessed or April 20I7). (In English)

55 Lynch Kathleen M. The social mode of Restoration comedy. New York and London, MacMillan, I926. 242 p. (In English)

56 Steiner George. The Hermeneutic motion. The Translation Studies Reader, ed. by Lawrence Venuti. London and New York, Routledge, 2000, pp. I86-I9I (first published: Steiner George. After Babel: Aspects of language and Translation. Oxford, Oxford University Press, 1975, pp. 296-303). (In English)

57 Venuti Lawrence. [I900s-I930s. Introduction]. The Translation Studies Reader, ed. by Lawrence Venuti. London and New York, Routledge, 2000, pp. II-I4. (In English)

58 Witt Susanna. Byron's “Don Juan” in Russia and the "Soviet school of Translation”. Translation and Interpreting Studies, 20I6, vol. II, no I, pp. 23-4I. (In English) 
УДК 82І.ІІ2.2

ББК $83.3(4$ Гем $) 53$
ЛИТЕРАТУРНЫЙ ПРОЦЕСС В ГЕРМАНИИ НА РУБЕЖЕ XIX-XX ВВ.:

ВЗАИМОДЕЙСТВИЕ ХУДОЖЕСТВЕННЫХ ТЕЧЕНИЙ

(C) 2017 г. Т.В. Кудрявцева

Институт мировой литературы

им. А.М. Горького Российской академии наук, Москва, Россия

Дата поступления статьи: 23 апреля 2017 г.

Дата публикации: 25 сентября 2017 г.

DOI: IO.22455/2500-4247-20I7-2-3-46-73

Статья создана при поддержке гранта РФФИ № I7-04-00о73

«Литературный процесс первой половины XX в. в Европе и Америке:

направления и школы»

Аннотация: В статье рассматривается динамика взаимодействия художественных течений (направлений), определявших специфику литературного пространства Германии на рубеже XIX-XX вв. Сравнительный анализ осуществляется в рамках историко-контекстуального подхода, особое внимание уделяется созданию панорамной картины литературного процесса, складывавшейся в условиях перестройки художественной системы под влиянием мировоззренческих и эстетических идей модернизма. Вскрываются сложные механизмы взаимодействия различных художественных школ и течений, прослеживается трансформация старых и отмечается зарождение новых жанрово-стилевых образований на фоне перманентно-турбулентных типологических и этимологических сдвигов переходной эпохи.

Ключевые слова: немецкая литература, литературный процесс, художественная общность, модернизм, стиль, трансформация.

Информация об авторе: Тамара Викторовна Кудрявцева - доктор филологических наук, ведущий научный сотрудник, Институт мировой литературы им. А.М. Горького Российской академии наук, ул. Поварская, д. 25 а, І2Іо69 Москва, Россия.

E-mail: muchina@yandex.ru 


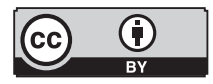

This is an open access article distributed under the Creative Commons Attribution 4.0 International (CC BY 4.0)

\section{LITERARY PROCESS IN GERMANY}

AT THE TURN

OF THE $19^{\text {th }}$ and $20^{\text {th }}$ CENTURIES:

INTERACTION OF LITERARY TRENDS

(C) 20I7. T.V. Kudryavtseva

A.M. Gorky Institute of World Literature

of the Russian Academy of Sciences, Moscow, Russia

Received: April 23, 2017

Date of publication: September 25, 2017

Acknowledgements: The essay is part of the research "Literary Process of the First Half of the $2 \mathrm{O}^{\text {th }}$ Century in Europe and United States" supported by Russian Foundation for Basic Research (RFBR), no I7-04-00073.

Abstract: The article discusses dynamic interaction among artistic communities (trends, movements, etc.) exploring the specificity of literary space in Germany at the turn of the $\mathrm{I}^{\text {th }}$ and $2 \mathrm{O}^{\text {th }}$ centuries. This is a comparative study that develops a historical and contextual approach and pays special attention to the panoramic overview of the literary process shaped by philosophical and aesthetic ideas of modernism. The essay exposes complex mechanisms of interaction of various artistic schools and trends, and traces transformation of the old and emergence of the new generic and stylistic, constructs against the background of permanently turbulent, typological, and etymological shifts of the transition era.

Keywords: German literature, modernism, trend, style, transformation.

Information about the author: Tamara V. Kudryavtseva, DSc in Philology, Leading Research Fellow, A.M. Gorky Institute of World Literature of the Russian Academy of Sciences, Povarskaya 25 a, I21069 Moscow, Russia.

E-mail: muchina@yandex.ru 
Главная особенность немецкого литературного процесса на рубеже XIX$\mathrm{XX}$ вв. - разновекторное взаимодействие (отталкивание, отрицание, заимствование, влияние) компонентов художественной системы, проявившее себя в чрезвычайной неоднородности ее структуры, в причудливом сочетании художественно-эстетических новшеств с переосмысленным опытом прошлых эпох. Сосуществование множества течений, которые на какое-то время оформляются в мейнстрим, ярче проявляя себя в том или ином эстетическом, стилистическом ключе, индивидуальном авторском стиле, элементы которого могут заимствоваться разными школами, дало повод современным исследователям использовать для характеристики искусства тех лет понятия «стилевой плюрализм» [5, s. 83] или «конкуренция стилей» [58, s. 23I]. Моделирование литературно-художественного пространства той эпохи позволяет вскрыть не только причины столь мозаичной картины, но и обозначить динамику литературного процесса.

Произведения, определявшие картину литературного процесса в I870-е - начале г880-х гг. с его культом национального величия, верноподданнических идеалов, повышенным интересом к искусству прошлых времен стали мишенью для критики со стороны литераторов нового поколения, «самых молодых» (die Jüngsten), как они себя называли. «Самые молодые», следуя завету Г. Гейне, призывали распрощаться с романтическим прошлым, выдвинув в качестве главного закона современной литературы ее неразрывную связь с жизнью.

В соответствии с одной из задач движения («вернуть немецкой литературе былое величие») [26, s. 22], выдвинутой Г. Гартом еще в I878 г., 
«самые молодые» вначале сохраняют верность традиции. В программных документах прослеживается идея о связи новой литературы с национальным самосознанием, с «духом вновь пробудившейся нации» [I8, s. III]. Не случайно поэтому, что мироощущение молодых писателей во многом определяют воззрения Гегеля и Шлегеля, а эстетические взгляды в полной мере сформированы под влиянием наследия Лессинга, Гердера и молодого Гёте [37, s. 8]. Примечателен вывод известного литературного критика того времени Самуэля Люблинского, связывавшего новое направление с романтизмом: занятые поисками новых идеалов «самые молодые» дополняют романтическое «мистифицированное понятие свободы» современным «мистифицированным понятием развития» [37, s. 8].

«Современность», сопрягаемая молодыми литераторами с признаками актуальности и злободневности, органично включает в свою атрибуцию и семантику «реалистичности». Так, братья Гарты, потребовав в г883 г. от литературы «большого идеально-реалистического содержания» [28, s. 20], по сути, демонстрируют приверженность проблематике и эстетике немецкого «бюргерского», или по-другому «идеалистического», «поэтического» реализма XIX в., в художественной системе которого присутствовал сильно выраженный элемент вымысла, идеализации, эстетизма.

Примечательно и то, что термин «натурализм», закрепившийся в Германии на рубеже XIX-XX вв. для обозначения начальной фазы классического модерна, первыми стали использовать литературоведы и литературные критики (ср.: [13; 35; 55]), а не сами творцы новой литературы. В терминах «реализма, а не натурализма» (ср.: [II]) определяет новое искусство в труде «Естественнонаучные основы поэзии. Пролегомена к реалистической эстетике» один из теоретиков нового направления Вильгельм Бёльше. В «Двенадцати статьях о реализме» (г889) (ср.: [4]) находит выражение и кредо участника движения Конрада Альберти. Лишь в г890-е гг., когда само движение идет на спад, термин «реализм», по сути получивший наряду с «модерном» статус самоидентификатора, отражавшего один из базисных компонентов художественного сознания «самых молодых», постепенно вытесняется конкурировавшим с ним «натурализмом». Как правило, с последним в Германии связывались негативные коннотации. Отчасти сказывалась близость программных установок набиравшего силу движения к одноименному художественному течению в чуждой национальным герман- 
ским интересам Франции. Отечественная традиция естественным образом входит в противоречие с принципами научности, которые провозгласил французский натурализм. Для братьев Гарт «правда» Золя оказывается немыслимой без «пропитанной поэзией» правды Гёте. Именно Гёте надлежало стать посредником «между земным реализмом и высоким идеализмом, между космополитическим гуманизмом и самодостаточным национализмом, между мужественным интеллектуализмом и глубоко проникновенной чувствительностью». А литература, «черпая импульсы из современной жизни, получала возможность представить субъективно осмысленную первозданную природу в виде просветленного идеала натуралистичности», с которой могла поспорить «лишь сама природа» [27, s. 44].

В I889 г. театральный критик Отто Брам провозглашает главной целью искусства «правду, правду и ничего, кроме правды». Однако речь идет не об «объективной правде», а о правде «индивидуальной», которая, «свободно черпается и высказывается на основе внутреннего убеждения: о правде независимого духа» [ı2, s. I]. Другое дело, что этот «независимый дух» оказался у самих натуралистов сломлен тяжестью внешних обстоятельств. Несмотря на приверженность будущему, произведениям был присущ «некий налет мировой скорби», которой объята «больная душа» [22, s. 387] писателей.

Самым ярким примером, подводящим своеобразную черту под натуралистической литературой «упадка и распада» доброго бюргерского порядка, стал первый роман Томаса Манна «Будденброки. История гибели одного семейства» (I90I). Эпический показ гибели прежнего социального уклада уже целиком соотносится с декадентским мироощущением, овладевшим сознанием личности и общества в г890-е гг., когда само «слово “декаданс” стало, по выражению Т. Манна, неотъемлемым атрибутом «интеллектуального жаргона эпохи» [43, s. 3II]. Сам писатель выделял в качестве одной из характерных черт, присущих его творчеству, показ неразрешимой дилеммы, гнездящейся в сознании: приверженность «бюргерской традиции», желание ее сохранить и осознание неотвратимого разрушения, «дегенерации» биологической и духовной. Наделенные автобиографическими чертами герои Манна олицетворяют это переходное состояние времени, пропитанного настроениями растерянности, вызванной утратой привычных ценностей и неопределенностью перспектив в жизни общества 
и индивида. В условиях, когда надежды на всепоглощающую витальность оборачивались химерой, противопоставить пессимизму можно было лишь собственный интеллект, способность к рефлексии и саморефлексии (ср., в частности: [33, s. I39]).

Именно в русле подобных умонастроений началась в Германии жизнь постнатуралистических течений fin de sciècle. По сути, в их основе лежит соотносимое с ценностной шкалой философской антропологической парадигмы обостренное внимание к личностной стороне субъектно-объектных отношений. Не случайно поэтому, что наряду с Ницше, произведения которого стали настольными книгами всякого уважающего себя интеллектуала, безусловной принадлежностью искусства рубежа веков, как, впрочем, и всего XX в., воспринимается постижение тайн подсознания посредством методики психоанализа, разработанной 3. Фрейдом. Его идеи, по словам T. Манна, буквально «витали в воздухе» (цит. по: [6, s. 33I]), а сами писатели своими произведениями оспаривали у знаменитого психоаналитика пальму первенства.

В условиях крайнего индивидуализма личная свобода становится мерилом всех ценностей, как об этом говорит герой Ф. Ведекинда Карл Гетман из пьесы «Гидалла или Быть и Иметь» (I904): «С сегодняшнего дня я преследую лишь одну цель, сохранить собственную свободу! Мою ничем не ограниченную свободу! Мою неприкосновенную свободу!» [64, s. 658]. На смену порывам социального сострадания униженным и оскорбленным в литературе натурализма приходит упоение возведенной в культ собственной личностью, воспринимающей себя в отрыве от общества. В ситуации, когда провозглашается анархистское верховенство «собственного блага» над «благом всеобщим» (Б. Вилле) [65, s. 388], происходит «атомизация» ${ }^{\perp}$ общества, порождающая тотальное отчуждение, «пафос дистанции» (Ф. Ницше) [50, s. 727], а вместе с ним - одиночество. Собственная личность воспринимается, с одной стороны, как нечто самодостаточное, не нуждающееся в чужой оценке и авторитете. С другой стороны, это непонятное, часто враждебное, «другое» не «я», попытки осознать которое оборачиваются наблюдением за тенью à priori недостижимого и неясного идеала.

I Развитие социологических аспектов теории атомизации современного общества принадлежало среди прочих (Ф. Тённис, М. Вебер и др.) неокантианцу Г. Зиммелю. См., в частности: [6I, s. 377]. 
Отсюда проистекает резкая смена в настроениях «самых молодых»: их анархо-социалистические порывы уступают место явно выраженной аполитичности и внутренней рефлексии.

Оставаясь в плане философском в границах позитивистского мировоззрения, натурализм в целом сохранил признаки традиционного художественного мышления, не перешагнув границ миметического искусства. Он отвечал требованиям нового вектора развития, модернизма, ориентированного на разрыв с традицией, преимущественно на декларативном уровне. К заслугам натуралистов можно отнести осознание того, что прежние способы художественного освоения действительности себя исчерпали. Новое творческое сознание столкнулось с необходимостью поиска новых поэтических средств, адекватных духу времени, меняющимся представлениям о человеке и окружающем его универсуме. Это не в последнюю очередь обусловлено и развитием самого концепта «современность» в тот период. В нем, как указывает современный компаративист Х.У. Гумбрехт, актуализируется звено, в котором соотносятся не прошлое и настоящее, а настоящее и будущее, вырастающее из этого настоящего [23, s. I2I]. Другими словами, речь идет о слиянии модернистского и авангардистского ракурсов в художественном видении мира. Не случайно писателю современности вменяется в обязанность «по-боевому прокладывать пути будущему» [67, s. 8Iо], т. е. новому. В г89г г. журналист Фридрих Михаэль Фельс в своем докладе «Die Moderne» по случаю открытия театра «Свободная сцена» определяет специфику времени как «рубеж двух миров» и усматривает предначертанную им роль для современников как «подготовку грядущего величия» (цит. по: [69, s. 73]), о котором те еще не имеют ни малейшего представления.

В качестве разновекторной реакции на реализм и натурализм в немецкой литературной историографии рассматриваются импрессионизм (Impressionismus, I890-I9Iо), неоромантизм (Neuromantik, I890-I9I4/I9I5, в других источниках І920) (см.: [66, s. 559]), югендстиль (Jugendstil, I895I905), символизм (Symbolismus, I890-I9I4), областническая (почвенническая) литература (Heimatdichtung, г890-І933) и неоклассицизм (Neuklassik, Neuklassizismus, I90о-I920). Хронологически они вызревали как продолжение или преодоление прежней традиции почти одновременно с натурализмом и реализмом, сообразуясь с мироощущением и эстетическими пристрастиями представителей культурно-художественной элиты. 
Импрессионизм в искусстве как стилевое направление (Stilrichtung), соположенное с категориями пассивности, созерцательности и впечатлительности, проявляет себя в диахронической перспективе в разных эстетических системах. Философской основой немецкого импрессионизма на рубеже XIX-XX вв. послужили главным образом идеи Эрнста Маха и Генриха Риккерта об имманентности бытия сознанию.

Г. Бар, испытавший сильное влияние творчества братьев Гонкуров, заявляя о преодолении натурализма, а точнее, о расширении его границ («Критика модерна», І89о; «Новая психология», І890; «Преодоление натурализма», I89I и др.), связывает импрессионизм прежде всего с обновлением психологического метода и распространяет «правду жизни» натуралистов на внутренний мир человека («правда чувства»). О том же, в частности, говорили и представители немецкого натурализма, включавшие в содержание понятий «природа», «действительность» не только мир эмпирически воспринимаемых предметов и явлений, но и сферу сознания, психики человека. Не случайно многие исследователи того времени, часто употребляли термины «натурализм» и «импрессионизм» в качестве синонимов (см. подробнее: [59, s. 72; 8, s. 45]). Тем не менее, как отмечает современный исследователь венского модерна А.И. Жеребин, есть существенное отличие «психологического анализа субъективных ощущений» Бара от «психологизма натуралистической прозы» в берлинском модерне. Для последнего «мир внутренний есть лишь маленькая производная часть большого чувственно-предметного мира, всецело подчиненная его законам. $<. .>$ для Бара же <...> не душа вписана в большой чувственно-материальный мир, а этот мир вписан в необъятное пространство души и может быть в любую минуту затоплен иррациональной стихией космической жизни» [I, s. 727].

Психологизм раннего немецкого модернизма в его импрессионистическом преломлении - несомненная дань идеям «философии жизни» и идеографической психологии В. Дильтея («Введение в науку о духе», I883), ядро которых составляет «переживание» как таковое («Переживание и творчество», І906). От них, а в свою очередь от основателя психологии как отрасли научного знания Вильгельма Вундта, проистекает убеждение, что лишь субъективный опыт дает возможность приблизиться к предмету знания. Применительно к искусству это означало, что душевные состояния 
индивида становятся главным объектом творчества. Внешние события и явления жизни уже не провоцируют художника на их художественное воссоздание (моделирование), а лишь исполняют роль генератора переживаемого мгновения. Таким образом, отпадает необходимость в организации текста по правилам традиционного повествования, жанрово-сюжетная логика которого обусловлена линейными причинно-следственными отношениями. На первый план выступает ассоциативный принцип композиционных связей, в основе которых лежит поток сенсорных впечатлений от внешней действительности, рождающих в сознании реципиента те или иные мысли, настроения, образы. Их передача и становится в импрессионизме основным содержанием малых и крупных литературных форм.

При этом индивидуальность восприятия не ограничивается сферой чувственного. Как писал Ницше еще в I873 г., не может быть одной правды на всех. Это убеждение базируется на отрицании универсальных понятийных категорий: «Что такое истина? Подвижное море метафор, метонимий, антропоморфических образов, одним словом - сумма человеческих отношений, которые, будучи поэтически приукрашены и переосмыслены, постепенно закрепляются в народном сознании в той или иной канонической форме: эти истины - иллюзии, о происхождении которых забыли» [53, s. 3I4]. Поэтому истинно лишь то, что у каждого индивида своя правда. Так «аскет делает из добродетели нужду» [49, s. 497], а «сострадание - добродетель проститутки» [49, s. 47]. Подобное мировосприятие провоцирует и соответствующие способы художественной рефлексии, что в наиболее концентрированном виде дает о себе знать в так называемой поэзии намеков, ассоциаций, умолчаний и все большей герметизации смысла.

Многие литературоведы и литературные критики рубежа веков воспринимали импрессионизм не как оформившееся литературное направление или даже движение, но как художественный стиль, отличный от стиля натуралистического либо реалистического совокупностью эстетической программы и поэтических средств выражения. Так, Р. Хаман, следуя в русле идей Винкельмана, Гёте и современников-искусствоведов Г. Земпера («Стиль в технических и тектонических искусствах», I860-I863), А. Ригля («Вопросы стиля», І893), склонен, как несколько позже и Г. Вёльфлин («Основные понятия истории искусства», I915), О. Вальцель («Немецкая словесность после смерти Гёте», I9I3) и др., включать признаки импресси- 
онизма в стиль времени (Zeitstil), сложившийся на рубеже XIX-XX вв. Под ним понимается совокупность новых антиреалистических тенденций, которые описываются в терминах декадентства, символизма, неоромантизма, и с которыми главным образом ассоциируется искусство fin de sciècle.

Если импрессионизм во многом можно рассматривать как результат расширения сферы художественной рефлексии натурализма, то другие постнатуралистические течения строили свои программы главным образом на его отторжении. Одним из самых решительных противников модернистского вектора развития слыл Стефан Георге. Нарочито затрудненная для понимания форма огражденных от «толпы» произведений Георге была призвана стать воплощением этического кодекса поэта-служителя в храме искусства. Вливаясь в ряды декадентской литературы, отмеченной настроениями меланхолии, аристократизмом духа в понимании Ницше, немецкие символисты все более теряют связь с реальной действительностью, углубляясь в рассмотрение метафизических, апокалипсических, эзотерических и космических тем.

Элементы символистской эстетики и поэтики прослеживаются у целого ряда писателей, не принадлежавших к кругу Георге. Влияние символизма испытали на себе мастер гротеска Генрих Манн («Шаг к воротам», "Ein Gang vors Tor," I905) и приверженец образно-архетипического мышления Г. Гессе («Демиан», “Demian,” I9I9), «реалистический символист» или «символист-реалист» [25, s. I4] Т. Манн. Поздние романы известного автора тривиальных приключенческих романов Карла Мая отличаются религиозно-мистической пацифистской направленностью и пронизаны философскими аллегориями о добре и зле: «И мир на земле» (1904), «Ардистан и Джиннистан» (1909), «Виннету» (І9Іо) ${ }^{2}$.

Мимо символизма не прошли и «самые молодые» Р. Демель («Двое», І903), Г. Гауптман («Вознесение Ганнеле», І893; «Затонувший колокол», I896).

С. Люблинский рассматривает символ как вневременную эстетическую категорию на примере творчества натуралистов, вводя термин «натуралистический символ» (das naturalistische Symbol) для излюбленных содержательных топосов, своеобразных фетишей натурализма, в частности,

2 Любопытной представляется связь стилистики произведений Мая с сюрреализмом, которую проводят современные исследователи. См., в частности: [зо, s. 249]. 
таких как пьянство (Trunksucht) [37, s. I4]. С помощью этого «искусственного приема мир забывает о том, что общество - не “бордель”, а мир - не “кабак”, и в нем живут не только пропойцы» [37, s. I6]. Другими словами, как об этом впоследствии напишет 3. Фрейд, человек «утрачивает чувство реальности» [20, s. 355].

Достаточно вольно трактует символизм и Г. Манн. Причислив к этому направлению свое стихотворение «Рука» (I892), писатель характеризует его в терминах «нового, самого “современного” тона» [20, s. 232]. Под последним подразумевается продолжение психологизма француза П. Бурже, а именно его метода «хладнокровной дефибрации души», продемонстрированного в романе «Ученик» (I889). По мнению Г. Манна, символисты превосходили Бурже тем, что их интересовали «нервы не только жертвы (персонажа. - Т.К.), но и наблюдателя (читателя. - Т.К.)» [40, s. 232].

Если принять во внимание точку зрения немецких ученых, что европейский символизм в романских литературах явил себя «запоздавшей и отчасти насильственной реализацией немецкой романтической традиции» [66, s. 8о2; 46, s. 45I], то логично рассматривать творчество представителей круга Георге в границах неоромантизма, ставшего в свою очередь, по словам $\Phi$. Меринга, не без оснований полагавшего неоромантизм «законным детищем натурализма» [44, s. 232], неизбежной реакцией на бессилие последнего показать альтернативу существующей реальности [44, s. 229].

Г. фон Гофмансталь, рецензировавший «Современный альманах муз» за І893 г., охарактеризованный издателем, О.Ю. Бирбаумом, как репрезентативный срез «всех направлений современного искусства» [9, s. II] $]^{3}$, определяет основное настроение содержавшихся в нем произведений как проистекавшую из разочарования «тоску по романтическому бегству из мира явных вещей», сопровождавшуюся «причудливыми хитросплетениями фантазии, обращенной к далекому и чудесному» [3I, s. II3]. Любопытно отметить, что Г. Бар описывает «новый символизм», почти дословно предвосхищая мысли Гофмансталя: «Лишь бы прочь, любой ценой прочь из явной действительности» [7, s. 576].

Примечательно, что Г. Гауптман предпочитал относить свое творче-

3 В числе 58 авторов упомянутого «Современного альманаха муз» были известный сатирик и публицист Оскар Паницца, фантаст Пауль Шеербарт, а также К. Альберти, В. Арент, Г. Манн, М. Даутендей и др. 
ство после І893 г. (год постановки «Ткачей») также в разряд неоромантического искусства (см., в частности: [29, s. 429]). Следует, однако, отметить, что натуралистические черты не исчезли полностью из произведений писателя, проявляя себя как в их проблематике, так и в стилистике. В качестве примера могут служить, в частности, его историко-революционная драма «Флориан Гейер» (I896) и социальная пьеса, написанная на силезском диалекте, «Извозчик Геншель» (1898).

Неоромантизм можно рассматривать поэтому как обобщенное название для разрозненных и более или менее структурно оформленных художественных тенденций, характеризующих fin de siècle. Главным проявлением такой литературы служит уход от повседневной жизни, обращение к истории, чудесному, таинственному, магическому, экзотическому, а вместе с тем и метафизическому. Не случайно в своей критике творчества Вагнера, оцениваемого уже в 1876 г. как проявление декадентства негерманского свойства [52, s. I05I, I054], Ницше подчеркивает его связь с французскими поздними романтиками, с их пристрастием к эротике, психическим расстройствам, эстетизму возвышенного свойства [50, s. 724].

Нельзя, однако, обойти вниманием и такую черту неоромантизма, как разрушение иллюзий жестокой правдой жизни, которая беспощадно врывается в неоромантический контекст (например, детская идиллия): Г. Гессе («Под колесами», I906), Ф. Ведекинд («Пробуждение весны», I891), Э. Штраус («Друг Хайн», І902) и др.

В I896 г. с началом издания мюнхенского литературно-художественного еженедельника «Югенд» («молодежь», «молодость», «юность») в немецкий культурный обиход входит понятие «югендстиль», ставшее одним из главных маркеров немецкого искусства рубежа XIX-XX вв. У представителей югендстиля, одного из вариантов международного феномена (Arts and Crafts, Art Nouveau, Modern Style, Floreale, Stile modernista, Modernisme, Stile Liberty, Wiener Secession, Style Belge, Мир искусства и др.), как ранее у натуралистов, на передний план выдвигается отказ от строгого следования каноническим стилям и формам. В то время как импрессионизм, утонченная форма натурализма, занят художественной обработкой «потока впечатлений» от внешнего мира, югендстиль на первый взгляд возвращает читателя в этот мир, однако, прежде подвергнув последний искусной аранжировке, соответствующей эстетическим пристрастиям художника. Заим- 
ствуя разностилевые элементы из прежних эпох (поздняя готика, рококо, романтизм), представители нового направления, в отличие от натуралистов, изображавших самые неприглядные стороны действительности, искали в природе идеал красоты, олицетворяющий земной рай.

Литературный югендстиль тесно связан с (нео)романтизмом (см., в частности: [36, s. 230-235]). С последним его сближает неприятие натуралистической эстетики, поиски идеалов в иных пространственно-временных плоскостях. Однако если для неоромантиков главным местом эскапистских устремлений было историческое прошлое и сельский пейзаж, то средоточием художественных исканий представителей югендстиля стала не лишенная элементов эпатажа (эротика, светский скандал) эстетизация биологической витальности, богемности. «Виталистичность» свойственна практически всей немецкой литературе с г880 по г9І4 гг., от реализма (Келлер, Майер) и натурализма до экспрессионизма в его первой фазе (Ведекинд, Гофмансталь) (см. подробнее: [34, s. I98-20I]). Писатели и художники словно соревнуются, присягая на верность формуле Ницше: «В сущности я люблю только жизнь» [48, s. 365]. Среди слагаемых многообразных жизненных проявлений, претендующих на роль одного из главных источников наслаждения, важное место занимает эротика. Свобода любви идентифицируется с борьбой против общественных норм и условностей.

Примечательно, что идеолог «нового человека» Ф. Ницше объясняет свое требование отказаться от традиционного понимания (прежде всего христианского) совести и морали тем, что они несут на себе печать прошлого. «Переоценка ценностей», по Ницше, предполагает преодоление декадентского упадничества и пессимизма шопенгауэровского образца, выработку новых ценностей, соответствующих идеалам жизнеутверждения «новых людей» [49, s. I6г]. Тем не менее восприятие разнообразия и многогранности жизненных проявлений не складывается у представителей югендстиля в цельный образ, а служит лишь целям отображения переживаемого мгновения, сулящего богемное забвение от обыденных забот. Один из способов такого ухода от действительности - получивший большое распространение в литературе рубежа веков мотив опьянения, экстаза. Вино, наркотики и прочие атрибуты, позволяющие снять внутренние ограничители и получить удовлетворение от пьянящего чувства свободы, прочно входят в образно-поэтический ряд литературы югендстиля. Основ- 
ная тональность этих произведений: жизнь есть сон, сродни состоянию опьянения, в котором забываются невзгоды и удары судьбы. На религиозно-философском уровне экстаз самоупоения находит выражение в увлечении пантеизмом, который, как отмечал в свое время Р. Хаман, возводится в культ (см. подробнее: [24, s. I67]), поскольку растворение в безграничном и неопределенном космосе дает, как в случае с героиней музыкальной драмы Р. Вагнера «Тристан и Изольда», ощущение «высочайшего наслаждения» [63, s. 334] собственной неуловимостью, а значит, свободой.

С неоромантизмом югендстиль роднит и поляризация настроений, характерная для так называемых маньеристских стилей. Стремление к обновлению, весенние настроения «прорыва», подхваченные затем экспрессионистами, соседствуют с индифферентностью и эсхатологическими предчувствиями, а красота всегда оказывается подвержена болезненному разрушению, как это демонстрирует «биологический декаданс» ранних произведений Т. Манна, не в последнюю очередь спровоцированный идеями М. Нордау. Тем не менее именно экспрессионизм вслед за югендстилем подвергнет уничижению лицемерие бюргерской добродетели, отдав предпочтение чувственности «эротического стиля». А то особое значение, которое придавал югендстиль форме и цвету, экстатичной религиозности в описании эротического чувства, вызвало к жизни термин «экспрессионистический югендстиль» [68, s. I35].

Неотъемлемая часть современной картины мира, создаваемой представителями югендстиля, - нарочито подчеркнутая мифологизация и символизация действительности. Не случайно творчество главного представителя символизма, С. Георге, оказывается вовлеченным в сферу этого искусства. Исследователи отмечают у Георге такой характерный атрибут югендстиля, как культ совершенного тела, пристрастие к экстравагантной флористической декоративности [Iо, s. 53-54].

Именно в югендстиле находит наиболее полное воплощение ницшеанский принцип эстетической стилизации жизни, ее конструирование посредством и по законам искусства (жизнетворчество). Тем не менее художественный мир югендстиля, несмотря на приверженность аллегориям, символам, сказочным сюжетам и пр., еще не окончательно порывает с миром реальных вещей, не погружается целиком в сферу внутренних видений и абстракций. Задача художника - сделать из произведения ис- 
кусства богемный жизненный эрзац, создающий эффект правдоподобности переживаемого мгновения. Признаками этого стиля служит прежде всего соответствующая содержательная топика, языковой орнаментализм, преимущественное обращение к миру растений как чистой материи, незамутненной зоологическими, стадными инстинктами. А это в свою очередь сближает югендстиль как с буколикой барокко, так и с ранним романтизмом (Ф.О. Рунге).

Уже в І890 г. в противовес модернистам в лице натуралистов, импрессионистов и представителей югендстиля, а также эстетизму и герметизму произведений символистов заявляют о себе писатели-регионалисты. Областническая литература возникла в лоне идеологически окрашенного движения «родное искусство», или «искусство родного края» (Heimatkunst). Оно было вызвано к жизни неприятием негативных последствий индустриализации и урбанизации, одновременно и в поддержку так называемого аграрного движения (Agrarbewegung).

В художественно-стилистическом плане областническая литература продолжает традиции деревенского романа (Bauernroman) и деревенской повести (Dorfgeschichte), получивших большое распространение в бюргерском реализме XIX в.

Весьма примечательно определение М.Г. Конрадом реализма своего времени, данное им еще в I885 г. по отношению к роману, как «современного» и «отечественного» (“moderner vaterländischer Roman”) [14, s. 832-836]. Если под «современностью» литературы Конрад наряду с субъективным взглядом писателя и актуальностью материала понимает вовлеченность литературы в общественно-политическую жизнь, то атрибуция «отечественный» включает семантические признаки националистичности и близости к родной земле [I7, s. 553].

Однако в рамках движения «родное искусство» реальная действительность все чаще отходит на задний план, вытесняясь односторонней мифоидеализацией внеисторической деревенской жизни. В этом смысле областническая литература смыкается с эскапистскими устремлениями неороманитиков и югендстилевцев.

Местечковая идеология, постепенно переросшая в национал-шовинистическую, в полной мере проявит себя спустя десятилетия, найдя свое полное завершение в литературе «крови и почвы» (Blut-und Boden), широ- 
ко востребованной идеологами нацизма. Не всем известно, что это устойчивое словосочетание задолго до О. Шпенглера, которому приписывают авторство неологизма («Закат Европы», І9І8-1922), употребил М.Г. Конрад: «В тайне крови и почвы кроется тайна искусства» [I6, s. 4]. Поэтому «немецкий роман, если он претендует на что-то толковое, должен всеми порами испускать немецкий дух» [I4, s. 833]. В качестве примера писателя, отвечающего этим требованиям, Конрад приводит реалиста Т. Фонтане, который, по его мнению, «не парит в классических небесах и космополитическом тумане, а прочно укоренен в родной земле и пропитан ее духом» [I5, s. 4I8].

Примечательно, что если в начале творческого пути поселившийся в «башне из слоновой кости» С. Георге не приемлет никаких дискуссий на мировоззренческие темы, то с г9Іо-х гг, а особенно после начала Первой мировой войны, утонченный аристократизм мистико-мифологического свойства уступает место активному мессианству. Так, в предисловии к изданию поэтического сборника «Звезда Союза» (I9I4) он повелевает поэту, призванному посредством воли к художественному творчеству, формировать в себе и в других нового человека, «вернуться из далекого далека к животрепещущим проблемам реальной жизни и, беря на вооружение народный язык, обратить свои взоры к молодым на полях сражений» [2I, s. I]. Суть поэзии для него отныне - выражать «глубины народной души» [2I, s. I]. Георге отводит себе роль народного пророка, возвещающего, вслед за Вагнером, возрождение германского духа, подвергающего критике несостоятельность позитивистского научного знания, пагубность капиталистической модернизации и либерализации. Не случайно поэта называют одним из духовных отцов движения «консервативной революции», которое по отношению к литературе выражается, прежде всего, в попытках сформировать сознание личности, основанное на национальных традиционных ценностях.

После І90о г. прямой реакцией на новые веяния модернизма с его стилевой размытостью явился, помимо «областнической литературы», в некотором смысле соприкасавшийся с ней неоклассицизм. Отказывая модернизму в способности вырваться за границы капиталистической действительности, а оттого лишь прокладывавшему дорогу неоромантике и символизму, Ф. Меринг и С. Люблинский, не сговариваясь, видят возмож- 
ность настоящей эмансипации на путях к «новому классическому веку» [45, s. 7 ; 38, s. 225].

Немецкие неоклассики (начинавший как натуралист П. Эрнст и его последователь Вильгельм фон Шольц) прокламируют классическую строгость формы и идейную насыщенность содержания, следование выбранным эстетическим нормам, прежде всего законам традиционных жанров. В качестве образцов для подражания предпочитались произведения предромантических эпох (итальянская новеллистика Ренессанса, средневековые мистерии и античная трагедия). «Прошедшие эпохи, - как отмечают Н. Павлова и Л. Юрьева, - должны были стать заимодавцами общезначимых идей, которых писатели не обнаруживали в современности» [2, с. 327], пораженной, если перефразировать слова Ницше из «Антихриста», вирусом декаданса. Отсюда проистекает и его требование (в полном соответствии с воззрениями учителя, Льва Толстого) «переоценки всех ценностей» в ситуации, когда прежний духовный фундамент разрушен: «бог мертв», христианская мораль - ущербна.

На формирование эстетических воззрений неоклассиков оказали влияние работы историка культуры Я.К. Буркхардта. В своих трудах по культуре итальянского Возрождения («Культура Возрождения в Италии», І860; «История Возрождения в Италии», г867) он последовательно проводил мысль о том, что целью любой деятельности должно рассматриваться стремление к прекрасному. А его четырехтомная «История культуры Греции» (I898-1902), демонстрировавшая пагубное влияние урбанизации на развитие греческой культуры, послужила неоклассикам образцом для критики современной культуры декаданса.

Существенно, что неоклассицизм больше заявил о себе теоретическими обоснованиями программы, не создав сколь бы то ни было ценных художественных произведений. Так, П. Эрнст выдвигает в своих сочинениях («Путь к форме», І906; «Кредо», г9І2, и др.) идею вечного вневременного искусства, в основе которого лежат принципы красоты и одухотворенной формы. Не находя в современной действительности почвы для реализации подобного эстетического идеала (и здесь нельзя не вспомнить Р. Вагнера с его отторжением ненавистного ему «человеконенавистнического прогресса культуры» [3, с. 37]), писатель обращается к стилизации древнегерманских 
и древнегреческих сюжетов (драма «Деметриос», І905; трагедии «Каносса», І908; «Брунгильда», І909, и др.).

Прокламируя строгое следование классическим (т. е. устоявшимся) эталонам («Мысли о драме», І905), ученик Эрнста, ярый противник модернистских веяний, певец южной Швабии, и в этом смысле регионалист, В. фон Шольц на протяжении всей жизни проявляет интерес к мистицизму и оккультизму, выбирая историческим фоном для своих произведений позднее Средневековье и предреволюционную Францию («Еврей из Констанцы», І905 и др.).

Примечательны названия трудов С. Люблинского («Классическое искусство», І903-І904; «Итог модерна», 1904, и «Исход модерна», 1905). В них содержится критика «современных» направлений в искусстве, прежде всего натурализма. Неудовлетворенность Люблинского была вызвана их якобы ограниченностью, которая выражалась, по его мнению, среди прочего, в том, что они ратовали «не за новый стиль, но за новый материал изображения» $[37$, s. 3], отказываясь видеть в прежних эпохах какую бы то ни было художественную ценность [37, s. 5].

Не случайно обращение к искусству прошлого и в марксистской эстетике. В духе «антихриста» Ницше и борца с дегенеративным искусством Нордау связывает свои рассуждения о преодолении неоромантического упадка, декаданса «современной» литературы Ф. Меринг. Декларируя наступление нового классического века, он предписывает литературе не ограничиваться показом только лишь язв на теле буржуазного общества, а главным образом высвечивать ростки новой жизни. Именно поэтому в классическом наследии (в первую очередь в эпохе Просвещения и в литературе «Бури и натиска») марксистов привлекает заложенный в них идеал красоты и общий оптимистический, прогрессивный настрой, что впоследствии в полном объеме будет востребовано эстетикой ГДР.

На фоне разворачивающей свой художественный потенциал эпохи «современности» Т. Манн усматривает отличие нового классического искусства XX в. от предшествующих образцов в его большей логической и формальной строгости и интеллектуальности [4I, s. 799]. В продолжение мысли Манна композитор Х. Тиссен выдвигает тезис о «новой “современной” классичности» (neue moderne Klassizität), подчеркивая, что речь в дан- 
ном случае идет не о «возвращении к традиции, но о поисках новых путей к новой классичности» [62, s. 39I], в частности, по аналогии с «волей к форме» П. Эрнста, посредством уложения нового содержания в рамки регламентированной формы. Причем это содержание не должно было сводиться, по Эрнсту, к простому показу жизни. Писателю вменялось в обязанность отражать в художественной форме сущностные проблемы человеческого бытия и ставить читателя перед выбором ценностных ориентиров: «Наша человеческая сущность заключается не в способности мыслить, а в том, чтобы разглядеть те ценности, которые заставят воспылать наше сердце» [і9, s. 28]. Это не означало, однако, что писатель, занятый, вслед за Метерлинком, поисками в языке жизни языка души, невысказанных смыслов, «замыкается на изображении проблем, оторванных от реальности, игнорирует природную естественность и простоту» [І9, s. 44].

В конечном итоге неоклассицизм в плане требования возврата к строгой организации текста может рассматриваться в некоторой степени проводником и предтечей «новой вещественности (деловитости)», явившей себя как прямая реакция на патетику позднего экспрессионизма и антиформу дадаизма. Не случайно в качестве синонима «классицистическому» (Klassizität) и в противовес личностному искусству романтиков Люблинский использует термин «вещное искусство» (“Sachkunst”) и «вещественность» ("Sachlichkeit”) [39, s. I5I, I59], с его семантическими признаками «реальность», «материальность», «объективность», «целесообразность». На наш взгляд, последний термин наиболее точно отражает суть нового направления. Примечательно, что в І9І9 г., во времена революционного хаоса и разрушений, будущее Германии, в том числе и ее культуры, видится Т. Манну через призму доброго немецкого порядка, соразмерности, в основе которых лежат принципы целесообразности (Sachlichkeit) [42; цит. по: [32, s. 349], несовместимые, в частности с программатикой экспрессионизма, идеи которого не нашли ни малейшего позитивного отклика в творчестве самого Манна. Любопытно отметить, что в творчестве П. Эрнста современники усматривали черты «новой деловитости» (ср., в частности: [57, s. 66I-667]). Таким образом, несмотря на формальное отмежевание неоклассиков от модернизма, они, по сути, объективно находились в сфере его инновативной нормативности. Так, указывая в I9I4 г. на «вещностную» природу прусского стиля, историк искусства и публицист Артур Мёллер ван 
ден Брук подразумевает под этим наполнение традиционной формы содержанием, отвечающим современным запросам [47, s. I6]. Другими словами, если практика неоклассиков, став частью массовой литературы, в целом не перешагнула границ традиционного, во многом эпигонского искусства, то постулаты теоретиков скорее корреспондируют с общей тенденцией к его модернистскому обновлению.

Следует также учитывать то обстоятельство, что, несмотря на узкий круг непосредственных участников движения, обращение к классике вовсе не было чуждо представителям других постнатуралистических течений от С. Георге, Т. Манна, Г. Гессе и др. до группы писателей, озаботившихся в конце I920-х гг. сохранением литературного наследия (Р. Борхардт - античность, М. Мелль - Средние века, А. Шеффер - классицизм, Ф. Юнгер - романтизм и т. д.). В качестве представителя немецкого неоклассицизма помимо названных авторов фигурирует один из популярнейших писателей времен Веймарской республики и «Третьего рейха», новеллист Рудольф Биндинг. Известную дань этому течению отдал и Г. Гауптман.

Однако в целом неоклассицизм можно рассматривать, с одной стороны, как проявление общего тяготения к преемственности, которая в любом разворачивающемся во времени процессе гарантирует определенную устойчивость вовлеченных в него взаимодействующих и трансформирующихся элементов. С другой стороны, как справедливо отмечают Н. Павлова и Л. Юрьева, воссоздававшийся в новых условиях, в частности, трансформированный «образ античности был для многих писателей рубежа веков скрытой интерпретацией современности» [2, s. 330].

Причина стилевого и эстетического плюрализма, создававшего столь пеструю картину литературной жизни в Германии конца XIX- начала $\mathrm{XX}$ вв., кроется в характере самой эпохи, определяемой участниками литературного процесса и их исследователями как поворотной, или переломной. Это был переход от старого бюргерского уклада к обществу интенсивного развития. Ломка прежних отношений и представлений требовала объяснения новых явлений и их оправдания, защиты либо порицания средствами политики, идеологии, философии, морали и пр. Духовная сфера, в частности культура, не могли не быть вовлечены в эти неоднозначные процессы познания и оценки новой ситуации. Их результатом и стала «узорчатая мозаика» в виде искусства рубежа веков. 
Фактически большинство писателей рубежа веков заняты решением сходных проблем. Кризисное сознание становится главным посылом к новому постижению (невозможности постижения) мира, к поискам (либо осознанию потери) в нем своего места, к переосмыслению личностных характеристик (свободы / несвободы), поведенческих (гармонизированных / лишенных гармонии) установок, другими словами, к разрешению, по Г. Зиммелю, конфликта между старым и новым [6о].

Таким образом, плюрализм или кажущийся хаос художественных тенденций на рубеже XIX-XX вв. может быть приведен к единому знаменателю. Если всю первую половину XX в. можно обозначить как эпоху становления новой, модернистской традиции, то рубеж XIX-XX вв. предстает как время изменения культурного кода, выработки программных положений «классического модерна» (Klassische Moderne), художественный облик которого (на уровне глубинной структуры текста) окончательно оформится в литературе экспрессионизма, дадаизма и «новой деловитости».

Не случайно проблема обновления художественного языка занимает центральное место как в эстетике и поэтике модернизма, так и в искусстве приверженцев традиции. Поэтому, с одной стороны, мы имеем дело, в частности, в поэзии с развитием верлибра, с другой - перед нами изощренная шлифовка твердых форм в сторону их обновления (например, развитие формы сонета у Рильке). Одним из главных итогов художественных исканий на рубеже XIX-XX вв. предстает предвосхищение легитимизации в искусстве XX в. принципов деструкции, фрагментации и деконструкции, а в конечном итоге - стирание жанровых и видовых границ на новом витке спирали литературного процесса.

\section{Список литературы}

I Жеребин А.И. На стороне Вены (Об одной реалии в романе Т. Фонтане «Эффи Брист») // Немецкоязычная литература: единство в многообразии. Сборник статей к 75-летию профессора Владимира Денисовича Седельника. М.: ИМЛИ РАН, 2010. С. 28-34.

Павлова Н.С., Юрьева Л.М. Неоромантизм и неоклассицизм: [Немецкая литература на рубеже XIX и XX веков] // История всемирной литературы: в 8 т. М.: Наука, I994. T. 8. С. 326-330.

3 Вагнер Р. Искусство и революция. СПб.: Горизонт, І9о8. 39 с.

4 Alberti C. Die zwölf Artikel des Realismus. Ein litterarisches Glaubensbekenntnis // Gesellschaft. I889. № 5. S. 49-58. 
Andreotti M. Die Struktur der modernen Literatur: neue Wege in der Textanalyse;

Einführung: Erzählprosa und Lyrik. 3., vollständig überarb. u. stark erw. Auflage. Stuttgart: UTB, 2000. Bd. II27. 440 S.

6 Anz Th. Indikatoren und Techniken der Transformation theoretischen Wissens in literarische Texte - am Beispiel der Psychoanalyserezeption in der literarischen Moderne // Literatur und Wissen (schaften) I890-I935 / Ch. Maillard, M. Titzmann. Stuttgart; Weimar: Metzler, 2002. S. 33I-347.

Bahr H. Symbolismus // Die Nation. Wochenschrift für Politik, Volkswirthschaft und Litteratur. I892. Jg. 9. № 38. I8 Juni. S. 576-577.

8 Bartels A. Geschichte der deutschen Lit(t)eratur. 2 Bde. Leipzig: Avenarius, I90I. Bd. I. $823 \mathrm{~S}$.

Bierbaum O. Zur Einführung // Moderner Musen-Almanach auf das Jahr I893. München. S. II.

Blume B. Die Insel als Symbol in der deutschen Literatur // Monatshefte. Wisconsin. I949. № 4I. S. 239-247.

Bölsche W. Die naturwissenschaftlichen Grundlagen der Poesie. Prolegomena einer realistischen Ästhetik. Leipzig: Carl Reißner, I887. I7I S.

Brahm O. Zum Beginn // Freie Bühne für modernes Leben. I889. № I. S. I-2. Bromberg-Bytkowski Z. Gerhart Hauptmanns Naturalismus und das Drama. Hamburg; Leipzig: Leopold Voss, I908. $208 \mathrm{~S}$. Conrad M.G. Vom vaterländischen Roman // Die Gesellschaft. I885. Jg. I. № 44 . 3I Oktober. S. 832-836.

Conrad M.G. Aus dem Münchener Kunst- und Litteraturleben // Die Gesellschaft. I890. Jg. 6. März. S. 4II-422.

I6 Conrad M.G. Von Emile Zola bis Gerhart Hauptmann. Erinnerungen zur Geschichte der Moderne. Leipzig: Hermann Seemann Nachfolger, I902. I23 S.

I7 Conrad M.G. Zur Geschichte der deutschen Kritik. I. Der Herr Pfarrer in Mähringen bei Ulm // Die Gesellschaft. I889. Jg. 5. April. S. 550-559. Conradi H. Unser Credo. Einleitung // Moderne Dichter-Charaktere / W. Arent. Berlin, I885. S. I-VIII.

Ernst P. Der Weg zur Form: ästhetische Abhandlungen, vornehmlich zur Tragödie und Novelle. Berlin: Julius Bard, I906. 219 S.

Freud S. Realitätsverlust bei Neurose und Psychose // Psychologie des Unbewußten. Frankfurt am M., I975. S. 355-361. George S. Einleitung // Blätter für die Kunst. № I. I9I4. S. I. Gottschall R. Dichtungen und Gedichte // Blätter für literarische Unterhaltung. 24.06.I886. S. 386-390.

23 Gumbrecht H.U. Modern, Modernität, Moderne // Geschichtliche Grundbegriffe. Historisches Wörterbuch zur politisch-sozialen Sprache / Hrsg. von R. Koselleck, W. Conze, O. Brunner. Stuttgart: Klett-Cotta, I978. Bd. 4. S. 93-I3I. 
24 Hamann R. Der Impressionismus in Leben und Kunst. Köln: DuMont Schauberg Verlag, I907.319 S.

25 Hamburger K. Der Epiker Thomas Mann // Orbis Litterarum. I958. Vol. I3. Issue I. P. 7-I4.

26 Hart H. Neue Welt // Deutsche Monatsblätter. Zentralorgan für das literarische Leben der Gegenwart / H. u. J. Hart. Bremen, I878. Bd. I. S. 2I-32.

27 Hart J. Für und gegen Zola // Kritische Waffengänge. Leipzig. I882. H. 2. S. 44-55.

28 Hart.J., Hart. H. Wozu? Wogegen? Wofür // Naturalismus: bürgerliche Dichtung und soziales Engagement / H. Scheuer. Stuttgart: Kohlhammer W., I974. 264 S.

29 Hauptmann G. Brief vom I9. Februar I885 an den dänischen Literaturkritiker // Correspondance de Georg Brandes. Lettres choisies et annotees par Paul Krüger. III: L'Allemagne. Copenhague: Rosenkilde og Bagger, I966, S. 429.

30 Heinemann E. Der "ganze Karl May": Eine "fröhliche Wissenschaft". Kleine Visitenkarte der Karl-May-Gesellschaft // die horen. I995. Bd. I78. S. 249-252.

3I Hofmannsthal H. Gesammelte Werke in Einzelbänden / Hrsg.von H. Steiner. Frankfurt.a. M.: S. Fischer, 1956. Bd. 4. 282 S.

32 Koenen $G$. Betrachtungen eines Unpolitischen. Thomas Mann über Rußland und den Bolschewismus // Deutschland und die russische Revolution / G. Koenen, L. Kopelew. München: Wilhelm Fink Verlag, I998. S. 313-379.

33 Koopmann H. Thomas Mann // Deutsche Dichter des 20. Jahrhunderts / H. Steinecke. Berlin: Erich Schmidt, I996. S. I36-I39.

34 Lehnert H. Vom Jugendstil zum Expressionismus // Geschichte der deutschen Literatur von den Anfängen bis zur Gegenwart. Stuttgart: Philipp Reclam jun., I978. Bd. 6.

S. I98-20I.

35 Lessing O.E. Die neue Form: Ein Beitrag zum Verständnis des deutschen Naturalismus. Dresden: C. Reissner, I9I0. 233 S.

36 Lindner $W$. Jugendbewegung als Äußerung lebensideologischer Mentalität. Die mentalitätsgeschichtlichen Präferenzen der deutschen Jugendbewegung im Spiegel ihrer Liedertexte. Schriften zur Kulturwissenschaft. Hamburg: Verlag Dr. Kovač, 2003. Bd. 48. 492 S.

37 Lublinski S. Bilanz der Moderne. Berlin: Siegfried Cronbach, I904. 26 S.

38 Lublinski S. Der Ausgang der Moderne. Ein Buch der Opposition. Dresden: Carl Reissner, I909. 3I4 S.

39 Lublinski S. Klassische Kunst // Die Zukunft XII. I903-I904. Bd. 46. S. I5I-I59.

40 Mann H. Briefe an Ludwig Ewers. I883-I9I3 / U. Dietzel, R. Eggert. Berlin; Weimar: Aufbau, 1980. 591 S.

4I Mann Th. Auseinandersetzung mit Wagner // Der Merkur. I9II. S. 798-800.

42 Mann Th. Goethe und Tolstoi. Zum Problem der Humanität. Berlin: S. Fischer, I932. I53 S.

43 Mann Th. Meine Zeit // Mann Th. Gesammelte Werke in I3 Bdn. Frankfurt a. M.:

S. Fischer, I990. Bd. II. S. 302-324. 
Mehring F. Aufsätze zur deutschen Literatur von Hebbel bis Schweichel // Mehring F. Gesammelte Schriften: In I5. Bdn. / Hrsg. Von H. Koch. Berlin: Dietz, I96I. Bd. II. $627 \mathrm{~S}$.

Mehring F. Etwas über den Naturalismus // Die Volksbühne. № I. I892. S. 7-II. Metzler Literatur Lexikon. Begriffe und Definitionen. Stuttgart: Metzler, I993. 525 S. Moeller van den Bruck A. Der preußische Stil. München: Piper, I9I6. I84 S. Nietzsche F. Also sprach Zarathustra // Nietzsche F. Werke: In 3 Bdn. / Hrsg. von K. Schlechta. München: Hanser, I954. Bd. 2. S. 277-293. Nietzsche F. Die fröhliche Wissenschaft. Erstes Buch // Nietzsche F. Werke: In 3 Bdn. / Hrsg. von K. Schlechta. München: Hanser, I954. Bd. 2. S. 9-26I. Nietzsche F. Jenseits von Gut und Böse // Nietzsche F. Werke: In 3 Bdn. / Hrsg. von K. Schlechta. München: Hanser, I954. Bd. 2. S. I-759. Nietzsche F. Menschliches, Allzumenschliches I // Nietzsche F. Werke: In 3 Bdn. / Hrsg. von K. Schlechta. München: Hanser, I954. Bd. 2. S. 436-735. Nietzsche F. Nietzsche contra Wagner // Nietzsche F. Werke: In 3 Bdn. / Hrsg. von K. Schlechta. München: Hanser, I954. Bd. 2. S. I037-I06I. Nietzsche F. Über Wahrheit und Lüge im außermoralischen Sinn // Nietzsche F. Werke: In 3 Bdn. / Hrsg. von K. Schlechta. München: Hanser, I954. Bd. 3. S. 308-322. Nordau M. Entartung: In 2 Bdn. Berlin: Duncker, I892-I893. 206 S. + 506 S. Pietschker K. Carl Gussow und der Naturalismus in Deutschland: Kunstgeschichtliche Streitschrift. Berlin: Mitscher \& Röstell, I898. I56 S.

56 Sander E. Johannes Schlaf und das naturalistische Drama. Rostock: Reclam, I922. 96 S. Schäfer W.E. Paul Ernst // Deutsches Volkstum. I928. Jg. IO. S. 66I-667.

58 Schlosser H.D. dtv-Atlas Deutsche Literatur. Frankfurt a. M.: dtv, 2002. 309 S.

59 Servaes F. Präludien: Ein Essaybuch. Berlin; Leipzig: Schuster \& Löffler, ı899. 434 S.

60 Simmel G. Der Konflikt der modernen Kultur: Ein Vortrag. München; Leipzig: Duncker \& Humblot, I9I8. 48 S.

6I Simmel G. Philosophie des Geldes. Berlin: Duncker \& Humblot, I900. 557 S.

62 Tiessen $H$. Wo steht Strauss mit seinem Rosenkavalier? // Allgemeine Musik-Zeitung. XXXVIII. I9II. S. 39I-392.

63 Wagner R. Tristan und Isolde // Wagner R. Die Musikdramen. Hamburg: Hoffmann und Campe, I97I. S. 336-344.

64 Wedekind F. Hidalla oder Sein und Haben // Werke: In 3 Bdn / M. Hahn. Berlin; Weimar: Aufbau, I969. Bd. I. 662 S.

65 Wille B. Philosophie der Befreiung durch das reine Mittel: Beiträge zur Pädagogik des Menschengeschlechts. Berlin: S. Fischer, I894. 424 S.

66 Wilpert G. Sachwörterbuch der Literatur. Stuttgart: Kröner, 200I. 925 S.

67 WolffE. Thesen zur literarischen Moderne // Magazin für die Litteratur des In- und Auslandes. I8. I2.I886. S. 8Io.

68 Worringer W. Fragen und Gegenfragen. München: Piper, I956. I9I S. 
69 Wunberg G. Die literarische Moderne: Dokumente zum Selbstverständnis der Literatur um die Jahrhundertwende. Frankfurt a. M.: Athenäum-Verlag, I97I. 397 S.

\section{References}

I Sherebin A.I. Na storon`e Veny (Ob odnoi realiji v romane T. Fontane "Effi Briest") [On the side of Vienna (About a reality piece in the novel of T. Fontane "Effi Briest")]. Nemeckojasychnaja literatura: jedinstvo v mnogoobrasiji. Sbornik statej $k$ 75-letiju professor Vladimira Denisovitcha Sedelnika [German literature: unity and variety. Collection of essays in honor of the 75 year anniversary of Vladimir Denisovitch Sedelnik]. Moscow, IMLI RAN Publ., 20IO, pp. 28-34. (In Russ.) Pavlova N.S., Jurjeva L.M. Neoromantism i Neoklassicism. Nemeckaja literature na rubeshe $19-20 \mathrm{vv}$. [Neoromantism and Neoclassicism. German literature at the turn of $19^{\text {th }}$ and $2 \mathrm{O}^{\text {th }}$ Centuries]. Istorija vsemirnoi literatury: $v 8 t$. [History of World Literature: in 8 vol.]. Moscow, Nauka Publ., I994, vol. 8, pp. 326-330. (In Russ.)

3 Wagner R. Iskusstwo I revolucija [Art and Revolution]. St. Petersburg, Gorisont Publ., I908. 39 p. (In Russ.)

4 Alberti C. Die zwölf Artikel des Realismus. Ein litterarisches Glaubensbekenntnis. Gesellschaft. № 5. I889. S. 49-58. (In German)

5 Andreotti M. Die Struktur der modernen Literatur: neue Wege in der Textanalyse; Einführung: Erzählprosa und Lyrik. 3., vollständig überarb. u. stark erw. Auflage. Stuttgart, UTB, 2000. Bd. II27. 440 S. (In German)

6 Anz Th. Indikatoren und Techniken der Transformation theoretischen Wissens in literarische Texte - am Beispiel der Psychoanalyserezeption in der literarischen Moderne. Literatur und Wissen (schaften) I890-1935, Ch. Maillard, M. Titzmann. Stuttgart; Weimar, Metzler, 2002. S. 33I-347. (In German)

$7 \quad$ Bahr H. Symbolismus. Die Nation. Wochenschrift für Politik, Volkswirthschaft und Litteratur. I892. Jg. 9. №. 38. I8 Juni. S. 576-577. (In German)

8 Bartels A. Geschichte der deutschen Lit(t) eratur. 2 Bde. Leipzig, Avenarius, I90I. Bd. I. 823 S. (In German)

9 Bierbaum O. Zur Einführung. Moderner Musen-Almanach auf das Jahr I893. München. S. II. (In German)

Io Blume B. Die Insel als Symbol in der deutschen Literatur. Monatshefte. Wisconsin. 1949. № 4I. S. 239-247. (In German) Bölsche W. Die naturwissenschaftlichen Grundlagen der Poesie. Prolegomena einer realistischen Ästhetik. Leipzig, Carl Reißner, I887. I7I S. (In German) Brahm O. Zum Beginn. Freie Bühne für modernes Leben. I889. № I. S. I-2. (In German)

I3 Bromberg-Bytkowski Z. Gerhart Hauptmanns Naturalismus und das Drama. Hamburg; Leipzig, Leopold Voss, I908. 208 S. (In German)

I4 Conrad M.G. Vom vaterländischen Roman. Die Gesellschaft. I885. Jg. I. № 44. 3I Oktober. S. 832-836. (In German) 
Conrad M.G. Aus dem Münchener Kunst- und Litteraturleben. Die Gesellschaft. I890. Jg. 6. März. S. 4II-422. (In German)

Conrad M.G. Von Emile Zola bis Gerhart Hauptmann. Erinnerungen zur Geschichte der Moderne. Leipzig, Hermann Seemann Nachfolger, I902. I23 S. (In German)

Conrad M.G. Zur Geschichte der deutschen Kritik. I. Der Herr Pfarrer in Mähringen bei Ulm. Die Gesellschaft. I889. Jg. 5. April. S. 550-559. (In German)

Conradi H. Unser Credo. Einleitung. Moderne Dichter-Charaktere, W. Arent. Berlin, I885. S. I-VIII. (In German)

Ernst P. Der Weg zur Form: ästhetische Abhandlungen, vornehmlich zur Tragödie und Novelle. Berlin, Julius Bard, I906. 219 S. (In German)

Freud S. Realitätsverlust bei Neurose und Psychose. Psychologie des Unbewußten. Frankfurt am M., I975. S. 355-36I. (In German)

George S. Einleitung. Blätter für die Kunst. № I. I9I4. S. I. (In German)

Gottschall R. Dichtungen und Gedichte. Blätter für literarische Unterhaltung. 24.06.I886. S. 386-390. (In German)

Gumbrecht H.U. Modern, Modernität, Moderne. Geschichtliche Grundbegriffe. Historisches Wörterbuch zur politisch-sozialen Sprache, Hrsg. von R. Koselleck, W. Conze, O. Brunner. Stuttgart, Klett-Cotta, I978. Bd. 4. S. 93-I3I. (In German) Hamann R. Der Impressionismus in Leben und Kunst. Köln, DuMont Schauberg Verlag, I907. 3I9 S. (In German)

Hamburger K. Der Epiker Thomas Mann. Orbis Litterarum. I958. Vol. I3. Issue I. P. 7-I4. (In German)

Hart H. Neue Welt. Deutsche Monatsblätter. Zentralorgan für das literarische Leben der Gegenwart, H. u. J. Hart. Bremen, I878. Bd. I. S. 2I-32. (In German)

Hart J. Für und gegen Zola. Kritische Waffengänge. Leipzig. I882. H. 2. S. 44-55. (In German)

Hart. J., Hart. H. Wozu? Wogegen? Wofür. Naturalismus: bürgerliche Dichtung und soziales Engagement, H. Scheuer. Stuttgart, Kohlhammer W., I974. 264 S. (In German) Hauptmann G. Brief vom I9. Februar I885 an den dänischen Literaturkritiker. Correspondance de Georg Brandes. Lettres choisies et annotees par Paul Krüger. III: L’Allemagne. Copenhague, Rosenkilde og Bagger, I966, S. 429. (In German) Heinemann E. Der "ganze Karl May”: Eine “fröhliche Wissenschaft”. Kleine Visitenkarte der Karl-May-Gesellschaft. die horen. 1995. Bd. I78. S. 249-252. (In German) Hofmannsthal H. Gesammelte Werke in Einzelbänden, Hrsg.von H. Steiner. Frankfurt.a. M., S. Fischer, I956. Bd. 4. 282 S. (In German)

Koenen G. Betrachtungen eines Unpolitischen. Thomas Mann über Rußland und den Bolschewismus. Deutschland und die russische Revolution, G. Koenen, L. Kopelew. München, Wilhelm Fink Verlag, I998. S. 313-379. (In German)

Koopmann H. Thomas Mann. Deutsche Dichter des 2o. Jahrhunderts, H. Steinecke. Berlin, Erich Schmidt, I996. S. I36-I39. (In German) 
34 Lehnert H. Vom Jugendstil zum Expressionismus. Geschichte der deutschen Literatur von den Anfängen bis zur Gegenwart. Stuttgart, Philipp Reclam jun., I978. Bd. 6. S. I98-20I. (In German)

35 Lessing O.E. Die neue Form: Ein Beitrag zum Verständnis des deutschen Naturalismus. Dresden, C. Reissner, I910. 233 S. (In German)

36 Lindner W. Jugendbewegung als Äußerung lebensideologischer Mentalität. Die mentalitätsgeschichtlichen Präferenzen der deutschen Jugendbewegung im Spiegel ihrer Liedertexte. Schriften zur Kulturwissenschaft. Hamburg, Verlag Dr. Kovač, 2003. Bd. 48. 492 S. (In German)

37 Lublinski S. Bilanz der Moderne. Berlin, Siegfried Cronbach, I904. 26 S. (In German)

38 Lublinski S. Der Ausgang der Moderne. Ein Buch der Opposition. Dresden, Carl Reissner, I909. 3 I4 S. (In German)

39 Lublinski S. Klassische Kunst. Die Zukunft XII. I903-I904. Bd. 46. S. I5I-I59. (In German)

40 Mann H. Briefe an Ludwig Ewers. I883-I9I3, U. Dietzel, R. Eggert. Berlin; Weimar, Aufbau, 1980. 59I S. (In German)

4I Mann Th. Auseinandersetzung mit Wagner. Der Merkur. I9II. S. 798-800. (In German)

42 Mann Th. Goethe und Tolstoi. Zum Problem der Humanität. Berlin, S. Fischer, 1932. I53 S. (In German)

43 Mann Th. Meine Zeit. Mann Th. Gesammelte Werke in I3 Bdn. Frankfurt a. M., S. Fischer, I990. Bd. II. S. 302-324. (In German)

44 Mehring F. Aufsätze zur deutschen Literatur von Hebbel bis Schweichel. Mehring F. Gesammelte Schriften: In I5 Bdn., Hrsg. Von H. Koch. Berlin, Dietz, I96I. Bd. II. 627 S. (In German)

45 Mehring F. Etwas über den Naturalismus. Die Volksbühne. № I. I892. S. 7-II. (In German)

46 Metzler Literatur Lexikon. Begriffe und Definitionen. Stuttgart, Metzler, 1993.525 S. (In German)

47 Moeller van den Bruck A. Der preußische Stil. München, Piper, I9I6. I84 S. (In German)

48 Nietzsche F. Also sprach Zarathustra. Nietzsche F. Werke: In 3 Bdn., Hrsg. von K. Schlechta. München, Hanser, I954. Bd. 2. S. 277-293. (In German)

49 Nietzsche F. Die fröhliche Wissenschaft. Erstes Buch. Nietzsche F. Werke: In 3 Bdn., Hrsg. von K. Schlechta. München, Hanser, I954. Bd. 2. S. 9-26I. (In German)

$50 \quad$ Nietzsche F. Jenseits von Gut und Böse. Nietzsche F. Werke: In 3 Bdn., Hrsg. von K. Schlechta. München, Hanser, I954. Bd. 2. S. I-759. (In German)

5I Nietzsche F. Menschliches, Allzumenschliches I. Nietzsche F. Werke: In 3 Bdn., Hrsg. von K. Schlechta. München, Hanser, I954. Bd. 2. S. 436-735. (In German) 
52 Nietzsche F. Nietzsche contra Wagner. Nietzsche F. Werke: In 3 Bdn., Hrsg. von K. Schlechta. München, Hanser, I954. Bd. 2. S. I037-I06I. (In German)

53 Nietzsche F. Über Wahrheit und Lüge im außermoralischen Sinn. Nietzsche F. Werke: In 3 Bdn., Hrsg. von K. Schlechta. München, Hanser, I954. Bd. 3. S. 308-322. (In German)

54 Nordau M. Entartung: In 2 Bdn. Berlin, Duncker, I892-1893. 206 S. + 506 S. (In German)

55 Pietschker K. Carl Gussow und der Naturalismus in Deutschland: Kunstgeschichtliche Streitschrift. Berlin, Mitscher \& Röstell, I898. I56 S. (In German)

56 Sander E. Johannes Schlaf und das naturalistische Drama. Rostock, Reclam, I922. 96 S. (In German)

57 Schäfer W.E. Paul Ernst. Deutsches Volkstum. I928. Jg. IO. S. 66I-667. (In German)

58 Schlosser H.D. dtv-Atlas Deutsche Literatur. Frankfurt a. M., dtv, 2002. 309 S. (In German)

59 Servaes F. Präludien: Ein Essaybuch. Berlin; Leipzig, Schuster \& Löffler, I899. 434 S. (In German)

$60 \quad$ Simmel G. Der Konflikt der modernen Kultur: Ein Vortrag. München; Leipzig, Duncker \& Humblot, I9I8. 48 S. (In German)

6I Simmel G. Philosophie des Geldes. Berlin, Duncker \& Humblot, I900. 557 S. (In German)

62 Tiessen H. Wo steht Strauss mit seinem Rosenkavalier? Allgemeine Musik-Zeitung. XXXVIII. I9II. S. 39I-392. (In German)

63 Wagner R. Tristan und Isolde. Wagner R. Die Musikdramen. Hamburg, Hoffmann und Campe, I97I. S. 336-344. (In German)

64 Wedekind F. Hidalla oder Sein und Haben. Werke: In 3 Bdn., M. Hahn. Berlin; Weimar, Aufbau, I969. Bd. I. 662 S. (In German)

65 Wille B. Philosophie der Befreiung durch das reine Mittel: Beiträge zur Pädagogik des Menschengeschlechts. Berlin, S. Fischer, I894. 424 S. (In German)

66 Wilpert G. Sachwörterbuch der Literatur. Stuttgart, Kröner, 200I. 925 S. (In German)

67 Wolff E. Thesen zur literarischen Moderne. Magazin für die Litteratur des In- und Auslandes. I8. I2.I886. S. 8Io. (In German)

68 Worringer W. Fragen und Gegenfragen. München, Piper, I956. I9I S. (In German)

69 Wunberg G. Die literarische Moderne: Dokumente zum Selbstverständnis der Literatur um die Jahrhundertwende. Frankfurt a. M., Athenäum-Verlag, I97I. 397 S. (In German) 
УДК 82I.ІІІ

ББК 83.3(4Вел)
«А БУДУЩЕЕ ТАИЛОСЬ В ПРОШЕДШЕМ» :

О МЕХАНИЗМЕ ДВИЖЕНИЯ ПОЭЗИИ

БРИТАНСКОГО МОДЕРНИЗМА

ОТ Т.С. ЭЛИОТА К ТЕДУ ХЬЮЗУ

(C) 2017 г. Т.Н. Красавченко

Институт научной информации по общественным наукам (ИНИОН) Российской академии наук, Москва, Россия

Дата поступления статьи: го апреля 2017 г.

Дата публикации: 25 сентября 2017 г.

DOI: I0.22455/2500-4247-20I7-2-3-74-8I

Аннотация: В статье выявляется связь поэтов казалось бы совершенно разных творческих индивидуальностей и эпох. Тед Хьюз (1930-1998) - широко признанный в Великобритании и за ее пределами поэт-натурфилософ второй половины XX в., его интересует противостояние Природы и человека, самоубийственно разрушающего Природу. Т.С. Элиот (I888-І965) - реформатор англоязычной модернистской поэзии, поэт городской цивилизации. В его время поэзия «Природы» существует, но уходит на второй план, в тень, хотя представлена даже в творчестве самого Элиота, в его «Пейзажах» - стихотворениях, написанных в начале г93о-х гг. Элиота и Хьюза объединяет то, что оба они - поэты-модернисты. Элиот стоит у начала модернизма, Хьюз - у его конца, хотя он жил уже в период расцвета постмодернизма, однако постмодернистом не был, ибо не занимался деконструкцией, дроблением «модели мира». И Элиот, и Хьюз - поэты эсхатологической направленности, поэты мифологи. Как и Элиот, Хьюз - традиционалист, хотя Элиот, американец, был «осознанным традиционалистом», а Хьюз, англичанин, - скорее традиционалист интуитивный, прирожденный. Элиота нет в его «великой традиции», ибо его время - время отрицания Элиота, вызванного закономерной сменой «мейнстримов»: во второй половине XX в. британская поэзия «устала» от урбанизма, от «пренебрежения Природой» и вернулась «на круги своя», и, что у Элиота было на периферии творчества, в поэзии Хьюза выходит на первый план.

ключевые слова: британская поэзия, модернизм, Т.С. Элиот, Тед Хьюз, традиционализм, мейнстрим, постмодернизм.

Информация об авторе: Татьяна Николаевна Красавченко - доктор филологических наук, ведущий научный сотрудник, Институт научной информации по общественный наукам Российской академии наук, Нахимовский просп., д. 5I/2I, II7997 Москва, Россия.

E-mail: tatianakras@mail.ru 


\section{"AND TIME FUTURE CONTAINED IN TIME PAST": BRITISH MODERNIST POETRY FROM T.S. ELIOT TO TED HUGHES}

This is an open access article distributed under the Creative Commons Attribution 4.0 International (CC BY 4.0)
(C) 20I7. T.N. Krasavchenko Institute of Social Sciences Information of the Russian Academy of Sciences, Moscow, Russia Received: April IO, 2017 Date of publication: September 25, 2017

Abstract: It seems that T.S. Eliot (I888-I965) and Ted Hughes (I930-I998) are poets of different individual talents and epochs. Hughes, a poet of the second half of the $20^{\text {th }}$ century, concentrated on the conflict between Nature and the human being destroying Nature and thus preparing the end of the humanity. T.S. Eliot was a poet of urban civilization, a reformer of the Anglophone modernist poetry. In his days, the "poetry of Nature" rooted in the pastoral poetry of the $17^{\text {th }}-18^{\text {th }}$ centuries and in Romanticism, existed but only at the margins of mainstream poetic trends. Nevertheless, one can find it even in Eliot's poetry, particularly in his Landscapes - poems written at the beginning of the I930s. Also, both Eliot and Hughes were modernists. Eliot standing at the beginning of modernism, Hughes at its end; though the latter lived in the time of postmodernism, he was not a postmodernist himself since he was not engaged in the deconstruction and fragmentation of the "world model." Like Eliot, he was a poet with integral Weltanschauung and a bright individual talent. Like Eliot, he was a traditionalist, though Eliot being an American was a "conscious traditionalist," while Hughes, an Englishman, was most likely a "born" traditionalist: instead of deconstructing tradition, he was bearing on it. His "great tradition" included Shakespeare, Blake, Coleridge, Kipling, Graves, and Dylan Thomas. Both Eliot and Hughes are poets of eschatological trend and mythologists. However, one will not find Eliot among the authorities enlisted by Hughes in his "great tradition." In the time of Hughes, Eliot was rejected due to the regular change of mainstreams trends. British poetry in the second half of the $20^{\text {th }}$ century is "tired" of urban poetry, of "Nature denial," so it comes back to its track, and the motives that existed in Eliot's poetry only in the background are now brought to the forefront.

Keywords: British poetry, modernism, T.S. Eliot, Ted Hughes, mainstream, traditionalism, postmodernism.

Information about the author: Tatiana N. Krasavchenko, DSc in Philology, Leading Research Fellow, Institute of Social Sciences Information (INION) of the Russian Academy of Sciences, Nakhimovsky av. 5I/2I, II7997 Moscow, Russia.

E-mail: tatianakras@mail.ru 
Типология возникновения модернизма в Англии - та же, что и в других странах. Адрес во времени - начало XX в., ключевые события - Первая мировая война; типологические черты: отказ от антропоцентризма; ремифологизация истории, восприятие времени не как линейного, поступательного феномена, а как единого ряда - прошлого-настоящего-будущего, в пространственной перспективе, сосредоточенность на сознании человека, т. е. «интернизация мира».

Однако у британского модернизма была и своя специфика - это прежде всего роль «пришельцев». Вирджиния Вулф и группа «Блумсбери» играли в модернизме свою роль, но наиболее радикальные новации принадлежали «пришельцам», американцам - Эзре Паунду и, главным образом, Т.С. Элиоту, ирландцам Джеймсу Джойсу и У.Б. Йеитсу, хотя следует учесть: идеологом британского модернизма был неоклассицист англичанин Томас Эрнст Хьюм.

Но то, что общеевропейская эстетическая революция проходила в английской поэзии и, шире, английской литературе начала XX в. под «флагом традиционализма» [2, с. 328] было в значительной мере делом Э. Паунда и, главным образом, Т.С. Элиота, который в І9Іо-г920-е гг. ввел в английский критико-литературный обиход понятие «традиция» и разработал ее теорию, основанную на обостренном ощущении утраты связи времен, а в I930-І940-е гг. он развил как философию культуры.

То, что в Англии это сделали американцы, лишь на первый взгляд кажется парадоксом. Архетипные положения английского консерватизма, основы английского традиционализма сформулировали и обосновали еще британские философы конца XVIII в. - Д. Юм, Э. Бёрк, А. Смит, А. Фергюсон, считавшие общество организмом, развивающимся эволюционно. 
Истоки признанного традиционализма английской культуры - в отторжении феномена социальных революций, испытанных англичанами сначала на собственном опыте в XVII в., потом в качестве наблюдателей событий во Франции. Для англичан чувство традиции органично, оно у них «в крови», на уровне «инстинкта», именно поэтому они не сознают его, т. е. «говорят прозой», не сознавая этого. Американцам же, как заметил еще в I908 г. (в книге «Вино пуритан») американский литературовед В.В. Брукс, свойственно обостренное «чувство традиции», рожденное «комплексом неполноценности», вызванным отсутствием вековых традиций.

В Гарвардском университете, где Элиот в 1906-г909 гг. изучал философию и литературу, система гуманитарного образования ориентировала его на восприятие европейской культуры как целостного явления. Именно там и тогда наметился прочный, сохранявшийся всю жизнь круг его интересов Средневековье, Данте, английская литература XVII в., французские символисты. И в дальнейшем европейские увлечения Элиота проявлялись в форме, обычной для американца, воспринимающего Европу и ее культуру в более широкой перспективе, чем сами европейцы с их острым чувством национальных различий. И в сущности почти всё, что Элиот сделал в английской поэзии и критике, он сделал именно благодаря тому, что был представителем авангардной американской культуры в культуре традиционной, английской.

Таким образом, врожденный и привнесенный традиционализм уберег английский модернизм от крайностей авангардизма.

В литературоведении, зарубежном и отечественном, преувеличивается разрыв между экспериментаторством Элиота в поэзии и его консерватизмом, традиционализмом в критике. Тут следует учитывать тот факт, что впервые он опубликовал стихи - «Любовная песнь Дж. Альфреда Пруфрока» - в чикагском авангардистском журнале «Поэтри» в I9I5 г., а «Прелюдии», «Рапсодия ветреной ночи» - в авангардистском, вортицистском журнале Уиндема Льюиса «Blast» - «Взрыв». А как критик начал печататься в престижном английском литературном издании, приложении к газете «Таймс», где порой крайне оригинальные суждения был обязан выражать умеренно и бесстрастно, как того требовали правила этого еженедельника. Таким образом, сразу даже на поверхностном уровне - возникла видимость расхождения между 
его реноме поэта-авангардиста и репутацией традиционалиста в критике. На самом деле принципиального расхождения не было; скорее можно говорить об отличии «раннего» Элиота от «позднего», по сути же его творчество цельный, единый мир, создатель которого был вполне последователен. В его творчестве - поэзии, критике, в эссе о литературе и культуре - доминирует идея «динамической традиции», не только не противоречившей его новаторским реформам в поэзии, а, напротив, служившей их источником.

Он вошел в историю литературы и культуры XX в. как реформатор англоязычной поэзии, который на новом историческом этапе привел в соответствие формы поэтического выражения и урбанистическое мироощущение человека нового века, пережившего катастрофу войны. Объявив себя неоклассицистом, он отверг либерально-романтические представления о совершенствовании человека в ходе якобы целесообразного исторического процесса. Модернисты, по его замечанию (о Джойсе), «убили XIX век», что, прежде всего, означало отказ от «светлых», романтических иллюзий и новую философию человека и времени (хотя учитывая неоднородность XIX в., теперь ясно, что модернисты многое наследовали у него, допустим, тот же Т.С. Элиот у У. Вордсворта - из его теории языка поэзии). Для понимания природы британского модернизма того этапа важно то, что Элиот выступил как поэт-урбанист, поэт городской цивилизации. В его время традиция «поэзии Природы», истоки которой - в пасторальной поэзии XVI-XVIII вв., в сентиментализме, в романтизме (ее кульминации), сохраняется, но отходит на второй план, становится маргинальной. Более того, эта традиция представлена и в творчестве самого Элиота в «Пейзажах» (“Landscapes”), пяти стихотворениях, написанных им в начале І930-х гг. в США, но и они маячат где-то в глубине, не на авансцене его творчества; авансцена - это хорошо всем известные «Бесплодная земля», «Полые люди», «Пепельная среда», «Четыре квартета».

Но и традиция, и тема Природы принадлежат сфере английской национальной органики. На какое-то время урбанист Элиот затмевает, точнее, отодвигает «поэтов Природы», но неизбежно рано или поздно все возвращается на свои круги. Во второй половине XX в. в рамках философии и эстетики модернизма мы наблюдаем ренессанс «поэзии Природы» - главная траектория английской литературы приводит к неоромантизму - к ощущающему свою особую, «пророческую миссию» Теду Хьюзу (г930-г998). Подобно Вордсворту и Теннисону, он избран поэтом-лауреатом и вписыва- 
ется в один ряд с английскими поэтами-натурфилософами, однако Хьюзу свойственно свое видение натурфилософской темы, во многом переворачивающее представления об английской традиционной поэзии природы: его интересует прежде всего противостояние человека и природы, в его творчестве романтизм сочетается с модернизмом.

Конечно, романтическая идея природы вернулась в английскую литературу еще раньше, скажем, в творчестве «оптимистического пантеиста» [I, c. 485] антропоцентриста Дилана Томаса, но в творчестве Теда Хьюза она не просто возродилась, она сочеталась с модернистским антиантропоцентризмом. Творчество Хьюза, сформировавшееся в условиях апогея технократического общества и предельно прагматико-потребительского отношения к природе, представляет собой новый образец мифотворчества; его «ядро» восстановление магического взгляда на Природу. В его поэзии воплощен глубочайший, сформировавшийся в процессе развития цивилизации конфликт между человеком и Природой в широком смысле слова. «Человек в согласии с Природой» - идеал Хьюза, совпадающий с идеалом Вордсворта, но кардинально отличающийся в деталях осуществления этого идеала, ибо между ними лег XX в. Хьюз пришел к этому идеалу лишь в поздней поэзии, пережив этапы поклонения Природе и отрицания человека. Долгое время человек в его поэзии выступал как своего рода самоубийца, разрушающий Природу и энергично подготавливающий свой крах и конец. В рамках натурфилософской темы Хьюз создал беспощадную и трезвую поэтическую аналогию, возможно, «последнего кризиса», переживаемого человеком XX в. Живший в эпоху постмодернизма, Хьюз не был постмодернистом, не занимался деконструкцией традиции, он основывался на традиции. Его традиция - это Шекспир, Блейк, Кольридж, Киплинг, Роберт Грейвз, Дилан Томас.

В отличие от постмодернистов, которые деконструировали, дробили «модель мира», т. е. целостное представление о нем, и таким образом дробили «творческую индивидуальность», Хьюз - поэт с целостным мировоззрением, яркой творческой индивидуальностью.

Постмодернизму свойственна эрозия веры в «великие метаповествования», объясняющие и тем самым легитимирующие целостные представления о реальности. Поэзия же Хьюза, особый целостный мир, - это и есть «метаповествование», дающее «модель мира», что объединяет его с художниками-модернистами - Т.С. Элиотом, Уиндемом Льюисом. 
В английской критике (Терри Иглтон и др.) наметилась тенденция рассматривать не только Т.С. Элиота, но и модернизм вообще как «транскультурную имплантацию», как революцию, осуществленную не англичанами, а американцами и ирландцем Джойсом; в поэзии и поэтике Элиота видят чужеродное явление. Причина не в том, что он действительно чужероден английской традиции. Просто его «великая традиция», включавшая в себя, кроме Шекспира, елизаветинцев, английских поэтов-метафизиков, еще и Данте, и французских символистов, «сошла со сцены» и стала маргинальной.

Но вот, например, стихотворение:

Here the crow starves? Here the patient stag

Breeds for the rifle. Between the soft moor

And the soft sky, scarcely room

To leap or soar. Substance crumbles, in the thin air

Moon cold or moon hot. The road wind in

Listlessness of ancient war,

Langour of broken steel,

Clamour of confused wrong, apt

In silence...

[3, c. 204]

Здесь голоден ворон, здесь кроткий олень

Пригоден для пули. В пространстве неярком

Меж небом и вереском ловкий прыжок и полет

Ни к чему. В тонком воздухе лунный

Либо жар, либо лед. Путь колеблется между

Равнодушием вечной вражды

И апатией сломанных копий,

Между шумом греха и безмолвием зла....

(перевод М. Ерёмина) [3, с. 205]

Чье это стихотворение?

Попадись оно мне просто на листе бумаги, я бы решила, что это Тед Хьюз. Но это Т.С. Элиот. Один из его вышеупомянутых «Пейзажей» - 
«Рэннох, долина Гленкоу». В «Пейзажах» на свой лад намечается то, что достигнет кульминации в поэзии Хьюза.

Отрицание же Элиота, «пересмотр» авторитетов вызван, вероятно, общим, закономерным, периодически происходящим в литературе пересмотром «мейнстрима» в поэзии (и, шире, в литературе, культуре): к концу XX в. английская поэзия в рамках модернизма проделала свой путь: она устала от урбанизма, от «пренебрежения Природой», «искусственности» и вернулась «на круги своя».

\section{Список литературы}

I Коренева M.M. Тед Хьюз // Энциклопедический словарь английской литературы ХХ века / отв. ред. А.П. Саруханян. М.: Наука, 2005. С. 484-487.

2 Красавченко Т.Н. Эстетическое переживание пограничной эпохи в Англии и России: традиционализм и футуризм // Кануны и рубежи. Типы пограничных эпох типы пограничного сознания: в 2 ч. / отв. ред. В.Б. Земсков. М.: ИМЛИ РАН, 2002. Ч. II. C. $328-337$.

3 Элиот Т.С. Избранная поэзия. Поэмы, лирика, драматическая поэзия. Изд-е подг. Л. Аринштейн, С. Степанов. СПб.: Северо-Запад, 1994. 446 с.

4 Eliot T.S. Four Quartets. URL: https://www:davidgorman.com/4Quartets (Accessed Io April 20I7).

5 Hughes T. Selected Poems I957-I98I. London, Boston: Faber and Faber, 1982. 238 p.

\section{References}

I Koreneva M.M. Ted Hughes. Entsiklopedicheskiy slovar' angliiskoy literaturi XX veka [Encyclopedic Companion to English Literature], ed. by A.P. Sarukhanian. Moscow, Nauka Publ., 2005, pp. 484-487. (In Russ.)

Krasavchenko T.N. Esteticheskoye perezhivaniye pogranichnoy epokhi v Anglii i Rossii: traditsionalism i futurism [Aesthetic experience of a borderline epoch in England and Russia: traditionalism and futurism]. Kanuni I rubezhi. Tipi pogranichnikh epokh - tipi pogranichnogo soznaniya: $v 2 \mathrm{ch}$. [Eves and boundaries. Types of borderline epochs types of borderline consciousness: in 2 parts], ed. by V.B. Zemskov. Moscow, IMLI RAS Publ., 2002, part II, pp. 328-337. (In Russ.)

3 Eliot T.S. Izbrannaia poeziia. Poemy, lirika, dramaticheskaia poeziia [Selected Poetry. Poems, lyrics, dramatic poetry], sel. and edited by L. Arinshtein, S. Stepanov. St. Petersburg, Severo-Zapad Publ., I994. 446 p. (In Russ.)

4 Eliot T.S. Four Quartets. Available at: https://www:davidgorman.com/4Quartets (Accessed Io April 20I7). (In English)

5 Hughes T. Selected Poems 1957-I98r. London, Boston, Faber and Faber, I982. 238 p. (In English) 
УДК 82I.І33.I

ББК $83.3(4 Ф$ ра $) 5 \mathrm{I}$

\section{«ГЕРОИЧЕСКИЕ КОМЕДИИ» КОРНЕЛЯ}

(C) 2017 г. М.Л. Андреев

Институт мировой литературы

им. А.М. Горького

Российской академии наук, Москва, Россия

Дата поступления статьи: 27 марта 2017 г.

Дата публикации: 25 сентября 2017 г.

DOI: I0.22455/2500-4247-20I7-2-3-82-93

Аннотация: В статье рассматривается особый, выделявшийся самим автором жанр драматургии Корнеля - «героическая комедия». Автор считал его положение срединным между двумя главными драматическими разновидностями, трагедией и комедией, и вместе с тем обособлял данный жанр от трагикомедии, пик популярности которой пришелся как раз на начало театральной деятельности Корнеля. Стандартная трагикомедия в первой половине XVII в. строилась либо на основе комедии (в которую добавлялись трагические интонации и обертоны), либо на основе трагедии (в которую вводились комические фигуры и ситуации). Корнель, как показано в статье, осуществляет межжанровые альянсы с помощью более сложной процедуры. Он берет из своих трагедий проблемное наполнение - конфликт с родительской властью, эвфемистически представленной через государственную власть, но лишает этот конфликт той предельной остроты и неоднозначности, которой он наделен в трагедиях. В итоге жанровые характеристики приобретают иное качество, и «героическая комедия» предстает не комбинацией разножанровых элементов, а их синтезом, образующим особый жанр.

ключевые слова: Пьер Корнель, трагикомедия, комедия, трагедия, поэтика жанра.

Информация об авторе: Михаил Леонидович Андреев - член-корреспондент РАН, доктор филологических наук, главный научный сотрудник, Институт мировой литературы им. А.М. Горького Российской академии наук, ул. Поварская, д. 25 а, І21069 Москва, Россия.

E-mail: mikhailandreevı@gmail.com 


\section{CORNEILLE'S HEROIC COMEDIES}

(C) 20I7. M.L. Andreev

A.M. Gorky Institute of World Literature

This is an open access article

distributed under the Creative of the Russian Academy of Sciences, Moscow, Russia Received: March 27, 2017.

Commons Attribution 4.0

Date of publication: September 25, 2017.

International (CC BY 4.0)

Abstract: The article deals with a special type of drama specified by Corneille himself as heroic comedy. The playwright placed it somewhere in between two major types of drama, comedy and tragedy, and at the same time distinguished it from tragicomedy that was at the peak of fashion at the beginning of Corneille's literary career. A typical tragicomedy of the first half of the $\mathrm{I}^{\text {th }}$ century derived either from comedy with the added tragic intonations and overtones or tragedy with various comic figures and situations introduced. The article demonstrates that Corneille practiced a more complex way of uniting different genres. From tragedies, he takes a conflict with parental power (euphemistically represented as a state power) but deprives it of its usual tragic severity and ambiguity. As a result, generic characteristics acquire a new meaning while heroic comedy, rather than a combination of elements of different genres, becomes a synthetic new genre in its own right.

Keywords: Pierre Corneille, tragicomedy, comedy, tragedy, the poetics of the genre.

Information about the author: Mikhail L. Andreev, Corresponding Member of RAS, DSc in Philology, Director of Research, A.M. Gorky Institute of World Literature of the Russian Academy of Sciences, Povarskaya 25 a, I2I069 Moscow, Russia.

E-mail: mikhailandreevi@gmail.com 
Пик популярности трагикомедии в европейской драматургии приходится на конец XVI - первую половину XVII вв. В Италии начало этому жанру (и одновременно начало оживленной теоретической дискуссии) положил «Верный пастух» (ок. I583) Баттисты Гварини. Во Франции после «Брадаманты» (I583) Робера Гарнье в жанре трагикомедии подвизались Александр Арди, Жан Ротру, Пьер Дю Рие, Жорж Скюдери; трагикомедией в первом издании (г637) назвал своего «Сида» Пьер Корнель ${ }^{\mathrm{I}}$. Встречаются трагикомедии и у Лопе де Вега (в частности, знаменитый «Периваньес и командор Оканьи»). В Англии шекспировской или околошекспировской эпохи трагикомедия - также один из самых популярных драматических жанров.

К трагикомедии при наличии чистых драматических форм можно двигаться как от комедии (сообщая ей трагические обертоны), так и от трагедии (вводя в нее комические фигуры и интонации). Есть мнение, что в Англии I560-I590 гг. трагикомедия опиралась на трагедию, позже - на комедию [8]. В то же время во Франции и практики, и теоретики пришли к более или менее единодушному убеждению, что основой этого жанрового типа должна быть трагедия [7, р. 274]. Немало было и тех, кто категорически отказывал трагикомедии в праве на существование: от Джазона Денореса, который в споре с Баттистой Гварини утверждал, что сама ее форма противоестественна и противозаконна, до Франсуа

I $\quad$ О трагикомедии во Франции см.: [5]. 
д’Обиньяка, который полагал, что эта позиция в жанровой номенклатуре просто является лишней².

Считается, что отличительными чертами трагикомедии этого периода является наличие в пьесе персонажей различного социального ранга, смешение стилей (или использование комического стиля для трагических предметов), смешение комических и трагических событий, счастливый поворот в финале трагического по всем показателям сюжета [6, p. Iо-II]. Эти признаки в трагикомедиях могут иметь место, но необязательно все разом: скажем, в «Сиде» персонажи принадлежат к одной сословной среде, нет никаких комических элементов, ни в стиле, ни в содержании, и имеется только благополучная развязка - отсутствие комизма не помешало Корнелю аттестовать свою пьесу в первой редакции как трагикомедию, присутствие нетрагического финала - переименовать ее в заключительной редакции в трагедию (при том, что никаких коренных изменений в свой текст автор не внес). Ясно, что в данном случае к организации драматического сюжета имеет отношение только последний признак, финал, и остается не снятым вопрос, можно ли в трагикомедии обнаружить другие характеристики столь же сильного сюжетообразующего качества. Обращение к особому виду комедий Корнеля дает возможность если не ответить окончательно на этот вопрос, то по крайней мере поставить его со всей определенностью.

Пьер Корнель в своей драматической практике использовал четыре жанровые наименования. Это трагедии (у него их двадцать), комедии (восемь) и «героические комедии» (три). Трагикомедией он называл только «Сида» в первой редакции.

Оснований для размежевания между трагедией и комедией, главными драматическими разновидностями, Корнель насчитывал два, считая их и необходимыми, и достаточными: «различие между двумя этими видами поэм зависит лишь от сана персонажей и от характера действия» [3, с. 365]. В самом деле, во всех его трагедиях на сцене цари, короли, императоры и ни в одной из его комедий нет лиц титулованных - это что касается «сана» персонажей. Что касается действия, то в трагедии оно «значительное, необычайное, серьезное» (illustre, extraordinaire, sérieuse), а в комедии - «обы-

2 «Я не хочу безоговорочно оспаривать это название, но утверждаю, что оно излишне, поскольку к поэмам со счастливым концом, если они описывают судьбы прославленных людей, вполне применимо название трагедия» [3, с. 359]. 
денное и веселое» (commune et enjouée) [3, с. 367]. Естественно, возникает вопрос, возможна ли перестановка этих характеристик. Скажем, что будет, если соединить социальный статус, присущий персонажам комедии, с типом действия, присущим трагедии? Мы знаем, что будет - будет «мещанская трагедия», но время для нее придет лет через сто, а Корнель о таком нарушении жанрового декорума пока даже не помышляет. Зато он готов, сохраняя высокий статус персонажей, приблизить к комедийному характер действия. Конечно, оно от этого не станет ни «обыденным», ни «веселым», даже сохранит «значительность» и «серьезность», поскольку в соответствии с рангом персонажей в нем будет присутствовать «большой государственный интерес» (grands intérêts d'État), но если из него удалить «угрозу для жизни, возможность гибели государства или опасность изгнания» [3, c. 367], то такое драматическое сочинение уже не будет заслуживать имени трагедии. Тем более если главный сюжетный интерес такого драматического сочинения будет сосредоточен на изображении любви: трагедия, как отмечает Корнель, требует «страстей более высоких и мужественных, чем любовь, например честолюбия или мести» [3, с. 366]. Любовь вводить в трагедию можно и нужно, но на второстепенных ролях.

Во всех трех «героических комедиях» Корнеля в действии участвуют царственные особы, присутствует «большой государственный интерес» и главным двигателем событий является любовь. В «Доне Санчо Арагонском» (I649) государственный интерес заключается в том, что королева Кастилии должна избрать себе мужа; при этом к трем кандидатам, предложенным ей на выбор, она равнодушна, а любит того, кто в число кандидатов не входит: Карлос - прославленный воин, но происхождения темного и неизвестного. Похожая ситуация в «Пульхерии» (I672): императрица Восточной Римской империи также должна для укрепления власти выйти замуж, и у нее также есть в этом деле сердечный интерес. Развязка, однако, иная: донья Изабелла смогла согласовать сердечный выбор с королевским, поскольку Карлос благодаря узнаванию превратился из сына рыбака в наследника арагонского трона - Пульхерия отказалась от Льва, несмотря на свою к нему любовь, ибо он слишком молод и не успел прославить свое имя, и отдала свою руку знаменитому, хотя и престарелому полководцу. В «Доне Санчо» любовь и 
государственный интерес пришли к согласию, в «Пульхерии» договориться не смогли.

В «Тите и Беренике» (І670) ситуация несколько иная, но коллизия в сущности аналогична. Тит любит Беренику, но не дает волю этой любви, поскольку считает, что брачный союз с царицей будет не угоден сенату и народу Рима. Сенат принимает решение объявить Беренику римской гражданкой и тем самым открывает ей путь к браку с Титом. Береника отказывается, считая, что именно так она может достойным образом ответить Риму на его благородный жест (согласовывать государственный и сердечный интерес должен мужчина - в отличие от двух других героических комедий, но решение принимает женщина - как в «Пульхерии»). Отношения внутри заглавной линии осложняются наличием параллельной пары героев: у Тита есть невеста, Домиция, которая, однако, любит его брата Домициана, но не хочет отказываться от Тита, поскольку снедаема честолюбием - ей нужен не брат императора, а сам император. Домициан также любит Домицию и ищет способы разрушить брак своего брата. В финале Тит отдает Домицию брату и считает, что теперь она согласится, поскольку сам он решил никогда не вступать в брак и объявил Домициана своим наследником. Тем самым для первой пары в конфликте государственного интереса и любви верх взял государственный интерес (как в «Пульхерии»), во второй он вообще не возникал.

В «Доне Санчо» разрешение конфликта дается самым традиционным из всех возможных способов: узнавание комедия использовала, начиная с аттической комедии и кончая Уайльдом и Шоу. Этого никак нельзя сказать о развязках двух поздних героических комедий: отказ от любовного выбора - прием непривычный, в том числе и для самого Корнеля. Нечего и говорить, что в его «негероических» комедиях любовь безоговорочно торжествует, но и для трагедий подобное решение героя - редкость. Мы встречаемся с ним, к примеру, в «Сертории», где заглавный герой любит царицу лузитанов, но готов уступить ее другому и стать мужем разведенной жены Помпея, чтобы обеспечить поддержку ее сторонников - собственно, раздвоенность между политикой и любовью, неспособность принять окончательное решение его и губит. Отказывается от своей любви и заглавный герой «Агесилая» - здесь никто не погибает, и все заключают брачные союзы. (Эту трагедию вообще можно считать своего рода подступом к двум 
последним героическим комедиям: отказ Агесилая от любви продиктован предсказуемым недовольством Спарты, которой не пришелся бы по нраву брак ее царя с персиянкой.) Между тем в «Сурене», если взять противоположный пример, герой идет на смерть, но не отрекается от любви, отказываясь подчиняться прямому приказу своего государя.

И в «Тите и Беренике», и в «Пульхерии» голос государственного интереса, диктующий героям линию поведения в любви, воплощается в голосе сената (в «Доне Санчо» - в собрании грандов). Этот голос - весьма снисходительный (герои явно ожидают от него большей строгости). В «Тите и Беренике» сенат снимает ожидаемые возражения против брака римского гражданина с неримлянкой и царицей, в «Пульхерии» - дает императрице полную волю распоряжаться своим сердцем и рукой. Поскольку речь в обоих случаях идет о браке и любовном выборе, высший государственный авторитет явно ассоциируется с родительским авторитетом. Это особенно очевидно в «Тите и Беренике»: по воспоминаниям Домиции, Веспасиан в свое время не соглашался на ее брак с Домицианом, потому что прочил ее за Тита, который тогда был поглощен любовью к Беренике - похоже, что сенат перенимает родительскую роль у покойного императора и в роли родителя оказывается более либерален.

Непреклонность, которая отнята у внешней инстанции, присваивается самими героями в отношении самих себя. Пульхерия заявляет, что лучшей гарантией ее власти будет власть над собой (Et jalouse déjà de mon pouvoir suprême, Pour l'affermir sur tous, je le prends sur moi-même). Присваиваются ими и некоторые родительские функции (право распоряжаться брачным выбором своих родных). Тит женит брата и свою бывшую невесту, Пульхерия - своего возлюбленного и дочь своего мужа.

В плане снисходительности корнелевский метафорический родитель вполне сопоставим с реальными родителями корнелевских «негероических» комедий. Вообще говоря, отцовский запрет - один из основных видов препятствия в классической комедии. У Корнеля не так, у него главное препятствие - любовное соперничество [г, с. 93-95]. Родители присутствуют, и с их стороны ожидаются некоторые возражения, которые, однако, либо не возникают вовсе, либо преодолеваются без особого труда. В «Мелите» о существовании у заглавной героини матери все знают, знают также, что она своенравна и уломать ее непросто, но когда все недоразумения, 
порожденные коварным соперником, благополучно разрешаются, Мелита удостаивает эту трудность одной фразы: Mon amour et soins, aidés de mes doulers, / Ont fléchi la rigueurs d'une mère obstinée. Мать при этом на сцене вообще не появляется. Во «Вдове» семейное положение главной героини указано названием, и она в своем выборе совершенно свободна, тогда как другая героиня, Дорис, всячески подчеркивает свою полную покорность матери и брату (votre vouloir di mien absolument dispose), и хотя время от времени сетует на свое подчиненное положение, но против него не протестует, так как ни к кому из претендентов у нее нет сильного чувства. Мать же решительно не желает к чему-либо ее принуждать (ne crains pas que je veuille user de ma puissance; cp. с pouvoir Пульхерии), тем более что у нее самой в юности был роман, не завершившийся браком из-за сопротивления родителей возлюбленного, и она не хочет, чтобы дочь повторила ее судьбу. В «Галерее Дворца правосудия» мать одной из героинь также была в юности выдана замуж против воли и именно поэтому не способна насиловать волю дочери (je ne suis pas femme à forcer son courage). А отец главной героини всецело одобряет ее роман с героем и проявляет недовольство, лишь когда в этом романе что-то начинает идти наперекосяк, и, как ему кажется, из-за капризов дочери. Жераст, отец Дафны, героини «Компаньонки», представляется поначалу более крепким орешком; во всяком случае, дочь уверена, что он не согласится выдать ее замуж за любимого, но небогатого претендента, однако, когда у этого претендента обнаруживается сестра, в отношении которой Жераст питает матримониальные планы, им быстро удается договориться. Наконец, в «Королевской площади» нежеланный претендент на руку и сердце Анжелики сговаривается с ее отцом, но лишь будучи уверенным, что оскорбленная прежним возлюбленным девушка ему не откажет. Другая героиня той же комедии также отправляет своего возлюбленного за окончательной санкцией к отцу, но не предвидит с его стороны никаких возражений. Ни того, ни другого отца на сцене мы не увидим.

Совсем другую картину мы наблюдаем в трагедиях, в тех из них, где наличествуют вертикальные родственные отношения. Может возникнуть впечатление, что они складываются в две группы: в одной («Сид», «Цинна», «Ираклий») герои мстят за отца, в другой («Гораций», «Полиевкт», «Никомед», «Родогуна») вступают в конфликт с отцом или матерью. На самом деле этот конфликт, в пределе граничащий с отцеубийством (иногда эвфе- 
мистически затушеванным), присутствует в обеих группах. Бунт Камиллы в «Горации» направлен против брата, но и против отца тоже. Герой «Сида» убивает отца возлюбленной и уже фактически невесты - это даже не эвфемизм. Эмилия в «Цинне» подбивает заглавного героя на заговор против Августа: оба не могут простить императору казнь отцов, но в отношении обоих, Цинны в особенности, Август принял на себя родительскую роль, которую и осуществляет в финале, прощая заговорщиков и сочетая их браком. В «Ираклии» дочь ненавидит императора Фоку, свергнувшего и казнившего ее отца, но здесь еще есть сыновья двух императоров, свергнутого и свергнувшего, их подменили в младенчестве, и теперь мнимое и настоящее отцеубийство замышляют оба, и мнимый, и настоящий. Раздвоенность чувств и целеполаганий также мучает двоих - и узурпатора (Фока: «Ты (Маврикий, свернутый император) мертв, но и в гробу двух сыновей обрел; Я жив, но некому мне передать престол»), и мнимого его сына («Нахожу отца я В том, кто отца меня лишил»). В «Родогуне» стремление овладеть властью и стремление овладеть возлюбленной противопоставлены как выбор между двумя одинаково морально невозможными действиями: королева-мать (Клеопатра) требует, чтобы сыновья убили Родогуну во имя преданности матери, обещая за это трон; Родогуна - чтобы убили мать во имя преданности отцу (убитому в свое время Клеопатрой), обещая за это свою руку.

Внутреннего разрешения эти конфликты не находят. Развязку всегда привносит внешняя инстанция - как в «Сиде» (король) или в «Горации» (царь). Даже результативное действие, обеспечивающее развязку, исходит от лица, постороннего конфликту - как в «Ираклии», где смертельный удар тирану наносит не его явный противник, а его мнимый сторонник. И в «Никомеде», где финал всех и все примиряет, заглавный герой оказывается в стороне от конфликта личных и внеличных долженствований и именно поэтому может выступать в отношении лиц, этим конфликтом затронутых, в качестве арбитра (его отец, царь Вифинии, хочет примирить в себе супруга и отца, Никомед советует ему быть не ими, а быть царем).

В комедиях Корнеля конфликт с родительской властью существует только в качестве возможности, которая никогда не обретает драматического воплощения. В трагедиях Корнеля, в тех, где он присутствует, 
он является главным двигателем действия. В «героических» комедиях, в отличие от комедий «чистых», этот конфликт есть (хотя тоже только в виде своего рода эвфемизма), и из него есть выход, в отличие от трагедий. В трагедии, в том же «Горации», правда и неправда противолежащих позиций не уничтожаются финальным синтезом, а входят в него, сохраняя свою оппозиционность (ср.: «Слово Корнеля, подчиняясь на редкость сбалансированному логико-риторическому принципу, ищет не разрешения противоречий, но их равновесия» [4, с. 26]). В «Тите и Беренике» и в «Пульхерии» финал подводит под борьбой позиций окончательную черту. Из трагедии в этот жанровый извод берется проблемное наполнение, но проблема не доведена до той предельной остроты, которой она в трагедии достигает - комедийная составляющая отнимает у него какую-либо неоднозначность. Героическая комедия, рассмотренная в этом свете, действительно выступает как среднее арифметическое двух жанровых полюсов. 


\section{Список литературы}

I Андреев М.Л. Классическая европейская комедия: структура и формы. М.: РГГУ, 2OII. 234 C.

2 Корнель П. Театр / сост. А.Д. Михайлова. М.: Искусство, І984. Т. 2. 688 с.

3 Литературные манифесты западноевропейских классицистов / под ред. Н.П. Козловой. М.: МГУ, І980. 6I7 с.

4 Чеснокова Т.Г. Поэтика «римской доблести» в трагедии Корнеля «Гораций» // Arbor mundi. 2009. № I5. C. 9-27.

5 Baby H. La tragi-comédie de Corneille à Quinault. P.: Klincksieck, 200I. 306 p.

6 Guthke K.S. Modern Tragicomedy. An Investigation into the Nature of the Genre. N.Y. Random House, 1966. 204 p.

$7 \quad$ Herrick M.T. Tragicomedy. Its Origin and Development in Italy, France, and England. The University of Illinois Press, Urbana, I955. 33I p.

8 Pearson J. Tragedy and Tragicomedy in the Plays of John Webster. Manchester: Manchester University Press, I980. I5I p. 


\section{References}

I Andreev M.L. Klassiceskaia evropeiskaia komedia: struktura iformy [The Classical European Comedy: its Structure and Forms]. Moscow, RGGU Publ., 20II. 234 p. (In Russ.)

2 Kornel'. Teatr [Theatre], ed. A.D. Mikhailov. Moscow, Iskusstvo Publ., I984. Vol. 2. 688 p. (In Russ.)

3 Literaturnye manifesty zapadnoevropejskikh klassitsistov [Literary Manifests of Western European Classicists], ed. N.P. Kozlovoj. Moscow, MGU Publ., I989. 6I7 p. (In Russ.)

4 Chesnokova T.G. Poetika "rimskoj doblesti” v tragedii Kornelia “Goratsij” [The Poetics of "Roman courage" in Corneille's Tragedy Horace]. Arbor mundi, 2009, no I5, pp. 9-27. (In Russ.)

5 Baby H. La tragi-comédie de Corneille à Quinault. P., Klincksieck, 200I. 306 p. (In French)

6 Guthke K.S. Modern Tragicomedy. An Investigation into the Nature of the Genre. N.Y. Random House, I966. 204 p. (In English)

7 Herrick M.T. Tragicomedy. Its Origin and Development in Italy, France, and England. The University of Illinois Press, Urbana, I955. 33I p. (In English)

8 Pearson J. Tragedy and Tragicomedy in the Plays of John Webster. Manchester, Manchester University Press, I980. I5I p. (In English) 
УДК 82I.ІІІ

ББК 83.3(4Вел)5
ДВА ЖЕНИХА И ДВА СОНЕТА:

О ПОЭТИЧЕСКИХ ФОРМАХ

В «РОМЕО И ДЖУЛЬЕТТЕ»

DOI: I0.22455/2500-4247-20I7-2-3-94-II7

Аннотация: Статья посвящена вопросам семиотики сонетной формы, использованной в шекспировской трагедии «Ромео и Джульетта». Особое внимание уделено сонетам двух женихов Джульетты, в которых отразились разные типы любовных ухаживаний. Шекспироведы многократно обсуждали в научной печати поэтическое «подношение» от Ромео Джульетте, сонетный диалог во время бала (Act I, Sc. 5, ls. 92-Іо9). Другой сонет-ухаживание - от лица Париса, произнесенный матушкой Капулетти (Act I, Sc. 3, ls. 8o-95), - читатели и исследователи обычно обходят молчанием. В этой статье сопоставлены сонеты Ромео и Париса, построенные на основе развернутых метафор (кончетто). Сонет Ромео обладает большим запасом драматической энергии, которая реализуется в непринужденном споре и сплочении заглавных героев. Семантическая заряженность этого сонетного диалога подсказывает сценический рисунок ролей, предопределяет общий ход событий. В противовес этой поэтической вставке, сонет Париса статичен, сообразен мертвой букве книжного наставления, не предполагает диалога между влюбленными и не волнует Джульетту. В статье также уделено внимание перекличке сонетов Ромео и Париса с сонетами І28 и І26 шекспировского цикла, опубликованного в I6о9 г.

Ключевые слова: вставные сонеты, сонет-диалог, усеченный сонет, сонет из двустиший, эксперименты Шекспира с формой сонета.

Информация об авторе: Елена Владимировна Халтрин-Халтурина - доктор филологических наук (РФ), PhD in English (USA), ведущий научный сотрудник, Институт мировой литературы им. А.М. Горького Российской академии наук, ул. Поварская, д. 25 а, І2І069 Москва, Россия.

E-mail: elenahaltrin@yandex.ru, el.haltrin@imli.ru 


\section{TWO WOOERS AND THEIR SONNETS: ON POETIC FORMS IN ROMEO AND JULIET}

This is an open access article

distributed under the Creative

Commons Attribution 4.0

International (CC BY 4.0)
(C) 20I7. E.V. Haltrin-Khalturina,

A.M. Gorky Institute of World Literature

of the Russian Academy of Sciences, Moscow, Russia

Received: February 28, 2017

Date of publication: September 25, 2017

Abstract: The article looks at the semiotics of the sonnet form used by Shakespeare in his tragedy Romeo and Juliet. Particular attention is paid to two sonnets, of Paris and of Romeo, in which different manners of courting are played out. The poetic "gift" from Romeo to Juliet, their shared sonnets, one complete and one interrupted (Act I, Sc. 5, ls. 92-Io9), is a notorious and much discussed piece of Shakespeare's dramatic poetry. However, the other wooing sonnet representing desires of Paris and mouthed by Lady Capulet (Act I, Sc. 3, 1s. 80-95), seems to lack that kind of attention. Our essay juxtaposes the two sonnets in question, which are built around extended metaphors (conceits). Romeo's sonneteering is endowed with dramatic power that quickens the debate and inspires accord between the title's heroes. The semantic charge of this shared sonnet resonates in the heroes' scenic gestures, prompting the play's outcome. By contrast, the rather inert sonnet of Paris is like a dead letter of bookish instruction, which neither inspires amorous response, nor moves Juliet. The article also places Romeo's and Paris's pieces against Shakespeare's sonnets I 28 and 126 of the I6o9 edition.

Keywords: inset sonnets, shared sonnet, truncated sonnet, sonnet written in couplets, Shakespeare's experiments with the sonnet form.

Information about the author: Elena V. Haltrin-Khalturina, DSc in Philology, PhD in English (USA), Leading Research Fellow, A.M. Gorky Institute of World Literature of the Russian Academy of Sciences, Povarskaya 25 a, Moscow I21069, Russia.

E-mail: elenahaltrin@yandex.ru, el.haltrin@imli.ru 
На титульном листе первого печатного издания «Ромео и Джульетты» (QI,

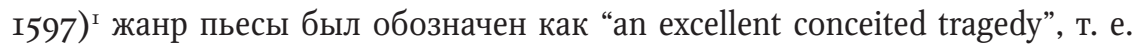
«превосходнейшая трагедия, исполненная кончетто», - указание, снятое со всех последующих, непиратских изданий. О приемах использования кончетто в шекспировской комедии и о значении высказывания "conceited comedy” нам уже приходилось говорить [7, с. 73I-733]: остроумные развернутые метафоры (кончетто) нередко вызывают улыбку. Однако что касается подзаголовка откровенно печальной истории, то сочетание "conceited tragedy” воспринимается здесь как неуместный оксюморон, который заслоняет собой и сводит на «нет» глубину горестных переживаний. Не случайно этот подзаголовок был снят с «законных» изданий пьесы. Ведь в трагедии красота речи и юмор должны не нивелировать печальную составляющую, а оттенять и высвечивать ее.

Сочетание острой грусти и красивого слова, россыпь дивных поэтических форм - вот чем богата трагедия «Ромео и Джульетта». Обращал внимание на поэтичность языка этой пьесы и А.С. Пушкин, сказавший, что в шекспировской пьесе «Ромео и Джульетта» «отразилась Италия, совре-

I Напомним: по сведениям текстологов, пьеса была написана около I595 г. В 1597 г. вышло ее первое печатное издание, которое сегодня называют «плохим» или «пиратским» кварто. Предположительно текст для этого кварто воспроизводили актеры, помнившие свои реплики лучше, чем остальные части трагедии. B I599 г. по черновику Шекспира было напечатано новое - «исправленное» - издание «Ромео и Джульетты». Это второе кварто «Превосходнейшая и наиплачевная трагедия о Ромео и Джульетте» (“The Most Excellent and Lamentable Tragedy of Romeo and Juliet”) - и является основой для современных републикаций и переводов пьесы. Мы цитируем пьесу по: [15]. 
менная поэту, с ее <...> сонетами, с ее роскошным языком, исполненным блеска и concetti» [6]. Современные комментаторы трагедии тоже обязательно упоминают присутствие в ней развернутых метафор и оригинальных сонетов [I7, loc. 437].

Разумеется, сонетный дух воцарился в «Ромео и Джульетте» не случайно: к г590-м гг. в Великобритании, благодаря творчеству Сидни, Спенсера и Дэниела, сонет зарекомендовал себя как поэтическая форма, идеальная для воплощения любовных переживаний. Примечательно, однако, что изощренность этой твердой формы, которая, казалось бы, не отвечает запросам живых диалогов (сонеты в Англии того времени широко циркулировали в списках и являлись частью рукописной и книжной культуры), не помешала Шекспиру применять сонет для самых разнообразных драматических нужд.

Трагедию «Ромео и Джульетта» Шекспир структурировал особым образом. Пьесу отличает необыкновенная стремительность развития действия. Здесь почти что можно говорить о предвосхищении Шекспиром классицистического правила единства времени. Все события трагедии «Ромео и Джульетта» укладываются в одну неполную неделю июля. Небывалая любовь героев очень быстротечна: они знакомятся в воскресный вечер, венчаются в понедельник, расстаются на заре во вторник и погибают в ночь со среды на четверг (о таком раскладе событий по дням и часам см.: [I7, loc. 842]).

Еще одна особенность пьесы - ее насыщенность всяческими разножанровыми и разностилевыми вставками. Здесь и музыкально-танцевальные номера (танцы на балу, шествие с факелами, элементы маски, элементы пантомимы, выступление приглашенных музыкантов $)^{2}$. Здесь и декламации, которые нельзя не упомянуть: панегирик

2 Обыкновение елизаветинцев сочетать танцевальные жесты с сопроводительными речами отмечает на примере английской маски шекспировского времени балерина и искусствовед В.M. Красовская: «Как театральный жанр маска утвердилась к концу XVI в. при дворе Елизаветы, пройдя примерно тот же путь, что и танцевальные интермедии в Италии и Франции. Свободную импровизацию здесь также сменила упорядоченная планировка танца костюмированных персонажей, а поэты в стихах объясняли действие. <..> [В то же время] принцип свободного варьирования не столько темы, сколько на тему, принцип окружения центрального замысла венком разнообразных эпизодов свойствен и маске» [2, с. 78]. Интересно замечание исследователя о том, что скорее поэтическое слово структурировало танец, нежели наоборот: «Вместе с музыкой на регламентацию танца 
в адрес царицы Мэб (повитухи фей), произнесенный Меркуцио в начале пьесы; словесное сражение между Меркуцио и Тибальтом, разыгранное одновременно с их сражением на шпагах; эпиталама (свадебная песнь), вложенная в уста Джульетты (начало 2-й сцены 3-го акта); альба (утреннее прощание Ромео и Джульетты и их спор о соловье и жаворонке, акт 3 , сц. 5); элегия, произнесенная Парисом в память «почившей» Джульетты. В пьесе имеется несколько клятв, а также речей на смертном одре. К другим, если можно так сказать, «церемониальным речам», относятся: приговор герцога об изгнании нарушителя порядка, предсмертная речь Меркуцио со своеобразным рефреном «Чума на оба Ваших дома», который в силу многократного повторения приобретает весомость проклятия. Слуги обоих домов - Капулетти и Монтекки - в перепалках часто прибегают к грубой брани. Монах Лоренс тяготеет к кратким изречениям нравоучительного характера (типа сентенций) и к стилю проповеди. Временами с его уст срывается нечто напоминающее проповедь-пророчество, хотя пророчествует он не об истине Божией, а о судьбе героев, чья жизнь проходит перед нами: «Тем, кто спешит, грозит паденье» предупреждает Лоренс нетерпеливого Ромео.

Насыщая пьесу регламентированными элементами, Шекспир обнаруживает виртуозное владение драматической «техникой» и включает в пьесу элементы вольной поэтической игры, импровизации. Как именно это выглядит, мы рассмотрим на примере двух инкорпорированных в трагедию сонетов, в которых воплотились сердечные чаяния двух разных претендентов на руку Джульетты: Ромео и Париса.

Эти два любовных сонета - далеко не самые приметные в тексте трагедии. Мимо них легко «проскочить», обратив внимание совсем на другие поэтические вставки: сонеты-прологи перед первым и вторым актом. В прологах Хор сообщает, что за трагедия разыгрывается на сцене. Приведем их в переводе Т.Л. Щепкиной-Куперник:

влияла английская поэзия. Известна поэма ученого юриста Джона Девиса “Оркестра, или Поэма о танце” (1596). Сюжет там таков: красавец Антиной, чтобы завоевать сердце Пенелопы, жены Улисса, рассказывает ей, как Любовь дала миру Танец, создав таким образом порядок в природе и у людей. Танцевальные размеры Девис объяснял терминами поэзии» [2, c. 79]. 
В двух семьях, равных знатностью и славой,

В Вероне пышной разгорелся вновь

Вражды минувших дней раздор кровавый,

Заставил литься мирных граждан кровь.

Из чресл враждебных, под звездой злосчастной,

Любовников чета произошла.

По совершенье их судьбы ужасной

Вражда отцов с их смертью умерла.

Весь ход любви их, смерти обреченной,

И ярый гнев их близких, что угас

Лишь после гибели четы влюбленной, -

Часа на два займут, быть может, вас.

Коль подарите нас своим вниманьем,

Изъяны все загладим мы стараньем.

Первый пролог излагает суть трагедии, а также призывает зрителей к тишине и вниманию. Следующий пролог, размещенный перед вторым актом, кажется вовсе излишним: он едва ли откроет зрителю что-то неожиданное.

Былая страсть поглощена могилой -

Страсть новая ее наследства ждет,

И та померкла пред Джульеттой милой,

Кто ранее была венцом красот.

Ромео любит и любим прекрасной.

В обоих красота рождает страсть.

Врага он молит; с удочки опасной

Она должна любви приманку красть.

Как враг семьи заклятый, он не смеет

Ей нежных слов и клятв любви шепнуть. 
Настолько же надежды не имеет

Она его увидеть где-нибудь.

Но страсть даст силы, время даст свиданье

И сладостью смягчит все их страданья.

(Пер. Т.Л. Щепкиной-Куперник)

Тем не менее и этот сонет-пролог сценически необходим. Требуется выиграть время, чтобы Ромео, ушедший со сцены после диалога с Джульеттой и кормилицей (акт I, сц. 5), успел сцену обогнуть и выйти на нее с другой стороны (начало акта 2, сц. I), дабы «подслушать» шутки в свой адрес, которые отпускают Меркуцио и Бенволио [г, p. XV].

Главная художественная роль этих прологов обнаруживается не сразу. «Сухие» сонеты Хора, взятые вместе, образуют контрастное обрамление для третьего сонета - I4-стишия совершенно иного рода, размещенного в пространстве между ними: в пятой сцене первого акта (act I, sc. 5, 1s. 92-Іо5; 1s. I06-I09). Имеется в виду диалог Ромео и Джульетты на балу, о котором много говорилось в литературоведении [5; 7; II; І2; І13]. Насколько сонеты-прологи публичны, формальны и бесстрастны, настолько сонет-диалог интимен и полон чувства. Рассмотрим его.

\section{Сонет Ромео}

Любовное подношение Джульетте от Ромео - это отнюдь не сонет-монолог влюбленного, обращенный к бессловесной даме. Скорее это сонетный «диспут» (в смысле “debate”, напоминающий диалогические эклоги), свершающийся на глазах зрителя. В устах заглавных героев совершенный английский сонет легко, без натуги, рождается как бы сам по себе - прямо в живом диалоге. С обеих сторон - с мужской и женской мысль, развиваемая в сонете, получает подпитку, а взаимно нарастающее чувство - поддержку. В сложении катренов и куплета, октета и сестета Ромео и Джульетта проявляют равные усилия. Они равноправные творцы совершенного - поистине обоюдного - сонета. 
Romeo: If I profane with my unworthiest hand

This holy shrine, the gentle sin is this:

My lips, two blushing pilgrims, ready stand

To smooth that rough touch with a tender kiss.

Juliet: Good pilgrim, you do wrong your hand too much,

Which mannerly devotion shows in this;

For saints have hands that pilgrims' hands do touch,

And palm to palm is holy palmers' kiss.

Romeo: Have not saints lips, and holy palmers too?

Juliet: $\quad$ Ay, pilgrim, lips that they must use in prayer.

Romeo: $\quad$ O then, dear saint, let lips do what hands do!

They pray: grant thou, lest faith turn to despair.

Juliet: $\quad$ Saints do not move, though grant for prayers' sake.

Romeo: $\quad$ Then move not, while my prayers' effect I take.

(He kisses her)

Ромео: Коль обижает грешная Рука

Святыню эту смелым прикасаньем,

Как два Паломника мои Уста

Загладят грех смиренным целованьем.

Джульетта: Паломник милый! Вы к Руке строги,

Она не заслужила порицанья:

Касаются с почтеньем и святых.

Ладонь к ладони - чем не целованье?

Ромео: $\quad$ Но есть ведь у паломников уста?

Джульетта: Уста творят молитву, милый друг!

Ромео: $\quad$ Молитву, Лик небесный?! Вот она:

Пусть следуют Уста примеру Рук! 
Джульетта: Тих лик небес - но слышат там мольбу.

Ромео: $\quad$ Что ж, будь тиха - я плод молитв приму.

(целует ее)

(Пер. Е. Халтрин-Халтуриной)

Образной основой для диспута служит развернутая метафора, изображающая паломников и объекты их чинных поклонений. Ромео и Джульетта дискутируют о том, прилично ли пилигримам прикладываться к святыне устами. Пилигрим, которого изображает Ромео, получает свыше (от «святыни» - Джульетты) негласное одобрение: она не противится проявлению благих чувств и поддерживает паломника в его искренних порывах. Прикосновение становится взаимным. А целованье, упомянутое в стихах, материализуется на сцене: превращается в настоящий, живой поцелуй. Так религиозной символикой освящается в этом диспуте любовь юноши и девушки. От этого шекспировского кончетто рукой подать до дерзких метафизических метафор Джона Донна («Канонизация», «Блоха», «К восходящему солнцу» и др.).

Интересна звуковая и стилистическая сторона сонета-диспута. Мужской и женский голос здесь ритмично чередуются, перекликаются эхом, сливаются в одну мелодию. В диалоге много слогов и слов, которые молодые люди повторяют друг за другом голосом и губами. Реплики Ромео и Джульетты переплетаются, образуют различные фигуры речи. Быстрая смена реплик героев (стихомифия) - вплоть до членения диалога на полустишия (hemistichomythia; см. продолжение диалога после поцелуя) - обнаруживает пылкость чувств и зажигательный темперамент говорящих. В сонете используется прием амплификации (повторение отдельных слов и речевых конструкций, накопление синонимов), результатом которого становится изменение значения и значимости слова «целованье» (kiss). Само это слово выделено рифмой и эпифорой (одинаковые окончания строф). Диалог достигает своей кульминации, когда эпифора «поцелуй» актуализируется в действиях Ромео и Джульетты: слово воплощается в дело.

Схожий прием превращения слова «поцелуй» (kiss) в живой жест после переосмысления разного вида касаний пальцев, рук и губ, использован Шекспиром и в сонетах цикла І6о9 г. Я имею в виду І28 сонет, в кото- 
ром тоже заложен большой перформативный потенциал: сонет этот вполне можно инсценировать:

How oft when thou, my music, music play'st, Upon that blessed wood whose motion sounds With thy sweet fingers when thou gently sway'st The wiry concord that mine ear confounds,

Когда на свет, о музыка моя, Из дерева ты музыку зовешь, То в пальцах столько дивного чутья, Что мой восторг меня приводит в дрожь.

Do I envy those jacks that nimble leap, Я клавишам завидую тогда. To kiss the tender inward of thy hand, Они с тобою нежно говорят, Whilst my poor lips which should that harvest reap, Покуда губы, не сорвав плода, At the wood's boldness by thee blushing stand! Поодаль от смущения горят.

To be so tickled, they would change their state And situation with those dancing chips,

O'er whom thy fingers walk with gentle gait, Making dead wood more bless'd than living lips.

Since saucy jacks so happy are in this, Give them thy fingers, me thy lips to kiss.
Я этим звонким щепкам все отдам За нежное касанье рук твоих. Ты пальцы рассылаешь по ладам, И дерево счастливей губ живых.

Как примирить нас, долго не гадай:

Ты пальцы им, а губы мне отдай. (Пер. Игн. Ивановского)

О том, какое звучание получал сонет Ромео и Джульетты на сцене, какими жестами следует сопровождать его чтение, имеются разные мнения. Поскольку знакомство героев состоялось во время бала, не исключено, что Ромео и Джульетта исполняют диалог-сонет во время танца. Вероятно, Ромео подает девушке руку. Жестом же он может дать понять, что к ней относится и слово «святыня». Джульетта в свою очередь совмещает свои ответы с красноречивыми сложениями рук. Многие постановщики пьесы синхронизируют диалог-сонет и пластический рисунок танца. Например, в знаменитой экранизации I936 г. актеры произносят это г4-стишие, исполняя павануз.

3 «Подробное описание простой паваны, представляющей собой танец, в ходе которого пары двигались вперед, поочередно исполняя простые и двойные шаги, дано в “Орхезо- 


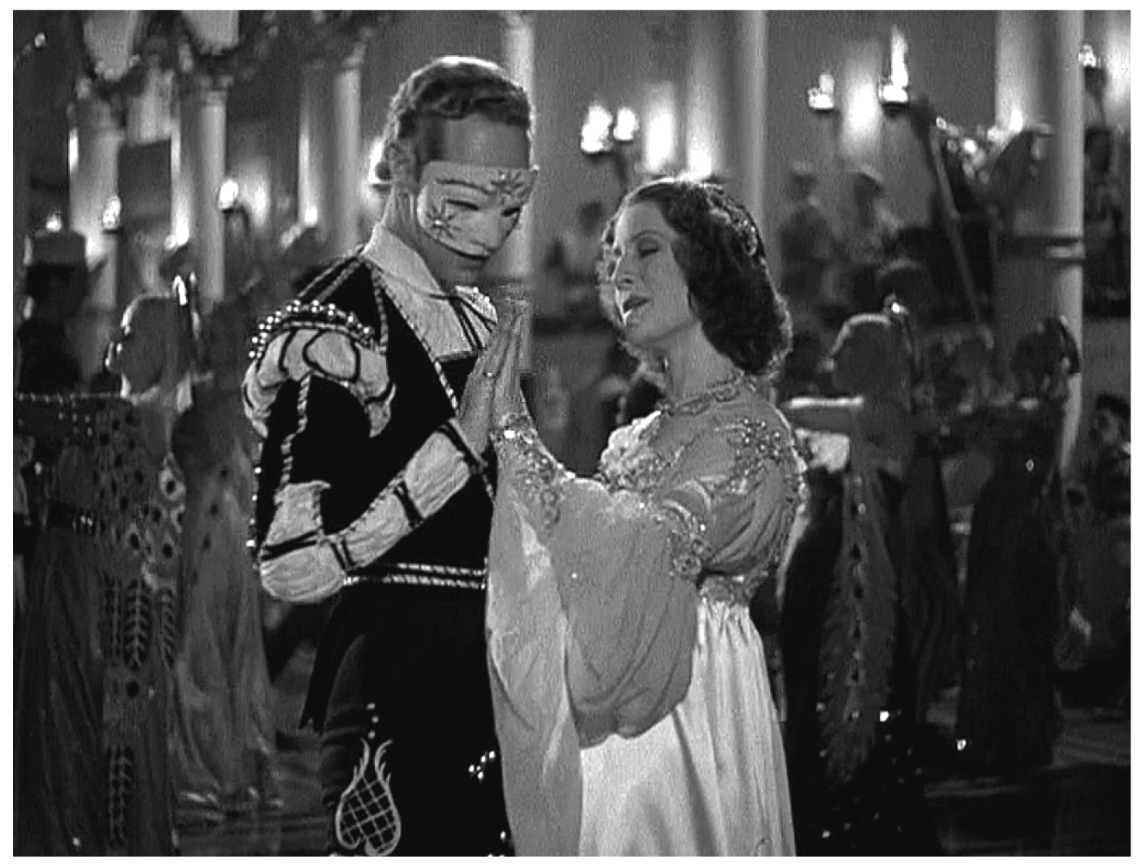

Сонетный диалог Ромео и Джульетты во время танца. Экранизация I936 г., голливудская студия MGM.

(В роли Ромео - Лесли Ховард, Джульетты - Норма Ширер; режиссер Джордж Кьюкор)

Romeo and Juliet share their sonnet while dancing. The I936 film adaptation, MetroGoldwyn-Mayer. (Leslie Howard as Romeo, Norma Shearer as Juliet; directed by George Cukor)

Конечно, павана - это «торжественный процессиальный танец» [4, с. Іо6], исполнители которого находятся у всех на виду. Личного пространства у танцоров не так много, и обмен замедленным трепетным поцелуем в этот танец вписать непросто (как, впрочем, и в исполнение алеманды, куранты и даже гальярды). Вот почему хотя бы часть сонета читается Ромео и Джульеттой в стороне от танцующей толпы.

графии” Арбо. Продолжительность танца была произвольной и зависела от музыкального сопровождения. Из описания паваны у Арбо не следует, исполнялась ли она одной или несколькими парами в колонну, но, судя по иконографии и традиции исполнения бассдансов того же периода, исполнение танца всеми парами в колонну вполне вероятно» [4, с. Iо7]. Музыка, под которую двигаются актеры в фильме 1936 г., - это павана из Арбо в современной обработке. В титрах указания на павану нет. 
Некоторые исследователи склонны вовсе выносить сонет за пределы общего танцевального шествия. Так, Алан Бриссенден, знаток литературы и балов эпохи Тюдоров, посвятивший танцам шекспировских пьес специальную монографию [9], полагает, что на сцене Ромео и Джульетта, произносящие сонет, не танцуют. Бал и музыка служат для их диалога лишь фоном [9, с. 63-65]. Пластика движений героев в этом контексте ближе к пантомиме, чем к танцу. Не случайно после бала Джульетта, говоря о юном Ромео своей старой кормилице, описывает его как «не любителя танцевать» (“hе $<\ldots>$ that would not dance", act I, sc. 5, ln. I30).

По мнению Бриссендена, нежелание Ромео участвовать в общей кутерьме, будь то танцевальное шествие или уличные бои, выделяет героя из группы других персонажей пьесы и придает ему особый “лирический” статус. И в танцах, и в драке Ромео - скорее зритель, нежели участник. Когда он подходит к Джульетте и протягивает к ней руку, словно приглашает на танец, он действует не по привычке и не по указке танцмейстера, а по зову души. Когда он вынужден схватиться за оружие и отплатить Тибальту за смерть Меркуццио - это тоже исключительный случай. Ромео дерется не потому, что он обязательный участник уличных боев. Совсем наоборот: затевать ссору не в его характере. Тем горше ирония финала дуэли. Ромео наказан и изгнан за смертоубийство, которое он пытался предотвратить.

Но вернемся к сонету-диалогу. На поцелуе сонетные речи Ромео и Джульетты не обрываются. Разомкнув губы, юные герои сразу начинают создавать следующий сонет, который прервется из-за вторжения кормилицы, явившейся звать Джульетту к матушке (в шекспироведческой литературе традиционно считается, что за сонетом-диалогом Ромео и Джульетты следует катрен оборванного сонета. См., например: [I7, loc. 705; I4, с. 64-68]).

В переводе Т.Л. Щепкиной-Куперник это выглядит следующим образом:

Ромео. К Когда рукою недостойной грубо Я осквернил святой алтарь - прости. Как два смиренных пилигрима, губы Лобзаньем смогут след греха смести. 
Джульетта. Любезный пилигрим, ты строг чрезмерно

К своей руке: лишь благочестье в ней.

Есть руки у святых: их может, верно,

Коснуться пилигрим рукой своей.

Ромео. Даны ль уста святым и пилигримам?

Джульетта. Да, - для молитвы, добрый пилигрим.

Ромео. Святая! Так позволь устам моим

Прильнуть к твоим - не будь неумолима.

Джульетта. Не двигаясь, святые внемлют нам.

Ромео. Недвижно дай ответ моим мольбам.

(Целует её.)

Твои уста с моих весь грех снимают.

Джульетта. Так приняли твой грех мои уста?

Ромео. Мой грех... О, твой упрек меня смущает!

Верни ж мой грех.

Джульетта.

Вина с тебя снята.

Кормилица. Синьора, ваша матушка вас просит.

Прозаическая реплика кормилицы, которая не пожелала заметить, какое таинство свершалось на ее глазах, вносит диссонанс в дуэт двух влюбленных. Поэтическая гармония оказывается нарушена, I4-стишие оборвано. Неожиданно прерванный сонетный диалог Ромео и Джульетты обретает весомость зловещего предсказания - становится символом оборвавшейся жизни заглавных героев.

Далее (после начала акта 2) сонеты в пьесе не встречаются. Имеется лишь одно шестистишие, которое можно присоединить к сонету, прерванному кормилицей, как некое подобие концовки. Я говорю о самых последних, заключительных строках пьесы, произнесенных герцогом Веронским. Если дополнить упомянутым сестетом оборвавшуюся беседу Ромео и Джульетты, то получим следующий составной сонет: 
Ромео. $\quad$ Твои уста с моих весь грех снимают.

Джульетта. Так приняли твой грех мои уста?

Ромео. Мой грех... О, твой упрек меня смущает!

Верни ж мой грех.

Джульетта.

Вина с тебя снята.

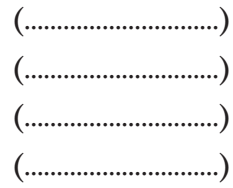

Герцог. Лик прячет с горя в облаках густых.

Идём, рассудим обо всём, что было.

Одних - прощенье, кара ждет других.

Но нет печальней повести на свете, Чем повесть о Ромео и Джульетте.

В начале этого составного сонета - мотив «снятия греха» чистым поцелуем любви; в конце - переживание катарсиса. На одном краю - дуэт Ромео и Джульетты; на другом - голос правителя их родного города, вещающий о печали и искуплении. Между этими полюсами - зияние пропущенного катрена, немое неприятие «совершенья их судьбы ужасной».

Пропущенный, немой катрен вмещает многое. Это гиблая «зона», где всё «пошло наперекос» и к чистому поцелую любви была подмешана отрава. Ее источники - давняя вражда кланов Монтекки и Капулетти, а также разлаженность действий Ромео и его наставника Лоренцо.

Предсмертная реплика Ромео, вспоминающего поцелуй Джульетты и склоняющегося над ее спящим телом, "Here’s to my love! O true apothecary, / Thy drugs are quick. Thus with a kiss I die.” (act V, sc. 3, ls. II9-I20), звучит как эхо их первого сонета-диалога. Подхватывает это эхо и пробудившаяся Джульетта: 
Что вижу я! В руке Ромео склянка!

Так яд принес безвременную смерть.

О жадный! Выпил все и не оставил

Ни капли милосердной мне на помощь!

Тебя я прямо в губы поцелую.

Быть может, яд на них еще остался, -

Он мне поможет умереть блаженно.

(Целует Ромео.)

Уста твои теплы.

(Пер. Т.Л. Щепкиной-Куперник)

Этот поцелуй, как и в первом диалоге влюбленных, оказывается прерван чужим вторжением. Услышав чьи-то приближающиеся шаги, Джульетта находит на теле Ромео кинжал и вонзает его в себя, утверждая, что для его клинка нет лучших ножен (еще одно актуализированное кончетто).

Сегодня тайна диалога Ромео и Джульетты - диалога, воплощенного в «целовальном» І4-стишии (эхо которого звучит и в конце пьесы), известна каждому шекспироведу. Однако в «Ромео и Джульетте» имеется еще один сонет-ухаживание, на который читатели и исследователи практически никогда не обращают внимание. Назовем его «сонетом Париса», ибо он является частью сватовского обряда первого жениха Джульетты. Влюбленный Парис просит руки девушки у ее родителей, а затем его голос опосредованно звучит в речи матушки Джульетты: леди Капулетти говорит дочери о брачном сговоре, нахваливая будущего зятя.

\section{Сонет Париса}

Итак, создал ли Парис какое-нибудь «сонетное подношение» Джульетте? Коль скоро Джульетта не отвечала ему взаимностью, то, разумеется, ни о каком подобии сонета-диалога здесь речи идти не может. Парис и не пытался лично объясняться с Джульеттой языком пылкой поэзии: как и подобало благовоспитанному юноше знатного рода, он честно-благородно соблюдал все приличествующие случаю условности. Поэтическим голосом Париса становится будущая теща - мать Джульетты. В объеме трех сонетных катренов леди Капулетти старается нарисо- 

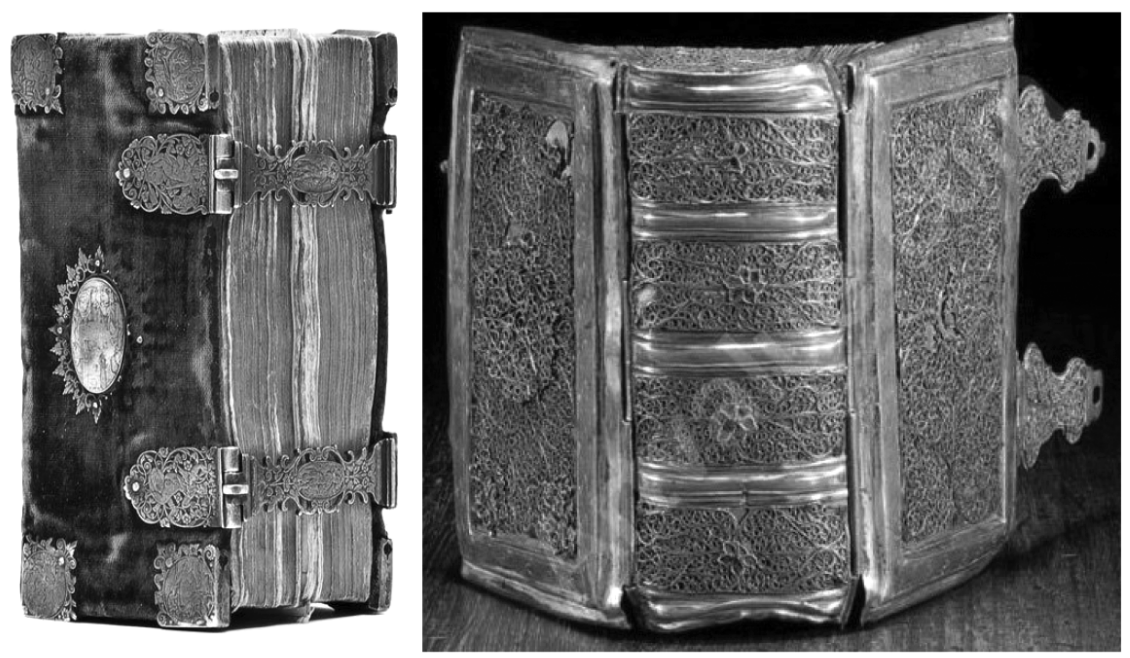

Старинные книги с «застежками» Antique books with clasps

вать для своей дочери лестный портрет посватавшегося Париса - «Читай, как книгу, юный лик Париса...». Приведем эту речь в образном и хорошо запоминающемся переводе Т.Л. Щепкиной-Куперник (перевод не эквилинеарен оригиналу), а затем только поговорим об использованной Шекспиром форме.

Читай, как книгу, юный лик Париса,

В нем красотой начертанную прелесть.

Вглядись в черты, которых сочетанье

Особое таит очарованье;

И все, что скрыто в чудной книге той,

Ты в выраженье глаз его открой.

Как книга без обложки, он лишь ждет,

Какой его украсит переплет.

Но не поймал никто еще той рыбы,

Чью кожу взять на переплет могли бы.

Да, смело может красота гордиться,

Коль эти заключит в себе страницы. 
Когда рассказ прекрасный в книге скрыт,

То ею всякий больше дорожит.

Ценней ее застежка золотая,

Смысл золотой собою охраняя.

Так раздели, что есть в его судьбе;

Не станешь меньше, взяв его себе.

Очевидно, что в центре монолога леди Капулетти - эротическая развернутая метафора. Парис нарисован как книга с ценным содержанием, а Джульетта - как драгоценная обложка («чехол» с застежками, «футляр») вместилище, предназначенное для этой книги. (Ср. предсмертное кончетто Джульетты, которая предпочла сделаться иным вместилищем - ножнами для клинка Ромео).

Теперь приведем речь леди Капулетти в оригинале и в переводе Б.Л. Пастернака:

What say you? can you love the gentleman? This night you shall behold him at our feast;

Read o'er the volume of young Paris' face, And find delight writ there with beauty's pen;

Examine every married lineament,

And see how one another lends content

And what obscured in this fair volume lies

Find written in the margent of his eyes.

This precious book of love, this unbound lover,

To beautify him, only lacks a cover:

The fish lives in the sea, and 'tis much pride

For fair without the fair within to hide:

That book in many's eyes doth share the glory, Картина требует красивой рамы,

That in gold clasps locks in the golden story;

So shall you share all that he doth possess, By having him, making yourself no less. (R\&J, act I, sc. 3, ls. 8I-94)
Что скажешь? По сердцу ли он тебе? Сегодня на балу его изучишь.

Прочти, как в книге, на его лице Намеки ласки и очарованья. Сличи его черты, как письмена, Измерь, какая в каждой глубина,

А если что останется в тумане, Ищи всему в глазах истолкованья. Вот где тебе блаженства полный И переплета лишь недостает.

Как рыба - глуби, с той же силой самой И золотое содержанье книг Нуждается в застежках золотых,

Вот так и ты, подумавши о муже, Не сделаешься меньше или хуже. 
Две первые строки этой речи леди Капулетти обращает к дочери, призывая ее ко вниманию. Далее следует сонет, написанный, как и 126 сонет цикла I609 г. («O thou, my lovely boy, who in thy power...), куплетами пятистопного ямба. Внутренняя организация монолога леди Капулетти следует обычной сонетной схеме:

- в I и 2 катренах (условно назовем их «октетом») она метафорически сравнивает Париса с прекрасной книгой, которая еще только ждет своего переплета, своей обложки. Леди использует два примечательных каламбура: характеризует черты лица Париса как “married” (т. е. «гармонично сочетающиеся друг с другом» и «супружеские»), а также называет Париса “unbound” (в одном значении - «без переплета», в другом - «не связанный ни с кем крепкими узами»);

- в 3 катрене (составляет начало «сестета») леди расписывает завидную участь обложки, которая сможет украсить такую книгу. Мать Джульетты полагает: нет унижения в том, чтобы служить чему-нибудь хорошему обложкой, обрамлением, вместилищем - само́ великое море не стыдится скрывать в своих глубинах чудесную маленькую рыбку;

- наконец, в финальном куплете-«замке» звучит призыв к Джульетте уподобиться богатому переплету - и согласиться на брак с Парисом.

Любопытно, что в этой речи имеются два окольцовывающих двустишия - первое и последнее, - которые, словно верхняя и нижняя покрышки переплета («обложка» = Джульетта), замыкают в себе три внутренние катрена («книгу» = портрет Париса). Окольцовывающие двустишия - пространство, где чувствуется присутствие Джульетты, так как именно там леди Капулетти напрямую обращается к дочери, пытаясь заручиться ее вниманием.

Если убрать эти окольцовывающие двустишия с обращением к невесте (= «покрышки переплета»), то средняя часть речи леди Капулетти (три катрена, состоящие из двустиший) совпадет по форме с сонетом I264 шекспи-

4 Сонет номер г26 издания I6о9 г. завершает часть цикла, обращенную к «юному другу». Как и подобает итоговому сонету, он подхватывает темы, оглашенные в начале этой части. Одна из них - адресованное юноше пожелание уберечь от тлена красоту его лица и фигуры. Сохранить прекрасные черты можно повторив их в детях, передав по наследству физическую привлекательность. Чтобы такая «передача» свершилась, молодой человек должен жениться и обрести потомство. Поэтому матримониальный призыв настойчиво звучит в первых I7 сонетах цикла г6о9 г. Специфика формы г26-го сонета отмечалась неоднократно. Отсутствие у него завершающего двустишия, по устоявшемуся мнению шекспироведов, означает внезапно прерванную жизнь героя. Кроме того, благодаря удале- 
ровского цикла І6о9 г. Имеется между названными стихами и тематическое сходство. В І26 сонете нарисован портрет молодого красавца, который так и не нашел своей «обложки», навсегда оставшись в состоянии “unbound”:

O thou, my lovely boy, who in thy power

Dost hold Time's fickle glass, his sickle, hour;

Who hast by waning grown, and therein

showest

Thy lovers withering, as thy sweet self

growest.

If Nature, sovereign mistress over wrack, As thou goest onwards still will pluck thee

back,

She keeps thee to this purpose, that her skill May time disgrace and wretched minutes kill.

Yet fear her, O thou minion of her pleasure! She may detain, but not still keep,

her treasure:

Her audit (though delayed) answered must be, And her quietus is to render thee.
О, милый мальчик! Времени косы Не убоясь, ты взял его часы. И вот, цветя и набираясь сил, Поклонников своих ты подкосил.
А если мать-Природа не дает Лететь тебе безудержно вперед, Она тебя оберегает тем Чтоб время не смело тебя совсем.

Но берегись! Капризна, неверна, Не станет вечно клад хранить она, И - будет день тот близок иль далек Наступит, наконец, расплаты срок. (Пер. А.М. Финкеля)

В отличие от Париса, желающего сочетаться браком с Джульеттой, юноша сонетов г609 г. избегает семейных уз. И потому посвященные ему три катрена г26 сонета можно рассматривать как антитетичные по отношению к трем четверостишиям сонета Париса. В самом деле:

- в I катрене сонета Париса провозглашается торжество симметрии и гармонии (ср. “every married lineament”), а в I26 сонете царит асимметрия и неестественность (ср. "by waning grown”, "withering/growest”);

нию итогового куплета-замка, сонет приобретает симметричность относительно среднего катрена (как у песочных часов: сосуд / узкая горловина / сосуд) (подробнее о замечаниях литературоведов по этому поводу см.: [3, с. 844-845]). Здесь, сопоставив сонет г26 с декламацией леди Капулетти, мы находим еще одно объяснение его необычной форме: три четверостишия, содержащие портрет молодого красавца, являют собой своего рода замкнутую форму: они создают иллюзию самодостаточности и изолированности. Добавление куплета «разомкнуло» бы этот круг, нарушило бы атмосферу полной «холостяцкой» (ср. “unbound”) отстраненности от всяческих связей. 
- во 2 катрене сонета Париса оглашается, чего именно недостает юноше для достижения полного совершенства (ср. "this unbound lover, / То beautify him, only lacks a cover”). В противовес тому, в г26 сонете утверждается, что совершенство на пути, избранном юношей, недостижимо (“As thou goest onwards still will pluck thee back");

- в 3 катрене сонета Париса прославляется успешный и крепкий союз равных половин: внутреннего и внешнего «сокровищ» (“That book in many's eyes doth share the glory, / That in gold clasps locks in the golden story"). В контраст тому, І26 сонет рисует союз некрепкий и неравный: юноша представлен как игрушка госпожи по имени Время - как сокровище, которое она, набаловавшись, бросит (“She may detain, but not still keep her treasure”).

Таким образом, два сонета Шекспира - І26 сонет цикла І6о9 г. и сонет от лица Париса, произнесенный леди Капулетти, - выглядят как комплементарные (companion sonnets): они дают «асимметричные» ответы на одни и те же вопросы о гармонии и совершенстве, о жизненных и семейных ценностях. К тому же эти шекспировские сонеты схожи своей редкой формой: написаны они куплетами.

Подведем нашим наблюдениям некоторые итоги. В шекспировской пьесе имеются два претендента на руку Джульетты Капулетти: это граф Парис, родственник герцога Веронского, и Ромео Монтекки. Первый - друг семьи Капулетти, достойный, красивый, воспитанный молодой человек, соблюдающий все правила ухаживания. Он был бы Джульетте хорошим, спокойным мужем и добрым другом. Второй жених, казалось бы, совсем неподходящий, «неправильный»: он - наследник вражеского клана, который - пусть и по вдохновению свыше - нарушил в своем сватовстве границы традиционных условностей. Но Джульетта выбрала именно Ромео. Их любви и посвящена вся пьеса.

Эти два типа любовных отношений нашли отражение в двух сонетах, включенных Шекспиром в текст трагедии. Оба сонета «интимные»: в тексте они не выставлены напоказ, а погружены в гущу диалога. Оба сонета строятся на основе развернутых метафор (ср. сонеты-прологи, в которых кончетто отсутствуют). Оба I4-стишия перекликаются с шекспировским сонетным циклом I609 г.: декламация от лица Париса - со г26 сонетом 
(завершающим часть к «юному другу»); диспут Ромео и Джульетты о поцелуе - со г28 сонетом (начало части, адресованной «смуглой даме»). Однако по запасу энергии, заключенной в сонете, по перформативности поэтическое подношение Ромео и подношение Париса несопоставимы. Сонет Ромео оживает в жестах героев и отдается эхом в разных частях пьесы, определяя ее исход: образы, рожденные этим сонетом, повторяются и в финале. Творческий потенциал у сонета Париса гораздо ниже: однажды полюбовавшись этой поэтической вставкой, мы забываем о ней, словно о красочной книжной странице, которую давно перелистнули. 


\section{Список литературы}

I Алексеев М.П. Пушкин и Шекспир // Алексеев М.П. Пушкин: Сравнительно-исторические исследования / АН СССР; Ин-т рус. лит. (Пушкинский Дом). Л.: Наука, Ленингр. отд., 1972. С. 240-280.

2 Красовская В.M. Западноевропейский балетный театр. Очерки истории. От истоков до середины XVIII века. 2-е изд., испр. (г-е изд. г979 г.). СПб.: Планета музыки, 2008. 320 c.

3 Макаров В.С. Примечания // Шекспир У. Сонеты / отв. ред. А.Н. Горбунов. М.: Наука, 20I6. С. 770-868. (Серия «Литературные памятники» РАН).

4 Михайлова-Смольнякова Е.С. Старинные бальные танцы. Эпоха Возрождения. СПб.: Планета музыки, 20Iо. I76 с.

5 Морозов M.M. Сонеты Шекспира в переводах С. Маршака. М.: Сов. писатель, 1948. 256 c.

6 Пушкин А.С. Примечание А.С. Пушкина к «Сцене из трагедии Шекспира: Ромео и Юлия» в переводе П.А. Плетнева // Альманах «Северные цветы на г8зо г.» СПб., І829. XI, 83.

7 Халтрин-Халтурина Е.В. Сонетные вставки в пьесах Шекспира // Шекспир У. Сонеты / отв. ред. А.Н. Горбунов. М.: Наука, 20I6. С. 725-769. (Серия «Литературные памятники» $\mathrm{PAH})$.

Халтрин-Халтурина Е.В. Шекспировские сонеты-диалоги: от «Бесплодных усилий любви» к «Ромео и Джульетте» // Известия РАН. Серия литературы и языка. 2016. Т. 75 , № 4. С. 35-4I.

9 Brissenden A. Shakespeare and the Dance. Atlantic Highlands (USA): Humanities Press Inc., I98I. Reprinted: Alton (UK): Dance Books Ltd, 200I. XII + I45 p.

Io Gill R. Romeo and Juliet: Commentary // Shakespeare W. Romeo and Juliet. Oxford: Oxford Univ. Press, I982. («Oxford School Shakespeare» Series.) Levenson J.L. The Definition of Love: Shakespeare's Phrasing in Romeo and Juliet // Shakespeare Studies. Vol. I5 (1982). P. 21-36. Levenson J.L. Romeo and Juliet before Shakespeare // Studies in Philology. Vol. 8I. № 3 (Summer 1984). P. 325-347.

I3 Perrine L. When Form and Content Kiss / Intention Made the Bliss: The Sonnet in Romeo and Juliet // The English Journal. Vol. 55. № 7 (Oct. 1966). P. 872-874.

I4 Schalkwyk D. Speech and Performance in Shakespeare's Sonnets and Plays. Cambridge: Cambridge Univ. Press, 2002. 262 p. Shakespeare W. Romeo and Juliet / Ed. René Weis. Electronic edition. L.: Bloomsbury Publishing Plc., 20I3. ePub ISBN: 978I408I5I983. ("The Arden Shakespeare” Ser.). Shakespeare W. Sonnets / Ed. with analytic commentary by Stephen Booth. New Haven: Yale Univ. Press, I977. XX +583 p. 
I7 Weis R. Introduction // Shakespeare W. Romeo and Juliet / Ed. René Weis. Electronic edition. L.: Bloomsbury Publishing Plc., 20I3. ePub ISBN: 978I408I5I983. ("The Arden Shakespeare" Ser.).

\section{References}

I Alekseyev M.P. Pushkin i Shekspir [Pushkin and Shakespeare]. Pushkin: Sravnitel'noistoricheskie issledovaniya [Pushkin: A Comparative/Historical Research]. Leningrad, Nauka Publ., 1972, pp. 240-280. (In Russ.)

Krasovskaya V.M. Zapadnoyevropeisky baletny teatr. Ocherki istorii. Ot istokov do serediny I8veka [Ballet Performances in Western Europe. Essays in History. From the Beginnings to the Mid I $8^{\text {th }}$ cent.], 2nd, corr. ed. St. Petersburg, Planeta muzyki Publ., 2008. 320 p. (In Russ.)

3 Makarov V.S. Primechaniya [Notes]. Shekspir. Sonety [Shakespeare's Sonnets], ed. A.N. Gorbunov. Moscow, Nauka Publ., 20I6, pp. 770-868. (In Russ.)

4 Mikhailova-Smol'nyakova E.S. Starinnye bal'nye tantsy. Aepokha Vozrozhdeniya [The Ancient Ballroom Dances. The Age of Renaissance]. St. Petersburg, Planeta muzyki Publ., 20IO. I76 p. (In Russ.)

5 Morozov M.M. Sonety Shekspira v perevodakh Marshaka [Shakespeare's Sonnets in Marshak’s Translation]. Moscow, Sovetsky pisatel’ Publ., I948. 256 p. (In Russ.)

6 Pushkin A.S. Primechaniye Pushkins k "Stsene iz tragedii Shekspira Romeo i Juliya" v perevode P.A. Pletneva [Pushkin's Note to a "Scene from Shakespeare's Romeo and Juliet” in P.A. Pletnyov Translation]. Severnye Tsvety na I830 g. [The Northen Flowers for the year I830]. St. Petersburg, I829. (In Russ.)

$7 \quad$ Haltrin-Khalturina E.V. Sonetnye vstavki v p'esakh Shekspira. [On Inset Sonnets in Shakespeare's Plays]. Shekspir. Sonety [Shakespeare's Sonnets], ed. A.N. Gorbunov. Moscow, Nauka Publ., 20I6, pp. 725-769. (In Russ.)

8 Haltrin-Khalturina E.V. Shekspirovskiye sonety-dialogi: ot "Besplodnykh usilii liubvi” k "Romeo i Dzhul'ette" [Shared Sonnets in Shakespeare: From Love's Labour's Lost to Romeo and Juliet]. Izvestiia Rossiiskoi Akademii Nauk. Seriia Literatury I Iazyka, 2016, vol. 75, no 4, pp. 35-4I. (In Russ.)

9 Brissenden A. Shakespeare and the Dance. Atlantic Highlands (USA), Humanities Press Inc., I98I. Reprinted: Alton (UK), Dance Books Ltd, 200I. XII + I45 p. (In English)

IO Gill R. Romeo and Juliet: Commentary. W. Shakespeare. Romeo and Juliet. Oxford, Oxford Univ. Press, 1982. (“Oxford School Shakespeare” Series.) (In English)

II Levenson J.L. The Definition of Love: Shakespeare's Phrasing in Romeo and Juliet. Shakespeare Studies, vol. I5 (I982), pp. 2I-36. (In English)

I2 Levenson J.L. Romeo and Juliet before Shakespeare. Studies in Philology, vol. 8I, no 3 (Summer I984), pp. 325-347. (In English)

I3 Perrine L. When Form and Content Kiss, Intention Made the Bliss: The Sonnet in Romeo and Juliet. The English Journal, vol. 55, no 7 (Oct. 1966), pp. 872-874. (In English) 
I4 Schalkwyk D. Speech and Performance in Shakespeare's Sonnets and Plays. Cambridge, Cambridge Univ. Press, 2002. 262 p. (In English)

I5 Shakespeare W. Romeo and Juliet, ed. René Weis. Electronic edition. London, Bloomsbury Publishing Plc., 20I3. ePub ISBN: 978I408I5I983. (“The Arden Shakespeare” Ser.). (In English)

I6 Shakespeare W. Sonnets, ed. with analytic commentary by Stephen Booth. New Haven, Yale Univ. Press, I977. XX + 583 p. (In English)

I7 Weis R. Introduction. Shakespeare W. Romeo and Juliet, ed. René Weis. Electronic edition. London, Bloomsbury Publishing Plc., 2013. ePub ISBN: 978I408I51983. ("The Arden Shakespeare" Ser.). 
УДК 82I.ІІ2.2

ББК $83.3(4$ Гем $) 6$

\section{О СИМВОЛИЗМЕ ТОМАСА МАННА}

(C) 2017 г. В.М. Толмачёв

Московский государственный университет

им. М.В. Ломоносова

Москва, Россия

Дата поступления статьи: г5 апреля 2017 г.

Дата публикации: 25 сентября 2017 г.

DOI: IO.22455/2500-4247-20I7-2-3-II8-I37

Аннотация: В статье ставится вопрос о параметрах символизма Томаса Манна, а также о манновской трактовке кризиса европейского духа. В связи с этим определены значение Ф. Ницше для Манна, переклички с произведениями О. Уайлда, А. Жида. «Будденброки» прочитаны как роман о конце немецкого Ренессанса; двойственность современного художника показана на примере новеллы «Тонио Крёгер»; парадоксы эротизма проанализированы на примере новеллы «Смерть в Венеции».

Ключевые слова: Томас Манн, немецкий символизм, конфликт бюргера и художника, здоровье и болезнь в романе «Будденброки», границы творчества в новелле «Тонио Крёгер», эротика в новелле «Смерть в Венеции».

Информация об авторе: Василий Михайлович Толмачёв - доктор филологических наук, профессор, заведующий кафедрой истории зарубежной литературы, Московский государственный университет им. М.В. Ломоносова, Ленинские горы, д. I, стр. 5I, Іі999г Москва, Россия.

E-mail: tolmatchoff@hotmail.com 


\title{
ON THE SYMBOLISM OF THOMAS MANN
}

(C) 20I7. V.M. Tolmatchoff

This is an open access article

Lomonosov Moscow State University,

distributed under the Creative

Moscow, Russia

Commons Attribution 4.0

Received: April I5, 2017

International (CC BY 4.0)

Date of publication: September 25, 2017

\begin{abstract}
The essay discusses Thomas Mann's symbolism and its parameters as well as Mann's interpretation of the crisis of European spiritual values. The author examines the role of Nietzsche in Mann's heritage as well as interconnections between Mann and Wilde, Mann and Gide. Buddenbrooks is interpreted as a novel about the end of the German Renaissance; duality of the modern artist is shown on the example of "Tonio Kröger" while the paradoxes of his eroticism are analyzed on the example of "Der Tod in Venedig."

Keywords: Thomas Mann, German symbolism, conflict between bürger and artist, health and sickness in Buddenbrooks, the limits of art in "Tonio Kröger," eroticism in "Der Tod in Venedig."

Information about the author: Vasily M. Tolmatchoff, DSc in Philology, Professor, chairman of department of history of foreign literature, Lomonosov Moscow State University, Leninskie gori, I/5I, II999I Moscow, Russia.

E-mail: tolmatchoff@hotmail.com
\end{abstract}


Вопрос именно о символизме Томаса Манна в отечественной науке практически не ставился. Основных причин тому несколько - особенности советского и постсоветского понимания реализма-гуманизма (в подобном контексте Манну отводилась и отводится важнейшая роль, но при этом он как художник становится весьма плоским, «усмиренным»), специфика понятийного словаря российской германистики (где сфера символизма как явления, якобы связанного с опытом прежде всего французской литературы или «обязательного» направленного влияния французских поэтов, чаще всего ограничивается творчеством С. Георге или, да и то весьма робко, P.М. Рильке, - и тем более, что немецкие дефиниции творчества рубежа веков, апеллируя, скажем, к «модерну», «неоромантизму», «неоклассицизму», ряду других нестойких обозначений, избегали определение символизм), а также неразработанность вопроса о параметрах символизма, увиденного в связи с немецкой литературой как в международном масштабе (см. редкое исключение из этого общего правила: [6]), так и применительно к прозе. Опираясь на наше понимание символизма [13; 5; 7; 8; 9; го; І1; І4; 2; г2], попробуем восполнить этот пробел на материале предвоенного творчества Т. Манна, хотя связь с символистской традицией, на наш взгляд, сохранилась и в более позднем манновском творчестве.

Творчество Томаса Манна при кажущейся взвешенности его манеры, как бы навсегда сложившейся по опубликовании романа «Будденброки» (І9ог), обладает немалым нервическим напряжением. Его поддерживает весьма непростой диалог писателя с самим собой. Тема этого диалога пробуждение в бюргере художника, носителя «духа музыки». С одной сто- 
роны, приобщение к этой глубинной стихии первично-поэтического рода внушает ему радость творения, с другой, отчуждает от других людей и самого себя как «просто человека», грозит его нравственному и психическому существованию.

Настойчиво обыгрывая важнейшие источники своего вдохновения (образ Фауста-художника; вагнеровское тристанизольдовское сближение любви и смерти; ницшевская поэтизация «смерти Бога» и человекобожия), Т. Манн не только нашел интеллектуальные маски для тех или иных событий своей биографии, но и откликнулся как писатель на центральную тему европейского символизма - тему глубинного кризиса европейской культуры. Он распознается прежде всего человеком Творчества, который под покровом буржуазных прогресса, благополучия, «здоровья», истертых слов, всех видов идеологического и творческого утилитаризма распознает приметы «конца века», приближающегося разгула стихии, а также пытается обратить эти мучительно переживаемые «размыв контуров», «декаданс», «болезнь» в пролог зорь, открываемых именно Поэтом новых горизонтов бытия.

Поле артистической рефлексии Т. Манна - трагическая попытка самопонимания под знаком смены органической эпохи на критическую, где истинное бюргерство, восходящее в виде немецкой народной идеи к Реформации (эквиваленту северного Ренессанса), если и может сохраниться, и в этом рок культуры, то лишь в виде аутсайдера, «иностранца» - художника. Один из манновских «художников в юности» неслучайно наделен немецкой фамилией (Крёгер) и «ненемецким» именем (Тони). Творчество Манна может рассматриваться поэтому как проблема и проблематичность бытия самого Манна: двойника - одновременно бюргера и художника, консерватора и либерала, идеолога и эстета, столпа буржуазного общества и преступника (носителя тайной вины), как серия интеллектуальных и поэтических приближений к своему «другому» (другим) «я», «невыразимому».

Все ключевые тексты Манна - так или иначе о творце и творчестве, о пересмотре границ искусства (соотношение искусства и жизни, искусства и морали, искусства и зла), его многозначности и неразрешимых в конечном счете дуализмах (эрос и танатос, дух и тело, хаос и порядок, мораль и преступление).

И в этом смысле он, конечно же, как символист европейского масштаба, современник, к примеру, А. Жида и О. Уайлда, Г. Д’Аннунцио и 
М. Пруста, Р.М. Рильке и К. Гамсуна (с которыми легко сопоставим), так и автор, давший своему символизму немецкое, и во многом вдохновленное Ф. Ницше, неоромантически-фаустианское прочтение. Опыт сближения со своим даймоном (см. проницательное название эссеистической книги С. Цвейга «Борьба с демоном»), пакт с ним давался Манну, насколько можно судить по его романам, новеллам, записным книжкам, непросто, нередко был связан с образом болезни, «ныряния вглубь», самоубийства.

У этого потомственного бюргера, человека, исходно словно не предназначенного для писательской судьбы, периодически давали о себе знать некие комплекс вины, очарованность смертью. «Больны» и Ганно Будденброк, и Тонио Крёгер, и Густав Ашенбах, и Ганс Касторп («Волшебная гора»), и Адриан Леверкюн («Доктор Фаустус»). Но болезнь здесь и высокое состояние духа... Без преувеличения, болея собой, Т. Манн болел Германией (тема книги «Рассуждения аполитичного»), болел братом Генрихом (их ссора в годы Первой мировой войны не прошла бесследно), детьми (Клаус Манн покончил с собой в І949 г.), болел своими «вечными спутниками» (Гёте, Шопенгауэр, Вагнер, Ницше, Фрейд).

В этом смысле Т. Манн, несмотря на обостренное германофильство и сосредоточенность на взлетах и провалах немецкой фаустианской идеи, один из самых русских европейских авторов. На свой манер восприняв Л. Толстого, Ф. Достоевского, он, сохраняя индивидуальность, говорил по существу на одном языке с Д. Мережковским, А. Блоком, А. Белым, Вяч. Ивановым, Н. Бердяевым. Сближает их, помимо частных схождений, напряженное внимание к тому, что А. Блок в докладе г9І9 г. назвал «крушением гуманизма», а Н. Бердяев в І924 г. - «концом Ренессанса» (книга «Новое средневековье»): «По всем признакам мы выступили из дневной исторической эпохи и вступили в эпоху ночную. Это чувствуют наиболее чуткие люди. Плохо ли это, мрачно ли это, пессимистично ли это? Самая постановка такого рода вопросов совершенно неверна... человечество ищет новой символики... Мы живем в эпоху обнажений и разоблачений» [I, с. 223, 225, 229].

Для большинства читателей роман «Будденброки: История гибели одного семейства» был и не без некоторых оснований остается сагой о четырех поколениях одной семьи (приблизительно между I835 и I880 гг.), в которой описания быта, нравов перемежаются с различными сценами, как 
отчасти комичными (история женитьбы Тони на Грюнлихе), так и трагическими (смерть старой консульши). В силу определенной иронии именно по таким образам немцев зарубежная аудитория долгое время будет составлять свое представление о Германии, немецком...

Читатель же, в большей или меньшей степени знакомый с обстоятельствами жизни Т. Манна, ощущает, что роман является отнюдь не опытом элегичного национального бытописательства. С одной стороны, это ответ молодого автора на вызов «литературы прорыва», натурализма скандинавских авторов (Г. Банг), с другой - апология того, как становятся художниками в нехудожнической среде. В соответствии с натуралистской мифологией, которую Манн во многом разделяет, Будденброки от поколения к поколению вырождаются. Правда, слабея в одном, и исторически главном для себя (торговля зерном в ганзейском городе, духовном продолжении Реформации), они начинают проявлять себя эстетически, демонстрируют гибельную для продолжения рода «тонкость нервов». Таково неожиданное для практического человека желание взять в жены «иностранку» (именно в роли чуждого бюргерскому миру элемента выведена музицирующая Герда, мать Ганно), читать шопенгауэровскую книгу «Мир как воля и представление» (консул Томас Будденброк), интересоваться театром (Христиан Будденброк) или всецело посвятить себя музыке (Ганно). Разумеется, что созерцатель, приоткрывший завесу мира, впитавший в себя бациллу «небытия», и тем более музыкант, играющий романтическую музыку (музыку смерти), нежизнеспособны, поскольку идут против естества, будденброковской (бюргерской) природы.

По мере нарастания этого мотива (отречение от практической жизни) роман начинает читаться как повествование об уходе в прошлое некоего золотого века (что также не противоречит интересам натурализма), «детства». Им до поры до времени было бюргерство, защищенное стенами города (для старого Любека образ «внутри стен» более чем реален), богатого дома, сословного снобизма. В нем сочетаются деловитость (тщательное ведение торговых книг и, по аналогии, записей в семейной Библии), своеобразное эпикурейство, любовь к навсегда заведенным ритуалам. И вот, в этот мир, где, казалось бы, вечно «плодятся и размножаются», «вечно торгуют», «вечно играют», где фигурируют бессмертные торговый дом, люди, вещи (Иоганн Будденброк с его Библией, семейный доктор Грабов, массив- 
ная серебряная салатница), приходят упадок, разорение, смерть. Старшие Будденброки, олицетворение всего естественного, к этому не готовы. Сцена смерти старой консульши - одна из самых сильных в романе. Тело, пораженное недугом, уже сдалось, но сознание долгое время не желает расставаться со всем земным. Однако эта кончина по-своему героична.

По мере того как эпический театр жизни становится иллюзорным, меняется в романе и образ смерти. На смену бившей ключом деловой энергии, гармоничным женитьбам, кончинам в окружении родных приходят усталость, бесконечные разводы (Тони Будденброк), одинокая гибель на улице из-за больного зуба (Томас). Здесь следует упомянуть и другое обстоятельство. Будденброки в годы процветания олицетворяют негоциантов старого типа. Этих людей Ганзы интересует дело и действие как таковые, они стихийно свободны, а потому уверены в себе, по-своему честны. Новое же поколение торговцев (его олицетворяют Хагенштремы), уже не торговых аристократов (герб Будденброков - болотистая равнина с одинокой ивой на берегу), а законченных буржуа, интересуют только деньги и их символы (одежда, дом). Ради них они идут на обман, сомнительные сделки, спекуляции. В качестве примет наступления капиталистической цивилизации в романе фигурируют не только характерные для мира натурализма безналичный расчет (франкфуртский капитал), железные дороги, тротуары, увлечение театром, вульгарность нуворишей, но и массы, массовое. Золотой век людей, в которых действие и дух нерасторжимо связаны (учитывая историю Любека, Манн имеет в виду «ренессансный», в его понимании лютеровско-дюреровский тип немца), начинает активно уходить в прошлое после г848 г. Революция в Любеке показана в романе несколькими энергичными штрихами. Их цель - показать, что права Будденброков мира Будденброков на глубине поколеблены и что цельной личности, открытой миру, природе, делу, противостоит ограниченная городская толпа.

Подобный антилиберальный акцент (Манн неслучайно ценил К. Гамсуна) помогает понять, как Т. Манн модифицирует натурализм. Его критика современности перерастает из социально-биологической в духовно-психологическую и культурологическую. И ее главные темы - конфликт культуры и цивилизации, культа и культуры, а также опыт самокритики как самопознания. Нельзя не заметить, что никто из поздних Будденброков не осуждается за их «падение». Даже Христиан в желтом клетчатом костюме 
(деталь, словно заимствованная из гамсуновских «Мистерий») выведен под знаком своего рода вечности. Через эти фигуры, даже через их слабость действует рок северной культуры, пережившей свою материальную кульминацию, но все еще способной спеть свою лебединую песнь на территории творчества. В докладе с характерным названием («Любек как форма духовной жизни», Lübeck als geistige Lebensform, I926) Манн говорит о «Будденброках» как о «натуралистическом романе, интернациональном по литературной форме», сочетающем «пессимистическую метафизику с сатирической характеристикой» [3, т. 9, с. 72]. Уже в этом смысле бюргерство в «Будденброках» не столько конкретно-историческое, социальное, топографическое понятие, сколько гештальт, форма мировидения, духовного пейзажа, - составная часть «духовной истории немецкого бюргерства вообще» [3, т. 9, с. 77]. Подобный идеалистический индивидуализм, квинтэссенцию которого Манн находит в Гёте, охватывает, в его оценке (см. также доклад «Гёте как представитель бюргерской эпохи», Goethe als Repräsentant des bürgerlichen Zeitalters, I932), четыре столетия (XV-XIX вв.). За ним музыкальный порыв к бесконечности («мощная энтелехия»), имперская открытость миру, а также принадлежность органическому началу, стихии жизни, которая, противясь формализации, «не дает [подлинному бюргеpу. - В.Т.] себя увлечь ни вправо, ни влево...» [3, т. 9, с. 9І].

Речь, таким образом, идет в «Будденброках» об архетипичном - и о «конце северного Ренессанса» и, согласно логике ницшевского понимания нигилизма, об отпадении культуры от культа, торжестве познания над жизнью и волей, о трагической остановке роста. Упоминание Ницше в этом контексте не случайно. Его сочинения с середины г890-х гг. стали для Манна тем «магическим экраном», «другим я», на которые он осознанно или неосознанно проецировал свои самые сокровенные мысли и переживания.

В эссе «Философия Ницше в свете нашего опыта» (1947) Манн отмечает, что Ницше был «крупнейшим критиком и культурфилософом, первоклассным, европейского масштаба прозаиком и эссеистом шопенгауэровской школы... <...> Философия не холодное абстрагирование, нет, это переживание, страдание, самопожертвование во имя человечества; и Ницше знал это и был сам тому примером. И хотя путь его был ложен... его любовь все же принадлежала будущему, и грядущие поколения, точно так же, как и мы, чья молодость обязана ему столь многим, еще долго будет прико- 
вываться взглядом к этому образу, исполненному хрупкого и внушающего уважение трагизма, озаренному грозными зарницами перевала, разделяющему два столетия» [3, т. Іо, с. 355-356, 39г].

Ницшевский пласт «Будденброков» связан с темами апологии жизни (органической целостности культуры) и болезненности современного гения. Именно поэтому роман может считаться городской хроникой по форме и философическим рассуждением по глубинному содержанию. Во времена Иоганна Будденброка-старшего сама жизнь была искусством, полновесным проявлением бюргерского гения. Раздвоение бюргера на делателя и созерцателя, лишение жизни спонтанности являются, по логике повествования, главными приметами духовно-исторического кризиса. Бюргер, выражаясь иначе, лишается дееспособности в той степени, в какой в нем убывает бюргерский дионисизм - та этическая веселость духа, которая предшествует всякому поступку. Это особый, отличный от церковного, катехизис веры. На его наличие в классическом бюргере намекается уже в первой главе романа. Мало-помалу эта сила (наличие которой в прошлом Манн вслед за Ницше берет за поэтическую аксиому) начинает слабеть. И напротив, эстетическое начало, романтика заявляют о себе все сильнее и сильнее. Томас Будденброк на первый взгляд мало отличается от отца и деда (основателя торгового дома). Однако при ближайшем рассмотрении перед нами психологически иной склад личности. Дело для него долг, обязанность - традиция, получившая формализацию, застывшая. Этот трудноуловимый, но очень существенный, согласно Манну, сдвиг лишает его радости созидания. Томас психологически двойственен: торговец в нем приходит в противоречие с эстетом (умное лицо, «копанье в собственной душе», усы по французской моде, портсигар с тонко инкрустированной крышкой, чтение Шопенгауэра и т. п.), невольным актером, который имитирует деятельность, инстинктивно страшась ее. Рядом с Томасом его антипод и в то же время двойник - брат Христиан. Этому «романтизму» передается и физическая болезнь. Под стать ей грязь, дождь, те далеко негероичные (и как бы гиперъестественные) разновидности вечности, которые окружают Томаса перед смертью... Однако болезнь помимо своего прямого значения имеет и переносное: существуют небуржуазные формы здоровья, как существует, помимо плоского существования, углубленное бытие. 
Итак, Томас Будденброк оказывается «последним негоциантом», тогда как его в юности умирающий сын Ганно - «первым художником», который влюблен в море, музыку. Философия романа, безусловно трагическая по звучанию, отнюдь не безысходна. Ганно в чем-то ничем не уступает предкам. Ему-таки присуща искра будденброковского «бюргерства». Но он - такова особенность «конца века»! - воспроизводит ее не в физическо-материальной, а в чисто духовной форме, а потому нежизнеспособен. В ином виде подлинное бюргерство в век лжебюргеров сохраниться не может. В то же время Ганно не страшится смерти и даже ищет ее... «Музыка» Будденброков в прямом и переносном смысле покинула храм (средоточие жизни) - мальчика обучает игре на инструменте органист знаменитой любекской Мариенкирхе, - торговую фирму (должна быть продана), дом (куплен Хагенштремами) и устремилась в небытие... Но она, музыка культуры (не конкретной личности!), неуничтожима. В этом Манн по-своему солидарен с Р. Ролланом (см. финал романа «Жан-Кристоф»). Грядет новое, новый цикл.

Концовка романа осталась многими непонятой. Собрание женской части Будденброков (подобие «великих матерей»), описанное в последней главе, намекает на возможность нового катехизиса веры, «нового гуманизма». В этом смысле только что умерший Ганно - Гермес-Тристан, посланник не только ночи, смерти, мучений любви, но и любви освобождающей, того откровения будущего, о котором говорится с полным убеждением, но при этом весьма туманно: «Это сбудется!» Как искатели этого нового света (Тонио Крёгер, Густав Ашенбах, Ганс Касторп, Адриан Леверкюн), так и его загадочные носители (например, поляк Тадзио в «Смерти в Венеции», русская Клавдия Шоша в «Волшебной горе») возникнут в прозе Т. Манна еще не раз.

Роман «Будденброки» содержит лейтмотивы большинства будущих произведений Т. Манна. Лейтмотивен он и по повествовательной технике. Это относится, во-первых, к общему импрессионизму романа, где отсутствует сквозной нарратив - его заменяют в виде фрагментов и «волн» целые 87 главок (они неравномерно распределены по II частям, в каждой из них своя ритмически-музыкальная тема), которые, сплетаясь между собой, образуют общее полотно текста. И, во-вторых, - к устойчивым портретным, речевым, а также символическим (вода, дождь как образы смерти, вечности) характеристикам. 
В новеллах, непосредственно посвященных творчеству, читатель встречается в одном случае с «художником в юности» («Тонио Крёгер», I903), а в другом - со стареющим писателем («Смерть в Венеции», I913). Общим для них является романтическо-символистское представление о художнике как одиноком гении, носителе неразрешимого конфликта между творчеством и жизнью. В новелле «Тонио Крёгер» об этом конфликте говорится следующим образом: «Литература не призвание, а проклятие. <...> Когда ты начинаешь чувствовать его на себе? Рано, очень рано. В пору, когда еще нетрудно жить в согласии с Богом и человеком, ты уже видишь на себе клеймо, ощущаешь свою загадочную несхожесть с другими, обычными, положительными людьми; пропасть, зияющая между тобой и окружающими, пропасть неверия, иронии, протеста, познания, бесчувствия становится все глубже и глубже; ты одинок - и ни в какое согласие с людьми прийти уже не можешь. <..> познавать, примечать, наблюдать - с усмешкой откладывать впрок плоды наблюдения даже в те минуты, когда твои руки сплетаются с другими руками, губы ищут других губ, когда чувства помрачают твой взгляд...» (пер. Н. Ман).

«Тонио Крёгер» предлагает развитие темы артиста, отчетливо намеченной в «Будденброках» лишь в заключительных частях. Тонио - продолжение Ганно, с тем лишь отличием, что любекская страница его биографии перевернута. Точнее, он - молодой писатель, живущий на юге, в Мюнхене, достигший известности, но продолжающий вспоминать о детстве, той теперь уже «другой стране», где у него, бюргера по плоти, сформировалось небюргерское чувство вины, непохожести на других, словом, чувство творческого призвания. Стихийное, несцентрированное, с пробуждением любви сходное, оно поначалу обратилось на друга (голубоглазый Ганс Гансен), затем - на белокурую девочку и девушку (Инге Хольм), чтобы в конечном счете стать страданием, одиночеством, гамлетизмом. Таково алиби искусства, любви ко всему без права обладания им. Но белокурым, голубоглазым, танцующим, с аппетитом едящим искусство, внушает инстинктивное опасение. Ганс и Инге, пройдя мимо Крёгера, не узнают своего друга детства. Он - чужой на празднике жизни.

Конфликт бюргера (толпа, здоровье) и художника (поэт, болезнь) таким образом - реальность жизни Тонио, стоящего на пороге зрелости (ему около тридцати лет). Параллельно это состояние его внутреннего мира - 
инструмент иронии, борьбы с самим собой. То, что для стороннего взгляда является олицетворением завершенности, «моральности» тщательно отделанного художественного текста, для самого художника иллюзорно. Лишь он, этот вечный лицедей, знает сполна, что стоит за этой фикцией и сколь аморальны, преступны исходные импульсы творчества, так или иначе связанные с Дионисом, эротикой, растерзанием Орфея, как знает он, что самовыражение «я» (особый и очень изощренный вид сладострастия) в конечном счете безразлично к материалу, нарциссически холодно. Тонио Крёгер даже сомневается, «мужчина ли художник», постоянно любя, «утверждая человеческое и не имея в нем своей доли»? Эти рассуждения Крёгера, как показывает Т. Манн (перенося наблюдения Ф. Достоевского о преступнике на творческую личность), не лишены некоторых оснований. Когда писатель возвращается на родину после долгих лет отсутствия, его принимают в силу недоразумения за авантюриста. По трагической иронии, Тонио отпускают в тот момент, как только он предъявляет документ своего alter ego - гранки рассказа. То есть Крёгер лишний раз вынужден осознать, что «домой возврата нет», что бюргерский «рай» утрачен... Случайная встреча с Гансом и Инге на взморье лишь укрепляет его в этом трагическом признании.

Обнаруживая глубокое понимание романтического типа творчества (с ним в новелле косвенно соотнесены как Шекспир, так и Ницше), Т. Манн, скорее, проблематизирует его и, проблематизируя, ставит к нему вопросы, чем отрицает.

Поэтому на новелле, повторяющей и несколько расширяющей мотивы (море, музыка, болезнь, художник-бюргер), сюжетные ходы «Будденброков» (связанные с Ганно), лежит несомненная печать эссеизма, автокомментария. По существу, несмотря на наличие нескольких вставных сюжетов, ироническую интонацию, это монологическое рассуждение о поэте, «стоящем между двух миров» и ни в одном «не чувствующем себя дома». Наличие эпизодически напоминающего о себе адресата крёгеровской исповеди (русская художница Лизавета Ивановна, нарекающая Тонио «заблудшим бюргером») не меняет этого обстоятельства. Сократически беседуя прежде всего с самим собой, проводя своеобразный опыт психоанализа, Тонио не только пускается в воспоминания, но и, приоткрывая тайны ночной стороны творчества, пытается оправдаться. Он желал бы верить, что интерес к бюргерам (как материалу творчества), а также бюргерское нача- 
ло в нем самом спасут его, не дадут музыке, лирике оторваться от материи, утратить тепло человечности.

По сравнению с «Будденброками» в «Тонио Крёгере» больше говорится об эротическом томлении. У «здоровяков» Инге и Ганса любовь, в восприятии Тонио, гармонична; ее символическое воплощение - танцы. Самому же Крёгеру, «соглядатаю» чужого счастья, она несет боль. Танцы для него - «пошловатая мелодия». Вестницей любви как дисгармонии, особого недуга, рокота моря за окном становится в новелле несколько таинственная фигура - «немного горбатая» датчанка. Встреченная Тонио на танцах, она в какой-то момент теряет сознание от атмосферы залы, буквально наэлектризованной эросом.

Тема эротизма творчества центральная в новелле «Смерть в Венеции». Поначалу новелла была задумана в виде осовремененной истории того, как Гёте в преклонном возрасте страстно полюбил І7-летнюю Ульрику фон Леветцов, встреченную им в курортном Мариенбаде (I82I), где она находилась с матерью и сестрами. Затем к мотиву «унижения старости любовной страстью» Т. Манн, по его собственному выражению из письма к К.М. Веберу (4.07.I920), добавил «одно лирически-личное дорожное переживание, надоумившее меня заострить тему “запрещенной любви”...» [4, с. 27]. Писатель не обманывал. Как установили биографы, находясь в Венеции в г9гі г., он открыто восхищался юным польским бароном Владиславом (Владзио) Моесом.

«Двужалость» красоты и пола обыгрывается Т. Манном на примере любви 53-летнего писателя Густава фон Ашенбаха к юному Тадзио (Тадеушу). Ашенбах по сюжету - всегермански и даже всемирно известный прозаик, который посвящен кайзером в дворяне за роман о Фридрихе Прусском («Майя»). Помимо того, что Ашенбах пишет о монархе, заложившем фундамент новейшей прусской государственности, он сам является олицетворением неуклонной воли, строжайшей творческой дисциплины. Однако, упрямо, чуть ли не механически отсеивая слова и выстраивая их в аполлонически безукоризненном порядке, Ашенбах перестал получать от творчества радость. И вот, «новый Флобер», всем жертвующий ради законченности формы, спасительной «иллюзорности» творчества, встречает на улице Мюнхена загадочного человека с альпийской палкой в руках. Он принимает этого незнакомца с рыжей бородкой («кобольда» с молотком? «Гермеса» с 
жезлом? Ницше, бежавшего от немецких «сумерек» в Италию?), который расположился не где-нибудь, а на ступеньках византийской часовни, за вещий знак и отправляется в Венецию. Однако путешествие, задуманное как гигиеническая мера от творческой усталости, оказывается роковым.

В Венеции Ашенбах проходит испытание чем-то в его положении классика, моралиста, верноподданного явно недозволенным. Он влюбляется в четырнадцатилетнего мальчика, прибывшего с семьей на отдых у моря. Этим «катастрофе», «разгулу чувств» символически соответствуют и атмосфера Венеции (города-призрака; города карнавала и роковых романтических страстей; города Байрона и Вагнера; города Аида, смерти, кладбищ всяческих знаменитостей; города музеев, самой музейности цивилизации, из которой ушла, оставив после себя одни декорации, «жизнь» - это ощущение, как известно, испытал А. Блок, посетивший Венецию в г909 г.), и неожиданно вспыхнувшая эпидемия азиатской холеры. Подобно ордам варваров, она грозит опустошить некогда всесильный аванпост Запада, но всячески скрывается лицемерными властями. Пир любви во время «чумы» стоит писателю жизни. Когда до Ашенбаха доходят вести о холере, он не стремится покинуть город, не сообщает матери Тадзио об опасности. Никогда он не чувствовал себя столь раскрепощенным, столь радостным, как в минуты созерцания выходящего из воды «божественно прекрасного» Тадзио. Но этому наслаждению приходит конец. В день отъезда польской семьи из Венеции Ашенбах, в последний раз наблюдая своего любимца на пляже, умирает у кромки моря. Физическая причина его смерти - холера, но духовная (и известная только самому писателю) - совсем иного рода. «Потрясенный мир» узнает лишь о первой.

Надо сказать, что в своей новелле Т. Манн коснулся скандальной темы. Чего больше в ашенбаховской «смерти от любви»? Осмысления соответствующей романтической (различные физические и умственные перверсии в художественном мире Байрона, Э. По, Бодлера, Достоевского; «Тристан и Изольда» Р. Вагнера, который, отметим, умер, находясь в Венеции) и символистской (противоестественное в «Наоборот», «Портрете Дориана Грея», «Имморалисте») образности? Страсти, описанной В. Набоковым на примере Гумберта Гумберта («Лолита», 1959)? Апологии гомосексуальности как особой разновидности эстетизма (в этом ключе экранизировал новеллу в І97І г. Л. Висконти)? Чего-то глубоко личного, уходящего кор- 
нями еще в детство, а затем сублимированного в виде оппозиции бюргер (гражданин, восхищающийся искусством, но при этом относящийся к нему с некоторой настороженностью) / художник (личность с «нечистой совестью» - носитель внутренних терзаний, гордо скрываемого страдания)? Обойти эти или подобные им вопросы при чтении новеллы Т. Манна весьма сложно. Разумеется, Ашенбах болен, как больны и другие центральные манновские персонажи, что делает бытие, окружающее их, также больным гротескным, несколько фантастичным, театрализованным.

Но при этом столь же очевидно, что новелла не писалась с целью именно развенчания и осуждения романтическо-декадентской личности, как это считалось в советском литературоведении. В то же время она иронична, и «лирическое начало» граничит в ней с «самоотчуждением», самоанализом. Не является она неким исключением из правил у Манна. Прототип Тадзио имеется уже в «Будденброках» (граф Кай). Да и в целом новелла связана с большинством манновских произведений. Именно при работе над ней у немецкого писателя зародился замысел сюжета о «простаке», который, как и Тангейзер, попадает в грот Венеры. Реализацией его со временем стал роман «Волшебная гора».

Итак, «Смерть в Венеции» - один из самых острых, концентрированных у Манна опытов самокритики, «авантюры духа». Главное в новелле - как творчество в целом, так и эротическое, демоническое (согласно сократовскому пониманию) начало в нем. Вне всякого сомнения, Манн утверждает, что демоническое реально. Кому же служит художник, «любя» (будучи ранен стрелой Амура-Эрота-Пана и летя, подобно Психее, на огонь) и «творя», оборачивая «недозволенное» в «дозволенное»? Идеалу, высокому типу красоты или своей слабости? Да и сам эрос, прислужник ли он творчества или его сущность, болезнь (ужас) или здоровье, трагедия или счастье художника, мираж обостренных нервов или реальность?

Заостряя эти вопросы, Т. Манн смотрит на Ашенбаха как бы чужими глазами, иронически. Такой взгляд не столько оценочен, сколько учитывает наследственность героя. Ашенбах двойственен генетически (отец из потомственного рода силезских офицеров и чиновников, мать - дочь чешского капельмейстера), интеллектуально (он борется с самим собой, с морально недолжным, и лишь сны напоминают ему о звере, притаившемся в чаще). К тому же Ашенбах иностранец, отправлен в «другую страну», 
где мысленно вступает в отношения и с другим иностранцем, и через него с чужим, ранее неизвестным ему богом радости. Чужим он становится и для себя самого, что делает его носителем маски, актером, а Венецию (в лице гондольера, гитариста на улице, парикмахера) - подмостками особого маскарада. Поначалу он дистанцируется от него, испытывая презрение к накрашенному старику, который на пароходике заигрывает с молодежью, но затем сам, приобщаясь к карнавальной стихии, пытается вернуть себе молодость с помощью грима.

Вместе с тем стареющий писатель не показан Дон Жуаном, ярко выраженным соблазнителем - он так и не познакомился с Тадзио. То есть Т. Манн, не избегая иронии, выводит Ашенбаха перед читателем в виде особого платоника, искателя идеала. В его трактовке Манн проявляет себя как сторонник внеморальности творчества, как современник Ф. Ницше и О. Уайлда: поэзия не нравственность, а другое; гений поэзии, который по-символистски приравнивается гению любви, шире границ, разделений (духа и плоти, мужского и женского пола, старика и юноши, этики и эстетики, любви и смерти). Улавливая глубокое, зыбкое, неизведанное в «чуде» телесных форм Тадзио, Ашенбах и мучим чувством вины, и, вопреки всем своим сомнениям, счастлив. В момент счастья он, опьяненный радостью, и умирает, минуя, таким образом, по воле Т. Манна, тот роковой момент, когда романтический идеал и его отражение расходятся, демонстрируя конечную недостижимость мечты.

Итак, страсть писателя показана Т. Манном символичной, имеющей целую радугу оттенков: от порочности, призрачности, смерти до религиозно-творческого экстаза, доступного только художнику. На символичность любви в новелле намекает многое: отголоски мифа об Афродите (два типа поклонения родившейся из морской пены богине - «пошлое», «всенародное» и «небесное»; история любви Ашенбаха разворачивается именно на берегу моря, в присутствии вышедшего из вод «бога» - Тадзио) и Орфее; рассуждения Сократа (они воспроизводятся в сознании Ашенбаха, как будто обращенные лично к нему); гётевские мотивы (юноша на берегу моря); гомосексуальное переиначивание образа христианской святости (св. Себастьян, пронзенный стрелами).

Подведем итог. Новелла Т. Манна не только сводит вместе самые разные реминисценции (Платон, Сократ, Гёте, Гёльдерлин, А. фон Платен, 
Шопенгауэр, Вагнер, Ницше, Г. Малер), не только предлагает новую трактовку знаменитым образам (диалоги Платона, «классическая Вальпургиева ночь», тристанизольдовское тождество любви-смерти), но и загадывает читателям характерно символистскую загадку на тему соотношения искусства и жизни, творчества и эроса. Имеется ли у нее одно-единственное решение? Едва ли. Другое дело, что в отличие от символистов-эстетов («Портрет Дориана Грея» О. Уайлда), настаивавших на превосходстве всего искусственного над естественным, Т. Манн по-неоромантически (в этом он ближе символистам, творившим уже в XX в., - А. Жиду, Г. Д’Аннунцио, К. Гамсуну, Д.Г. Лоренсу) настаивает на вторжении «жизни» в мир прекрасных дам, балаганчиков и картонных невест, отчего, правда, его творцы не утрачивают амбивалентности, присущей всей символистской культуре.

Интеллектуальным комментарием Манна к этому обстоятельству может быть признание, сделанное им в книге «Рассуждения аполитичного» (1918): «Отношения жизни и духа - это крайне деликатные, трудные, волнующие, болезненные, заряженные иронией и эротикой отношения... Причем страсть исходит и от духа, и от жизни. Жизнь тоже желает духа. Два мира, взаимоотношения которых эротичны, без явственной полярности полов, без того, чтобы один мир представлял мужское начало, а другой женское - вот что такое жизнь и дух. Поэтому у них не бывает слияния, а бывает лишь короткая опьяняющая иллюзия слияния и согласья, и между ними царит вечное напряжение без разрешения.... Проблема красоты заключена в том, что дух воспринимает как “красоту” жизнь, а жизнь - дух» (nер. С.К. Апта, курсив Т. Манна). 


\section{Список литературы}

I Бердяев Н.А. Судьба России. Кризис искусства. М.: Канон; ОИ «Реабилитация», 2004. 35I c.

2 Зарубежная литература конца XIX - начала XX века / под ред. В.М. Толмачёва, изд. 4-е, перераб. и дополн. М.: Юрайт, 2огз. 8II с.

3 Манн Т. Собр. соч.: в го т. М.: ГИХЛ, І959-І96І.

4 Манн Т. Письма / изд. подготовил С.К. Апт. М.: Наука, I975. 463 с.

5 Ришар Л. Энциклопедия экспрессионизма: Живопись и графика. Скульптура. Архитектура. Литература. Драматургия. Театр. Кино. Музыка / Л. Ришар, В.Д. Дубе, А. Арнольд, и др.; пер. с фр. Н.В. Кисловой, и др.; науч. ред. В.М. Толмачёв. М.: Республика, 2003. 430 с.

6 Сегал Д.М. Русский и немецкий символизм в сравнительном освещении // Пути искусства: Символизм и европейская культура XX века. М.: Водолей, 2008. C. $85^{-223}$.

7 Толмачёв В.M. «Незнакомка» А. Блока. Пять разборов. V // Вестник ПСТГУ. Филология. М., 2009. № 2 (16). С. 69-го8.

8 Толмачёв В.М. Гамсун и символизм // Вестник ПСТГУ. Филология. М., 2010. № 2 (20). C. $143^{-1}$ - 5 .

9 Толмачёв B.M. Лирический цикл «Куст» М. Цветаевой: семь интерпретаций. VII // Вестник ПСТГУ. Филология. М., 201о. № 3 (21). С. 9-23.

Iо Толмачёв B.M. О границах символизма // Вестник ПСТГУ. Филология. Философия. История. М., 2004. № 3. С. 247-267.

II Толмачёв B.М. Экспрессионизм, экспрессия, субъективность: О границах экспрессионизма // Вестник ПСТГУ. Филология. М., 2007. № 4. С. II4-I42.

I2 Элиот Т.С. Бесплодная земля / изд. подгот. В.М. Толмачёв, А.Ю. Зиновьева. М.: Ладомир; Наука, 20I4. 528 с.

I3 Энциклопедия символизма: Живопись, графика и скульптура. Литература. Музыка / Кассу Жан, Брюнель Пьер, Клодон Франсис и др.; науч. ред. и авт. послесл. В.М. Толмачёв; пер. с фр. Н.В. Кисловой, Н.Т. Пахсарьян. М.: Республика, г999. 432 с.

I4 Tolmatchov $V$. Sobre as fronteiras do simbolismo // Tipologia do simbolismo nas culturas russa e occidental / org. por A. Cavaliere, E. Vassina, N. Silva. São Paulo, 2005. P. I5-35. 


\section{References}

Berdiaev N.A. Sud'ba Rossii. Krizis iskusstva [The fate of Russia. The crisis of art]. Moscow, Kanon; OI “Reabilitatsiia” Publ., 2004. 35I p. (In Russ.)

Zarubezhnaia literatura kontsa XIX - nachala XX veka [Foreign literature of the end of the $\mathrm{I}^{\text {th }}-$ the beginning of the $2 \mathrm{O}^{\text {th }}$ centuries], ed. V.M. Tolmachev, $4^{\text {th }}$ edition, revised and with ammendments. Moscow, Iurait Publ., 20I3. 8II p. (In Russ.) Mann T. Sobranie sochinenii: $v$ Io $t$. [Collection of works: in Io vols.]. Moscow, GIKhL Publ., I959-I96I. (In Russ.) Mann T. Pis'ma [Letters], ed. S.K. Apt. Moscow, Nauka Publ., I975. 463 p. (In Russ.) Richard L. Entsiklopediia ekspressionizma: Zhivopis' i grafika. Skul'ptura. Arkhitektura. Literatura. Dramaturgiia. Teatr. Kino. Muzyka [Companion to expressionism: Art and graphic. Sculpture. Architecture. Literature. Drama. Cinema. Music], L. Richard, V.D. Dube, A. Arnol'd and others; trans. from French N.V. Kislova and others; ed. V.M. Tolmachev. Moscow, Respublika Publ., 2003. 430 p. (In Russ.)

Segal D.M. Russkii i nemetskii simvolizm v sravnitel'nom osveshchenii [Russian and German symbolism in comparative perspective]. Puti iskusstva: Simvolizm i evropeiskaia kul'tura XX veka [The paths of art. Symbolism and $20^{\text {th }}$ century European culture]. Moscow, Vodoley Publ., 2008, pp. 85-223. (In Russ.)

Tolmatchoff V.M. "Neznakomka” A. Bloka. Piat' razborov. V. [“The Unknown woman” by Alexander Blok. Five readings]. Vestnik PSTGU. Filologiia. Moscow, 2009, no 2 (I6), pp. 69-Io8. (In Russ.)

Tolmatchoff V.M. Gamsun i simvolizm [Gamsun and Symbolism]. Vestnik PSTGU. Filologiia. Moscow, 2010, no 2 (20), pp. I43-I5O. (In Russ.)

Tolmatchoff V.M. Liricheskii tsikl “Kust” M. Tsvetaevoi: sem’ interpretatsii. VII. [Marina Zvetaeva's lyrical circle "Bush": five interpertations]. Vestnik PSTGU. Filologiia. Moscow, 20IO, no 3 (2I), pp. 9-23. (In Russ.)

Tolmatchoff V.M. O granitsakh simvolizma [On the limits of symbolism]. Vestnik PSTGU. Filologiia. Filosofiia. Istoriia. Moscow, 2004, no 3, pp. 247-267. (In Russ.)

Tolmatchoff V.M. Ekspressionizm, ekspressiia, sub"ektivnost': O granitsakh ekspressionizma [Expressionism, expression, and subjectivity: on the limits of Expressionism]. Vestnik PSTGU. Filologiia. Moscow, 2007, no 4, pp. II4-I42. (In Russ.)

Eliot T.S. Besplodnaia zemlia [The Waste land], ed. V.M. Tolmatchoff, A.Iu. Zinov'eva. Moscow, Ladomir; Nauka Publ., 20I4. 528 p. (In Russ.)

Entsiklopediia simvolizma: Zhivopis', grafika i skul'ptura. Literatura. Muzyka, Kassu Zhan, Briunel' P'er, Klodon Fransis i dr. [Companion to expressionism: Art and graphic. Sculpture. Architecture. Literature. Drama. Cinema. Music, Jean Cassous, Pierre Brunel, Francis Cloudon, etc.], ed. and foreword V.M. Tolmachev; trans. from French N.V. Kislova, N.T. Pakhsaryan. Moscow, Respublika Publ., I999. 432 p. (In Russ.) 
I4 Tolmatchov V. Sobre as fronteiras do simbolismo [On the boundaries of symbolism]. Tipologia do simbolismo nas culturas russa e occidental [Symbolism typology in Russian and Western cultures], Org. por A. Cavaliere, E. Vassina, N. Silva. São Paulo, 2005, pp. 15-35. ( In Portuguese) 
УДК 82I.I6I.I + 82I.I3I.I

ББК 83.3(4Ита) $52+$

$83.3(2 \mathrm{Poc}=\mathrm{Pyc})$

\section{А.С. ПУШКИН В ИТАЛЬЯНСКОЙ ДРАМАТУРГИИ ХІХ В.}

(C) 2017 г. А.В. Голубцова

Институт мировой литературы

им. А.М. Горького Российской академии наук,

Москва, Россия

Дата поступления статьи: 03 июня 2017 г.

Дата публикации: 25 сентября 2017 г.

DOI: I0.22455/2500-4247-20I7-2-3-I38-I49

Аннотация: В статье рассматривается проблема рецепции образа А.С. Пушкина в Италии XIX в. В первой половине столетия, в эпоху освободительной борьбы, итальянских интеллектуалов заботят вопросы формирования национальной идентичности и поиска общих культурных основ итальянской нации. В Италии, которая по ряду причин чувствует определенное родство с русской культурой, Пушкин воспринимается как символическая фигура национального поэта. Итальянское восприятие Пушкина представляет собой набор стереотипов, не складывающихся в целостный образ. Одновременно присутствуют элементы мифологизации, встраивающие образ русского поэта в общеевропейский и итальянский романтический контекст. Во второй половине XIX в. итальянский миф о Пушкине получает художественное воплощение в двух драмах - «Александр Пушкин» В. Карреры и «Пушкин» П. Коссы. В пьесах, переплетающих факты биографии Пушкина с представлениями, почерпнутыми из его произведений, образ русского поэта трактуется в русле романтического мифа, однако включает в себя противоречивые, даже взаимоисключающие элементы. Пушкин изображается как романтический поэт байронического толка, при этом оба драматурга подчеркивают национальную самобытность Пушкина, его связь с русским языком и народной поэзией, и в то же время акцентируют внимание на его экзотическом, африканском происхождении. Содержание пьес Карреры и Коссы указывает не только на бытовавшие в Италии мифы о Пушкине, но и на то, какая часть пушкинского творчества была освоена итальянской культурой к началу І870-х гг.: прежде всего это романтические поэмы - в особенности «Цыганы».

Ключевые слова: А.С. Пушкин, В. Каррера, П. Косса, итальянская драматургия, Рисорджименто, национальная идентичность, миф, романтизм, байронизм.

Информация об авторе: Анастасия Викторовна Голубцова - кандидат филологических наук, старший научный сотрудник, Институт мировой литературы им. А.М. Горького Российской академии наук, ул. Поварская, д. 25 а, г2Іо69 Москва, Россия.

E-mail: anai294@yandex.ru 


\section{ALEXANDER PUSHKIN \\ IN THE $19^{\text {th }}$ CENTURY ITALIAN DRAMA}

This is an open access article

distributed under the Creative

Commons Attribution 4.0

International (CC BY 4.0)
(C) 20I7. A.V. Golubtsova

A.M. Gorky Institute of World Literature

of the Russian Academy of Sciences, Moscow, Russia

Received: June 03, 2017

Date of publication: September 25, 2017

Abstract: The article deals with the problem of Alexander Pushkin's reception in the $19^{\text {th }}$ century Italy. In the first half of the century, during the years of national liberation movement, Italian intellectuals were concerned with the question of national identity and with the search for common cultural grounds of the Italian nation. In Italy, a country that for various reasons felt a certain affinity with Russian culture, patriotic intellectuals considered Pushkin as a model national poet. "Italian" Pushkin was perceived through a set of stereotypes failing to form a coherent image. At the same time, his reception was not free from mythologization that made his image fit into the context of European and Italian Romanticism. In the second half of the $19^{\text {th }}$ century, Pushkin's myth inspired two plays, "Alessandro Puschin" by V. Carrera and "Puschin" by P. Cossa. The plays combining biographical facts with concepts and images drawn from Pushkin's own, works model the image of the Russian poet in accordance with the Romantic myth albeit including contradictory, even incompatible elements. Pushkin is represented as a Romantic poet of Byronic type, an integral part of European literary tradition; nevertheless, both playwrights emphasize Pushkin's national identity, his close ties with Russian language and folk poetry and above all, point out his exotic African origin. Not only Carrera's and Cossa's plays retranslate Italian myths related to Alexander Pushkin, they also show which Pushkin's works were better known in Italy at the beginning of the I870s (mostly his Romantic poems such as The Gypsies).

Keywords: A. Pushkin, V. Carrera, P. Cossa, Italian plays, Risorgimento, national identity, myth, Romanticism, Byronism.

Information about the author: Anastasia V. Golubtsova, PhD in Philology, Senior Researcher, A.M. Gorky Institute of World Literature of the Russian Academy of Sciences, Povarskaya 25 a, I21069 Moscow, Russia.

E-mail: anai294@yandex.ru 
Италия знакомится с русской литературой в первой половине XIX в., в разгар Рисорджименто - борьбы за национальное освобождение и объединение. В этот период идет постепенное формирование национального самосознания и поиск общих культурных основ итальянской нации. Процесс оказывается долгим и мучительным: политическая раздробленность Италии усугубляется культурной отсталостью, страна долгое время ощущает себя оторванной от общеевропейской культурной среды, и интеллектуальные круги настойчиво призывают к преодолению разрыва между Италией и Европой. Основным ориентиром в «погоне» за актуальными европейскими тенденциями становится Франция. Иностранная литература по большей части приходит в Италию именно во французских переводах, и в целом Франция воспринимается как главный источник культурных новаций. Однако внимание итальянцев к русской литературе обусловлено не только и не столько французским влиянием.

Представляется, что интеллектуальные круги Италии чувствуют определенное родство с Россией, которая тоже долгое время существовала в изоляции от европейской культуры. Для охваченной национально-освободительным подъемом Италии русская литература являет собой важный пример развития национального духа. В понимании итальянских интеллектуалов русская словесность впитала все достижения европейской культуры и при этом сумела сохранить свою первозданную мощь и обрести подлинно национальный характер, т. е. хотя бы частично решить те же самые задачи, которые ставили перед итальянской культурой мыслители эпохи Рисорджименто: стать полноправной частью об- 
щего поля европейской культуры и одновременно сберечь (или заново сформировать) свою национальную идентичность (подробно об этом см.: [3]).

Первым русским автором, получившим известность в Италии, оказывается А.С. Пушкин. Еще при жизни поэта появляются первые переводы (с французских подстрочников). Из всего наследия Пушкина наибольшее распространение в итальянских интеллектуальных кругах получают отдельные стихи и романтические поэмы - не только из-за характерного для Италии того времени интереса к экзотике, но и потому, что романтический пафос в принципе близок идеологии Рисорджименто, а влияние романтизма в культуре Италии сохраняется на протяжении большей части XIX в.

В конце г820-х - начале 30-х гг. фигура русского поэта вызывает интерес прежде всего у патриотически настроенных интеллектуалов, в том числе и видных идеологов Рисорджименто, которые воспринимают Пушкина в рамках итальянской романтической парадигмы: Пушкин выступает как символ возрождающейся национальной литературы, как образцовая фигура национального поэта, чье творчество органически связано с народной культурой, языком и национальным характером. Никколо Томмазео в одном из писем I828 г. трактует фигуру Пушкина как важный фактор сохранения своеобразия русской культуры: «Если у Александра Пушкина, поэта нации, любимца молодого императора, найдутся смелые последователи; если, вместо того, чтобы брать нравы и вкус у иностранцев, самые могучие умы будут посвящать себя очищению и усовершенствованию нравов и вкуса в созвучии с собственным строем, климатом, обычаями, нуждами, то свет, который день ото дня все ярче сияет нам из этих холодных земель, будет не бесплодной вспышкой, а жизненным и плодотворным лучом» [Io, p. II4-II5]. Джузеппе Мадзини в I829 г. в эссе «О европейской литературе» отмечает роль Пушкина в приобщении России к европейской культуре («...в стихах Козлова, Пожарского и Пушкина просматривается европейская тенденция» [6, p. II7]): для интеллектуалов эпохи Рисорджименто это означает не утрату собственной национальной идентичности, a, напротив, выступает как знак обретения себя после эпохи отсталости и упадка. Правда, как отмечает славист С. Гардзонио [г, с. 6], со временем отношение к России меняется из-за ее имперских амбиций и расхожего 
представления о деспотизме российских властей ${ }^{\mathrm{I}}$, а итальянские интеллектуальные круги обращаются к изучению истории и культуры других славянских народов - сербского и в особенности польского. У того же Мадзини в «Славянских письмах» І850-х гг. (опубликованы в I857 г.) образ России связывается с царской тиранией, которая препятствует становлению самосознания народа, в то время как центром подлинно народного национального движения в славянском мире объявляется Польша [6, p. 587-606].

Однако, несмотря на изменение итальянского восприятия России, интерес к Пушкину не исчезает. В конце 40-х - начале 50-х гг. XIX в. выходят работы видного итальянского популяризатора русской культуры Карло Тенки: эссе «О славянской литературе» (Della letteratura slava, I847) и цикл публикаций «О русской литературе» (Della letteratura russa, апрель-июнь I852) - первый в Италии обзор истории русской словесности. В этих работах Пушкин неоднократно характеризуется как русский Байрон, или даже «соперник Байрона» [9, р. 339]. Это представление надолго определяет итальянскую рецепцию Пушкина (и отчасти сохраняется в итальянском литературоведении до сих пор). Именно с влиянием Пушкина связывается пробуждение и распространение русского национального чувства. Он характеризуется как высочайший гений России и пылкий революционный поэт, чьи «пламенные стихи» «неудержимо изливаются из сердца» [9, p. 380].

В итальянской рецепции «байронического» Пушкина особо выделяется элемент, наиболее актуальный для Италии эпохи Рисорджименто: это борьба за свободу, противостояние власти и политические преследования. В частности, Тенка проводит прямые параллели между характером, судьбой, мироощущением и творчеством Пушкина и Байрона. В его интерпретации блестящий путь байронического гения оказывается омрачен тиранической властью самодержавия и незрелостью русского общества, его неготовностью воспринять новые идеи свободы и национального возрождения. Бунт Пушкина и его соратников-декабристов обречен на пора-

I Важным компонентом сложившегося в XIX в. «русского мифа» является представление о неограниченной и жестокой власти царя-самодержца. Этот момент подчеркивает в своих знаменитых путевых заметках (“La Russie en I839”) маркиз Астольф де Кюстин, распространяется данное представление и в Италии. Как справедливо отмечает С. Гардзонио, уже Томмазео и Мадзини представляют Россию «скорее империей, чем нацией» [2]. 
жение. В конце концов Пушкин, который в интерпретации Тенки является не такой целостной и стойкой личностью, как Байрон [9, p. 384], отказывается от юношеских надежд и идеалов и умирает царедворцем и сторонником самодержавия. Когда Пушкин лишается своей независимости, прежняя связь между поэтом и нацией рвется, и его творчество превращается в пустую и злую иронию, теряется среди приземленных жизненных реалий, становится все более субъективным по мере того, как поэт утрачивает способность выражать чаяния общества. Возможно, Тенка, воспринимающий современную ему литературу в рамках романтической парадигмы, столь нелестным образом трактует постепенный отказ Пушкина от романтической поэтики и осмысляет как чрезмерную приземленность и холодность элементы реализма, проникающие в пушкинское творчество. При этом, анализируя ранние творения русского поэта, Тенка не может отказать Пушкину в оригинальности, подчеркивая, что его романтические поэмы («Бахчисарайский фонтан», «Цыганы» и др.) не являются простым подражанием Байрону: герои, природа и действие поэм представляются ему глубоко русскими.

В г856 г. появляется первый подробный очерк жизни и творчества Пушкина - предисловие переводчика Луиджи Делатра к прозаическим переложениям поэм Пушкина на итальянский язык. Делатр также поддерживает стереотип о байронизме Пушкина: русский поэт характеризуется как «соперник, почти брат» английского романтика, напоминающий Байрона беспокойным нравом, бродячей жизнью и ранней смертью [8, p. XXVI]. В предисловии Делатра окончательно оформляются контуры итальянского романтического мифа о Пушкине, которые будут неоднократно воспроизводиться в дальнейшем. Этот миф включает в себя в качестве компонентов как произведения Пушкина, так и факты (и вымыслы), касающиеся его биографии. Судя по всему, среди итальянских авторов именно у Делатра впервые звучит легенда о том, что поэт некоторое время кочевал с цыганским табором [8, p. XII]: якобы из этих впечатлений и родилась поэма «Цыганы».

Во второй половине XIX в. итальянский романтический миф о Пушкине получает свое художественное воплощение в двух драматических произведениях - «Александр Пушкин» (Alessandro Puschin, I865) Валентино Карреры и «Пушкин» (Puschin, I870) Пьетро Коссы. 
Каррера во вступлении к своей пьесе выражает надежду, что не слишком исказил образ великого поэта. Однако на самом деле реальные факты биографии Пушкина в драме причудливым образом искажаются и соединяются с довольно нелепыми вымыслами, характер которых определяется сложившимся к тому времени романтическим представлением о поэте. То же можно сказать и о пьесе Коссы. В сюжете и трактовке образа главного героя явно прослеживается влияние поэм «Цыганы» и «Кавказский пленник» - произведений Пушкина, которые первыми получили известность в Италии и во многом определили итальянскую рецепцию русского поэта. У обоих авторов Пушкин наделяется характерными чертами романтического героя: он горд, отважен, свободолюбив и находится в трагическом конфликте с властью и обществом.

Действие драмы Коссы разворачивается в Петербурге, и примет русской (или тем более южной) экзотики там немного - разве что представление о холодном петербургском климате. Каррера в своей пьесе, напротив, всеми способами подчеркивает экзотический элемент. Пьеса начинается со сцены в цыганском таборе, стоящем у подножия Кавказских гор. Пытаясь передать колорит цыганской жизни, Каррера подробно описывает декорации и костюмы актеров в авторских ремарках, а также вводит соответствующие экзотические элементы в диалоги героев. В этом смысле показательна ремарка к первой сцене: «Цыганский табор в дикой долине Кавказских гор. Слева от зрителя, среди кустов, раскинут большой шатер из цветной полосатой ткани, поддерживаемый веревками, привязанными к деревьям. Над входом в шатер, как вывеска, - несколько игральных карт и подков; на деревьях развешаны скрипка со смычком, кобза (мандолина с девятью струнами), москалу (род трубы), мавританская гитара и несколько бубнов. <..> На фоне скалы, по которым вверх ведет тропинка; за скалами, вдали, возвышается двуглавый Эльбрус, покрытый вечными льдами. <...» [4, p. 9] ${ }^{2}$.

2 В описании цыганского быта драматург, вероятно, опирался на вышедшую в I84I г. книгу Франческо Предари «Происхождение и история цыган». В частности, у Предари среди излюбленных цыганских инструментов упоминаются именно скрипка, «кобза - инструмент с девятью струнами, распространенный исключительно у цыган и напоминающий мандолину», бубен и «москалу, или древняя syrinx, к которой у них [цыган] есть особая склонность» [7, p. Iо7-Іо8]. Этот фрагмент Предари практически дословно заимствует из изданной на французском языке книги румынского политика и публициста Михаила 
Описание явно базируется, в том числе, и на текстах романтических поэм Пушкина.

Главный герой пьесы Карреры впервые упоминается в разговоре цыган и характеризуется как «молодой господин, сбежавший из Кишинева в Крыму (sic!), где находился в ссылке» [4, p. І2]. Мы узнаем, что этот молодой человек - поэт, который был сослан на юг за свои стихи, бежал из ссылки, присоединился к цыганскому табору, чтобы скрыться от преследования, и влюбился в дочь предводителя цыганского племени, Динку. Далее мы видим и самого Пушкина в довольно своеобразном костюме: «На Александре приталенное одеяние, отороченное черным мехом, узкие штаны и сапоги. На голове берет <...> из черной шерсти. Густая борода и длинные волосы» [4, p. I5]. Косса уделяет меньше внимания описаниям декораций и костюмов, однако, если отвлечься от внешних деталей, образ главного героя в обеих пьесах трактуется сходным образом и отражает элементы пушкинского мифа, бытующего в итальянских интеллектуальных кругах.

Оба автора вслед за Делатром воспроизводят миф о странствиях Пушкина с цыганским табором и повторяют один и тот же сюжетный ход: молодая цыганка страстно влюбляется в поэта и следует за ним в Петербург. Пушкинские «Цыганы», подобно байроновскому «Чайльд-Гарольду», явно воспринимаются итальянскими интеллектуалами как биографическое произведение. В обеих итальянских пьесах цыганка, способная на искреннюю и жертвенную любовь, противопоставляется Наталье Гончаровой, которая неизменно изображается как холодная светская дама, не умеющая любить и не способная в полной мере оценить величие Пушкина. Наталья выступает как бы воплощением лицемерного и бесчувственного светского

Когэлничану «Очерк истории, нравов и языка цыган» (Esquisse sur l'histoire, les moeurs et la langue des Cigains, connus en France sous le nom de Bohémiens, I837). Национальный характер цыган, каким он представлен в пьесе, также, скорее всего, опирается на описание Предари: исследователь отмечает любовь цыган к табаку, броской яркой одежде, особенно красного цвета, и украшениям [7, p. 83-86]. Ср. у Карреры: «Вы любите табак, яркие цвета, блестящие пуговицы и музыку» [4, p. I8]. Цыганский театр марионеток в пьесе тоже описывается, судя по всему, с опорой на Предари (или непосредственно на Когэлничану, у которого Предари заимствует данный фрагмент): «Затем появляются турок и казак <...>: когда в Молдавии правят османы, турок отрубает голову казаку, а когда правителями княжества являются русские, напротив, казак обезглавливает турка» [7, p. ІІо]. Ср. у Карреры: «Они [марионетки] отныне будут нравиться как туркам, так и христианам, потому что поэт позаботится о том, чтобы в Турции Пульчинелла всегда колотил русского, а в России турка...» [4, p. I9]. 
общества, противопоставленного простой и вольной жизни цыган. В итоге именно холодность, тщеславие и кокетство Натальи Гончаровой служат поводом для трагедии: у Карреры Пушкин вызывает на дуэль Дантеса, у Коссы соперником поэта становится князь Инзов (дуэль же происходит не на пистолетах, а на шпагах). Однако если Коссу в большей степени интересуют перипетии семейной жизни Пушкина (хотя он и упоминает угнетенный народ, страдающий под властью аристократии [5, p. 28]), то Каррера сосредоточивает свое внимание на отношениях Пушкина с властью и социумом. В драме Коссы поэт тоже страдает от лицемерия светского общества и нападок критиков, но у Карреры романтический конфликт выдающейся личности с обществом и властью выходит на первый план. Необходимость содержать семью заставляет Пушкина, прежде бывшего ярым противником самодержавия, принимать милости от царя и подчиняться законам высшего света, и он чувствует, что изменяет себе и продает свой талант: «<... Я всего лишь поэт... человек, рожденный для духовных битв <...>, а не для зарабатывания денег, не для пустой суеты света, и тем более не для того, чтобы продавать свои стихи!» [4, p. 85]. Здесь Каррера явно ориентируется на трактовку, предложенную Тенкой: в конце концов Пушкин отказывается от своих идеалов и своего предназначения национального поэта. Именно это в конечном счете и приводит его к гибели. Его соперник и убийца, Дантес, изображен конформистом, поддерживающим царскую тиранию ради собственной выгоды и спокойствия. В сущности, дуэль с Дантесом предстает как символическое воплощение более масштабного конфликта, единственным выходом из которого является смерть.

В обеих пьесах образ Пушкина выстраивается строго в рамках байронической парадигмы. В драме Коссы Пушкин прямо говорит: «Я питал безумную надежду достичь славы Байрона» [5, р. 63]. У Карреры имя английского поэта прямо не упоминается, но черты биографии и характера главного героя - изгнанничество, противостояние тиранической власти, презрение к обществу - отсылают к узнаваемому образу байронического героя. В то же время у обоих драматургов Пушкин изображается как национальный поэт, черпающий вдохновение в народной стихии: у Карреры Пушкин называет родную природу и народную жизнь «великим источником вдохновения, искусства, стойкости, свободы» [4, p. 85]; у Коссы главный герой пьесы говорит, что его учителем в поэзии был «живой язык народа» 
и его поэзия [5, p. 2о]. Косса - вероятно, опираясь на Делатра, который первым из итальянских авторов упоминает няню Пушкина, - устами своего героя отмечает, что именно няня открыла ему «изначальную порочность всякой фразы, которая не дышала народным духом» [5, p. 20]. Не случайно внимание обоих авторов привлекает именно этот аспект пушкинского таланта. В 6о-х - 70-х гг. XIX в. политическое объединение Италии завершается, но становление национального самосознания представляется еще не оконченным. Интеллектуалы эпохи Рисорджименто проявляют живой интерес к народной культуре как основе выстраивания национальной идентичности: в их глазах именно благодаря своей близости к народу Пушкин заслуживает звание национального поэта и выразителя народного духа.

В пьесах находит свое отражение и другой важный компонент пушкинского мифа, который до сих пор оказывает влияние на итальянскую рецепцию Пушкина: представление о страстном и вольнолюбивом характере поэта, которым он обязан своему африканскому происхождению. У Карреры Пушкин, говоря о своей страстности и вспыльчивости, подчеркивает собственное сходство с цыганами следующими словами: «Вы - не европейцы, а во мне есть африканская кровь; у вас нет родины, а я - русский...» [4, p. І8]. У Коссы главный герой, объясняя свое стремление к вольной бродяжьей жизни, замечает: «...Мой предок родился // В африканской земле, в той земле, // <...> где еще жива // Арабская страсть к скитаниям; // Эта страсть горит у меня в крови, // А среди домашних стен // Я как в тюрьме» [5, p. 22].

В двух итальянских пьесах, причудливо переплетающих факты биографии Пушкина с представлениями, почерпнутыми из его произведений, фигура русского поэта трактуется в русле романтического мифа, однако миф этот лишен целостности: в нем парадоксальным образом соединяются противоречивые, едва ли не взаимоисключающие элементы. Пушкин изображается как романтический поэт байронического толка, вписывающийся в европейскую литературную традицию; при этом оба драматурга подчеркивают национальную самобытность Пушкина, его связь с русским языком и народной поэзией, и в то же время акцентируют внимание на его экзотическом, африканском происхождении. Содержание пьес Карреры и Коссы указывает не только на бытовавшие в Италии мифы о Пушкине, но и на то, какая часть пушкинского творчества была освоена итальянской культурой 
к началу І870-х гг.: прежде всего это романтические поэмы - в особенности «Цыганы»3. А сам факт превращения Пушкина в персонажа, возможно, свидетельствует о том, что к концу эпохи Рисорджименто вокруг фигуры русского поэта начинает формироваться литературный культ. Однако ни целостного пушкинского мифа, ни полноценного культа в Италии XIX в. не складывается: скорее, можно говорить о наборе стереотипов, противоречащих друг другу и при этом сосуществующих - нередко в творчестве одних и тех же авторов. В XIX в. в Италии отсутствует единый развивающийся пушкинский «сюжет»: знакомство итальянских интеллектуалов с творчеством русского поэта долгое время остается эпизодическим и ограниченным, моменты пробуждения интереса к фигуре Пушкина сменяются периодами забвения. Вероятно, поэтому итальянский образ Пушкина распадается на отдельные элементы, которые не образуют устойчивой целостности и актуализируются или уходят на второй план в зависимости от исторического контекста или взглядов и целей отдельных авторов.

\section{Список литературы}

I Гардзонио С. Итальянская пушкиниана // «Служенье муз не терпит суеты...»: избранная поэзия в переводах Т. Ландольфи. М.: Вагриус, 20о8. С. 6-I7.

2 Гардзонио С. Пушкин и Данте: общие элементы культурного сопоставления // Ruthenia. Проект Объединенного гуманитарного издательства и кафедры русской литературы Тартуского университета. URL: http://www.ruthenia.ru/ document/5309I4.html (дата обращения: 02.06.2017). Голубцова А.В. Пушкинский миф и национальная идентичность в Италии XIX века // Русская литература в зеркалах мировой культуры: рецепция, переводы, интерпретации. М.: ИМЛИ РАН, 2ОI5. С. 4OІ-424.

4 Carrera V. Alessandro Puschin. Milano: Libreria Editrice, I876. I43 p.

$5 \quad$ Cossa P. Puschin. Milano: Libreria editrice, I876. 75 p.

6 Mazzini G. Opere: in 2 vol. Milano: Rizzoli, I967. Vol. 2. Scritti. IOor p.

7 Predari F. Origine e vicende dei zingari. Milano: Tipografia di Paolo Lampato, I84I. $275 \mathrm{p}$.

8 Racconti poetici di Alessandro Puschin, poeta russo, tradotti da Luigi Delatre. Firenze: F. Le Monnier, 1856. 243 p.

9 Tenca C. Saggi critici. Firenze: Sansoni, I969. 442 p.

3 Драма Коссы включает в себя также перевод сцены дуэли из «Евгения Онегина», но эта цитата воспринимается вне общего контекста романа, исключительно в биографическом и романтическом ключе (как предвосхищение трагической судьбы самого Пушкина). 
Tommaseo N. Lettera al signor Giaxich sulla letteratura russa // Antologia; giornale di scienze, lettere e arti. Firenze, I828. Vol. 32. P. II4-II7.

\section{References}

I Gardzonio S. Ital'ianskaia pushkiniana [Pushkin in Italy]. "Sluzhen'e muz ne terpit suety...”: izbrannaia poeziia v perevodakh T. Landol'fi [Selected Poetry translated by T. Landolfi]. Moscow, Vagrius Publ., 2008, pp. 6-I7. (In Russ.)

2 Gardzonio S. Pushkin i Dante: obshchie elementy kul'turnogo sopostavleniia [Pushkin and Dante: Common Elements of Cultural Comparison]. Ruthenia. Proekt Ob"edinennogo gumanitarnogo izdatel'stva i kafedry russkoi literatury Tartuskogo universiteta. [Ruthenia. Project of Joint Humanities Edition and Department of Russian literature of the Tartu University]. Available at: http://www.ruthenia.ru/ document/5309I4.html (Accessed o2 June 20I7). (In Russ.).

3 Golubtsova A.V. Pushkinskii mif i natsional'naia identichnost' v Italii XIX veka [Pushkin's myth and national identity in the $\mathrm{I}^{\text {th }}$ century Italy]. Russkaia literatura $v$ zerkalakh mirovoi kul'tury: retseptsiia, perevody, interpretatsii [Russian Literature in the Mirrors of the World Culture: reception, translations, interpretation]. Moscow, IWL RAS Publ., 20I5, pp. 4OI-424. (In Russ.)

4 Carrera V. Alessandro Puschin. Milano, Libreria Editrice, I876. I43 p. (In Italian)

5 Cossa P. Puschin. Milano, Libreria editrice, I876. 75 p. (In Italian)

6 Mazzini G. Opere: in 2 vol. Milano, Rizzoli, I967. Vol. 2. Scritti. Ioor p. (In Italian)

7 Predari F. Origine e vicende dei zingari. Milano, Tipografia di Paolo Lampato, I84I. 275 p. (In Italian)

8 Racconti poetici di Alessandro Puschin, poeta russo, tradotti da Luigi Delatre. Firenze, F. Le Monnier, I856. 243 p. (In Italian)

9 Tenca C. Saggi critici. Firenze, Sansoni, I969. 442 p. (In Italian)

Io Tommaseo N. Lettera al signor Giaxich sulla letteratura russa. Antologia; giornale di scienze, lettere e arti. Firenze, I828, vol. 32, pp. II4-II7. (In Italian) 
УДК 82.09

ББК $83.3(2 \mathrm{Poc}=\mathrm{Pyc})$
ГЛАВЫ ИЗ ПУШКИНСКОГО РОМАНА.

«ПОСЛЕДНИЙ ТЕКСТ» И «ШПАГА

ЩЕКОТЛИВОГО ДВОРЯНИНА» АНДРЕЯ

БИТОВА - КУЛЬТОВЫЕ МЕХАНИЗМЫ

И ПОЭТИКА ТЕКСТА

\author{
(C) 2017 г. Ж. Калавски \\ Институт Литературоведения \\ Венгерской Академии Наук, \\ Будапешт, Венгрия \\ Дата поступления статьи: о2 февраля 2017 г. \\ Дата публикации: 25 сентября 2017 г.
}

DOI: I0.22455/2500-4247-20I7-2-3-I5O-I65

Статья выполнена при поддержке

гранта Яноша Бояи Венгерской Академии Наук

Аннотация: В данной статье сделана попытка проследить и показать, как в эссе Андрея Битова «Последний текст» и «Шпага щекотливого дворянина» конструируется культ Пушкина, как в этих текстах работают культовые механизмы, включая специфические риторические формулы. В то же время такой подход отнюдь не предполагает догматического отношения к Пушкину и прескриптивной, «единственно верной» точки зрения на его наследие. Как раз наоборот: тексты Битова сохраняют присущие им признаки открытости, диалогичности, обращенности к читателю. Конечно, нас интересует в первую очередь то, как «встречается» научный подход, исследование в истории рецепции этого пушкинского произведения с другим, писательским подходом Битова, но на этот раз самым интересным, с нашей точки зрения, является то, как Битов излагает свою концепцию по этой теме. Он пишет эссе, в которых не высказывает что-то, а внушает, подсказывает, дает одну интерпретацию так, что при этом не исключает другую. Таким образом, в статье анализируется, как построен и как функционирует текст Битова.

Ключевые слова: Александр Пушкин, Андрей Битов, литературный культ, интертекстуальность, поэтический анализ.

Информация об авторе: Жофия Калавски - PhD, научный сотрудник, Институт Литературоведения Венгерской Академии Наук, III8 Budapest, Ménesi út II-I3, Budapest, Hungary.

E-mail: kalavszky.zsofia@btk.mta.hu 


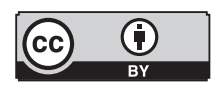

This is an open access article distributed under the Creative Commons Attribution 4.0 International (CC BY 4.O)
CHAPTERS FROM PUSHKIN'S NOVEL. CULTIC MECHANISMS AND TEXTUAL POETICS OF "THE LAST TEXT" AND THE SWORD OF "THE SENSITIVE NOBLEMAN" BY ANDREY BITOV

\author{
(c) 20I7. Z. Kalavszky \\ Institute for Literary Studies, Hungarian Academy \\ of Sciences, \\ Budapest, Hungary \\ Received: February 02, 2017 \\ Date of publication: September 25, 2017
}

Acknowledgments: This essay was supported by Bolyai János Research Scholarship of the Hungarian Academy of Sciences.

Abstract: This study aims to trace and demonstrate the construction of Pushkin cult in two essays by Andrey Bitov, "The Last Text" and "The Sword of the Sensitive Nobleman." It examines how cultic mechanisms including specific rhetoric formulas operate in both texts. Bitov's cultic approach, however, does not imply dogmatic attitude to Pushkin nor requires a prescriptive attitude to his heritage. Quite on the contrary: Bitov's texts are as always open, dialogical, and openly address themselves to the reader. I am interested primarily in the points of convergence between Bitov's scholarly approach to Pushkin's work, e.g. his study of the Pushkin's reception history, on the one hand, and his literary position, on the other; yet at the same time, I find most interesting the way he expresses his concept. He writes an essay where he suggests something rather than states it, prompts, hints, offers one interpretation the way that does not exclude an entirely different one. Thus, this article examines how Bitov's text is constructed and how it functions.

Keywords: Alexander Pushkin, Andrey Bitov, literary cult, intertextuality, poetic analysis.

Information about the author: Zsófia Kalavszky, Research Fellow at the Institute for Literary Studies, Hungarian Academy of Sciences, III8 Budapest, Ménesi út II-I3, Budapest, Hungary.

E-mail: kalavszky.zsofia@btk.mta.hu 
В конце 20I4 г. вышло в свет новое расширенное издание так называемых пушкинских произведений Андрея Битова. По поводу этого автор сказал: «Пушкинский дом - Пушкинский том, одну букву заменил, а вся жизнь прошла» . Возникает ряд вопросов: что значит акт замены буквы в текстовом универсуме Битова? Можно ли назвать этот авторефлективный жест автоописательным жестом битовской поэтики текста? И еще: что же происходило в этот период между двумя датами (I964 и 20I4), т. е. между двумя текстовыми корпусами? Этот вопрос скрыто предполагает, что мы рассматриваем отдельные единицы «Пушкинского тома» как единство. Можно ли интерпретировать как взаимосвязанное целое «Пушкинский том»? И в какой мере переосмысляется сейчас как единое целое создаваемая на протяжении последних 50 лет битовская пушкиниана, собранная в один сборник? Можно ли называть «Пушкинский том» романом, расширяя до крайности рамки жанра романа? И наконец: не будет ли более продуктивным, если мы займемся рассмотрением понимаемой не в самом строгом смысле жанровой категории, а осмелимся предположить рождение какого-то имагинарного пушкинского романа в «Пушкинском томе»?

Ответы на поставленные нами выше вопросы во всяком случае требуют нескольких объемных сопоставительных исследований, статей. Но в настоящей работе мы задались целью представить только один из возможных подходов к осмыслению «Пушкинского тома». На наш взгляд, получен-

I Битова цитирует Новая Газета: [4]. 
ные в результате проведенного анализа опыт и выводы, в том числе и метод анализа, можно будет распространить если и не на целый текст «Пушкинского тома», то хотя бы на содержащуюся в нем эссеистику.

Этот анализ мы намерены провести в аспекте, который, как нам кажется, в научной литературе о поэтике пушкинских текстов Битова является периферическим. Мы попытаемся проследить и показать в одной выделенной части «Пушкинского тома», как (культовое) отношение к Пушкину, механизмы культового обращения, в том числе риторические формулы, выражающие культовое отношение, могут одновременно функционировать в тексте Битова таким образом, что сам текст остается культовым, но при этом не позволяет прескриптивного осмысления, прочтения текста, и даже сам он не становится однозначным, хотя все перечисленные эти признаки считаются в научной литературе основными признаками культовых текстов². Как раз наоборот: текст и тексты Битова сохраняют присущие им признаки открытости, диалогичности, обращенности к читателю. То есть в итоге нашего анализа мы приходим к описанию поэтики битовского текста.

Известно, что Битов, рядом с другими современными русскими писателями и писателями XX в. (см. так называемые «пушкинские тексты» Андрея Синявского, Сергея Довлатова, Михаила Эпштейна или Татьяны Толстой), в романе «Пушкинский дом», в повести «Фотография Пушкина» и в своей эссеистике неким способом тематизирует культовые жесты, направленные на Пушкина3. Битов или с помощью иронии, или с помощью пародии, или средствами деконструкции, или просто описательным образом выделяет или анализирует ритуальные эпизоды культа Пушкина или же характеризует

2 Исследование феномена литературного культа является относительно новой междисциплинарной исследовательской перспективой в области литературоведения и культурологии. Исследования по этой теме публиковались венгерскими, финскими и российскими учеными. Среди них следует особо выделить труды Петера Давидхази, академика Венгерской Академии Наук, основоположника исследования феномена литературного культа в Венгрии [І3; I4]; совместный сборник финских и венгерских исследователей [І2] и сборник научных трудов российских литературоведов, социологов, историков и философов [7]. О различных употреблениях и значениях терминов «литературный культ», «культовый текст» в русской и в венгерской научной литературе см. рецензию на книгу «Культ как феномен литературного процесса: автор, текст, читатель» [г9].

3 О культе Пушкина, который тематизируется в прозе Довлатова см.: [6]; в псевдонаучной работе Эпштейна см.: [І6]; в романе Татьяны Толстой см.: [І5]; в прозе Битова см.: [I7; I8]. 
риторическую сторону этого явления, перечисляя и интерпретируя постоянно повторяемые культовые выражения, словосочетания и темы. На этот раз из множества таких тем мы останавливаемся на одной: это последний текст как въіделенный объект культового обращения/отношения.

2

В цикле-эссе Битова «Предположение жить. І836. Воспоминание о Пушкине» (этот цикл входит в книгу «Предположение жить. I836. Воспоминание о Пушкине» (г999), в книгу «Моление о чаше. Последний Пушкин» (2007) и в «Пушкинский том» (20I4)) «вопрос о том, какой пушкинский текст является последним текстом?» - со своим взаимосвязанным вопросом о «законченности» Пушкина «проходит красной нитью» этом общеизвестно, что Битова уже очень рано начал интересовать вопрос о возможной цзелостности творчества Пушкина. В одном интервью 2005 г. он высказывается по этому поводу следующим образом:

Российская Газета: Не боитесь пушкинистов?

Битов: Я по неграмотности пушкинистику не читал, пользовался только компилятивной книгой Вересаева и академическим изданием Пушкина. Но если вы подряд расставите все черновики, письма, стихи, прозу и статьи Пушкина, то начнёт вычитываться то, что Пушкин скрывал. Он ведь не в наше время жил, когда всё тайное вываливается наружу. Я начал с последнего слова, им оказалось слово «Пушкин». А кончил первым - «к Наталье». Получилось: «к Наталье - Пушкин».

РГ: Пушкин как единый текст?

Битов: Да, в случае гения идея единого текста срабатывает. Хронологическое прочитывание всего, включая записки, письма, долговые расписки, оконченные и неоконченные варианты, создаёт картину живого процесса [Іо].

4 «Вопрос о том, ВСЕ ли сделал Пушкин и, когда он сделал ВСЕ, закончен ли его путь, его назначение ещё при жизни, не есть ли эта свершённость глубинная причина его гибели, ибо уход неизбежен <...> до сих пор возникает» [2, с. I4]; «Важно это становится все больше и больше, когда мы приближаемся к концу, к последним вещам, написанным поэтом. И чем больше к концу, тем важнее. Потому что, хотим или не хотим мы этого, психология наша такова, что то, что ближе к смерти, мы неизбежно нагружаем все тем же ЗАВЕЩАНИЕМ. Мы исподволь воспринимаем последнее слово поэта как последнее, что он нам хотел сказать» [2, с. I7]; «В поисках завещания мы приходим к проблеме воскрешения (чтобы спросить...) [2, с. 20]. 
В этих словах улавливается такая писательско-филологическая точка зрения на пушкинский текстовый корпус, которая рассматривает пушкинское творчество как единый текст-калейдоскоп. Считаю важным отметить, что вопреки плюрализму калейдоскопа Битов выделяет временную упорядоченность как основной организующий принцип. Он подчеркивает равноценность и плюрализм каждого написанного текста, текстового отрывка, а это значит также, что он говорит о единстве и взаимном переплетении творчества и судьбы, текста и биографии. Битов в жанре эссе в вольном, непринужденном тоне открывает читателю тот сверхинтересный, исследовательский процесс, в котором он выстраивает в один ряд пушкинские письма, записки, черновики, появившиеся во время, до или после литературных произведений, и показывает нам то, как он их сопоставляет друг с другом. Он указывает на то, как жизнь пронизывает литературные произведения или как тексты вырастают из этой текстовой ткани. Битов распространяет свое исследование на все сохранившиеся рукописи Пушкина, и из этого исследования рождаются новые тексты.

Битов в первых двух эссе цикла «Предположение жить. 1836. Воспоминание о Пушкине» настаивает на том, чтобы мы переосмыслили следующее: действительно ли, согласно пушкиноведам, написанное Пушкиным редакторское письмо детской писательнице Александре Ишимовой является последним текстом Пушкина перед дуэлью и смертью и можно ли считать это письмо каким-то завещанием поэта? Можно ли на творчество поэта смотреть как на замкнутое, завершенное целое, которое замыкается последним текстом? А также: какое законченное художественное произведение Пушкина является последним?

Битов считает, что Пушкин, творчество которого всю жизнь характеризовала многотональность, диалогичность, множество жанров, и осенью, и зимой I836-I837 гг., как и прежде, продолжал работать в разных творческих направлениях. Он всегда мыслил вариациями, несколькими возможностями, в последние месяцы жизни его также характеризует плюралистическое мышлениег. Он же утверждает и то, что, если внимательно прочитать

5 «Но чем больше я не могу понять, зачем же он написал эту внезапную редакционную записку в конце пути, тем больше осознаю, что сам Пушкин отнюдь не склонен был превратить своё творчество в замкнутую систему, что перед лицом Судьбы он оставил свой контур разомкнутым, прекрасно сознавая, что делает» [2, с. 32]. 
все последние тексты поэта, окажется, что последним художественным (!) законченным текстом, датированным І837 г., является «статья» «Последний из свойственников Иоанны д’Арк», которую поэт написал для своего журнала «Современник». Эта «статья» была опубликована только посмертно. Но, продолжает Битов, эта статья не только является псевдостатьей, здесь, по словам В. Ходасевича, «Пушкин (и на этот раз) насквозь автобиографичен» [II].

3

Пушкин пишет свою статью, опираясь на корреспонденцию английского журнала Morning Chronicle. Английский журналист информирует читателей о том, что в I836 г. умер некий дворянин, господин Дюлис, среди бумаг которого нашли автографное письмо, написанное его отцом Вольтеру. Дюлис-отец в возмущенном тоне пишет французскому писателю о том, что он в I767 г. приобрел и прочитал произведение Вольтера «Орлеанская девственница», и он, как свойственник Жанны д’Арк, протестует против «грубых ошибок», которые относятся в том числе и к Орлеанской девственнице. «А посему, не только я полагаю себя в праве, но даже и ставлю себе в непременную обязанность требовать от вас удовлетворения за дерзкие, злостные и лживые показания, которые вы себе дозволили напечатать касательно вышеупомянутой девственницы» [8]. Дюлис-отец в конце письма вызывает Вольтера на дуэль. Пушкин публикует и ответное письмо Вольтера, в котором последний, ссылаясь на свою слабость, старость и болезнь, хочет избежать поединка и даже отказывается от авторства своего произведения, от сатирической пародийной поэмы. Статья Пушкина заканчивается цитированием слов английского журналиста. В этом послесловии журналист в довольно патетическом и раздраженном тоне воздает должное Дюлису, защитив его честь от интриги французского дворянства и циничного Вольтера. «Все с восторгом приняли книгу, в которой презрение ко всему, что почитается священным для человека и гражданина, доведено до последней степени кинизма. Никто не вздумал заступиться за честь своего отечества; и вызов доброго и честного Дюлиса, если бы стал тогда известен, возбудил бы неистощимый хохот не только в философических гостиных барона д’Ольбаха и M-me Joffrin, но и в старинных залах потомков Лагира и Латримулья. Жалкий век! Жалкий народ!» [8]. 
Битов направляет внимание на то, что, если эту «статью» сопоставить с той перепиской, которую Пушкин в последние свои месяцы ведет с бароном Геккерном, Бенкендорфом и Жуковским, проясняется, что история и конфликт между Вольтером и Дюлисом по поводу Жанны д’Арк, т. е. по поводу поэмы «Орлеанская девственница», собственно является историей конфликта между Геккерном, Дантесом и Пушкиным по поводу Натальи Пушкиной и анонимного диплома «Патент на звание рогоносца». То есть псевдостатья есть не что иное, как пушкинская интерпретация, в которой зашифрованы автобиографические события жизни Пушкина, глубоко затронутые честь и достоинство поэта. По мнению Битова, эту псевдостатью по количеству участвующих в ней героев и по качеству и характеру конфликта можно отнести к жанру «маленьких трагедий» Пушкина.

В начале I980-х гг., когда Битов изложил свою концепцию, еще не было в пушкинистике доступного серьезного исследования по этой теме. «Последний из свойственников Иоанны д’Арк» в I949 г. в I2 томе Академического издания «Полного собрания сочинений Пушкина в I6 томах» было опубликовано в разделе Критика и публицистика. Статьи и заметки. Из научной статьи 2008 г. «Как понимать мистификацию Пушкина Последний из свойственников Иоанны д’Арк» Александра Долинина, который суммирует современные результаты исследования, выясняется, что до І920-х гг. никто даже не подозревал, что это пастиш [5]. Потом нашли дневники Александра Тургенева - он был единственным, кому Пушкин показал свой текст прижизненно. Слова Тургенева считаются первыми намеками на мистификацию, но в 1937 г. даже Борис Томашевский только догадывался о том, мистификация это или литературное произведение. (А. Долинин детально описывает историю отношения исследователей-пушкинистов к пушкинской статье, см.: [5, с. 197-199].) Впервые Анна Ахматова настаивала на том, что на заднем плане этой статьи могут стоять отношения Пушкина и Дантеса. Несмотря на статью Дмитрия Благого, опубликованную в 1970-е гг., надо было ждать до 200о-х гг., чтобы пушкинистика проявила серьезный интерес к пушкинской псевдостатье. Среди трудов Т. Биньона, И. Сурат, С. Бочарова, В. Сайтанова, С. Фомичева, С. Абрамовича в основополагающей работе Александра Долинина по этой теме в рецепции пушкинской «статьи» важное место отводится эссе Битова [5, с. 198]. 
Конечно, нас интересует в первую очередь то, как «встречается» научный подход, исследование в истории рецепции этого пушкинского произведения с другим, писательским подходом Битова, но на этот раз самым интересным, с нашей точки зрения, является то, как Битов излагает свою концепцию по этой теме. Он пишет эссе, в котором не высказывает итоmо, а внушает, подсказывает, дает одну интерпретацию так, что при этом не исключает другую. То есть мы пришли к самому важному вопросу: как построен и как функционирует текст Битова?

4

Анализируемое нами битовское эссе характеризует следующий признак: оно конструирует и тематизирует то фиктивное коммуникативное и «реципирующее» / «воспринимающее» пространство, в котором оно зарождается и читается. Эссе «Шпага щекотливого дворянина» в сущности является непосредственным продолжением эссе, стоящего перед ним в цикле («Последний текст»), в котором автор размышляет о том, как можно понять написанное Пушкиным редакторское письмо детской писательнице Ишимовой. Эссе «Шпага щекотливого дворянина» начинается с того, что нарратор в полном недоумении обращается к нам, читателям: после того как он опубликовал свое предыдущее эссе («Последний текст»), он получил два читательских письма. (Начинается игра-мистификация, игра с фиктивными корреспондентами, письмами.) Авторы писем не согласны с рассуждениями Битова. Один из них заявляет, что последним произведением Пушкина является незавершенная статья «Песнь о полку Игореве», а другой хотя и не называет, какое, по его мнению, художественное произведение Пушкина можно считать последним, но возмущен до крайности. Он утверждает, что Битов оклеветал Пушкина. Битов это письмо полностью публикует в эссе.

Битов-писатель письменно интерпретирует ито-то, а эта концепция, по мнению одного читателя, оскорбляет Пушкина, и поэтому этот читатель пишет письмо в защиту Пушкина и в сущности вызывает на дуэль писателя-Битова. Но это эпистолярная дуэль не состоится, потому что читатель-корреспондент не указывает свой обратный адрес. Литературная игра следующая: Битова оклеветали, но у него нет возможности объясниться, защищать себя и свою концепцию в обратном письме: для того что- 
бы у него была возможность отстаивать свою точку зрения, он принужден написать эссе.

Писатель, текст, читатель, письмо, клевета, защита, вызов на дуэль, несостоявшаяся дуэль и новый текст - перед нами в битовском эссе структуральная, нарративная репродукция двухчленного событийного ряда. Первым составным элементом этого является (по Битову) сложная жизненная ситуация Пушкина, которая обострилась по поводу анонимного диплома «Патент на звание рогоносца», авторство которого Пушкин приписывал барону Геккерну, и вследствие которого Пушкин в защиту своей чести вызвал его на дуэль. Вторым составным элементом этого ряда является псевдостатья Пушкина относительно «Орлеанской девственницы» Вольтера. Этот текст, в котором в защиту Жанны д’Арк выступает его свойственник Дюлис и вызывает на дуэль Вольтера, по Битову, можно читать как пушкинскую интерпретацию своей жизненной ситуации и как объяснение потомкам. И этот «ряд», эта комплексная игра между жизненной и текстовой действительностью, бытием отражается в битовском эссе, которое строится как сложный метатекст. Рождается текст (анонимный или от авторства которого отреклись), в этом тексте кого-то оклеветали, и «реальный» или мнимый свойственник оклеветанного в своем письме требует удовлетворения. Этому могла бы послужить дуэль, но она по определенным причинам не может состояться. У Дюлиса нет возможности драться на шпагах с Вольтером из-за трусости французского писателя, у Пушкина нет возможности требовать удовлетворения у барона Геккерна, потому что он выходит из конфликта таким образом, что Дантес договаривается о заключении брака с сестрой жены Пушкина, а «прием» Битова в следующем: он «не знает» адреса своего корреспондента, подписывающегося под именем д’Аш.

Пушкин «выпускает на сцену» английского журналиста, который спустя 6о лет после случившегося пишет об истории конфликта Вольтера Дюлиса, выясняет ситуацию и защищает достоинство и честь Жанны д’Арк и ее свойственника. А Пушкин, согласно концепции Битова, пишет свою псевдостатью «Последний из свойственников Иоанны д’Арк», где излагает свою версию о подлом поведении барона Геккерна, Дантеса и о развратности участвующего в этой игре «высшего света». Битов же пишет свое эссе «Шпага щекотливого дворянина», в котором путем ввода в свой текст фиктивных корреспондентов и публикации их писем в диалогической форме 
излагает множество вариаций, интерпретаций последних месяцев жизни поэта и последних художественных произведений Пушкина.

\section{5}

У Битова сама речь, сам письменный акт и процесс относительно пушкинского текстового события становятся текстовым событием. Битов приближается к тексту и к жизни Пушкина со стороны текстов, он уделяет особое внимание пушкинским текстовым играм, языковым играм. Его цель состоит в том, чтобы найти ту языковую игру, которая больше всего отражает пушкинскую языковую игру.

Пушкин в русскоязычной псевдостатье делает имитации-переводы, ведь он «переводит» письма Вольтера и Дюлиса с французского, а послесловие - с английского языка. Не ускользает от внимания Битова этот прием, который влияет на смысл, на интерпретацию. Он эту игру перевода-искажения тоже пускает в действие, но у него передача значений происходит не между языками, у него значения теряются или искажаются между оригиналом и копией. Он повторяет прием посредничества в метафорично-технической форме связи с письмом его так называемого второго корреспондента д’Аша. Самым хорошим примером этого является то, что в одной ссылке к тексту он сообщает читателю о том, что д’Аш послал не оригинал, а копию письма: «...доказательством чего явилась как раз последняя страница, размашисто подписанная “д’Ащ”» (курсивы мои. - Ж.К.) [2, с. 35]. Намек на небрежную, неаккуратную - может быть и неразборчивую - подпись корреспондента в контексте того, что анонимность и проблематизация (отречение от) авторства текстов и в жизненной истории Пушкина, и в его псевдостатье являются очень важными, открывает возможность игры с именем и у Битова: рукописная подпись д’Аш может быть прочитана из плохо различимых букв фамилии д’Арк-а и одновременно может намекать на фамилию д’Аршиак (он был секундантом Дантеса), но во всяком случае мы стоим перед деперсонализированным приемом и постгуманной перспективой.

Но само письмо, полный текст фиктивного корреспондента, как и, конечно, псевдостатья Пушкина, содержит множество скрытых намеков, следов, которые призывают читателя задуматься и внимательно читать, ведь, по мнению Битова, псевдостатья Пушкина оставалась без отклика более века, потому что она оставалась непрочитанной в своем контексте. 
Фиктивное письмо д’Аша, однозначной функцией которого в тексте Битова является создание диалогичности благодаря разрушению одноголосия авторского слова, представляет собой текстовый монтаж. Без указания на первоисточники, в нем фигурируют отрывки из пьесы Л. Толстого «Живой труп», из псевдостатьи Пушкина, из письма Пушкина к барону Геккерну от І7-2I ноября г836 г. и из Евангелия от Матфея.

Структура письма, которое представляет собой текст в тексте, функционирует как mise en abyme и с помощью процитированных в нем интертекстов повторяет, репрезентирует тот сюжет, который переосмысляет последние месяцы Пушкина.

В центре драмы Толстого - любовный треугольник: муж, жена и любовник жены. В процитированном отрывке мы оказываемся на месте судебного заседания, где муж протестует против того, что судья, который, будучи посторонним человеком, выносит решения, получает за это зарплату, судит о ситуациях (добро, зло, измена, верность, эмоциональные состояния, отношения), на которые он смотрит только извне. Не трудно узнать в этом, с одной стороны, намек на треугольник Пушкина-Натальи-Дантеса, с другой - на всех тех, кто это отношение осуждал, осмыслял, каким-то образом тематизировал: так называемый «высший свет», участники салонов и балов. По мнению д’Аша, обязательно надо защитить Пушкина, его эпоху и жизнь от таких писателей, как Битов, которого он с помощью скрытых пушкинских интертекстов выводит в роли Вольтера и барона Геккерна. Битов, по его мнению, препятствует настоящим исследованиям.

Д’Аш свое письмо заканчивает, с одной стороны, цитатой из Евангелия от Матфея, которая адресована лицемерным книжникам и фарисеям, с другой стороны, последними словами псевдостатьи Пушкина: «Жалкий век! Жалкий народ!» В самой последней и самой патетичной части письма Битов представлен как поклонник идеологической интерпретации Пушкина, как безбожник, развивающий варварский культ Пушкина, как книжник, заинтересованный в создании языческого идола, кумира Пушкина.

Хотя корреспондент Битова не называет, какой текст считает последним, но составляет свое письмо так - и в этом играют большую роль скрытые пушкинские цитаты, - чтобы внимательный читатель догадывался. То есть, если читатель не просто читает, но и прочитывает его текст, он осознает и может разобраться в замысле д’Аша. 
Итак, Битов на вопрос о последнем произведении Пушкина «отвечает» в тексте, построенном с помощью той пушкинской поэтики, которую Битов открывает в написанном им произведении. Одновременно он выделяет для себя из пушкинской поэтики «закон», поэтики-вариаций - диалогичность, множество жанров, тем, героев, языков - и единства. Игра с текстами у Битова превращается в текстовое событие, но со скрыто присутствующей культовой точки зрения дает ей метафизическую перспективу (Пушкин как альфа и омега).

Мы попытались в этом микроанализе показать способ существования, способ функционирования одного из текстов «Пушкинского тома», который в основном является «романом романа», т. е. монтажом пушкинских текстов, объединяющихся из истолковывающих их эссе в имагинарный роман. Монтаж пушкинских текстов, который имеет игровое, полифоническое, многоязыковое, многожанровое начало и который сам варьируется, модифицируется и стремится не к окаменению своего объекта.

\section{Список литературы}

I Битов А. Предположение жить. I836 / сост. А.Г. Битов. М.: Изд-во Независимая газета, $1999.920 \mathrm{C.}$

2 Битов А.Г. Моление о чаше (Последний Пушкин). М.: Изд-во Фортуна ЭЛ, 2007. I $76 \mathrm{c}$.

3 Битов А.Г. Пушкинский том. М.: Изд-во АСТ, 20I4. 460 с.

4 Битов А.Г. Эссе о Пушкине // Новая Газета. 20I4. 29 сентября. URL: http://www. novayagazeta.ru/arts/65485.html (дата обращения: 15.12.2016).

5 Долинин А.А. Как понимать мистификацию Пушкина «Последний из свойственников Иоанны д’Арк» // И время и место: Историко-филологический сборник к шестидесятилетию Александра Львовича Осповата. М.: Новое изд-во, 2008. C. 198-217.

6 Калавски Ж. Равнодушная природа как пушкинский мотив в романе Сергея Довлатова «Заповедник» // Studia Slavica Academiae Scientiarum Hungaricae. 2011. № 56. C. $39 \mathrm{I}-407$.

7 Культ как феномен литературного процесса: автор, текст, читатель / ред. М.Ф. Надъярных, А.П. Уракова. М.: ИМЛИ РАН, 20II. 480 с.

8 Пушкин А.С. Последний из свойственников Иоанны д’Арк // Пушкин А.С. Полн. собр. соч.: в г6 т. М.; Л.: Изд-во АН СССР, І937-1959. Т. І2: Критика. Автобиография. 1949. С. 153-155. 
Толстой Л.Н. Живой труп // Толстой Л.Н. Полн. собр. соч.: в 90 т. М.: Гос. Изд-во Худож. Лит. І952. Т. 34. С. 5-гоО. Шевелев И. Андрей Битов о кризисах Пушкина, теории относительности и всесоюзной переписи царей // Российская газета. 2005. 5 апреля. URL: https:// rg.ru/2005/04/05/a59424.html (дата обращения: I5.I2.2016). Ходасевич В.Ф. О чтении Пушкина (К І25-летию со дня рождения) // Ходасевич В.Ф. Собрание сочинений: в 4 Т. М.: Согласие, І996. Т. 2. Записная книжка. Статьи о русской поэзии. Литературная критика I922-I939. 572 c. URL: http:// az.lib.ru/h/hodasewich_w_f/text_o750.shtml (дата обращения: I5.I2.20I6). Cultic Revelations: Studies in Modern Historical Cult Personalities and Phenomena // Spectrum Hungarologicum. Vol. 4 / ed. A. Halmesvirta. Jyväskylä, Pécs: University of Jyväskylä, Faculty of Humanities, Hungarian Studies, 20IO. I96 p.

I3 Dávidházi P. The Romantic Cult of Shakespeare: Literary Reception in Anthropological Perspective. Basingstoke, London, New York: St. Martin’s Press, Macmillan, I998. 240 p. (Romanticism in Perspective: Texts, Cultures, Histories)

I4 Literature and its Cults. An Anthropological Approach / eds. P. Dávidházi, J. Karafiáth. Budapest: Argumentum, I994. 270 p.

I5 Kalavszky Zs. “Downkóros. Hatujjú szeráf. Pofon a közízlésnek”: Puskin, az isteni és az idióta Tatyjana Tolsztaja Ksssz! címú regényében // Puskintól Tolsztojig és tovább...: Tanulmányok az orosz irodalom és költészettan köréből. Budapest: Argumentum Kiadó; ELTE Orosz Irodalom és Irodalomkutatás Doktori Program, 2006. P. I6I-I73. Kalavszky Zs. "Puskin - a kenyerünk, a vérünk, a levegőnk”: Mihail Epstejn Új szektásság című könyvéhez // 2000. 2008. April. P. 50-57.

I7 Kalavszky Zs. Ki a múzeumból! El a romoktól! Egy Puskin-“esszéregény” kezdetei Andrej Bitov A Puskin Ház címú regényében // Ex Symposion. № 66. 2008. P. 27-34. Kalavszky Zs. Puskin, Apuskin, Nyepuskin: Andrej Bitov: Puskin fotója (I799-2099) // In honorem Hetesi István 70 / ed. G. Kocsis. Budapest: ELTE BTK “Orosz Irodalom és Irodalomkutatás” Doktori Program, 20I2. P. I27-I39.

I9 Kalavszky Zs. Recenzió a Kul't kak fenomen literaturnogo protsessa: avtor, tekst, chitatel' címú könyvről / eds. M.F. Nad”iarnykh, A.P. Urakova. M.: IMLI RAN, 20II // RECITI. 20I4. December 25. URL: http://reciti.hu/20I4/2389 (дата обращения: I5.I2.20I6). 


\section{References}

Bitov A.G. Predpolozhenie zhit’. I836 [A proposal to live. I836], ed. Bitov A.G. Moscow, Izd-vo Nezavisimaia gazeta Publ., I999. 920 p. (In Russ.)

Bitov A.G. Molenie o chashe (Poslednii Pushkin) [A prayer for the hour (The last Pushkin)]. Moscow, Izd-vo Fortuna EL Publ., 2007. I76 p. (In Russ.)

Bitov A.G. Pushkinskii tom [Pushkin volume]. Moscow, Izd-vo AST Publ., 20I4. 460 p. (In Russ.)

Bitov A.G. Esse o Pushkine [Essay about Pushkin]. Novaia Gazeta, 20I4, September 29. Available at: http://www.novayagazeta.ru/arts/65485.html (Accessed I5 December 20I7). (In Russ.)

5 Dolinin A.A. Kak ponimat' mistifikatsiiu Pushkina "Poslednii iz svoistvennikov Ioanny d'Ark” [How to understand Pushkin's hoax “The Last of Jean d'Arc's Connections]. I vremia i mesto: Istoriko-filologicheskii sbornik k shestidesiatiletiiu Aleksandra L'vovicha Ospovata [Time and space: historico-philological collection in memory of the 60 year anniversary of Alexander L’vovitch Ospovat]. Moscow, Novoie izd-vo Publ., 2008, pp. I98-2I7. (In Russ.)

6 Kalavski Zh. Ravnodushnaia priroda kak pushkinskii motiv v romane Sergeia Dovlatova “Zapovednik" [Indifferent nature as a Pushkin motif in Sergei Dovlatov's Sanctuary]. Studia Slavica Academiae Scientiarum Hungaricae, 20II, no 56, pp. 39I-407. (In Russ.) Kul't kakfenomen literaturnogo protsessa: avtor, tekst, chitatel' [Literary Cult as a Phenomenon of Contemporary Literary Process: Author, Text, Reader], ed. Nad”iarnykh M.F., Urakova A.P. Moscow, IMLI RAN Publ., 20II. 480 p. (In Russ.) Pushkin A.S. Poslednii iz svoistvennikov Ioanny d'Ark [The Last of Jean d'Ark's Connections]. Pushkin A.S. Polnoe sobranie sochinenii: $v$ I6 t. [Complete Works: in I6 vols.]. Moscow; Leningrad, Izd-vo AN SSSR Publ., I937-I959. Vol. I2: Kritika. Avtobiografiia [Criticism. Autobiography], I949, pp. I53-I55. (In Russ.) Tolstoy L.N. Zhivoi trup [Living corpse]. Tolstoy L. N. Polnoe sobranie sochinenii: $v$ go $t$. [Complete Works: in 90 vols.]. Moscow, Gos. Izd-vo Hudozh. Lit. Publ., I952, vol. 34, pp. 5-IOO. (In Russ.)

Shevelev I. Andrei Bitov o krizisah Pushkina, teorii otnositel'nosti i vsesoiuznoi perepisi tsarei [Andrey Bitov on Pushkin's crises, the theory of relativity and the allUnion census of the tzars]. Rossiiskaia gazeta, 2005, April 5. Available at: https:// rg.ru/2005/04/05/a59424.html (Accessed I5 December 20I6). (In Russ.) Khodasevich V.F. O chtenii Pushkina (K I25-letiiu so dnia rozhdeniia) [On the reading of Pushkin: to the I25 year anniversary]. Khodasevich V. F. Sobranie sochinenii: $v 4$ t. [Works: in 4 vol.]. Moscow, Soglasie Publ., I996. Vol. 2. Zapisnaia knizhka. Stat'i o russkoi poezii. Literaturnaia kritika I922-I939 [A notebook. Essay on Russian literature. Literary criticism I922-I939]. 572 p. Available at: http://az.lib.ru/h/ hodasewich_w_f/text_0750.shtml (Accessed I5 December 20I6). (In Russ.) 
Cultic Revelations: Studies in Modern Historical Cult Personalities and Phenomena. Spectrum Hungarologicum, Vol. 4, ed. A. Halmesvirta. Jyväskylä; Pécs, University of Jyväskylä, Faculty of Humanities, Hungarian Studies Publ., 20Io. I96 p. (In English) Dávidházi P. The Romantic Cult of Shakespeare: Literary Reception in Anthropological Perspective. Basingstoke, London, New York, St. Martin’s Press, Macmillan, I998. 240 p. (Romanticism in Perspective: Texts, Cultures, Histories). (In English) Literature and its Cults. An Anthropological Approach, eds. P. Dávidházi, J. Karafiáth. Budapest, Argumentum Publ., I994. 270 p. (In English)

Kalavszky Zs. “Downkóros. Hatujjú szeráf. Pofon a közízlésnek”: Puskin, az isteni és az idióta Tatyjana Tolsztaja Ksssz! című regényében [“Complete moron. Six-fingured seraph. A slap in the face of public face!” Pushkin idiotic and divine in Tatyana Tolstay's novel Kys']. Puskintól Tolsztojig és tovább...: Tanulmányok az orosz irodalom és költészettan köréből [От Пушкина до Толстого и дальше...Собрание трудов по русской литературе и поэзии], ed. Á. Kovács. Budapest, Argumentum Kiadó Publ.; ELTE Orosz Irodalom és Irodalomkutatás Doktori Program [Eötvös Loránd University Faculty of Humanities PhD Programme "Russian Literature and Literary Studies”], 2006, pp. I6I-I73. (In Hungarian)

I6 Kalavszky Zs. "Puskin - a kenyerünk, a vérünk, a levegónk”: Mihail Epstejn Új szektásság címú könyvéhez [Pushkin is our bread, our blood, our air: About the Book New Sectarianism by Mikhail Epstein. The Varieties of Religious-Philosophical Consciousness in Russia]. 2000, 2008, April, pp. 50-57. (In Hungarian)

Kalavszky Zs. Ki a múzeumból! El a romoktól! Egy Puskin-"esszéregény" kezdetei Andrej Bitov A Puskin Ház címü regényében [Get out of the museum! Away from the ruins! The beginning of the essay-novel in Bitov's novel Pushkin House]. Ex Symposion, no 66, 2008, pp. 27-34. (In Hungarian)

Kalavszky Zs. Puskin, Apuskin, Nyepuskin: Andrej Bitov: Puskin fotója (I799-2099) [Pushkin, Apushkin, Nepushkin. Andrei Bitov's short story “Pushkin’s Photograph (I799-2099)”]. In Honorem Hetesi István 7o. [In honorem Istvan Hetesi 70], ed. G. Kocsis. Budapest, ELTE BTK “Orosz Irodalom és Irodalomkutatás” Doktori Program [Eötvös Loránd University Faculty of Humanities PhD Program "Russian Literature and Literary Studies"], 20I2, pp. I27-I39. (In Hungarian)

Kalavszky Zs. Recenzió a Kul't kakfenomen literaturnogo protsessa: avtor, tekst, chitatel' című könyvről, eds. M.F. Nad”iarnykh, A.P. Urakova. Moscow, IMLI RAN Publ., 2OII. [Review of Literary Cult as a Phenomenon of Contemporary Literary Process: Author, Text, Reader Eds. M.F. Nadyarnyh, A.P. Urakova. Moscow, A.M. Gorky Institute of World Literature Press, 20II.] RECITI, 20I4, December 25. Available at: http://reciti. $\mathrm{hu} / 2014 / 2389$ (Accessed I5 December 20I6). (In Hungarian, with abstracts in English and in Russian) 
УДК 82.09

ББК $83.3(7 \mathrm{Coe}) 53^{+}$

$76.02(2)$
МАРК ТВЕН В РУССКОЙ

ДОРЕВОЛЮЦИОННОЙ

ПЕРИОДИЧЕСКОЙ ПЕЧАТИ

Часть вторая

(C) 2017 г. Е.А. Стеценко

Институт мировой литературы

им. А.М. Горького Российской академии наук, Москва, Россия

Дата поступления статьи: 20 марта 2017 г.

Дата публикации: 25 сентября 2017 г.

DOI: IO.22455/2500-4247-20I7-2-3-I66-I89

Аннотация: В статье анализируется интерпретация творчества известного американского писателя Марка Твена в русской дореволюционной периодической печати (1872-1916). Предметом исследования являются критические статьи, очерки, рецензии, корреспонденции, а также предисловия к публикациям рассказов и романов Твена, некрологи по случаю его смерти и прочие материалы, печатавшиеся в столичных и провинциальных газетах и журналах. Восприятие Твена в России менялось в зависимости от многих факторов - политической и культурной ситуации в стране, состояния общественной мысли и литературной критики, журнальной или газетной конъюнктуры и пр., всегда оставаясь многогранным и противоречивым. В разное время, в годы демократического подъема и реакции, в произведениях писателя искали то, что соответствовало духу времени и помогало решению тех или иных идеологических и художественных задач. Твен характеризовался то как «чистый юморист», то как крупный писатель, философ и моралист. Творчество писателя стало предметом дискуссий демократов, либералов и консерваторов, феминисток, приверженцев реалистического и натуралистического литературного направления. Высокую оценку получил Твен как автор книг для детей и юношества. Замалчивались и подвергались цензурным сокращениям те произведения, где содержалась критика монархии и империализма. История отражения и толкования творчества Твена в русской печати служит доказательством того, что восприятие инонациональных литератур - это динамический и неравномерный процесс, складывающийся из колебаний, повторов, возвратов к прошлому и движения вперед, к более глубоким уровням анализа.

ключевые слова: американская литература, журналистика, творчество Марка Твена, литературная критика, общественная и культурная ситуация.

Информация об авторе: Екатерина Александровна Стеценко - доктор филологических наук, главный научный сотрудник, Институт мировой литературы им. А.М. Горького Российской академии наук, ул. Поварская, д. 25 а, г2Іо69 Москва, Россия.

E-mail: estetsenko@mail.ru 
This is an open access article distributed under the Creative Commons Attribution 4.0 International (CC BY 4.0)

\section{Part 2}

(C) 20I7. E.A. Stetsenko

A.M. Gorky Institute of World Literature of the Russian Academy of Sciences, Moscow, Russia Received: March 20, 2017

Date of publication: September 25, 2017

Abstract: This article deals with the analysis of interpretation of the works by Mark Twain, famous American author, in the Russian pre-revolutionary periodical press (I872-I9I6). The objects of research are critical articles, essays, reviews, correspondences, introductions to publications of Twain's short stories and novels, obituaries, and other materials printed in central and provincial magazines and newspapers. Perception of Twain in Russia was contingent on many factors including political and cultural situation in the country, state of social thought and literary criticism, newspaper and magazine conjuncture etc., always remaining polysemantic and conflicting. In different times, in the years of democratic rising or reaction critics looked for something in Twain's works that corresponded to the spirit of their time and helped solve ideological and aesthetic problems. Twain had reputation of either a "pure humorist" or a great writer, philosopher, and moralist. Democrats, liberals, conservatives, feminists, adepts of realistic or naturalistic trends in art discussed Twain's works that became a source of knowledge about the United States and inspired polemics about Russia's further development. Twain was highly esteemed as the author of books for children and young people. Yet his works that criticized monarchism and imperialism were often ignored or abridged. The history of Twain's interpretation in the Russian press serves as evidence of the fact that perception of foreign literature is a dynamic and bumpy process, repeating itself and moving backwards but also getting to deeper levels of meanings.

Keywords: American literature, Mark Twain, Russian periodicals, literary criticism, journalism, social and cultural situation.

Information about the author: Ekaterina A. Stetsenko, DSc in Philology, Director of Research, A.M. Gorky Institute of World Literature of the Russian Academy of Sciences, Povarskaya 25 a, Moscow, Russia.

E-mail: estetsenko@mail.ru 
Начало статьи см. Studia Litterarum. 20I7. T. 2, № 2. С. I20-I43.

В течение многих лет Твен-юморист заслонял от русского читателя Твена - социального критика и моралиста, но серьезные материалы о писателе продолжали появляться на страницах периодической печати. Заслуживает внимания помещенная в газете «Минский листок» (I893, II мая, № 38) рецензия на перевод в «Вестнике иностранной литературы» рассказа «Банковский билет в I.о0о.ооо фунтов стерлингов», где отмечается умение Твена «построить фантазию на почве реальной правды» и проводится параллель между Америкой и Россией, многие граждане которой также «бледнеют перед миллионным билетом». Попытка дать объективную оценку творчества Твена делается в «Книжках недели» (г896, № 9), называющих писателя «исключительным явлением в современном мире» и подчеркивающих его тягу к самообразованию, изучению средневековой истории. Биографический очерк в «Нови» (І897, № 9) характеризует Твена как непримиримого ко злу моралиста, обладающего огромным жизненным опытом, пишущего с юмором о серьезных вещах.

Вообще в конце г89о-х гг. усилилась тенденция к более глубокому осмыслению твеновского творчества, что связано, главным образом, с публикацией в I897 г. «Воспоминаний об Иоанне д’Арк ее пажа и секретаря Луи де Конта» и переводом ряда статей солидных американских критиков. Большинство современных исследователей полагает, что роман «Жанна д’Арк», к которому Твен относился с особой любовью и серьезностью, произведение далеко не лучшее в его наследии, грешащее несвойственной писателю сентиментальностью и значительными художественными про- 
счетами. Но в дореволюционной России книга была принята с интересом и получила довольно большую прессу. В условиях цензуры историческая проза была особо популярна, поскольку русская интеллигенция нередко использовала исторические факты и сюжеты в качестве аналогий современной ситуации и как примеры для воспитания гражданского духа. Образ же простой девушки, руководившей королями и возглавившей освободительную борьбу, вызвал понятное сочувствие в эпоху распространения демократических и народнических идей.

Многие оценили роман как исторически достоверное повествование, привлекательное своей фактической стороной. Известный генерал М. Драгомиров, вдохновленный чтением «Жанны д’Арк», напечатал в «Военном сборнике» (I898, № I) самостоятельное изложение судьбы героини, сопроводив его подробным разбором военных действий и полным описанием осады Орлеана с приложением чертежей и схем. Называя книгу «подарком русской читающей публике», по сравнению с «десятками переводных амурных романов, наполняющих наш книжный рынок», он сожалеет, что Твен не остановился на документальном жанре, а выбрал беллетристическую форму, по мнению Драгомирова, являющуюся помехой и придающую сочинению неестественность. Близкая точка зрения содержится в «Русском вестнике» (I897, март), отмечающем тщательность изученности исторического материала и верность автора фактам, но критикующем невыдержанность стиля, искусственность и фрагментарность композиции романа.

Рецензент П. Краснов («Всемирная иллюстрация», I897, 24 мая, № 2) считает, что у Твена все время сквозят приемы фельетониста и даже «самое заглавие книги отзывается шутовством». Попытку писателя выступить в качестве исторического романиста он считает неудачной и служащей уроком для других мастеров смеха. «Раз публика привыкла смотреть на него как на юмориста, - пишется в рецензии, - он не может писать серьезных исследований, тем более о возвышенных и трогательных предметах»․․․ Совершенно противоположную позицию заняли «Неделя» (г897, № 15), назвавшая достоинством писателя беллетризацию исторического материала, оживляющую фигуру героини, и «Северный вестник» (I897, № 4), похваливший

I Всемирная иллюстрация. I897. № 2 (24 мая). 
Твена за выбранную форму воспоминаний и отсутствие «юмористического намерения автора».

Новую волну откликов вызвали два последующих издания «Жанны д’Арк» в I9O2 г. - в качестве приложения к журналу «Детский отдых» и как первого из серии исторических романов, задуманной издательской фирмой А. Ильина. В этой серии предполагалось выпустить десять книг, в том числе произведения Абеляра, Э. Сю, Бальзака и др. В предисловиях к этим изданиям Е.В. Лавровой и известного историка и журнального деятеля А.С. Трачевского сочетание в повествовании достоверности и вымысла признается оправданным. Положительно отозвалась о «Жанне д’Арк» и педагогическая печать. В журнале «Образование» (І902, № I) П. Морозов называет роман одним из лучших исторических сочинений времени, где гармонично соединились научное знание и художественный талант.

«Жанна д’Арк» попала в список литературы, рекомендованной для народного чтения весьма строгой комиссией, установившей высокие идейные и художественные критерии для отбора². Переиздание романа приветствует А.А. Фаресов в своей рецензии в «Историческом вестнике» (СПб., I902, № 2), пишущий, что «исторический роман, эта “вселенская панорама”, по выражению Белинского, несомненно, будет содействовать в русском обществе поднятию общественного духа и ознакомлению с миросозерцанием лучших деятелей всемирной истории в разные ее эпохи»3.

Рецензент П.С. Климентов в предреволюционном демократическом органе «Курьер» (І902, № 28) также подходит к роману с социальными мерками, но, с его точки зрения, Твен не находится на уровне современной исторической науки, поскольку не изображает массы как деятелей истории, не показывает экономических условий, определяющих историческую ситуацию, а уделяет слишком большое внимание психологии героини, чудесам и легендам. Считая выбор «Жанны д’Арк» в качестве первого романа исторической серии неоправданным, Климентов корит редакцию за отсутствие у нее четкой концепции исторического развития и личности. Аналогичным образом отмечается, что «культ героини идет в разрез с современными научными и воспитательными течениями», и в «Вестнике воспитания» (1903, № 8).

2 Народная литература. Сборник отзывов библиотечной комиссии. Киев, г903. Вып. I.

3 Исторический вестник. СПб., І902. № 2. 
Как можно видеть, вся эта разноголосица мнений связана не только с действительной противоречивостью и художественным несовершенством романа, но и с борьбой идей в русском обществе, обострившейся в конце I890-x - начале I900-х гг. и стимулировавшей более вдумчивое отношение к литературе. Попыткой изменить облегченное представление русской публики о Твене можно объяснить перевод статьи американского ученого Карлиля Смайта («Журнал журналов», I898, № 22), прямо утверждавшего, что неверно считать писателя только юмористом, призванным смешить людей, что существует серьезный Твен, страдающий от непонимания, выражающий глубокие мысли и чувства, автор романов «Янки из Коннектикута при дворе короля Артура» и «Простофиля Вильсон». Статья Смайта впервые познакомила русского читателя с позицией прогрессивной американской критики, уровень которой в осмыслении твеновского творчества тогда в целом был выше, чем в России. Уже в I882 г. был написан очерк У.Д. Хоуэллса «Марк Твен», где подчеркивался национальный характер и вместе с тем общечеловеческая значимость произведений писателя. Пришло понимание подвижности, эволюции его творчества в сторону серьезной, социально-философской прозы.

Перепечатывавшиеся из американской прессы материалы добавляли новые штрихи и к представлению о личности Твена. В «Литературных вечерах» «Нового мира» (І899, № 9) появились воспоминания Н. Брукса, некогда редактировавшего письма молодого автора с парохода «Квакер-Сити». В этих свидетельствах очевидца описывалось пребывание Твена в Калифорнии в I86о-е гг. и приводились не анекдоты, а подлинные факты из жизни писателя. Приближали читателей к Твену-человеку и художнику также интервью, к сожалению, очень немногочисленные.

В І897 г. «Одесские новости» (8 октября, № 4Іо7) поместили материал за подписью П. 3-ич (П.И. Ротенштерн), пересказывавший интервью, данное Твеном в Вене австрийским журналистам. Сначала венский репортер приводит вымышленный разговор с Твеном, какой мог бы состояться, если бы характер писателя соответствовал представлению, составленному о нем широкой публикой. В этом комическом интервью у Твена все «юмористическое», даже волосы и руки, и никто не в состоянии принять его всерьез, в том числе врачи, не верящие испытанным им страданиям. Далее следует подлинная беседа, из которой можно узнать об отношении писателя к 
немецкому языку и его любви к классикам немецкой литературы - Шиллеру, Гете и Гейне. В ответ на просьбу интервьюера дать автограф Твен пишет следующую фразу: «Правда - высшее благо, которым мы владеем. Будем же бережно обращаться с нею». Более насыщено фактами второе венское интервью, напечатанное в «Вестнике иностранной литературы» (I897, № II), где содержатся сведения о планах писателя, его намерении издать новую книгу путешествий, его впечатления от посещения Венского городского совета и воспоминания о молодых годах.

В г899 г. в «Одесских новостях» (7 марта, № 456I) появляется интервью, данное Твеном 2 (I4) марта венскому корреспонденту этой газеты В. Симону [перепечатано «Смоленским вестником» (2І899, № 86)]. В этой беседе писатель предстает человеком широких передовых взглядов, интересующимся самыми острыми проблемами современности и имеющим на них свою точку зрения. Он поддерживает позицию Э. Золя в деле Дрейфуса, которое называет «постыдным для цивилизации», и с симпатией говорит о женском движении в Австрии, считая, что у мужчин не должно быть никаких привилегий и недопустимо преграждать прекрасному полу путь к свободе. «Только продолжительная реакция, - говорит Твен, - способна создать такие безумные вопросы, как “женский” и наряду с ним “еврейский”»4.

Для русского читателя это интервью было особенно интересно столь редкими высказываниями об их родине. Планы Твена приехать в Россию по-прежнему неопределенны (в этой стране у писателя только один знакомый - художник В.В. Верещагин, с которым он беседовал на его выставке в Нью-Йорке), хотя желание познакомиться с таким «популярным» государством и с его «известными особами» остается. С огромным уважением Твен относится к русской литературе и особенно к Толстому, чьи произведения он «основательно изучил». «Вообще, - признается Твен, - все, что лишь переведено на английский язык с русского, я читаю с большим интересом» 5 . Он отказывается характеризовать любимых писателей более подробно, так как не владеет в совершенстве немецким языком, на котором давалось интервью, a «русская литература достойна того, чтобы, говоря о ней, не отделываться общими фразами, вроде “восхитительна”, “превосходна” и даже “велика”»․

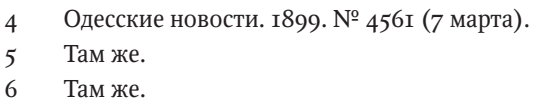


Следующее интервью, по-видимому взятое из какого-то иностранного источника, было напечатано в 1902 г. в Прибавлении к «Новому времени», перепечатано в «Вестнике иностранной литературы» (I902, № II) и кратко изложено в «Курьере» (I902, № 232) и «Асхабаде» (г902, № 249). Интервьюер Б. Нортроп, посетивший Твена в горах на вилле, явно поставил перед собой задачу показать неоднозначность твеновской судьбы и натуры. Он нарисовал портрет невеселого, занятого человека, испытавшего нешуточные удары и потери, вынужденного из-за долгов «заложить мозг», тяжко трудиться и на старости лет «начать жизнь сначала». В приведенной Нортропом краткой биографии Твена выделяются, главным образом, печальные события - нелегкая работа в типографии, трагическая гибель брата Генри, банкротство.

И, наконец, в І9Іо г. в «Раннем утре» (№ 82) было помещено последнее в русской печати интервью с Твеном, правда уже представлявшее собой воспоминания о встрече 2О-летней давности. Некий М.С., корреспондент одной из московских газет, пересказывает разговор, состоявшийся после вечера берлинских писателей и касавшийся литературных вопросов. Высказавшись скептически о будущем натуралистического течения и выразив удивление по поводу парадоксального факта выдвижения из немецкой мещанской среды гениальных художников, Твен с присущим ему юмором сделал несколько замечаний о русской прессе. «Ваша пресса, - сказал он, американизируется, как уже американизировалась печать в Париже и Лондоне. Вообще, ваша культура молодая. Только вашей русской молодежью и неопытностью я и объясняю, что у вас переводят мои произведения в большом количестве, но не платят мне ни пенса» 7 . На сетования интервьюера об отсутствии в России литературной конвенции и тяжелом положении издателей Твен ответил: «Значит, они издают мои сочинения ad majorem gloriam? Значит, ваши писатели пишут не для денег, а для славы? И это у вас со временем изменится... ${ }^{8}$. Подводя итог беседе, автор очерка подтверждает, что во многом Твен оказался провидцем, - натурализм пережил себя, русская пресса американизировалась, «и только русские издатели все еще думают, что писатели, русские и иностранные, пишут только для славы»9.

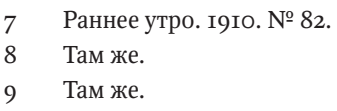


«Американизацией прессы», которую предвещал Твен, далеко не исчерпывалось влияние Америки на жизнь европейских стран в конце XIX начале XX в. Эта заокеанская держава продолжала вызывать противоречивые чувства и оживленные споры. Поэтому, хотя в России все больше росло понимание, что Твен - фигура общечеловеческого масштаба и значения, интерес к нему как к писателю американскому не только не ослабевал, но усиливался, приобретая разные оттенки в зависимости от той или иной точки зрения на саму американскую действительность. Еще в I886 г., в небольшом предисловии, помещенном на обложке «Очерков и рассказов» Твена, подчеркивалось, что жизненный путь писателя - это типичный путь американца. В Америке, пишет издатель, «всякий честный труд пользуется таким почетом, что в скромном прошлом ее знаменитых впоследствии общественных деятелей там нет ничего особенного. Между тем живое соприкосновение с природой и народной средой дает американским писателям отпечаток мужественной стойкости и хорошего нравственного закала» [4, с. I]. Национальной принадлежностью Твена объяснялась и специфика его юмора, оптимистического, грубого, склонного к гиперболизации, шаржу, бытовым подробностям, и его пристрастие к комическому в целом, так как американцы, занятые бизнесом и не умеющие развлекаться, видят в веселой книге единственный источник развлечения («Всемирная иллюстрация», І89І, 30 ноября, № 23).

Американские корни твеновского комизма отыскиваются во многих рецензиях, появлявшихся на вновь выходящие переводы произведений Твена (очень популярного, напечатанного в нескольких журналах рассказа «Смертный жребий», «Дневника Адама», «Жизни на Миссисипи» и пр.). В предисловии к «Избранным сочинениям Твена» (І898) отличительной чертой его юмора называется не европейская холодная ироничность, а американская открытая обличительность, переходящая в сатиру на общественные недостатки. Статья о С.Л. Клеменсе в «Энциклопедическом словаре» [7], подписанная известной писательницей и переводчицей 3.А. Венгеровой, также отмечает типично американский характер твеновского эксцентричного смеха. Изображая столкновение простаков-янки с действительностью, автор, по мнению Венгеровой, рисует цельные, практичные, преуспевающие благодаря хитрости и находчивости натуры, делая при этом тонкие наблюдения над человеческой природой. 
Традиционные представления об Америке как стране противоречивой, но молодой, имеющей большие перспективы, и о национальном характере, энергичном и жизнерадостном, сохранялись в русском обществе и в I900-х, и в І9Іо-х гг., определяя тон многих материалов о Твене. «Вестник иностранной литературы» (I906, № I), уделявший значительное внимание Соединенным Штатам и их литературе, откликнулся на 7о-летие писателя статьей, где Твен изображался «новым Адамом», воплощением «американской наивности», всегда руководствовавшимся инстинктом и «скрывавшим под серьезной маской взрослого человека лицо дитяти». Известный писатель и журналист И.И. Ясинский (псевдоним - Максим Белинский) в критико-библиографическом очерке к «Полному собранию сочинений» Твена (I9II) также связывает демократический, рассчитанный на всех, а поэтому «поверхностный» юмор Твена с его «американизмом». Северная Америка названа Ясинским «страной неожиданностей, своеобразной страной демократических странностей и чисто библейских карьер, напоминающих то блаженное время, когда пастухов выбирали в цари, а рыбаки становились апостолами» [5, с. 3]. Твен - порождение этой цивилизации, имеющей исключительно благоприятные условия и отличающейся уважением к техническому прогрессу и мечтой о вселенской гегемонии. Его биография пример американского умения добиваться успеха, а в его характере одна из главных черт - предприимчивость, которая появилась еще в детстве, когда он оригинальным способом заработал свой первый гонорар.

Символом Америки видит Твена К.И. Чуковский, опубликовавший в І9Іо г. в «Современном слове» (№ 8І4) живо и мастерски написанный очерк, богато иллюстрированный выдержками из книг писателя и фактами его биографии. В юморе Твена Чуковский не усматривает ничего «гоголевского» с его «полуулыбкой» и «самобичеванием». Этот смех выражает любовь к жизни, «трезвую, здоровую, бодрую “американскую” любовь», «без всякой трагедии, истерии». «Ничего писательского, кабинетного! - восклицает Чуковский. - Загорелое лицо землекопа, узкие, веселые глаза “юморист и чернорабочий сразу”, как назвал его один американец. Потом он опять бродяга, опять в рудниках, то банкрот, то репортер, то редактор американец с головы до ног. Он не то чтобы “знал Америку”, не то чтобы “изучил Америку”, он впитал Америку в себя, и жизнь его была “самая американская” и творчество его было “самым американским” изо всех... Марк 
Твен первое, полнейшее порождение американской культуры, совершеннейший ее выразитель. И читая его книги, видишь: какая это нищая культу$\mathrm{pa},-$ и какие огромные у нее возможности. Вся духовная сила Твена была в сверхъестественном необычайном слиянии со своим народом» ${ }^{10}$.

Правильно заметив и выделив главные черты твеновского творчества - его национальную и народную природу, Чуковский в этой первой своей публикации о Твене прошел мимо Твена-сатирика, критика нравов и философа. Не поняв внутренней трагедии писателя, только что завершившего свой жизненный путь, Чуковский написал: «Он был в полнейшей гармонии со своим миром и отсюда его величайшее доверие к Богу, к смерти, к судьбе, - тоже такое американское, - и отсюда его смех, самый счастливый, какой только слыхала вселенная. Обличать ему в этом мире было нечего, - для этого он был слишком свободен и слишком силен, и если его смех кажется нам зубоскальством, что ж? - в этом виноваты мы, а не он» ${ }^{\mathrm{II}}$.

Можно упрекнуть маститого литератора, известного детского писателя и литературного критика, тогда только начинавшего свою литературную деятельность, в ограниченности трактовки Твена, столь очевидной современному читателю, знакомого с трактатом «Что такое человек?», «Таинственным незнакомцем», «Автобиографией» и антиимпериалистическими памфлетами. Но нельзя не почувствовать в несколько восторженном пафосе статьи и в явном преувеличении оптимистической направленности творчества Твена тоску русского интеллигента начала века по уверенности в будущем, умению радоваться в жизни.

В русской печати тех лет публиковались, однако, и такие материалы, которые содержали более сдержанный и трезвый взгляд на Новый Свет. Корреспондент М. Назаревский в своем «Письме из Америки» («Русские ведомости», I9I4, № І73) вспоминает рассказы Твена для того, чтобы показать, как изменилась жизнь в США за прошедшие полстолетия. В описанном им «железном городе» Гарри, этом создании «капиталистического гения», все принесено в жертву девизу «делай деньги», природа испорчена, власти творят беззакония, растет преступность, рабочие подвергаются угнетению и живут в нищете.

Iо Современное слово. I9го. № 8I4.

II Там же. 
Автор статьи «Марк Твен и наши юмористы» («Одесские новости», I9Iо, № 809) поражается ограниченности героев Твена и обилию у него описаний «человеческой глупости». «А между тем, - пишет он, - нельзя забывать, что дело всегда происходит в великой заатлантической республике, в стране свободы и простора жизни, среди наиболее культурных и приспособленных к борьбе за существование обитателей земли» ${ }^{\mathrm{I}}$. В контексте статьи подобная характеристика американского бытия является не констатацией реального положения вещей, а, скорее, идеальным пожеланием. В обществе с контрастами богатства и нищеты одинаково нелепы и смешны и «жертвы праздности и сытости», и те, кто тщетно карабкается вверх. Утверждая, что «Марка Твена отнюдь нельзя назвать обличителем буржуазных нравов, ни печальником народных интересов, ни, тем менее, отрицателем существующих общественных форм и отношений»³, автор статьи считает смех писателя направленным в равной степени против богатых и бедных, успеха и поражения ${ }^{14}$. По этой причине, говорится далее, часть твеновского юмора для русских читателей «прошла совсем бесследно, ибо не до смеху и не до забав им было часто. Американская сатира являлась для них слишком веселой и беззаботной и трогала постольку, поскольку в ней слышались сквозь смех знакомые им слезы» ${ }^{15}$. «Это смех сына нации, уже устроившей свою жизнь», - так охарактеризовал юмор Твена «Одесский листок» (I9I5, № 96) в заметке к пятилетию со дня смерти писателя. Американцы верят, что человек - господин мира, и смеются над неудачниками. В России же, где смех был горьким и бичующим, всегда «братался с идеей» и «отправлял свои гражданские обязанности», принято смеяться над сильными мира сего и сочувствовать обездоленным.

Понимание авторами этих публикаций отрицательных сторон американского «культа успеха», обернувшегося эгоизмом, бездуховностью и жестокостью, сказалось на их интерпретации творчества Твена, которому,

I2 Одесские новости. І9го. № 809.

I3 Там же.

I4 В качестве примера, как это ни парадоксально, приводится «Принц и нищий». Интересно, что в других статьях о Твене («Южный край», Харьков, г9го, № 996о; «Голос Москвы», I9Iо, № 82) особая популярность этого романа в России объясняется как раз тем, что в нем Твен следовал европейской гуманистической традиции и выражал жалость к слабым. А «Новое время» (I9Iо, № I224I) сравнивает Твена по снисхождению к человеческим недостаткам с Диккенсом.

I5 Одесские новости. І9Іо. № 809. 
как признанному выразителю национального духа, стали приписывать и пороки его страны. В.Г. Тан-Богораз, народоволец, этнограф, лингвист и писатель, совершенно несправедливо назвал Твена средним писателем, не создавшим ничего, кроме остроумных, но малосодержательных очерков. Возмутившись позицией Твена в скандале, который разразился по поводу приезда в Америку А.М. Горького и его гражданской жены М.Ф. Андреевой, он откликнулся на этот инцидент большой статьей, озаглавленной «Что такое американская свобода?» («Двадцатый век», І906, № I8). Америка, по его мнению, обладает неоспоримыми достоинствами - богатством, энергией народа, отсутствием религиозных гонений, феодальных институтов и рабства, с которым она покончила в Гражданской войне. В отличие от России, у нее нет засилья казенщины и бюрократии и есть «простонародная свобода». «Но одно из правильных условий правильного развития, пишет Тан-Богораз, - высшая интеллигентная культурность, находится в Америке в состоянии довольно зачаточном» ${ }^{16}$. Развивая свою мысль, он характеризует положение американской интеллигенции, малочисленной, подчиненной власти «денежного мешка» и плохо обеспеченной. Приводя в качестве примера низкого престижа высшего образования тот факт, что «в ньюйоркском музее натуральной истории <...> секретарь отдела с университетским образованием получал 80 долл. в месяц, а столяр, починявший шкафы и принадлежавший к союзу столяров, вырабатывал г2о долл. в месяц» ${ }^{17}$, Тан-Богораз называет Америку раем для капиталистов, матерью для ремесленников и мачехой для интеллигентов. Он считает необходимым писать в России о недостатках США: о существовании денежной аристократии, о показной морали и лицемерии, о низком уровне литературы и журналистики. У русской интеллигенции, пишет автор, нет прав, но она выше интеллигенции американской, так как не идет на поводу у обывательских предрассудков, являясь носительницей идей «личной и общественной свободы, братства, общего мира и труда, отрицания условности и общественного лицемерия» ${ }^{18}$.

Таким образом, критические высказывания в адрес Твена в начале века были во многом связаны с негативным отношением к самим Соеди-

I6 Двадцатый век. I906. № I8.

I7 Там же.

I8 Там же. 
ненным Штатам, все больше демонстрировавшим хищническую сущность империализма и несовершенство буржуазной этики. Литераторы, сравнивавшие американских писателей с русскими, часто подчеркивали гуманистические традиции отечественной литературы, ее гражданский пафос и независимость от ханжеской морали. Но немало было статей и иной направленности, где разговор об авторах зарубежных, в том числе о Твене, служил поводом для критической оценки и обсуждения собственной культурной ситуации.

В предисловии А. Аверченко к «Собранию сочинений» Твена (СПб., I9IO), где причиной необыкновенной популярности произведений писателя называется сочетание в них «здравого смысла», «забавной карикатуры и абсурда», «сочувствия к обездоленным, ненависти к угнетателям», любви к жизни и уважения к «идеальным порывам человечества», пишется: «Все это, в соединении с меткостью выражений, живым, простым, прекрасным языком и благодушной англо-саксонской мудростью, сделало Твена самым любимым писателем холодной Англии и сухой, набитой, как мешок, долларами - Америки. Эти невозмутимые, хладнокровные страны, как будто отдыхают на веселом, кипучем, порывистом Твене, как отдыхала в свое время Англия на Диккенсе. Впрочем, Твен завоевал сердца не только своих соотечественников < ...> все его любили, прекрасного, веселого сатирика, даже мы, русские. А уж это известно, что нет народа более нудного, печального, с отчаянной скорбью в истерзанных натурах и мучительными вопросами на устах, чем мы, русские» [6, с. XXV]. А С. Лорие в предисловии к «Жизни на Миссисипи» (М., І9Іо), подчеркивая наличие у Твена трагических сторон жизни, считает и его юмор, и его трагизм одинаково «по-американски» здоровыми, лишенными присущих русским «насильственного смеха и искусственных слез, болезненных страхов и нервных исканий» [3, с. 4].

В газете «Приднепровский край» (Екатеринослав, І9Іо, № 3942) С. Соломин в «Маленьком фельетоне» пытается объяснить, почему в России нет своего Твена, и предсказать условия, при которых он может появиться. Главной чертой Твена, отличающей его от русских юмористов, Соломин называет добродушие, любовь и снисходительность к человеку, перед которым писатель не ставит неразрешимых задач. Твен, по мнению критика, принимал людей такими, какие они есть, исходя из реальности, что не свойственно русским юмористам, «возящимся с воображаемым че- 
ловеком». Именно отсутствие любви к человеку, «независимо от того, соответствует ли он идейной программе», а не политический строй, толкуется далее, причина того, что личность в России унижена так, как ни в какой другой стране. Русские писатели упрекаются в умении радоваться жизни и в пристрастии к отвлеченному умствованию. Единственным «беспримесным» юмористом, пишется в статье, был в России Козьма Прутков. Гоголь «загубил» свой юмористический талант, «вздумав решать судьбы русского народа и став отыскивать его суть». Такой же путь от комического до трагического мировосприятия прошел Г. Успенский, задумавший «разгадать русского мужика» и сошедший с ума. Его, Чехова, Горького и многих других автор считает жертвами радикалов, оказавших на отечественную литературу пагубное влияние. «Юмор тонкий, - утверждает он, - не переходящий в грубый фарс, нам или вовсе недоступен, или мы до него не доросли. Сейчас пропустим гражданскую слезу, партийную программу, вещательное пророчество, проповедничество или даже богоискательство» ${ }^{\text {19. }}$ «Русский мир оторвался от своей естественной почвы - быта, поскольку в России быт - “одряхлевшее здание”, а для нового “не видно и фундамента” ${ }^{20}$. «И, конечно, быт этот сложится не по какой-либо партийной программе и народ русский не оправдает интеллигентных надежд и теорий, а заживет как-нибудь по-своему» ${ }^{21}$. Вот тогда, пророчествует Соломин, и появится свой Марк Твен.

Сравнения между юмором американского писателя и русской юмористикой проводились даже в некрологах Твена. В некрологе, озаглавленном «Любовь и юмор» («Двинский листок», І9Іо, № I058), В. Лесовой пишет: «Со смертью Марка Твена мы, русские, потеряли больше, чем кто бы то ни было, ибо мы меньше, чем кто бы то ни было, умеем просто и искренне смеяться. Мы смеемся всегда над чем-нибудь, а не по внутренней органической потребности, мы в сущности даже не смеемся, а осмеиваем, насмехаемся, отравляем свой смех ядом сатиры и желчи. Русская литература совершенно не знает того здорового и естественного смеха, который составляет у нас удел одних детей и наиболее ярким выражением которого был покойный Марк Твен. Это не гоголевский и не чеховский смех “сквозь 
слезы”, это не саркастическая усмешка Щедрина, это не злорадно-торжествующий хохот Мефистофеля, - это простой и веселый смех здорового человека, который полюбил жизнь со всеми ее уродствами и нелепостями, которому просто и весело хочется смеяться от ощущения жизни, силы и энергии. Благословение Божие этот радостный смех, и какое несчастье, что мы лишены его, что мы готовы стреляться из-за двойки по алгебре» ${ }^{22}$. Жизнь Твена, подчеркивает автор, была полна лишений, которые не смогли бы вынести в России, однако он сохранил оптимизм. В России плохо понимают «Смех от любви к жизни»: «Мы прощаем смех и юмор только тогда, когда он служит сатире, когда он имеет в виду унизить Пуришкевича или изобличить Гучкова...»²3.

Откликнулся на смерть Твена и известный писатель, мастер реалистического рассказа А.И. Куприн, уже ранее сравнивавший творчество Твена с русской литературой в заметке «Проказливый юмор» [2], где пишется, что комическое в России свелось к «юмору висельников», жестокой сатире, пародии и мрачному анекдоту. В некрологе «Умер смех» («Одесские новости», № 8087) Куприн говорит, что «вместе с Клеменсом ушла - и, я думаю, безвозвратно - та смеющаяся печаль, та окрыленная светлыми слезами веселость, которую мы зовем юмором <..> Мы, теперешние люди, оглушенные ревом автомобилей, звонками телефонов, хрипом граммофонов и гудением экспрессов, мы, ослепленные электрическими огнями вывесок и кинематографов, одурманенные газетой и политикой, - разве мы смеемся когда-нибудь? Мы - или делаем кислую гримасу, которая должна сойти за усмешку, или катаемся от щекотки в припадке истерического хохота, или судорожно лаем на жизнь, отплевываясь желчью. Но тот светлый смех, за который Достоевский называл Диккенса “самым христианским из писателей” и который так пленял Пушкина в ранних гоголевских повестях, - этот смех почти на наших глазах растаял и испарился. Он начался громоподобным смехом гомеровских богов <...> и окончился вчера, в тот момент, когда на лице Марка Твена легла вечная улыбка мудрости <...> надолго, если не навсегда, мы обре-

\footnotetext{
22 Двинский листок. І9Іо. № 1058.

23 Там же. Интересно, что в помещенном рядом с некрологом Твену («Бессарабская жизнь», І9Іо, № 83) некрологе выдающемуся украинскому актеру и драматургу М.Л. Кропивницкому звучит та же мысль. О классическом водевиле Кропивницкого «По ревизии» говорится, что он «написан в радостных, ликующих тонах, совершенно неведомых нынешнему хмурому поколению».
} 
чены переходить от двухсложного анекдота к бешеной сатире. Но истинный, здоровый и беззлобный смех умер в трескотне и пыли города» ${ }^{24}$.

Подобные нарекания в адрес русской литературы и русского общества, разумеется, прежде всего отражают реальное положение вещей. Американская и русская юмористика действительно опирались на разные традиции и развивались в несхожих условиях. Та реальность, которая существовала в России, слабом и отсталом звене капиталистического мира, не давала особых поводов для жизнерадостности и оптимизма. Расстояние между действительностью и идеалом было слишком велико, жизнь не представлялась прекрасной «сама по себе», и больше надежд возлагалось не на ее самодвижение, а на ее преобразование в соответствии с той или иной идеей. Общество, скованное архаичными государственными и экономическими институтами, нуждалось в преобразовании. Русские писатели, в отличие от американских, всегда творившие в условиях цензуры и игравшие активную роль в общественно-политической жизни, выступали в качестве критиков, учителей, пророков, они были «властителями дум». Отсюда и «незримые слезы», и сатира, и гнев, и идейная тенденциозность. Ожидать от истинно гражданственной литературы «беззлобного» смеха и упрекать ее за отсутствие такового по меньшей мере странно и неоправданно.

Но критический пафос упомянутых статей направлен в первую очередь против духовной атмосферы кризисного периода начала века, характеризовавшегося настроениями упадничества, безверия, озлобленности, ухода от реальности в мир абстрактных идеалов и романтических грез. Полный энергии юмор Твена как бы восполнял в России необходимый элемент духовной жизни и помогал оздоравливать национальный дух. Американский прагматизм, грубоватая жизненная сила, даже некоторая приземленность и поверхностность, в определенной степени, противопоставлялись декадентскому мироощущению. При этом в пылу полемики нередко сгущались краски - отечественная литература подвергалась несправедливым нападкам, ее картина искажалась, факты получали неверную трактовку. Упрощалось и творчество Твена, в оценке которого делался акцент на черте, нетипичной для русского юмора, - «здоровом оптимизме», а сатира, сарказм, горькая ирония упускались из виду. 
Представление о восприятии Твена в России в начале века дают его некрологи, десятки которых появились в столичной и провинциальной прессе. Одновременно с Твеном ушли из жизни Э. Ожешко, Б. Бьернсон, М. Кропивницкий, П. Виардо, но сообщения о кончине американского писателя были многочисленнее, подробнее и носили более сенсационный характер. Из этих материалов, часто перепевавших друг друга, очевидно, что широкая публика по-прежнему относилась к Твену как к веселому шутнику. Даже на столь печальное известие многие газеты и журналы откликнулись перепечаткой популярных анекдотов, а масса некрологов начиналась известной шуткой Твена о преувеличенных слухах по поводу его смерти.

Повторялись и легенды об этом удивительном человеке, причем иногда противоречащие друг другу. Так, корреспондент из Калифорнии П. Тверской («Вестник Европы», І9Іо, № 7) писал, что Твен - «мудрый и снисходительный государственный деятель», влиявший на политику и общественное мнение, которого слушались правительство и народ, и в то же время свободный и беспечный представитель артистической богемы. Детищем молодой культуры Нового Света, певцом дикой природы и безграничной свободы называется Твен в «Вестнике знания» (І9Іо, № 5). «Голос Москвы» (I9Iо, № 82) представил Твена как литератора американского образца - не далекого от мирской суеты художника, а предприимчивого дельца, в чьих книгах «катехизис и основы мировоззрения его сородичей, знаменитостей другого типа, всех этих Вандербильдов, Рокфеллеров, Морганов и иных» ${ }^{25}$. Твен отличается от них якобы лишь тем, что делал деньги не нефтью, рудниками или железными дорогами, а литературой. В «Вестнике иностранной литературы» (І9Іо, № 6), «Вокруг света» (І9Іо, № I8), «Природе и людях» (І9Іо, № 27) Твен нарекается апостолом практического ума, жизнерадостным янки, «Клондайком веселья», неунывающим весельчаком и вечным шутником. В «Баяне» (І9Іо, № 6) говорится, что лучшее в наследии писателя - это мелкие рассказы, а не серьезные романы, «все эти “Янки при дворе короля Артура” и т. д.» В. Дорошевич в «Русском слове» (I910, № 82) писал о роли Твена-утешителя, отвлекавшего людей от печали. Блестящий, остроумный некролог принадлежит А. Аверченко («Сати- 
рикон», I9Іо, №17), но и здесь Твен оценивается как чистый юморист, цель которого - «развеселить читателя», и как типичный американец, «из железа кованный», «достигший всего того, что только может подсказать самая изощренная фантазия». «Твену как-то не к лицу смерть, - пишет Аверченко. - Странно, чтобы она стояла у такого неподходящего ей изголовья: изголовья самого веселого человека в мире» ${ }^{26}$.

Но во многих некрологах о Твене говорится как о «великом писателе». «Только совсем поверхностные критики видели в нем не более как записного зубоскала», - утверждает автор общего некролога о Твене и Бьернсоне во «Всем мире» (г9г, № І2). В произведениях Твена «видна рука искусного, вдумчивого и гуманно-настроенного бытописателя», - пишет «Смоленский вестник» (І9го, № 80). А в «Одесских новостях» (I9Iо, I4 апреля) приводятся слова Т. Рузвельта: «Это была краса и гордость наша! Марк Твен был не только первым юмористом нашего времени, - это было, прежде всего, золотое сердце, философ, в лучшем значении этого слова, всегда жизнерадостный и такими же жизнерадостными делавший всех своих многочисленных читателей».

В некоторых некрологах подчеркивались одновременно и национальный характер, и общечеловеческое значение творчества Твена. В «Нижегородском листке» (I9Iо, № 97) «Принц и нищий» помещается в один ряд с «Робинзоном Крузо» и «Дон Кихотом». В «Ниве» (І9Іо, № 2I) Твена, наряду с Бретом Гартом, Э. По, Дж. Лондоном, относят к тем писателям, которые подняли литературную репутацию Америки, считавшейся неспособной к художественному творчеству. «Одесское обозрение» (I9I9, № 694) оценило Твена настолько высоко, что назвало его почти единственным представителем современной литературы США, кончившейся вместе с ним.

Такое разное прочтение твеновского наследия показывает, насколько неоднородным было восприятие этого писателя в России, по-разному понятого людьми различных культурных уровней, убеждений и вкусов. Пресса в той или иной мере и форме отражала эти противоречивые мнения, не всегда, однако, давая верную картину их распространенности и важности благодаря своей зависимости от цензуры, моды, обывательских запросов, принятых клише. 
После смерти писателя значительно уменьшился поток сенсационных материалов и анекдотов, хотя интерес к его творчеству не иссякал. Журнал «Сатирикон» затеял г2-томное издание Твена, первое из серии сочинений популярных юмористов. В «Солнце России» (І9І2, № 5) печатались отрывки из воспоминаний секретаря Твена А. Пейна, были переведены мемуары Марион Аллен, хозяйки дома, где жил писатель в последние месяцы жизни («Вестник иностранной литературы», І9І4, № 3; «Руль», І9І4, № 455). В «Раннем утре» (І9Іо, № 83) появилась статья знаменитого московского репортера В.А. Гиляровского (за подписью Пропеллер), рассказавшего о своих встречах с Твеном в Париже и сетовавшего на то, что далеко не все твеновские произведения переведены на русский язык. Поводы для отказа от перевода нередко были курьезными. Например, одно издательство решило не печатать рассказ Твена, рекламировавший подтяжки, чтобы не делать рекламы фирме, которая никаких отношений с Европой не имеет. Печатались сообщения об оставшихся после Твена рукописях, о его незаконченной пьесе, о памфлете «Что такое человек?». «Речь» (I9Iо, № I2I) писала, что этот памфлет автор не решался публиковать как единственное свое неюмористическое произведение. Рецензировались вновь выходящие книги Твена. Положительно был встречен роман «Янки при дворе короля Артура», появившийся в I9II г. в 3-4 т. «Собрания сочинений». Рецензенты («Современное слово», І9Іі, № І378; «Бюллетень литературы и жизни», I9II, № 6) хвалили роман за новый жанр «утопии о будущем», видя его актуальность для современной Европы в разоблачении социального гнета с демократических позиций.

Заслуживают внимание печатавшиеся в русской периодике материалы зарубежной критики. В заметке о книге А. Гендерсона «Марк Твен» (Лондон, І9ІІ) в журнале «За 7 дней» (І9ІІ, № I8) Твен оценивается как юморист, социолог и моралист, много страдавший и глубоко знавший жизнь. Здесь он и Уолт Уитмен называются «великими истолкователями и воплотителями духа Америки», «драгоценнейшим вкладом демократии во всемирную сокровищницу литературы». Нетрадиционный взгляд на Твена предложен в переведенной книге В. Трента и Д. Эрскина «Великие американские писатели» (I9I4). Ее авторы высказывают мысль о разочарованности Твена к концу жизни, о трагизме и психологизме, присущих не только его позднему, но и раннему творчеству. 
Необходимость пересмотреть отношение к Твену ощутили и некоторые русские литераторы. Известный театральный деятель П. Гнедич («Ежегодник императорских театров», І9І2, вып. 3) пишет о том, что в России до сих пор плохо понимали Твена и публика, и критика, не заметившие его сатиры и пародийной направленности против бульварных романов. Таким образом, публикации поздних вещей Твена, фрагментов его автобиографии и воспоминаний о нем, а также ставшая более глубокой точка зрения на его творчество в Америке и Европе, где в г90о-г9го-е гг. значительно увеличилось число критических статей и серьезных книг о писателе, повлияли на оценку его наследия в русской печати.

Восприятие Твена в России менялось в зависимости от многих факторов - политической и культурной ситуации в стране, состояния общественной мысли и литературной критики, журнальной и газетной конъюнктуры и пр., всегда оставаясь многозначным и «многослойным». В разные годы в произведениях писателя искали то, что соответствовало духу времени и помогало решению тех или иных идеологических и художественных задач. А.В. Касьян в своей диссертации, посвященной Твену в России, в целом верно выделяет следующие четыре этапа восприятия Твена в России: I - до I880 г., когда преобладала точка зрения демократической критики, относящейся к Твену, главным образом, как к сатирику; 2 - І880-І890-е гг., время реакции, когда Твен трактовался прессой как «чистый юморист»; 3 - конец I890-х гг., когда появились серьезные статьи о Твене и начало формироваться мнение о нем, как о крупном писателе; 4 - І9го-І9І6 гг., когда в условиях жесткой цензуры снова возродилась легенда о Твене «беззлобном шутнике» [I].

Обращение к инонациональной литературе неизбежно сопровождалось ее вписыванием в свой социально-культурный контекст, ее преломлением через свое мировосприятие, что, с одной стороны, могло привести к искаженной и поверхностной трактовке оригинала, а с другой стороны, помогало выделить в нем общечеловеческие мотивы и ценности. У Твена русский читатель нашел многое, импонировавшее ему, и в первую очередь гуманизм, демократические идеалы, нетерпимость к несправедливости и угнетению. Кроме того, книги Твена в какой-то мере удовлетворяли подавленную историческими условиями потребность русского человека в свободе самовыражения и непосредственной жизнерадостности. Делая Твена, 
как и многих других зарубежных писателей, частью собственной культуры, русские читатели расширяли свой кругозор, преодолевая навязанную внутренними обстоятельствами ограниченность.

История отражения и толкования творчества Твена в русской периодической печати в 1872-I9I6 гг. служит еще одним доказательством того, что восприятие инонациональной литературы - это динамический и неравномерный процесс, складывающийся из колебаний, повторов, возвратов к прошлому и движения вперед, к более глубоким уровням анализа.

B XIX в. литературоведение, еще не ставшее окончательно особой отраслью филологии, редко обращалось к современной ему литературе. Творчество Твена осмыслялось его современниками преимущественно в критике, законы которой - привязанность к сегодняшнему дню, полемичность, стремление к пропаганде, идейная тенденциозность - накладывали свой отпечаток на объективность, широту и многосторонность исследований. Но в кратких разноречивых рецензиях, аннотациях, заметках уже были намечены мысли, тенденции и направления, получившие развитие в фундаментальных трудах ученых-литературоведов XX в. Для отечественной науки трактовка Твена в дореволюционной русской периодической печати может рассматриваться как предварительный, но важный этап, как необходимая веха в восприятии наследия великого американского писателя. 


\section{Список литературы}

I Касьян А.К. Марк Твен в России (г872-І966): автореф. дис. ... канд. филол. наук. Ленинградский гос. пед. ин-т им. А.И. Герцена, I967. 23 с.

2 Куприн А.И. О литературе / сост. Ф.И. Кулешов. Минск: Изд-во БГУ, 1969. 455 с.

3 Твен М. Жизнь на Миссисипи. СПб., г9Іо.

4 Твен М. Очерки и рассказы. СПб., І 886.

5 Твен М. Полное собрание сочинений. СПб., І9ІІ.

6 Твен М. Собрание сочинений. СПб., г9го.

7 Энциклопедический словарь / под ред. проф. И.Е. Андреевского. СПб.:

Ф.А. Брокгауз, И.А. Ефрон, І890-І907. Т. І5: Керосин - Коайе, І895. 478 с. 


\section{References}

I Kas'yan A.K. Mark Tven v Rossii (I872-I966): avtoref. dis. ... kand. filol. n. [Mark Twain in Russia. PhD Diss. Synopsis]. Leningradskij gos. ped. in-t im. A.I. Gercena Publ., I967. 23 p. (In Russ.)

2 Kuprin A.I. O literature [About Literature], ed. F.I. Kuleshov. Minsk, Izd-vo BGU Publ., I969. 455 p. (In Russ.)

3 Tven M. Jizn na Missisipi [Life on Missisipi]. St. Petersburg, I9Io. (In Russ.)

4 Tven M. Ocherki I Rasskazi [Essays and Short Stories]. St. Petersburg, I886. (In Russ.)

5 Tven M. Polnoe sobranie sochinenii [Complete Works]. St. Petersburg, I9II. (In Russ.)

6 Tven M. Sobranie sochinenii [Collected Works]. St. Petersburg, I9Io. (In Russ.)

7 Entsiklopedicheskii slovar' [Encyclopedia], ed. prof. I.E. Andreevskii. St. Petersburg, F.A. Brokgauz, I.A. Efron, I890-I907. Vol. I5: Kerosin - Koaie, I895. 478 p. (In Russ.) 
УДК 82I.I6I.I+82I.II2.5

ББК $83.3(2 \mathrm{Poc}=$ Рус $)+$

86.4(4Нид)
ГОЛЛАНДСКАЯ СВЯЗЬ: ВКЛАД

ЙОХАННЫ ВАН ДЕР МЕЙЛЕН В РУССКИЙ СИМВОЛИЗМ

\author{
(C) 2017 г. М. Юнггрен \\ Гетеборгский универстет \\ Стокгольм, Швеция \\ Дата поступления статьи: 25 марта 2017 г. \\ Дата публикации:25 сентября 2017 г.
}

DOI: IO.22455/2500-4247-20I7-2-3-190-203

Аннотация: Произведения символиста Эллиса (Льва Кобылинского), относящиеся к московскому периоду, акцентируют разрыв, разделение и дихотомию между материальной действительностью и неземным ви́дением. Произведения, написанные в годы эмиграции в швейцарском Локарно-Монти, пытались разрешить эти противоречия путем наведения мостов между католицизмом и православием, культурой и религией, земным и потусторонним и, наконец, между Востоком и Западом. Поэт и критик, Эллис стал переводчиком и культурологом, «доктором Лео Кобылинским-Эллисом». Голландская медиум Йоханна ван дер Мейлен, которую он встретил в теософской (в скором времени антропософской) общине Рудольфа Штайнера, сыграла ключевую роль в этой фундаментальной для Эллиса метаморфозе. С ней он прожил тридцать пять лет и их союз оказался невероятно благотворным для обоих. Ван дер Мейлен разработала собственную мистическую доктрину под названием «Космософия», основанную на гностическом мировидении и написанную под сильным влиянием русской религиозной философии. Доктор Кобылинский-Эллис опубликовал синопсис и собственную интерпретацию ее тетралогии, где он определяет сущность Космософии как синтез «иоаннического» элемента медитативной мудрости восточной церкви и «петровского» компонента в энергической вере католицизма.

ключевые слова: Эллис, Ван дер Мейлен, Творческий симбиоз, Мистическая доктрина. Космософия. Гностицизм. Католицизм. Культурный синтез.

Информация об авторе: Магнус Льюнгрен, почетный профессор русской литературы. Университет Готенбурга. Gröndalsvägen I77, II7 69 Stockholm, Sweden.

E-mail: magnusljunggren@telia.com 


\section{THE DUTCH CONNECTION: JOHANNA VAN DER MEULEN'S CONTRIBUTION TO RUSSIAN SYMBOLISM}

This is an open access article distributed under the Creative Commons Attribution 4.0 International (CC BY 4.0)
(C) 20I7. M. Ljunggren

University of Gothenburg, Stockholm, Sweden

Received: March 25, 2017

Date of publication: September 25, 2017

Abstract: The Symbolist Ėllis' (Lev Kobylinskij) writings during his Moscow period emphasize the split, the division and dichotomy between material reality and celestial vision. His works written in exile in Locarno-Monti in Switzerland are devoted to resolving these antitheses by building bridges on all levels: between Catholicism and Orthodoxy, between culture and religion, between worldly and otherworldly, ultimately between East and West. From being a poet and critic he became a translator and culturologist: "Dr. Leo Kobilinski-Ellis.” The Dutch medium Johanna van der Meulen - whom he had met in I9II in Rudolf Steiner's Theosophical, soon Anthroposophical colony - played a crucial role in this fundamental metamorphosis. With her he lived in a thirty-five-yearlong creative symbiosis that proved extremely beneficial to the two of them. Van der Meulen developed a mystical doctrine of her own, "Cosmosophy”, based on a Gnostic world view, strongly influenced by Russian religious philosophy. As she had finished her work in four parts Dr. Kobilinski-Ellis published his summary and interpretation of her teachings, in which he defines the core of Cosmosophy as a synthesis of the "Johannian" element in the meditative wisdom of the Eastern Church and the "Petrine" component in the energetic faith of Catholicism.

Keywords: Ellis, Van der Meulen, symbiosis, mystical doctrine, cosmosophy, gnosticism, catholocism, cultural.

Information about the author: Magnus Ljunggren, Professor Emeritus of Russian literature at the University of Gothenburg. Gröndalsvägen I77, II7 69 Stockholm, Sweden.

E-mail: magnusljunggren@telia.com 
Lev Kobylinskij's biography can be divided into two halves. First he is Ėllis the Russian Symbolist, visionary and rebel. Then, in exile in southern Switzerland, he becomes a synthesizer who strives above all to help heal the almost thousand-year-old schism between the Eastern Orthodox and Western Catholic Churches. His writings in Moscow emphasize the split, the division and dichotomy between material reality and celestial vision. The works written in Locarno-Monti are devoted to resolving these antitheses by building bridges on all levels: between Catholicism and Orthodoxy, culture and religion, worldly and otherworldly. It also led him to change genres. From being a poet and critic he becomes a translator and culturologist: "Dr. Leo Kobilinski-Ellis" [7].

Lev Kobylinskij's friend Johanna van der Meulen played a crucial role in his metamorphosis. His "change of skin" would have been inconceivable without her active involvement. As the woman who helped transmit one of the central tendencies in Russian Symbolism, she deserves to be presented in more detail. Who was she? How could she become so important? [I7, p. I79-I8I; Io; 8, p. 806-8I4].

Johanna van der Meulen was born in 1874 in Bussum, twenty kilometers southeast of Amsterdam. Her family was well-off, her father being the president of a mortgage bank, and she received a Protestant upbringing. She showed a talent for languages at an early age, and in addition to her native Dutch she eventually became fluent in German, Italian, English, Spanish, and to some degree Russian. Practical by nature, she at the same time had spiritual experiences that first led her to Spiritism and then to Theosophy. During a visit to England she became a pupil of Annie Besant, and she was deeply interested in astrology. Ac- 
companied by her husband John (Johannes) Polman-Mooij, around I909 she turned to Rudolf Steiner, who headed the German section of the Theosophical Society. The couple followed Steiner's lectures across Europe, and eventually he delegated to her the responsible task of holding "esoteric lessons" in accordance with his instructions for a circle of initiates [2, p. 370]. When in the summer of I9I2 Steiner broke with Theosophy, she unhesitatingly made common cause with him.

At that point she had already met the Russian rebel. Steiner had found it difficult to cope with his intense personality and assigned van der Meulen to "tame" him. She did so with amazing results. On 6 May I9I2, shortly after she and Ėllis had really gotten to know each other, Ėllis wrote delightedly to Ėmilij Metner: "ja vstretil sredi intimnych učenic Doktora odnu - soveršenno prekrasnuju Damu, kotoraja pomnit menja v prežnej inkarnacii, imenno v srednevekovoj, o kotoroj Doktor govoril mne, kak o real'nom pereživanii mnoju moich simvoličeskich grez teperešnich." He describes their meeting as a "neverojatnoe sobytie v moej žizni." "This was hardly an overstatement, for their respective needs complemented each other remarkably well. Ėllis's complicated relationship to his mother had ended in a falling out. As is amply clear from his poetry, he continued to deeply identify with the abandoned child [7, p. 70-7I]. For her part, Johanna van der Meulen was by nature strongly altruistic and was known to take both animals and people under her maternal wing. He looked to the West for guidance, while she was attracted to Eastern mysticism and reportedly had already read Vladimir Solov'ev in translation.

Subsequently it becomes more and more difficult to distinguish between Ėllis and van der Meulen, for the creative pact they concluded erased their boundaries. To his Dutch partner Ėllis brought in particular his Russian experience. As for her, she was now involved with developing a mystical doctrine of her own that increasingly deviated from and competed with the Anthroposophical movement Steiner had just founded around the turn of the year I9I2-I9I3. By the spring of I9I3 she and Ėllis were already heading toward a new break, this time with Steiner himself, in favor of van der Meulen's "Astrosophy" or "Cosmosophy," which aspired to establish an esoteric Christianity that was closer to religion than his so called spiritual science. Steiner, she thought,

I Letter of 6 May I9I2 to Ėmilij Metner (РГБ. Ф. г67. Карт. 7. Ед. хр. 59, 1. I), quoted in [I5, p. 310 (note)]. 
had betrayed his fundamental Rosicrucianism. A trip that van der Meulen, Ėllis and Polman-Mooij made to Italy consolidated their turn toward Catholicism².

Van der Meulen was working on an Astro/Cosmosophical tract and regarded herself as a medium, a tool of a higher wisdom that guided her pen. Ėllis, who joked about Anthroposophical feminism and thought that both Belyj and Steiner were under the thumb of their domineering wives 3 , greatly admired her writing, to which he himself contributed. Eventually he undertook a translation of the work, intending to publish it with Orfej, a branch of Medtner's Musaget, which at the time was about to collapse due to Andrej Belyj's move to Anthroposophy.

It is worth noting that Belyj, who was deeply troubled by Ėllis's defection, later noted that he very much missed his conversations with van der Meulen as well. It was she and Ėllis who had introduced Belyj and Asja Turgeneva to the new spiritual worlds. Belyj put special emphasis on the Dutch woman's intellect, acumen and culture. In short, she was an "exceptional nature" who was capable of defining certain of the new states of consciousness that Belyj had achieved in the meditation exercises prescribed by Steiner [I, p. 780, 782, 787]. From their intense meetings in Stuttgart in the fall of I9I2 he recalled her as "vysokaja, tonkaja, kak osa, s interesnym licom, s oslepitel'nymi sero-sinimi, kristal'nymi glazami i s černymi volosami, - v černejuščem tunike, v černoj stole is krestom na grudi, obramlennym puncovymi rozami” [I, p. 793].

Who was responsible for the break with Rudolf Steiner? Steiner's wife Marie von Sivers blamed everything on van der Meulen's "pride" [4, p. 356]. For his part, Belyj maintains that Ėllis was upset because Steiner did not give her the recognition she deserved and therefore "stirred her up" against him [I, p. 794]. It is a fact that in his maximalist pamphlet "Vigilemus" published with Musaget in the spring of I9I4, Ėllis vehemently rebelled against Steiner, whereas van der Meulen continued to show him respect and even visited the new Anthroposophical commune in Dornach [Io, p. 66].

\footnotetext{
2 A poem from this period entitled "Svjataja Kniga" (published in Ėllis's last collection Argo in I9I4), depicts St. Teresa of Avila receiving her visionary vocation as a child. Van der Meulen had a similar experience, which renders the dedication of the poem to her especially suggestive (see [5, p. I22-I23]).

3 Ėmilij Metner's letter of 4 April (dated 5 April) 1915 to his wife Anna (РГБ. Ф. І67. Оп. І. Карт. 25. Ед. хр. 6).
} 
At the same time as "Vigilemus!", van der Meulen's debut work "Christliche Theologie und Cosmosophie nach dem Zeichen des Heiligen Graal” appeared in Leipzig. She signed it "Intermediarius," which remarkably enough was a masculine pseudonym intended to emphasize her role as a go-between. She was not out to advertise herself.

The work is based on a Gnostic worldview. Our universe is divided into cosmos and chaos. Due to Lucifer's interference, we humans broke away from our holy origins. Christ's act of redemption on the cross points the way to our future resurrection. After Golgotha the earthly strives to reunite with the divine. We have entered an apocalyptic time. Modern humanity is deepening its consciousness and awakening to the world's being and unity with the astral cosmos.

At the outbreak of WWI, Metner (deeply hurt by Belyj's break with his publishing house), Ėllis and van der Meulen were deported from Germany to Switzerland. They all met there, and van der Meulen made a strong impression on Metner. After visiting her and Ellis in January I9I5 outside Basel (near the Anthroposophical commune in Dornach), he wrote to his wife Anna that they were in a solid spiritual (but not physical) relationship and were economically secure, which of course made their life considerably easier. He emphasized that he had never been able to guess van der Meulen's nationality. Her intellect and wide reading led him to suspect she might be Jewish, yet there was also something American in her demeanor. Her smile radiated goodness and motherliness: she laughed at Ėllis's mischief as though he were a little child. She dressed tastefully and stylishly and in every way had an aura of "distinction"4.

In many respects van der Meulen's ideas were in line with those of the Germanophile Metner. She declared that German culture (to which she regarded herself as belonging) and Russian culture were "karmically bound" to each other. Under the palpable influence of her partner, she warned of the femininity inherent in men as well, who because of their proximity to chaos needed to be subdued5.

Metner, who due to his difficult predicament had begun intensive therapy with Carl Gustav Jung, found obvious similarities between Cosmosophy and

4 Metner's letter of Ir January (dated 22 January) I9I5 to Anna (РГБ. Ф. І67. Оп. г. Карт. 24. Ед. хр. 48).

5 Metner's letter of 2I January (dated 23 January) I9I5 to Anna (РГБ. Ф. І67. ОП. І. Карт. 24. Ед. хр. 49). See also [12, p. І02]. 
Jungian psychology. Van der Meulen had concluded that many dreams contain an objective and a subjective meaning: objectively they confront the dreamer with future tasks, while subjectively they point to events in his or her past, possibly even in earlier incarnations. Not long before this Jung had expressed almost the same idea during a session with Metner: "The unconscious presents to us in symbols details from the past that are usable in the future, the materials with which the future is to be built" 6 .

A few months later Metner wrote enthusiastically to Anna that van der Meulen was "simple in her sublimity and sublime in her simplicity." In her proximity he felt transported to "an atmosphere of absolute purity." He strolled with the couple around the Wallensee, near which they were staying during the summer of I9I5. Because she "understood everything," Metner found it easier to discuss the occult and his complex dealings with the Anthroposophists with her than he did with Ėllis. ${ }^{7}$ Via Ėllis she was already familiar with the anti-Steiner polemic he presented in Razmyšlenija o Gete in connection with Belyj's apostasy.

John Polman-Mooij was against a divorce, which led to two trials in I9I6-I9I7. Two wings among the Anthroposophists were represented in court. Belyj suddenly found himself in the van der Meulen camp and, faced with the prospect that the Polman-Mooij side (which also included Steiner's wife Marie von Sivers) would cast suspicion on Ėllis, was prepared to testify in favor of his erstwhile friend ${ }^{8}$. He did not need to do so, as in the end van der Meulen won both cases [3].

In the final issue of the Musaget journal Trudy i dni (I9I6) van der Meulen published Ėllis's translation of her "Astrosophical" commentary on Dante [I6]. His appreciation of his friend and colleague reached new heights at this time, as he put her work on an equal footing with The Divine Comedy itself. Soon he was hoping that the Russian translation of her tract published with Orfej would help give Russia direction in its revolutionary turmoil. Belyj allotted

\footnotetext{
6 The above-mentioned letter of II January (dated 2I January) I9I5 to Anna.

7 Metner's letter of August 1915 to Anna (Ponsov family archive, now at РГБ).

8 Letter in the spring of I9I6 from Belyj to Natalija Turgeneva-Pozzo. According to Metner's letter of 8 June I916 to her, the partisans of Polman-Mooij had on the contrary counted on Belyj's support. (Both letters are in the Turgeneva-Pozzo file in the Goetheanum archive in Dornach.)
} 
a similar role to Anthroposophy, and Metner attempted to interpret the Russian political drama on the basis of Jung. Paradoxically enough, it was a woman whom the gynophobic Ėllis wanted to view as the person who could offer Russia healing in this fateful historical moment 9

In I9I8 the second part of van der Meulen's mystical doctrine appeared in Basel. Entitled Homo Coelestis. Das Urbild der Menschheit, it developed her account of how humanity lost its natural place in a celestial whole and became isolated in time and space.

In I9I9 van der Meulen and Ėllis turned southward, settling in Italian-speaking Locarno-Monti, where they bought a house with a magnificent view of Lake Maggiore. They were doubtless trying to come nearer to medieval Catholic culture. For that purpose Monti della Trinità - Mount Trinity - overlooking Locarno was an ideal starting point, located as it is near the famous Madonna del Sasso Monastery built on the site of a Franciscan monk's vision of the Virgin Mary. Franciscan piety seems to have been if anything even more important to van der Meulen than it was to Ėllis.

In I920 Metner arrived for an extended visit. He had been in Monti as early as I9I5 and perhaps to some degree inspired the couple to move there. Before long, however, the guest came into conflict with his host. It turned out that Metner's faithful partisan could not accept his master and - to some extent benefactor - Jung. Ėllis dismissed Jung’s analytical psychology as "black magic," and that sealed the break [9, p. 4IO].

Van der Meulen stayed in the background, working on her third volume, Der Cosmos und der cosmische Mensch. Liber Mundi, which came out in Basel in I922. Its message was the same: the global mission is to restore the lost equilibrium, revitalize the cosmic individual, put an end to earthly dualism. As for Dr. Kobilinski, around this time, he began in earnest writing a series of works in German, devoting special attention to translating and presenting texts by Vladimir Solov'ev [I7, p. I9I-203; I4]. Van der Meulen obviously helped him with the language, but certainly not only with that.

The couple's house had been christened in the Franciscan manner "Casa Fioretti," and next to it van der Meulen had a little outdoor temple built that

9 Ėllis thought that van der Meulen would bring to life the slumbering Orfej publishing house (by assuming the future leadership of the Musaget project). See [3]. 
featured a fresco depicting St. Francis surrounded by animals. ${ }^{\text {Io }}$ They were seen attending Mass at Madonna del Sasso every Sunday. They lived a quiet, affluent life, adhering to regular daily routines. Van der Meulen managed their finances and household matters. It was she who quite naturally took charge of Dr. Kobilinski's income. He lived on the upper floor of the house, while she had command of the first floor, including the study and kitchen.

In 1928 van der Meulen finished her tetralogy with Das Grosse Zeichen. Arcana sapientiae, also published in Basel. It highlights Golgotha as the critical juncture in history, the point at which the redemption of the world begins under the sign of the rose and the cross. It also marks the revelation of the "true esotericism" that for two millennia had been trying to assert itself in a struggle with repressive matter.

In 1929 Dr. Kobilinski published his summary and interpretation of van der Meulen's teachings: Christliche Weisheit. Sapientia divina. Cosmologia perennis nach der Lehre des Intermediarius, in which he defines the core of Cosmosophy as a synthesis of the "Johannian" element in the meditative wisdom of the Eastern Church and the "Petrine" component in the energetic faith of Catholicism, a notion that he views as naturally related to Vladimir Solov'ev's universalism and Sophiology [II, p. 29, 4I (note), 97 (note), I33 (note)]. The book is dedicated "with reverence" to "Intermediarius."

Dr. Kobilinski was a diligent letter writer. Characteristically enough, there was some uncertainty among his friends and contacts as to the identity of "Intermediarius." For example, Vice-Mayor of Vienna (until 1936) Ernst Karl Winter, who was very interested in ecumenicalism, believed to the last that it was a case of Kobilinski broadening his horizons, and Dr. Kobilinski himself did little to disabuse him ${ }^{\mathrm{II}}$.

A reprint of van der Meulen's tetralogy appeared in Bad Wörishofen, Germany in 1933. Her life's work was now behind her, but she continued to support her friend and gave special attention to the linguistic side of his articles and books, which in itself was a significant contribution. She converted to Catholicism, while as Kobilinski himself puts it, his Solovyovian, ecumenical

Io Conversation in November 199I with Elisabeth Rezzonico-Valentin, widow of composer Lucas Valentin, Dr. Kobilinski's close friend and collaborator in Monti.

II Typewritten copy in my possession (a gift from Reimund Egger, I988) with statements about "Intermediarius" by Ernst Karl Winter, Franz Wetzel, Fra Tedesco and Alois Mager. 
aspirations led him to the Uniate Church [13, p. 367 $]^{\mathrm{I2}}$. Behind his back van der Meulen hinted to another neighbor, Lore Müller, that no one before her had really understood her partner. Müller recalled later that the couple surrounded themselves with a large Newfoundland dog, another smaller dog, two pedigree cats and two turtles. St. Francis was their life's ideal'3.

During the early I940s Kobilinski suffered from severe depression caused in part by the extreme difficulty he encountered publishing anything in the increasingly grim atmosphere of those years. He died in 1947 in Bellinzona.

At about this time the radical theologian August Zechmeister in Vienna discovered "Intermediarius"” writings. He and his circle of adherents began studying and learning from them. In the postwar climate that reigned in Allied-occupied Austria he joined a leftist movement that promoted intercultural understanding and bridge building. Suddenly "Intermediarius" synthetic idea seemed relevant [8]. Eventually the Vienna group managed to get in touch with van der Meulen. In I95I she answered their questions in a letter, strongly downplaying her personal contribution to the tetralogy: "Der Pseudonim 'Intermediarius' habe ich gewählt, weil beim Schreiben esoterischen Büchern der Verfasser nur als Vermittler betrachtet werden muss, sonst kommt das persönliche Element leicht zu viel auf den Vordergrund. Hauptsache ist, dass jene esoterisch-christliche Weisheitslehre überliefert wird, ungetrübt von persönlichen Denken, Empfinden und Wollen." She did, however, include the photograph of herself that her Vienna followers had requested ${ }^{\mathrm{in}}$.

Van der Meulen obviously had difficulty coping with loneliness. In the early I950s, a Sicilian gardener and father of six by the name of Rosario was going around Monti looking for work. Van der Meulen hired him, which to some extent again gave her someone to support. She also traveled with him a couple of times to his native Sicily. On December 30 I953 in Palermo she suddenly died of a heart attack. Up until then she had reportedly been thoroughly healthy. Some said that the Sicilian had hoped for an inheritance and seemed disappointed when in accordance with the will, all of her assets went

\footnotetext{
I2 I confirmed this information in several conversations with Elisabeth Rezzonico-Valentin.

I3 Conversations with the Monti neighbour Lore Müller, who in the I930s was in regular contact with van der Meulen and Kobilinski.

I4 Van der Meulen, Johanna. Letter of I7 July 195I to Reimund Egger (copy in my archive). Her orthography has been preserved.
} 
to van der Meulen's Dutch relatives ${ }^{15}$. Soon rumors were circulating among her neighbors in Monti that something about her death was not quite right ${ }^{16}$. Thus the restless Symbolist Ėllis and the Dutch medium van der Meulen entered into a thirty-five-year-long creative symbiosis that proved extremely beneficial to the two of them and for Lev Kobylinskij in particular brought about an almost ideal transformation of both his life and his writing.

Translated by Charles Rougle

I5 Conversation with Hubert Palm in Konstanz, June I989. Palm had been very impressed with "Intermedarius," and together with his mother had visited van der Meulen on several occasions in Monti. He and his mother received a modest inheritance from her. Van der Meulen had been buried at the S: te Orsola cemetery in Palermo.

I6 Conversations with Elisabeth Rezzonico-Valentin, November I99I, and with Lore Müller, July 2003 and July 2004. 


\section{Список литературы}

I Белый А. Начало века. Берлинская редакция (I923) / ред. А.В. Лавров. СПб.: Наука, 20I4. I064 с.

2 Белый А. Рудольф Штейнер и Гете в мировоззрении современности. Воспоминания о Штейнере / ред. И.Н. Лагутина, М.Л. Спивак. М.: Республика, 200о. 720 с.

3 Глуховская Е. Последний год «Мусагета»: Эллис между Э.К. Метнером и Белым // Арабески Андрея Белого / ред. К. Ичин, М.Л. Спивак. М.; Белград: Филологический факультет Белградского ун-та, 2016. С. 287-294.

4 Мальмстад Д. Белый и антропософия // Минувшее, г988. Т. 6. С. 337-450.

5 Эллис. Стихотворения. Томск: Водолей, І996. 288 с.

6 Юнггрен М. Русский Мефистофель: Жизнь и творчество Эмилия Метнера. СПб.: Академический проект, 200I. 288 с.

7 Юнггрен М. Эллис и доктор Кобилински - символист с двумя карьерами // Андрей Белый в изменяющемся мире. К І25-летию со дня рождения / ред. М.Л. Спивак, Е.В. Наседкина, И.Б. Делекторская. М.: Наука, 2008. С. 76-8о. Юнггрен М. Лев Кобылинский, Intermediarius и вице-бургомистр Винтер // На рубеже двух столетий. Сборник в честь 6о-летия А.В. Лаврова. М.: Новое Литературное Обозрение, 2009. С. 806-8I5.

9 Юнггрен M. Эмилий Метнер в жизни и сновидениях. Две заметки к теме // Russian Literature. 20I5. № LXXVII-IV. C. 409-4I8.

Io Boejtes I. Wer war Intermediarius? Leben und Werk einer ehemaligen Schülerin Rudolf Steiners (I) // Novalis. 200I. № I-2. P. 65-69.

Kobilinski-Ellis L. Christliche Weisheit. Sapientia divina. Cosmologia perennis nach der Lehre des Intermediarius. Basel: Buchdruckerei Frobenius A.-G., I929. I8I p. Ljunggren $M$. The Russian Mephisto. A Study of the Life and Work of Emilii Medtner. Stockholm: Almqvist \& Wiksell International, I994. 240 p. Pfleger K. Unionsgespräch mit einem “Römisch Orthodoxen” // Hochland. I934-I935. № 32. P. 363-370.

I4 Poljakov F. Literarische Profile von Lev Kobylinskij-Ėllis im Tessiner Exil. Forschungen-Texte-Kommentare. Cologne/Weimar/Vienna: Böhlau Verlag, 2000. 285 p. Rizzi D. Из архива H.А. Тургеневой: Письма Эллиса, А. Белого и А.А. Тургеневой // Europa Orientalis. I995. № I4/2. P. 30I-313.

I6 Vander Meulen J. О планетных сферах Дантова «Рая» в свете астрософии / пер. с гол. // Труды и дни. І9І6. № 8. С. 9-22.

I7 Willich H. Lev L. Kobylinskij-Ėllis. Von Symbolismus zur ars sacra. Eine Studie über Leben und Werk. Munich: Verlag Otto Sagner, I996. 299 p. 


\section{References}

I

Belyi A. Nachalo veka. Berlinskaia redaktsiia (1923) [The beginning of the century. Berlin edition], ed. A.V. Lavrov. St. Petersburg, Nauka Publ., 20I4. Io64 p. (In Russ.)

Belyi A. Rudol'f Shteiner $i$ Gete v mirovozzrenii sovremennosti. Vospominaniia o Shteinere [Rudol'f Steiner and Goethe in the religious worldview. Memoirs of Steiner], ed. I.N. Lagutina, M.L. Spivak. Moscow, Respublika Publ., 2000. 720 p. (In Russ.)

Glukhovskaia E. Poslednii god "Musageta”: Ellis mezhdu E.K. Metnerom i Belym [The last year of "Musaget": Ellis between E.K. Metner and Belyj]. Arabeski Andreia Belogo, [Andrey Belyj's arabesques], ed. K. Ichin, M.L. Spivak. Moscow, Belgrad, Philological Dept. Of Belgrad University Publ., 20I6, pp. 287-294. (In Russ.)

Mal'mstad D. Belyi i antroposofiia [Bely anthroposophy]. Minuvshee [The past], I988, vol. 6, pp. 337-450. (In Russ.)

Ellis. Stikhotvoreniia [Poems]. Tomsk, Vodolei Publ., I996. 288 p. (In Russ.)

Iunggren M. Russkii Mefistofel': Zhizn' i tvorchestvo Emiliia Metnera [Russian Mephistopheles: Life and work of Emilii Medtner]. St. Petersburg, Akademicheskii proekt Publ., 200I. 288 p. (In Russ.)

Iunggren M. Ellis i doktor Kobilinski - simvolist s dvumia kar'erami [Eliss and Dr. Kobilinski - a Symbolist with two careers]. Andrei Belyi v izmeniaiushchemsia mire. $K$ I25-letiiu so dnia rozhdeniia [Andrey Bely in the changing world: on his I25th anniversary], eds. M.L. Spivak, E.V. Nasedkina, I.B. Delektorskaia. Moscow, Nauka Publ., 2008, pp. 76-80. (In Russ.)

Iunggren M. Lev Kobylinskii, Intermediarius i vitse-burgomistr Winter [Lev Kobylinsky: Intermediarius and vice-mayor Vinter]. Na rubezhe dvukh stoletii. Sbornikv chest' 6o-letiia A.V. Lavrova [At the turn of two centuries: a collection in honor of A.V. Lavrov's 6oth anniversary]. Moscow, Novoe Literaturnoe Obozrenie, 2009, pp. 806-8I5. (In Russ.)

Iunggren M. Emilii Metner v zhizni i snovideniiakh. Dve zametki k teme [Emilii Metner in life and dreams. Two notes on the subject]. Russian Literature, 2015, no LXXVII-IV, pp. 409-4I8. (In Russ.)

Boejtes I. Wer war Intermediarius? Leben und Werk einer ehemaligen Schülerin Rudolf Steiners (I). Novalis, 200I, no I-2, pp. 65-69. (In German)

Kobilinski-Ellis L. Christliche Weisheit. Sapientia divina. Cosmologia perennis nach der Lehre des Intermediarius. Basel, Buchdruckerei Frobenius A.-G., I929. I8I p. (In German)

Ljunggren M. The Russian Mephisto. A Study of the Life and Work of Emilii Medtner. Stockholm, Almqvist \& Wiksell International, I994. 240 p. (In English)

Pfleger K. Unionsgespräch mit einem 'Römisch Orthodoxen'. Hochland, I934-I935, no 32, pp. 363-370. (In German)

Poljakov F. Literarische Profile von Lev Kobylinskij-Ëllis im Tessiner Exil. Forschungen-Texte-Kommentare. Cologne/Weimar/Vienna, Böhlau Verlag, 200o. 285 p. (In German)

5 Rizzi D. Iz arkhiva N.A. Turgenevoi: Pis'ma Ellisa, A. Belogo i A.A. Turgenevoi [From 
N.A, Turgeneva's archive: Letters by M.L. Ellis, A. Bely and A.A. Turgeneva]. Europa Orientalis, I995, no I4/2, pp. 30I-3I3. (In Russ.)

I6 Vander Meulen J. O planetnykh sferakh Dantova "Raia” v svete astrosofii [About planetary spheres of Dante's "Paradiso" in the light of astrosophy], Trans. from Dutch. Trudy $i$ dni, I916, no 8, pp. 9-22. (In Russ.)

I7 Willich H. Lev L. Kobylinskij-Ellis. Von Symbolismus zur ars sacra. Eine Studie über Leben und Werk. Munich, Verlag Otto Sagner, I996. 299 p. (In German) 
УДК 82I.I6I.I+82I.I33.I ББК $83.3(2 \mathrm{Poc}=\mathrm{Pyc}) 53^{+}$ $83.3(4 \Phi$ ра $) 5 \mathrm{I}$

\section{РАСИН И МАНДЕЛЬШТАМ}

(C) 2017 г. М.Ю. Игнатьева (Оганисьян)

Православный Свято-Тихоновский гуманитарный университет,

Москва, Россия

Дата поступления статьи: 9 марта 2017 г.

Дата публикации: 25 сентября 2017 г.

DOI: I0.22455/2500-4247-20I7-2-3-204-2I9

Аннотация: Статья представляет собой фрагмент кандидатской диссертации «Философско-эстетические принципы трагедии Кальдерона и Расина», защищенной на кафедре истории зарубежной литературы МГУ в г988 г. Автор стремился к тому, чтобы рассмотреть расиновскую тему у Мандельштама в контексте теории трагического. В статье, эссеистичной по форме, последовательно анализируются основные образы и ключевые понятия изучаемой темы: ниспадающая шаль как образ тяжести-легкости («Спадают с плеч классические шали»), слово-признание как выражение искупленного, очищенного страдания («Слово - чистое веселье, // Избавленье от тоски»), смерть через слово к освобождению («Зловещий голос горький хмель - // Душа расковывает недра») и др. Особое внимание уделено образу «черного солнца», «запятнанного дня» расиновской Федры, этот образ полон различных коннотаций, он «не выбрасывает из себя готового смысла» («Разговор о Данте»). У Расина Солнце - сакральный символ, «Бог сокровенный» - Deus absconditus янсенизма: греховность Федры пятнает солнце, делает его черным. Предсмертные слова Федры утверждают искупительный смысл ее гибели. В статье «Пушкин и Скрябин» Мандельштам пишет о трагическом смысле гибели художника и сопоставляет ее с подвигом Федры. Взгляд на расиновское присутствие у Мандельштама с учетом исследований таких знатоков Расина, как Р. Барт, Л. Гольдманн, Ж. Пуле и др., позволяет лучше понять и прямые, и косвенные расиновские аллюзии у Мандельштама, а также его взгляд на трагедию и трагическое c I9I4 по I920 г., когда поэт читал и переводил великого французского трагика, и осмыслял те трагические события, свидетелем которых он стал.

Ключевые слова: Мандельштам, Расин, трагическое, трагедия, черное солнце, Скрябин.

Информация об авторе: Мария Юльевна Игнатьева (Оганисьян) - кандидат филологических наук, доцент, Православный Свято-Тихоновский гуманитарный университет, ул. Иловайская, д. 9, стр. 2, Іо965г Москва, Россия.

E-mail: maria.ignatieva@gmail.com 


\title{
RACINE AND MANDELSTAM
}

\author{
(C) 20I7. M.Yu. Ignatieva (Oganisyan) \\ St. Tikhon's Orthodox University, \\ Moscow, Russia \\ Received: March 9, 2017 \\ Date of publication: September 25, 2017
}

This is an open access article

distributed under the Creative

Commons Attribution 4.0

International (CC BY 4.0)

Abstract: This article is a fragment of the PhD thesis Philosophical and Aesthetic Principles of Tragedy in Calderon and Racine (Department of the History of Foreign Literature, Moscow State University, I988). In her dissertation, the author examined Racine's presence in Mandelstam's poetry against the theory of the tragic. Written in the essayistic form, the article examines the following basic images and key concepts of this general theme: (I) cascading shawls as emblematizing heaviness / lightness; (2) a word-confession as expression of pure and redemptive suffering; (3) death by word followed up by redemption. It pays particular attention to the image of the "black sun" and the "tainted day" in Racine's Phaedra. According to Mandelstam, this image has different connotations and "does not evoke a ready-made meaning" ("Conversation about Dante”). In Racine, Sun is a sacred symbol, it is "the Hidden God”, or Deus absconditus of Jansenism. Phaedra's sin stains the Sun and darkens it. Phaedra's last words confirm the redemptive effect of her death. In the article "Pushkin and Scriabin," Mandelstam writes about the tragic meaning of the artist's death and compares it with Phaedra's deed. The study of Racine's presence in Mandelstam, taking into account the studies of such scholars as Barthes, Goldmann, Poulet and others, allows us to point out explicit and implicit allusions to Racine in Mandelstam's poetry. It also helps to understand Mandelstam's idea of the tragedy and the tragic as it developed from I9I4 through I920 when the poet was translating the great French tragedian and at the same time was trying to comprehend the tragic events he witnessed.

Keywords: Mandelstam, Racine, tragic, tragedy, black sun, Scriabin.

Information about the author: Maria Yu. Ignatieva (Oganisyan), $\mathrm{PhD}$ in Philology, Associate Professor, St. Tikhon's Orthodox University, Ilovaiskaya 9-2, I0965I Moscow, Russia.

E-mail: maria.ignatieva@gmail.com 
Тому не быть - трагедий не вернуть, Но эти наступающие губы, Но эти губы вводят прямо в суть Эсхила-грузчика, Софокла-лесоруба.

Быть может, прежде губ уже родился шепот...

И в наказанье за гордыню, неисправимый звуколюб,

Получишь уксусную губку ты для изменнических губ ${ }^{\mathrm{I}}$.

Губам самим корневым основанием свойственна уксусная губка, как шепот, как стихиㄴ․ Такова метафизика поэзии по Мандельштаму.

В его поэтике важное место занимает то, что мы бы назвали «образ-движение» или «образ движения» - знак чужого присутствия. Например, Вийона: «Размотавший на два завещанья // Слабовольных имуществ

I Произведения Мандельштама цит. по: [г].

2 Данная статья представляет собой фрагмент диссертации на соискание ученой степени кандидата наук «Философско-эстетические принципы трагедии Кальдерона и Расина», защищенной на кафедре зарубежной литературы МГУ им. М.В. Ломоносова в I988 г. Эссе было включено в диссертацию в качестве приложения. Этим объясняется отсутствие ссылок на позднейшие исследования и переводы. 
клубок»... Или Данте: «Легче было вам, Дантовых девять, // Атлетических дисков, звенеть».

Движение у Расина - спадающая классическая шаль.

\section{І. «СПАДАЮТ С ПЛЕЧ КЛАССИЧЕСКИЕ ШАЛИ»}

Самый весомый и полнозвучный для Мандельштама стих «Федры»:

Que ces vains ornements, que ces voiles me pèsent!

(Как давят на меня эти украшения, эти шали!)

Парадоксальный образ (тяжесть легких покрывал) органично перешел в поэзию Мандельштама, и не только в стихи-реминисценции из «Федры»: образ тяжести (и дальше - тяжести-беременности, тяжести-нежности, тяжести-легкости) во всех стихах, где он появляется, несет в себе воспоминание о «Федре».

Но чем внимательней, твердыня Notre Dame,

Я изучал твои чудовищные ребра,

Тем чаще думал я: из тяжести недоброй

И я когда-нибудь прекрасное создам.

С такой определенной любовью к плодородной тяжести (из недоброй - прекрасное, а легкое - тяжело: «И колесо вращается легко») Мандельштам не мог не восхититься в двойственном и парадоксальном Расине этой строкой, которую так любовно примерял к русской речи. Кажется, что он не закончил перевода «Федры» только потому, что до этого стиха надо было пробираться еще через две сцены.

Образы у Мандельштама наполнены (полонены) плотью: они воспринимаются на глаз, на слух, на вкус. Расиновские образы конкретны весомостью, тяжестью: 
Спадая с плеч, окаменела

Ложно-классическая шаль.

Как этих покрывал и этого убора

Мне пышность тяжела средь моего позора!

Его Трезен ощутимо каменный. Мандельштам одел в камень ту замкнутость трагического пространства, которую почувствовал и Ролан Барт [2].

Будет в каменной Трезене

Знаменитая беда.

Царской лестницы ступени

Покраснеют от стыда. (I9I6)

Даже в переведенном отрывке из «Федры» у Мандельштама появляется образ трезенских стен, которого в подлиннике нет.

Le dessein en est pris, je pars, cher Théramène,

Et quitte le séjour de l'aimable Trézène.

(Решение принято, я уезжаю, дорогой Терамен, // И покидаю любезный Трезен).

Решенье принято, час перемены пробил!

Узор трезенских стен всегда меня коробил.

Ясно, что в названии первой книги Осипа Мандельштама - «Камень» - обозначена и расиновская тема. Однако ключевое стихотворение к пониманию этой темы содержится во второй книге - Tristia. Это «Сестры тяжесть и нежность» (1920).

Ах, тяжелые соты и нежные сети,

Легче камень поднять, чем имя твое повторить! 
У меня остается одна лишь забота на свете:

Золотая забота, как времени бремя избыть.

Мы уже сказали, что образ тяжести, как бы по-разному он ни был воплощен, у Мандельштама всегда расиновский (хотя и не только расиновский). Тяжесть - это безмолвие. Слово - освобождение.

Божье имя, как большая птица,

Вылетело из моей груди.

Впереди густой туман клубится,

И пустая клетка позади.

Слово - чистое веселье,

Избавленье от тоски.

(I9I5)

(Запомним эти последние стихи, написанные в том году, к которому относится начало прямых реминисценций из «Федры» в стихах Мандельштама; мы к ним позже вернемся, а пока важно понимать их как выражение не чистого веселья, но веселья как искупленного, очищенного страданья.)

Сказать слово («имя повторить») тяжелее, чем камень поднять. Каменные шали сковывают, но жизнь разрешена. Слово же - это умирание, избывание бремени (=тяжести) жизни (=времени) [г, с. 66]. Следуя цепочке инверсий, приходим к такому уравнению:

слово = избывание тяжести - избывание времени - умирание $=$ чистое веселье.

Смерть через слово к освобождению, чистоте - таков вектор трагического у Расина, и Мандельштам точно определяет его:

Зловещий голос - горький хмель -

Душа расковывает недра:

Так - негодующая Федра -

Стояла некогда Рашель. 
Действительно, высшее мгновение Федры - то, когда она произносит Слово. Это равнозначно освобождению от тяжести, но по ту сторону уравнения - смерть. Или наоборот: сказать Слово значит погубить себя, но и - вину искупить, сбросить каменные покрывала, вернуть чистоту (веселья - у Мандельштама, дня - у Расина).

Спадают плеч классические шали.

Расплавленный страданьем крепнет голос

И достигает скорбного закала

Негодованьем раскаленный слог.

Вот это расиновское движение у Мандельштама: спадают - крепнет - достигает. От тяжести к освобождению от нее; от безмолвия к слову; через смерть к чистоте.

\section{II. «ЭТО СОЛНЦЕ НОЧНОЕ ХОРОНЯТ»}

Мы попытались показать расиновский жест у Мандельштама. Этот жест-образ синхронен трагическому движению - движению к развязке, к гибели, к искуплению, т. е. центростремительному движению к трагедии. Характерно, что этот образ парадоксален, двулик (тяжесть и легкость). Но такая двойственность является, скорее, одним ликом двух начал: «Сестры - тяжесть и нежность - одинаковы ваши приметы». Противоречивое, парадоксальное у Мандельштама (и у Расина - ср., например, такое существенное понятие поэтики Расина, как герой-двойник [4], скреплено одной кровной связью: не разнородность, но двоюродность).

Теперь мы можем перейти к главному расиновскому образу у Мандельштама - «черное солнце». Известно, что это один из любимых образов Мандельштама, имеющий множество литературных, философских, религиозных и других источников. Интересно, что, развивая мысль о том, что слово несет в себе множество импульсов к «припоминанию» его смысла неоднозначного, «пучкообразного», Мандельштам в «Разговоре о Данте» приводит пример именно с солнцем: «Когда мы произносим, например, 
“солнце”, мы не выбрасываем из себя готового смысла, - это был бы семантический выкидыш, - но переживаем своеобразный цикл». Образ солнца в поэзии Мандельштама не просто ведет за собой широкий круг культурноисторических ассоциаций, он и внутри отдельного аспекта он не однозначен, не «выбрасывает из себя готового смысла». Так «черное солнце» Расина у Мандельштама связано с картиной пушкинских похорон, причем так тесно, что подчас трудно сказать, когда речь идет о Расине, когда - о Пушкине. Вернемся к стихотворению «Сестры - тяжесть и нежность». Оно начинается строфой, которая подтверждает нашу мысль о том, что это стихотворение - расиновское, и, шире, что образ тяжести у Мандельштама всегда реминисценция из Расина:

Сестры - тяжесть и нежность - одинаковы ваши приметы.

Медуницы и осы тяжелую розу сосут.

Человек умирает, песок остывает согретый,

И вчерашнее солнце на черных носилках несут.

То, что эти стихи о Пушкине, доказывает фрагмент из статьи «Пушкин и Скрябин», о которой подробно речь пойдет ниже. Пушкин был для Мандельштама солнечным поэтом:

\section{Стояло солнце Александра}

Сто лет назад, сияло всем...

Но Солнце - ночное, Солнце похороненное. Цветаевское «с проходного двора - умнейшего мужа России» перекликается с темой похорон Солнца у Мандельштама. «И вчерашнее солнце на черных носилках несут» - пластический образ носилок здесь выражает связь двух образов: тяжесть и черное солнце. Черное - потому что вчерашнее, потому что ночное, потому что хоронится чернью. К этому нас подводит возможная интерпретация стихотворения «В Петербурге мы сойдемся снова» (г20) в аспекте пушкинско-расиновской темы у Мандельштама. В Петербурге, поглотившем солнце, в черном «бархате всемирной пустоты», в ночи черной, в ночи черни остается только молиться «за блаженное бессмысленное слово», ко- 
торое одно - искупление. Петербург - это могила солнца (вспомним из другого стихотворения: «В Петербурге жить - словно спать в гробу», I93I), это театр, доставшийся «черным душам и низменным святошам». В стихотворении «Я не увижу знаменитой «Федры» Мандельштам скажет: «Уйдем, покуда зрители-шакалы // На растерзанье Музы не пришли». И здесь тот же мотив ухода: «Что ж, гаси, пожалуй, наши свечи». Ср.: «Когда бы грек увидел наши игры» - при сопоставлении двух стихов из разных стихотворений становится понятным двойной смысл каждого: признание того, что игры общие, и трагическая невозможность выйти из игры иначе, как через Слово; но оно - гибель. Тема черни проходит почти через все расиновские стихи Манделыптама. С ней связан и тот факт, что образ солнца всегда появляется в обстановке похорон. Но образ самого солнца меняет значения. Рассмотрим некоторые из них в контексте расиновской темы.

Во-первых, солнце - это сама трагедия Расина, это солнце вчерашнее, похороненное. «Я опоздал на празднество Расина». Главное здесь отделение себя от черноты-пустоты, уход, отказ от участия в играх черни. Приведем полностью стихотворение I9I8 г., демонстрирующее этот аспект расиновской темы.

Когда в темной ночи замирает

Лихорадочный форум Москвы,

И театров широкие зевы

Возвращают толпу площадям,

Протекает по улицам пышным

Оживленье ночных похорон,

Льются мрачно - веселые толпы

Из каких-то божественных недр.

Это солнце ночное хоронит

Возбужденная играми чернь, Возвращаясь с полночного пира

Под глухие удары копыт. 
И как новый встает Геркуланум,

Спящий город в сияньи луны,

И убогого рынка лачуги,

И могучий дорический ствол.

Но такой аспект темы является как бы внешним по отношению к самой трагедии. Это восприятие ее извне, из театральной ложи. Но вот снимаются кавычки, и уже не «Федра», а сама героиня трагедии - черное похороненное солнце, солнце черной страсти, солнце-ночь. Этой линии у Мандельштама созвучны концепция и терминология Р. Барта. Барт говорит, что вся трагедия Расина строится на конфликте тени и света. «Федра, дочь Солнца, пылает страстью к Ипполиту, человеку тени - растительной, лесной» [2, с. 28]. «Рожденное чаще всего вместе с самой трагедией (которая - день), солнце становится смертоносным одновременно с нею». Солнце, по Барту, это взрыв, ослепление, пожар, кризис. Солнечные персонажи у Расина - цари, императоры, т. е. те, кто наделен властью; природа тени плен, зависимость. Но имеющий власть любит своего пленника, а пленник не любит того, от кого зависит. Солнце преследует тень, пронзает ее, разрушает и губит. Однако Солнце иногда пытается себя сдерживать, смирять и умерять, тогда оно «приобретает парадоксальное свойство: сияние. Но сияние это не обязательно качество собственно света, это состояние материи: существует и сияние ночи» [2, с. 3I].

Сравним с двумя строфами из мандельштамовского стихотворения, построенного на перебивании двух планов: классического (еврипидовского) и ложноклассического (расиновского), что передает драматизм сияния черного солнца, конфликт дня (Ипполита) и ночи (Федры). Приводимые ниже стихи имитируют голос античного хора:

- Черным пламенем Федра горит

Среда белого дня.

Погребальный факел чадит

Среди белого дня.

Бойся матери ты, Ипполит:

Федра - ночь - тебя сторожит

Среди белого дня. 
- Мы боимся, мы не смеем

Горю царскому помочь.

Уязвленная Тезеем

На него напала ночь.

Мы же песнью похоронной

Провожая мертвых в дом,

Страсти дикой и бессонной

Солнце черное уймем.

Нетрудно заметить, как тесно соприкасаются эти стихи со страницей Барта: день трагедии; Федра - «ночь» (ночное солнце), сторожащая Ипполита. «Погребальный факел» символизирует не только приближающуюся гибель Ипполита, но и гибель самой Федры. Ее образ для Мандельштама неотделим от представления о ее гибели, поэтому за ним всегда следует образ похорон.

В процитированных строках интересно настойчивое противопоставление черного и белого. Оно, во-первых, подчеркивает виновность Федры - по контрасту с невинностью Ипполита; а во-вторых, означает (и здесь мы подходим к основному значению солнца у Расина), что черная любовь Федры оскорбляет чистоту небес. Между этими строфами у Мандельштама один стих «из Расина»:

- Любовью черною я солнце запятнала.

Солнце - сакральный символ, «Бог сокровенный» - Deus absconditus янсенизма [3]. Греховность Федры пятнает солнце, делает его черным. Предсмертные слова Федры утверждают искупительный смысл ее гибели.

Et la mort, a mes yeux dérobant la clarté

Rend au jour qu'ils souillaient toute sa pureté.

(И смерть, скрывая свет от моих глаз, // Возвращает дню, что они запятнали, всю его чистоту). 
Наиболее убедительная, на наш взгляд, интерпретация этих стихов, принадлежащая французскому критику Жоржу Пуле, созвучна представлению Мандельштама І9Іо-І920-х гг. о смысле смерти (об этом ниже): «Мне, мой Бог, говорит Федра, как мне безразлично, что меня больше не будет, потому что ты не перестанешь быть, и быть тем, кто очищает пятна мира, но пусть пятна мира больше не пятнают» [5, с. II9].

Итак, «солнечность» - это категория священного, которое проявляется в разных формах: черное солнце «Федры», солнце «черной страсти» Федры, солнце - Бог, запятнанный черной любовью Федры.

\section{III. «МИФ О ЗАБЫТОМ ХРИСТИАНСТВЕ»}

«И вчерашнее солнце на черных носилках несут». Авторская расшифровка этого образа - в статье «Пушкин и Скрябин» (I9I5): «Пушкина хоронили ночью. Хоронили тайно. Мраморный Исаакий - великолепный саркофаг - так и не дождался солнечного тела поэта. Ночью положили солнце в гроб, и в январскую стужу проскрипели полозья саней, увозивших для отпевания прах поэта» [г, с. 48].

Солнце, похороненное чернью в черноте ночи, - это солнце Пушкина. И солнце Федры: «Я вспоминаю картину пушкинских похорон, чтобы вызвать в вашей памяти образ ночного солнца, образ последней греческой трагедии, созданной Еврипидом, - видение несчастной Федры». Это солнце эллинское.

Тинслей в лекции «Христианская теология и границы трагедии» говорит: «Для греков трагедия человека неминуема: его жизнь - постоянный объект “ревности богов” [6, с. 7]. Прихоть богини сделала до сих пор невинную Федру участницей (орудием) гибели Ипполита. Поэтому она виновна. Эллинское солнце - солнце вины.

...мы вознесли над собой Скрябина, чье солнце-сердце горит над нами, но - увы! - это не солнце искупления, а солнце вины. Утверждая Скрябина своим символом в час мировой войны, Федра-Россия...

дальше текст не сохранился). Но это солнце остается эллинским до тех пор, пока не становится солнцем искупления. 
Если сорвать покров смерти с этой творческой жизни, она будет свободно вытекать из своей причины - смерти, располагаясь вокруг нее, как вокруг своего солнца, и поглощая его свет.

Смерть «безумствующего эллина» Скрябина, смерть этого черного солнца вины возвращает ему чистоту и сияние христианства. Христианство, по Мандельштаму, это Эллада, возведенная на Голгофу. «Рим железным кольцом окружил Голгофу: нужно освободить этот холм, ставший греческим и вселенским. Римский воин охраняет распятье и копье наготове: сейчас потечет вода: нужно удалить римскую стражу... Бесплодная, безблагодатная часть Европы восстала на плодную, благодатную. Рим восстал на Элладу... Нужно спасти Элладу от Рима. Если победит Рим - победит даже не он, а иудейство - иудейство всегда стояло за его спиной и только ждет своего часа и восторжествует страшный противуестественный ход: история обратит течение времени - черное солнце Федры».

Попробуем скрепить новую цепочку мандельштамовских соответствий: течение времени - черное солнце Федры - солнечная тяжесть, положенная на черные носилки - избываемое времени бремя.

У меня остается одна лишь забота на свете:

Золотая забота, как времени бремя избыть.

Избыть это бремя можно только умерев. Точнее, это избывание и есть сама смерть. Сказать имя для Мандельштама значит вспомнить имя. В его статье можно найти еще одно звено для этой цепочки, которое мы уже восстанавливали на материале расиновских стихотворений Мандельштама: сказать слово - умереть. Но сказать - значит вспомнить, значит умереть: «С легкого, хрупкого лица спадает маска забвения, проясняются черты; торжествует память - пусть ценою смерти: умереть значит вспомнить, вспомнить - значит умереть». Ценою смерти! Но - и в этом все «веселье», вся «нежность» не смерти эллинской, не смерти ветхозаветной («Всему и всем - одно: одна участь праведнику и нечестивому... они отходят к умершим», Еккл. 9: 2), но смерти христианской: от вины к искуплению, от смерти к бессмертию, через Слово-плоть. 
«Дух греческой трагедии проснулся в музыке. Музыка совершила круг и вернулась туда, откуда вышла: снова Федра кличет кормилицу, снова Антигона требует погребения и возлияния для милого братнего тела».

... Долго, долго мы играли с музыкой, не подозревая опасности, которая в ней таится, и пока - быть может, от скуки - мы придумывали миф, чтобы украсить свое существование, музыка бросила нам миф - не выдуманный, а рожденный, пенорожденный, багрянорожденный, царского происхождения, законный наследник мифов древности - миф о забытом христианстве.

Возвращением христианского мифа, по Мандельштаму, музыка обязана Скрябину. Его смерть «есть высший акт его творчества», потому что именно ее ценою художник преодолел забвение и вспомнил забытый миф. Но не полна ли такого же значения и гибель Федры? - нет, не Федры Еврипида, но Федры христианского поэта? Это уже Федра Расина кличет кормилицу. Та Федра, солнце-сердце которой в разгар мировой войны для Мандельштама было символом «эллинизированной смерти». «Эллинство, оплодотворенное смертью, и есть христианство». Таково значение гибели, по Мандельштаму. Бог в «Федре» мифологический, но - христианский. Барт считает, что единственный, настоящий расиновский бог «ни греческий, ни христианский», это Бог Ветхого Завета в своей буквальной и почти эпической форме: это Яхве [2, с. 50]. Дело, нам кажется, в том, что Барт рассматривает смерть трагического героя только в рамках структуралистского анализа: смерть - единственный возможный выход из трагического пространства. Смерть как творческий акт, полный смысла и величия, существует только в христианстве.

Теперь понятно, почему «черное солнце» Федры у Мандельштама всегда солнце похороненное. Умирая, Федра обретает свое высшее мгновение. Это искупительная жертва Солнцу, приобщение страданиям Христа.

Рассмотренные примеры дают представление о некоей единой теме, пронизывающей творчество поэта приблизительно с I9I4 по I920 г. 3 B последующие годы эта тема с присущим ей романтическим трагизмом, вероятно навеянным стихами и прозой Вяч. Иванова (ср. рассуждения Иванова

3 Здесь же можно было бы вспомнить стихи, посвященные Анне Ахматовой («Ахматова», 1914, «Кассандре», 1917, и др.), они также полны расиновских аллюзий. 
о трагедии, его статьи о Скрябине), уступит место предметам «правдивей и страшнее», однако, ее отголоски будут слышны и в поздних стихах («Не искушай чужих наречий», «Да, я лежу в земле, губами шевеля» и др.).

\section{Список литературы}

I Мандельштам О.Э. Собр. соч.: в 4 т. Вашингтон; Париж: Международное Литературное содружество, I967-I98I. 599 с. +737 с. + 55I с. + 203 с.

2 Barthes R. Sur Racine. Paris: Seuil, I963. I66 p.

3 Goldmann L. Le Dieu caché. Étude sur la vision tragique dans les "Pensées" de Pascal et dans le théâtre de Racine. Paris: Gallimard, I959. 454 p.

4 Mauron Ch. L'Inconscient dans l'oeuvre et la vie de Racine. Gap: Ophrys, I957. 350 p.

5 Poulet G. Notes sur le Temps racinien // Poulet G. Etudes sur le temps humain. P.: PIon, I949. T. I. P. I04-I2I.

6 Tinsley $B$. Christian theology and the frontiers of tragedy. Cambridge: Leeds univ. press, I963. $25 \mathrm{p}$. 


\section{References}

I Mandelstam O.E. Sobranie sochinenii: $v 4 t$. [Complete works: in 4 vols.]. Washington, Paris, Mezhdunarodnoe Literaturnoe sodruzhestvo Publ., I967-I98I. 599 p. + 737 p. + 55I p. + 203 p. (In Russ.)

$2 \quad$ Barthes R. Sur Racine. Paris, Seuil, I963. I66 p. (In French)

3 Goldmann L. Le Dieu caché. Étude sur la vision tragique dans les “Pensées” de Pascal et dans le théâtre de Racine. Paris, Gallimard, I959. 454 p. (In French)

4 Mauron Ch. L'Inconscient dans l'oeuvre et la vie de Racine. Gap, Ophrys, I957.350 p. (In French)

5 Poulet G. Notes sur le Temps racinien. Poulet G. Etudes sur le temps humain. Paris, PIon, I949, t. I, pp. I04-I2I. (In French)

6 Tinsley B. Christian theology and the frontiers of tragedy. Cambridge, Leeds univ. press, I963. 25 p. (In English) 
УДК 821.І6г.І

ББК $83.3(2 \mathrm{Poc}=\mathrm{Pyc}) 6$
ШЕКСПИР И БОРЬБА

ЗА ВСТРЕЧНЫЙ ПРОМФИНПЛАН, ИЛИ КАК СДЕЛАНО «ВЫСОКОЕ НАПРЯЖЕНИЕ»

(C) 2017 г. Д.С. Московская

Институт мировой литературы

им. А.М. Горького Российской академии наук, Москва, Россия

Дата поступления статьи: 20 апреля 2017 г. Дата публикации: 25 сентября 2017 г.

DOI: I0.22455/2500-4247-20I7-2-3-220-235

Аннотация: В пьесе «Объявление о смерти» (первоначальное название пьесы «Высокое напряжение») Платонов использовал реальные факты, с которыми он познакомился в 1929-І930 гг. во время пребывания на Ленинградском металлическом заводе. Пьеса должна была ответить на политический заказ РАПП представить «живой и конкретный пример предприятий и живых конкретных людей». Платонов с этой задачей справился. Он показал острый конфликт характеров и мировоззрений. В репликах главных героев можно узнать лексику жестких отзывов, данных Платонову его критиками и Сталиным, в их поведении можно угадать судьбы представителей творческой интеллигенции эпохи реконструкции, Маяковского и Зелинского. Особое место в пьесе занимает тема любви, которая переводит события на новый стилевой и содержательный уровень. В производственной пьесе проступают контуры трагедии с чертами «пограничной ситуации», которая ставит в центр событий человека с его правами, с его свободой выбора как единственную подлинную ценность мира. Платонов не мог не быть в курсе дискуссий о Шекспире, которые развернулись в І93І г. Критики РАПП призывали «догнать и перегнать не какого-нибудь Пильняка, - это не большая честь, да и пролетарская литература уже догнала и перегнала - догнать и перегнать Шекспира...». Платонову удалось сочетать высокую поэтику шекспировской трагедии с ликвидацией прорывов на производстве, и он сделал это вопреки общим насмешкам над рапповскими попытками «шекспиризировать» пьесу об ударниках производства.

Ключевые слова: производственное искусство, Андрей Платонов, Сталин, пьеса, Шекспир, документальность, прообраз, дискуссия, РАПП, критика, экзистенциальная ситуация, драматургический узел, иносказание.

Информация об авторе: Дарья Сергеевна Московская - доктор филологических наук, заместитель директора по научной работе, заведующий отделом рукописей, Институт мировой литературы им. А.М. Горького Российской академии наук, ул. Поварская, д. 25 а, г21069 Москва, Россия.

E-mail: info@imli.ru 


\section{SHAKESPEARE AND THE FIGHT FOR PROMFINPLAN, OR HOW HIGH VOLTAGE IS MADE}

This is an open access article distributed under the Creative Commons Attribution 4.0 International (CC BY 4.0)
(C) 20I7. D.S. Moskovskaya

A.M. Gorky Institute of World Literature

of the Russian Academy of Sciences,

Moscow, Russia

Received: April 20, 2017

Date of publication: September 25, 2017

Abstract: In his play Announcement of Death (the initial title of the play High Voltage), Platonov used documentary facts he observed in I929-I930s while staying at the Leningrad metal factory. The play was intended to fulfil the political order of RAPP to represent "a live example of a specific enterprise and specific individuals." Platonov coped with this task. The play tells the story of heroic struggle of engineers and workers endeavoring to implement the factory's work plan. It shows a sharp conflict of characters and worldviews. In the replicas of the main characters, engineers of the "old school," one can recognize vocabulary and style of the harsh reviews of Platonov's work by literary critics and Stalin. In the characters themselves, one can recognize their alter egos - representatives of the so called creative intelligentsia of the reconstruction era, Mayakovsky and Zelinsky. The motif of love plays a special role in the play in that it introduces a new level of meaning. The "manufacture play" reveals a tragedy that stages the "borderline" situation and places a free-willed person at the center of the represented events as the only true value of the world. The essay argues that Platonov was aware of the discussions around Shakespeare unfolding in I93I. RAPP critics encouraged authors "to catch up with and overtake not only some Pilnyak - this it is not a great honor, the proletarian literature has already caught up with him and overtaken him. The challenge is to catch up with and overtake Shakespeare." Platonov succeeded in combining the high tone of Shakespearean tragedy with the plot of the "manufacture play" despite the general sneer at RAPP's attempts to shakespearize plays about Soviet factory leaders - the so called "udarniki."

Keywords: manufacture art, Andrey Platonov, Stalin, drama, Shakespeare, documentary, prototype, discussion, RAPP, criticism, existential situation, dramaturgical knot, allegory.

Information about the author: Darya S. Moskovskaya, DSc in Philology, Deputy Director of the A.M. Gorky Institute of World Literature, Head of the Manuscript Department, A.M. Gorky Institute of World Literature of the Russian Academy of Sciences, Povarskaya 25 a, I21069 Moscow, Russia.

E-mail: info@imli.ru 
Производственная пьеса «Высокое напряжение» (первоначальное название - «Объявление о смерти», в дальнейшем Платоновым не использовалось) стала ответом Платонова на обрушившуюся на него с мая І93І г., после выхода в свет повести «Впрок (Бедняцкая хроника)», сокрушительную критику ревнителей классовой чистоты искусства. Первое, в феврале 1932 г., обсуждение пьесы [I] имело целью выяснить, произошла ли перестройка мировоззрения этого писателя из пролетариата. Вопрос об эстетических достоинствах пьесы мог быть поднят лишь после апрельского (1932) Постановления Политбюро ЦК ВКП(б) «О перестройке литературно-художественных организаций»: 5 июня 1932 г., на творческом вечере Платонова [4, с. 615-618], впервые прозвучала мысль о недюжинном таланте автора. А. Караваева сравнила пьесу с «Последним решительным» Вс. Вишневского. И сравнение было не в пользу последнего: «Пьеса несравненно выше "Последнего решительного” [4, с. 6І6]. Выступавший на вечере Д. Тальников отметил нестандартность произведения: «...ьеса условного реализма, не бытовая, но и не схематическая <...>. Ее условные образы, вместе с тем реалистические, полны художественной типичности и значимости идеологической. Это пьеса идей, идеологических образов-знаков, социально-обнаженных идей, показанных в экспрессионистическом напряжении» [4, с. 6I8].

С «формально-литературной» стороны в 1932 г. рассмотрел пьесу А.М. Горький и охарактеризовал ее как «своеобразную, интересную и достойную сцены», написанную «очень хорошим языком» [5, с. 314].

Современные литературоведы рассматривают «Высокое напряжение» в рамках «литературы факта», поэтики «производственного» искус- 
ства [6, с. 62-72]. Для этого есть основания: Платонов использовал фактический материал, накопленный в г929-І930 гг. во время пребывания на Ленинградском металлическом заводе (ЛМЗ) и на ленинградской Зиновьевской писчебумажной фабрике. Созданная на его основе пьеса была воистину идеальным ответом на Обращение ВЦСПС и РАПП к советским писателям с призывом о ликвидации прорыва на литературном фронте. Сложность задачи, как видел ее теоретик РАПП В. Ермилов, была в том, чтобы суметь изобразить «живой и конкретный пример предприятий и живых конкретных людей», которых должна знать вся страна, и с этой точки зрения провести проверку «лозунга и живого человека, и борьбы с лакировкой». Он подчеркнул: «...задача не только отдавать готовыми и сложившимися этих людей, но задача показать, какие трудности им приходилось преодолевать, и эту среду, которая им помогала это преодолевать. Задача показать лучших людей нашей страны именно в процессе их борьбы»․

«Объявление о смерти» с поставленными партией и РАПП задачами справилось. Установленный факт работы Платонова с писательской бригадой на ЛМЗ [9, с. 6о-6I, 338-343] придал изучению пьесы документально-биографическое направление. В пьесе действуют, вступая в острый конфликт характеров, мировоззрений, ценностей, идей, шестеро мужчин и одна женщина. Из каких былей пришли они, чтобы зажить новой, литературной жизнью?

О главном герое пьесы Мешкове в набросках к пьесе Платонов пишет: «Мешков - обнаженный социально» [7, с. І83]. И правда, открывающий пьесу монолог Мешкова недвусмысленно обращен к недавним событиям жизни общей (страны) и частной (Андрея Платонова) и обнажает острые социальные проблемы времени: «Нужно скончаться <...>. Я мелочь, прослойка, двусмысленный элемент и прочий пустяк <...> никто ко мне в гости не приходит, и мне пойти некуда» [7, с. 203]. «Чужое» слово в монологе Мешкова после разговора с комсомолкой-ударницей Крашениной: «Неужели я отстал, неужели я дурак?..» [7, с. 213] и его спор с «чужими» голосами, сопровождающий чтение заметки о героической гибели во время производственной аварии инженера Абраментова, окрашивают словесный портрет перепуганного «вредителя» неприкрытой иронией: 
Партком, завком, дирекция, рабочие-ударники... о смерти в огне... верного пролетариату товарища, храбрейшего инженера Сергея Дмитриевича Абраментова, пришедшего из рядов врагов... Из рядов врагов! А я откуда? Я врагом не был. Я все время сочувствовал. Я наоборот даже. Я слишком честный, я умираю от честности, потому что я осознал, что я дурак новой жизни, - я стесняюсь жить [7, с. 233].

В причитаниях Мешкова узнается лексика жестких отзывов, данных Платонову его критиками, в частности, самим Сталиным, начертавшим на полях третьего номера «Красной нови» с публикацией повести «Впрок» «дурак и пошляк новой жизни» [2, с. І 50], или функционерами МАПП: «Вот характерный и показательный пример откровенной вылазки классового врага. Я говорю о рассказе Платонова “Впрок” <...> Кадры колхозные, как он изобразил их! Дурак на дураке, идиот на идиоте <...> нам нужно <...> подойти к идейному расстрелу этой публики»². Пародийно снижает Платонов и собственные недавние, I929-І93і гг., покаянные письма Сталину, Горькому, в редакции центральных газет: «Я несколько сознательней его [Макара] $<. .>$ я не герой своего рассказа» [Іо, с. 272, 273], «я увидел, что товарищи <...> правы, что я заблудился и погибаю» [Іо, с. 285], «нижеподписавшийся отрекается от всей своей прошлой литературно-художественной деятельности» [Іо, с. 29I], «я не классовый враг, <...> я классовым врагом стать не могу <...> рабочий класс - это моя родина» [Іо, с. 304]. Сообщая в письме жене о все возрастающих нападках на него, писатель делится планом спасения: «Перемучившись, обдумав все <...> я решил отказаться, отречься от своего литературного прошлого и начать новую жизнь. Об этом я напишу в газеты “Правда" и “Лит<ературная> газ<ета>” <...>. Другого выхода нет. Другой выход - гибель» [го, с. 295]. Платоновское «двунаправленное» слово в монологах Мешкова свидетельствует: в г93і г. автор «Высокого напряжения» был столь же готов к расправе над собой, как и пребывающий в ожидании «чистки» его герой. В набросках к пьесе эта в глубинном смысле экзистенциальная ситуация лета І93і г., в которой оказались представители творческой и научной интеллигенции, лаконично очерчена обращением Абраментова к портрету Дзержинского: «Ты меня ругал, я тебя уважал, в 
конце пятилетки я попрошусь к стенке» [7, с. І89]. Рядом с небескорыстным, скуповатым и трусливым Мешковым, этим «дураком новой жизни», который, подобно эрдмановскому самоубийце, так и не решится на суицид, высится фигура его антипода, «товарища пролетариата» Абраментова, одинокая, мощная, сумрачная. В его образе и судьбе, емко переданных в диалоге с Девлетовым, собралась вся полнота трагического модуса пьесы: «Скажите - вы белогвардеец? Абраментов. - Был. Девлетов. - А теперь? Абраментов. - Теперь я одинокий» [7, с. 200].

Фигура Абраментова переводит события на новый стилевой и содержательный уровень, и в конъюнктурной партийной суете проступают контуры трагедии с чертами «пограничной ситуации», ставящей в центр событий человека с его судьбой, с его правами, с его свободой выбора как единственную подлинную ценность мира. Наброски к пьесе и восстановленная правка автографа первой редакции «Высокого напряжения» представляют несовместимое с жизнью и единственно отвечающее реальности первой пятилетки понятие свободы этого трагического героя, которое не войдет в текст ни одной из последующих редакций: «Абраментов: там только одна свобода - свобода исчезновения, свобода быть забытым» [7, с. I96]; «Сережа, [y нас есть / одна у нас с тобой / одна свобода] ты скоро уйдешь в материк, в [тесноту земли, и я тоже] тесную землю» [7, с. 23I].

Мне уже приходилось называть события и указывать лица, послужившие реальным источником сюжета и образов «Высокого напряжения». Это инициированная парторгом завода П.И. Семячкиным борьба за встречный план, повлекшая производственные аварии [8, с. I78-237], и противостояние заданным парторгом «темпам» со стороны инженеров «старой школы», среди которых были прежний директор Металлического завода А.Ю. Винблад, заведующий турбинным цехом В.И. Андреев, назначенный главным конструктором паровых турбин в І929 г. М.И. Гринберг, инженер С.А. Бобровщиков, И.И. Кириллов, М.Я. Бень, Ф. Кравченко, Б.В. Шестакович.

Документальный пласт «Высокого напряжения» - низшая ступень политического и философского иносказания, призванного создать обобщающий образ времени. Следующий уровень образуют события последнего года жизни В. Маяковского. Этот «внебрачный сын современности», «сми- 
ренно ожидавший» от РАПП «усыновления»3 [13, с. 27], прообразуя собою Абраментова, стал трагическим героем и жертвой «высокого напряжения» реконструктивного периода. Вспоминается определение Тальникова: «Это пьеса идей, идеологических образов-знаков, социально-обнаженных идей, показанных в экспрессионистическом напряжении». Ни вступление в РАПП, ни Іоо томов его партийных книжек не дали Маяковскому желанного «усыновления», и он ушел в «тесную землю», доказав самоценность несовместимого с установившимся внешним миропорядком личного бытия. Разбор причин смерти Маяковского на страницах центральной прессы поясняет цитированный выше комментарий Мешкова к газетному некрологу: «“...о смерти в огне... верного пролетариату товарища, <...> пришедшего из рядов врагов...” Из рядов врагов! А я откуда?» Абраментов, подобно Маяковскому, анархоиндивидуалист, не более чем «товарищ пролетариата», так и не ставший, несмотря на все усилия, пролетарием.

Характерна для платоновского окружения г929-г932 гг. и фигура инженера Жмякова, «радостного человека средних лет». Управляя пультом турбины, он пританцовывает и напевает: «Их паровоз летит вперед, а нам всем - остановка!..» «Элегантный и грустный до торжественности», он распоряжается у гроба Абраментова, заказывает оркестр, полагая, что «печаль растворится в звуках», а звуки рассеются.

В последнем акте его ожидает жесткий диалог с директором завода Девлетовым, скульптурно одетым в риторику героя-резонера классицистической пьесы:

Девлетов. - Ну, Владимир Петрович, а вы что такое?

Жмяков (серьезно). - А я же, Илья Григорьевич, последний мелкий буржуй на свете. Прикажите - и меня не будет.

Девлетов. - Дурите пореже, Жмяков... Но нравитесь вы мне чемто, - черт вас знает...

Жмяков. - А тем, что я счастливый гад, Илья Григорьевич. <...> я человек дешевый и веселый, - я в социализм бубенчиком, бубенчиком вкачусь, позвоню немного и замолкну сам.

3 Источник цитации: «Бедные внебрачные дети современности, сделавшие подлинную революцию в искусстве и - смиренно выжидающие времени... усыновления», был адресован покинувшим лоно «Нового Лефа» Маяковскому, Асееву и Брику. 
Девлетов. - Прямо хуже вредителя, сукин сын! [7, с. 235].

Напускная веселость циника Жмякова рифмуется с названием книги Б. Шкловского «Поиски оптимизма» (I93I) и смыслами эссе «БОД» (I929), принадлежащего перу бывшего конструктивиста К. Зелинского. В эссе утверждается мысль, что для «построения социализма нужны люди полнокровного самочувствия, веселого жизнеощущения», что «каждый шаг мы должны чувствовать радость бытия». Реакция РАПП на новое бодрое мироощущение была жесткой: автор «БОД» рассматривался как спец, «деформированный практикой Октября» и «наполовину духовный эмигрант» [Іо, с. 270-27I]. Как отмечает Н. Умрюхина, статья Л. Авербаха «О целостных масштабах и частных Макарах» отчасти приравняла мысли платоновских героев к рассуждениям Бода. Сам же Платонов, как показало его письмо Ступенкеру, не принял сопоставления себя с Зелинским и резко с ним размежевался: «Самое грустное для меня - сопоставление с Бодом и Сельв-Зелинским. Я этих людей уважаю как литераторов, но не люблю тех, кого они выражают, - советских дельцов-американцев» [Іо, с. 269].

История показала, что Зелинский, подобно Шкловскому, несмотря ни на что, уцелел и сохранил свои позиции в советской литературе, он даже выступил критиком Платонова на вечере ВССП в г932 г. Фраза Девлетова была пророческой в отношении этого «веселого» типажа: «...нравитесь вы мне чем-то - черт вас знает».

Как уже было сказано, в составе главных персонажей пьесы 6 мужчин и одна женщина. И вместе с представительницей «прекрасного пола» в «Высоком напряжении» рождаются и реализуют себя два конфликта политико-социальный, связанный с отношением к невыполнимому встречному промфинплану, и второй, касающийся актуальной для эпохи социалистического строительства темы взаимоотношений полов.

Ольга Крашенина - инженер лет двадцати пяти. Директор завода Девлетов предваряет ее появление на сцене следующей характеристикой: «... она не выходит из цехов по двадцати часов. Вчера я ее нашел спящей в силовой, третьего дня она стояла на ремонте фильтра тридцать часов» [7, с. 2оI]. Зрителю она предстает еле живой от многодневного бдения в комнате Мешкова, к которому она явилась, намереваясь договориться о смене дежурства. Однако в следующей момент она уже спит, побежденная предельной 
усталостью, и... видит во сне компрессорную с испорченным экономайзером. Трудовой энтузиазм этой женщины, граничащий с подвигом, пугает Мешкова, который, склонившись над спящей, говорит: «Они и во сне все чувствуют! Ведь действительно экономайзер в котельной испорчен...! Как я наяву об этом ни разу не вспомнил?!» [7, с. 3І2].

У красавицы Крашениной, подобно другим персонажам пьесы, есть реальный прототип. Его нетрудно было найти по подсказкам в тексте: это первая женщина-инженер турбинщик Металлического завода и специалист по экономайзерам Надежда Дмитриевна Гончарова - потомок писателя И. Гончарова [3, с. 22-24]. Окончившая со вторым выпуском Высшие женские бестужевские политехнические курсы, она проходила практику на питерской электростанции «Гелиос», где всякий раз ей приходилось подписывать бумагу: «В случае моей гибели от несчастного случая в смерти моей прошу никого не винить», так как женщинам инженеры-мужчины не доверяли. После победы в конкурсе на создание лучшей схемы обмотки статора генератора она была приглашена на штатную работу в трамвайной станции Петербурга. Пришлось поработать ей и на приемке угля. В І9I4 г. ее взяли на завод «Экономайзер» как победившую в соревновании двух инженеров на создание формулы расчета теплопередачи ${ }^{4}$. Отметим эту традиционно считающуюся мужской способность ее ума к расчетам и формулам, которую потерял перепуганный Мешков и сохранил, несмотря на все испытания, Абраментов: «Мешков. <...> Ты знаешь, я забыл однажды формулу живой силы! Абраментов - Эм вэ квадрат, деленные на два... [7, с. 204]. По-видимому, память и точность расчетов для Платонова, электротехника и изобретателя, была признаком свободы ума и самообладания, которыми он наделял в набросках к пьесе представителей «нового мира»: «Сюжет: г. Производ. риск. 2) «Нас всех уволят, мы умрем с голоду, мы - старый мир» Я разучился, Я забыл технику, Я забыл формулу энергии» [7, с. І9г].

В г923 г. Гончарова защитила дипломный проект на тему «Электрические станции на подмосковном угле с передачей энергии с места углеразработки» (заметим, что в набросках главная героиня пьесы работала на торфоразработках). И в том же году попыталась поступить на Металличе-

4 Ряд фактов из биографии Н.Д. Гончаровой восстановлен по данным архива ЛМЗ. 
ский завод, в чем ей, как женщине, отказали. Только благодаря поддержке директора завода, «инженера старой школы», А.Ю. Вимблада и возглавлявшего конструкторское бюро по производству водяных турбин В.И. Андреева она все же была принята и работала на ЛМЗ до 8 июля І929 г.

Вряд ли Платонов встречался с ней лично, в то время как Вимблада и Андреева он застал. Однако он не мог не знать о ней - первой, блестящей женщине-турбостроителе. В г929-І93І гг. она работала старшим инженером в турбинной группе объединения «Котлотурбина», оставаясь в той же сфере производственной деятельности, что и первый турбинный цех, где в составе бригады писателей трудился Платонов.

Следует заметить, что Крашенина не просто талантливый инженер. Она прежде всего инициативный организатор производства и человек активной жизненной позиции, коммунистка. Кроме того, она гораздо моложе Гончаровой, которая в 1929 г. была зрелой дамой 43 лет. Напомню, Крашенина - очень красивая 25-летняя девушка.

Образ Крашениной был данью времени - на острие социального заказа. 5 июня І93І г. на заседании МАПП прозвучала критика «Союзкино», указавшая на то, что «выпадет совершенно из тематики <...> участие женщины в социалистическом строительстве»5. Причина тому, как сказал заведующий отделом кадров Союзкино Яковлев, в отсутствии «в промышленности - на Днепрострое, Автострое женщин-активисток. Из фактического материала мы знаем, что там нет, а кино дает только факты без приукрашивания...» ${ }^{6}$.

В фонде Отдела рукописей ИМЛИ РАН сохранились списки членов киносекции Всеросскомдрама, где в І93I-I932 гг. числится «литератор» Платонов, по социальному происхождению «из рабочих» [II, с. 7]. И как член киносекции Платонов, отвечая упрекам Киршона, дает образ женщины-активистки, ударницы, имеющий реальную, фактическую основу.

Активистка Крашенина замужем. Она отчасти аристофанова Лисистрата, о которой говорил Киршон на том же пленуме МАПП 3 июня І93І г., когда громил повесть Платонова «Впрок». Киршон сообщил, что

6 Там же. 
...в ЦЧО встретился с такой историей, когда бабы заявляли, что “мы не будем жить с мужьями”, если они пойдут в колхоз. А комсомолки заявили: “мы будем жить с вашими мужьями”. Причем, поверьте мне, товарищи, что это гораздо более героическая и интересная эпопея, чем Лисистрата. Ибо, надо принять во внимание еще одну деталь, что в этом районе был большой процент зараженных сифилисом, и когда комсомолки говорили, “мы будем жить с мужьями”, многие из них рисковали и могли получить сифилис ${ }^{7}$

Но комсомолка Крашенина «Высокого напряжения» с мужем не живет не из гигиенических соображений, а потому что отдала себя полностью работе. Обнаруживший заснувшую от усталости на постели Мешкова жену Крашенин «в неврозе» кричит: «Оля! Ты забыла меня, девочка? Я ведь твой Коля... Ах ты так, - прочь от меня, сука!! <...> Обезличку, сволочь, на мужьев ввела!» [7, с. 215].

Но, как бы политически актуальна ни была Крашенина, с ней и с Абраментовым связано глубоко трагическое, экзистенциально-высокое звучание любовной темы «Высокого напряжения». Платонов избирает старинный драматургический узел - неразделенную любовь и любовь взаимную, но разделенную смертью, - и работает с фактическим материалом не как хроникер-очеркист, а как поэт. Его документальность, как мы видим на примере Крашениной и Абраментова, не образует сплошной фактности: «Высокое напряжение» - это сплав документальных и воображаемых портретов, что не опровергает достоверности событий. Встреча Крашениной с Абраментовым, возникшее чувство, трагическая разобщенность социальной принадлежностью, примирение на смертном одре и вечная разлука - все это происходит или в цеху на фоне бушующего пламени, или в старинной дворянской усадьбе эпохи русского классицизма, окруженной богатым соловьями садом, принадлежавшей видному царскому сановнику Дурново. Эта усадьба, ставшая клубом им. Сталина ЛМЗ, предоставила свои классические интерьеры для сцены прощания с погибшим Абраментовым и для запоздалого признания в любви. Усадебный державинский хронотоп преодолел не только пространство, но и время: Крашенина и Абраментов, мчавшиеся (или гонимые?), как в античной трагедии, навстречу Року, к 
предрешенному финалу, перешагнули, наконец, порог человеческого земного бытия: Абраментов в гробу на сцене клуба им. Сталина уже принадлежит Вечности, как и любовь к нему Крашениной. Возле гробов суетятся и распоряжаются лишь Жмяковы и Девлетовы, их показное внимание можно уподобить публикациям и инициативам РАПП, посвященным увековечению памяти Маяковского, в частности, присвоению имени Маяковского писательскому клубу: «...ведь Маяковский сам любил идти в рабочие массы» ${ }^{8}$. И вопрос Пужакова над телами жертв борьбы за «встречный» теряет сиюминутный, политически-актуальный смысл: «Вот скоро хорошо уж будет, а тебя нету; - нам, брат, без тебя тоже стыдно оставаться. Ты, значит, сделал, а другие жировать будут, - это ведь неверно!» [7, с. 229].

Член Всеросскомдрама с г93і г., Платонов не мог не быть в курсе дискуссий о Шекспире, развернувшихся в стенах Общества в г93І г. и проникавших в газетную и журнальную публицистику. Так, на заседании МАПП 27 мая г93г г. В. Ермилов обратился к присутствующим с призывом: «Наш лозунг, который мы выбрасываем перед пролетарской литературой: “догнать и перегнать” не какого-нибудь Пильняка, - это не большая честь, да и пролетарская литература уже догнала и перегнала - догнать и перегнать Шекспира...». И объяснил, как это сделать - надо:

...не равняться на их авторитет, учиться у них, но исходить из практики сегодняшнего дня9.

Давать ли конкретно ту или иную личность в разрезе борьбы на производстве или давать его и в разрезе личной жизни, <...> за какое основное звено ухватиться <...>? Первая опасность та, что описывая данную конкретную личность, он не сумеет схватиться за основное звено, за то, что ведет его в борьбе, то, что сделало его передовиком. А вторая опасность - это сусальность, интеллигентское сюсюканье. <..> Чтобы была действительно только такая книжка - как лучше писать? <...> Писатель ставит вопрос таким образом, - нас заставляют давать сегодняшние факты стройки, посылают с бригадами, но как это умещается с задачей борьбы за большое искусство? 
Мысль о том, насколько совместимы «факты стройки» и посылка писательских «бригад» с большим искусством, развивал в своем выступлении во Всеросскомдраме 27 февраля того же г93г г. Афиногенов:

Я познакомился с Шекспиром. Я думал, счастливый, черт возьми, Шекспир, он мог писать о ревности, о скупости, о любви. Ведь все эти чувства из арсенала нашей драматургии изъяты, но можно писать о влиянии промфинплана на психологию рабочих масс, а просто взять какой-нибудь случай - я не могу, потому что я буду назван: перерожденцем, ренегатом и т. п. [II, с. I9I].

И хотя Афиногенов считал поэтику Шекспира несовместимой с ликвидацией прорывов на производстве, а Третьяков высмеивал рапповские потуги «шекспиризации», Платонов смог сказать «о пролетарских Отелло, советских Гамлетах, комсомольских Ромео и интеллигентских професcopax Лир» [І2, с. I], о подлинной ревности, о скупости, о любви, о большой человеческой истории на фоне «крохоборства борьбы» за встречный промфинплан. В «Высоком напряжении», как мы стремились показать, он непротиворечиво сочетал два сюжетно-образных, стилевых, проблемных слоя: документально-биографический и экзистенциальный, позволившие ему поднять повседневность эпохи реконструкции до высот шекспировской трагедии, когда суд над сегодняшним днем вершит вечность. 


\section{Список литературы}

I Андрей Платонов. Воспоминания современников. Материалы к биографии. М.: Сов. писатель, І994. 497 с.

2 Власть и художественная интеллигенция. Документы ЦК РКП(б) - ВКП(б), ВЧК - ОГПУ - НКВД о культурной политике. І9І7-I953. М.: Международный фонд «Демократия», 2002. 87 г с.

3 Исаев В. Одна из пятисот // Техника - молодежи. 1987. № 3. С. 22-24.

4 Корниенко Н.В. Борьба за постановку пьесы «Высокое напряжение». Документы I932 г. // «Страна философов» Андрея Платонова: Проблемы творчества. М.: ИМЛИ РАН, 2ОІг. ВЫп. 7. 652 с.

5 М. Горький и советские писатели. Неизданная переписка. Литературное наследство. М.: Изд-во АН СССР, І963. Т. 70.736 с.

6 Малыгина Н.М. Принципы «производственного» искусства в пьесе А. Платонова «Высокое напряжение» // Вестник московского городского педагогического университета. Серия «Филологическое образование». 2013. № I. С. 62-72. Московская Д.С. Первая редакция пьесы «Высокое напряжение»: «Объявление о смерти» // Архив А.П. Платонова. М.: ИМЛИ РАН, 2009. Кн. І. С. І78-237. Московская Д.С. «Я по существу мастеровой, братцы». Владимир Маяковский в реминисценциях пьесы Андрея Платонова «Высокое напряжение» // Русская литература. 2012. № I. С. I78-193.

9 Платонов А.П. Записные книжки. Материалы к биографии. М.: ИМЛИ РАН, «Наследие», 2000, 42I с.

Iо Платонов А. «...я прожил жизнь»: Письма І920-І950 гг. М.: Астрель, 2013. 688 с.

II Плотников К.И. История литературного объединения Всеросскомдрам: по материалам Отдела рукописей ИМЛИ РАН: дис. ... канд. филол. наук. М., 2015. 258 с.

I2 Третьяков С. Наши товарищи // Новый Леф. І928. № Іо. С. І-2.

I3 Чужак Н. Левее ЛЕФа // Новый Леф. І928. № І2. С. 27-32. 


\section{References}

Andrej Platonov. Vospominanija sovremennikov. Materialy k biografii [Memoirs of contemporaries. Materials for biography]. Moscow, Sovetskij pisatel' Publ., I994. 497 p. (In Russ.) Vlast' $i$ hudozhestvennaja intelligencija. Dokumenty CK RKP(b) - VKP(b), VChK OGPU - NKVD o kul'turnoj politike. I9I7-I953 [Power and artistic intelligentsia. Documents of the Central Committee of the RCP (B) - VKP (b), the Cheka OGPU - the NKVD on cultural policy. I9I7-I953]. Moscow, Mezhdunarodnyj fond “Demokratija” Publ., 2002. 87I p. (In Russ.)

Isaev V. Odna iz pjatisot [One of the five hundred]. Tehnika - molodezhi, I987, no 3, pp. 22-24. (In Russ.)

Kornienko N.V. Bor'ba za postanovku p'esy “Vysokoe naprjazhenie”. Dokumenty I932 g. [The struggle for staging High Voltage. Documents of I932]. "Strana filosofov" Andreja Platonova: Problemy tvorchestva [Andrey Platonov's "country of philosophers": The problems of his work] Moscow, IWL RAN Publ., 20II. Vol. 7. 652 p. (In Russ.) M. Gor'kij i sovetskie pisateli. Neizdannaja perepiska. Literaturnoe nasledstvo [M. Gorky and Soviet writers. Unpublished correspondence. Literary heritage]. Moscow, Izd-vo AN SSSR Publ., I963. Vol. 70. 736 p. (In Russ.) Malygina N.M. Principy “proizvodstvennogo” iskusstva v p'ese A. Platonova "Vysokoe naprjazhenie" [The principle of "manufacture art" in the play High Voltage by Andrey Platonov]. Vestnik moskovskogo gorodskogo pedagogicheskogo universiteta, Serija "Filologicheskoe obrazovanie" [Series "Philological Education”], 20I3, no I, pp. 62-72. (In Russ.) Moskovskaja D.S. Pervaja redakcija p'esy “Vysokoe naprjazhenie”: “Objavlenie o smerti” [The first version of the play High Voltage: The Announcement of Death]. Arhiv A.P. Platonova [A. Platonov's archives]. Moscow, IWL RAS Publ., 2009, vol. I, pp. 178-237. (In Russ.)

Moskovskaja D.S. “Ja po sushhestvu masterovoj, bratcy”. Vladimir Majakovskij v reminiscencijah p'esy Andreja Platonova "Vysokoe naprjazhenie” [“I am essentially a worker, brothers." Vladimir Mayakovsky in the reminiscences of Andrey Platonov's play High Voltage]. Russkaia literature, 2012, no I, pp. I78-I93. (In Russ.) Platonov A.P. Zapisnye knizhki. Materialy k biografii [Notebooks. Materials for biography]. Moscow, IWL RAS, "Nasledie” Publ., 2000, 42I p. (In Russ.) Platonov A. “...ja prozhil zhizn": Pis"ma I920-I950 gg. [“... I lived my life”: Letters I920-I950]. Moscow, Astrel’ Publ., 2013, 688 p. (In Russ.) Plotnikov K.I. Istorija literaturnogo ob'edinenija Vserosskomdram: po materialam Otdela rukopisej [The history of the literary association Vserosskomdram: based on the materials of the Department of Manuscripts of the IWL RAS] IWL RAS. Dissertacija... kandidata filologicheskih nauk [PhD Thesis in Philology]. Moscow, 20I5. 258 p. (In Russ.) 
Русская литература / Д.С. Московская

I2 Tret’jakov S. Nashi tovarishhi [Our comrades]. Novyj Lef, I928, no ı,, pp. I-2. (In Russ.)

I3 Chuzhak N. Levee LEFa [More Left than LEF]. Novyj Lef, I928, no ı2, pp. 27-32. (In Russ.) 
УДК 821.І6г.І

ББК $83.3(2 \mathrm{Poc}=\mathrm{Pyc}) 6$

\section{ПУТЕШЕСТВИЕ В ДРЕВНЮЮ РУСЬ \\ И ОБРАТНО. «БОГАТЫРИ» \\ ДЕМЬЯНА БЕДНОГО}
(C) 2017 г. М.Л. Федоров
Институт мировой литературы
им. А.М. Горького Российской академии наук,
Москва, Россия
Дата поступления статьи: 03 июля 2017 г.
Дата публикации: 25 сентября 2017 г.

DOI: I0.22455/2500-4247-20I7-2-3-236-25I

Аннотация: В статье рассматривается история создания и постановки на сцене Камерного театра пьесы Демьяна Бедного «Богатыри». В ее основе - летописное предание о принятии христианства на Руси. Образы былинных богатырей и легендарного князя Владимира представлены поэтом в сатирическом, и даже гротескном виде. Такое понимание древней русской истории отвечало представлениям советских историков І920-х гг. В изменившихся условиях второй половины I930-х гг. (разгром исторической школы М.Н. Покровского) такая трактовка воспринималась как глубоко ошибочная. Спектакль был закрыт, а режиссер А.Я. Таиров и Демьян Бедный были подвергнуты опале.

Ключевые слова: Камерный театр, богатырь, Таиров, Демьян Бедный, история.

Информация об авторе: Максим Львович Федоров - кандидат филологических наук, старший научный сотрудник, Институт мировой литературы им. А.М. Горького Российской академии наук, ул. Поварская, д. 25 а, г2Іо69 Москва, Россия.

E-mail: maksimfyodorov@yandex.ru 


\section{A JOURNEY TO THE OLD RUSSIA AND BACK. BOGATYRY BY DEMYAN BEDNY}

This is an open access article distributed under the Creative Commons Attribution 4.0 International (CC BY 4.0)
(C) 20I7. M.L. Fyodorov

A.M. Gorky Institute of World Literature of the Russian Academy of Sciences, Moscow, Russia Received: July 03, 2017

Date of publication: September 25, 2017

Abstract: The article examines the history of writing and staging of Demyan Bedny's play Bogatyry (Epic Heroes) at Kamerny theater. The play is based on the legend about the Baptism of the Rus.' Bedny represents the images of epic heroes and the legendary prince Vladimir in satirical, even grotesque light. Such understanding of ancient Russian history was congenial with the ideas of the Soviet historians of the I920s. In the changed climate of the second half of the i930s (defeat of the historical school of M.N. Pokrovsky), such attitude became perceived as deeply wrong. The performance was closed while the director A.Y. Tairov and Demyan Bedny were subjected to disgrace.

Keywords: Kamerny theater, Tairov, Demyan Bedny, history.

Information about the author: Maksim L. Fyodorov, $\mathrm{PhD}$ in Philology, Senior Researcher A.M. Gorky Institute of World Literature of the Russian Academy of Sciences, Povarskaya 25 a, I21069 Moscow, Russia.

E-mail: maksimfyodorov@yandex.ru 
От Демьяна Бедного, давно и основательно забытого читателями, сегодня, пожалуй, осталась лишь написанная на его стихи песня «Проводы» («Как родная меня мать провожала») и история, связанная с постановкой в 1936 г. в Камерном театре его пьесы «Богатыри».

В этой пьесе соединились, с одной стороны, любовь поэта к театру (как известно, он в юности входил в театральный кружок, тесно дружил с Н.П. Охлопковым, И.М. Москвиным, М.М. Тархановым, Ф.И. Шаляпиным; до «Богатырей» несколько его произведений увидели сценическое воплощение). С другой стороны, Демьяна Бедного отличала любовь к русскому фольклору и летописным сказаниям, знатоком которых, по воспоминаниям современников, он был. Поскольку пьеса специально создавалась для Камерного театра и по заказу А.Я. Таирова, то авторская интенция в ней была ограничена задачами режиссера и репертуарной политикой театра. Приступая к работе над «Богатырями», Камерный театр пытался решить две остро стоящие перед коллективом проблемы. Во-первых, принципиальным для Таирова при создании театра было утвердить в его репертуаре линию комическую, стоящую на грани буффонады, арлекинады, оперетты, фарса. «Богатыри» идеально подходили к этому направлению. Во-вторых, на театр сыпались не лишенные оснований упреки в том, что основа репертуара - западные пьесы, что театр не обращается к русской классике и современной драматургии. Да и предыдущие постановки отечественной классики имели сомнительный успех. Чего стоит, например, спектакль «Гроза» по А.Н. Островскому, о котором едко заметил Н.Р. Эрдман: 
Есть театры и такие,

Что таких на свете нет, -

Сам находится в России,

А на самом деле нет...

Что в нем русского помину,

На французский все манер,

И играет Катерину -

Адриенна Лекуврер [г2, с. 7].

В случае с «Богатырями» для театра это был опыт обращения и к отечественной теме, и к современной драматургии одновременно. Таиров незадолго до премьеры оперы-фарса так скажет об этом:

Линия музыкальных спектаклей Камерного театра за последние годы временно пресеклась. Мы считали необходимым в связи с творческой реконструкцией театра сосредоточиться преимущественно на современном советском репертуаре. С другой стороны, мы не находим музыкального произведения, которое давало бы возможность продлить нашу линию музыкальных спектаклей в новом, нужном нам аспекте.

Поэтому нас, естественно, чрезвычайно заинтересовала находка неопубликованной рукописи оперы-фарса А. Бородина «Богатыри». Музыка Бородина сразу же обнаружила замечательные сценические возможности. Иное оказалось с либретто. Оно было написано ходовым по тому времени драматургом Крыловым. Но текст его был мало интересен и сильно устарел. Свое либретто Крылов построил главным образом на высмеивании оперных штампов. Между тем, партитура наводила на мысль о создании спектакля, опирающегося на народное творчество и, одновременно, высмеивающего «лженародность» в искусстве, ту самую «смесь французского с нижегородским», над которой так зло насмехался Грибоедов и которую высмеял и Бородин в своих «Богатырях». Мы обратились за творческим содействием к Демьяну Бедному. В результате поэт создал совершенно новое произведение, базирующееся не только на народном эпосе, но и на материалах русских летописей [2I, с. 4]. 
В соответствии с законами оперетты у Крылова в центре либретто - мелодраматический сюжет: не лишенная трогательности любовь Соловья к княжне Забаве, дочери удельного князя Густомысла. Параллельно с ней развивается сюжетная линия богатырей: Аники, Алеши Поповича, Кита Китыча, Авось и Небось. Им, по замыслу Крылова, необходимо в поединке победить дочь Змея Горыныча Амельфу Змеевну. И заканчивается все, как в сказке или в оперетте, - свадьбой Соловья с Забавой, а одного из богатырей с богатыршей Амельфой. Таким образом, текст оказывается построенным на фольклорных (былинных и сказочных) мотивах. Из летописных реалий можно выделить лишь языческого бога Перуна. Очевидно, что фольклорный мир пьесы носит условный характер, подчеркнутый к тому же и композиционно. Одним из жанрообразующих принципов оперетты считается ее репризный характер. Этот вид музыкального театра отличает острая социальная направленность и злободневность, выраженная в репризах, которые нежестко закрепляются в либретто и носят импровизационный характер. Текст Крылова щедро наполнен репризами, но практически все они, имеющие общественно-социальное звучание, были вырезаны цензурой. Например, реплика Милитрисы, жены удельного князя, богатырю Анике: «Рабство - великое зло. А кто губит рабов, тот уничтожает рабство. Нам приятно видеть ваши гуманные цели» [2, с. І2].

Реплика Фомы: «Эк, удивил нас кисельными берегами. У нас на Руси не только берега, а все дороги кисельные» [2, с. 15].

Алеша обращается к богатырше: «Всяка рыба хороша, коли на уду попалась. У пруссаков выучилась с побежденного две шкуры-то брать» [2, с. 22].

Цензура даже вычеркнула в устах удельного князя летописную фразу: «Земля наша велика и обильна, но порядку в ней нет» [2, с. 28].

Демьян Бедный значительно изменил либретто, по сути создал, как верно заметил Таиров, самостоятельное произведение. За основу поэт взял летописную историю крещения Руси, поэтому и удельный князь Гостомысл заменен на Владимира, а жена Гостомысла на Рогнеду. Поэт оказывается верен самому себе: он создает текст не пародирующий оперные штампы, а имеющий прежде всего антиклерикальную и антицерковную направленность. Из текста ушла и репризность, и острое социальное зву- 
чание. Либретто Демьяна по сравнению с текстом Крылова оказывается плоскостнее, одномернее, одноцветнее. Среди источников, которыми пользовался поэт при переработке текста, помимо либретто Крылова (в ОР ИМЛИ в его фонде сохранилось несколько экземпляров со следами активной работы Демьяна Бедного над текстом), надо указать былины про Анику и Чудо, из которых поэт делал многочисленные выписки, выписки из книги «Русские песни», выписки из книг известных фольклористов братьев Соколовых (все материалы с многочисленными пометами Демьяна Бедного хранятся в его фонде в ОР ИМЛИ).

Можно предположить, что знал поэт и о существовании «разоблачительной» пьесы-буффонады «Крещение Руси», четырьмя годами раньше «Богатырей» поставленной на сцене ленинградского Театра сатиры и комедии (автором пьесы был Н. Адуев, постановка И. Кролль). В I932 г. в журнале «Рабочий и театр» появилась рецензия на эту работу: «Спектакль имеет ряд смелых проекций в современность, что повышает политическую действенность пьесы <..> Былинные богатыри выступают в роли жандармской охранки, Соловей-разбойник становится олицетворением именитого купечества, Византия перекликается с фашистским Западом. Сам князь Владимир обобщен как представитель самодержавия и не случайно поэтому к концу спектакля принимает образ предпоследнего царя-держиморды. Однако основная, не преодоленная театром ошибка автора кроется в показе всей “православной Руси” - пришибленным, с расслабленной волевой мускулатурой, появляющимся в неукоснительно пьяном виде и произносящим путанные и непонятные слова Микулой Селяниновичем. Обобщая “культурный” византийский деспотизм до фашизма (связь истории с современностью вообще в спектакле носит отпечаток наивной механистичности), Н. Адуев не подчеркивает мракобесия деспотов, и в сопоставлении с былинной дикостью расейского князя византийцы выглядят как... светочи культуры» [3, с. I4]. И заканчивается рецензия: «Подводим итоги: “Крещение Руси” - не плохой развлекательный спектакль, несущий в себе некоторую, но явно недостаточную, социальную, в частности, антирелигиозную нагрузку. Все достоинства спектакля, в том числе режиссерская и актерская работа, не могут снять вопроса о том, что эти достоинства завоеваны театром в стороне от основной его линии» [3, с. I4]. 
Прочтение «богатырской» темы в духе Адуева было типичным и для Демьяна Бедного, он, например, в г930 г. в стихотворении «Закалка» использует образ богатыря, вернее, его «богатырского» сна, в качестве сатиры на прежнюю Россию:

Храп «богатырский» постоянный.

На неоглядный весь пустырь!

Спал беспробудно-деревянный

Российский горе-богатырь. <...>

Глядь, богатырь насквозь гнилой!

Гнилая жизнь, гнилые нравы,

Грунт - помесь плесени с золой [4, с. 59-60].

Или в стихотворении «Вытянем!», где строителям Магнитки противопоставлен образ Святогора-богатыря, один из самых глубоких и сложных образов, созданных поэтическим гением народа. Народ связывал с ним свою веру в героя, способного даже землю перевернуть. А у Демьяна Бедного все прочитано упрощенно, в его восприятии Святогор лишь «бахвальщик»:

Чай, слыхали былину вы о Святогоре,

Старорусском бахвальщике-богатыре?

Похвалился он, плечи свои разминая:

«Эх, кабы мне в руки да тяга земная,

Всю бы землю я, кажется, перевернул!» [6, с. 64]

Похожим образом решается «богатырская тема» и в либретто. Отказавшись от лирических интонаций фарса Крылова, поэт погружает читателя в мрачную, беспросветную атмосферу тотального пьянства, грубости и невежества. В произведении Демьяна Бедного нет положительных героев. Даже богатырь Фома, который влюблен в Забаву, и эта сюжетная линия, как и у Крылова, могла бы придать мелодраматическую краску тексту, у Демьяна оказывается переодетым разбойником Угаром во главе с шайкой разбойников-богатырей, лишенных всякого романтического ореола. Владимир Красно Солнышко становится пьяницей и слабоум- 
ным, Рогнеда на протяжении всей пьесы распаляема похотью, а в начале либретто богатыри и Владимир долго не могут проснуться после пьянки, во время которой грек Анастас крестил их в греческую веру. Сверхзадаче отвечала и тактика текста, герои Демьяна Бедного говорят на подчеркнуто сниженном, грубом языке.

Богатыри в восприятии Адуева и Демьяна Бедного отвечали распространенному тогда, в том числе и в академической среде, мнению о некрестьянском происхождении русского фольклора. Такая точка зрения не была порождением советской идеологии, ученые, разделявшие эту позицию, опирались на работы фольклористов и историков культуры дореволюционной России, например - академика В.Ф. Миллера и особенно - В.А. Келтуяллы, который в своем «Курсе истории русской литературы» настаивал на феодальных корнях русского эпоса. А Д.Н. Овсянико-Куликовский в книге «История русской интеллигенции» писал о том, что «героический эпос (в том числе и такой, как поэмы Гомера) - не народного, не крестьянского происхождения, а “господского” [І6, с. I43].

В І93І г. выходит «Антология крестьянской литературы послеоктябрьской эпохи», где во вступительной статье составитель Александр Ревякин, ссылаясь на выводы известного искусствоведа того времени А.И. Некрасова, отмечает: «Обращение к так называемой устной народной поэзии дает те же результаты - большинство ее жанров возникает и развивается в высшей привилегированной социальной среде. Былина, являвшаяся одним из любимейших крепостным людом жанров устной поэзии и в некоторых случаях явно окрестьяниваемая (былины об Илье-Муромце), несет и по своей идейно-психологической направленности и по форме явно не крестьянские черты. Ее корни лежат несомненно где-то в социальных “верхах”, в общественном бытии военно-служилых, придворно-княжеских и буржуазно-городских слоев» [I, с. 6].

Знаменитый фольклорист Юрий Соколов еще в 1935 г. призывал коллег не объективно собирать фольклор, а подвергать его цензурированию и редактированию и увязывать это с «местными педагогическими, политпросветными организациями и обязательно проводить в полном согласовании с местными партийными и комсомольскими организациями» [19, с. І6]. Но спустя три года тот же Соколов в учебнике по фольклору тезис об аристократическом происхождении эпоса уже объявляет 
фашистским, упоминая при этом Ганса Наумана и теорию «утопленного культурного достояния» (gesunkenes Kulturgut). А певцы-орденоносцы Сулейман Стальский и Джамбул Джабаев, лезгинский ашуг и казахский акын, назначались продолжателями традиции, восходящей к аэдам и рапсодам Древней Греции [20, с. 539-540].

Демьян Бедный даже к середине І930-х гг. не осознал, как изменилось время и что, как отмечает один из исследователей, «Проблема прочности СССР перед лицом будущей войны особенно заботила руководство страны уже в первой половине І930-х гг. Эта прочность представлялась Сталину как сплоченность народов СССР вокруг русского народа» [8].

В «Правде» в 1937 г. как бы в ответ непонятливому Демьяну Бедному прозвучало: «...введение христианства было прогрессом по сравнению с языческим варварством, что вместе с христианством славяне получили письменность и некоторые элементы более высокой византийской культуры» [17, с. 2].

Между тем спектакль Камерного театра собрал хорошую критику. О. Литовский в «Советском искусстве» отмечал особый успех постановки у рабочего зрителя. Автор заметки объяснял, что «качества текста оказались таковы, что, в сущности говоря, из скромной попытки обновить старое либретто, вырос в конечном счете принципиально значительный спектакль». Критик писал, что произведение получилось подлинно народное, что богатыри - это народ, и его герой - Фома, и на их стороне симпатии автора. «А Владимировы богатыри ничтожны и жалки. Именно они олицетворяют слабую и отсталую древнюю Русь. <...> Демьян объектом для сатиры взял не подлинных сказочных народных героев богатырского эпоса - Илью Муромца, Добрыню Никитича, Микулу Селяниновича, а тех самых “богатырей”, над которыми народ издевается в своих былинах» [14, с. 3]. На премьере присутствовали рабочие и инженерно-технический персонал автозавода Сталина, и в антракте заведующий культмассовым отделом завода товарищ Арнфельд от имени рабочих приветствовал Демьяна Бедного и создателей спектакля. Автор либретто и Таиров выступили с ответным словом.

В «Вечерней Москве» появилась заметка М. Загорского о спектакле. Критик писал: «Хороший новый спектакль показал Камерный театр. Свежий, радостный, полный юмора, улыбки и умной шутки. Отныне уже 
нельзя будет строить ни один музыкальный, сатирический и пародийный спектакль, не учтя опыта “Богатырей” [Іо, с. 3]. Критик говорил о долгой жизни спектакля в театре.

На шестом спектакле «Богатырей» І2 ноября присутствовал B.М. Молотов. После первого действия он ушел, а вскоре Таирову передали его слова: «Безобразие! Богатыри ведь были замечательные люди!»

На следующей день Молотов созвал заседание политбюро, утвердившего проект постановления Комитета по делам искусств Совнаркома СССР о снятии пьесы «Богатыри» с репертуара.

П.М. Керженцев, председатель Комитета по делам искусств, который когда-то посоветовал Таирову обратиться к Демьяну Бедному для исправления либретто, теперь сказал: «Пьеса Демьяна Бедного в постановке Таирова, проявившего исключительное усердие в раздувании фальшивых сторон незадачливого произведения, - это вовсе не народная пьеса, а произведение лженародное, антинародное, искажающее народный эпос, извращающее историю народа, ложное по своим политическим тенденциям. И автор и театр этой постановкой оказали услугу не народам Советского Союза, строящим свое социалистическое искусство, а кому-то другому» [II, с. I5].

Несмотря на специальные оговорки театра, сделанные в программах к спектаклю, несмотря на пояснения самого Демьяна Бедного, опубликованные заранее в «Правде», что поэт берет для оперы-фарса «не былинных богатырей (Святогора, Илью Муромца и т. д.), созданных народно-героическим творчеством, а тех пропойц, о которых говорит летопись, что они, напившись, шумели против Владимира, зачем им на пиру дают деревянные, а не серебряные ложки» [5, с. 4], был сделан вывод, что Демьян Бедный и театр оскорбляют героев народного эпоса. Поскольку, по словам П.М. Керженцева, «образы богатырей выявляют думы и чаяния народа. Они в течение веков живут в народе именно потому, что они олицетворяют героическую борьбу народа против иноземных нашествий, народную удаль, смекалку, храбрость, хитрость, великодушие, находившие особенно яркое выражение в определенные переломные моменты истории народа и его борьбы за свою лучшую долю» [ІІ, с. 8].

Похожие упреки получал Демьян Бедный и раньше. Так, Луначарский еще в І93І г. писал о поэте: «Иногда Д. Бедный увлекался и прошлое 
рисовал сплошной черной краской, сажей, а настоящее, наоборот, слишком светлым. Его упрекали: если бы прошлое наше было так темно, то из него не могло бы получиться настоящее. Каким чудом оно получилось, если бы в нашем народе не было прогрессивной тенденции, если бы раньше наши рабочие не были проникнуты этой идеей?» [15, c. 40].

После закрытия спектакля всем театрам на собрании трупп было предписано обсудить ситуацию, возникшую в связи с постановкой «Богатырей». В «Правде» от I7 ноября І936 г. появился отчет о совещании театральных деятелей и работников искусств, приводились слова деятелей культуры:

Выступавший на совещании директор Эрмитажа академик Орбели сказал:

- Постановление Комитета по делам искусств имеет значение не только для Камерного театра. Необходимо поэтому просмотреть и многое другое, что показывается в наших театрах, да и в литературу заглянуть с этой точки зрения. Нужно искоренить случаи наплевательства на героическое прошлое нашего народа.

- Искусство, - сказал академик Орбели, - должно воспитывать чувство национального достоинства народа. Великий русский народ может гордиться и великими революционными деятелями, и гениальными учеными, и былинным эпосом. Недопустимо превращать народный эпос в предмет шутовства и карикатуры [18, с. 3].

Заканчивалась статья грозным выводом: «Выступавший на совещании А. Таиров, словесно признавая серьезность допущенной ошибки Камерного театра, не соглашался с резкой оценкой, данной в статье тов. Керженцева. Это значит, что А. Таиров не понял постановления Комитета и не делает из него необходимых выводов» [І8, с. 3].

20 ноября 1936 г. «Правда» в лице анонимного зрителя вспомнила уже все огрехи и лично Таирова, и Камерного театра. Вспомнили спектакль по пьесе М. Левидова «Заговор равных» І927 г. - «пьесу, содержащую клевету на партию»;

«Багровый остров» 1928 г. - «В этой пьесе под видом пародии содержался пасквиль на нашу жизнь»; 
«Наталью Тарпову» 1929 г. - «Эта пьеса подвергала нашу действительность грубому искажению и содержала классово враждебные нам высказывания» [13, с. 3].

От Демьяна Бедного почти все отвернулись. Но остались и верные друзья. Так, поэт А. Жаров прислал ему из Харькова 29 ноября 1936 г. теплое письмо, где в частности говорилось:

Сужу, как надо: по-партийному, по справедливости... Демьян останется Демьяном и без «Богатырей» и богатырем без Таирова.

Камерные поэты думают урок с «Богатырями» использовать для себя, объявляя крах демьяновской линии... Этот номер не пройдет! Будьте здоровы и не считайте себя одиноким. Это главное [9, с. 236].

Закрытие спектакля и кампания, начавшаяся против Демьяна Бедного, имела плоды. Поэт раскаялся, исправил ошибки, преодолел свои прежние неправильные взгляды. В разговоре со всесильным тогда В.П. Ставским он покаянно признался: «Ты знаешь, когда Молотов пришел и посмотрел пьесу и вскипел, только тут я понял: Мать честная! А мы то прикрашивали разбойников... Где они богатыри? Разве такие были богатыри? Вырастим своих богатырей из народа...У меня первая мысль, чтобы не свалиться, не сорваться. Хочется жить, просто из любопытства. Хочется смотреть дальше, как это завершится» ${ }^{\text {. }}$

Очень быстро кардинально изменилось его понимание истории: в героических деяниях давно прошедших лет он видит теперь залог нынешних побед советского народа. Куликово поле в стихотворении «Помянем, братья, старину», сражение на Березине в стихотворении «Над Харьковом взвилось родное наше знамя» оказываются необходимыми поэту, чтобы воодушевить воинов на борьбу с фашистами. По-новому осмысляет Бедный и традиции народного творчества, героического русского эпоса. Отказавшись от концепции, которая легла в основу его «Богатырей», он видит теперь в образах русских былинных героев воплощение непобедимости народа, его любви к своей родине. Образ воина-богатыря присутствует в ряде поздних произведений поэта («Богатырская переправа» 
и др.). И своего рода обобщением взглядов поэта на отечественную историю стало одно из последних стихотворений поэта - «Русь», написанное им в конце Отечественной войны:

Где слово русских прозвучало,

Воспрянул друг, и враг поник.

Русь - наших доблестей начало

И животворных сил родник [7, с. 2І2]. 


\section{Список литературы}

Антология крестьянской литературы послеоктябрьской эпохи / вступ. Ст., выбор и ред. художественного и автобиографического текста А. Ревякина. М.; Л.: ГИХЛ, І93І. 66г с. Бородин А.П. Богатыри. Опера-фарс. Либретто В.А. Крылова. М.: «Дека-ВС», 2005. $32 \mathrm{c}$.

3 Видре В., Донико Н., Магницкая Н. «Крещение Руси» // Рабочий и театр. 1932. № I. C. I4.

4 Демьян Бедный. Полное собрание сочинений. М.; Л., І93І. Т. XVII. 275 с.

5 Демьян Бедный. «Богатыри». К премьере в Камерном театре // Правда. I936. 24 октября. № 294. С. 4 .

6 Демьян Бедный. Собр. соч.: в 5 т. М.: ГИХЛ, г954. Т. 4. 4 Іо с.

7 Демьян Бедный. Собр. соч.: в 5 т. М.: ГИХЛ, г954. Т. 5. 383 с.

8 Дубровский А.M. От проблем исторического образования к новому облику исторической науки. URL: http://www.opentextnn.ru/history/ historiografy/?id=299I (дата обращения: I5.05.20I7).

9 Жаров А. Демьян Бедный в моей памяти // Воспоминания о Демьяне Бедном. М., І966. С. 227-24I.

го Загорский M. «Богатыри» в Камерном театре // Вечерняя Москва. I936. 3I октября. № 251. С. 3.

II Кержениев П.М. Фальсификация народного прошлого. О «Богатырях» Демьяна Бедного // Против фальсификации народного прошлого. М.; Л.: Искусство, I937. С. 5-I6.

I2 Левитин М.З. Таиров. М.: Молодая гвардия, 2009. 359 с.

I3 Линия ошибок (О Камерном театре) // Правда. I936. 20 ноября. № 3I9. С. 3.

I4 Литовский О. «Богатыри». Новая постановка Камерного театра // Советское искусство. І936. № 50. С. 3.

I5 Луначарский А.В. Художник народных масс // Воспоминания о Демьяне Бедном. М., І966. С. 39-44.

I6 Овсянико-Куликовский Д.Н. Сочинения. СПб., г9гі. Т. 8. 224 с.

I7 Постановление жюри правительственной комиссии по конкурсу на лучший учебник для 3 и 4 классов средней школы по истории СССР // Правда. 937. 22 августа. № 23I. С. 2.

I8 Совещание театральных деятелей и работников искусств // Правда. 1936. I7 ноября. № 3І6. С. 3 .

I9 Соколов Ю. О собирании фольклора // Советское краеведение. І935. № 2. C. I2-I8.

20 Соколов Ю.М. Русский фольклор. М., І94I. 557 с.

2 І Таиров А. «Богатыри» в Камерном театре // Известия. I936. 26 октября. № 249. C. 4 . 


\section{References}

Antologija krest'janskoj literatury posleoktjabr'skoj jepohi [An anthology of peasant literature of the post-October time], intro, ed. A. Revyakin. Moscow, Leningrad, GIHL Publ., I93I. 66I p. (In Russ.) Borodin A.P. Bogatyri. Opera-fars. Libretto V.A. Krylova [Bogatyry. Opera-farce. Libretto by V.A. Krylov]. Moscow, “Deka-VS” Publ., 2005. 32 p. (In Russ.) Vidre V., Doniko N., Magnickaja N. “Kreshhenie Rusi” [The Baptism of Rus']. Rabochij i teatr, I932, no I, p. I4. (In Russ.)

4 Dem'jan Bednyj. Polnoe sobranie sochinenij [Complete collection of works]. Moscow-Leningrad, I93I. Vol. XVII. 275 p. (In Russ.)

5 Dem'jan Bednyj. “Bogatyri”. K prem'ere v Kamernom teatre [Bogatyry. The first night at the Kamerny theater]. Pravda, I936, October 24, no 294, p. 4. (In Russ.) Dem'jan Bednyj. Sobranie sochinenij: $v 5 t$. [Collected works: in 5 vols.]. Moscow, GIKhL Publ., I954. Vol. 4. 4IO p. (In Russ.)

7 Dem'jan Bednyj. Sobranie sochinenij: $v 5$ t. [Collected works: in 5 vols.]. Moscow, GIKhL Publ., I954. Vol. 5. 383 p. (In Russ.)

8 Dubrovskij A.M. Ot problem istoricheskogo obrazovanija k novomu obliku istoricheskoj nauki [From the problems of historical education to the new image of historical science]. Available at: http://www.opentextnn.ru/history/ historiografy/?id=299I (Accessed I5 May 20I7). (In Russ.)

9 Zharov A. Dem'jan Bednyj v moej pamjati [Demyan Bedny in my memory]. Vospominanija o Dem'jane Bednom [Memoirs about Demyan Bedny]. Moscow, I966, pp. 227-24I. (In Russ.)

Zagorskij M. "Bogatyri” v Kamernom teatre [Bogatyry at the Kamerny theater]. Vechernjaja Moskva, I936, October 3I, no 25I, p. 3. (In Russ.) Kerzhencev P.M. Fal'sifikacija narodnogo proshlogo. O “Bogatyrjah” Dem'jana Bednogo [Falsification of the national past. About Bogatyry by Demyan Bedny]. Protiv fal'sifikacii narodnogo proshlogo [Against the falsification of the national past]. Moscow, Leningrad, Iskusstvo Publ., I937, pp. 5-I6. (In Russ.) Levitin M.Z. Tairov [Tairov]. Moscow, 2009. 359 p. (In Russ.)

I3 Linija oshibok (O Kamernom teatre) [A sequence of mistakes (On the Kamerny theater)]. Pravda, I936, November 20, no 319, p. 3. (In Russ.)

I4 Litovskij O. "Bogatyri”. Novaja postanovka Kamernogo teatra [Bogatyry. The new production of Kamerny theater]. Sovetskoe iskusstvo, I936, no 50, p. 3. (In Russ.) Lunacharskij A.V. Hudozhnik narodnyh mass [Artist of the masses]. Vospominanija o Dem'jane Bednom [Memoirs about Demyan Bedny]. Moscow, I966, pp. 39-44. (In Russ.) Ovsjaniko-Kulikovskij D.N. Sochinenija [Works]. St. Petersburg, I9ıı. Vol. 8. 224 p. (In Russ.) 
I7 Postanovlenie zhjuri pravitel'stvennoj komissii po konkursu na luchshij uchebnik dlja 3 i 4 klassov srednej shkoly po istorii SSSR [Decision of the jury of the government commission on the competition for the best textbook in the history of the USSR for the 3 rd and 4th grades of the secondary school]. Pravda, I937, August 22, no 23I, p. 2. (In Russ.)

I8 Soveshhanie teatral'nyh dejatelej i rabotnikov iskusstv [Meeting of theatrical and artistic stuff]. Pravda, I936, November I7, no 316, p. 3. (In Russ.)

I9 Sokolov Ju. O sobiranii fol'klora [On the collection of folklore]. Sovetskoe kraevedenie, I935, no 2, pp.I2-I8. (In Russ.)

20 Sokolov Ju.M. Russkij fol'klor [Russian folklore]. Moscow, I94I. 557 p. (In Russ.)

$2 \mathrm{I}$ Tairov A. "Bogatyri" v Kamernom teatre [Bogatyry at the Kamerny theater]. Izvestija, I936, October 26, no 249, p. 4. (In Russ.) 
УДК 821.І6г.2

ББК $83.3(4$ Укр)

\section{«ПСАЛМЫ ДАВИДА» ТАРАСА ШЕВЧЕНКО: ОТ САКРАЛЬНОГО ТЕКСТА К ПОЭТИЧЕСКОМУ «ТЕКСТУ»

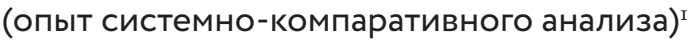

\author{
(C) 2017 г. Ю.Я. Барабаш \\ Институт мировой литературы \\ им. А.М. Горького Российской академии наук, \\ Москва, Россия \\ Дата поступления статьи: I5 января 2017 г. \\ Дата публикации: 25 сентября 2017 г.
}

DOI: I0.22455/2500-4247-20I7-2-3-252-273

Аннотация: Предпринимается попытка системно-компаративного прочтения цикла Т.Г. Шевченко «Псалмы Давида» в сопоставлении с первоисточником - ветхозаветной Книгой псалмов. В синхроническом срезе выделяются главные факторы и узловые признаки, которые, по мнению автора, есть основания признать их ключевыми для трактовки цикла как системного объекта, или как «текста». Анализ проводится на двух структурно-семантических уровнях: один, на котором поэт осуществляет выбор для переложения десяти псалмов из ста пятидесяти, второй - уровень переформатирования прецедентного текста. Система внутренних связей формирующегося в этом процессе нового, принадлежащего Шевченко как автору, литературного текста определяется: а) возникающими в результате переформатирования изменениями «отношений соседства» между его компонентами и b) «кодом говорящего» - системой текстологических, смысловых, образных, акцентуационных корректировок и дополнений, которые автор переложения вносит в тексты выбранных им псалмов. В ракурсе темы в статье рассматриваются такие категории, как претекст, контекст и интертекст, также предлагаемые автором понятия «off-текст» и «диалог интерпретаций». И последнее, что следует оговорить: предусматривается нарочитое - как прием «суммы технологий» и в эвристических целях - сужение аналитического поля, вне его пределов остается широкий круг фактов и проблем, многие из которых, впрочем, уже были предметом исследования в шевченковедении.

Ключевые слова: система, текст, структура, семантика, выбор, переформатирование, «код говорящего».

Информация об авторе: Юрий Яковлевич Барабаш - доктор филологических наук, профессор, главный научный сотрудник, Институт мировой литературы им. А.М. Горького Российской Академии наук, ул. Поварская, д. 25 а, г2го69 Москва, Россия.

E-mail: barabash.yuri@gmail.com

I 3десь и ниже кавычки к лексеме «текст» указывают на отличие означаемого понятия как структурно-семиотического феномена от текста прагматичного, письменного либо печатного. 
This is an open access article distributed under the Creative Commons Attribution 4.0 International (CC BY 4.0)
(C) 20I7. Yu.Y. Barabash

A.M. Gorky Institute of World Literature of the Russian Academy of Sciences, Moscow, Russia

Received: January I5, 2017

Date of publication: September 25, 2017

Abstract: The article attempts to compare a poetic circle David's Psalms by Taras Shevchenko with its origin - Book of Psalms in The Old Testament. It singles out, in the synchronical aspect, major factors and key attributes that allow us to interpret this poetic circle as a systematic object, or "text." The circle is analyzed on two levels: (I) the poet's choice of ten psalms out of I50 for adaptation; (2) the actual adaptation and transformation of the original text. This two-level process forges a new literary text authored by Shevchenko. The system of inner connections within the new text is defined by (a) textual transformation and changes in the "neighborhood relations" between the textual components; b) the "speaker's code," e. g. the system of textological, semantic, and figurative revisions, additions and accentuations introduced by the author of the adaptation into the texts of the chosen psalms. The article examines such categories as pretext and context and introduces such notions as "off-text" and "the dialogue of interpretations." The essay deliberately narrows down its scope of examination implying the method of the "sums of technology" and pursuing euristic purposes. Thus, a wide range of facts and problems widely discussed within Shevchenko Studies is intentionally left behind.

Keywords: system, text, structure, semantics, choice, adaptation, the "speaker's code."

Information about the author: Yuri Y. Barabash, DSc in Philology, Professor, Director of Research, A.M. Gorky Institute of World Literature of the Russian Academy of Sciences, Povarskaya 25 a, I21069 Moscow, Russia.

E-mail: barabash.yuri@gmail.com 
В посвященных «Псалмам Давида» исследованиях, составляющих в шевченковедении отдельный корпус, этот цикл рассматривается в диапазоне как собственно историко-литературной, так и общегуманитарной проблематики - историо- и нациософской, религиеведческой, религиозно-этической, социопсихологической, в компаративистском и герменевтическом ракурсах ${ }^{2}$. Примечательная черта, общая для различных уровней и звеньев этого дискурса, - превалирование диахронического подхода, с акцентом на хронологических параметрах и сравнительно-исторических сопоставлениях, обычно с соблюдением принципа последовательности в анализе компонентов исследуемого объекта. Плодотворность такого подхода, разумеется, вне сомнений. Сомнений, однако, нет также и в том, что полноте и эффективности исследований будет содействовать комплексный подход, основанный на принципе сочетания, взаимодополнения диахронии и синхронии, рассмотрения цикла как сложной, иерархической целостной системы, как «текста» - в структурно-семиотическом ракурсе и в структурно-семантическом толковании этого понятия.

$* * *$

В отличие от исходного, иудейского, Псалтыря, состоявшего в так называемой масоретской редакции из I50 псалмов, в его церковнославян-

2 См. работы Т. Бовсунивской, И. Даниленко, И. Дзюбы, В. Домашовца, Л. Киселевой, Р. Коропецкого, М. Ласло-Куцюк, Т. Мейзерской, Н. Павлюка, В. Радуцкого, Б. Струминского, В. Сулимы, Л. Ушкалова, Д. Штогрина.

3 В текстах богословской направленности обычно употребляется форма женского рода Псалтирь. 
ском переводе, позднее также в русском синодальном, за основу взята нумерация древнегреческого (III в. до Рождества Хрстова) перевода Ветхого Завета - Септуагинты, или «перевода семидесяти толковников» (в литературе он сокращенно определяется как «LXX»), включающего I5I псалом. Шевченко в своем цикле, а также позднейшие украинские переводчики (ко времени создания им «Псалмов Давида» украинского перевода Псалтыря еще не было 4 , поэт, судя по всему, пользовался церковнославянским переводом) придерживаются масоретской нумерации.

Из этого количества псалмов Шевченко отобрал (г845) для своего переложения только го - момент важнейший, ибо он связан с проблемой выбора. Обратим внимание: поэт не идет простейшим путем, не берет для своего переложения первые десять псалмов, что выглядело бы логичным, если бы целью было простое сокращение объема; нет, он их выбирает из всех пяти книг Псалтыря, от первого до ста сорок девятого, т. е. вычленяет часть из целого, по существу, создавая новый, свой цикл.

Начинает Шевченко с первого псалма, причем его переложение максимально приближено к оригиналу как по содержанию, по его центральной идее утверждения Божиего закона, так и по средствам медитативной поэтики: воспроизведение (конечно, в переводе, о чем - ниже) вступительной формулы о «блаженном муже», двух ключевых метафор - «Над водою окрепшее / Древо» (в библейском тексте: «дерево, посаженное при потоках вод») и пепла, «что по свету / Ветер развевает» («как прах, возметаемый ветром [с лица земли]»)5. Это выглядит так, словно автор переложения с самого начала стремится засвидетельствовать свое намерение строго придерживаться первоисточника.

Далее, однако, происходит структурный перелом: Шевченко минует второй псалом, еще девять следующих и переходит сразу к псалму двенадца-

\footnotetext{
4 Только в г859 г., через І4 лет после шевченковского цикла, в № I альманаха «Украинец» были опубликованы «Псалмы, переложенные на украинское наречие», их автором был Михаил Максимович (а не Иван Максимович, историк церкви и гебраист, профессор Киевской духовной академии, которому эти переложения приписывает о. Александр Мень в своем «Библиологическом словаре». См. об этом: [г]). Еще почти через полтора десятилетия, в начале 70-х гг. XIX в., такой перевод был осуществлен ученым-физиком и литератором Иваном Пулюем, а свет он увидел в г903 г. в составе Библии, переведенной ранее П. Кулишом, И. Нечуем-Левицким и И. Пулюем и изданной Британским библейским обществом. 5 Цитаты из «Псалмов Давида» Шевченко приводятся в переводе Л. Вышеславского, из текста Библии - в синодальном переводе.
} 
тому. Понять смысл этого действия автора переложения поможет сопоставление второго и двенадцатого псалмов библейского оригинала. Первый принадлежит к числу так называемых царских псалмов, в нем земной властитель, царь Иудеи, предстает как Помазанник, он идентифицирует себя как Сына Божиего. Мессианистическому мотиву этого псалма придается особое значение как в иудейской, так и в христианской традициях, в иудейской он трактуется в духе утверждения сакральности царя Иудеи, христианские богословы прочитывают в нем откровение о грядущем приходе Иисуса Христа.

Если для второго псалма в оригинале характерен интегральный, поистине вселенский масштаб, то религиозно-этический вектор псалма двенадцатого направлен в сторону сугубо человеческих проблем и переживаний. Это глубоко личностный монолог лирического субъекта, пронизанная душевной болью ламентация, смиренное моление. Псалмопевец обращается к Господу с просьбой о защите, укреплении силы духа перед лицом врага («Призри, услышь меня, Господи Боже мой! Просвети очи мои, да не усну я сном смертным»), высказывает свою веру в Него («да не скажет враг мой: [я одолел его]. Да не возрадуются гонители мои, если я поколеблюсь»). Вместе с тем - обратим внимание - он не удерживается от обращенных к Богу вопросов, окрашенных чувством обиды, или по крайней мере нескрываемого недоумения: «Доколе, Господи, будешь забывать меня вконец, доколе будешь скрывать лице Твое от меня? <...> Доколе врагу моему возноситься надо мною?» Молитвенный дискурс, как видим, перемежается живыми, «человеческими, слишком человеческими» реакциями. Стилистический контрапункт отражает скрытое эмоциональное напряжение, душевные борения личности, и это корреспондирует с тем трудным диалогом, который ведет с Богом Шевченко-лирик, мучительно стараясь найти решение одной из сложнейших в христианском учении проблемы - проблемы теодицеи, примирить свое безоговорочное приятие Господней благости со столь же безоговорочным неприятием зла на земле. Параллель подкрепляется включением в текст переложения отсутствующего в оригинале, но характерного для лирики Шевченко в целом мотива людской насмешки («все злые посмеются, / Коль упаду в руки, / В руки вражьи»), узнаваемых шевченковских образности и интонации («И воспою снова / Твои блага чистым сердцем, / Псалмом тихим, новым»).

Сопоставление двух псалмов первоисточника проясняет мотивацию выбора Шевченко между ними, поэт делает выбор в пользу того псал- 
ма, который ближе ему по содержанию, настроению, интонации, - двенадцатого.

Отмеченная тенденция прослеживается и в дальнейшем, становится сквозной и определяющей. Напряженный диалог с Богом получает в библейском цикле продолжение в псалме сорок третьем; здесь, как в двенадцатом, мотивы благодарности Господу и прославления Его («О Боге похвалимся всякий день, и имя Твое будем прославлять вовек»), верности Божией воле («Не отступило назад сердце наше, и стопы наши не уклонились от пути Твоего») сочетаются на контрапунктной основе с упреками («Но ныне Ты отринул и посрамил нас», «Ты отдал нас, как овец, на съедение и рассеял нас между народами», «Для чего скрываешь лице Твое, забываешь скорбь нашу и угнетение наше?»), более того, с довольно дерзкими призывами («Восстань, что спишь, Господи!»).

Мы убеждаемся, что переход Шевченко после двенадцатого псалма сразу к сорок третьему и в данном случае мотивирован и понятен.

Та же логика лежит в основе перехода от восемьдесят первого псалма к девяносто третьему, они коррелируют друг с другом мотивами социальной справедливости, милосердия («Давайте суд бедному и сироте; угнетенному и нищему оказывайте справедливость»), возмездия «гордым», которые «попирают народ Твой, Господи, угнетают наследие Твое; вдову и пришельца убивают, и сирот умерщвляют». Эту линию корреляции поэт проводит дальше, минуя сразу тридцать восемь псалмов первоисточника, сделав короткую остановку на теме братского единения в псалме сто тридцать втором («Как хорошо и как приятно жить братьям вместе!») и снова миновав еще три псалма, - к псалму сто тридцать пятому с присущим ему акцентом на теме «родина - чужбина», столь созвучной обстоятельствам жизни Шевченко («Если я забуду тебя, Иерусалим...»). Как именно, какими художественныии средствами реализуется в тексте эта созвучность, к каким приемам интерпретации прибегает автор переложения, об этом разговор пойдет ниже.

$* * *$

Что, собственно, произошло?

Самое очевидное - сокращение объема текста, из некоторой совокупности текстовых единиц автором переложения вычленена количественно иная совокупность. 
Можем ли мы, однако, считать эту операцию чисто количественной?

Два сравнения: I) некоторых выбранных Шевченко псалмов с теми, которые формально были «на очереди», но остались вне поля его внимания, и 2) особенностей выбранных псалмов с характерными чертами творчества поэта в целом, - склоняют к мысли, что в основе выбора лежали определенные мотивации. Иначе и быть не могло, ведь процесс поэтического переложения не механическое воспроизведение оригинала, в нем уже с самого начала в качестве активного фактора выступает авторская воля, проявляющаяся в мотивированном выборе компонентов (псалмов-первоисточников) - именно этих, а не других, что, вполне понятно, придает процессу субъективный, причем осознанный, целенаправленный характер. Корреляция содержания первоисточника с представлениями и взглядами поэта (как, например, в отмеченном выше примере парадигмального в его лирике трудного «диалога с Богом»), с актуальными для него в данный момент жизни религиозно-этическими и психологическими приоритетами, созвучность тональности, эмоциональной окрашенности псалма с личными переживаниями, душевным состоянием и настроением автора переложения, ощущение им близости для себя присущих библейскому псалмопевцу тех или иных способов и средств лирического выражения - этим факторам, думается, принадлежала решающая роль.

Происходит системное переформатирование первичного текстового материала, в результате чего некое количество выбранных поэтом и переложенных им псалмов обретает значение принципиально нового литературного феномена, обладающего выраженными структурно-семиотическими признаками, - «текста».

Стадии этого процесса прочерчиваются как причинно-следственная цепочка: выбор закономерно ведет к переформатированию текстового материала, переформатирование, в свою очередь, - к изменениям «отношений соседства» между компонентами. В Псалтыре-претексте эти отношения, как правило, не имеют четко выраженного характера, псалмы «соседствуют» и соотносятся между собой в рамках общего мотивно-тематического репертуара книги. Так, следом за псалмом двенадцатым идет тринадцатый, а мог бы - чисто теоретически - идти текстуально почти идентичный ему 
пятьдесят второй ${ }^{6}$. Иначе у Шевченко. Скажем, сближение в сформированном им цикле переложений псалма сорок третьего с двенадцатым или девяносто третьего с восемьдесят первым определено не сугубо формальным, сущностно нейтральным, «соседством», а содержательной близостью этих произведений между собой и обоих - с мыслями и чувствами поэта, т. е. отношения обретают семантическое наполнение и системный характер, выступают в функции структуро- и смыслообразующего фактора.

Это ключевой момент, в нем с наглядностью выступает различие между двумя понятиями - композицией, т. е. построением произведения, и структурой как системой связей между компонентами. В первом случае, применительно к Псалтырю, перед нами текст в профанном, прагматическом значении данного термина, это совокупность материально выраженных и зафиксированных на письме текстовых единиц. В этом смысле можно говорить о внешнем сходстве между оригиналом и его поэтическим переложением, поскольку шевченковский цикл как литературное произведение так же, как Псалтырь, реализуется в форме письменного текста, в чем проявляется его (впрочем, разве не любого художественного феномена?) амбивалентная природа лингвокоммуникативной ситуации, диалектика внутреннего пограничья между традиционным текстом и «текстом» как семиотической системой. Если библейский цикл - это совокупность текстов, коррелирующих между собою в общесемантическом поле, то в случае шевченковских «Псалмов Давида» речь идет о «тексте», о лишенной материальной субстанции, по сути, виртуальной, структуре, «структуре отношений», в которой средствами семиотической системы - языка - отражено и выражено восприятие первоисточника автором переложения и поэтическая интерпретация им этого первоисточника.

Можно решиться - с четким осознанием определенной (впрочем, думается, допустимой) меры условности - на немного рискованную трехсоставную параллель, сопоставив: а) библейский цикл псалмов как совокупность текстов c parole $\Phi$. де Сосюра - конкретным актом индивидуальной речи, b) «Псалмы Давида» Шевченко как «текст», модернизированную систему интертекстуальных отношений, с языком (langue), который, как и

6 Имеется в виду церковнославянская редакция, которой, напомню, вероятнее всего, пользовался Шевченко. В масоретской редакции это были, соответственно, псалмы тринадцатый и пятьдесят третий. 
«текст», не имеет физической формы воплощения, а представляет собой семиотическую систему, свод конвенций и правил, и с) обе пары между собой. Соотношение между библейским первоисточником и их переложением - «Псалмами Давида» - это процесс творческого взаимодействия, где в сложном переплетении предстают моменты сближения и дистанцирования, сродства и переосмысления; Ю. Лотман в этой связи говорит о «континууме», вмещающем в себя разные «семиотические пространства» [4, с. 586].

Движитель этого процесса, его ключевой структуро- и смыслообразуюший фактор - это, по определению У. Эко, «код говорящего» [7, с. 85]. Имеется в виду сформировавшаяся и достаточно выраженная система применяемых автором, в данном случае Шевченко в «Псалмах Давида», сближений и различий, которой он придерживается, в целях реализации своего замысла, неких исходных принципов в определении форм и меры дистанцирования от претекста (в данном случае - библейского, «прецедентного» текста) и вместе с тем сохранения коммуникационных связей с ним, более или менее четко очерченной общности духовно-культурной семиосферы.

Осуществленные уже на начальном этапе выборочность подхода автора переложения к компонентам первоисточника и его, первоисточника, переформатирование влекут за собой смену внутренних «отношений соседства», определяют противоречивый, двойственный характер связей между двумя объектами, а значит, актуализируют функции «кода говорящего» как регулятора этих связей. С одной стороны, сохраняется их коррелятивность как на когерентном уровне - по семантическим параметрам, по соотнесенности религиозно-этических рефлексий, психологических реакций, исторических мотивов, так и на уровне когезии, т. е. по сходству, нередко и прямой близости, отдельных элементов - образов, жанровых признаков, стилистических приемов и библейских оборотов (в последнем случае предметом специального рассмотрения должен быть языковой аспект), по дейктическому характеру упоминания в «Псалмах Давида» ряда знаковых топологических единиц сакрального пространства - локусов, хоронимов, урбанонимов («росы Ермонские», «Сионские горы», Вавилон, Израиль, Иерусалим), библейских имен (Иаков, Аарон), по нумерции псалмов-переложений, точно совпадающей с первоисточником. 
Не менее очевидна присутствующая в «Псалмах Давида» декогерентная тенденция, это примеры отступления от первоисточника, трансформации и переосмысления - в разных формах и с разной мерой выраженности - некоторых его компонентов как смыслового характера, так и относящихся к сфере поэтики. Совокупность таких отступлений обладает признаками системности, что проявляется в подчинении их определенным целям и критериям. Это и есть «код говорящего».

Важнейшая сфера его применения - язык переложения.

В шевченковском цикле вычленяется несколько языковых пластов, в которых отражаются различные способы выражения и функционирования «кода говорящего». Это, в частности: а) достаточно щедрое вкрапление в украинский текст лексических и фразеологических церковнославянизмов, а также лексем и конструкций старославянского типа («блаженний муж», «древо», «воспою», «вскую», «ізбави», «яко», «всує», «мя», «ніже», «хваленіє», «злая», «Господа глаголи», «яко в притчу», «міро добровонне», «врачуєш», «отмщениіє язикам»), порой с элементами трансформации в направлении приближения к украинским формам («оддав єси», «покивання головою», «дщере окаянна»), b) природные украинские словосочетания, близкие к устоявшимся фольклорно-поэтическим либо разговорным формам («ворог лютий», «тії літа», «той попіл», «серцем боліти», «слід пропадає», «жеруть», «добра доля», «ще лютіша», «неситі», «неслава», «добро певне», «не співають веселої», «серцем нелукавим» и др.) и с) стилистические обороты и выражения, корреспондируюшие по своей структуре и интонации с чертами стилистики, поэтической манеры и интонационного лада сочинений самого поэта, а нередко и текстуально перекликающиеся с характерными для него выражениями и образными формулами («псалмом тихим, новим», «нерозумні люди», «розіб’є неволю», «незлим моїм оком», «вдові убогій поможіте», «Твоя правда, / І воля, і слава», «Од віка до віка», «на чужому полі», «Окують царей неситих»).

Процесс декогеренции затрагивает не только язык «Псалмов Давида». Не забудем: Шевченко не переводит библейские псалмы, он их перелаzaem. Если сопоставим шевченковский цикл со сложившейся литературной практикой - как мировой, так и украинской - в этом жанре, то в условной шкале версий, в разной степени приближенных к претекстам или, наоборот, удаленных от них, переложения Шевченко тяготеют ко второй тенденции. 
Опираясь на заданный мотивный репертуар, находясь в кругу основных мотивов библейского первоисточника, сохраняя фабульно-сюжетные ситуации, элементы образной системы, устоявшиеся в библейской традиции сакральные и поэтические формулы, Шевченко вместе с тем не чувствует себя скованным в своем переложении. Одного только факта - перевода выбранных им текстов Псалтыря в стихотворный формат, преимущественно в I4-сложный, так называемый коломыйковый, стих ${ }^{7},-$ достаточно для того, чтобы говорить о коренной трансформации поэтики первоисточника. Ритмомелодика шевченковского стихотворного переложения, его интонационная гамма также не имеют ничего общего с оригиналом.

Перед нами совершенно иная по сравнению с библейским первоисточником поэтика, иная система структуризации текста, а в ряде случаев и иные - новые - смыслы.

$* * *$

Как было отмечено выше, авторское интерпретационное «вмешательство» в тексты первоисточника начинается уже на начальной стадии, с выбора объектов для переложения, оно становится фактором и критерием подхода к переформатированию составляющих библейской книги, определяя принципы переформатирования и его вектор. Далее этот вектор направляется в глубь текста(ов), в его семантическое пространство.

Происходит это не сразу. Первый шевченковский псалом («Не явится муж блаженный...») еще вполне созвучен соответствующему тексту Псалтыря. Семантическая близость к первоисточнику сохраняется в основных чертах и в общей направленности также в псалме двенадцатом («Ты ли меня, Боже милый...»), хотя тут уже появляются на уровне семантики некоторые отличные от первотекста элементы.

Румынский украинист Магдалена Ласло-Куцюк справедливо связывает эти элементы с субъективной позицией Шевченко - поэта-романтика, с его стремлением к «более драматическому звучанию произведения», повышению тонуса «эмоционального стиля». К числу изменений (отказ автора в переложении двенадцатого псалма от трехразового повтора слова «доколь», восклицательная интонация вместо вопросительной, высокая частотность

7 Версификационная форма, сложившаяся на основе украинского фольклорного жанра «співанки», напоминающей русскую частушку. 
употребления прилагательных, отсутствующих как в оригинале, так и в церковнославянском переводе) исследовательница относит введение поэтом в текст переложения отсутствующего в первоисточнике мотива издевательской насмешки со стороны «хитрого недруга», неких безымянных «злых» [2, с. 69, 72, 70]. Поэтическая мысль здесь «заземляется», переключается с плоскости духовного просветления личности, трактуемого псалмопевцем в сугубо религиозном ключе, в плоскость светского нравственного чувства, к тому же с достаточно выразительной переакцентуацией социального плана.

С этого места в двенадцатом шевченковском псалме берет начало проходящая через весь цикл - хотя, впрочем, дискретная - линия интерпретационного «вторжения» автора переложений в семантическое пространство прецедентных текстов. Прослеживаются главные направления, на которых действует «код говорящего»: социальное и историософское, или, точнее, историо- и нациософское, воплощенные в серии мотивных версий и их ответвлений; в этом же ряду стоят угадываемые в подтексте отзвуки биографических коллизий, личных и творческих проблем самого поэта.

Уже в следующем, сорок третьем, псалме («Про твою, всесильный Боже...») повторяется намеченный в псалме двенадцатом мотив вражеской насмешки, теперь в более жизненно-конкретизированном, чем в оригинале, общественном и личностном контексте («На заклание нас гонят, / Как овец!..», «Обмануты, замучены, / В путах умираем»), что придает концепту насмешки (а у Шевченко это именно концепт) социальную окрашенность.

Характерным примером целенаправленной «социализации» содержания первоисточника может служить переложение псалма восемьдесят первого («Меж царями-судиями...»). Надо заметить, что и в Псалтыре этот псалом, проникнутый пафосом осуждения неправедных судей, принадлежит к числу социально ориентированных, разумеется, в рамках библейских этических представлений и образной системы. Шевченко, сохраняя религиозный дух и общую гуманистическую направленность сакрального текста, вместе с тем прибегает к различным способам актуализации содержания, к выраженному усилению социальных моментов. В тексте переложения с очевидностью просматривается тенденция к существенно более четкому по сравнению с оригиналом - выявлению социального вектора: конкретизируются фигуры адресатов, к которым обращены гневные инвективы («цари-судьи», «земные владыки» вместо библейского «сонма богов»); 
определение «богатые», отсутствующее в оригинале, прямо указывает на тот общественный слой, которому помогает «суд неправый» (в первоисточнике действия судей охарактеризованы в общеморальном ключе: «...доколе будете вы судить неправедно и оказывать лицеприятие нечестивым?»); появляются выражения отчетливо актуального для шевченковского времени звучания: «развеять тьму неволи», «Цари, рабы - все равные / Сыны перед Богом». Недаром эти строки в первой публикации были изъяты цензурой.

Историософская линия в шевченковском цикле связана с интерпретацией ветхозаветного повествования о страданиях еврейского народа в плену и рабстве, зарождается она в псалме сорок третьем, перетекает в сто тридцать шестой («На потоках Вавилонских...») и там завершается. Шевченко удается, не теряя связи с первоисточником, оставаясь в рамках узнаваемого исторического сюжета, а в псалме сто тридцать шестом также фактологических «маркеров» - географических (Вавилон, Иерусалим) и этнических (едомляне), внести в нарратив такие штрихи, которые придают ему национально-историческую актуальность, вводят мысль читателя (достаточно подготовленного, разумеется) в русло украинской исторической проблематики.

Шевченко существенно переделывает вступительные строки сорок третьего псалма, выделяя тему героического подвига народа, при этом замена библейских отцовских заветов («отцы наши расказывали нам...») дедовскими («Нам рассказывают деды...») вносит в стилистику псалма краску, характерную для украинской поэтической традиции. И. Даниленко обращает внимание на внесенный в переложение сорок третьего псалма отсутствующий в первоисточнике мотив «нашего недруга нового», некой враждебной народу силы, которая «еще страшней», чем предшествовавшая ей, «первая»; исследовательница справедливо усматривает в этом прозрачный намек «на исторические реалии украинского бытия: на польско-шляхетское угнетение в прошлом и гнет Российской империи нынешнего времени» [2, c. I08]. С этим намеком коррелирует в переложении псалма сто тридцать шестого мотив издевательской насмешки, с которой «Едомляне злые» предлагают невольникам запеть песню - хотя бы свою, а лучше «нашу». В Библии речь в этом случае идет не об «едомлянах», а о «пленивших нас» вавилонянах, такая замена автором переложения носителей злой силы не может быть случайной. Если принять во внимание, что, согласно библейской исто- 
рии, едомляне были хотя и этническими родственниками израильтян, но одновременно их лютыми врагами, то шевченковская версия этого сюжета обретает характер скрытого историософского намека достаточно высокой степени актуальности ${ }^{8}$.

Еще два момента маркируют национально-историософскую составляющую шевченковского цикла.

Один из них - мотив Страха, точнее, трактовка этого мотива. В библейском оригинале псалма пятьдесят второго и сам страх, и возможность его преодоления целиком зависят от Бога («Там убоятся они [«делающие беззаконие». - Ю.Б.] страха, где нет страха, ибо рассыплет Бог кости ополчающихся против тебя»). Шевченко интерпретирует этот мотив в параметрах человеческой морали, с точки зрения социальных, психологических и в конечном счете нациологических критериев: «...Самих себя боятся / Лукавые люди». Слепой страх калечит человека, превращает его в покорного раба, калечит он и нацию (Шевченко дважды прибегает к форме первого лица множествнного числа: «нам», «восхвалим»), следствие его воздействия - паралич коллективной воли, неготовность людей к сопротивлению чужой злой силе, к действию, к борьбе. Этот мотив созвучен с мощной струей шевченковской национальной самокритики как предпосылки самоочищения нации, преодоления ею комплекса покорности.

Другой семантический «маркер» украинской составляющей - мотив Слова и художника-пророка, его божественного призвания и драматизма его судьбы. Проникнутый лиризмом и глубоким религиозным чувством пятьдесят третий псалом Шевченко относится к числу тех в его цикле, которые теснее всего коррелируют с первоисточником. Однако в строке пятой, в молитвенном обращении к Богу, у Шевченко появляется отсутствующая у псалмопевца грамматическая конструкция «внуши им», в результате сопоставление строк оригинала и переложения выглядит так: «Боже! услышь молитву мою, внемли словам уст моих» и «Молю, Господи, внуши им /

8 Из «Книги Бытия» узнаем, что едомляне (эдомитяне, идумеи) были потомками Исава, променявшего первородство на чечевичную похлебку. Пророк Авдий, предсказывая гибель народа Едома, в качестве одной из главных его провинностей называет то, что едомляне вместе с чужеземцами боролись против своих этнических братьев - потомков Иакова. «В тот день, когда ты стоял напротив, в тот день, когда чужие уводили войско его в плен и иноплеменники вошли в ворота его и бросали жребий о Иерусалиме, ты был как один из них» (Авдий г: ІІ). 
Уст моих глаголы» (курсив мой. - Ю.Б.). Злесь утверждается концепция Слова как богодухновенного оружия, проводника Божией воли и поэта как осознающего свою высокую миссию носителя этого Слова. В конкретном политическом, социальном, идеологическом, литературном контексте эта концепция обретает значение характерной и актуальной приметы национального бытия на определенном историческом этапе. Такой приметой стала в шевченковском творчестве и утвердилась в шевченковской традиции тема поэта, художника - Пророка и духовного лидера нации.

Итак, в процессе преобразования десяти отдельно взятых и, как может показаться на первый взгляд, разрозненных псалмов в структурированную идейно-художественную целостность вырисовываются три этапа:

a) целенаправленный выбор псалмов для переложения,

b) как результат этого выбора - переформатирование прецедентного текста, складывание новых «отношений соседства» между отобранными единицами текста,

c) осуществляемая на основе «кода говорящего» - объединенной общим смыслом совокупности различий, изменений, дополнений - поэтическая (пере)интерпретация первоисточника, охватывающая практически все уровни текста - семантический, языковой, образный, композиционный, жанровый.

Сопоставительный анализ примеров смысловых трансформаций в «Псалмах Давида» приводит к выводу о семантической близости и функциональной связанности между ними, что проявляется преимущественно имплицитно, в ассоциативном ключе. Эти примеры обретают характер и функции семиотических единиц - компонентов «кода говорящего» как знаковой системы, а преобраованный в результате его воздействия текст первоисточника - признаки «текста».

Если мы принимаем трактовку цикла переложений Шевченко «Псалмы Давида» как «текста», то должны признать амбивалентный характер ситуации: с одной стороны, этот «текст» находится в системно обозначенных границах, в определенной если не автономности, то во всяком случае выделенности, с другой - он предстает в связях и взимодействии с совокупностью таких внешних для «текста» и одновременно так или иначе соотно- 
симых с ним структур, как претекст и контекст, возможно также интертекст. Эту совокупность я обозначаю как «оff-текст».

\section{Претекст.}

В широком плане претекст «Псалмов Давида» - это Книга псалмов Ветхого Завета как духовная и литературная целостность, в плане прагматическом, «рабочем» - выбранные Шевченко из ста пятидесяти псалмов библейской Книги десять прецедентных текстовых единиц, положенных им в основу цикла своих переложений, который мы теперь определяем термином «текст».

\section{Контекст.}

Говоря о контексте, имеем в виду полиморфную и иерархическую совокупность фактов, явлений, тенденций, связанных с жизненными обстоятельствами и ситуациями, психологическими реакциями, с параметрами литературного, шире - духовного пространства, в котором возник и сформировался авторский замысел, осуществлялась его творческая реализация и в дальнейшем проходило функционирование «Псалмов Давида» в ходе историко-литературного процесса.

Над циклом «Псалмы Давида» работа шла осенью I845 г. Знаковые поэтические произведения этого периода - времени второй поездки Шевченко на Украину, его исключительно плодотворной «полтавской осени»9 - пронизаны библейскими ассоциациями, реминисценциями, прямыми цитатами и ссылками. В «Еретике» и «Подземелье» («Великий льох») эпиграфы из псалмов сто семнадцатого и сорок третьего, в «Кавказе» - из Книги пророка Иеремии, в послании «И мертвым, и живым...» - из Соборного послания Иоанна Богослова.

В пору «полтавской осени» эта парадигма максимально сближается с процессом нарастания в творчестве Шевченко революционной направленности. Обратим внимание: короткий временно́й отрезок (вторая половина октября - первая половина декабря I845 г.), когда были написаны «Еретик», «Подземелье» («Великий льох»), «Кавказ», «И мертвым, и живым...», «Холодный Яр», непосредственно предшествует этапу завершения «Псал-

9 Сочинения I845 г., помеченные в автографах октябрем / ноябрем - первой половиной декабря, связаны с полтавским топологическим пространством - Миргород, Переяслав (в то время уездный город Полтавской губернии), села Марьинское, Вьюнище. 
мов Давида», а частично («Холодный Яр») совпадает с ним. Вряд ли этого достаточно для нередко высказывавшейся, особенно в советском шевченковедении, преувеличенной оценки революционного начала, якобы закамуфлированного в «Псалмах Давида» библейской образно-стилистической «атрибутикой», однако фактом, с которым нельзя не считаться, остается то, что именно наиболее бунтарские сочинения Шевченко составляют литературный фон - впрочем, нет, не фон, а контекст «Псалмов Давида», причем контекст не только литературный, но и духовно-нравственный, психологический, «настроенческий». В синхроническом срезе творчества периода «полтавской осени» категории «текста» и контекста применительно к «Псалмам Давида» находятся в диалектическом сочетании.

Сказанное относится и к диахроническому уровню - рассмотрению «Псалмов Давида» в развернутом историко-литературном контексте, как ретроспективном, так и перспективном. Здесь цикл предстает, с одной стороны, как компонент и завершающее звено в западно- и восточнославянской традиции литературной актуализации псалмов (поляк Я. Кохановский, украинцы Лазарь Баранович и Григорий Сковорода, белорусы Франциск Скорина и воспитанник Киевской академии Симеон Полоцкий), с другой - как инспирирующий фактор на послешевченковском и новейшем этапах вариативного, сопровождаемого трансформационными и модификационными процессами, развития этой традиции в украинской литератуpe (П. Кулиш, М. Максимович, И. Франко, О.Ю. Федькович, Б.И. Антонич, П. Тычина, Е. Маланюк, Лина Костенко, Д. Павлычко $\left.{ }^{\mathrm{Io}}\right)$. «Псалмы Давида» Шевченко, первое поэтическое переложение сакральных текстов живым украинским литературным языком (ранее написанные «Псалмы Руслановы» М. Шашкевича были скорее фактом стилизации, к тому же прозаической, чем творческого освоения этих текстов), содержали большой инспирационный потенциал, в частности (и особенно) в утверждении креативных возможностей украинского языка ${ }^{\text {II }}$

Iо Интересный материал для компаративистских штудий дают, например, три версии переложения первого псалма («Блажен муж...) - Т. Шевченко, И. Франко и Лины Костенко. II Этот момент подчеркивает П. Кулиш в письме к М. Костомарову от 26 июня I848 г. Полемизируя с адресатом, считавшим, что украинский язык подходит лишь для написания «мужицких повестей», Кулиш пишет: «Но у вас перед глазами Шевченко, который выражает на этом языке и псалмы Давида, и чувства, достойные уст самого высшего общества..» [4, c. 88]. 


\section{Интертекст.}

Этот термин в 6о-е гг. прошлого века «отпочковывается» от концепции интертекстуальности, которая возникла и получила распространение в рамках французской семиотики, в среде писателей и интеллектуалов, объединившихся вокруг журнала «Тель Кель» (франц. Tel Quel - «такой, какой есть»). Концепция была направлена на обоснование и осмысление опыта постмодернистских течений в искусстве с применением постструктуралистских формул типа «литература как игра», творческий процесс как «письмо» (или как процедура [ре]генерирования текстов), «смерть автора», автор как «скриптор» и т. п. Практика научных исследований свидетельствует, что принцип интертекстуальности может служить полезным (дополнительным) инструментом анализа не только фактов постмодернистской культуры, но и - в определенных границах и, главное, при условии строгого соблюдения методологической и терминологической корректности - некоторых художественных явлений, принадлежащих другим эпохам, другим национальным традициям, другим эстетическим направлениям и школам. Хотя при этом речь идет в первую очередь о таких явлениях и системах, для которых характерны - в качестве структурных принципов - высокая степень нормативности, повторяемости устоявшихся элементов и приемов (например, фольклор, средневековая литература, особенно чисто религиозные ее ответвления, традиционная поэзия Востока, поэтика классицизма и барокко); впрочем, инструментарий интертекстуальности бывает нелишним и при исследовании более поздних и более сложных художественных структур, во всяком случае некоторых их аспектов и компонентов.

С этой точки зрения нельзя не признать небезосновательным момент «искушения интертекстуальностью» при анализе шевченковских «Псалмов Давида», поскольку процесс выбора фрагментов претекста, его переформатирования и интерпретации естественным образом сопровождается использованием определенного количества так или иначе связанных с первоисточником текстовых элементов - прямых и косвенных ссылок, парафраз, аллюзий и т. п. Однако поддаваться этому «искушению» следует с осторожностью, со скрупулезным соблюдением методологических разделительных линий; масштаб и структурно-семантическую значимость подобных элементов вряд ли стоит преувеличивать. Что касается 
украинских переложений библейских псалмов Давида, то, кроме того, что они отгорожены от первоисточника по крайней мере тремя языковыми кордонами (древнееврейский / греческий / церковнославянский), существуют еще такие сдерживающие «интертекстуальную экспансию» факторы, как символический код языка, через призму которого национальное сознание воспринимет и преломляет универсальные истины и приобщается к ним, и во всех случаях глубоко субъективный «код говорящего» автора переложения, которым («кодом») определяются и обозначаются принципиальные смысловые различия между «Псалмами Давида» Шевченко и ветхозаветной Книгой псалмов, так что говорить об интертекстуальности шевченковского цикла можно скорее в ключе условном, метафорическом, нежели в строго терминологическом.

Более перспективной в методологическом плане, более адекватной сути ситуации сопоставления двух текстов («текста» и претекста) и сложной системы возникающих при таком сопоставлении текстуальных, эстетических, семантических, идеологических соотношений, или «резонансов», как их называет американский исследователь Д. Клигингер [3, с. І7о, ст. II], представляется бахтинская концепция диалогизма и «чужого слова». В свете этой концепции отношения между шевченковскими «Псалмами Давида» и библейским первоисточником могут быть определены как диалог сознаний и высказываний, за которыми стоят «говорящие» - субъекты речи, личности, каждая со своим «кодом», с неповторимой (и в то же время типичной) судьбой, с особенным (и в то же время отмеченным унверсальными чертами) историческим и социальным опытом, а не, по Ю. Кристевой, «мозаикой цитаций».

Диалоговый подход дает ориентир для решения некоторых сложных вопросов, касающихся структурно-семантической природы шевченковского цикла и его связей с Книгой псалмов Давида. Таковы, например, соотношение между сакральным текстом и его преобразованной в поэтический «текст» версией, степень и формы сохранения - в мировоззренческом и эмоциональном диалоге интерпретаций - присущих первоисточнику всепроникающей религиозности, богодухновенное начало и его сочетание со смелым, порою на грани литературной дерзости, внесением в текст переложений сугубо личностной струи, шире - момента творческого обновления. 
Свою заключительную мысль сформулирую следующим образом: если Книга псалмов - это сакральный текст с литературной составляющей, то созданные на ее основе «Псалмы Давида» Шевченко - поэтический «текст» с сакральной составляющей. «Псалмы Давида» как произведение и «Псалмы Давида» как «текст» - это один и тот же духовно-литературный феномен или, можно и так сказать, две его ипостаси. 


\section{Список литературы}

I Головащенко С. «Українська Псалтир» М.О. Максимовича як феномен європейської біблеїстики. Кілька запитань до тексту. URL: http://www.religion.in.ua/main/ history/9340-ukrayinska-psaltir-mo-maksimovicha-yak-fenomen-yevropejskoyibibleyistiki-kilka-zapitan-do-tekstu.html (дата обращения: І2.I2.20І6). Даниленко $\dot{I}$. Молитва як літературний жанр: генеза та еволюція. Миколаїв: Вид-во МДГУ ім. Петра Могили, 2008. 304 с.

3 Клігінгер Д. Інтертекстуальність // Енциклопедія постмодернізму. За редакцією Чарлза Е. Вінквіста та Віктора Е. Тейлора. Переклав з англ. В. Шовкун. Київ, 2003. Куліш П. Повне зібрання творів. Листи. К.: Критика, 2005. Т. I: I84I-I850 / Упоряд., комент. О. Федорук; підгот. текстів О. Федорука, Н. Хохлової; відп. ред. С. Захаркін. 648 с.

5 Ласло-Куцьюк М. Велика традиція. Українська класична література в порівняльному висвітленні. Бухарест, І979. 288 с.

6 Лотман Ю. Текст у тексті // Слово. Знак. Дискурс. Антологія світової літературно-критичної думки XX ст. Львів, 2002. С. 428-442.

7 Эко У. Отсутствующая структура. Введение в семиологию. СПб.: ТОО ТК «Петрополис», I998. 432 c. 


\section{References}

I Golovashhenko S. "Ukrai'ns'ka Psaltyr" M.O. Maksimovycha jakfenomen jevropejs'koi" biblei'styky. Kil'ka zapytan' do tekstu [Ukrainian Psalms by M.O. Maksimovych as a phenomenon of the European library]. Available at: http://www.religion.in.ua/main/ history/9340-ukrayinska-psaltir-mo-maksimovicha-yak-fenomen-yevropejskoyibibleyistiki-kilka-zapitan-do-tekstu.html (Accessed I2 December 20I6). (In Ukrainian)

2 Danylenko I. Molytva jak literaturnyj zhanr: g'eneza ta evoljucija [Prayer as literary genre: genesis and evolution]. Nikolaev, MDGU im. Petra Mogyly Publ., 2008. 304 p. (In Ukrainian)

3 Klig'ing'er D. Intertekstual'nist' [Intextuality]. Encyklopedija postmodernizmu [Postmodernist encyclopedia], ed. E. Charlza, Winquist and V.E. Tailor, trans. V. Shovkun. Kiev, 2003. (In Ukrainian)

4 Kulish P. Povne zibrannja tvoriv. Lysty [Complete collection of works. Letters]. Kiev, Krytyka Publ., 2005. Vol. I: I84I-I850, comment O. Fedoruk; preparation of text O. Fedoruka, N. Hohlovoi', ed. S. Zaharkin. 648 p. (In Ukrainian) Laslo-Kucjuk M. Velyka tradycija. Ukrai'ns'ka klasychna literatura v porivnjal'nomu vysvitlenni [Great tradition. Ukrainian classical literature in the comparative light]. Bucharest, I979. 288 p. (In Ukrainian)

6 Lotman Ju. Tekst u teksti [Text in the text]. Slovo. Znak. Dyskurs. Antologija svitovoi' literaturno-krytychnoi' dumky XX st. [Word. Sign. Discourse. Anthology of world literary criticism of the $20^{\text {th }}$ century]. L'viv, 2002, pp. 428-442. (In Ukrainian)

$7 \quad$ Эco U. Otsutstvujushhaja struktura. Vvedenye v semyologyju [Missing Structure. Introduction into Semiology]. St. Petersburg, Petropolys Publ., I998. 432 p. (In Russ.) 
УДК 398

ББК $82.3(2 \mathrm{Poc}=\mathrm{Pyc})$

\section{«МОЛИТВА АРХАНГЕЛУ МИХАИЛУ» И «СОН БОГОРОДИЦЫ» В ЗАПИСЯХ П.Г.БОГАТЫРЕВА (ПО АРХИВНЫМ ИСТОЧНИКАМ)}
(C) 2017 г. Е.А. Самоделова
Институт мировой литературы
им. А.М. Горького Российской академии наук, Москва, Россия
Дата поступления статьи: І8 апреля 2017 г. Дата публикации: 25 сентября 2017 г.

DOI: IO.22455/2500-4247-20I7-2-3-274-299

Аннотация: Впервые публикуются и анализируются «Сон Богородицы» и «Молитва архангелу Михаилу», записанные П.Г. Богатыревым в 1914-1915 гг. в с. Бавыкино Серпуховского у. Московской губ. Процитированы большие фрагменты докладов Богатырева, касающиеся собранных произведений духовного фольклора. Приведены протоколы заседаний Комиссии по народной словесности Общества любителей естествознания, антропологии и этнографии (ОЛЕАЭ), посвященные докладам П.Г. Богатырева об апокрифах и других результатах фольклорных экспедиций тех лет. Богатырев решал научную задачу: доказать, что в селениях вблизи крупных промышленных центров в начале XX в. сохранился традиционный фольклор. Будучи студентом Московского университета, уже в первой своей экспедиции он записал на диалекте произведения почти всего фольклорного комплекса. Ценными являются произведения духовного фольклора, которые восходят к книжным и богослужебным источникам, существуют в устной и письменной форме. При подготовке к научным докладам о совершенной экспедиции Богатырев выявил корпус опубликованных аналогичных произведений и сопоставил с ними свои фольклорные находки, изучил исследовательскую литературу и сделал собственные выводы.

Ключевые слова: П.Г. Богатырев, экспедиции, Московская губерния, Серпуховской уезд, апокрифическая молитва, «Сон Богородицы», Комиссия по народной словесности Общества любителей естествознания, антропологии и этнографии, Московский лингвистический кружок.

Информация об авторе: Елена Александровна Самоделова - доктор филологических наук, старший научный сотрудник, Институт мировой литературы им. А.М. Горького Российской академии наук, ул. Поварская, д. 25 а, І2І069 Москва, Россия.

E-mail: helsa@rambler.ru 


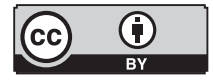

This is an open access article distributed under the Creative Commons Attribution 4.0 International (CC BY 4.0)
"PRAYER TO THE ARCHANGEL MICHAEL" AND "THE DREAM OF OUR LADY" IN THE RECORDS OF PETR G. BOGATIREV (ON THE ARCHIVAL MATERIALS)

\author{
(C) 20I7. E.A. Samodelova \\ A.M. Gorky Institute of World Literature \\ of the Russian Academy of Sciences, Moscow, Russia \\ Received: April I8, 2017 \\ Date of publication: September 25, 2017
}

\begin{abstract}
This is the first publication of "The Dream of Our Lady" and "The Prayer to Archangel Michael," two pieces recorded by Petr G. Bogatirev in I9I4-I9I5 in the village Bavykino of the Moscow region with a commentary. The publication contains extensive passages from Bogatirev's presentations on collected works of spiritual folklore and proceedings of the meetings of the Society of Lovers of Natural Science, Anthropology and Ethnography (OLEAE) dedicated to Bogatirev's lectures about apocrypha and other results of his folklore expeditions. Bogatirev attempted to prove that at the beginning of the $20^{\text {th }}$ Century, traditional folklore was still preserved in the settlements near large industrial centers. Already during his first expedition as a student of Moscow University, he recorded the work of the entire folklore complex in dialect. His valuable works on spiritual folklore bearing on book and church sources exist both in verbal and written form. While preparing presentations about his expeditions, Bogatirev pointed out a corpus of already published analogical works and compared it with his own folklore discoveries, analyzed previous research on the subject and made his own conclusions.
\end{abstract}

Keywords: Petr G. Bogatirev, expeditions, Moscow region, Serpukhov district, apocryphal prayer, "The Dream of Our Lady," Commission of the Society of Lovers of Natural Science, Anthropology and Ethnography, Moscow linguistic group.

Information about the author: Elena A. Samodelova, DSc of Philology, Senior Researcher, A.M. Gorky Institute of World Literature of the Russian Academy of Sciences, Povarskaya 25 a, I21069 Moscow, Russia.

E-mail: helsa@rambler.ru 
Петр Григорьевич Богатырев (I893-1971) - известный славист, специалист в области этнографии и фольклора западных и южных славян; доктор филологических наук (I943), переводчик «Похождений бравого солдата Швейка во время мировой войны» Я. Гашека.

Уже будучи студентом Московского университета, П.Г. Богатырев являлся активным членом Общества любителей естествознания, антропологии и этнографии (ОЛЕАЭ), слушал на его заседаниях доклады Ю.М. Соколова по фольклору и ездил в фольклорно-диалектологические экспедиции - как самостоятельно, так и в компании с Р.О. Якобсоном и Н.Ф. Яковлевым (в частности, в Верейский уезд Московской губ. летом І9І5 г.) (ГЛМ. ФА. Инв. № 23. П. г. Л. 46).

Экспедиция в с. Бавыкино Серпуховского у. Московской губ., вероятно, стала первой полевой работой начинающего фольклориста. Туда П.Г. Богатырев ездил дважды: на Пасхальной неделе (Светлая седмица в I9I4 г. пришлась на 6-І2 апреля) и летом того же года.

2I апреля I9I4 г. в ОЛЕАЭ состоялось заседание Комиссии по народной словесности под председательством Владимира Александровича Гордлевского. В протоколе секретарь Е.Н. Елеонская отметила: «К следующему заседанию доклад обещал приготовить П.Г. Богатырев» (ГЛМ. ФА. Инв. № 23/г. Ед. хр. г. Протокол ХХ. № 28. Л. 35 - Протоколы Комиссии по народной словесности при этнографическом отделе ОЛЕАЭ. I9II-I9I6. Рукоп.).

В протоколе следующего заседания ОЛЕАЭ сообщалось о докладе Богатырева: 
I6-го мая I9I4 г. состоялось заседание Комиссии по народной словесности, под председательством В.А. Гордлевского. Присутствовали члены Комиссии М.С. Абрамова и Б.С. Абрамов, П.Г. Богатырев, Н.В. Васильев, И.Ф. Голубев, Г.Г. Дингес, Е.А. Рябков, А.С. Якуб и секретарь Е.Н. Елеонская. По прочтении и утверждении был подписан протокол предыдущего заседания. Затем П.Г. Богатырев сообщил результаты своих наблюдений в Серпуховском у. в селе Бавыкине. П.Г. Богатырев имел возможность ознакомиться с певцами и сказочниками этого селения, от которых им и были записаны сказки и песни, прибаутки и детские щиталки <считалки>. Сказки, записанные П.Г. Богатыревым, представляют собою параллели ко многим сказкам, заключающимся в сборнике А.Н. Афанасьева, причем на них весьма заметен современный налет, выражающийся в различных подробностях. Песни, записанные П.Г. Богатыревым, разнообразны и позволяют убедиться в том, что народная поэзия еще не иссякла. Между прочим, П.Г. Богатырев упомянул о некоторых суевериях описываемой им местности; интересные сведения о знахарях и случаях порчи дал М.М. Щеголихин, живущий в Бавыкине и хорошо знающий местных жителей. По поводу сведений, сообщенных П.Г. Богатыревым, некоторые из членов Комиссии обменялись мнениями и председатель, поблагодарив докладчика, выразил ему пожелание дальнейшей плодотворной работы.

Секретарь Е.Н. Елеонская доложила собранию, что печатание библиографического указателя идет к концу, а печатание сборника несколько замедляется, но что летом типография обещает ускорить работу.

Заседание закончилось обещаниями членов приготовить к осени материал для обсуждений в Комиссии.

Председатель Вл. Гордлевский.

Члены: Богатырев, Г. Дингес, Б. Абрамов, Н. Васильев, М. Абрамова, А. Якуб, А. Глазов.

Секретарь Елена Елеонская

(ГЛМ. ФА. Инв. № 23/г. Ед. хр. І. Протокол ХХІ. № 29. Л. 36-36 об. Протоколы Комиссии по народной словесности...).

Из надписи на фиолетовом штампе известен адрес проведения заседания: «Комиссия по народной словесности при Этнографическом отделе ИОЛЕАЭ. Москва, Политехнический музей» (ГЛМ. ФА. Инв. №23/ı. 
Ед. хр. г. Протокол XXI. № 29. П. г. Л. 36 - Протоколы Комиссии по народной словесности...).

Следующее заседание ОЛЕАЭ - № 30 - произошло через пять месяцев и было отражено в протоколе:

I6-го октября I9I4 г. состоялось заседание Комиссии по народной словесности под председательством председателя Комиссии В.А. Гордлевского. Присутствовали члены Комиссии Б.С. Абрамов, М.С. Абрамова, П.Г. Богатырев, Н.В. Васильев, Алн. Вас. Глазов, Г.Г. Дингес, А.В. Позднеев, Н.Ф. Яковлев, А.С. Якуб, Е.Г. Богатырева, Н.В. Сорокина, И.Е. Лахерма, при секретаре Е.Н. Елеонской.

Был прочтен, утвержден и подписан протокол предыдущего заседания. Н.В. Васильев сделал сообщение о академике Ф.Ф. Фортунатове, скончавшемся <оставлен пропуск для даты $>^{\mathrm{I}}$

(ГЛМ. ФА. Инв. № 23/г. Ед. хр. г. Протокол XXII. № 30. П. І. Л. 37 Протоколы Комиссии по народной словесности...).

Потом речь пошла о собирательской работе Богатырева в с. Бавыкино:

Затем председатель обратил внимание присутствовавших на важность начатого Комиссией дела - собирания произведений народной словесности в Московской губернии, на трудности, сопряженные с этим собиранием, и на то, что настоящие обстоятельства ${ }^{2}$ значительно препятствуют этой работе, и что материал, собранный летом, доказывает, что в Московской губернии можно будет усиленно вести записи.

П.Г. Богатырев, собиравший произведения народной словесности в с. Бавыкине Серпух<овского > у., сделал сообщение о своих записях. Им был записан целый ряд песен, несколько заговоров и сказок. П.Г. сделал интересные наблюдения над сказочниками с. Бавыкина, из которых некоторые отличаются умением передавать сказки. Запись заговоров была сопряжена с некоторыми трудностями, т. к. знавшие их лица не хотели сообщать их

I Ф.Ф. Фортунатов (I848-I9I4), российский лингвист, основатель московской лингвистической школы, скончался 20 сентября І9І4 г. в д. Косалма под г. Петрозаводск.

2 Имеется в виду недавно начавшаяся Первая мировая война. 
собирателю, но тем не менее П.Г. Богатырев достал рукописные заговоры, которые, по сверке их с заговорами разных сборников, оказались довольно распространенными. Между ними был «Сон Богородицы».

Сообщение П.Г. Богатырева возбудило обмен мнений среди присутствовавших; записи П.Г. будут им приведены в порядок и войдут в предполагаемый сборник Московской губ.

(ГЛМ. ФА. Инв. № 23. Ед. хр. г. Протокол ХХІІ. № 30. П. І. Л. 37-38 Протоколы Комиссии по народной словесности...).

Публикация этого сборника не состоялась до сих пор.

В подготовительных материалах І9І5 г. к одному из докладов Богатырев назвал весенне-летний экспедиционный период: «Весь материал по народной словесности, помещенный здесь и состоящий из сказок, заговоров, загадок и песен, собран мною на Пасхальной неделе, а также в июне, июле и половине августа І9I4 года в одном селе Бавыкине Серпуховского уезда Московской губернии» (ГЛМ. Ф. 392 - фонд П.Г. Богатырева. Ед. хр. 90. Л. II7).

В «Матерьялах для curriculum vitae П.Г. Богатырева», подготовленных для Московского лингвистического кружка не ранее г9г9 г., он отметил первую свою поездку в с. Бавыкино: «Род. І893 г. 2-ая Саратовская гимназия, затем поступил на историко-филол<огический> факультет Московского университета. Со второго курса совершил ряд этнографических экспедиций. В I9I4 г. ездил в Серпуховской у. Московской губ. Собрал около 5о сказок, 20 песен, загадки, заговоры и т. д.» [9, с. І38; ИРЯ РАН. РО. Ф. 2 О. Ед. хр. г6. Л. 403].

Имеются сведения, что Богатырев посещал с. Бавыкино и в I9I5 г.

Во-первых, в материалах І9І5 г. к одному из своих докладов П.Г. Богатырев отмечал: «Все это лето, т. е. месяца июнь, июль и половину августа я провел в селе Бавыкине Серпух<овского> уезда, где собирал народные произведения. Я уже в прошлом году \{в своем докладе\} останавливался на местности и населении Бавыкина. Теперь только напомню, что мужское население в Бавыкине незначительно, т. к. все почти мужчины \{живут в Москве, где\} занимаются различными ремеслами, поэтому, естественно, большая часть моего матерьяла записана от женщин. Весь матерьял, собранный мною, состоит из песен хороводных, величальных, игровых, сатирических 
и частушек, затем сказок, загадок, заговоров и причитаний»3 (ГЛМ. Ф. 392. Ед. хр. 90. Л. ІІІ).

Заметим, что в разных письменных фиксациях (в полевых тетрадях и позднейших перебеленных записях) П.Г. Богатырев относил свою работу в с. Бавыкино к июню, июлю и половине августа I9I4 или I9I5 г. То ли эта путаница произошла в связи с многократным переписыванием тезисов доклада, основанных на экспедиционных заметках, то ли Богатырев действительно в течение двух лет весь летний сезон проводил в с. Бавыкино или хотя бы наездами бывал там в I9I4 и І9І5 гг.

Во-вторых, из неопубликованного «Отзыва о фольклорных материалах из Серпуховск<ого> уезда, доставленных П.Г. Богатыревым» II июля І9І9 г. Ю.М. Соколова следует, что Богатырев возвращался в с. Бавыкино на следующий год, потому что профессор указывает І9І5 г. как время записи сказки «Солдат и государь» и подчеркивает особенности предреволюционного времени, отраженные в тексте. Экспедиционная деятельность П.Г. Богатырева в І9г5 г. велась и в другом уезде Подмосковья - в Верейском (в конце мая - июне, совместно с Р.О. Якобсоном и Н.Ф. Яковлевым) [20, с. Iо4].

Журнал «Этнографическое обозрение» (І9І5, № 3/4) в разделе «Хроника. Отчет о деятельности Этнографического отдела ИОЛЕАиЭ и состоящих при Отделе Музыкально-этнографической комиссии и Комиссии по народной словесности за I9I4-I9I5 академический год» упомянул один из докладов П.Г. Богатырева:

В отчетном году работа Комиссии заключалась в собирании произведений народной словесности в Московской губернии... <... Было прочитано одиннадцать рефератов. <...>

2. П.Г. Богатырев: Запись произведений народной словесности в с. Бавыкине, Серпуховского уезда [І9, с. I47-I48].

В ГЛМ хранятся «Серпуховские материалы» Богатырева: это импровизированная обложка, сооруженная из согнутого почти пополам машинописного листа, с расчерченными простым карандашом четырьмя ли-

3 Здесь и далее в фигурных скобках \{\} содержатся текстовые вставки, сделанные П.Г. Богатыревым поверх строки, в квадратных скобках [] - его вычеркивания, в угловых скобках $<>-$ наши уточнения. - E.C. 
нейками и надписью-заглавием, выполненным чертежным шрифтом тем же карандашом. В обложку вложены остальные бумаги - отдельные листы из школьной тетради в линейку (кроме двух двойных листов и вложенного отдельного листа).

Среди «Серпуховских материалов», которые легли в основу прочитанных в ОЛЕАЭ докладов, содержатся фрагменты под № III и IV, повествующие о копировании Богатыревым в экспедиции старинных апокрифических текстов:

\section{III}

Кроме этих заговоров, записанных со слов хранителей их, я нашел в Бавыкине тетрадь в осьму\{ю\} листа, где были написаны 3 апокрифа: Богородицын сон, апокриф, известный под названием Ерусалимское письмо и «О I2-ти пятницах». Хранение, чтение и списывание апокрифа Сон Богородицы, так же, как и заговоры, избавляет [и] от болезней, пожара и других несчастий. [Сле] Апокрифы эти я сравнивал с собраниями Тихонравова «Памятники отреченной русской литературы», Лавров<а> «Апокрифические тексты», Кушелева-Безбородко «Памятники старой русской литературы», Виноградова и Порфирьева. В общем, конечно, апокрифы, записанные в тетрадке, сходны с напечатанными, но есть небезынтересные частности, которые я сейчас отмечу. Так, в апокрифе «Богородицын сон» я не нашел нигде в просмотренных мною напечатанных апокрифах моление в Гефсиманском саду.

В апокрифе, известном в напечатанных сборниках под названием «Ерусалимское письмо», $\{\mathrm{I})<\mathrm{I}>\}$ иное начало, $\{2)<\mathrm{II}>\}$ не встречается о замене субботы воскресением, \{3) <III>\} о молитве к Архангелу и \{4) $<$ IV>\} причины, почему не следует ругаться матерно, $\{5)<\mathrm{V}>\}$ из грехов встречается грех мескороватите ${ }^{4}$.

IV

В апокрифе «О І2-ти пятницах», мною найденном, есть обещание избавления от «рематизенной» боли, чего нет в печатных апокрифах. Пятницы нередко заменяются другими, чем это мы находим в печатных сборниках, как меняются и блага, обещающиег за проведенную в посте пятницу.

4 Очевидно, Богатырев написал кириллицей иностранное название греха, причем сначала указал - «мескороватися», потом последние две буквы слова он исправил.

5 Должно быть: обещаемые. 
[(Писал все эти апокрифы очень безграмотный)]

Написаны эти апокрифы очень безграмотно, так что иногда невозможно понять смысл некоторых мест. [Запись эта представляет \{известный\} интерес, как показатель тех ошибок, какие делает акающий безграмотный писец. Например, часто можно встретить «коко» вместо «како».]

(ГЛМ. Инв. № 392. Ед. хр. 90. Л. ІІ3-ІІІ4).

П.Г. Богатырев сравнил со своим текстом один из вариантов «Иерусалимского свитка» начала XIX в. из издания Н.Н. Виноградова [5, с. I9, № 25]. К сожалению, местонахождение скопированных Богатыревым списков апокрифов «Ерусалимское письмо» и «О І2-ти пятницах» нам неизвестно.

Вероятно, именно с. Бавыкино и находящаяся рядом Давыдово-Вознесенская мужская пустынь (как единая административно-территориальная единица) упомянуты в выписке из вкладной книги Солотчинского Рождества Богородицы женского монастыря в связи с рязанским князем Федором Олеговичем, отец которого великий князь Олег Иванович Рязанский основал обитель на высоком берегу реки Старицы (Оки), при впадении в неё р. Солотчи: «<...> князь великий Федор Олгович придал в Дом Пречистыя Богородицы на Солотчу Бовыкинскую пустошь с Якушевскою дубровою, з бортными угожьи и з бобровыми ловлями и с рыбною ловлею по Паре реке <...> [15, c. 35-36]. Показательно, что угодья отстояли за полтораста верст от Солотчинского монастыря, но находились южнее, были богатыми и плодоносными, за что и ценились.

В начале XX в. село (деревня - по др. данным) Бавыкино было крупным населенным пунктом и являлось центром Бавыкинской волости, относившейся ко второму стану по административно-территориальному делению; ближайшая железнодорожная станция - Лопасня Московско-Курской железной дороги. В І9I4 г. волостным старшиной в с. Бавыкино был И.П. Гуров, волостным писарем - крестьянин А.Т. Ескин [ІІ, с. 398].

В I9I4 г. в с. Бавыкино имелось Трудовое сельскохозяйственное общество крестьян Бавыкинской волости (председатель С.В. Жигулев) единственное в Серпуховском уезде [ІІ, с. 382].

Чуть раньше, в г9І2 г., при с. Бавыкино числился известковый завод Ивана Пантелеевича Гурова, на котором трудилось І2 мужчин; создан 
в I890 г.; имел почтовый адрес: ст. Лопасня Московско-Курской железной дороги (своего почтового отделения в селе не было) [Іо, с. І8о]. В «Памятной книжке Московской губернии на I9I4 год» этот завод не значится, а его хозяин к тому времени стал волостным старшиной.

Ныне с. Бавыкино относится к Чеховскому р-ну Московской обл., находится в 55 км от Московской кольцевой автодороги (МКАД) по Симферопольскому шоссе.

Неизвестно, почему П.Г. Богатырев избрал с. Бавыкино местом базирования своей фольклорно-диалектологической экспедиции: ведь Московская губ. обширна! Интересно, что неподалеку находится с. Мелехово с усадьбой А.П. Чехова (1860-I904) - драматурга, а Богатырев очень любил театр и впоследствии изучал народную драму славян.

Записи П.Г. Богатырева сделаны на отдельных линованных и нелинованных листках (некоторые из них с оборванными краями), а также в тонких и общих школьных тетрадях в линейку; они находятся в двух московских государственных архивах - РГАЛИ и ГЛМ - и представляют собой черновики и чистовики соответственно, причем выполненные в разное время - в период с I9I4 по І9І9 гг. Можно выделить два этапа составления рукописей: I) I9I4-I9I5 гг., непосредственно в полевых условиях; 2) І9І9 г., в Саратовский период Богатырев переписывал экспедиционные материалы набело для передачи их в архив, а в идеале - для подготовки книги.

В І9І8 г. П.Г. Богатырев окончил Московский университет, недолго работал в Наркомпросе и в г9І9 г. стал ассистентом кафедры русской литературы Саратовского университета, возглавляемой молодым профессором из Москвы Б.М. Соколовым.

Можно предположить, что П.Г. Богатырев переписывал экспедиционные тексты набело для сдачи их в архив Губернского совета депутатов (Губсовдепа): на такую мысль наводит «Отзыв...» Ю.М. Соколова от ІІ июля I9I9 г. с упоминанием этого учреждения. Дополнительным, хотя и косвенным, доказательством служит, возможно, наиболее полное копирование почти без автоцензуры. И все-таки автоцензура была: оказались пропущенными описания физиологических отправлений персонажей, игравшие важную сюжетную роль в сказочных концовках. Между тем П.Г. Богатырев переписывал полевые материалы набело, по-прежнему используя букву «ять», отмененную реформой орфографии г9І8 г. 
К сожалению, ситуация с архивом Губсовдепа нам неизвестна: был ли создан этот архив или только предполагался? Во всяком случае материалы Богатырева, предназначенные для такого архива (вероятно, в Саратове или в Москве), в итоге оказались в столице - в ГЛМ, откуда часть их была передана в РГАЛИ.

Возникают текстологические вопросы о принадлежности публикуемых материалов П.Г. Богатыреву и об их датировках.

В РГАЛИ (Ф. І547 - фонд ГАИМК. ОП. І. Ед. хр. 88) хранятся фольклорные материалы, присланные в адрес Государственной академии истории материальной культуры (Московское отделение). Их авторство ошибочно приписывается В.С. Евлахову, исходя из пометы на одной из тетрадей. Это три общих линованных тетради по I8 л. в темных обложках (темно-коричневого цвета с декоративными розово-красными мелкими пятнами разного размеpa - от I,5 до 5 мм) из тонкого картона; третья тетрадь не имеет обложки.

В тетрадях РГАЛИ (по крайней мере - в третьей тетради) Богатырев иногда применял ластик: некоторые неточно записанные простым карандашом строки стерты собирателем и на этих же местах вновь начертаны уже правильно услышанные строки (однако следы от стирания остались).

В тетрадях РГАЛИ часто наблюдается беглый почерк, свидетельствующий о стремлении Богатырева успеть записать со слуха ценную информацию в полевых условиях. Собиратель придерживался единого принципа ведения записей (с учетом палитры карандашей - фиолетового для основного текста, синего и зеленого - для зачеркивания, а также с использованием черных чернил для беловых записей и разного рода уточняющих обозначений). Записи выполнялись фиолетовым карандашом (это удобно в полевых условиях) и далее неотчетливо записанные слова и фразы дополнительно обводились простым карандашом, дополнения делались черными чернилами. Справа и слева вверху на свободном пространстве проставлялись фамилии и имена исполнителей - опять же черными чернилами и, вероятно, по памяти.

В тетрадях (ГЛМ) имеются аналитические наброски с описанием села Бавыкино, с характеристиками сказочников, с сопоставлением записанных сказок со сказочными текстами А.Н. Афанасьева (чего нет в тетрадях РГАЛИ). Это было необходимо Богатыреву для запланированных докладов в ОЛЕАЭ, и показывает более позднее происхождение тетрадей (ГЛМ). 
В ГЛМ (Ф. 392) фольклорным записям П.Г. Богатырева в с. Бавыкино отведены две архивные единицы: ед. хр. 90 (беловики) и ед. хр. 9г (собственно экспедиционные записи и, возможно, отдельные переписанные еще вчерне тексты, предваряющие беловики).

Ед. хр. 9I состоит из трех тонких школьных тетрадей в линейку, с розовыми обложками, а также из отдельных листков писчей бумаги и даже обороток разорванных реклам.

Тексты во всех трех тетрадях и на отдельных листах записаны фиолетовым карандашом (по старой орфографии), зачеркнуты синим или зеленым карандашом, имеют незначительные позднейшие вставки черными чернилами. На одном вырванном тетрадном листке в линейку записан текст черными чернилами почерком другого человека.

Вероятно, тексты П.Г. Богатырева в тетрадках (в отличие от текстов на листках) являются не изначальными экспедиционными записями, а переписанными текстами, однако еще не беловыми рукописями, а неким промежуточным звеном.

Ед. хр. 90 представляет собой набор школьных тетрадей с беловыми текстами, записанными черными чернилами. Эти тексты - перебеленные экспедиционные записи П.Г. Богатырева в с. Бавыкино. Среди планомерно переписанных целостных фольклорных произведений встречаются отдельные обрывки текстов (по крайней мере одна фольклорная тетрадь Богатырева отсутствует в коллекции ГЛМ - РГАЛИ).

О саратовском периоде жизни Богатырева свидетельствуют однотипные наклейки на школьных тетрадях под номерами III-IV, VII, X-XI, а также похожие на них наклейки на тетрадях VIII, XII и чуть отличающиеся - на тетрадях V-VI, содержащие саратовские топонимы (ГЛМ. Ф. 392. Ед. хр. 90). Среди таких топонимов - «Митрофан<ьевская> площадь», находящаяся в г. Саратове; «Книжный склад Саратовского губернского земства» и др.

Все номера на чистовых тетрадях проставлены простым карандашом.

Всего в ГЛМ хранится I3 (го + 3 - в ед. хр. 90-9I) тетрадей П.Г. Богатырева и еще отдельные листы с фольклорными записями. Из «Отзыва...» II июля І9І9 г. Ю.М. Соколова следует, что ему было известно то же общее число «тетрадок с записями сказок, анекдотов, песен, заговоров» - I3, при- 
чем студента-собирателя он уважительно именует «специалистом-этнографом П.Г. Богатыревым» (ГЛМ. Ф. 392. Ед. хр. 92. Л. г). Вместе с тремя тетрадями из РГАЛИ на сегодняшний день известно общее количество тетрадок Богатырева - I6, но по крайней мере еще одна утрачена.

Об этом свидетельствует как отсутствие тетради IX (ГЛМ), так и наличие фрагментарных записей, в том числе фрагментов сказок: «Дудик», текст про попадью без начала (CУC I358 C = AA* I730 IV: «Попадья по-немецки заговорила») [I7]. Также нумерация частушек идет планомерно с № 39 по 6I, однако имеется частушка № 5 . Кроме того, в докладе для ОЛЕАЭ П.Г. Богатырев называет «з апокрифа: Богородицын сон, апокриф, известный под названием Ерусалимское письмо, и “О г2-ти пятницах” (ГЛМ. Ф. 392. Ед. хр. 90. Л. ІІ3), указывает особенности записанных конкретных вариантов (ЛЛ. ІІзII4), но только первое произведение присутствует в его тетрадях. Еще в «Серпуховских материалах» (набросках к докладам) Богатырев упомянул сказку о собаке и волке (СУС Іог) [І7] (ГЛМ. Инв. № 392. Ед. хр. 90. Л. ІІ6), но она тоже отсутствует в изученных архивных материалах (ГЛМ и РГАЛИ).

Скопированный из рукописного сборника с. Бавыкино или его окрестностей в I9I4 г. П.Г. Богатыревым «Сон Богородицы» оказался не менее объемным и интересным, по сравнению с уже опубликованными текстами. Богатырев в своей школьной тетради очертил контур рукописной тетради - получился прямоугольник со слегка закругленными краями 8,5+10,5 см - и указал простым карандашом: «Размер рукописи». Внизу черными чернилами начертал:

\section{Описание}

В начале помещены молитвы:

I) Кресту твоему; 2) Да воскреснет Бог (старообр.); 3) Молитва Пресвятеи Богородицы (старообр.) вроде акафиста; 4) молитва архангелу г и 2-ая (ГЛМ. Инв. № 392. Ед. хр. 90. Тетр. без №. Л. Іо6).

По мнению А.И. Яцимирского, «Похвала кресту ценилась в старину не за свою гимнологическую красоту и художественность образов, а за ту таинственную силу, которая по традиции соединялась с произнесением или хранением, чаще ношением на себе написанного текста Похвалы» [2I, с. 23]. Эта мысль подтверждается скопированной Богатыревым рукописью, чей 
небольшой размер позволяет носить ее в кармане или иным способом прикреплять к одежде.

Псалом 67 «Да воскреснет Бог...» известен в записях с начала XVI в. в качестве молитвы-заговора [2I, с. 3I]. А.И. Яцимирский привел библиографию списков молитв «Кресту твоему» и «Да воскреснет Бог» [2I, с. 32-33; 33-34].

«Сон Богородицы» - апокрифическое сочинение наподобие молитвы, появившееся на Руси на рубеже XVII-XVIII вв., входит в круг чтений Пасхального цикла [3, с. 485].

Сегодня фольклористика обладает данными о широком распространении «Сна Богородицы» у христианских народов южной, центральной и восточной Европы: у белорусов, болгар, боснийцев, греков, итальянцев, македонцев, немцев, поляков, португальцев, румын, русских, сербов, словенцев, украинцев, хорватов [І4, с. 416].

К моменту копирования П.Г. Богатыревым «Сна Богородицы» уже были известны его ранние рукописные фиксации на итальянском (XIV в.), польском (I546), русском (I642), церковнославянском сербской редакции (вторая половина XVII - начало XVIII вв.) языках.

У славян одна из ранних записей «Сна Богородицы» сделана на польском языке в Летописце Иоахима Ерлича под г66о г. - с указанием о записи протографа 25 августа I546 г. Первая известная фиксация на русском языке находится в составе следственного дела о бывшем стрельце Афоньке Науменко (I642)

Также имеется предположение о некоем средневековом латинском источнике, на который намекает относительно поздняя фиксация апокри$ф а$, география его распространения и некоторые особенности содержания [I3, c. 425].

В Россию «Сон Богородицы» мог попасть в первой половине XVII в. из Польши через территорию Украины и/или Белоруссии. «Сон Богородицы» представлен в народной рукописной и устной традиции, принимает форму прозаического повествования, духовного стиха, народной молитвы (заговора). Он сохранился в сотнях списков XVII-XX вв., а в начале XXI в. продолжает бытовать в устной передаче и даже проник в Интернет благодаря усилиям участников чатов и блогов 6 .

6 URL: http://freemolitva.narod.ru/son.html; http://dekor-n.com/Raphael/pic/BogorSpis.gif; http://gutan.ru/celitelstvo/4-celitelstvo/308-bogorodica.html (дата обращения: 05.05.2015). 
П.А. Бессонов указал, что в основе «Сна Богородицы» лежит известное церковное песнопение «Не рыдай мене, Мати...» [3, с. 487]. А.Н. Веселовский предполагал, что форма диалога между Христом и Богородицей восходит к апокрифическим текстам об Успении Богородицы [4, с. 357].

К моменту доклада Богатырева самый большой и содержательный вариант «Сна Богородицы» был опубликован в «Памятниках старинной русской литературы, издаваемых графом Григорием Кушелевым-Безбородко: в 4 вып.» [І2, с. І25-І28]: именно его анализировал А.Н. Веселовский в I876 г. [I2, с. I25-I28; 4, с. 347-348].

Существовали и другие публикации вариантов и версий (редакций) «Сна Богородицы» [16, с. 48-50; 2, с. I75-235; г, с. I-2; 8, с. 259-278].

Н.Ф. Сумцов обратил внимание на двухчастность композиции «Сна Богородицы», наиболее часто состоящего из основного сюжета и указания, при каких обстоятельствах следует читать эту апокрифическую молитву [18; 3, с. 485].

В первой части говорится о том, как Богородица спала в Вифлееме, Иерусалиме или другом городе, в пещере, на скале и видела сон о предстоящих муках Иисуса Христа. И Сын Божий подтверждает, что материнское предчувствие сбудется.

Во «Сне Богородицы» один фрагмент, посвященный мучениям Христа, основан на канонических евангельских и апокрифических повествованиях о суде над Христом, распятии на кресте, мучениях, снятии с креста и последующем воскресении. В ряде вариантов развернуто повествуется о сошествии Христа во ад, победе над Сатаной, освобождении Адама и других обитателей ада. Такие подробности восходят к апокрифическому Евангелию от Никодима и другим текстам о сошествии Христа во ад, включая соответствующие литургические песнопения.

Во второй части «Сна Богородицы» обычно перечислены жизненные ситуации, в которых бывает полезен апокриф; для этого его надо многократно переписывать и распространять; и наоборот, если человек не поверит в целительную силу «Сна Богородицы» и пренебрежет им, его постигнет суровое наказание. Наиболее частотны призывы хранить текст «Сна Богородицы» дома, брать его с собой в путь, в суд и на войну, начинать с ним сев, прибегать к нему при родах, читать перед смертью и т. д.; в конце идет типичная для христианских текстов «закрепка» «Аминь». В результате 
«Сон Богородицы» предстает универсальным оберегом, который призван защитить человека в самых разных обстоятельствах [I4, с. 4I6-422].

Когда «Сон Богородицы» находился в составе рукописного сборника, его обычно сопровождали апокрифические «Епистолия о неделе» («Иерусалимский свиток») и «Сказание о двенадцати пятницах». Именно такой состав апокрифов наблюдался в рукописных тетрадях П.Г. Богатырева из с. Бавыкино, но на данный момент известна лишь его первая часть (см. выше).

В рукописи П.Г. Богатырева сообщается, что Богородица «спала еси во святом граде Иерусалиме иудейстем в марте в месеце в треттем часу дня». Март считается знаковым временем и упоминается уже в списке I642 г.: «<...> рече Свитая Богородица: спала есми намаевсе во святом граде во Ефлиеме на марте месяце, унудив меня сон» [7, с. 3I]. 25 марта по ст. ст. праздновалось Благовещение, когда архангел Гавриил явился к Деве Марии с вестью о скором рождении Иисуса Христа. На вторую половину марта начало мая приходится христианская Пасха.

В рукописи П.Г. Богатырева приведены сведения о том, что Христос «приведен на гору Голгофу на трех древах - кипарисе и певке и кедре». При многократной переписке разными людьми текст оказался испорченным, и Богатырев копировал его уже в таком виде. Указан обычный состав древесины креста, как это часто встречается в фольклоре старообрядцев; представление о троичности использованных деревьев восходит к апокрифам о крестном древе, не отражено в канонических Евангелиях и напоминает типично фольклорный прием о тройственности предметов (объектов или субъектов) либо повторяющихся эпизодов (событий). В апокрифах о крестном древе обычно рассказывается о распятии Христа на кресте, сделанном из древесины трех деревьев: певги, кипариса и ивы или кедра [15, с. 420]. В «Толковом словаре живого великорусского языка» В.И. Даля первое дерево - певг трактуется как хвойное дерево, предположительно пихта [6, с. 27].

В рукописи Богатырева «Сну Богородицы» предшествует «Молитва Архангелу Михаилу». А.И. Яцимирский отнес ее к «молитвам общего содержания», однако обладающим «силой мистической» [2I, с. 5I]. В тексте Богатырева нет «закрепки», обещающей всякие блага человеку (вплоть до отвержения души адом по смерти), который читает эту молитву. А.И. Яцимирский полагал, что редакторы печатных изданий молитвенников-требников специально пропускали это обещание. Следовательно, рукопись, ско- 
пированная Богатыревым, может восходить к книжной традиции. Молитва известна по большей части в русских списках, а более поздние болгарские тексты также основаны на них [2I, с. 53]. А.И. Яцимирский привел обширный библиографический перечень списков этой молитвы [2I, с. 53-6о], древнейший текст которой относится к XVI в. На Московской земле молитва зафиксирована в различных рукописных сборниках Троице-Сергиевой лавры конца XVI-XVII вв.

По мнению А.И. Яцимирского, «основной характер молитвы apх. Михаилу объясняется верой в специальные его дарования <...>, указанные в списках «Каким святым от каких болезней и в каких случаях молиться»: «I) когда просыпаешься, б) когда идешь в суд, т. е. против всяких “соперников” и “супостатов”», а также в надписях на иконах [2I, с. 63]. Важная роль архангела Михаила объясняется тем, что, согласно Библии и христианским легендам, он стал первым и главным противником дьявола-супостата и сверг его с небес.

Апокрифические произведения, записанные П.Г. Богатыревым в с. Бавыкино Серпуховского уезда Московской губ., впервые печатаются по источнику: ГЛМ. Инв. № 392. Ед. хр. 90. Тетр. без №. Л. Іо3-ІІо об.

Тексты-чистовики были записаны черными чернилами, без заглавных букв и знаков препинания, с выносными поверх строки буквами («М» и «Х» на конце существительных, прилагательных и числительных; в самом частотном сочетании «оТ» в предлоге и значимых частях речи), иногда со слитным написанием пары слов (наиболее часто - существительного с предлогом или союзом, глагола с отрицательной частицей или местоимением), с диалектным аканьем и цоканьем (непоследовательным), что свидетельствует о его большой древности и локальном распространении на «акающей» и «цокающей» территории. Очевидно, та условная прарукопись, с которой носители фольклорной традиции начали переписывать произведения, отстояла от последнего переписчика на несколько поколений и была выполнена древнерусским полууставом или скорописью, сохранившей выносные буквы для экономии места. Указание «sic» принадлежит П.Г. Богатыреву.

На Л. І03 находится изображение голгофского креста с расходящимися от него двумя орудиями пыток - копьем и тростью (нарисованные кресты почти всегда имеются на обложке или титульном листе подобных 
рукописных сборников); там же помещена молитва «Да воскреснет Бог». Л. гоз об. - «Молитва Пресвятеи Богородицы» («Богородице Дево радуйся»). Л. Іо4 об. - «Молитва Архангелу Михаилу». Л. Іо3-Іо5 - двойные и с пустой частью листы вложены в начало тетрадки.

На Л. Іо6 указан размер рукописи и дано ее краткое описание.

На ЛЛ. Іо6 об. - гіо об. содержится «Сон пресвятыя владычецы нашея Богородицы <...>.

Как уже было сказано, перед «Сном Богородицы» помещена «Молитва архангелу Михаилу», которая начинается обращением к Господу Богу некой «рабы твоей Матрены», что свидетельствует о владелице данного сборника. Еще дважды имя Матрены повторяется ближе к завершению молитвы и в ее конце. Вероятно, Матрена сама переписала с какой-то рукописи молитвы для себя, указав свое имя, либо попросила писаря составить для нее такой сборничек, если была неграмотна. Типовая формула - «рабу (-е) твоему (-и)» - предполагает такое же стандартное продолжение: «(имярек)», вместо которого каждый читающий молитву вставляет собственное имя (мужское или женское). Логичным оказалось бы и написание - «рабе твоей Матрене», предназначенное конкретной владелице рукописного сборника. Однако в данной рукописи оказалось своеобразное сочетание сразу двух приемов указания лица, читающего молитву.

Тексты публикуются по современной орфографии, со знаками препинания, но с сохранением описок и специфических написаний многих слов.

\section{Л. го4 об. // Молитва архангелу Михаилу}

Господи Боже велики царе безначальны, пошли, Господи, архангела твоего Михаила на помощь рабу (-е) твоему (-и) Матрены, Господи, от враг моих видемых и невидимых. Господи, Господи (sic), велики архангеле Михаиле, излеи мира благаго на раба твоего Ма $<\mathrm{T}>$ рену. Господи, Господи (sic), велики архангели Михаиле шестыкрылаты, первы княже и воевода небесных сил, херувим и всех святых Господи, архангеле Михаиле, хранителе неизреченныи, буди ми помощник во всех, во всех (sic) во обидах, в скорбех, // Л. го5 // в печалех, в пустынях и на распутьях, и на реках, и на морях тихое пристанища. Избави мя, велики архангела Михаиле, от всякия прелести дьявольския, егда услыши мя, грешнаго раба (-y) (sic) твоего, Ма- 
трену, молящегося тебе и призываещаго имя твое святое. Ускори на помощь мае и услыши молитву мае, о велики архангеле Михаиле, победи вся противящиися мне силое честнаго и животворящаго креста Господня, молитвами пресвятыя Богородицы, святых аньгел и святых апостол, и светаго Миколы чудотворца и светаго пророка Ильи, и святых великомучеников Никиты, ЕвъЕвъстафия (sic) и преподобных отец и святых святителеи, мученик и мучениц, и всех святых небесных сил. Аминь

Л. І05 об. // Со велики архангеле Михаиле, помози мне, грешному рабу (-е) твоеи (-му), Матрены, избави мя от труса, потопа, от огня, меча и от напрасныя смерти, и от всякого зла, и о<т> бури наносимыя, и от лукавого избави мя, велики архангеле Михаиле Господнь! Всегда ныне и присно во веки веком.

Аминь.

Л. го6 об. // Сон пресвятыя владычецы нашея Богородицы и присно Девы Марии

Пресветая пречистая владычеца наша Богородица, мати Христа Бога нашего спала еси во святом граде Иерусалиме иудейстем в марте в месеце в треттем часу дня, и приде к неи Господь наш Исус Христос, истиный единородныи сын божии, и рече матери своеи: спиши ли, мати, мати (sic) моя, или не спиши? И возбудися она от сна своего, мати божия, и рече сыну своему Исусу Христу: видела про тебе, Господа моего Исуса Христа, от жидов поиман, связан ужем железным и приведен во святы град Иерусалим пред Понтискаго Пилата игемона на одр судима и биенна, и светое лице твое // Л. Іо7 // оплеванно [из] и заушено ${ }^{7}$, по ланите ударинъ и по земли влекома, и палицами биша и жезлием суковатым, святое тело твое аки кора от дуба отпадаша, приведен на гору Голгофу на трех древах - кипарисе и певке и кедре, руце и нозе гвоздием пригвоздиша и тернов венец на главу твое святуе возложиша, и во уста желчие напоен бысть, в ребра твоя, твоя (sic) святыя копием прободоша, абие истече кровь и вода на исцелении (и или я) провославных и на очищения болящим, на спасения всему миру и душам православным, аки речная струя тече на земле и земля от крови обо-

7 Заушено - краткое причастие от глагола «зауши́ть, зауша́ть» - отодрать за уши, ударить по уху, дать оплеуху (древнерусск., устар.). 
грившися, тогда Никодим старец, Иоанн Богуслов пречистое тело твое со креста // Л. Іо7 об. // снял, и благообразны Иосиф плащеницее чистое обвив и во гробе нове положив, жидове на гроб положиша камень и стражеи поставиша римлень < ь наверху стерто> иудеев до тысечи человек. А заутра рано приидоша ко гробу жены мироносицы помазати тело миром, узреша аньгела на камени седяща и ужашошася, глагола к ним аньгел: что плачите, нетленного во тли (sic), шедша в Галилее и тамо его узрите и проповедите учиником его, яко воста от мертвых, в трети день воскресе, всему миру дорова <так!> живот вечны, раздери рукописание адамово и видел: есть неки святы старец, всегда размышляше страдания Христово, того ради горце рыдаше, [явися] // Л. го8 // явися ему Исус Христос, сказа ему: страдания вся от светаго великого четверга даже до погребения, а сам в выздыхании сердцем испусти ран Христос 159, порыван Христос І40 раз смертных ударении, принял Христос 9г рану в голени, принял Христос 65, 65 (sic) ран в ноги, принял Христос I2 ран, истече крови на пле<ч >и (sic) из Христа 300о, по главе прободоша Христа гооо раз. Возложен бысть венец терновы на главу твое святуе, спаде на земле, и земля бысть, за власы влачим по земли, ко кресту пригвожден, плевотин в лице принял Христос 83, падал на землие Христос 6 раз - тогда сонце померше и луна в кровъ <кровь > превратися, небо и земля потресеся, церковная завеса раздрася, мер // Л. Іо8 об. // твыя из гробов восташа, и тма бысть по всеи земли от перваго чеса даже до дивятого. И рече еи Господь наш Исус Христос, истинныи единородныи Спаситель всему миру: о, мати моя возлюбленная, пресветая Богородица, Дева Мария! Воистинну не ложен сон твои праведен, но все сие збудится.

Аще кто в путь поидет и сон пресвятыя Богородицы с собою возметь, тому человеку на всяком месте будеть милосердие божие, путь ему чист и корыстен и радостен, и зло ему никто не сотворить - не еретик, не еретица, ни калдун, ни калдунья, и никто зла ему не сотворить, и гад его на земли не уязвить, на воинах от убиения, // Л. Іо9 // на лесу от заблуждения, от злого человека и от напрасныя смерти, в мори тишину, в торгах прибыль, на морях и на реках и на озерах тихое пристанища и поветрие, в беседе честь и на судех превознесется.

Аще которыи человек сон пресвятыя Богородицы в дому своем в чистоте держить, хотя и неграмотнои, к тому дому не прикоснется ни огнь, ни тать, ни разбоиник, и никакое зло не прикоснется, нечисты дух не при- 
ближится, от грому и от бури наносимыя и от лукавого человека рабам и рабыням здравия, скоту приплот.

В дому женам бе $<$ ре $>$ менным (sic) сеи сон пресвятыя Богородицы $=$ в дому своем в чистоте // Л. го9 об. // держать да радить отроча лехко, избавить ее Господь Бог от всякия скорби и болезни, сказавши те слова: Исусе искрет мя (sic) и сохрани мя от всякого зла в день и в нощи, прошу тебе, Господа маего Исуса Христа, чрез муку твое святуе, которое ты претерпел за нас, грешных, о святыи Иоанн пророче и предтече Христов, которои крестил Исуса Христа в реце Иорданстей, и сохрани мя от огня, меча и от напрасныи смерти в час сеи. Сей сон бысть у гроба Господня, писан во Иерусалиме граде от назареиского царя иудеискаго.

Аминь.

Аще которыи человек сон пресвятыя Богородицы при смерти своеи воспомнить и заставить // Л. ІІо // кого прочитать, тот человек милость мае будеть иметь при смерти ево, аз сам и мати моя пресветая Богородица и аньгели хранители возьмуть душу ево и донесуть до царства небеснова и отдадуть Авраму в раи. Всегда, ныне и присно и во веки веком. Аминь.

Во имя отца и сына и светаго духа аминь. А сие святое слово сосланно от самого Господа нашего Исуса Христа, освятивы посла на неприятеля великое мочь имеет. Кто хощеть его писать или читать или слушать, тот человек отпущения грехов получить.

Во имя отца и сына и светаго духа аминь. Во креста человек родися, крест водрузися, Бог прославися, сатана от всех предел и ярости отгнася и не бысть християне. // Л. гіо об. // Здесь престоль (sic) пресвят поставлен во имя Господа нашего Исуса Христа. Четыре Еваньгелия, еваньгелист Марк, Лука, Матвеи, Иоанн Богуслов, человек духов, небесных сил, аньгел и архангел Гавриил, Михаил к робъ божиим <оставлен пробел примерно для двух слов> в Христовом месте Иерусалимском знамением. Ныне и присно и во веки веком. Аминь. 


\section{Условные сокращения}

ГЛМ - Государственный литературный музей (г. Москва)

РГАЛИ - Российский государственный архив литературы и искусства (г. Москва)

ИРЯ РАН - Институт русского языка им. В.В. Виноградова Российской академии наук (г. Москва) 


\section{Список литературы}

I Барсов E.В. Историко-этнографические материалы, собранные Е.В. Барсовым. I. Сон Богородицы в живом народном пересказе // Чтения в Императорском Обществе истории и древностей российских. М., І886. Кн. 3. Отд. V. С. I-2. Бессонов П.А. Калеки перехожие. М.: Тип. А. Семена, І864. Вып. 6. 328 с. Варенцова Е.M. Сон Богородицы // Словарь книжников и книжности Древней Руси. XVII в. СПб.: Дмитрий Буланин, І998. Ч. 3: П-С. С. 485-487.

Веселовский А.Н. Очерки по истории развития христианской легенды. III. Сон Богородицы и сводные редакции эпистолии // Журнал Министерства народного просвещения. СПб., І876. № 4. С. 34I-363.

Виноградов Н.Н. Заговоры, обереги, спасительные молитвы и прочее: в 3 вып. СПб.: Тип. Мин-ва путей сообщения (Тов-ва И.Н. Кушнерев и Кํ), І908. Вып. І. IO2 C.

Даль В.И. Толковый словарь живого великорусского языка: в 4 т. М.; СПб.: Изд-е книгопродавца-типографа М.О. Вольфа, г882. Т. 3. (Репринт: М.: Русский язык, І990). 576 с.

Зерцалов А.Н. К материалам о ворожбе в древней Руси. Сыскное дело г642I643 гг. о намерении испортить царицу Евдокию Лукьяновну // Чтения в Императорском Обществе истории и древностей российских при Московском университете. М., І895. Кн. 3. Отд. І. С. I-38. Материалы к истории и изучению русского сектантства и раскола / Зап. и собрал В. Бонч-Бруевич. СПб.: Тип. М.Б. Вольфа, г909. Вып. 2. 327 с. Фольклорные темы на заседаниях Московского лингвистического кружка (вст. статья и подготовка текста А.Л. Топоркова; коммент. А.Л. Топоркова и А.А. Панченко) // Неизвестные страницы русской фольклористики / отв. редактор: чл.-корр. РАН А.Л. Топорков. М.: Индрик, 2ОІ5. С. 56-I4I. Памятная книжка Московской губернии на І9І2 год / под ред. Б.Н. Пенкина. М.: Моск. столичный и губ. стат. комитет, Губ. тип., І9ІІ. 700 с. Памятная книжка Московской губернии на I9I4 год / под ред. Б.Н. Пенкина. М.: Моск. столичный и губ. стат. комитет, Губ. тип., І9г3. I78 с. Памятники старинной русской литературы, издаваемые графом Григорием Кушелевым-Безбородко: в 4 вып. СПб.: Тип. Кулиша, І862. Вып. 3. І8о с. Райан В.Ф. Баня в полночь: Исторический обзор магии и гаданий в России / пер. с англ. М.: Новое литературное обозрение, 2006. 7І8 с. Русские заговоры из рукописных источников XVII - первой половины XIX в. / сост., подг. текстов, статьи и коммент. А.Л. Топоркова. М.: Индрик, 20Iо. 830 с. Рязанская энциклопедия: Справочный материал. Рязань: Тов-во «Рязанская энциклопедия», I992. Т. 9. І7І с. Сборник русских духовных стихов, составленный В. Вренцовым. СПб.: Кожанчиков, I86о. 248 с. 
I7 Сравнительный указатель сюжетов: Восточнославянская сказка / сост. Л.Г. Бараг, И.П. Березовский, К.П. Кабашников, Н.В. Новиков. Л.: Наука, І979. 437 с.

I8 Сумщов Н.Ф. Очерки истории южнорусских апокрифических сказаний и песен. Киев: Без изд., І888. г6г с.

I9 Хроника. Отчет о деятельности Этнографического отдела ИОЛЕАиЭ и состоящих при Отделе Музыкально-этнографической комиссии и Комиссии по народной словесности за I9I4-I9I5 академический год // Этнографическое обозрение. I9I5. № 3/4. Отд. VII. С. I47-I48.

20 Якобсон Р.О. О русском фольклоре (I975) // Якобсон Р.О. Язык и бессознательное. М.: Гнозис, 1996. С. 97-105.

2 I Яцзимирский А.И. К истории ложных молитв в южнославянской письменности // Известия Отделения русского языка и словесности Императорской Академии наук. СПб., І9І3. Т. І8. № 3. С. I-I02. 


\section{References}

Barsov E.V. Materialy jetnograficheskie iz zapisej E.V. Barsova. I. Son Bogorodicy $\mathrm{v}$ zhivom narodnom pereskaze [Ethnographical materials from the records by E.V. Barsov. I. "The Dream of Our Lady"]. Chtenija v Imperatorskom Obshhestve istorii i drevnostej rossijskih [Reading in The Emperor's Society of Russian History and Antiquities]. Moscow, I886, vol. 3, part. V, pp. I-2. (In Russ.) Bessonov P.A. Kaliki perehozhie [Wandering cripples]. Moscow, Tip. A. Semena Publ., I864. Issue 6. 328 p. (In Russ.)

3 Varencova E.M. Son Bogorodicy [The dream of Our Lady]. Slovar' knizhnikovi knizhnosti Drevnej Rusi [The dictionary of scribes and book culture of the Old Rus']. XVII v. St. Petersburg, Dmitrij Bulanin Publ., I998, book 3, pp. 485-487. (In Russ.) Veselovskij A.N. Ocherki po istorii razvitija hristianskoj legendy. III. Son Bogorodicy i svodnye redakcii jepistolii [Essays on the history of the development of Christian legend. III. Dream of Our Lady and consolidated editions of the Epistole]. Zhurnal Ministerstva narodnogo prosveshhenija. St. Petersburg, I876, no 4, pp. 34I-363. (In Russ.) Vinogradov N.N. Zagovory, oberegi, spasitel'nye molitvy i prochee: $v 3$ vyp. [Charms, talismans, prayers and other: in 3 issues.]. St. Petersburg, Tip. M.M.S. (Tov-va I.N. Kushnerev i $\mathrm{K}^{\circ}$ ) Publ., I908. Issue I. I02 p. (In Russ.) Dal' V.I. Tolkovyj slovar' zhivogo velikorusskogo jazyka: $v 4 t$. [Explanatory dictionary of the living great Russian language: in 4 vols.] Moscow; St. Petersburg, Izdanie knigoprodavca-tipografa M.O. Vol'fa Publ., I882. Vol. 3. (Reprint: Moscow: Russkij jazyk, I990). 576 p. (In Russ.)

7 Zercalov A.N. K materialam o vorozhbe v drevnej Rusi. Sysknoe delo I642-I643 gg. o namerenii isportit' caricu Evdokiju Luk'janovnu [On fortune-telling in the Old Rus'. Criminal investigation of the I642-I643 case about the intention to spoil tsarina Eudochia Lukianovna]. Chtenija v Imperatorskom Obshhestve istorii i drevnostej rossijskih pri Moskovskom universitete [The Emperor's Society of Russian History and Antiquities]. Moscow, I895, vol. 3, part I, pp. I-38. (In Russ.)

8 Materialy $k$ istorii $i$ izucheniju russkogo sektantstva i raskola [Materials to the history and study of Russian sectarianism and schism]. Recorded and compiled by V. Bonch-Bruevich. St. Petersburg, Tipografia M.B. Vol'fa Publ., I909. Issue 2. 327 p. (In Russ.)

Fol'klornye temy na zasedanijah Moskovskogo lingvisticheskogo kruzhka [Folklore themes as discussed at the meetings of Moscow linguistic circle] (intro. and ed. A.L. Toporkov; comments by A.L. Toporkov and A.A. Panchenko). Neizvestnye stranicy russkojfol'kloristiki [Unknown pages of Russian folklore studies], ed. A.L. Toporkov Corresponding Member of RAS. Moscow, Indrik Publ., 20I5, pp. 56-I4I. (In Russ.) Pamjatnaja knizhka Moskovskoj gubernii na I9I2 god [Memorandum book of the Moscow province for I9I2], ed. B.N. Penkina. Moscow, Gubernskaia tipografia Publ., I9II. 700 p. (In Russ.) 
Pamjatnaja knizhka Moskovskoj gubernii na I9I4 god [Memorandum book of the Moscow province for I9I4], ed. B.N. Penkina. Moscow, Gubernskaia tipografia Publ., I9I3. I78 p. (In Russ.)

Pamjatniki starinnoj russkoj literatury, izdavaemye grafom Grigoriem

Kushelevym-Bezborodko: $v 4$ vyp. [Sources of ancient Russian literature published by a count Grigory Kushelev-Bezborodko: in 4 issues]. St. Petersburg, Tip. Kulisha Publ., 1862. Issue 3. I80 p. (In Russ.)

Rajan V.F. Banja v polnoch': Istoricheskij obzor magii i gadanij v Rossii [Taking a bath at midnight: Historical review of Russian magic and fortune-telling], trans. from English. Moscow, Novoe literaturnoe obozrenie Publ., 2006. 7I8 p. (In Russ.)

Russkie zagovory iz rukopisnyh istochnikov XVII - pervoj poloviny XIX v. [Russian charms from hand-written sources of the $I 8^{\text {th }}$ - first half of the $I 9^{\text {th }}$ centuries], comp., ed., articles and comments by A.L. Toporkov. Moscow, Indrik, 20IO. 830 p. (In Russ.)

Rjazanskaja jenciklopedija: Spravochnyj material [Ryazan' encyclopedia: Reference information]. Rjazan', Bez izd., I992. Vol. 9. I7I p. (In Russ.)

Sbornik russkih duhovnyh stihov, sostavlennyj V. Varencovym [Collection of Russian spiritual poems, comp. by V. Varentsov]. St. Petersburg, Kozhanchikov Publ., I860. 248 p. (In Russ.)

Sravnitel'nyj ukazatel' sjuzhetov: Vostochnoslavjanskaja skazka [Comparative index of plots: East Slavic fairy tale], comp. by L.G. Barag, I.P. Berezovskij, K.P. Kabashnikov, N.V. Novikov. Leningrad, Nauka Publ. 1979. 473 p. (In Russ.)

Sumcov N.F. Ocherki istorii juzhnorusskih apokrificheskih skazanij i pesen [Essays on the history of South-Russian apocryphal stories and songs]. Kiev, Bez izd., I888. I6I p. (In Russ.)

Hronika. Otchet o dejatel'nosti Jetnograficheskogo otdela IOLEAiJe i sostojashhih pri Otdele Muzykal'no-jetnograficheskoj komissii i Komissii po narodnoj slovesnosti za I9I4-I9I5 akademicheskij god [Chronicle. Report on the activity of the Ethnographic Department of the Emperor's Society of the Lovers of Natural Science, Anthropology and Ethnography and of the Musical-ethnographic Commission and Commission on Folk Literature adjacent to the Departments for I9I4-I9I5 academic years]. Jetnograficheskoe obozrenie, I9I5, no 3/4, pp. I47-I48 (In Russ.) Jakobson R.O. O russkom fol'klore [About Russian folklore] (I975). Jakobson R.O. Jazyk i bessoznatel'noe [Language and the unconscious]. Moscow, Gnozis Publ., I996, pp. 97-I05. (In Russ.)

Jacimirskij A.I. K istorii lozhnyh molitv v juzhnoslavjanskoj pis'mennosti [To the history of false prayers in the South-Slavic written language]. Izvestija Otdelenija russkogo jazyka i slovesnosti Imp. Akademii nauk. St. Petersburg, I9I3, vol. I8, no 3, pp. I-IO2. (In Russ.) 
УДК 82.09

ББК $83.3(2 \mathrm{Poc}=$ Рyc $)+83+$ 83.3 (4Вел) 5 I

\section{«ФАЛЬСИФИКАЦИЯ ШЕКСПИРА»: НЕИЗДАННАЯ СТАТЬЯ ГЕОРГИЯ \\ ШЕНГЕЛИ О ПЕРЕВОДАХ \\ БОРИСА ПАСТЕРНАКА}

\author{
(C) 2017 г. В.А. Резвый \\ Издательство «Водолей», \\ Москва, Россия \\ Дата поступления статьи: І8 апреля 2017 г. \\ Дата публикации:25 сентября 2017 г.
}

DOI: IO.22455/2500-4247-20I7-2-3-300-333

Аннотация: Поэт, переводчик, специалист в области стиховедения Георгий Шенгели в статье «Пастернаковский Шекспир» (<I945>) детально разбирает фрагменты из трагедий Уильяма Шекспира «Ромео и Джульетта» и «Гамлет» в переводах Бориса Пастернака, критикуя работу последнего с собственных переводческих позиций, согласно которым главные требования, предъявляемые к переводу, - точность и художественность. При этом игнорируются обстоятельства возникновения переводов Пастернака и поставленные в них задачи - создать намеренно свободное, удобное для произнесения со сцены переложение, судить которое следует как оригинальное произведение русской словесности. Признавая безусловным достижением переводов Пастернака естественный и свободный синтаксис, Шенгели путем статистических подсчетов и построчного сопоставления перевода с подлинником стремится доказать, что с точки зрения верности оригиналу работа Пастернака является фальсификацией Шекспира. Справедливо подмечая некоторые смысловые и стилистические огрехи переводов, Шенгели при этом сам допускает неточности в толковании оригинала и в духе времени переводит литературную полемику в идеологическую плоскость, призывая к «политическим выводам».

ключевые слова: Шенгели, Пастернак, Шекспир, художественный перевод, история перевода, теория и критика перевода.

Информация об авторе: Владислав Александрович Резвый - редактор-составитель, Издательство «Водолей», ул. Гончарова, д. І7 а, корп. 2, І27254 Москва, Россия.

E-mail: telemachusı98ı@gmail.com 


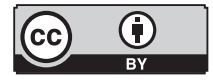

This is an open access article distributed under the Creative Commons Attribution 4.0 International (CC BY 4.0)

\author{
"FALSIFICATION OF SHAKESPEARE": \\ GEORGY SHENGELI'S UNPUBLISHED \\ ARTICLE ON BORIS PASTERNAK'S \\ TRANSLATIONS \\ (C) 20I7. V.A. Rezvy \\ Vodoley Publ., \\ Moscow, Russia \\ Received: April I8, 2017 \\ Date of publication: September 25, 2017
}

\begin{abstract}
In his article "Pasternak's Shakespeare" (I945), Georgy Shengeli, poet, literary translator and expert in prosody, examines the fragments from Shakespeare's tragedies Romeo and Juliet and Hamlet translated by Boris Pasternak, criticizing the latter in the light of his own views on translation, according to which accuracy and artistry are the main literary translation requirements. At the same time, Shengeli ignores the circumstances in which Pasternak made his translations as well as his intentions: to adapt Shakespeare to the Russian stage; the adaptation should be therefore judged as an original work of Russian literature. While recognizing natural and free syntax as an unquestionable merit of Pasternak's translations, Shengeli seeks to prove by means of statistical calculations and line-by-line comparison of the translation with the original that Pasternak's work is a falsification of Shakespeare. This essay shows how Shengeli, albeit aptly noting semantic and stylistic flaws in Pasternak's translations, himself makes inaccuracies in the interpretation of the original and, in the spirit of the time, translates literary polemics into ideology, calling for "political conclusions."
\end{abstract}

Keywords: Shengeli, Pasternak, Shakespeare, literary translation, translation history, translation theory and criticism.

Information about the author: Vladislav A. Rezvy, Editor, Vodoley Publ., Goncharova I7 a, 2, I27254 Moscow, Russia.

E-mail: telemachusı98ı@gmail.com 
Первая же переведенная Борисом Леонидовичем Пастернаком трагедия Уильяма Шекспира - «Гамлет» ${ }^{\mathrm{I}}-$ вызвала диаметрально противоположные отклики. Серьезные замечания к переводу были высказаны в рецензиях М. Алексеева, М. Морозова, Л. Резцова, Б. Соловьева², недавно переизданных [2, с. 773-809]. При этом критики занимали в общем сходную позицию, наиболее лаконично обозначенную тем же Морозовым во внутреннем отзыве на другой перевод Пастернака из Шекспира - «Ромео и Джульетту» [2, с. 8І6-8I8]: «Очень, очень досадно, когда замечательное в целом произведение загублено отдельными промахами». В аналогичном ключе высказывался о переводе «Гамлета» в частном письме крупнейший специалист по Шекспиру А.А. Смирнов: «Странное произведение! С одной стороны, есть прекрасные места и вообще красивый стих, много поэзии и глубокого чувства, а с другой стороны, - такая кустарщина, что становится стыдно. Перевод переполнен смысловыми ошибками и стилистическими дикостями» [6, с. 24]. В числе «дикостей» авторы отзывов также достаточно единодушно называли вульгарность словаря, неоправданную модернизацию текста, множество тяжелых и невнятных речевых конструкций и т. д.

В дальнейшем критические отзывы на переводы Пастернака из Шекспира не появлялись в печати до конца г960-х гг. Уже упомянутый А. Смирнов в 1947-1948 гг. объяснял это так: «Пастернак сейчас настолько скомпрометирован как поэт, что лишь переводы дают ему средства к су-

I Впервые полностью: Молодая гвардия. І940. № 5-6. С. I5-I3I.

2 Литература и искусство. І940. № 8; Театр. І94I. № 2; Литературное обозрение. I940. № 20; Литературный современник. г940. № І2. 
ществованию. Если я выступлю против его переводов, то все скажут, что я поступаю бесчеловечно, отнимая у него последний кусок хлеба» [6, с. 28]. Справедливо замечание исследователя: «Обаяние великого поэта и история с “Доктором Живаго” побуждали нашу интеллигенцию автоматически становиться на сторону Пастернака. <...> Ныне, когда месту Пастернака в истории русской литературы и его славе ничто не угрожает, не пора ли “выслушать и другую сторону” и разобраться в этом вопросе без сакрального трепета и фанатизма?» [6, с. 20]. Публикуемый отзыв - еще одно не прозвучавшее своевременно выступление «другой стороны». Принадлежит оно поэту, переводчику, филологу-стиховеду Георгию Аркадьевичу Шенгели (г894-г956).

Вопросам художественного перевода Шенгели посвятил несколько работ. Из опубликованных при его жизни важнейшими являются послесловия к двум авторским изданиям переводов из Дж.Г. Байрона - двухтомнику поэм [4, с. 289-3ог] и роману в стихах «Дон-Жуан» [3, с. 522-535]. Посмертно опубликованы статья «О моей работе» [І5, с. 357-384] - своеобразный отчет переводчика за все годы творчества и «Критика по-американски» [г, с. 208-299] - развернутый ответ на критические выступления И.А. Кашкина против перевода «Дон-Жуана». Таким образом, статья «Пастернаковский Шекспир» впервые представляет Шенгели не излагающим или защищающим свои творческие установки, а рассматривающим исходя из этих установок работу другого переводчика.

Самый ранний документ, фиксирующий отношение Шенгели к Пастернаку, - его письмо редактору недолговечного альманаха «Утренники» Д.А. Лутохину от I6 июня I922 г.: Шенгели предлагал для публикации статью3, содержащую «отрицательную оценку поэзии Пастернака как со стороны ее художнических методов, так и со стороны ее идеологического багажа» [7, с. І93]. В конце г924 г. Шенгели послал стихотворение «У гроба Брюсова» 4 М. Шкапской, своей постоянной корреспондентке в г920-е гг.; очевидно, она усмотрела в стихотворении нечто близкое Пастернаку - на ее несохранившееся ответное письмо поэт отреагировал бурно: «Ваша характеристика моего стих<отворения> о Брюсове меня взбесила! Не оценка, а именно характеристика. Пастернак! У меня! Да пусть он умоется прежде!

3 Текст не сохранился.

4 Звезда. І925. № т. С. Іо2; позднее вошло в авторский сборник «Норд» (М., І927). 
Умоется в слезах Адалис» [Iо, с. 268]. В сатирическом ключе упомянут Пастернак в шуточном стихотворении «Проект», где Шенгели обращается к Шарлю Леконту де Лилю и Осипу Мандельштаму, намереваясь вместе с ними стать воплощением трехликого бога: «И будем мы втроем парить на небе, / Леконт де Лиль - ругая иудеев, / А Осип - искупая перед ним / Грех первородный Пастернака» [7, с. 270; I5, с. 271]. Наконец, за год до появления публикуемой статьи, в январе 1944 г. Шенгели написал стихотворение «Поэту» - отклик на «Страшную сказку» (I94I) Пастернака, оканчивающийся перефразированными строками: «И писк жеманного чижа / Вовеки не простится!» [7, с. I94-І95].

Статья «Пастернаковский Шекспир», датируемая второй половиной I945 г. - между выходом в свет упоминаемого в тексте номера газеты «Британский союзник» и отдельного издания «Отелло», - является, по-видимому, одним из последних проявлений негативного отношения Шенгели к Пастернаку. Примечательно, что, в отличие от первых рецензентов «Гамлета», Шенгели как будто совершенно не принимает в расчет творческие установки переводчика, вкратце изложенные в предисловии к журнальной публикации «Гамлета»: «Мне несколько раз предлагали перевести “Гамлета" <...> речь шла об особом, вольном, свободно звучащем переложении, удовлетворительном в сценическом, а не книжном смысле5. <...> Работу надо судить как русское оригинальное драматическое произведение <...> в ней больше всего той намеренной свободы, без которой не бывает приближения к большим вещам» [8, с. 42-44]. Едва ли Шенгели не был знаком с этим текстом: заслугой Пастернака он считает именно то, что тот ставил во главу угла, - «естественный и свободный синтаксис» и гибкость стиха. Однако Шенгели подходит к работе Пастернака исключительно с позиции собственных требований к переводу, обстоятельно изложенных в более поздней статье «О моей работе» (I95I), где он, в частности, писал: «...идеалом является тождество перевода и подлинника. Тождество это неосуществимо, но максимальное приближение к нему не может не быть основной задачей переводчика» [15, с. 358]. В этих требованиях Шенгели ближе всего к своему старшему товарищу Валерию Брюсову, на что указал еще в I9I8 г. Максимилиан Волошин в отзыве на пер-

5 Предложение перевести «Гамлета» в таком ключе исходило от Вс. Мейерхольда [8, с. 754], о чем Пастернак вынужден был умолчать: перевод публиковался спустя несколько месяцев после гибели режиссера. 
вую крупную переводческую работу Шенгели - избранные сонеты Ж.М. де Эредиа 6 . При этом сам Брюсов, рецензируя в г923 г. «Полное собрание поэм» Верхарна в переводе Шенгелит, упрекал его среди прочего именно в недостатке точности. Позднее Шенгели признавался, что благодаря этому отзыву «стал переводить много бережней» [І, с. 296].

Отстаивая принцип точности на материале, опирающемся на противоположные принципы, Шенгели, в сущности, доказывает, что Пастернак в переводах из Шекспира не добился того, к чему изначально не стремился: его подсчеты пропущенных знаменательных слов оригинала составлены для переложений, целенаправленно уходящих «от перевода слов и метафор $<$...> к переводу мыслей и сцен» [8, с. 43], упреки в отсебятине предъявляются переводам, выполненным с «намеренной свободой». Однако даже если пренебречь несоответствием подходов к переводу, окажется, что аргументы Шенгели далеко не всегда бесспорны. Если его замечания по стилистике и словоупотреблению в основном справедливы, то в вопросах понимания текста Шенгели зачастую уходит в область интерпретации, противопоставляя свое субъективное толкование столь же субъективному пастернаковскому. Более того, в подстрочном переводе Шенгели допускает ряд неточностей, обусловленных, надо полагать, не вполне аккуратным разбором оригинала; при этом в предлагаемых им вариантах перевода некоторые неточности сглаживаются, но на других Шенгели продолжает настаивать, усматривая в рецензируемых переводах грубые смысловые ошибки.

Мотивы написания отзыва, в заключение призывающего к «политическим выводам», до конца неясны. Характерный для эпохи перевод литературной полемики в политическую плоскость или немногочисленные ошибки в понимании оригинала - недостаточное основание, чтобы утверждать, будто рецензент сводил счеты или же действовал из корыстных побуждений ${ }^{8}$.

6 «В общем я нахожу в Ваших переводах многие брюсовские недостатки. У Вас, как у него, большое мастерство стиха, но у Вас обоих волчьи негнущиеся шеи и поэтому нет гибкости, необходимой для полного перевоплощения. Часто перевод у Вас точен до буквальности и совсем нет впечатления подлинника <...> Брюсов этого часто тоже не чувствует, что буквальность вредит, а всё дело в соотношениях» [7, с. І23].

7 Брюсов В. Верхарн на прокрустовом ложе // Печать и революция. г923. Кн. 3.

8 Отметим, что в конце I940-х - начале г950-х гг. Шенгели сам стал объектом подобной критики: главный упрек, брошенный И.А. Кашкиным его переводу «Дон-Жуана» Байрона, - искажение образа Суворова, - носил именно политический характер. Подробнее см. в монографии А. Азова [г]. 
Остается допустить, что Шенгели был искренен как в заботе о повышении качества переводной продукции, так и в допущенных им неточностях. К тому же сведения об открытых его нападках на Пастернака отсутствуют, а стихотворение «Поэту» и статья о переводах Шекспира остались неопубликованными. Напротив, еще в І93I г. на дискуссии в Московском отделении ВССП по докладу Асеева «Сегодняшний день советской поэзии» Шенгели поддержал Пастернака, хотя тот упрекнул его за упоминание имени Маяковского, «которое он не смел вслух произносить»9 [7, с. І94]. В І944 г. Шенгели называл Пастернака в числе возможных рецензентов сборника его новых стихов «Панцирь» ${ }^{\mathrm{Io}}[7$, с. 459], в «Критике по-американски» рассказал о том, как по выходе в свет «Дон-Жуана» Пастернак звонил ему в три часа ночи, чтобы сообщить, «что он не может оторваться от книги» [I, с. 223], - поступок, едва ли возможный при отсутствии доброжелательных отношений. Не случайно и то, что в стихотворении «Он знал их всех...», написанном за год до смерти, Шенгели упомянул Пастернака в числе тех поэтов, кто, по его мнению, составляет «небывалый хор, / Четырнадцатизвездное созвездье!..» [7, с. 290].

Статья публикуется по авторской машинописи из личного фонда Г.А. Шенгели в Российском государственном архиве литературы и искусства (РГАЛИ. Ф. 286г. ОП. І. Ед. хр. 78. Л. 56-73).

\section{ПАСТЕРНАКОВСКИЙ ШЕКСПИР}

Известный поэт Борис Пастернак в последние годы усиленно занимается переводом произведений Шекспира. Уже переведены и изданы «Гамлет» ${ }^{\text {II }}$, «Ромео и Джульетта» ${ }^{12}$, «Антоний и Клеопатра»³; говорят, что

9 Шенгели принадлежит брошюра «Маяковский во весь рост» (М., I927), в основу которой легли тезисы доклада «Опыт социологического и морфологического анализа стихов Маяковского», прочитанного в Литературной секции ГАХН 25 октября 1926 г. Брошюра завершалась таким вердиктом Маяковскому: «Бедный идеями, обладающий суженным кругозором, ипохондричный, неврастенический, слабый мастер, - он вне всяких сомнений стоит ниже своей эпохи, и эпоха отвернется от него» [7, с. 440].

Iо При этом в состав сборника включено упоминавшееся стихотворение «Поэту».

II См.: [І2].

I2 См.: [I4].

I3 См.: [II]. 
уже готов «Отелло» ${ }^{14}$. «Ромео» вышел 25 -тыс<ячным> тиражом, «Гамлет» - 50-тыс<ячным> («Антония и Клеопатру» я не видел); «Гамлет» до отдельного издания был полностью напечатан в журн <але $>$ «Мол<одая > Гвардия» ${ }^{15}$, - честь, которой до сих пор не удостаивался ни один перевод европейского классика. Переводы эти, как говорят, приняты многими театрами, в частности, МХАТ’ом («Гамлет») ${ }^{16}$. Таким образом, переводческая продукция Пастернака получает широчайшее общественное обращение. Переводы его высоко расценены критикой и литераторским общественным мнением. В частности, в одном из майских или июньских номеров «Британского союзника» помещена большая статья одного лондонского профессора, восторженно отзывающаяся об этих переводах ${ }^{17}$. В «Британской энциклопедии» в статье о сов<етской> поэзии Б. Пастернак назван «undiscutably ${ }^{18}$ first poet of Russia», - «бесспорно первый поэт России».

Таким образом, его переводческая продукция приобретает значение образца для других советских переводчиков («вот как надо переводить»), а с другой стороны значение советского рекорда в глазах иностранного читателя («вот как переводит первый поэт России и, очевидно, лучший ее переводчик»).

Между тем, внимательный анализ этих переводов приводит к совершенно противоположным выводам: переводы Пастернака, при многих достоинствах, о которых я упомяну, страдают существеннейшими недостатками и являются в значительной мере фальсификацией Шекспира, что я докажу конкретным разбором.

Отрицательные следствия этого таковы: І) советский читатель получает неполноценную продукцию, 2) советский переводчик учится переводить небрежно и неточно, 3) внимательный иностранный критик, подвергнув эти переводы разбору, вправе усмехнуться: «что это за страна, первый поэт которой переводит так плохо?» А это имеет уже непосредственное по-

\footnotetext{
I4 См.: [13].

I5 I940. № $5-6$.

I6 Перевод Пастернака был принят к постановке В.И. Немировичем-Данченко в конце I939 г., роль Гамлета репетировал Б.Н. Ливанов; в г943 г., уже после смерти Немировича-Данченко, репетиционный процесс довели до конца, однако после негативного отзыва И.В. Сталина о характере Гамлета спектакль не вышел (см., например: [5, с. 324]).

I7 Ренн К. Шекспир в переводе Пастернака // Британский союзник. I945. № 22, 3 июня.

I8 Так в тексте. Следует: undisputably.
} 
литическое значение. В силу этого необходимо перейти от огульных и непродуманных дифирамбов к серьезной критике этих переводов и добиться от их талантливого автора существеннейшей переработки его труда.

Нижеследующему разбору, которым я обосную данную мною оценку, надо предпослать несколько общих (и, по необходимости, кратких) соображений о задачах стихотворного перевода.

От перевода мы требуем I) точности, 2) художественности. В идеале перевод должен быть равноценен подлиннику и равнозначен ему.

Однако точность не надлежит понимать как дословность; во-первых, дословность, ввиду различной природы языков, часто неосуществима (французское «comment vous portez-vous?» вовсе не означает «как вы себя несете?», а только «как вы поживаете?»); во-вторых, дословность, создавая иногда словосочетания, непривычные для того языка, на который переводят, разрушает нужное впечатление вместо того, чтобы его закреплять; напр<имер>, когда Гомер говорит (дословно), что у богини Геры «коровьи глаза», и говорит это в положительном смысле, подчеркивая их величину и кроткое выражение, то переводчик, употребив слово «коровьи», создаст комическое впечатление; поэтому Гнедич дает неточное слово: «волоокая Гера», торжественным славянизмом заставляя забывать о глупой корове, а звуком слова напоминая о «поволоке», о влажном блеске, столь украшающем глаза, - и этой «неточностью» лучше воспроизводит оригинал, чем дословностью. Тем не менее, конечно, перевод должен быть точен поэтически: воспроизводить все мысли оригинала, все его образы и, в основном, все его слова, ибо они и являются главными носителями содержания - идейного и чувственно-эмоционального. Художественность перевода заключается в воспроизведении художественной манеры автора - безупречным русским языком и таковым же стихом.

Надо сказать, что к числу бесспорных достоинств переводов Пастернака относится естественный и свободный синтаксис, - «легкая фраза», которую нетрудно произносить и интонировать, - в отличие от переводов, напр<имер>, Кузмина и Радловой, где конструкция фразы часто очень за- 
труднена и запутана ${ }^{19}$. Но это достоинство присуще также многим старым переводам - Вейнберга и др<угих $>^{20}$. Наряду с этим стих Пастернака также достаточно гибок и приближается по встречаемости своих форм к стиху «Маленьких трагедий» Пушкина, «Трилогии» Ал<ексея> Толстого и др<угим>, тогда как в переводах Радловой и Лозинского этот же стих дает необычную встречаемость форм и звучит, следовательно, «не по-русски» (всё это подтверждается с математической точностью специальным стиховедческим разбором, который я здесь опускаю). Надо сказать, однако, что и старые переводы (Вейнберга, Щепкиной-Куперник и др<угих>) в этом отношении не уступают или мало уступают переводам Пастернака.

Перехожу теперь к прямому разбору.

Первое, что бросается в глаза при параллельном чтении перевода и оригинал, это - постоянная неточность, приобретающая характер крайнего обеднения и упрощения оригинала.

Прежде всего - Пастернак пропускает значительное количество слов, имеющихся в оригинале (я говорю, конечно, о значимых словах, а не о служебных, как предлоги, союзы, вспомогательные глаголы и пр.). Эти потери превышают 20\%. Одна пятая шекспировского текста исчезает бесследно.

Вот несколько подсчетов:

«Ромео и Джульетта»

слов в перев<оде $>\quad$ потеря в ориг $<$ инале $>$

$\begin{array}{llll}\text { Пролог } & 72 & 56 & (\text { I6 }=22 \%) \\ \text { Монолог князя (акт I, сц<ена> I) } & \text { IO9 } & 88 & (2 \mathrm{I}=\text { I9\%) }\end{array}$

I9 В 1936 г. Шенгели редактировал первый том запланированного в Гослитиздате трехтомного издания Шекспира, не вышедшего в свет. В письме главному редактору Гослитиздата И.К. Лупполу от 8 декабря, назвав в качестве одной из причин неудачного перевода «внутреннюю несоизмеримость переводчика автору», Шенгели, в частности, писал: «Как может Кузмин, упадочник, сросшийся с Парни и Грекуром, с александрийством Пьера Льюиса, справиться с бешеными гротесками “Лира"?» [7, с. 364].

20 По воспоминаниям А.К. Тарасенкова, Пастернак в ответ предложения заново перевести Шекспира «отсылал издателей и театры к старым переводам Соколовского, Кронеберга. У меня с детства осталось впечатление, что эти переводы, несмотря на их провинциализм, характерный для конца прошлого века, - поэтичны, в них есть Шекспир» [8, с. 535]. 


$\begin{array}{llll}\text { Речь Меркуцио о фее Мэб (I, 4) } & \text { I93 } & \text { I55 } & (37=\text { I9\%) } \\ \text { Диалог Ромео и Дж. (I, 5) } & 88 & 66 & (22=25 \%) \\ & 46 \mathrm{I} & 365 & (96=2 \mathrm{I} \%)\end{array}$

«Гамлет»

$\begin{array}{llll}\text { Монолог Гамлета (акт I, сц<ена > 4) } & 89 & 78 & (\mathrm{II}=\mathrm{I2} \%) \\ ---\|-- \text { Призрака (I, 5) } & 230 & \text { I77 } & (53=23 \%) \\ ---\|-- \text { Актера (III, 2) } & \text { I54 } & \text { II } 8 & (36=23 \%) \\ & 473 & 373 & (\mathrm{IOO}=2 \mathrm{I} \%)\end{array}$

При этом любопытно отметить, что при переводе прозаических частей потери весьма невелики. Так, в монологе Гамлета (акт II, сц<ена> 2) IIO словам оригинала соответствует го5 слов перевода; в приветствии Гамлета актерам (акт II, сц<ена> 2) в оригинале 76 слов, в переводе 72. Из этого следует, что Пастернак плохо справляется с задачей вместить слова английской стихотворной строки в соответственную русскую. Задача эта трудна, так как английские слова короче русских (хотя в английской фразе очень много пояснительных и соединительных частиц, вспомогательных глаголов и артиклей, которые в переводе не нуждаются), - но вполне разрешима, что я докажу ниже конкретными примерами.

Если, однако, от механического подсчета мы перейдем к прямому сопоставлению текстов, то увидим картину несравненно более печальную. Потери шекспировского текста не только количественные, но и качественные. Смысл обедняется и искажается крайне приблизительной его передачей и прямыми отсебятинами.

Возьмем Пролог к «Ромео и Джульетте». Вот его английский текст:

Two households, both alike in dignity,

In fair Verona, where we lay our scene,

From ancient grudge break to new mutiny,

Where civil blood makes civil hands unclean.

From forth the fatal loins of these two foes

A pair of star-cross'd lovers take their life; 
Whose misadventured piteous overthrows

Doth with their death bury their parents' strife.

The fearful passage of their death-mark'd love,

And the continuance of their parents' rage,

Which, but their children's end, nought could remove,

Is now the two hours' traffic of our stage;

The which if you with patient ears attend,

What here shall miss, our toil shall strive to mend.

Вот его дословный перевод (нарочито грубый, без всякой заботы об изяществе):

Две семьи, обе равные по знатности,

В прекрасной Вероне, где происходит наше действие,

От старинной распри прокладывают дорогу к новым смутам,

Где кровь граждан делает руки граждан нечистыми.

Из роковых чрез ${ }^{21}$ этих двух врагов

Пара скрещеннозвездных ${ }^{22}$ любовников обрела свою жизнь,

Чья несчастная жалостная гибель

Должна, с их смертью, похоронить раздор их родителей.

Страшный путь этой, клейменной смертью, любви

И упорство ярости их родителей,

Которую успокоит лишь конец (гибель) их детей,

В течение этих двух часов предстанут на наших подмостках.

Если вы будете сопровождать (это действие) терпеливым слухом,

То возможные промахи наш труд (старание) попытается исправить.

Пролог этот произносит «Хор» - специальный персонаж старинных английских трупп, представлявший всю труппу и испрашивавший у публики снисхождения.

Вот перевод Пастернака:

2I Так в тексте. Следует: чресл.

22 Неверное толкование, которого Шенгели придерживается и далее (см.): переведенное дословно "star-crossed" означает несчастливого человека («кому не благоволят звезды»); следовательно, "star-cross'd lovers" - «несчастные влюбленные». 
Две равно уважаемых семьи

В Вероне, где встречают нас событья,

Ведут междоусобные бои

И не хотят унять кровопролитья.

Друг друга любят дети главарей,

Но им судьба подстраивает козни,

И гибель их у гробовых дверей

Кладет конец непримиримой розни.

Их жизнь и страсть, и смерти торжество,

И поздний мир родни на их могиле

На два часа составят существо

Разыгрываемой пред вами были.

Помилостивей к слабостям пера.

Грехи поэта выправит игра.

Нетрудно видеть, что перед нами не перевод, а лишь пересказ текста, где передан лишь «общий смысл», т. е. смысловой костяк, лишенный художественной плоти. Рассмотрим этот пересказ строка за строкой.

«Две равно уважаемых семьи» - в оригинале не то: там говорится о равных по знатности, по достоинству; их, может быть, вовсе и не уважают (в первой же сцене I акта, когда приверженцы обоих семейств дерутся, выбегают горожане с дубинами и кричат: «Бей Монтекки, бей Капулетти», какое уж тут «уважение»! С одинаковым правом переводчик мог бы сказать «две равно презираемых семьи»).

«В Вероне, где встречают нас событья», - пропущено «в прекрасной Вероне», - характерный штрих, подчеркивающий нелепость кровавых раздоров.

«Ведут междоусобные бои» - исчезло указание на длительность раздоров («старинная распря» - «новые смуты»); затем, выражение «междоусобные бои» неупотребительно: бывают междоусобные раздоры, войны и пр., но не конкретные схватки; так по-русски не говорят; в-третьих, слово «междоусобный» относится к враждебным действиям внутри коллектива, племени, государства и пр.; но две различные, противостоящие семьи не могут вести «междоусобную» борьбу; они борются между собой, но это не есть междоусобье, так же, как нельзя назвать междоусобьем войну Франции и Пруссии. 
«И не хотят унять кровопролитья» - почти полная отсебятина, где исчезло указание на социальный резонанс раздоров («кровь граждан»), исчезло осуждение («грязнит руки»). Затем здесь опять плохой русский язык: унять можно лишь такой процесс, в котором унимающий не участвует: дети поссорились, и отец их унял; но тот, кто сам участвует в ссоре или драке, не может ее унять, а может лишь прекратить. Кроме того, хотя это мелочь, родительный падеж «кровопролитья» здесь неуместен, так как отрицательная частица «не», требующая родительного падежа, стоит не при непосредственно управляющем глаголе, а при втором; Пушкин говорил, что в таких случаях электрическая сила» отрицательной частицы не доходит до существительного ${ }^{23}$.

«Друг друга любят дети главарей» - крайняя приблизительность: исчезли «роковые чресла», - указание на глубокую кровную связь любовников с их семьями, которую преодолевает любовь, указание на рок, несущий им гибель. И опять плохой русский язык: у семей бывают не главари, а главы; главари бывают у банд.

«Но им судьба подстраивает козни» - очень приблизительная передача смысла: исчезло указание на происхождение любовников, на «скрестившиеся звезды» - характерная астрологическая трактовка «судьбы». Вдобавок «подстраивать козни» - это нечто мелкое, подленькое, а речь идет о грозном и неумолимом роке.

«И гибель их у гробовых дверей» - крайне слабо и «от себя»: исчезли эпитеты «несчастная, жалостная гибель», зато появились «гробовые двери», которых в оригинале нет. Кроме того, в пьесе Ромео и Джульетта погибают внутри гробницы, а «у дверей» - без особой оговорки - по-русски означает всегда снаружи (ср.: «Как челобитчик у дверей Ему не внемлющих судей»²4).

«Кладет конец непримиримой розни» - исчезло острое сопоставление: «с их смертью похоронить раздор».

«Их жизнь и страсть, и смерти торжество» - это несравненно беднее, чем «страшный путь их клейменной смертью любви»: из пяти шекспировских слов осталось только одно, а образ исчез совсем.

23 Имеется в виду один из фрагментов критической прозы, обычно объединяемых под заглавием «<Опровержение на критики>» (см., например: [9, с. I47]).

24 Из поэмы «Медный всадник» (І833). 
«И поздний мир родни на их могиле» - опять не то: речь идет о неукротимости вражды, прекращенной лишь смертью, а не только о мире на могиле. Всё стерто.

«На два часа составят существо Разыгрываемой пред вами были» почти полная отсебятина и невнятица: Что это за «существо были»? Что это за «разыгрываемая быль»? ведь это и небылица! Опять дурное знание русского языка, его лексических возможностей. Вдобавок исчезло указание на «подмостки» - грустное противопоставление подлинной трагедии - игре.

«Помилостивей к слабостям пера» - ни о каких «слабостях пера» в оригинале не говорится, равно как и о «грехах поэта» (см. след<ующую> строку); это чистая выдумка переводчика. Вдобавок «Хор» почтительно и приниженно просит зрителей о внимании; а вместо этого переводчик дает отрывистую повелительную интонацию: «Помилостивей!..»

«Грехи поэта выправит игра» - ничего подобного! Актеры просто обещают стараньем (а не игрою) скрасить свое неуменье (играть). Обычный прием самоумаленья.

Таким образом, перед нами - довольно слабая работа, и Шекспира - с его образами и формулировками - в ней почти нет.

Могут сказать: «критиковать легко, а вот сделайте!» Исключительно в целях иллюстрации я и попытаюсь «сделать». Вот:

Два рода, равно знатные, в прекрасной

Вероне, где все действия пройдут,

В исконной распре ищут новых смут, -

И руки граждан кровью граждан красны.

Из рокового лона тех врагов

По воле звезд взросла чета влюбленных,

Несчастной жалкой гибелью сраженных,

Чтоб с ними в гроб сошел раздор отцов.

Любви, клейменной смертью, путь ужасный,

Настойчивость отцов, чьей злобе страстной

Лишь смерть детей поставила предел,

За два часа на сцене мы представим.

Я б испросить внимания посмел:

Мы промахи - старанием исправим. 
Здесь, правда, чередование рифм иное, чем в оригинале; но, думается, что лучше жертвовать порядком рифм, чем смыслом и образом.

Рассмотрим перевод другого отрывка, иной стилистической природы. Возьмем начало монолога Меркуцио о фее Мэб (акт I, сц<ена> 4). Вот английский текст первых I4 строк:

O, then, I see Queen Mab hath been with you.

She is the fairies' midwife, and she comes

In shape no bigger than an agate-stone

On the fore-finger of an alderman,

Drawn with a team of little atomies

Athwart men's noses as they lie asleep;

Her wagon-spokes made of long spiders' ${ }^{25}$ legs,

The cover of the wings of grasshoppers,

The traces of the smallest spider's web,

The collars of the moonshine's watery beams,

Her whip of cricket's bone, the lash of film,

Her wagoner a small grey-coated gnat,

Not $<$ half $>$ so big as a round little worm

Prick'd from the lazy finger of a maid.

Стих здесь белый, так что переводчик не стеснен рифмой; фраза представляет собою перечень особенностей упряжки и всего выезда феи Мэб, так что синтаксических сложностей не содержит. Вот дословный перевод:

О, тогда, я вижу, королева Мэб была с вами.

Она средь фей повитуха, и она является

В образе не больше чем камень-агат

На указательном пальце олдермена,

Влекомая упряжкой из крошечных пылинок

По носам людей, когда они лежат спящими;

Спицы ее кареты из длинных ног косарика (род паука); 
Верх (ее кареты) из крылышек кузнечика;

Постромки из тончайшей паутины;

Хомуты из влажных лунных лучей;

Ее кнут из членика сверчка; хлыст из паутинки (летающей $)^{26}$;

Ее кучер маленький в серой куртке комар,

Вполовину не такой большой, как маленький круглый червь,

Выковыриваемый из-под ленивого ногтя (досл<овно> пальца) молочницы... ${ }^{27}$

\section{Вот перевод Пастернака:}

Ну, это королевы Мэб проказы.

Она родоприемница у фей

И по размерам с камушек агата

В кольце у мэра. По ночам она

На шестерне пылинок цугом ездит

Вдоль по носам у нас, пока мы спим.

Из лапок паука в колесах спицы,

Каретный верх из крыльев саранчи,

Ремни гужей из ниток паутины

И хомуты из капелек росы.

На кость сверчка накручен хлыст из пены.

Комар на козлах ростом с червячка

Из тех, которые от сонной лени

Заводятся в ногтях у мастериц...

Несомненно, что этот отрывок переведен значительно более точно, чем Пролог, но, тем не менее, и в нем есть ряд ляпсусов, многое непонято, и многое сказано не совсем по-русски.

Разберем.

26 Точнее - из тонкой нити.

27 Очевидно, некорректный перевод слова "maid" как «молочница» повлек за собой совершенно неверное толкование строки (см. далее). Дословно: «Вытаскиваемый иглой из ленивого пальца служанки (девушки)»; согласно старинному поверью, мелкие паразиты иногда ютились в плоти лентяев [г, р. І22]. 
«Она родоприемница у фей». - Неверно: фея Мэб ни в одном сказании не выступает в качестве акушерки при феях (которые, к слову сказать, не рожают); она зато нередко присутствует при человеческих родах, подменяя данного ребенка другим; поэтому-то она «повитуха средь фей». Переводчик не ознакомился с нужными материалами и допустил грубый промах ${ }^{28}$.

«С камушек агата» - во-первых, не по-русски: мы не говорим «с камушек алмаза» и т. п., так как «камушек» не есть мера; можно сказать «с кусочек агата», «с капельку воды» и пр., но не иначе; во-вторых, агат сам по себе, как малоценный камень, нехарактерен в качестве украшения, но зато часто употребляется для вырезания печатей, и именно такая печать, вделанная в перстень, здесь имеется в виду; переводчику следовало бы именно здесь отойти от дословности и раскрыть внутренний смысл образа: на печатях часто вырезались геральдические фигурки, и с ними-то по величине сравнивается Мэб.

«Из лапок паука в колесах спицы» - во-первых, опущено, что паук - косарик, с очень длинными тоненькими ножками: у многих пауков ноги мохнатые и отвратительные, так что здесь это уточнение необходимо; во-вторых - не по-русски: «лапа» никогда не говорится по отношению к конечностям насекомых (у Даля сказано: «лапа - ступня с пальцами у четвероногих и птиц... у волка, черепахи и гуся - лапы, у коня - нога, у таракана - ножки...»).

«Каретный верх из крыльев саранчи» - в оригинале - кузнечика; хотя саранча весьма близка к кузнечику, и крылышки у нее такие же прозрачные, но с саранчой у нас прочно ассоциировано неприятное представление о прожорливом и вредном насекомом; таким образом, переводчик здесь явно сфальшивил.

«Ремни гужей из ниток паутины» - опять не по-русски: ремень есть ремень: длинная полоска кожи, и, как кожа, не может быть из паутины, даже в сказке. Почему было не сказать: «гужи из паутины»?

«И хомуты из капелек росы» - совсем не то, что в оригинале.

«На кость сверчка накручен хлыст из пены» - абсолютная путаница. В оригинале, во-первых, имеются в виду два кучерских орудия: бич, состоя-

28 Согласно другой легенде, на которую, возможно, опирается версия Пастернака, Мэб принимала сны, рождаемые воображением спящих людей. 
щий из палки с ремнем, и хлыст, состоящий из гибкого прута; «английский выезд» до сих пор, хотя уже давно не ездят цугом, включает в свой «инструментарий» бич и хлыст. Во-вторых - как это «накручен хлыст»? Это ничего не значит. В-третьих - откуда у сверчка «кость»? Правда, в оригинале сказано bone, кость; но, конечно, имеется в виду жесткая коленчатая ножка сверчка, «бряиальще», видом похожая на бич. И наконец - «хлыст из пеньъ; переводчик спутал film и foam.

«Комар на козлах ростом с червячка» - пропало «в серой куртке».

«Заводятся в ногтях у мастериц» - всё неверно и непонято. Прежде всего, «в ногтях» едва ли что может «заводиться»; может «под ногтями»; затем, в оригинале сказано не «мастерицы», а «молочницы», и это важно: речь идет о ленивых и неопрятных молочницах, у которых под ногтями скопляются молочные катыши, похожие на червячков («круглых»), выковыриваемые чем-нибудь.

Мы видим, что и этот легкий отрывок страдает в переводе неточностями и погрешностями против русского языка и здравого смысла.

«Критиковать легко, а вот сделайте»... Попробуем сделать:

Ах, так. Видать, ты встретил фею Мэб.

Она средь фей за повитуху. Меньше

Агатовой печати в перстне мэра,

Она летит по переносьям спящих,

В карете, где запряжены пылинки,

Где спицы из косариковых ног,

Где легкий верх из крылышек цикады,

Постромки из тончайшей паутины,

И хомуты из влажных лунных блесков.

Там бич - из плечика сверчка; хлыст - усик,

А кучером - комарик в серой куртке:

Он вдвое меньше круглых червячков,

Что выковыривает из-под ногтя

Ленивая молочница...

В дальнейших строках этого отрывка мы видим у переводчика и другие промахи. Карета Мэб названа «возком», тогда как по-русски возок 
всегда - «крытый экипаж на полозъях» (словарь Ушакова) ${ }^{29}$. Мэб мчится «По мозгам влюбленных» - и (как следствие этого) им снится любовь; у Пастернака же сказано: «Она пересекает по ночам Мозг любящих, которым снится нежность» (?). Она мчится «по коленям придворных, и им немедленно снятся поклоны ${ }^{30}$; у Пастернака вместо этого «(она пересекает) горбы вельмож, которым снится двор» (??). Дальше: Мэб порою щекочет «щетинкой свиньи, полученной как церковная десятина, в носу у священника, и ему начинает грезиться еще одна бенефиция», - у Пастернака так: «Щетинкой под ноздрею пощекочет У пастора, и тот увидит сон Про перевод в другое благочинье» (???) - и т. д.

Рассмотрим перевод диалога Ромео и Джульетты (акт I, сц<ена > 5), - одного из блестящих образчиков «изысканного стиля», полного острословий (concetti). Ромео и Джульетта, в масках и в костюмах монаха и монахини, танцуют и фехтуют словами. Вот английский текст:

Romeo

If I profane with my unworthiest hand

This holy shrine, the gentle fine is this:

My lips, two blushing pilgrims, ready stand

To smooth that rough touch with a tender kiss.

Juliet

Good pilgrim, you do wrong your hand too much,

Which mannerly devotion shows in this;

For saints have hands that pilgrims' hands do touch,

And palm to palm is holy palmers' kiss.

Romeo

Have not saints lips, and holy palmers too?

Juliet

Ay, pilgrim, lips that they must use in prayer.

Romeo

O, then, dear saint, let lips do what hands do;

They pray, grant thou, lest faith turn to despair.

29 В оригинале "chariot” (колесница).

30 Точнее - реверансы (courtesies). 
Juliet

Saints do not move, though grant for prayers' sake.

Romeo

Then move not, while my prayer's effect I take.

Thus from my lips, by yours, my sin is purged.

\section{Вот дословный перевод:}

POМ.: Если я осквернил моей недостойнейшей рукой

Этот священный алтарь (перед этим он стиснул ей руку и обнял ее), то кроткое искупление греха вот:

Мои губы, два краснеющих пилигрима, находятся в готовности

Смягчить это грубое прикосновение нежным поцелуем.

ДЖ.: Добрый пилигрим, вы слишком обижаете ваши рукизг,

Которые этим (прикосновением) показали лишь вежливую набожность,

Ибо святые (т. е. угодницы, монахини) ${ }^{32}$ имеют руки, которых касаются (вправе касаться) руки пилигримов,

И ладонь к ладони (т. е. прикосновение) вот благочестивый поцелуй паломника.

POM.: Разве у святых нет губ и у благочестивых паломников тоже?

ДЖ.: Да, пилигрим, - губы, которые должны употребляться для молитв.

POМ.: О, тогда, милая святая, позволь губам сделать то, что сделали руки.

Они молят: уступиз3, чтобы вера не превратилась в отчаяние.

ДЖ.: Праведницы не шелохнутся, даже ради молитвы ${ }^{34}$.

POМ.: Так не шевелись, пока мои молитвы я не сделаю осуществленными ${ }^{35}$.

Таким образом с моих губ твоими снят (очищен) мой грех.

(Целует ее.)

3I В оригинале единственное число.

32 Интерпретация Шенгели (см. далее); в оригинале просто “saints".

33 С учетом следующего стиха точнее было бы «внемли».

34 Неточность Шенгели; буквально: «Святые недвижны, хотя внемлют молитвам», здесь обыгрывается переносное значение оборота "do not move" - «не поддаются», а в следующем стихе Ромео повторяет его в основном значении [16, p. I3г].

35 Вновь неточность; буквально: «пока результат (эффект от) моей молитвы я не заберу». 
Пастернак переводит этот диалог следующим образом:

РОМ.: Я ваших рук рукой коснулся грубой. Чтоб смыть кощунство, я даю обет: К угоднице спаломничают губы И зацелуют святотатства след.

ДЖ.: Святой отец, пожатье рук законно. Пожатье рук естественный привет. Паломники святыням бьют поклоны, Прикладываться надобности нет.

РОМ.: Однако губы нам даны на что-то?

ДЖ.: Святой отец, молитвы воссылать.

РОМ.: Так вот молитва: дайте им работу. Склоните слух ко мне, святая мать.

ДЖ.: Склоненье слуха не склоняет стана.

POМ.: Не надо наклоняться, сам достану. (Целует ее.) Вот с губ моих весь грех теперь и снят.

Перед нами опять отдаленный и грубый пересказ, где, во-первых, совершенно не отражена манера жеманного, куртуазного ухаживания, во-вторых, даны некоторые нелепые формулы, в-третьих, опять проявлено недостаточное знание русского языка.

Характерные для «монаха» и «монахини» выражения: «осквернил», «недостойнейшей рукой», «священный алтарь», «кроткое искупление», «вежливая набожность», «благочестивый поцелуй» и пр., - всё это исчезло в переводе полностью. Всмотримся в первую фразу Ромео; она полна противоречий: он дает обет, что его губы «спаломничают» и зацелуют след (?) святотатства; однако обет предполагает некое твердое решение, приводимое в исполнение; на самом же деле Ромео вовсе не знает, разрешит ли Джульетта себя поцеловать; в оригинале он лишь робко намекает на эту возможность: «вот кроткое искупление; мои губы, краснеющие (т. е. стыдящиеся) паломники, готовы» и т. д.; затем: он «коснулся рук», целовать же он будет, очевидно, в губы; как же он сможет зацеловать след святотатства, т. е. своего прикосновения? ведь он не за губы же схватил Джульетту? И, наконец, кощунство по-русски совсем не то же, что святотатство: святотатство 
есть кража священного предмета ${ }^{36}$ (см. Номоканон, статья 50), а кощунство есть осквернение священного предмета. Затем, неологизм «спаломничать» носит совершенно жаргонный, школьный колорит, вроде «словчиться», «смотаться» («он смотался из школы») и абсолютно неуместен в данном тексте.

Еще хуже обстоит дело с первой репликой Джульетты. Помимо того, что она почти сплошь выдумана переводчиком, она нелепа. Ромео хочет поцеловать Джульетту, «угодницу», «святую мать»; она же отклоняет его пожелание: «Паломники святыням бьют поклоны, Прикладываться надобности нет». Прежде всего, никогда и ни при каких условиях ни один монах, епископ, апостол не назовет себя святым, а тем более святыней. Это абсолютный вздор, полная безграмотность. А затем, почему «нет надобности» прикладываться к святыням? Всегда и всюду к «святыням» именно прикладываются, а не только бьют перед ними поклоны.

Пропустим дальнейшие строчки, крайне загрубленные по интонации («губы даны нам на что-то?», «дайте им работу») и представляющие собою на три четверти отсебятину (исчезло тонкое «чтобы моя вера не превратилась в отчаяние»); посмотрим на финал. Джульетта говорит (хоть у Шекспира этого и нету): «Склоненье слуха не склоняет стана»; что здесь разумеется? То, что она, хоть и готова слушать, но не склонит стан, не поникнет в объятия Ромео. Но Ромео говорит в ответ: «Не надо наклоняться, сам достану» - и выходит, что Джульетта на голову выше Ромео, что ему приходится становиться на цыпочки, чтобы дотянуться до губ Джульетты!! Просто поразительно, как переводчик не видит того, что изображает словами. Из игры слов получилась нелепость и бессмыслица.

Что же «достигнуто» в переводе этого отрывка? Только то, что четные строки первой реплики Ромео и первой реплики Джульетты зарифмованы одинаково: обет-след-привет-нет; почти как у Шекспира, где в этих строках созвучны одни и те же слова: this и kiss. Надо признать, что достижение небольшое. Тем более, что исчезли чудесные звуковые повторы восьмой строки (palm-palm-palmer).

36 Шенгели не вполне справедлив, исходя из первоначальных значений «святотатства» и «кощунства», которые строго различались в русском праве до І9І7 г. К моменту возникновения перевода «святотатство» означало уже только осквернение святыни, а «кощунство»насмешку, неуважение к святыне. 
И опять я позволю себе в ответ на возможное возражение: «критиковать легко, а вот сделать» - сделать. Вот:

POMEO:

Коль осквернил я недостойной дланью

Святыню, - грех смиренно искуплю я:

Уста-паломники полны желанья

За грубость рук дать нежность поцелуя.

ДЖУЛЬЕТТА:

Честной чернец, вы строги нестерпимо:

В касаньях рук лишь набожность ловлю я;

Святой коснуться - право пилигрима,

Ладонь в ладонь - замена поцелуя.

POMEO:

Но чернецам даны уста не всем ли? ДЖУЛЬЕТТА:

Да, пилигрим, но только для моленья.

POMEO:

Тогда, святая, их моленью внемли

И дай свои, чтоб я не впал в сомненье. ДЖУЛЬЕТТА:

И вняв мольбам, не двинется черница. POMEO:

Не двигайся ж, чтоб им осуществиться. (Целует ее.)

Вот с губ моих твоими смыт мой грех...

Перейдем теперь к «Гамлету». Чтобы не затягивать разбор, который уже приобрел доказательные формы, я ограничусь лишь знаменитым монологом «Быть или не быть» (акт III, сцена I). Вот английский текст:

To be, or not to be! that is the question:

Whether 'tis nobler in the mind to suffer

The slings and arrows of outrageous fortune,

Or to take arms against a sea of troubles, 
And by opposing end them? To die: to sleep;

No more; and by a sleep to say we end

The heart-ache and the thousand natural shocks

That flesh is heir to, 'tis a consummation

Devoutly to be wish'd. To die, to sleep;

To sleep: perchance to dream: ay, there's the rub;

For in that sleep of death what dreams may come

When we have shuffled off this mortal coil,

Must give us pause: there's the respect

That makes calamity of so long life;

For who would bear the whips and scorns of time,

The oppressor's wrong, the proud man's contumely,

The pangs of despised love, the law's delay,

The insolence of office and the spurns

That patient merit of the unworthy takes,

When he himself might his quietus make

With a bare bodkin?

Вот дословный перевод:

Быть или не быть! Это вопрос -

Что благороднее для души: сносить (терпеть)

Пращи и стрелы неистовой (или: оскорбительной) судьбы

Или поднять оружие против моря несчастий

И, восстав, покончить с ними. - Умереть - уснуть,

Не больше. И, благодаря сну, сказать, что мы покончили

С болью сердца, с тысячью естественных ударов,

Что унаследовала плоть, - вот завершение,

Которого благоговейно можно желать. Умереть, - уснуть, -

Уснуть! И, может быть, грезить (видеть сны)? Да, здесь затруднение.

Ибо в этом смертном сне какие могут прийти грезы,

Когда мы сбросили с себя земную суету, -

Над этим мы должны помедлить (в смысле: задуматься). Здесь то основание, Что создает бедствия столь долгой жизни.

Ибо - кто захотел бы сносить бичи и презрение времени, 
Обиды насильника, поношение гордеца,

Страдания осмеянной любви, медлительность закона,

Наглость властей (досл.: учреждений) и пинки,

Заслуженные терпением (или: достоинством) от недостойных деяний,

Когда каждый сам мог бы создать себе покой

С помощью простого шила?..

Этот ответственнейший текст, переведенный, несомненно, с максимальной тщательностью, Пастернак передает так:

Быть иль не быть, вот в чем вопрос. Достойно ль

Души терпеть удары и щелчки

Обидчицы судьбы, иль лучше встретить

С оружьем море бед и положить

Конец волненьям? Умереть. Забыться.

И всё. И знать, что этот сон - предел

Сердечных мук и тысячи лишений,

Присущих телу. Это ли не цель

Желанная? Скончаться. Сном забыться.

Уснуть. И видеть сны? Вот и ответ.

Какие сны в том смертном сне приснятся,

Когда покров земного чувства снят?

Вот объясненье. Вот что удлиняет

Несчастьям нашим жизнь на много лет.

А то кто снес бы униженья века,

Позор гоненья, выходки глупца,

Отринутую страсть, молчанье права,

Надменность власть имущих и судьбу

Больших заслуг перед судом ничтожеств,

Когда так просто сводит все концы

Удар кинжала?..

Нетрудно видеть, что перевод весьма снижен и «затусклен» по сравнению с оригиналом. 
Прежде всего, сомнительно, надо ли переводить первую же фразy (to be, or not to be!) выражением «быть или не быть?»; речь идет не о бытии (которое для Гамлета не прекращается после смерти: он верит в загробную жизнь, поскольку страшится «видений в смертном сне»), а о земной жизни. Поэтому правильней было бы сказать «жить иль не жить»; это было бы более четко философски и не вступало бы в противоречие с дальнейшим. Впрочем, я на этом не настаиваю, так как большинство прежних переводчиков переводили так же, и это выражение приобрело даже характер поговорки. Далее, «вот в чем вопрос» относится не к этой формуле (которая в оригинале даже не в вопросительной форме, а в утвердительной, с восклицательным знаком), а к дальнейшему: «вопрос: достойно ли души переносить и пр.» Это - весьма существенная и недопустимая ретушь смысла и эмоции.

Далее идет ряд снижений и неточностей.

В оригинале «пращи и стрелы» - в переводе «удары и щелчки»; это мелковато для Гамлета, говорящего о судьбе. У Пастернака судьба названа «обидчицей»; в оригинале стоит outrageous, что означает «оскорбительный», но также «яростный», «неистовый», и уж, конечно, надо было остановиться на одном из этих определений, говорящих об ожесточенности и упорстве злобного рока.

В оригинале «поднять оружие против...» - в переводе «встретить с оружьем»; мятежная активность заменена «оборончеством».

В оригинале: «и, восстав, покончить» - в переводе просто «положить конец»; «восстав» пропущено; опять «смягчение».

Дальше существенная неточность. В оригинале «Умереть - уснуть», т. е. «как бы уснуть»: сопоставление двух сходных моментов; намек на то, что умереть - не страшно. В переводе почему-то «забыться»; забыться можно и наяву, и напившись вина и пр.; это слово никак «не играет» рядом с «умереть».

В оригинале «тысяча ударов» - в переводе «тысяча лишений»: гораздо слабее; пропущено «естественных». В оригинале «унаследовала плоть» - в переводе «присущих телу»; опять слабее, так как стерт момент преемственности.

В оригинале «завершение, которого благоговейно можно желать» в переводе просто «цель желанная»; исчезло «завершение», исчезло «благоговейно». 
В оригинале далее повторение, усиленное и подчеркнутое переносом дважды сказанного слова в другую строку: «умереть - уснуть. Уснуть». В переводе это стерлось: «скончаться. Сном забыться. Уснуть», - не говоря о том, что слово «скончаться», окрашенное официальным колоритом, тоном объявлений о смерти и некрологов, никак не заменяет слова «умереть».

В оригинале «здесь затруднение» - в переводе почему-то: «вот и ответ» (на неизвестно какой вопрос).

В оригинале «в этом смертном сне какие могут прийти грезы» - в переводе «какие сны в том смертном сне приснятся» - три раза «сон» и пять раз звук «с»: вся строка свистит.

В оригинале «когда мы сбросим земную суету» - в переводе «когда покров земного чувства снят»; что это за «покров чувства»? если снимают покров, то нечто под ним скрытое становится явным, - выходит, что либо само «земное чувство», либо что-то, находящееся под ним (а что - неизвестно), предстанет взорам. И еще: «снят», а не «сброшен»; снова притупление активности (ведь речь идет об акте самоубийства).

В оригинале: «над этим должно задуматься» - в переводе никакой задумчивости нет, всё ясно: «вот объясненье».

В оригинале «создает бедствия столь долгой жизни» - в переводе всё переставлено: «вот что удлиняет несчастьям жизнь», - совсем не то.

В оригинале «бичи и презрение времени» - в переводе мягко и просто «униженья века»; у Шекспира речь идет о беспощадном, всё уносящем времени, а у Пастернака - неизвестно о чем, так как слово «век» в его контексте и подобных означает всегда современность («загадка века», «достижения века» - всегда означает «нашего века»).

В оригинале «обиды насильника» - в переводе «позор гоненья» и слабо, и не очень осмысленно, так как гоненье не является позором для гонимого.

В оригинале «поношения гордеца» - в переводе «выходки глупца» - опять не то; выходки глупца могут быть и забавными.

В оригинале «медлительность закона» - в переводе «молчанье права»; совсем не то: я могу обладать правом и не осуществлять его по собственному желанию; оно будет «молчать», но в этом ничего предосудительного нет; но «медлительный закон», не дающий осуществить право, действительно, есть зло. 
В оригинале «пинки, заслуженные терпеньем от недостойных» горькая ирония: «пинки» - «заслуженные» - в переводе вязкое и вялое: «судьбу больших заслуг перед судом ничтожеств».

В оригинале «каждый мог бы создать покой» - в переводе «сводит все концы» - опять стирание активности; кроме того, выражение «сводить концы» - не русское: у нас «сводят счеты», «подводят итоги», но не иначе; сводят лишь «концы с концами», но смысл этого иной.

В оригинале «простое шило» - в переводе пышный «удар кинжала»; ненужное украшательство.

Мы видим, что даже в этом отрывке нет почти ни одной строки, которая не вызывала бы сомнения, досады или прямого протеста.

Можно ли сделать точнее? Можно. Вот:

Жить иль не жить! И вот вопрос: что выше,

Что благородней для души - терпеть

Пращу и стрелы яростного рока

Или поднять на море бед оружье

И, в бунте, кончить? Умереть - уснуть,

Не больше... И сказать, что сном покончил

С душевной болью, с тысячью ударов, -

Наследьем плоти. Вот какой развязки

Молить должны мы. Умереть - уснуть -

Уснуть! И, может, грезить... Вот препона;

Не зная, что за грезы в смертном сне

Придут к стряхнувшим суету земную, -

Мы вынуждены медлить. Вот причина

Того, что жизнь мы, хоть в терзаньях, длим.

Ведь кто б сносил годов бичи и хохот,

Обиды властных, гордецов презренье,

Боль презренной любви, законов косность,

Чинушей наглость и пинки, какие

Достоинству ничтожество дарит, -

Когда легко б снискать покой могли мы

Обычным шилом?.. 
На этом можно остановиться и не утруждать себя и читателя показом множества других мелких и крупных промахов, рассеянных в переводах Пастернака, - неприятные русизмы, вроде «Гуси, гуси, домой - волк за горой» («Гамлет», акт IV, сц. 2), тогда как в оригинале: «Беги, лиса, и все за ней», плеоназмы, вроде «разорившийся банкрот» («Ромео и Дж<ульетта>», акт III, сц. 2), тогда как в оригинале «бедный банкрот» (в сожалительном значении) - и банкроты не бывают неразорившимися; непонятные тонкости, например, - замена выражения аqua vitae словом «наливка» («Ромео», акт III, сц. 2; смысл в том, что огорченная кормилица требует лекарства, которое в то же время является водкой; Шекспир нарочно дает латинский, аптечный, термин), - и т. д., и т. п.

Мы видим, что работа Пастернака отнюдь не находится на уровне раздавшихся вокруг нее похвал. И следовательно - смотри вступление.

Теперь посмотрим, как переводят англичане русских поэтов. Вот перевод 46 строфы VIII главы «Евгения Онегина», исполненный Бабеттой Дэтш (цитирую по Moscow Daily News, го февр<аля> I937 г.), причем переводчица отнюдь не «первый поэт Англии».

Вот английский текст и его дословный перевод:

To me, Onegin, all these splendors,

The tinsel of unwelcome days,

The homage that the gay world tenders,

My handsome house and my soirees -

To me all this is naught. This minute

I'd give my house and all that's in it,

This giddy play in fancy-dress

For a few books, a wilderness

Of flowers, for our modest dwelling,

The scene where first I saw your face,

Onegin, that familiar place,

And for the simple churchyard, telling

Its tale of humble lives, where now

My poor nurse sleeps beneath the bough. 
Для меня, Онегин, всё это великолепие,

Мишура несносных дней,

Преклонение, которым дарит меня веселый свет,

Мой изящный дом и мои вечера -

Для меня всё это ничтожно. В эту же минуту

Я отдала б мой дом и всё, что в нем,

Эту головокружительную игру в маскарадных костюмах,

За несколько книг, за дикие заросли

Цветов, за наше скромное жилище,

За место, где я впервые увидела ваше лицо,

Онегин, - это родное место,

И за простое кладбище, рассказывающее

Свои предания о тихой жизни, - где теперь

Моя бедная няня спит под ветвями.

А вот текст Пушкина:

А мне, Онегин, пышность эта,

Постылой жизни мишура,

Мои успехи в вихре света,

Мой модный дом и вечера -

Что в них? Сейчас отдать я рада

Всю эту ветошь маскарада,

Весь этот блеск, и шум, и чад

За полку книг, за дикий сад,

За наше бедное жилище,

За те места, где в первый раз,

Онегин, видела я вас,

Да за смиренное кладбище,

Где нынче крест и тень ветвей

Над бедной нянею моей.

Перевод блистательный. Всё поэтическое содержание полностью донесено до читателя. Более того: сохранена конструкция фразы и связанная с нею интонация, почти полностью воспроизведен ритмический рисунок 
строфы, - и это при условии полного сохранения женской рифмы, столь трудной для английского стиха.

Производственные и политические выводы напрашиваются сами собой.

\section{ГЕОРГИЙ ШЕНГЕЛИ}

\section{Список литературы}

I Азов А.Г. Поверженные буквалисты: Из истории художественного перевода в СССР в І920-I960-е годы. М.: Изд. дом Высшей школы экономики, 20I3. 304 C.

2 Б.Л. Пастернак: pro et contra: Борис Леонидович Пастернак в советской, эмигрантской, российской литературной критике. Антология. СПб.: Изд-во РХГА, 20I2. T. I. II36 c.

3 Байрон Д.Г. Дон-Жуан / пер., послесл. и примеч. Г. Шенгели. М.: ГИХЛ, І947. 572 c.

4 Байрон Д.Г. Собрание поэм / в пер. Г. Шенгели; вступ. ст. М. Заблудовского. М.: Гослитиздат, І940. Т. І. 304 с.

5 Ивинская О. В плену времени: Годы с Борисом Пастернаком. М., I972. 437 с.

6 Каганович Б.С. А.А. Смирнов и пастернаковские переводы Шекспира // Вопросы литературы. 20I3. № 2. С. 20-7I.

7 Молодяков В.Э. Георгий Шенгели: Биография / науч. ред. В.А. Резвый. М.: Водолей, 20I6. $6 \mathrm{I} 6$ с.

8 Пастернак Б.Л. Полное собрание сочинений: в II т. М.: СЛОВО/SLOVO, 2004. T. V: Статьи, рецензии, предисловия; Драматические произведения; Литературные и биографические анкеты; Неоконченные наброски; Стенограммы выступлений. 752 с.

9 Пушкин А.С. Полн. собр. соч.: в г6 т. М.; Л.: Изд-во АН СССР, І937-І959. Т. гі: Критика и публицистика, I8I9-I834. 600 с.

Iо Рудин из Брюсовского института: Письма Г.А. Шенгели М.M. Шкапской. I923I932 / публ. С. Шумихина // Минувшее: Исторический альманах. I5. М.; СПб., г994. С. 248-279.

II Шекспир B. Антоний и Клеопатра / пер. Б. Пастернака; ил. М.И. Пикова. М.: Гослитиздат, I944. 148 с.

I2 Шекспир В. Гамлет, принц Датский: Трагедия / пер. Б. Пастернака; примеч. М. Морозова; грав. на дереве В. Фаворского. М.: Гослитиздат, І94I. I72 с.

I3 Шекспир В. Отелло - венецианский мавр / пер. с англ. Б. Пастернака. М.: Гослитиздат, I945. I40 с.

I4 Шекспир В. Ромео и Джульетта / пер. с англ. Б. Пастернака; рис. Ф. Константинова. М.: Гослитиздат, І944. 128 с. 
I5 Шенгели Г.А. Иноходец: Собр. стихов; Повар базилевса: Византийская повесть; Литературные статьи; Воспоминания / изд. подг. В. Перельмутером. М.: Совпадение, I997. 544 c.

Shakespeare W. Romeo and Juliet / with introduction and notes by K. Deighton. London: Macmillan and Co., Ltd., I905. 216 p.

\section{References}

I Azov A.G. Poverzhennye bukvalisty: Iz istorii khudozhestvennogo perevoda $v$ SSSR $v$ I920-1960-e gody [The "bukvalists" defeated. From the history of literary translation in the USSR in the I920-I960-s]. Moscow, Izd. dom Vysshei shkoly ekonomiki Publ., 20I3. 304 p. (In Russ.)

2 B.L. Pasternak: pro et contra: Boris Leonidovich Pasternak v sovetskoi, emigrantskoi, rossiiskoi literaturnoi kritike. Antologiia [B.L. Pasternak: pro et contra. Boris Leonidovich Pasternak in the Soviet, immigrant, and Russian literary criticism. An Anthology]. St. Petersburg, Russia Christian Humanities Institute Publ., 20I2. Vol. I. II36 p. (In Russ.)

3 Bairon D.G. Don Zhuan [Don Juan], translation, afterword and commentary by G. Shengeli. Moscow, GIKhL Publ., I947. 572 p. (In Russ.)

4 Bairon D.G. Sobranie poem [A Collection of Lengthy Poems], translated by G. Shengeli, with introduction by M. Zabludovsky. Moscow, Goslitizdat publ., I940. Vol. I. 304 p. (In Russ.)

5 Ivinskaia O. V plenu vremeni: Gody s Borisom Pasternakom [In the captivity of time: Years with Boris Pasternak]. Moscow, I972. 437 p. (In Russ.)

6 Kaganovich B.S. A.A. Smirnov i pasternakovskie perevody Shekspira [A.A. Smirnov and Pasternak's translations of Shakespeare]. Voprosy literatury, 20I3, no 2, pp. 20-7I. (In Russ.)

7 Molodiakov V.E. Georgii Shengeli: Biografiia [Georgy Shengeli: Biography], science ed. V.A. Rezvy. Moscow, Vodoley Publ., 2016. 6I6 p. (In Russ.)

8 Pasternak B.L. Polnoe sobranie sochinenii: $v$ II $t$. [Complete Works: in II vol.] Moscow, SLOVO/SLOVO Publ., 2004. Vol. V: Stat'i, retsenzii, predisloviia; Dramaticheskie proizvedeniia; Literaturnye i biograficheskie ankety; Neokonchennye nabroski; Stenogrammy vystuplenii [Articles, reviews, prefaces; Dramatic work; Literary and biographical resumes; Unfinished sketches; Verbatim reports]. 752 p. (In Russ.) Pushkin A.S. Polnoe sobranie sochinenii: $v$ I6 t. [Complete works: in I6 vol.] Moscow; Leningrad, Izd-vo AN SSSR Publ., I937-I959. Vol. II. Kritika i publitsistika, I8I9I834 [Criticism and journalism, I8I9-I834]. 600 p. (In Russ.)

IO Rudin iz Briusovskogo instituta: Pis'ma G.A. Shengeli M.M. Shkapskoi. I923-I932 [A Rudin from Bryusov Institute: G. A. Shengeli’s letters to M. M. Shkapskaya. I923-I932], publ. by S. Shumikhin. Minuvshee: Istoricheskii al'manakh [The Bygone: historical annual]. I5. Moscow; St. Petersburg, I994, pp. 248-279. (In Russ.) 
II Shekspir V. Antonii i Kleopatra [Antony and Cleopatra], trans. B. Pasternak; illustrations M.I. Pikov. Moscow, Goslitizdat Publ., I944. I48 p. (In Russ.)

I2 Shekspir V. Gamlet, prints Datskii: Tragediia [Hamlet: Prince of Danmark], trans. B. Pasternak; comments. M. Morozov, engravings V. Favorskii. Moscow, Goslitizdat Publ., I94I. I72 p. (In Russ.)

I3 Shekspir V. Otello - venetsianskii mavr [The Tragedy of Othello, the Moor of Venice], trans. B. Pasternak. Moscow, Goslitizdat Publ., I945. I40 p. (In Russ.)

I4 Shekspir V. Romeo i Dzhul'etta [Romeo and Juliett], trans. B. Pasternak; illustrations F. Konstantinov. Moscow, Goslitizdat Publ., I944. I28 p. (In Russ.)

I5 Shengeli G.A. Inokhodets: Sobr. stikhov; Povar bazilevsa: Vizantiiskaia povest'; Literaturnye stat'i; Vospominaniia [The Pacer: A Collection of poem; A cook of Basileus; Bysantian novella; Memoirs], ed. V. Perel'muter. Moscow, Sovpadenie Publ., I997. 544 p. (In Russ.)

I6 Shakespeare W. Romeo and Juliet, with introduction and notes by K. Deighton. London, Macmillan and Co., Ltd., I905. 216 p. (In English) 
УДК 821.I6I.I

ББК $83.3(2 \mathrm{Poc}=\mathrm{Pyc})+85$
ИЛЛЮСТРАТИВНЫЕ МАТЕРИАЛЫ

В БИОГРАФИЧЕСКИХ ИССЛЕДОВАНИЯХ

(ИЗ ОПЫТА ПОДГОТОВКИ «ЛЕТОПИСИ ЖИЗНИ И ТВОРЧЕСТВА С.А. ЕСЕНИНА»)

(C) 2017 г. М.В. Скороходов

Институт мировой литературы

им. А.М. Горького Российской академии наук,

Москва, Россия

Дата поступления статьи: І2 мая 2017 г.

Дата публикации: 25 сентября 2017 г.

DOI: IO.22455/2500-4247-20I7-2-3-334-345

Аннотация: Рассматриваются функции иллюстративных материалов в летописях жизни и творчества (деятельности). Детально характеризуется раздел «Приложение» «Летописи жизни и творчества С.А. Есенина» в 5 томах (7 книгах), включающий документальные и изобразительные материалы. Их широкое использование позволяет сделать биографическое исследование не только привлекательным для читателей, но и существенно дополнить сведения, содержащиеся в основной части Летописи.

Ключевые слова: биографические исследования, летопись жизни и творчества, биография С.А. Есенина, документальные источники, иллюстративные материалы.

Информация об авторе: Скороходов Максим Владимирович - кандидат филологических наук, старший научный сотрудник, Институт мировой литературы им. А.М. Горького Российской академии наук, ул. Поварская, д. 25 а, І2Іо69 Москва, Россия.

E-mail:msk2002@rambler.ru 


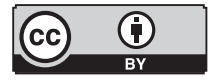

This is an open access article distributed under the Creative Commons Attribution 4.0 International (CC BY 4.O)

\section{ILLUSTRATIONS IN BIOGRAPHICAL}

STUDIES: SHARING EXPERIENCE OF

PREPARING THE CHRONICLE OF LIFE

AND WORK OF SERGEY ESENIN

(C) 20I7. M.V. Skorokhodov

A.M. Gorky Institute of World Literature

of the Russian Academy of Sciences, Moscow, Russia

Received: May I2, 2017

Date of publication: September 25, 2017

Abstract: The article discusses the function of illustrations in biographical studies. In particular, it examines a section "Appendix" in the 5-volume Chronicle of Life and Work of Sergey Esenin that includes documentary and visual materials. The use of illustrations not only makes a biographical study attractive to readers, but also serves as a welcome supplement to the information contained in the main part of the chronicle.

Keywords: biographical study, the chronicle of life and work, biography of Sergey Esenin, documentary sources, illustrations.

Information about the author: Maksim V. Skorokhodov, PhD in Philology, Senior Researcher, A.M. Gorky Institute of World Literature of the Russian Academy of Sciences, Povarskaya 25 a, I2I069 Moscow, Russia.

E-mail:msk2002@rambler.ru 
Для биографического исследования - научной биографии, творческой биографии, летописи жизни и творчества (деятельности) - важен иллюстративный ряд. Во многом это объясняется тем, что биографические исследования часто вводят в научный оборот значительный пласт новых материалов. Однако такие работы (за исключением материалов к биографии) не предполагают публикации изобразительных материалов и документов, в том числе архивных. Вместе с тем читателям, обращающимся к биографии известного человека, важно получить представление как о его жизни и деятельности, так и о восприятии его окружающими. Наконец - и это тоже немаловажно - читатели хотят иметь представление о внешнем облике главного героя исследования и его современников, именно поэтому необходимо воспроизведение изобразительных материалов - произведений живописи, графики, скульптуры, открыток и др.

В исследованиях биографического характера актуально представление не только биографии человека, которому посвящена работа, но частично и всей эпохи, в которую он жил и работал. Благодаря групповым фотографиям раскрывается круг общения главного героя. Иногда встречи, совместное участие в разного рода мероприятиях не находят отражения в текстовых документальных свидетельствах - анонсах и репортажах о прошедшем событии, письмах, дневниковых записях, мемуарной литературе, афишах и других источниках. Однако важные эпизоды личной и творческой биографии могут зафиксировать фотографы, причем совершенно не обязательно фотографы профессиональные.

Отметим, что иллюстративный ряд широко используется в различных справочных изданиях, в том числе энциклопедических - публикуются 
фотографии людей, которым посвящены биографические статьи, карты, отражающие содержание и этапы исторических событий, географических открытий. Приводятся всевозможные схемы, графики, диаграммы, облегчающие усвоение информации и дающие сжатое представление о том событии или явлении, которому посвящена энциклопедическая статья.

В летописях жизни и творчества (деятельности) как одном из научных биографических жанров использование иллюстративного материала, как правило, минимально. Этот вывод мы делаем на основе анализа многочисленных летописей, изданных в нашей стране и посвященных не только писателям, но и государственным деятелям, ученым, представителям сферы искусства. Очередной том может открывать портрет главного героя - часто этим иллюстративный ряд и ограничивается. Иногда может быть одна или несколько вкладок иллюстраций с фотографиями главного героя в разные периоды его жизни, портретами его родных и современников.

Например, первая книга «Летописи жизни и творчества Ф.И. Тютчева» открывается фотографией поэта $[7$, с. 2], а между летописной частью и «Приложениями» размещен не имеющий названия, не включенный в общую нумерацию и не обозначенный в содержании книги блок иллюстраций -26 страниц. Открывает подборку герб рода Тютчевых I802 г. Далее помещены портреты самого поэта, его родных и современников; рисунки и фотографии мест, в которых он бывал; обложки и страницы изданий, в которых печатался, автографы его произведений и иные материалы. В раздел «Приложения» [7, с. 277-304] входят две статьи научного руководителя и одного из составителей издания Т.Г. Динесман и статья другого составителя - С.А. Долгополовой.

Первый том «Летописи жизни и творчества Ф.М. Достоевского» открывается фотографией писателя [8, с. 2], а завершается семистраничной, расположенной в самом конце книги (после содержания, в которое данный раздел не включен) подборкой изобразительных материалов «Из собрания Литературного музея Пушкинского Дома» [8, с. 537-543].

Л.П. Гроссман, характеризуя особенности своей книги «Жизнь и труды Ф.М. Достоевского. Биография в датах и документах», отмечал: «В отличие от обычного типа <..> хронологических описей, мы включили в нашу работу ряд биографических документов, раскрывающих читателю глухое и беглое календарное указание и непосредственно вводящих его в 
историю жизни Достоевского. Ряд официальных актов, писем, статей, дипломов, счетов, договоров и контрактов, приведенных полностью в тексте настоящей работы, непосредственно обращает нас от сводки дат к биографии писателя» [2, с. 7]. В книге «воспроизведены наиболее значительные изображения Достоевского, причем иконография самого писателя дополнена иллюстративным материалом, относящимся к его современникам, родственникам, друзьям, местам его пребывания, документам его творческой истории - рукописям, рисункам, снимкам с различных изданий и пр.» [2, с. 9]. В небольшом, объемом четыре страницы, «Приложении» к «Летописи жизни и деятельности Н.А. Добролюбова» С.А. Рейсера [9] помещена родословная таблица и приведены некоторые другие материалы.

Для биографических изданий, посвященных С.А. Есенину, характерно внимание к документальному и иллюстративному материалу. В работе В.Г. Белоусова [I] наряду с основным разделом - «Литературная хроника» - имеются разделы «Дополнения» (комментарии к летописным статьям и дополнения их документальными источниками, обоснование датировок и др.) и «Иллюстрации» (воспроизведение фотографий Есенина, в том числе коллективных, автографов его произведений, заполненных им анкет, документов личного происхождения). Большое число иллюстраций - фотографий, рисунков, автографов и др. - включено в подготовленную С.И. Субботиным, Н.И. Гусевой (Н.И. Шубниковой-Гусевой) и С.В. Шумихиным книгу «С.А. Есенин. Материалы к биографии» [Іо].

При обсуждении концепции и структуры «Летописи жизни и творчества С.А. Есенина» инициатором создания этого труда и главным редактором первых двух томов Ю.Л. Прокушевым был поставлен вопрос о включении в Летопись раздела, который получил название «Приложение», - блока текстовых документов и иллюстраций. В период подготовки томов Летописи выяснилось, что этот раздел должен быть весьма объемным и нести значительную нагрузку в плане не только иллюстрирования, но и введения в научный оборот большого массива новых материалов.

В первом томе Летописи отмечено, что в состав «Приложения» входят «полностью те важнейшие новые документальные материалы, цитаты из которых фигурируют в основном тексте “Летописи...”. В “Приложение” включены фото- и ксерокопии наиболее характерных материалов, связанных с конкретными летописными статьями: автографы ряда стихотворе- 
ний, писем, дарственных надписей, журнальных публикаций произведений Есенина, обложки его книг, ряд документов, касающихся биографии поэта. Кроме этого, “Приложение” знакомит с портретами поэта, его родных и близких, друзей детства и юности, поэтов, писателей, издателей, с которыми встречался Есенин, <включает> фотографии памятных мест, связанных с жизнью поэта» [4, с. 73].

Определенная в «Предисловии к первому тому» структура «Приложения» характерна для всех томов «Летописи жизни и творчества С.А. Есенина». К материалам этого раздела имеются отсылки в основном тексте - после конкретных летописных статей. Таким образом, у читателя появляется возможность получить дополнительную информацию, расширяющую сведения, содержащиеся в той или иной летописной статье. «Приложение» раскрывает контекст эпохи, творческие и личные взаимоотношения Есенина с современниками.

В «Приложении» материал выстроен по местам пребывания поэта, а внутри каждого подраздела - по хронологии. В первом томе подразделы открывают видовые фотографии - пейзажи родного есенинского Константинова, села Спас-Клепики, в котором начинающий поэт учился во второклассной школе, виды Москвы, Петрограда, Царского Села. Эти материалы помогают читателю Летописи представить те реалии, которые были важны для поэта. Во втором томе, в котором материалы «Приложения» разделены на три подраздела - «Царское Село. г9І7», «Петроград. І9І7-г918», «Москва. I918-I920», - широко используются открытки начала XX в. Например, «Общий вид Царского Села», «Москва. Тверская улица», «Москва. Страстная площадь» $[5$, с. 463, 544, 545]. В следующих томах Летописи «Приложение» не делится на подразделы в соответствии с местами пребывания Есенина, что обусловлено его активными перемещениями в I92I-I925 гг. При этом во всех томах место нахождения Есенина обозначено в колонтитуле - это относится как к основному летописному тексту, так и к «Приложению».

Для исследователей творчества Есенина особую значимость имеют автографы. В «Приложении» представлены как черновые с многочисленными слоями правки, так и беловые автографы. В качестве иллюстративного материала приводятся адресованные современникам дарственные надписи поэта на книгах. 
$\mathrm{B}$ «Приложении» к первому тому по архивным источникам печатаются формулярные списки лиц, оказавших значительное влияние на формирование Есенина в детском и юношеском возрасте. Это отец Иоанн (Смирнов) - священник церкви Казанской иконы Божией Матери, законоучитель Константиновского земского училища, в доме которого Есенин проводил многие часы, беседуя или читая книги и журналы, Е.М. Хитров - первый литературный наставник начинающего поэта, преподаватель Спас-Клепиковской второклассной учительской школы и некоторые др. Информация о школьных учителях Есенина введена в Летопись в связи с тем, что ранее она нигде не публиковалась. Естественно, что биографические данные о более известных современниках поэта в «Приложение» не включены. При этом иллюстративные материалы, характеризующие деятельность таких людей, входивших в круг общения Есенина, широко представлены в «Приложении»: публикуются их фотографии, графические изображения, включая шаржи, воспроизведены обращенные к Есенину дарственные надписи, адресованные ему письма.

В Летописи, как и в персональных энциклопедиях, наблюдается интересная закономерность: чем известнее человек, тем меньший объем биографических сведений о нем приводится. Так, в «Лермонтовской энциклопедии» не объясняется, кто такой Пушкин, Гоголь или Блок. По этому пути пошли и составители есенинской Летописи. В тех случаях, когда информацию о человеке сложно получить из других источников, в летописных статьях характеризуется сфера его деятельности, а в «Приложении» приводятся документы, раскрывающие факты его биографии. Во вторую книгу пятого тома Летописи включен аннотированный указатель имен и названий, в котором характеризуется сфера деятельности и даты жизни каждого упоминаемого в Летописи лица.

В качестве иллюстраций в «Приложение» включены наиболее показательные и значимые печатные материалы, характеризующие восприятие есенинского творчества современниками. Приоритет отдается малоизвестным или впервые вводимым в научный оборот источникам. Если газеты, журналы и книги, вышедшие около столетия назад, можно прочитать в некоторых библиотеках (часть из них доступна теперь и в электронном виде), то, например, афиши и программы литературных вечеров до недавнего времени были практически недоступны. Вместе с тем эти документы раскрыва- 
ют круг общения, творческие контакты поэта. В афишах и программах перечисляются члены литературных групп - как соратники, так и литературные оппоненты Есенина. Отметим, что раздел «Афиши и программы вечеров» был включен в Полное собрание сочинений поэта, он находится в конце собрания - завершает вторую книгу седьмого тома. Такое расположение обусловлено тем, что «прямых сведений о непосредственном участии поэта в составлении большинства афиш не обнаружено». Однако «отсутствуют какие бы то ни было данные, что имя Есенина появилось на той или иной афише без его ведома. К тому же известно, что при подготовке вечеров, организуемых Всероссийским союзом поэтов (ВСП), составлением афиш и их публикацией занималась специально избираемая из числа членов ВСП “программная комиссия”, которая рассматривала заявки поэтов на участие в литературных мероприятиях <...> на афишу ВСП имя Есенина могло попасть лишь при наличии его заявки, то есть по его собственному желанию» [3, с. 566]. Если в Полном собрании сочинений воспроизводятся тексты афиш и программ, сопровождаемые необходимыми комментариями, то в Летописи некоторые документы даются в качестве иллюстративного материала. Например, афиша и программа первого вечера искусств литературно-художественного общества «Страда», состоявшегося I9 ноября I9I5 г. [4, с. 66о-662], недельные афиши выступлений поэтов на эстраде-столовой ВСП [5, с. 591, 602, 609, 626, 633, 637, 649, 650], афиша выступления имажинистов в Политехническом музее 3 апреля І9І9 г. [5, с. 6І4], афиши поэтических вечеров в Политехническом музее [5, с. 697, 713].

Отметим, что благодаря размещению в открытом доступе Государственного каталога Музейного фонда Российской Федерации (в данный момент далеко не все музейные предметы и коллекции оцифрованы и представлены в сети Интернет) появилась возможность поиска в этой базе данных как афиш, так и других иллюстративных материалов. Так, благодаря этому ресурсу при подготовке второй книги пятого тома Летописи нами была обнаружена афиша вечера памяти Есенина, прошедшего в Ленинграде 8 февраля 1926 г., из собрания Государственного литературно-мемориального музея Анны Ахматовой в Фонтанном Доме (в базе данных этот документ ошибочно отнесен к г927 г.).

Значительное место в «Приложении» занимают обложки книг Есенина, его современников, коллективных сборников с участием поэта, по- 
священных ему изданий, а также журналов. Обложка многое говорит об эпохе. Над некоторыми из них работали известные художники. На обложках журналов часто обозначены темы, актуальные для своего времени. По обложке можно определить, на какую группу читателей ориентировано издание, какие вопросы являются для него приоритетными. В «Приложении» в ряде случаев помещены титульные листы, а также содержание, в котором обозначены публикации произведений Есенина и посвященных ему работ. Порой в качестве иллюстраций, раскрывающих историко-литературный контекст, воспроизводятся страницы с перечнями печатавшихся в том или ином издании авторов. Приводятся редкие документы - например, «Положение о церковных школах ведомства православного исповедания» (воспроизведены страницы еженедельника «Церковные ведомости») - в соответствии с этими правилами не только составлялась программа обучения, но и строились школьные здания. Публикуются выдержки из учебных планов и программ Спас-Клепиковской второклассной учительской школы и Московского городского народного университета имени А.Л. Шанявского. Расписание занятий этого учебного заведения позволяет установить, в какие часы и дни читались те или иные лекционные курсы. Приводится фрагмент устава литературно-художественного общества «Страда», в деятельности которого молодой поэт принимал непосредственное участие.

Здания, которые посещал поэт, - это места, связанные с памятью о нем. Далеко не все они сохранились до наших дней. Многие утрачены, другие перестроены. При публикации предпочтение отдается фотографиям прижизненным или близким по времени к периоду нахождения поэта в населенном пункте. Так, в «Приложении» ко второй книге третьего тома Летописи, посвященной периоду заграничной поездки, публикуются фотографии мест пребывания поэта. В их числе редкие снимки гостиниц, в которых проживал Есенин вместе с А. Дункан, І924 г. [6, с. 447-448] из собрания английского слависта Г. Маквея (недавно вся коллекция этого ученого передана им в дар Государственному музею-заповеднику С.А. Есенина). В ряде случаев, когда известно, что здание избежало значительной перестройки, приводятся фотографии, сделанные в наше время.

Важная группа материалов - зарубежные источники. До подготовки «Летописи жизни и творчества С.А. Есенина» прижизненные публикации стихотворений поэта на иностранных языках и статей о нем в зарубежной 
периодике были введены в научный оборот в крайне ограниченном объеме. При подготовке томов Летописи выявлен значительный пласт новых материалов, их фрагменты представлены в «Приложении». Отметим, что в основном корпусе Летописи содержится предельно краткая информация: о выходе сборников, включающих произведения Есенина, небольшие цитаты из статей критиков и сопроводительных текстов переводчиков. В «Приложении» же даются целые газетные или журнальные полосы. Это позволяет проанализировать, в каком контексте публиковались есенинские тексты и материалы о нем.

Структура раздела «Приложение» в разных томах однотипна, однако имеются отдельные различия. Так, в завершающую издание вторую книгу пятого тома вошли разделы, включающие посмертные (появившиеся в течение полугода после гибели) материалы - о похоронах, вечерах памяти, публикации произведений Есенина, материалов о нем и др., - соответствующие документы и иллюстрации войдут в «Приложение». В последнюю книгу издания войдет и специальный указатель материалов, включенных в «Приложение», который позволит ориентироваться во всем многообразии вошедших в него материалов.

Опыт «Летописи жизни и творчества С.А. Есенина» свидетельствует о том, что широкое использование иллюстративного материала позволяет сделать биографическое исследование не только привлекательным для читателей, но и существенно дополнить данные, содержащиеся в основной части Летописи. Иллюстративный ряд книги, как и музейная экспозиция, адресован разным целевым группам. Одни заинтересуются «картинками», другие будут сопоставлять приведенные документы и материалы с уже известными им, а третьи используют сведения, полученные при знакомстве с иллюстративным рядом, для собственных научных разработок. 


\section{Список литературы}

I Белоусов В.Г. Сергей Есенин. Литературная хроника: в 2 ч. М.: Сов. Россия, 1969-I970. 304 с. +448 c.

2 Гроссман Л.Н. Жизнь и труды Ф.М. Достоевского. Биография в датах и документах. М.; Л.: Academia, I935. 386 c.

3 Есенин С.А. Полн. собр. соч.: в 7 т. М.: Наука; Голос, 2о0о. Т. 7. Кн. 2. 640 с.

4 Летопись жизни и творчества С.А. Есенина: в 5 т. М.: ИМЛИ РАН, 2003. Т. І. $736 \mathrm{c.}$

5 Летопись жизни и творчества С.А. Есенина. М.: ИМЛИ РАН, 2005. Т. 2. 760 с.

6 Летопись жизни и творчества С.А. Есенина. М.: ИМЛИ РАН, 2008. Т. 3. Кн. 2. $575 \mathrm{c}$.

7 Летопись жизни и творчества Ф.И. Тютчева. Кн. первая. І803-І844. М.: Литограф, I999. 34I с.

8 Летопись жизни и творчества Ф.М. Достоевского: в 3 т. СПб.: Академический проект, І993. Т. І. 544 с.

9 Рейсер С.А. Летопись жизни и деятельности Н.А. Добролюбова. М.: Гос. изд-во культ.-просвет. работы, І953. 370 с.

Iо С.А. Есенин. Материалы к биографии. М.: Историч. наследие, I993. 448 c. 


\section{References}

I Belousov V.G. Sergei Esenin. Literaturnaia khronika: $v 2$ ch. [Sergey Esenin: Literary chronicle in 2 vol.]. Moscow, Sov. Rossiia Publ., I969-1970. 304 p. + 448 p. (In Russ.)

2 Grossman L.N. Zhizn' i trudy F.M. Dostoevskogo. Biografiia v datakh i dokumentakh [Life and works of Fyodor Dostoevsky. Biographical facts and materials]. Moscow, Leningrad, Academia Publ., I935. 386 p. (In Russ.)

3 Esenin S.A. Polnoe sobranie sochinenii: $v 7 t$. [Complete collection of works: in 7 vol.]. Moscow, Nauka; Golos Publ., 2000. Vol. 7. Book 2. 640 p. (In Russ.)

4 Letopis' zhizni i tvorchestva S.A. Esenina: $v 5 t$. [The chronicle of Life and Work of Sergey Esenin: in 5 vol.]. Moscow, IWL RAS Publ., 2003. Vol. I. 736 p. (In Russ.)

5 Letopis' zhizni i tvorchestva S.A. Esenina [The chronicle of life and work of Sergey Esenin]. Moscow, IWL RAS Publ., 2005. Vol. 2. 760 p. (In Russ.)

6 Letopis' zhizni i tvorchestva S.A. Esenina [The chronicle of life and work of Sergey Esenin]. Moscow, IWL RAS Publ., 2008. Vol. 3. Book 2. 575 p. (In Russ.)

7 Letopis' zhizni i tvorchestva F.I. Tiutcheva. Kn. pervaia. I803-I844 [The chronicle of life and work of Fyodor Tyutchev]. Moscow, Litograf Publ., I999. 34I p. (In Russ.)

8 Letopis' zhizni i tvorchestva F.M. Dostoevskogo: $v_{3} t$. [The chronicle of life and work of Fyodor Dostoevsky: in 3 vols.]. St. Petersburg, Akademicheskii proekt Publ., I993. Vol. I. 544 p. (In Russ.)

9 Reiser S.A. Letopis' zhizni i deiatel'nosti N.A. Dobroliubova [The chronicle of life and activities of Nikolay Dobroliubov]. Moscow, Gos. izd-vo kul't.- prosvet. raboty Publ., I953. 370 p. (In Russ.)

Io S.A. Esenin. Materialy k biografii [Sergey Esenin. Biographical materials]. Moscow, Istorich. nasledie Publ., I993. 448 p. (In Russ.) 
УДК 82I.І6І.І

ББК $83.3(2 \mathrm{Poc}=\mathrm{Pyc}) 6$

\section{OPUS MAGNUM ИBAHA BEPЧA}
(C) 2017 г. Т. Николеску
Милан, Италия
Дата поступления статьи: І4 февраля 2017 г.
Дата публикации: 25 сентября 2017 г.
DOI: Io.22455/2500-4247-20I7-2-3-346-369

Информация об авторе: Татьяна Николеску - доктор филологических наук, профессор, независимый исследователь, Милан, Италия.

E-mail: alexandra.nicolescu@fastwebnet.it 


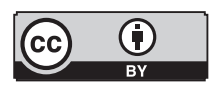

This is an open access article distributed under the Creative Commons Attribution 4.0 International (CC BY 4.0)

\section{OPUS MAGNUM BY IVAN VERCH}

(C) 20I7. T.Nicolescu

Independent Researcher,

Milan, Italy

Received: February I4, 2017

Date of publication: September 25, 2017

Information about the author: Tatiana Nicolescu, DSc in Philology, Professor, Independent Researcher, Milan, Italy.

E-mail: alexandra.nicolescu@fastwebnet.it 
В декабре 2016 г. вышел в свет четырехтомник - сборник статей известного в Италии слависта Ивана Верча. Впечатляющие размеры (около I50о с.) представляют публикацию, как подлинное «opus magnum» автора и, без сомнения, обогащают итальянскую библиографию в области славистики и в первую очередь русистики. Перед тем как перейти к рассмотрению главных тем и вопросов, которым посвящены тексты этого «opus magnum», думается нужно остановиться на небольшой статье, включенной, по нашему мнению, неоправданно (но тут, конечно, воля самого автора) в последний четвертый том, когда место ее было бы в первом томе. Ведь статья «Моя Россия» - это не золушка, скромно скрывшаяся (ее размеры - не полные пять страниц [г, т. 4, с. 74-79]), а важное вступительное слово, обращенное к читателю, подлинное «credo» автора, объясняющее фактически весь его труд исследователя и всю его деятельность на поприще славистики. Вступление написано эмоционально и так же эмоционально воспринимается читателем, что способствует углубленному пониманию с его стороны всего критического дискурса автора. Суть статьи «Моя Россия» автобиографическая. Иван Верч вспоминает свои студенческие годы и объясняет свой выбор, а именно изучать русскую культуру и литературу. Словенец, родившийся в итальянском городе Триесте и там постоянно проживающий и работающий профессором в университете, он пишет как важное признание: «Я давно убежден в том, что для приморских словенцев (Триесте - город на море. - T.Н.), Россия всегда значила нечто больше, чем для остальных словенцев», а именно: «русский «миф» (слова автора. - Т.Н.) был связан больше с культурологическим или даже психологическим восприятием 
мира, нежели с политической направленностью того или иного рода». Поэтому, несмотря на сложные исторические коллизии, пережитые Иваном Верчем, как и многими его современниками и соотечественниками, твердой и устойчивой осталась его связь с русской культурой. Об этом заявляет заключение статьи - «credo» «Моя Россия»: «Жизненный путь устроен так, что приводит тебя по петляющей дороге именно туда, откуда ты начал. Мне приятно признаться в том, что большая часть этого пути пройдена мною в плодотворном общении с русской культурой». В свете этой принципиальной установки следует обратиться к рассмотрению структуры и содержания указанных четырех опубликованных томов.

Они соединены общим названием, несколько неожиданным, непривычным для русского читателя (конечно, все время речь будет идти о специальном читателе, литературоведе, культурологе), быть может даже настораживающем его. Это название - «Проверки» [г]. Что подразумевает под ним автор? Проверки, как объясняют тексты, - это пересмотры, переоценки установленных подходов к различным вопросам, категориям эстетики, поэтики, литературоведения в широком смысле слова и выдвижение иных подходов. Два ключевых термина: пересмотр и подход, диалектически связанных между собой, - обусловливают структуру всех томов, составляющих единое целое, которое предстает перед нами в своей индивидуальности как диалог. Обширный, многомасштабный диалог, на разных литературоведческих уровнях, так что весь критический дискурс - не статичный, не ставший, а в становлении. Этот диалог ведется в основном с Бахтиным и Лотманом, как главными участниками, но привлекаются и Лукач, и Лихачев, обращается Иван Верч также к приемам формалистов, не исключает и ходы структурализма. Можно ли считать, что эта неоднородность ущемляет научное значение труда? Вряд ли, как это докажет анализ отдельных тем исследования. Тут же следует подчеркнуть, и это несомненно положительный аспект, ту постоянную опору и поддержку, которую оказывает богатая библиография.

В этом диалоге есть центральный герой, вокруг которого ведутся споры и проверяются подходы к его определению, к выявлению его сущности, его выразительности, его значимости. Этот герой - слово. Конкретное критическое рассмотрение проводится автором главным образом на основе нескольких литературных корпусов, а именно корпуса произве- 
дений Достоевского, произведений Пушкина и русской литературы послереволюционного периода, советской, другими словами. Самостоятельно стоят такие темы, как писательская этика, история русской литературы, культура и группа статей о некоторых театральных текстах. Весь этот богатый литературный материал распределен по томам, согласно тематическим критериям, а именно: первый том - «Анализ текста», второй том - «Литература различия», третий том - «О теории литературы. Об этике», четвертый том (наиболее объемный) - «Культура, преподавание, театр». Указанные выше корпусы не статичны, неподвижны, они, наоборот, мобильны, на требования, выдвинутые темами, они отвечают своими отдельными составными - статьями, фрагментами, которые таким образом могут встречаться в разных томах труда.

Первый том - «Анализ текста» - открывается симптоматичной, можно сказать, статьей, - это подробное исследование «О “неожиданном действии” у Достоевского», или более точно и конкретно, о наречии «вдруг» в произведениях Достоевского [І, т. І, с. 5-56].

Исследование открывается структуралистским комментарием исходя из «Введения в структуральный анализ рассказа» Барта, а именно утверждением о «весьма повышенном присутствии... приема неожиданности действия в произведениях Достоевского» и статистическим анализом этого факта с указанием полученного результата: «...на 25 I8 просмотренных страницах наречие “вдруг” появляется 2079 раз»г'. Верч подчеркивает, что «"вдруг” постоянно присутствует в творчестве Достоевского и хронологически это присутствие растет, независимо от размеров повествовательных текстов и от их художественной формы» [I, т. I, с. 5I]. Не отказываясь от статистических таблиц, исследователь сочетает их с библиографическим комментарием, рассматривая точки зрения других критиков и литературоведов, уже ранее обративших внимание на проблему «вдруг», таких как Слонимский, Тынянов, Чичерин, Горнфельд, Бицилли, Виноградов, Гроссман. Определение занятых этими авторами позиций приводит к заключению об их разновидности. Некоторые занимаются стилем, другие вопросом композиции, есть и такие, которые переносят все в план хронотопа или в историко-биографический план. Иван Верч

I Статистические таблицы, выявляющие в цифрах по разным произведениям Достоевского указанную частоту - убедительная иллюстрация. 
предлагает иной подход. Поскольку, по его мнению, указанные авторы не дают «глобального видения вопроса», он считает, что следует не просто отмечать факт присутствия наречия «вдруг» в разных произведениях Достоевского, но раскрыть его значение как прямое выражение особой повествовательной манеры Достоевского.

Не покидая структуралистский статистический метод, итальянский исследователь приходит к первой констатации: в произведениях Достоевского «“вдруг” - особенность речи повествователя», и это оправдывает его решение - «заниматься только речью рассказчика». Первая цель, преследуемая им, - установить «генеральные линии», на которых основывается творческий труд Достоевского». Первая - это «сжатость», лаконичность, вторая - представление персонажа «в момент кризиса». И тут исследователь покидает статистический структуралистский метод и обращается к Бахтину и Лихачеву. Специфика роли рассказчика в том, что он - репортер, газетный хроникер, материал которого - повседневный факт, событие краткое, но исключительное, важное своими необычными подробностями․․ Отсюда такие черты прозы писателя, по словам Бахтина, как «неопределенность - нерешимость» и «повествовательный объективизм», а также, по мнению Лихачева, стремление фиксировать «на ходу» происходящее. И в одном, и в другом случае подчеркивается видение Достоевским «мира в движении»³.

Рассмотренное в таком контексте «вдруг» - это «антилогика», «антитезис запрограммированной жизни, неизменных мнений». Отсюда своеобразное соотношение временных планов: на первом месте - настоящее нарративного дискурса - самое важное для репортера, для хроникера, прошедшее включено в настоящее и полностью отсутствует будущее. Настоящее время - это время реальное, время повествования, что подчеркивает преимущество диалога в романах писателя4 и выявляет особый характер хронотопа: обычно место действия - четко определенное пространство -

2 Как известно, Достоевский уделял большое внимание газете, газетным сообщениям и признавался: «Я считаю себя хроникером одного частного любопытного события, происшедшего у нас вдруг, неожиданно, в последнее время, и обдавшего всех нас удивлением». 3 Именно отсутствием «неопределенности», «нерешимости» и «динамики окружающего мира» объясняется, по мнению И. Верча, слабое присутствие «вдруг» в рассказе «Записки из подполья».

4 По указанию исследователя более 55\% текста отведено диалогам. 
Петербург, время очень короткое, и «все действия составляют временное оснащение романа». Заключает исследователь этот свой критический дискурс попыткой абстрагировать значение наречия «вдруг», и приоходит к выводу, что оно встречается в речи рассказчика, а не в речи персонажа, так что текст писателя-хроникера отличается «повествовательным объективизмом» и «вдруг» - «слово-ключ к этой манере изображения». Тут И. Верч следует мнению Бахтина. Нпречие«вдруг» «"объектное” до крайней степени», исключает «каузальность событий», не объясняет, не мотивирует, оно нейтрально. И в силу своей «нейтральности» несет лишь «функцию информирующую», отражая «точку зрения автора-рассказчика» [г, т. І, с. 56].

Занимает Достоевский важное место во втором томе, озаглавленном «Литература различия», где хоть далеко не на первых страницах, фигурирует статья, которая называется «Реализм как различие» [I, т. 2, c. IOI-II3]. Это анализ, разносторонний в исторической перспективе и сопоставительный в плане эстетики, термина «реализм». Очень интересная сама по себе, привлекающая к размышлениям, вызывающая вопросы, статья мотивирована функционально по отношению к «корпусу Достоевский». Исходный тезис итальянского исследователя касается природы языка и его функции «выступать в качестве реального мира». И поскольку «заключение мира в слово», пишет И. Верч, «не является нейтральной операцией», и это значимо и для реализма, и его отношения к «первичному языковому инструменту изображения», то постепенно реализм «превращался в литературу различия, именно благодаря языковым инструментам, которые выбирал». Урок реализма, который подчеркивает автор, - это изображение реального мира, и это «есть возможный выбор, а выбор невозможен без ответственности этического характера» [I, т. 2, с. III].

Пониманию аспектов творчества Достоевского посвящены статьи, напечатанные во втором томе: “Вечный муж” Достоевского и некоторые вопросы о жанре произведения», «“Бедные люди” Достоевского и вопросы реализма», «Достоевский и театр представления», «Некоторые аспекты изображения будущего в творчестве Ф.М. Достоевского в свете литературной традиции Города и Сада».

Но не эти статьи, прямо ссылающиеся на русского писателя, открывают второй том, а другая - с заглавием: «Границы и возможности традиции Данте в развитии русского романа» [І, т. 2, с. 7-31]. Исходная пози- 
ция исследователя, принимая во внимание значение Данте, этого «гиганта всемирной литературы», раскрыть не «количество присутствий Данте» в тех или иных литературных явлениях, но «качество этого присутствия» в перспективе «литературной эволюции». Естественно, автору необходимо было учитывать разницу культур (фактора и национального и хронологического) и, со ссылкой на Бахтина, разницу жанровую между «эпосом» и «романом», как противопоставление жанра завершенного, установленного, ставшего и жанра в развитии, формирующегося, меняющегося. Или, как уже отмечалось Лотманом, поэзия, тот же эпос, формируется «в поиске тождественного в отличном», а проза, наоборот, «подчеркивает отличное». Отсылая вновь к Бахтину, критический анализ И. Верча обращается к романам с преимуществом диалога (слово другого) над повествованием, в которых более остро ощущение «противоречий эпох или конец их», поскольку в произведениях такого рода сильнее чувствуется «непосредственно или посредственно традиция Данте». Путь исследования начинается с Гоголя, который уже ощущает «слово другого», следует затем Достоевский, у которого уже полная самостоятельность этого слова, выражающего идеологию другого, а у Белого оно осложняется, становясь частью «расчлененного самосознания», «единственной реальности не подлежащей сомнению». В этом контексте итальянский исследователь отмечает как основной вопрос хронотоп романа и его варианты. Это у Достоевского очень ограниченное время и узкое пространство, отведенные кризисам; в «Петербурге» Белого концентрация всего хаоса в пять дней, соединяя в едином сознании свое и другого; в повести В. Ерофеева «Москва-Петушки» в течение двух часов поездки на поезде синтез своего нелепого существования в враждебном человеку мире.

Особенно важным для выявления традиции Данте в русском романе считает исследователь «проблему ограничений и возможностей, стоящих перед романом в поисках “рая” [г, т. 2, с. 223]. В ее разрешении он обращается сперва к Гоголю и его «Мертвым душам», задуманным автором как трилогия о пути из «ада» повседневного пошлого мира помещиков в «рай» новой действительности русской возрожденной духовности. Переходя к творчеству Достоевского, итальянский исследователь представляет тему поиска «рая» как постоянную в его произведениях и как повторение гоголевской трагедии «неосуществленной утопии». Сложнее ставится во- 
прос касательно прозы Андрея Белого и тут, конечно, встает роман «Петербург». Нельзя сказать, что в нем отсутствует вовсе попытка найти этот «рай». Есть иллюзия о такой возможности: белое домино и пребывание Николая Аблеухова в Египте. Но эта иллюзия пасует перед эсхатологическим видением действительности, присущим писателю, катастрофическим ее отражением в его сознании. Однако случай Андрея Белого трактуется И. Верчем несколько односторонне. Иллюзия возможного «рая» присутствует в биографии Белого, и, можно сказать, не как утопия, а как реальность антропософского ухода в Дорнах и вообще как пожизненное увлечение штейнерьянством. И тут интересны воспоминания К.Н. Бугаевой о предсмертных часах писателя. Если же не ограничиться «Петербургом», то поиск «рая» как тема проходит через такие произведения как «Путевые заметки» и «Африканский дневник» (поиск «новой жизни»), или «Маски» (любовь как путь к единению и счастью человечества - проповедь Коробкина) как наименования: «Аэрия» - рай, где живут люди-звуки», или «Невидимый град» - будущее счастливое общество.

Повесть «Москва-Петушки» Вен. Ерофеева подводит критический дискурс исследователя к иному уровню. Действительность, представленная в повести, действительность сегодняшнего мира, переживает настолько глубокий кризис, что исчезла даже надежда на какую-либо иллюзию о возможном выходе из этого положения. И роман тоже потерял свой статус, свою миссию - выражать стремления людей к правде и справедливости, обнажил свою ограниченность. Так возникла необходимость превзойти традицию романа. Однако, несмотря на недостижимость искомого «рая», ограничения в статусе современного романа, по мнению И. Верча, допускают два исключения, которые он отмечает в русской литературе советского периода - одно - высокохудожественное, другое, вероятно, менее причастное к такому уровню. Первое - это «Мастер и Маргарита» Михаила Булгакова. Расчленив планы романа на идеальный (История Иешуа и Пилата Понтия) и повседневный, пошлый (Воланд и Москва зо-х гг.), писатель соединил их Мастером, которому предоставил миссию провозглашать правду, не абстрактную, а связанную с современной ему действительностью, которая живет в постоянных противоречиях и конфликтах. И это правда о свободе человека, внутренней духовной и интеллектуальной. Но писатель не исключает возможность выхода, разрешения, реализации поиска: Мастер и Маргарита находят вечный покой. 
Второе исключение, согласно И. Верчу, касается советских романов социалистического реализма: с одной стороны, как жанр, они сближаются, скорее, с эпосом, с поэмой, с другой - изображают фиктивную, фальшивую действительность. Эти свои оценки, в определенной мере не лишенные основания, нельзя абсолютизировать, относить ко всей литературе после революции; к сожалению, автор не конкретизирует, не приводит примеры, не цитирует даже заглавия. И это досадно, потому что вопрос, поставленный автором на обсуждение, несомненно, был и остается злободневным для истории литературы тех лет, отмеченной острой конфронтацией интерпретаций и требующим разных подходов к отдельным личностям и оценке произведений.

Вернемся к статьям, посвященным отдельным аспектам творчества Достоевского. И начнем с первой в хронологии томов, а именно с «"Вечного мужа” Ф.М. Достоевского и некоторых вопросов о жанре произведения» [I, т. I, с. IOI-II3]. Анализ текста дается, по указанию самого автора, в плане «литературных элементов, которые, как промежуточное звено, воздействовали на эволюцию жанра», другими словами, в плане «сдвига по отношению к литературной традиции и ее переосмысления на уровне содержания». История, рассказанная Достоевским, - классический пример треугольника, соотнесенный в данном случае с традицией Мольера и Тургенева (пьеса «Провинциалка»). Анализ текста Достоевского выявляет сложное сочетание некоторых эстетических категорий, обычно выступающих как противоположные друг другу (трагическое, комическое, ироническое, пародийное) и подчеркивает искусство русского писателя в создании нарративного дискурса. Согласно точке зрения итальянского исследователя, речь идет о двойной повествовательной перспективе Достоевского. Первая это традиционная перспектива, в которой представленное соотносимо с новыми возможностями, которые могут возникнуть из предшествующей, уже известной, ситуации. Вторая, наоборот, стремится влиять на восприятие адресата, отрицая уже известный типический характер представленного, созданного преимущественно литературными элементами.

В статье «“Бедные люди” Достоевского и вопросы реализма», теме не новой в литературоведении, можно даже сказать классической, автор ставит вопрос о соотношении между миром действительности и миром, представленном в слове. Слово Девушкина, который отказывает Гоголю в 
правдивом изображении чиновника, каким воспринимался Акакий Акакиевич, говорит о двойственности изображения действительности, претендует на знание правды.

Несомненный интерес представляет статья «Некоторые аспекты изображения будущего в творчестве Ф.М. Достоевского в свете литературной традиции Города и Сада» [I, т. 2, с. 223-238]. Она требует возвращения читателя к статье о традиции Данте в произведениях Достоевского. Их родственность определяет идея поиска «рая» как реализации идеального мира, гармонии в обществе, другими словами, речь идет об утопии. И более конкретно - о трех вариантах или типах утопии: Эдем или Сад. Иерусалим или Новый Иерусалим, т. е. Город и смешанный Сад в Городе или Город в Саду. Тема утопии трактуется автором глубоко и разносторонне со ссылками на источники (Библия, Откровение Иоанна, Книга пророка Иезеекиля и др.) и в историко-литературной перспективе «диахроническом срезе» творчества Достоевского. Конкретизации анализа способствует сопоставление с другими произведениями, такими, как «Что делать» Чернышевского или того же Достоевского «Зимние заметки о летних впечатлениях» и постоянное обращение к источникам (Библия, Апокалипсис или словарь Даля). Автор исследования точно и скрупулезно следит за эволюцией терминов и их символики в ракурсе периодизации творчества писателя и политической их субстанции, а именно отношения к восприятию социализма, балансируя между кодом Города-храма и Сада и их отрицательной и положительной символикой. Автор следует за периодизацией концептов-символов Город-храм и Сад, чтобы подробно остановиться на утверждении «типологических элементов» Сада в творчестве писателя после I87І г. (глава «У Тихона» в «Бесах»). Подробно рассматривает И. Верч типологические черты «Сада», чтобы прийти к заключению о тождественности понятий. Исследователь обращает внимание читателей на высокий статус, который придается понятию «Сад» как «имплицитно присутствующему в русской автохтонной культуре», и разрабатывает этот аспект, менее затронутый «достоевсковедением» в разных его проявлениях, таких как встречи и расхождения с народной традицией, что доказывает «синкретический характер видения писателя, в котором сливаются образы, подсказанные мифом, живописью и народной традицией» (например, «Сказание о граде Китеже», крестьянская утопия А.В. Чаянова, «общее дело» Н. Федорова) [1, т. 2, с. 223]. Отсюда вытекает заключение И. Верча, что «никакая другая тема не трактовалась Достоев- 
ским таким на редкость “монологичным” образом, как тема утопии» и что, как следствие, эта «синкретическая» утопия породила несколько «эволюционных линий», ее развивших (например, «Петербург» Белого, «Тост» Куприна, «Республика южного креста» Брюсова, «Чевенгур» Платонова). Статья «Заметки об утопических страницах В. Хлебникова» посвящена посмертно опубликованному произведению «Кол из будущего». С учетом некоторых европейских утопических тем исследователь отмечает родственные черты Хлебникова с утопией у Достоевского (обращение к русской народной культуре с синкретическим присутствием мифа, сказки, религиозных элементов).

В корпусе Достоевский фигурируют также две статьи, посвященные вопросу о традиции русского писателя. Одна из них озаглавлена, думается, не случайно: «К вопросу о так называемой “традиции” (!) Достоевского в двух редакциях романа “Вор” Леонида Леонова» [ı, т. І, с. 77-87]. Формулировка итальянского исследователя «так называемой» говорит, можно предполагать, об определенном дистанцировании от привычного понимания термина «традиция» по отношению к Достоевскому и роману Леонова. Вопрос непростой, поскольку речь идет о редком случае: это не две редакции романа, а два романа под тем же названием, того же автора, написанные на немалом расстоянии во времени (г27 и г959). Исходное, первое мнение исследователя: Леонов не эпигон Достоевского. Второе - это «близость» Леонова к Достоевскому, признанная им самим и критиками (связь между отдельными персонажами, сюжетами, темами, полифонизм как поэтическая структура). Важно уточнение исследователя: «...между двумя романами разница большая», это «два различных мировоззрения, выражающихся двумя различными и даже противоположными поэтиками» [г, т. І, с. 79]. Поэтому он ставит себе как цель «учитывать лишь важнейшие составные элементы поэтических систем Достоевского и Леонова - точки зрения автора и рассказчика, персонажей, хронотоп, сюжет и фабулу». Нельзя не отметить значительность состава этих элементов для поэтики Достоевского, к чему исследователь добавляет: «...в основе поэтики Достоевского лежит утверждение идеи». И. Верч начинает с определения разницы между двумя романами Леонова, условно «Вор»-г и «Вор»-2: «Вор»-I - это «роман о невозможности изображения действительности», принимая во внимание контекст литературного процесса г920-х гг. «Вор»-2 - «роман о необходимости истолкования действительности». Опираясь на теорию Тынянова 
о литературной эволюции, И. Верч находит объяснение смене литературного контекста. По-разному ставился в І927 и в І959 гг. вопрос о статусе писателя, о роли мировоззренческого фактора, а также о роли идеи в художественном произведении. Роман «Вор»-I «включается в поэтическую систему Достоевского», воспринимая «утверждение идеи» как «ядро поэтики Достоевского» и «эволюционирует у Леонова в вопрос о его художественном изображении. «Вор»-2 не допускает возможности «механического подражания Достоевскому», и «“традиция” Достоевского сводится к присутствию отрицания его художественного метода». Но И. Верч предупреждает читателя не спешить с заключением, потому что в этой второй редакции важна и существенна открытая позиция автора, полемичная по отношению к литературному контексту І920-х гг., то, что исследователь называет «ревалоризация» ремесла писателя, требование открытого высказывания своей мировоззренческой позиции, защиты своего достоинства, своего статуса, носителя определенной, «собственной идеи». И тут снова сближается Леонов и Достоевский, но «теперь сближение критическое и отрицательное с идеологической точки зрения».

Другая статья озаглавлена «Пильняк и Достоевский» [I, т. I, с. 213224]. Она следует непосредственно за эссе И. Верча, посвященным роману «Голый год». Соседство, скорее, подчиненность. В хаотической действительности романа «Голый год», в его монтажной структуре и рубленой прозе исследователь отмечает «двусмысленность изображаемого мира» и его хронотопа, отсутствие реального выхода, лишь его иллюзорную возможность, как и отсутствие абсолютной правды и лишь иллюзию ее возможности, чтобы в заключении указать на связь романа с «Записками из подполья». Отрицая предположение о возможном влиянии Достоевского, автор статьи находит, однако, параллелизм в поэтической структуре «Голого года» и «Записок из подполья», а именно их принадлежность к эстетической категории гротеска.

Следует перейти ко второму корпусу, к статьям о Пушкине. Нужно признать, что И. Верч не повторяется, типология содержания иная, нежели в корпусе Достоевского. Начать с того, что уже в первый том включен целый словарь корневых морфем в «Евгении Онегине» Пушкина, весьма интересный лингвистический проект - и сам по себе, и как образец для других тождественных инициатив [І, т. I, с. 299-326]. Автор скрупулезно оговаривает, 
что в данный момент этот опыт - «только теоретическое начало», которое «требует ответа на два вопроса: г. Что повторяется в “Евгении Онегине”? 2. Как оно повторяется?» [I, т. I, с. 299]. Компактно представлены статьи о Пушкине в третьем томе; тут они занимают всю вторую часть, стержнем которой, как выделено в заглавии, является тема этики. Вопрос об этике рассматривается в статьях «Литературная этика как праксис художественного мышления» [І, т. 3, с. I87-220], «Об этике автора» [I, т. 3, с. 3ІІ-3І7], «On ethics and its translation into the language of literature» [І, т. 3, с. 336-347]. Нужно отметить подход автора к указанному вопросу: подробный, разносторонний, в глубоком и компетентном диалоге с Бахтиным, Лотманом и по некоторым аспектам с Лукачем, однако не игнорируя историческую перспективу, эстетическую и философскую позицию, позволяющую прийти к заключению: этическое равно достижению человеком гармонии. Подход И. Верча отличается динамикой выдвигаемых и обсуждаемых терминов: поступок, событие, поведение автора, долженствование - не обязательное, но возможное, выбор как ответственный акт. И как «отличительная черта этики автора» «установка на постоянную словесную ре-моделизацию того, что нас окружает (текстового и нетекстового мира)». Подход проходит проверку на приемлемость и убедительность в статьях: «Об этике и поэтике в творчестве А.С. Пушкина» [I, т. 3, с. 258-279] и «Как и на что переводима литературная этика у Пушкина?» [I, т. 3, с. 27I-279]. Критический дискурс направлен преимущественно на рассмотрение романа в стихах «Евгений Онегин» под призмой «долженствования» и в сопоставительном плане определений «энциклопедия русской жизни» (Белинский) и «энциклопедия стилей и знаков эпохи» (Бахтин). Выбор Пушкина, и в этом - его «этический поступок», выразился в определенном отношении к миру, к той же действительности, которой, принимая ее, деформируя, восстанавливая, он прибавлял значение. И тут важна оценка исследователем всего творческого пути поэта - «не столько зачинателя литературной эпохи... сколько заключительный неповторимый этап длительного историко-литературного процесса, берущего свое начало по меньшей мере в XVIII веке - по крайней мере, для русской литературы» [І, т. 3, с. 263].

Корпус Пушкина замыкается статьей «Нарративность стихотворения “Я вас любил” А.С. Пушкина» с не лишенным значения подзаголовком: «Еще раз об этике художественного произведения» [I, т. 3, с. 28I- 
300]. Это краткий комментарий о кратком стихотворении (всего 8 строк). Предпринятая исследователем работа - образцовая в смысле глубокого, даже исчерпывающего, раскрытия текста, его содержания, как история любви и, можно сказать, филигранная в раскрытии валентности частей речи, ценности слова, его выразительности, точности передаваемого значения читателю при всей простоте в сообщении; ведь в стихотворении всего одна метафора, и та скорее стертая, нежели оригинальная. Согласно интерпретации И. Верча, история рассказанной любви конкретизируется глаголами, чередованием прошедшего времени, повтором три раза «я вас любил» в сочетании с настоящим и отсылкой к будущему. Тут мы добавим, со скрытым императивом, пожеланием. Эта интерпретация смысла стихотворения, казалось бы, простого, но на деле сложного, как сложно и его построение, тоже только внешне незамысловатое, дается в сопоставлении с романом «Евгений Онегин». Последний прием нам кажется, несомненно, интересным благодаря обилию цитат, составляющему в совокупности своеобразный словарь темы любви у Пушкина, и плодотворным для исследователей творчества поэта, учитывая хронологический принцип, которого придерживается расположение цитат. В заключении своей статьи И. Верч подчеркивает значение в стихотворении «речевого поступка как процесса понимания и объяснения самого себя как субъекта этого поступка» и тем самым расшифровывает подзаголовок - «Еще раз об этике художественного произведения» [I, т. 3, с. 298].

Перейдем к корпусу текстов, посвященных русской литературе послереволюционного периода. И. Верч ему предпослал как бы вступительное слово: «Некоторые отправные точки для анализа поэтики русско-советского романа 20-х гг.»5 [I, т. 2, с. 32I-332]. Первое, что отмечает автор, - это «тесная связь русско-советского романа с Октябрьской революцией» и сложный вопрос об ее восприятии в искусстве людьми, для которых это было неотъемлемо подчинено их отношению к самой истории. Последствием было разделение писателей на «pro» и «contra» по политическому и прагматическому критериям. Отсюда «объяснение

5 Alcuni punti di partenza per l' analisi della poetica del romanzo russo-sovietico degli anni venti. Текст написан по-итальянски, как и некоторые другие в четырехтомнике, наряду с текстами по-словенски и по-английски, но большая часть текстов - по-русски. 
и оценка поэтической действительности исходя из внелитературной действительности», противопоставление поэтического текста и «так называемой объективной действительности». Как примеры цитирует итальянский исследователь «Железный поток» Серафимовича, высоко ценимый советской критикой, и роман «Мы» Замятина, художественное значение которого отрицалось. Приводятся и другие примеры - это романы І920-х гг., которые говорят о менее догматичном подходе, в которых следует учитывать поэтические достоинства («Белая гвардия» Булгакова, «Зависть» Олеши, «Вор» Леонова, «Чевенгур» Платонова, «Голый год» Пильняка).

В этом корпусе читатель встретится с рядом таких писателей, как Маяковский, Пильняк, Платонов, и будет участвовать в обсуждении таких вопросов, как «Новый вал и традиция русской литературы» и место биографии в историко-литературном процессе XX в. в России. Но структура этого корпуса несколько аморфна, поэтому с некоторой натяжкой, но все-таки не без основания можно рассматривать тут и некоторые статьи из тематической группы «О театре», например, о пьесе «Марлин Мурло» Н. Коляды.

Маяковский, конечно, активный участник литературного процесса первых лет после революции и острых его конфронтаций (РАПП, Леф, Реф и др.). Но его статья «Два Чехова» [І, т. 2, с. 133-г44] была написана к десятилетию со дня смерти писателя (I9I4), т. е. Маяковским еще до его статуса советского поэта. И. Верч ее включил в корпус «советской литературы», исходя, думается, из места публикации в журнале «Новая жизнь» «ленинской ориентации», по его характеристике. Привлекал его, несомненно, подход Маяковского к творчеству Чехова как «писателя, который занимается в первую очередь словом». Маяковский отметил точно в своей статье: «слово рождает идею, а не идея слово». Отсюда и двойной облик писателя - «два Чехова». Но небольшая статья Маяковского остается сердцевиной, обрастая обширным комментарием о Чехове самого итальянского исследователя, начиная с подчеркивания двух основных тезисов, вычлененных им из статьи советского поэта. Конкретно: во-первых, Маяковский утверждал, что Чехов отвергал в своем творчестве, как это доказывает пьеса «Леший» и затем «Дядя Ваня», какие-либо «программы жизни». Во-вторых, по мнению Маяковского, Чехов 
искал в своих произведениях «разрешение проблем, касающихся слова». Эту тему развивает исследование И. Верча, подчеркивая ответственность Чехова перед произнесенным словом, которое в его время превратилось в «лингвистические формулы семантически пустые», лишенные стимулирующей силы. В исследовании дается много примеров из разных произведений Чехова, говорящих об этом «семантическом вакууме», особенно в его пьесах, начиная с «Иванова» и кончая «Вишневым садом». Исследователь отмечает такие характерные для Чехова факты: неопределенность фраз, отрывочность высказываний, паузы и молчания или реплики, достойные театра абсурда, даже как бы футуристическая заумь. Об этом отступлении семантики перед формой, которая «обновляет слово», говорил и Маяковский в своей статье. К нему возвращается и итальянский исследователь. Цитируя поэта-футуриста, который, в соответствии с поэтикой Чехова, внутренне связывает факт и слово, И. Верч указывает на присутствие у русского писателя универсальных тем и на возможность рождения сюжета из одного слова: авангард сместит окончательно внимание от «предмета» к «слову», т. е. от действительности «к ценности и автономности знака в себе». Это, подчеркивает он, «было изменением эпохального значения». «У Чехова была его интуиция», осуществлением же была художественная практика «футуриста» Маяковского [I, т. 2, с. I44].

В динамичной картине, какой представляется литературный процесс г920-х гг., И. Верч выдвинул на авансцену две фигуры: это Пильняк и Платонов. Роман «Голый год» Пильняка, вышедший в г92I г., был одним из первых значительных литературных откликов на Октябрьскую революцию и сразу же вызвал много споров, оброс, так сказать, богатым критическим материалом. Учитывая этот факт, итальянский исследователь так определил исходную позицию своего критического дискурса: «следует принимать во внимание три фундаментальных элемента: внешняя действительность, действительность поэтического мира и точка зрения автора по отношению и к одной, и к другой» [г, т. І, с. I49]. Цель, которую он предполагает достичь, - это: «определить систему, которой, возможно, принадлежит роман и пытаться установить новаторство, эпигонство или развитие этой системы по отношению к предыдущей литературной традиции» [г, т. І, с. I49]. Согласно этому плану и обсуждается роман. «Внешняя 
действительность» - это «Россия, Европа, революция», т. е. история. Верч интерпретирует ее в свете теории, изложенной в известном труде «Роль дуальных моделей в динамике русской культуры» Лотмана - Успенского. Тем самым внешнюю действительность роман выявляет в богатстве и разнообразии символов, распределенных в планах старой и новой культурной модели. Что касается действительности поэтического мира, исследователь предлагает ее рассмотреть в двух аспектах: определить отношение писателя к своему поэтическому миру и установить поэтическое значение решений или выходов, предложенных писателем. Заключение исследователя: «точка зрения писателя разносторонняя и двойственная или двусмысленная» [I, т. I, с. I75], точнее противоречивая, поскольку «художественная правда выступает как встреча противостоящих позиций». Тут возникает проблема идеологической позиции Пильняка и всех споров по этому поводу. Естественно и объяснимо внимание, которое ей уделяет И. Верч, и те вопросы, которые ставит в этой плоскости его исследование: роль повествователя (всезнающего в романе), смысл и роль цитат как зачин в разных главах и отношение к ним автора, видение внешней действительности (ироническое, сатирическое или пародийное). Причем, подчеркивает И. Верч, значительна не только точка зрения автора, но значительны и точки зрения различных персонажей романа, более того, у автора нет единой точки зрения, он относится двусмысленно к внешней действительности, и также двусмысленно и двойственно ее включение в его поэтический мир. Двойственность или двусмысленность в видении действительности проверяется и на хронотопе романа: внешне, казалось бы, что это долгое время, когда развивается исторический процесс, фактически все действие короткое, проходят лишь несколько дней, и разворачивается оно на небольшом пространстве. Также решение/выход, предложенный автором, не может быть абсолютным, однозначным; роман Пильняка создает лишь «иллюзию решения/выхода» (возрождение духовности, восстановление фабрики и вследствие этого возможность найти работу). И тем самым несостоятельно мнение тех, кто считает роман «Голый год» тенденциозным романом. Какому же типу поэтической структуры соответствует роман Пильняка? - задает вопрос И. Верч. Ответ: структура романа - гротеск. Но это определение требует объяснения и дополнения. Поэтому итальянский исследователь обращается к литературному контексту романа 
«Голый год», который состоит, по его мнению, из ряда произведений, ему родственных в плане гротеска, но апокалипсическое видение которых («Петербург» Белого, «Слово о погибели русской земли» Ремизова, «Пещера» Замятина) Пильняк «сумел превзойти», противопоставляя им «двусмысленную идею», что творение значит всегда разрушение. Охватывая в общих чертах литературный процесс г920-х гг., И. Верч указывает на «две главные линии» развития романов, а именно - «романы иллюзий и романы псевдоконкретных решений». В первую группу он включает романы «Белая Гвардия» Булгакова, «Вор» Леонова (первая редакция), «Зависть» Олеши, во второй он не дает названий, а только перечисляет фамилии: Фадеев, Гладков, Серафимович, Горький. Разница в занятой позиции объясняется: «С точки зрения поэтики романы “иллюзий”, - объясняет И. Верч, - «являются важной попыткой для русской литературы присоединиться к современному развитию европейского романа, который, начиная с “Замка” Кафки, отмечает практически рождение современного романа, в котором литература не требует больше от человека изменить мир, а лишь, но и это уже значительное усилие, не терять собственную идентичность, не позволяя “внешней действительности” проглотить его» [I, т. I, с. 2І2]. Констатация исторически очевидной сдачи позиций в первые годы советского периода романом иллюзий перед романом абсолютных достоверностей приводит И. Верча к выводу, что литература не дала возможность развиваться тем писателям, которые осознали радикальные изменения в отношениях человека с обществом. Тем самым «был пропущен поезд европейского литературного развития» и «последствия этого, несомненно, трагичные».

Статьи в четырехтомнике Ивана Верча касаются зрелого периода прозаика Платонова ${ }^{6}$ [І, т. 2, с. I67-І90]: это статья о романе «Котлован», статья «Роман-миф и роман о мифе» о романе «Чевенгур» [г, т. 2, c. I9I-202]. Включен в критический дискурс исследователя также рассказ «Впрок»7. Исследование дает глобальное впечатление о личности Платонова, писателя, политического мыслителя, даже философа (в последнее время в литературоведении все чаще встречается именно такое его понимание), о корнях и об эволюции его мировоззрения. Иван Верч рассма-

6 «Il riscatto della memoria», статья напечатана по-итальянски.

7 Сюда же относится статья «Пушкин и Платонов: к вопросу о формальных соотношениgX». 
тривает подробно источники этого мировоззрения, которые составляют любопытный конгломерат, можно сказать, довольно эклектичный по своему содержанию. Это - «философия общего дела» Николая Федорова, космическая философия Константина Циолковского, ноосфера Владимира Вернадского, «общая организация» А. Богданова, отголоски В. Розанова и С. Булгакова, мифы о счастье, народные утопии. Сама по себе уже эта осведомленность и критическое осмысление материала заслуживают положительной оценки и включают итальянское исследование в широкое литературоведческое обсуждение творчества Платонова, вызывающего все больше международный интерес. Но следует тут же отметить другой аспект статьи И. Верча - это историческая перспектива, в которой он рассматривает главные прозаические произведения - «Чевенгур» и «Котлован», определение позиции писателя и понимания места и судьбы человека-современника, подчеркивая значение хронотопа, отмеченного двумя важными событиями в истории советской жизни: индустриализация и коллективизация. Главным образом, в исследовании речь идет именно об этой писательской позиции. Верч точно оценивает ее: «Платонов принял социализм, уверенный в его целительных способностях и даже поставил на проверку смысл собственной жизни, участвуя активно в “строении” будущего своей работой инженера» [I, т. 2, с. I7I]. Исследователь подчеркивает важную черту: Платонов верил в правду, в правду предложенного проекта жизни, который обещал достижение счастья для всех и навсегда. Таким представляется роман «Чевенгур»: это роман о «“мифе” поиска счастья». Но ни один из романов: ни «Чевенгур», ни «Котлован» - не подтверждают надежду писателя. «Проверка затрудняется все больше и больше, “тотальное” мировидение крошится от пошлого существования, растекается в тысячах ручейков, ничего не имеющего общего с долгим путем развития культуры трудно созданной веками» [I, т. 2, с. I76], - пишет И. Верч. Надежда Платонова на новую, обещанную социализмом жизнь терпит крушение. Этот трагический финал, двойное крушение - и городской утопии, и крестьянской, по мнению итальянского исследователя, запечатлел роман «Котлован». Но, хотя Платонов и убедился, что предложенный и обсуждаемый тотальный проект оказался пустым обещанием, он не утратил веры в «правду», которая должна существовать, которая существует где-то, 
существовала когда-то, и нужно ее искать, постоянно искать ${ }^{8}$, отмечает И. Верч. И именно с таким тотальным проектом социализма знакомит читателя статья, посвященная рассказу «Впрок». В данном случае речь идет о колхозной утопии, и связана она с проблемой электрификации как эффективным шагом к построению нового мира социализма.

Но это новое солнце, колхозное солнце, электричество - в то же время и символ новой веры, которая заменяет старые концепты Бог, религия и их дериват «царь». И тем самым, отмечает исследование И. Верча, колхозное солнце одновременно - и колхозный Бог, и колхозный царь (т. е. власть), и ставится под сомнение значительность самой утопии.

Кроме таких, скорее, монографических исследований (о Пильняке, о Платонове), нужно отметить в этом корпусе статьи, посвященные некоторым общим вопросам истории русской литературы ХХ в., а именно «О жанре биографии в русском литературном развитии XX века» и «Новый вал в традиции русской литературы». Они рассматриваются исследователем в тесной связи, в соотнесении друг с другом, даже как бы вытекают одна из другой. В статье о биографии привлекает внимание исходная позиция итальянского автора. Это ссылка на статью Осипа Мандельштама «Конец романа» (I928) и принятие его авторитетного мнения: «мера романа - человеческая биография или система биографий... роман всегда предлагает нам систему явлений, управляемую биографической связью, измеряемую биографической мерой». И говорит «о связи, которая существует между судьбой романа и положением в данное время вопроса о судьбе личности в истории». Слова Мандельштама накладывает исследователь на ситуацию с биографией в советском литературоведении. В категорию личностей, достойных получить право на биографию, могли быть включены те, кто «свою личность заставлял полностью интегрироваться в Историю, уже заранее определенную». «Такая официальная модель осталась незыблемой до конца 8о-ых гг.», пишет И. Верч, когда произошел перелом, обозначенный выходом в свет повести Солженицына «Один день Ивана Денисовича». Этот момент был особенно важным не только с точки зрения политики и культуры, но и как «возвращение к литературной модели, годами искаженной официальными представителями культуры». Это показало, как подчер-

8 Жаль, что Иван Верч не включил в свой критический дискурс и роман «Счастливая Москва», даже если он и не окончен. 
кивает итальянский исследователь, значение, которое получила биография в мировоззрении и творчестве писателей «новой русской прозы» І990-х гг. (Попов, Л. Петрушевская, Пьецух). Для них биография как литературный текст предстает лишь как утверждение существования, констатация факта быть, жить. И. Верч правильно отмечает, что тут нет ничего нового, достаточно вспомнить Акакия Акакиевича и Макара Девушкина. Но думается, что это слишком далекая отсылка, так же как слишком близкая - обращение к прозе г990-х гг. Может быть, целесообразнее было начать с указания на биографию простого советского человека Андрея Соколова и на повесть «Судьба человека» Михаила Шолохова (1956), которая была полной противоположностью официальным советским шаблонам тех лет («Падение Берлина», «Журбины». «Кубанские казаки»), а также назвать прозу «окопной правды» (В. Некрасова, Г. Бакланова, Ю. Бондарева).

Интерес и симпатия итальянского исследователя обращены явно к прозе г990-х гг., значение которой он определяет словами «"новый вал” в традиции русской литературы». Если это «новый вал», то естественно возникает вопрос: «новый» по отношению к какому другому, старому? И тут - спорная сторона статьи И. Верча. Был этот другой, старый, но автор ничего о нем не говорит. А жаль, поскольку речь идет об очень важных моментах в истории русской литературы, в ее новом пути после смерти Сталина и разоблачения культа личности Хрущевым. Не знаю, адекватен ли термин «вал», но несомненно значение начального периода этого пути больших изменений, названного «Оттепель» (I956), как известно по одноименной повести И. Эренбурга. Затем другой этап - «шестидесятники», которые по-настоящему ознаменовали «новый вал» в прозе, в поэзии, в драматургии, и без них не могла сформироваться «деревенская проза», да и тот же вал г990-х гг. И как означить, если не новым поиском, «мовизм» Валентина Катаева? С учетом этого фона убедительнее выступают отличительные черты прозы І990-х гг., как их представляет текст И. Верча, - пересмотр предшествующих моделей русской литературы, в первую очередь Достоевского, а также и установленных традиционных концептов советской литературы и утверждение собственных поэтических принципов (отождествление автора и героя, отсутствие интереса к политическим вопросам, главная тема - ценность жизни как таковой). Нужно, однако, отметить, что сам этот «вал» прозы І990-х гг. представлен исследователем 
далеко не в своих полных масштабах. Он ограничен группой родственных писателей (Пьецух, Попов, Петрушевская), в то время как остались за бортом такие своеобразные таланты, как Татьяна Толстая, Виктор Пелевин, Владимир Маканин, Сергей Довлатов.

Хотя, быть может, кое-кому покажется не к месту, или даже лишним, присоединить к рассмотрению вопросов, касающихся современной русской литературы, обсуждение такой темы, как восприятие в Италии русского авангарда, думается, что целенаправленность статьи Ивана Верча - несомненная мотивация ее присутствия в этом контексте9. Статья небольшого размера уплотнена богатым материалом литературоведческой информации и, что самое ценное, историческим комментарием, соединяющим политический, идеологический и литературный факторы. Познакомив читателя с довольно длительным процессом восприятия русского футуризма (споров, оценок) в стране, которую можно считать родиной этого литературного явления, статья И. Верча глубоким и компетентным эстетическим анализом в сравнительном аспекте (итальянско-русским) приводит его к убедительному заключению, что русский футуризм отличен от итальянского, что он «феномен русский в своей специфике».

Охватила ли данная рецензия полностью вопросы, поставленные на обсуждение в четырех томах Ивана Верча, проследила ли все разные подходы к не менее разным темам? К сожалению, нет, хотя бы потому, что трудно объять огромный материал, разнообразный, который содержат эти четыре книги. Так что есть место и возможность для продолжения разговора, для других критических выступлений и оценок.

9 Appunt isulla ricezione dell' avanguardia russa in Italia, статья написана по-итальянски и включена в: [І, т. 2, с. 303-310]. 
Рецензии / Т. Николеску

\section{References}

I Verc I. Verifiche. Preverjanja. Проверки. Trieste, ZTT EST; EUT-Edizioni dell'Università di Trieste, 20I6. 4 volumi. 
УДК 82.09

ББК $83.3(0)$
КРУГЛЫЙ СТОЛ

«ИСТОРИОГРАФИЯ ГРАЖДАНСКОЙ ВОЙНЫ В РОССИИ В ПАМЯТНИКАХ

ЛИТЕРАТУРЫ, ЭГО-ДОКУМЕНТАХ

И ПУБЛИЦИСТИКЕ»

(C) 2017 г. 3.С. Закружная

Институт мировой литературы

им. А.М. Горького Российской академии наук,

Москва, Россия

Дата поступления статьи: 25 июня 2017 г.

Дата публикации: 25 сентября 2017 г.

DOI: I0.22455/2500-4247-20I7-2-3-370-38I

Обзор подготовлен при финансовой поддержке РФФИ, грант № 17-84-01005 а(ц)

«Историография Гражданской войны в России в памятниках литературы, дневниках писателей, переписке с читателями. Исследования и публикации архивных материалов».

Информация об авторе: Зоя Сергеевна Закружная - старший научный сотрудник, Институт мировой литературы им. А.М. Горького Российской академии наук, ул. Поварская, д. 25 а, г21069 Москва, Россия.

E-mail: z.zakruzhnaya@mail.ru 


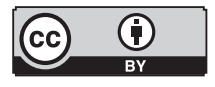

This is an open access article distributed under the Creative Commons Attribution 4.0 International (CC BY 4.0)

\section{ROUND TABLE}

"ISTORIOGRAPHY OF RUSSIAN

CIVIL WAR IN LITERATURE, EGO-DOCUMENTS AND CRITICISM"

(C) 20I7. Z.S. Zakruzhnaya

A.M. Gorky Institute of World Literature

of the Russian Academy of Sciences, Moscow, Russia Received: June 25, 2017

Date of publication: September 25, 2017

Acknowledgements: This conference summary is supported by Russian Foundation for Basic Research (RFBR), no I7-84-0I005 а(ц) "Instoriography of the Civil War in Russia as Reflected in Literature, Writers' Journals, and Their Correspondence with Readers. The Study and Publication of Archive Materials.”

Information about the author: Zoya S. Zakruzhnaya, Senior Researcher, A.M. Gorky Institute of World Literature of the Russian Academy of Sciences, Povarskaya 25 a, Moscow, Russia.

E-mail: z.zakruzhnaya@mail.ru 
6 июня 2017 г. в Институте мировой литературы им. А.М. Горького РАН состоялся круглый стол «Историография Гражданской войны в России в памятниках литературы, эго-документах и публицистике», организованный в рамках исследовательских грантов РФФИ № I7-84-0І0о5 а(ц) «Историография Гражданской войны в России в памятниках литературы, дневниках писателей, переписке с читателями. Исследования и публикации архивных материалов» (руководитель проекта - зам. директора ИМЛИ РАН, заведующая Отделом рукописей, д.ф.н. Д.С. Московская) и І7-84-0IоO2 а(ц) «Классическое произведение о Гражданской войне - “Бронепоезд I4-69” Всеволода Иванова: исторический и литературный контексты» (руководитель проекта - заведующая Отделом новейшей русской литературы и литературы русского зарубежья ИМЛИ РАН Н.В. Корниенко).

Проблематика, методологические и источниковые основания предложенных к обсуждению докладов находились на стыке научных интересов литературоведов, историков, политологов и культурологов. Однако, как подчеркнула открывшая работу круглого стола Д.С. Московская, столь же значительна их историко-литературная составляющая. Она заключается в стремлении осмыслить историко-литературный статус и социальное назначение сочинений, посвященных Гражданской войне. Д.С. Московская призвала участников попытаться сопоставить претендующую на документальность художественную «процессуальную историю» с «дневниковым летописанием», с отзывами читателей, установить, ответом на какие социальные вызовы явился тот или иной мотив или сюжет в исторической беллетристике, установить их историко-литературную перспективу - «форми- 
рование или развитие той или иной стилевой традиции художественного отображения выдающихся исторических (мифогенных) событий». В качестве примера были приведены упоминания об открытии «ревзаповедников» в самых кровавых «пунктах» Гражданской войны в полуфантастическом романе А. Платонова «Чевенгур», «геологическая катастрофа» - эвфемизм, за которым скрываются в платоновской фантастической повести «Эфирный тракт» события первых лет революции, стратегия цензурного редактирования сборника воспоминаний «Женщина в гражданской войне. Эпизоды борьбы на Северном Кавказе в І9I7-г920-х гг.» (1937), героизация белогвардейского лагеря в пьесе М. Булгакова «Дни Турбиных», крестьянская стихия партизанщины у Вс. Иванова, С. Есенина, Вяч. Шишкина, Л. Леонова, «персонализм» М. Шолохова и Ф. Крюкова, физиология войны у Б. Пильняка, И. Бабеля, Н. Никитина, «человеческая лава» («множества») у А. Серафимовича, И. Сельвинского и А. Малышкина и «кулеш социализма» у А. Платонова, кризис традиционного «гуманизма» у Б. Лавренева и А. Фадеева, стилевое и содержательное использования «документа» эпохи Гражданской войны у Д. Фурманова, Вс. Вишневского и А. Толстого. Все это и многое другое очерчивает, по словам докладчика, перспективы изучения новых художественно-идеологических тенденций в текстах о Гражданской войне советского и «антисоветского», «белого» и «красного», ушедшего в эмиграцию и осевшего в метрополии русского XX и XXI вв. Этими общетеоретическими и историко-литературными аспектами, как подчеркнула Д.С. Московская, не исчерпывается историко-литературная проблематика круглого стола. Важнейшей ее составляющей является неисследованность архивных фондов личного происхождения и литературных организаций, содержащих редакции и варианты произведений о Гражданской войне, Д. Фурманова, Э. Багрицкого, Демьяна Бедного, Алексея Толстого, А. Малышкина, Б. Пильняка, Артема Веселого, А. Серафимовича и др., дневников этих писателей, отзывов читателей на произведения о Гражданской войне, дискуссии о произведениях о Гражданской войне в ЛОКАФе (Литературное объединение Красной армии и флота), РАППе (Российской ассоциации пролетарских писателей), ВОКПе (Всероссийском объединении крестьянских писателей), Всеросскомдраме (Всероссийском объединении композиторов и драматургов). Неизученность этих документов является очевидной историко-литературной лакуной, требующей заполнения. Докладчик при- 
звала участников обратить внимание на гендерные особенности повествования о Гражданской войне, тематические и поэтологические аспекты ее изображения в документальных и литературных жанрах, на идеологемы, риторические стратегии и ракурсы интерпретации, уточнение творческих биографий писателей, историй их произведений, выявление отзывов на них современников, определение места этих текстов в историко-литературном процессе времени.

Гендерному аспекту - взгляду женщин на события Гражданской войны - было посвящено сразу несколько докладов. Первый из них - доклад докторанта Литературного института им. А.М. Горького, Астащенко Елены Васильевны «“За все благодарите”: проблема милости и справедливости в женской прозе о Гражданской войне», в котором рассматривалась «документальная» женская проза о революции, принадлежащая перу не только писательниц (В. Жуковской, А. Даманской), но и медицинских сестер (В. Шелепиной), офицерских жен и дочерей (М. Сливинской, Н. Щербачевой, А. Линден). Докладчик сосредоточился на нравственном аспекте рассматриваемых текстов, на нравственных установках и оценках женщинами Гражданской войны, и утверждал, что в этой прозе ценно именно то, что «выражено исподволь» - милосердие, даже к врагу. Докладчик считает, что «трогательная самонадеянность элиты, неразрывная с упованием на их Бога (официально большевиками отвергнутого), выдает белогвардейское присвоение прерогативы на истину», но, согласно поставленной авторами произведений задаче - «написать точно, верно, правдиво, как всё было, без всяких преувеличений» (В. Шелепина), «почти стенограмму» (В. Жуковская), женщины, «вопреки своей природе», избегали оценочных эпитетов, эмоционально-экспрессивной или инвективной лексики. И потому особенно ценно, считает докладчик, что сострадание, а иногда и уважение к идейным противникам исподволь высказывается в элементах самого повествования, рассмотрение которых и стало центром доклада Е.В. Астащенко.

«Женской прозе» о Гражданской войне был посвящен и доклад Татьяны Вячеславовны Марченко, д.ф.н., заведующей отделом культуры Российского Зарубежья Дома русского зарубежья им. А. Солженицына «“Брак в красном вихре” Али Рахмановой: немецкий роман русской писательницы о Гражданской войне в России», предметом рассмотрения в котором явились романы из дневниковой трилогии («Студенты, любовь, ЧК и смерть», 
I931, и «Брак в красном вихре», І932) малоизвестной в России, но весьма популярной за рубежом писательницы Али Рахмановой (настоящее имя Галина Дюрягина, в замужестве - фон Хойер) о событиях Гражданской войны, свидетелем которой она была. Изучение дневников писательницы (чье наследие хранится в государственном архиве кантона Тургау, Фрауэнфельд, Швейцария) и ее романов дает возможность, как полагает докладчик, коснуться проблемы соотношения эго-документа и художественного вымысла и расширить представления о рецепции западноевропейским сознанием русской послереволюционной смуты.

Еще один «женский взгляд» на события Гражданской войны был представлен в докладе Ольги Алексеевны Симоновой, с.н.с. Отдела рукописей ИМЛИ РАН, «Воспоминания А.А. Саксаганской о Гражданской войне (махновцы в Екатеринославе)», который был посвящен хранящимся в Архиве Горького двум воспоминаниям писательницы о Гражданской войне («В тылу», «Под черным флагом»), написанным в конце г920-х гг., но неопубликованным. Как сообщил докладчик, воспоминания «Под черным флагом» посвящены описанию деятельности Нестора Махно и его отряда в Екатеринославе в І9І9 г., а воспоминания «В тылу» представляют собой зарисовки жизни при разных режимах в Гражданскую войну, когда «писательница, как женщина, еврейка и богатая домовладелица, оказалась в особо уязвимом положении». Тексты, по мнению докладчика, существенно расширяют наши представления о военной тактике Нестора Махно и нравах времен Гражданской войны.

Документы, связанные с таким историческим лицом, как Нестор Махно, также оказались в центре внимания Галины Николаевны Воронцовой, с.н.с. Отдела новейшей русской литературы и литературы русского зарубежья ИМЛИ РАН, в ее докладе «Документы и материалы о Несторе Махно и “махновщине” в фонде А.Н. Толстого ОР ИМЛИ РАН». Докладчик сообщил, что в фонде А.Н. Толстого в ОР ИМЛИ сохранился комплекс материалов, которыми пользовался писатель при создании образа Нестора Махно в трилогии «Хождение по мукам». К таковым относятся книга И. Теппера (Гордеева) «Махно. От единого анархизма к стопам румынского короля» (1924) с многочисленными подчеркиваниями Толстого, выписки из «Дневника жены Махно», письмо С.Ф. Буданцева Толстому от 26 апреля 1928 г. из Днепропетровска (Екатеринослава) с подробностями взятия 
города армией Махно в конце I9I8 г., а также Акт о расстреле махновцами атамана Григорьева, подписанный самим Махно и людьми из ближайшего его окружения. Анализ этих документов, по мнению докладчика, позволяет не только расширить круг источников романа, но и уточнить целый ряд существенных моментов его творческой истории.

А.Н. Толстой стал одним из главных героев и другого доклада Юрия Николаевича Кирьянова, с.н.с. Отдела новейшей русской литературы и литературы русского зарубежья ИМЛИ РАН, - «Архивные материалы (воспоминания, беседы, письма участников гражданской войны) и повесть А.Н. Толстого “Хлеб”, посвященного стенограмме беседы Толстого с активным участником гражданской войны на юге России Е.А. Щаденко (РГАСПИ. Ф. 7І. ОП. № 35. Ед. хр. 905). По мнению докладчика, «неизвестные события и факты, человеческие судьбы, о которых идет речь в рассказе Щаденко, помогают понять причины и неизбежное нарастание революционного взрыва, показывают насколько была глубоко поражена острыми социальными и этническими конфликтами жизнь России того времени». Докладчик утверждал, что «сопоставление архивных документов с повестью “Хлеб” выявляет принципы отбора событий и эпизодов подачи их в произведении, показывает, как повесть вносила свой вклад в конструирование новой реальности в стране».

Проблема рецепции Гражданской войны в художественных произведениях последующих десятилетий поднималась также в докладе Елены Алексеевны Папковой, с.н.с. Отдела новейшей русской литературы и литературы русского зарубежья ИМЛИ РАН, «“Союзники” и Россия в период Гражданской войны: на материале сибирской периодики I9I9 г. (неизвестные материалы из газеты “Вперед!”) и “Бронепоезда І4-69” Всеволода Иванова». Докладчик рассматривал различные точки зрения на проблему взаимоотношений России и «союзников» в период Гражданской войны и сообщил, что важный для истории Гражданской войны вопрос об отношениях России и союзных держав: Франции, Америки, Японии - в неизвестной ранее публикации Вс.В. Иванова «Узы дружбы» (Вперед. Омск, І9І9. 26 сент.) решался «в общем ключе понимания его русской интеллигенцией, участвовавшей в Первой мировой войне: “союзники” и Россия, в отличие от прогермански настроенных коммунистов, защищают подлинно демократические интересы свободы и равенства людей». 
Другую сторону вопроса, по сообщению докладчика, демонстрируют публикации газеты «Вперед», посвященные «заговору во Владивостоке» эсеров, большевиков и «союзников» против законного Российского Правительства А.В. Колчака (I9I9. I7 окт.), а именно выражают опасение за национальные интересы России, которым угрожают двойственно ведущие себя «союзники».

Это противоречивое отношение русской интеллигенции к роли «союзников» в Гражданской войне, как считает Е.А. Папкова, нашло отражение в «Бронепоезде І4-69» Вс.В. Иванова (повести г92г г., пьесе 1927 г. и сценарии г963 г.), определив трактовку писателем центральных образов.

Одним из центральных проектов, связанных с восприятием и воссозданием (и пересозданием) истории Гражданской войны в г930-е и последующие годы, охватившем как историческую науку, политику и идеологию, так и литературное творчество, стал проект М. Горького, которому был посвящен доклад Ольги Васильевны Быстровой, с.н.с. Отдела издания и изучения творчества М. Горького ИМЛИ РАН, «Издательский проект М. Горького “История Гражданской войны”: По материалам РГАСПИ».

Предметом исследования докладчика стала книгоиздательская серия «История Гражданской войны», задуманная М. Горьким. Исследование вопроса, как показала О.В. Быстрова, позволяет увидеть само движение замысла І6-томной серии, который воплотился лишь в пяти книгах, посвященных трагическим годам Гражданской войны в СССР. Задуманная как серия научно-популярных книг для крестьянства, она превратилась в центр, объединяющий историков, политиков и писателей. Найденные докладчиком в РГАСПИ письма Горького, вводимые в научный оборот, позволяют осознать не только грандиозность замысла, но и увидеть «каждодневный труд ответственного редактора серии, каковым и являлся М.А. Пешков (Горький)».

Замысел проекта М. Горького вызвал новую волну интереса к теме Гражданской войны среди литераторов и критиков, о чем можно судить по докладу Зои Сергеевны Закружной, с.н.с. Отдела рукописей ИМЛИ РАН, «Принципы изображения героя гражданской войны в критических выступлениях членов ЛОКАФ (по материалам архива ОР ИМЛИ РАН)». Предметом рассмотрения 3.С. Закружной явился доклад Л.М. Субоцкого, одного из ведущих критиков ЛОКАФ, на Втором расширенном пленуме объединения. 
Доклад критика был посвящен принципам изображения героя Гражданской войны в художественной литературе. По мнению докладчика, можно предположить, что возобновление интереса критиков ЛОКАФ к Гражданской войне связано с проектом Горького и с вышедшими в июле-августе г93I г. постановлениями о издании «Истории Гражданской войны». 3.С. Закружная сообщила, что в докладе критика прозвучали теоретические положения о том, каким, согласно требованию времени (I932), должен быть представлен герой Гражданской войны в «литературной продукции» ЛОКАФ. Доклад критика позволяет увидеть не только то, как воспринималась Гражданская война ее непосредственными участниками десятилетие спустя, но и то, какие идеологические установки в отображении Гражданской войны превалировали в 1932 г., и то, какое именно воспитательное / идеологическое значение придавалось изображению Гражданской войны в контексте уже совсем иной эпохи.

На материале архивов литературных организаций ОР ИМЛИ РАН был основан и доклад Александра Александровича Гончаренко, аспиранта Отдела рукописей ИМЛИ РАН, «Обсуждение фильма “Чапаев” 29 ноября I934 г.: правда и вымысел в воспоминаниях очевидцев и создателей». В своем выступлении докладчик освещал неопубликованный документ - «Обсуждение фильма “Чапаев” , - выявленный в фонде Всероскомдрам (ОР ИМЛИ. Ф. 52. Оп. І. Д. 220. 78 Л.). По сообщению докладчика, дело содержит стенограмму выступлений деятелей культуры и участников Гражданской войны, состоявшихся в Доме советского писателя 29 ноября І934 г. Сфокусироваться на конкретном обсуждении докладчика заставляет следующая особенность документа: «...в тот вечер состав гостей отразил весь спектр публики». Выступали и соратники Чапаева (военные Васканов, И. Кутяков, Петроковский, М. Попова), и свидетели различной степени вовлеченности (писатель Бедный и военный Эйдеман), и создатели фильма (кинематографисты Васильевы и Мясникова), и представители «литературного истеблишмента» (литераторы Киршон и Сурков). И все выступавшие, по сообщению А.А. Гончаренко, встретили фильм восторженно. По словам докладчика, «эта пестрота бэкграундов выявляет общую линию, которой велось прославление фильма и актуализация на его материале большевистских идеологем».

О возросшем интересе к теме Гражданской войны в связи с замыслом М. Горького можно судить также по докладу Максима Львовича Федорова, 
с.н.с. Отдела рукописей ИМЛИ РАН, «Демьян Бедный и Гражданская война (по материалам ОР ИМЛИ РАН)», в котором рассматривались два текста участников Гражданской войны, присланные Демьяну Бедному, чье имя, по сообщению докладчика, в период Гражданской войны среди красноармейцев становится нарицательным, его агитками зачитываются, их ждут и заучивают наизусть; «в это время поэт много ездит по фронтам, в собственном, подаренном ему партией, вагоне, читает солдатам свои агитки». Первый текст - воспоминания М.М. Макарова (О Гражданской войне г9г9 г.) представляет, по мнению докладчика, интерес, поскольку автор был непосредственным участником описываемых событий - нескольких дней, проведенных им в белогвардейском плену. Как сообщил докладчик, лишенный откровенно выраженной большевистской идеологии, текст обнаруживает глубинные, христианские в своей основе ценностные позиции автора. Докладчик отмечал удивительность того, что автор не побоялся высказать их в начале г930-х гг., предназначив свой текст для горьковского проекта «История Гражданской войны», также докладчик отметил особенности поэтики текста, которые дают возможность, по мнению М.Л. Федорова, сравнивать его со знаменитым рассказом В.М. Гаршина «Четыре дня».

Второй текст - «Очерк финляндской революции г9г8 г. и взаимоотношений между Финляндией и Россией» И.А. Киреева, - по мнению докладчика, интересен тем, что написан по горячим следам описываемых событий и посвящен одной из самых малоизученных страниц Гражданской войны - событиям в независимой Финляндии. Как сообщил докладчик, текст наполнен переведенными автором с финского языка цитатами из прессы тех лет. Интерес представляет и фигура самого автора. На основании предварительных разысканий М.Л. Федорова стало понятно, что Иван Алексеевич Киреев - известный русский гидрограф, доктор военно-морских наук, автор многочисленных исследований, посвященных гидрографии. Объемный труд, посвященный истории Гражданской войны в Финляндии, - единственный опыт обращения ученого к гуманитарным наукам.

Важный вклад в уточнение событий Гражданской войны и роли отдельных личностей в ней вносит и доклад Ирины Глебовны Страховской, профессора кафедры славяноведения и культурологии РГУ им. А.Н. Косыгина (Институт славянской культуры), «Гражданская война в России: Орден “За Великий Сибирский поход”». Сбор, сопоставление и анализ новых 
материалов из различных источников, в том числе из семейного архива, дали возможность докладчику узнать и понять роль полковника Генштаба Ивана Ивановича Попова, І888 г. рождения, уроженца Якутска, в Великом Сибирском Ледяном походе. Докладчику стало известно не только то, что полковник Попов был назначен начальником штаба Северной колонны, которая смогла преодолеть самый тяжелый отрезок пути отступления, сохранив свою боевую организацию, но и то, что он был награжден Знаком отличия Военного ордена «За Великий Сибирский поход». Удалось узнать и о его наградах, полученных в Первой мировой войне, и о том, что «после иммиграции он был назначен Начальником Австралийского Отделения РОВС, идейная позиция которого наиболее полно изложена в трудах философа И.А. Ильина».

Необычные взгляды на события Гражданской войны были представлены в докладах Марины Альбиновны Ариас-Вихиль и Ларисы Григорьевны Жуховицкой.

Так, в докладе Марины Альбиновны Ариас-Вихиль, с.н.с. ИМЛИ РАН, «Герои Гражданской войны глазами Луи Арагона (В. Примаков, M. Тухачевский)» был представлен взгляд на события Гражданской войны иностранца, известного французского поэта и писателя Луи Арагона, в чьих воспоминаниях рассказывается о встречах с героями Гражданской войны Виталием Примаковым и Михаилом Тухачевским. Как сообщил докладчик, их рассказы о событиях Гражданской войны и политические пристрастия оказываются в центре внимания французского писателя, гостившего в доме Примакова, женой которого была Лиля Брик, сестра Эльзы Триоле, спутницы Арагона. Эти уникальные воспоминания, по мнению докладчика, «воссоздают не только эпизоды Гражданской войны, рассказанные их участниками, но и настроения и заботы последнего лета жизни Примакова и Тухачевского, над которыми уже сгущались тучи фабриковавшегося в Кремле дела об их измене родине».

В докладе же Ларисы Григорьевны Жуховицкой, сотрудника архива М. Горького ИМЛИ РАН, события Гражданской войны представлены в воспоминаниях «лишенцев» (лиц, лишенных избирательного права, заключенных, ссыльных). Докладчик сообщил о неисследованной части корреспонденции A.M. Горького І930-х гг., часть которой и составляют письма «лишенцев». Многие из них - участники Гражданской войны, - обращаясь 
к Горькому за помощью, вспоминают (как часть своей биографии) ее события. Именно эти воспоминания и оказались в центре внимания Л.Г. Жуховицкой, что добавляет еще одну неожиданную точку зрения на события Гражданской войны.

Подводя итоги круглого стола, член-корреспондент РАН, д.ф.н., заведующая Отделом новейшей русской литературы и литературы русского зарубежья ИМЛИ РАН Н.В. Корниенко отметила важность прошедшего обсуждения: события Гражданской войны и революции, подчеркнула она, изменили ход русского литературного процесса.

Одним из возможных дальнейших направлений работы Н.В. Корниенко указала переход от литературы г920-І930-х гг. к рассмотрению литературы 1950-І960-х гг., которая предоставляет совсем иной взгляд на события революции и Гражданской войны.

Можно ожидать, что итогом работы над проектами, посвященными отражению событий Гражданской войны в литературе I920-I930-х гг., станет издание материалов по теме исследования и публикация новых архивных материалов, которые будут способствовать выработке современного отношения к событиям Гражданской войны и пополнению информации о историко-литературном процессе XX в. 
УДК 82.09

ББК $83.3(0)$
ОТЧЕТ О НАУЧНОЙ КОНФЕРЕНЦИИ

«"ВЕЧНЫЕ" СЮЖЕТЫ И ОБРАЗЫ

В ЛИТЕРАТУРЕ И ИСКУССТВЕ РУССКОГО

МОДЕРНИЗМА: ИТОГИ И ПЕРСПЕКТИВЫ

ПРОЕКТА РНФ» (16-17 НОЯБРЯ 2016 Г., ИМЛИ РАН)

(C) 2017 г. С.А. Серегина

Институт мировой литературы

им. А.М. Горького Российской академии наук,

Москва, Россия

Дата поступления статьи: І5 июня 2017 г.

Дата публикации: 25 сентября 2017 г.

DOI: I0.22455/2500-4247-20I7-2-3-382-390

Информация об авторе: Светлана Андреевна Серегина - кандидат филологических наук, старший научный сотрудник, Институт мировой литературы им. А.М. Горького Российской академии наук, ул. Поварская, д. 25 а, І2Іо69 Москва, Россия.

E-mail: serjogina@mail.ru 


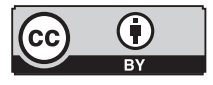

This is an open access article distributed under the Creative Commons Attribution 4.0 International (CC BY 4.0)
CONFERENCE "'ETERNAL' PLOTS AND IMAGES IN LITERATURE AND ART OF RUSSIAN MODERNISM (NOVEMBER 16-17, IWL RAS)

(C) 20I7. S.A. Serjogina

A.M. Gorky Institute of World Literature of the Russian Academy of Sciences, Moscow, Russia Received: June I5, 2017

Date of publication: September 25, 2017

Information about the author: Svetlana A. Serjogina, PhD in Philology, Senior Researcher, A.M. Gorky Institute of World Literature of the Russian Academy of Sciences, Povarskaya 25 a, Moscow, Russia.

E-mail: serjogina@mail.ru 
I6-I7 ноября 2016 г. в Институте мировой литературы им. А.М. Горького РАН прошла научная конференция «"Вечные” сюжеты и образы в литературе и искусстве русского модернизма: Итоги и перспективы проекта РНФ», обозначившая итоги трехлетней работы над проектом, поддержанным грантом Российского научного фонда № I4-I8-02709 (руководитель член-корреспондент РАН А.Л. Топорков). В состав коллектива входят известные ученые ИМЛИ РАН, а также молодые исследователи и аспиранты. Содержательное поле проекта определяла гипотеза о том, что русская культура эпохи войн и революций, социальных и политических катаклизмов сумела творчески воспринять и переработать «вечные» образы мировой цивилизации и выработать в результате новый художественный язык XX в.

Конференцию открыл доклад директора ИМЛИ РАН, проф. РАН, д.ф.н. В.В. Полонского «Мистерия, трагедия и мифологическая сюжетика в жанрово-эстетических ориентирах русских модернистов». В.В. Полонский обратился к проблематике, фундировавшей эстетическое поле как европейского, так и русского модернизма: экспериментальному поиску новых драматургических форм, размышлению о генезисе трагедии, созданию новых культурных кодов, направленных на тотальную театрализацию семиотического пространства. В центре доклада были «мистерии» в России рубежа веков: «русалии» А.М. Ремизова с их акцентированным музыкальным началом в синтетическом целом, лирические неомифологические драмы символистов, теоретический поиск и драматургический опыт Вяч. Иванова («Прометей» с его «выходом из жанра трагедии в синкретику мелопеи») и А. Белого, искавшего мистериального преображения мира. 
В докладе д.ф.н. М.Л. Спивак «Андрей Белый и мифотворчество кружка аргонавтов: образы и их источники» рассматривались произведения Андрея Белого начала I90о-х гг., ставшие программными для возникшего в I903 г. кружка аргонавтов (стихотворение «Золотое Руно», статья «Символизм как миропонимание», прозаический отрывок «Аргонавты» и др.). В этих произведениях был существенно переосмыслен древнегреческий миф о путешествии героев за золотым руном. Поэт-символист заменил традиционное золотое руно (шкуру барана) на солнце (символ недостижимого идеала). Таким образом, аргонавты-символисты интерпретировали миф об Язоне и его спутниках как солярный миф, их путешествие за золотым руном оказалось не плаванием, но полетом, а корабль «Арго» превратился в крылатый летательный аппарат. В докладе было показано, что источниками образности и трансформации мифа стали произведения Ф. Ницше, прежде всего книга «Веселая наука», переведенная на русский язык в І902 г. Автобиографические материалы Белого засвидетельствовали, что писатель открыл для себя Ницше в I899 г. и активно читал его в I900-І902 гг.

К.ф.н. Е.В. Глухова предприняла попытку систематизировать визуальное наследие Андрея Белого в связи с антропософией Р. Штайнера. В докладе «Антропософская симвология в творчестве Андрея Белого: геометрия и система образов» было предложено описание рисунков Белого с точки зрения двух основных визуальных подсистем, условно обозначенных как «телесность» и «геометричность». Геометрическая образность, по мнению исследовательницы, представлена, с одной стороны, поясняющими рисунками-схемами с элементами треугольников, кругов, спиралей; а с другой - целым набором архитектурных форм, в которых прослеживается типологическое представление об идеальном Солнечном Храме (это и антропософский Гетеанум, и «Город Солнца» Кампанеллы, и древний армянский храм Звартноц, но это и просцениум к постановке драмы «Москва», и схема построения фразы Гоголя в книге «Мастерство Гоголя»). «Телесная» подсистема визуализации у Белого представлена, с точки зрения Е.В. Глуховой, различными антропоморфами: от элементов человеческого тела (голова, туловище) до рисунков медитативного характера (например, антропософские «духи форм»). Особое внимание исследовательница уделила лекциям Белого о Блоке, продемонстрировав, с одной 
стороны, как «инициатический» антропософский сюжет, развернутый в одной части акварельных рисунков к лекциям, связан с размышлениями Белого о духовном и творческом пути поэта и, с другой, как филологический метод анализа Белым поэтического наследия Блока визуализируется в другой части рисунков.

Д.ф.н. Д.М. Магомедова в докладе «Вагнеровские сюжеты в культуре символизма: “Кольцо нибелунга” vs “Парсифаль” поставила вопрос о роли вагнеровских мотивов в творчестве «младших» символистов г9ооI9Іо-х гг. Д.М. Магомедова пришла к выводу, что сквозной анализ сюжетной и мотивной структуры художественных текстов А.А. Блока, А. Белого, Вяч. Иванова, Эллиса, Э.К. Метнера (Вольфинга) показывает, что для символистов важнейшую роль играли два архетипических сюжета, заданных творчеством Вагнера: тетралогии «Кольцо нибелунга» и оперы-мистерии «Парсифаль». В докладе были выявлены хронология обращений к вагнеровским сюжетам в г90о-е гг., а также логика движения от апологии индивидуализма к осознанию его трагической обреченности («Кольцо нибелунга»), к этике самоотречения и искупления («Парсифаль»), что, по мнению исследовательницы, в значительной степени повторяет вагнеровскую эволюцию как в его жизненном пути, так и в художественном творчестве.

Член-корр. РАН, д.ф.н. А.Л. Топорков обратился в своем докладе «Заклятия и заклинания в литературе Серебряного века» к четырем направлениям работы с жанрами магической поэзии, которые можно выделить в русской литературе XIX - начала XX в.: I) создание особого поэтического жанра заклятий и заклинаний; 2) использование мотивов заговоров в различных поэтических произведениях; 3) включение фольклорных заговоров в тексты прозаических произведений; 4) создание псевдофольклорных стилизаций, которые выдавались за аутентичный магический фольклор. А.Л. Топорков обратил внимание на факт многократного увеличения числа стилизаций в духе заговоров в начале XX в., что было вызвано активным интересом культуры модернизма к маргинальным явлениям в фольклоре. Частным случаем этого общего явления была статья А. Блока «Поэзия заговоров и заклинаний». На примере статьи А.Л. Топорков показал, как заговоры становились предметом эстетической рефлексии писателей. Представления А. Блока о магической природе заумных заговоров становятся частью его размышлений о теургии и магическом воздействии закли- 
наний на природу и человека. В вопросе о соотношении заговоров и поэзии особая роль отводится кудесникам и поэтам как творцам магического слова, а идеи телесного преображения человека, идеала действенного слова, единства слова и дела становятся центральными в художественном сознании поэта.

Д.ф.н. О.А. Богданова в докладе «Многоаспектность топики “земли” в литературе конца XIX - первой трети XX вв.: итоги и задачи осмысления» подвела итоги своей трехлетней работы по теме «Модификации культурной константы “земля” в литературе русского модернизма». Исследовательница затронула следующий круг проблем: «Диапазон значений мифологемы “земля” в творчестве Ф.М. Достоевского и их преломление в произведениях модернистов начала XX в.», «Топика “земли” в контексте представлений о русской дворянской усадьбе на рубеже XIX-XX вв. и в первые десятилетия XX в.», «Интермедиальные интерпретации образа “земли” в культуре Серебряного века», «Концепт “земля” в творчестве Ф.М. Достоевского и его интерпретация в литературе о писателе в 1920-1930-е гг.», «Межкультурная трансляция концепта “земля” в первой трети XX в.».

Д.ф.н. А.Г. Гачева в докладе «Образ труда в пролетарской и новокрестьянской поэзии: религиозно-философский контекст» на материале творчества М. Герасимова, В. Кириллова, В. Казина, Н. Клюева, С. Есенина и др. показала, как в литературе модернизма образ труда мифологизируется, обретает планетарный и даже космический масштаб, вырастает в символ новой веры, основополагающей чертой которой является активизм. А.Г. Гачева пришла к выводу, что апофеоз вселенского, преображающего труда, в который включаются не только люди, но и вся тварь, все стихии мира, сближает творчество пролетарских и новокрестьянских поэтов с наследием представителей русского религиозно-философского возрождения конца XIX - начала XX вв. (Н.Ф. Федоров, В.С. Соловьев, С.Н. Булгаков, Н.А. Бердяев и др.), давших религиозное оправдание труду, определявших его как мироустроительную деятельность, противостоящую силам хаоса и небытия.

К.ф.н. М.В. Скороходов представил источниковедческий доклад «Учебная литература в кругу источников поэтических образов и сюжетов», в котором показал, что смысловое поле культуры модернизма во многом формировалось благодаря активно развивавшейся во второй половине 
XIX в. отечественной системе образования. Знакомство в годы учебы будущих писателей и деятелей культуры с «вечными» сюжетами и образами во многом определило направления их творческих поисков.

С.А. Никитина сделала доклад на тему «А. Блок как читатель Платона». Исследовательница базировалась на дневниковых записях А.А. Блока, свидетельствующих о значимости идей Платона для поэта. В рамках доклада были проанализированы пометы А. Блока на книге «Платон. Творения» (М., І899. Т. I / пер. с греч. Вл. Соловьева) и составлен корпус платоновских текстов, которые были известны поэту.

Доклад д.ф.н. В.Б. Зусевой-Озкан «Триптих “Пенфесилея” и образ девы-воительницы в творчестве С.Я. Парнок» связывает этот «вечный» образ в поэзии Парнок с ее отношениями и творческим диалогом с М.И. Цветаевой, для которой воительница была своего рода альтер-эго. Прослеживая эволюцию образа, исследовательница устанавливает, что он наиболее часто появляется в стихах Парнок в I9I4-I9I6 гг., т. е. в период тесного общения с Цветаевой, а впоследствии - как его отголоски. В.Б. Зусева-Озкан раскрыла внутреннюю динамику, полемичную и сложную семантику образа девы-воительницы у Парнок.

К.ф.н. О.А. Симонова в докладе «Сюжет о бегстве Агари в русской поэзии первой четверти XX в.» продемонстрировала востребованность заявленного сюжета в литературе модернизма, обратившись к творчеству М.А. Лохвицкой, С.Я. Парнок, М.И. Цветаевой, Е.Г. Полонской, М.И. Шкапской, Е.И. Васильевой. По мнению исследовательницы, для одних авторов ветхозаветный сюжет был самоценен (Полонская, Парнок), другие соотносили с ним истории лирических героинь и девы Марии, манифестируя универсальность ситуации через обращение к архетипу. Большинство поэтов прочитывали образ Агари сквозь христианскую призму: она унижена, гонима, а потому вызывает сочувствие. Интерпретация образа Агари оказывалась включенной в поэтическую картину мира каждой поэтессы: это либо брошенная женщина, либо одинокая мать с ребенком. Таким образом, из сюжета о бегстве Агари извлекались отдельные эпизоды (Агарь, проклинающая Сарру, и Агарь, заботящаяся об Измаиле), которые и получали поэтическое развитие.

Е.В. Кузнецова в докладе «Образ-символ “чаши из черепа”: древняя традиция и поэзия Серебряного века» выделила две группы стихотвор- 
ных текстов на основании генезиса и функций образа «чаши из черепа»: историческую и метафорическую. Первая группа произведений (В. Брюсов, В. Хлебников, С. Есенин, Н. Гумилев) так или иначе связана с темой древней истории Руси и обстоятельствами гибели князя Святослава, из черепа которого печенеги изготовили чашу. Вторая группа текстов (М. Зенкевич, В. Маяковский) характеризуется метафорическим употреблением образа-символа «чаши из черепа» для художественного выражения антитезы «жизнь-смерть» и пограничного состояния лирического героя.

Доклад А.С. Тинниковой был посвящен образу Неопалимой Купины в стихах о войне и революции М.А. Волошина. Исследовательница установила возможные источники заглавия, предложила свою интерпретацию его символического значения и пришла к выводу, что обращение к образу Неопалимой Купины было особенно актуально для М.А. Волошина в период революции, так как с ним связаны мотивы поисков верного пути, стремления к достижению земли обетованной, темы прощения, искупления и ожидания будущего обновления мира через личное преображение каждого отдельного человека, идеи Богочеловечества и Богоматерии.

К.ф.н. С.А. Серегина в докладе «Андрей Белый, Николай Клюев и Сергей Есенин: типология мифа в творчестве I9I7-I9I8 гг.» описала структуру и семантику общего для этих поэтов литературного мифа: избранный поэт-теург преодолевает эзотерический путь, постигая тайное знание и приближаясь к идиллическому топосу. В то же время поэт является носителем «идеала бытия» и тайного знания, которое по мере прохождения этапов посвящения только углубляется и в конечном итоге посредством теургического акта должно способствовать воплощению идеала в действительности.

К.ф.н. А.С. Акимова в докладе «Творчество А.Н. Толстого в контексте культуры модернизма: трансформация образов и сюжетов» пришла к выводу, что литературно-эстетические и мировоззренческие искания начала века были восприняты А.Н. Толстым сквозь призму реалистической традиции русской литературы XIX в. и питались воспоминаниями о конкретных людях и событиях, что определило жанровое своеобразие творчества писателя, его тематическое богатство и разнообразие художественных приемов. В докладе рассматривались архивные материалы (ранние рукописные тетради), поэтический сборник «Лирика» (I907) и образы ранних рассказов г9го-х гг. 
Е.А. Извозчикова в докладе «Тип героя-авантюриста в прозе А.Н. Толстого І9Іо-х - I920-х гг.» проанализировала черты авантюрного жанра в произведениях А.Н. Толстого І9Іо-х - I920-х гг. и выявила особенности работы писателя над «вечным» образом авантюриста: от сатирической зарисовки героя в повести «Приключения Растегина» до характера плута, обрисованного исторически, в качестве типичного героя в повести «Похождения Невзорова, или Ибикус».

М.А. Соловьева в докладе «Поэтика названий в “есенинской Библии” обратилась к циклу революционных поэм Есенина I9I7-I9I8 гг., проясняя символический смысл их названий в контексте церковной литературы и на фоне религиозно-философских поисков самого поэта.

Таким образом, итоговая конференция по проекту «"Вечные” сюжеты и образы в литературе и искусстве русского модернизма» обозначила широкое научное поле, в котором вели работу участники проекта, а также позволила увидеть творчество главных культуртрегеров русского art nouveau в интертекстуальном пространстве мировой культуры: от религиозной философии и эзотерических практик до мифологических сюжетов и фольклорной образности. 
ПРАВИЛА

ОФОРМЛЕНИЯ СТАТЕЙ 
I K рассмотрению и опубликованию принимаются статьи, оформленные в соответствии с правилами, принятыми в журнале. Объем статьи вместе с примечаниями не более г п.л. - 40 ооо знаков вместе с пробелами (для аспирантов - не более о,5 п.л. - 20 ооо знаков вместе с пробелами), включая примечания.

2 Автор представляет все материалы (текст статьи, дополнительные шрифты, если таковые использовались в тексте, договор ${ }^{\mathrm{I}}$ ) по электронной почте: stud-lit@mail.ru или отправляет статью через услугу на сайте журнала www.studlit.ru

3 Текст должен быть напечатан в текстовом редакторе Microsoft Word, формат A4, поля - 2 см со всех сторон, шрифт - Times New Roman, кегль I4, межстрочный интервал - I,5, абзацный отступ (красная строка) - I,25, ориентация - книжная, без переносов.

4 Первая страница должна содержать следующую информацию:

- название рубрики, кегль - г4;

- УдК (см., например, teacode.com/online/udc или udk-codes.net), кегль - І4;

- ББК (см., например, http://roslavl.library67.ru/files/382/bbk.pdf), кегль - I4.

I B соответствии с частью четвертой Гражданского кодекса Российской Федерации (раздел VII «Права на результаты интеллектуальной деятельности и средства индивидуализации») представляемые в журнал статьи должны сопровождаться лицензионным договором о передаче Учредителю журнала неисключительных авторских прав. 
- Название статьи - по центру, без отступа, полужирным шрифтом, прописными буквами, кегль - I4.

- Под названием статьи по центру указывается знак авторского права, год, инициалы и фамилия автора/ов, кегль - I2.

- Далее по центру указывается полное название организации, город, страна, кегль - I2.

- По правому краю размещается информация о дате отправки статьи.

- Далее приводятся сведения о финансовой поддержке работы (грант и др.), кегль - I2, выравнивание по ширине.

- Размещаются аннотация (200-250 слов; она должна представлять собой реферат-резюме статьи с соблюдением последовательности изложения) и ключевые слова на русском языке, кегль - І2, выравнивание по ширине.

- Информация об авторе: имя, отчество, фамилия, ученая степень (если есть), звание (если есть), должность, полное название организации, адрес организации вместе с индексом, город, страна, E-mail, кегль - I2.

- После этого размещается та же самая информация на английском языке:

- Название статьи на английском языке - по центру, без отступа, полужирным шрифтом, прописными буквами, кегль - I4.

- Под названием статьи по центру указываются фамилия, имя, отчество автора/ов, кегль - I2.

- Далее по центру указывается полное название организации, город, страна, кегль - І2.

- По правому краю размещается информация о дате отправки статьи.

- Далее приводятся сведения о финансовой поддержке работы (грант и др.) (Acknowledgements), аннотация и ключевые слова (Abstract, Keywords), информация об авторе (Information about the author), кегль - I2, выравнивание по ширине.

- Далее - текст статьи - выравнивание по ширине, без переносов.

5 В конце статьи приводится СПИСОК ЛИТЕРАТУРЫ в алфавитном порядке (сначала русские источники, затем иностранные) в соответствии с ГОСТом 7.0.5.-2008 в виде нумерованного списка. Фамилия и инициалы авторов пишутся раздельно. В тексте статьи ссылки оформляются следующим образом: [1], [2, с. 5], [3, с. 34; 5, с. 2], [7, стб. 23], [го, л. 6]. 
6 Примечания оформляются в виде постраничных автоматических сносок. Цифра сноски в конце предложения ставится перед точкой. Шрифт сносок: Times New Roman, кегль I2.

7 Ссылки на архивные материалы даются в виде постраничных автоматических сносок.

8 После Списка литературы приводится REFERENCES:

- Транслитерируются только источники, написанные кириллицей; французские, немецкие, итальянские, польские и пр. источники не транслитерируются и не переводятся.

- Для выполнения транслитерации необходимо использовать специальную программу.

- Войти в программy http://translit.net/ и выбрать вариант системы Библиотеки Конгресса (LC).

- Вставить в специальное поле весь текст библиографии на русском языке и нажать кнопку «в транслит».

- Затем копировать транслитерированный текст в готовящийся список References.

- Далее необходимо отредактировать полученное и добавить переводы на английский язык:

- перевести на английский язык название книги, источника и др. и вставить его в квадратных скобках [ ] после соответствующих названий;

- заменить // на точку;

- заменить / на запятую;

- перевести на английский язык место издания (например, было M. - после редактирования: Moscow);

- заменить двоеточие после названия места издания на запятую;

- после транслитерации издательства добавить Publ.;

- исправить обозначение страниц: вместо 235 s. - 235 р., вместо S. 45-47 - pp. 45-47;

- курсивом выделить название источника;

- в конце библиографической ссылки необходимо добавить указание на оригинальный язык статьи (In Russ.).

9 Сокращения. При первом упоминании лица обязательно указываются И.О., И.О. отделяются пробелом от фамилии. Годы при указании опре- 
деленного периода указываются только в цифрах: 30-е гг., а не тридцатые годы. Конкретная дата дается с сокращением г. или гг.: I920 г., I920-I922 гг. Не век или века, а в. или вв. (римскими цифрами): IX в. Писать только полностью: так как, так называемые. Из сокращений допускаются: т. д., т. п., др., т. е., см.

Iо Кавычки - только «», если закавыченное слово начинает цитату или примыкает к концу цитаты, употребляются кавычки в кавычках: «раз”, два, три, “четыре”».

II Архивные материалы должны сопровождаться вступительной статьей, оформленной в соответствии с вышеизложенными правилами.

\section{ПОДПИСКА}

Уважаемые коллеги!

Оформить подписку на журнал «Studia Litterarum» можно во всех отделениях Почты России по каталогу ОАО Агентства «Роспечать» «Газеты. Журналы».

Подписной индекс -80538 .

Рассылка экземпляров журналов производится только по подписке.

По поводу приобретения отдельных номеров журнала необходимо обращаться в редколлегию: г2Іо69 г. Москва, ул. Поварская, д. 25 а. 


\section{ПОРЯДОК РЕЦЕНЗИРОВАНИЯ}

Рукописи, поступившие в редколлегию журнала «Studia

Litterarum», проходят обязательное рецензирование с целью их экспертной оценки.

2

На первом этапе редакцией проводится экспертиза рукописей на предмет их соответствия формальным требованиям.

3 Рукописи, не соответствующие требованиям к оформлению и не отвечающие содержательно-тематическому профилю журнала, не рассматриваются и не рецензируются. Решение об отклонении статьи от рассмотрения и публикации в этом случае принимается редколлегией.

4 Рукописи, соответствующие содержательно-тематическому профилю журнала и удовлетворяющие формальным требованиям, передаются на рецензирование двум независимым экспертам, имеющим наиболее близкую к теме статьи специализацию.

5 Экспертная оценка рукописи проводится по принципу внешнего двойного «слепого» рецензирования, когда ни рецензент не знает имени автора, ни автор не знает имени рецензента.

6 Для проведения экспертной оценки рукописи могут привлекаться как члены редколлегии, так и высококвалифицированные специалисты из ИМЛИ РАН и других организаций. Рецензенты обязаны следовать принятой в журнале Публикационной этике.

7 Рецензии пишутся в свободной форме или по разработанной редколлегией схеме.

8 Текст рецензии предоставляется автору по его запросу без указания Ф.И.О., должности и места работы рецензента. В случае наличия в рецензии рекомендации доработать и/или переработать текст статьи автору направляется сокращенный текст рецензии с конструктивными замечаниями без указания Ф.И.О., должности и места работы рецензента. В случае отклонения статьи от публикации автору направляется мотивированный отказ.

9 Статья, направленная автору на доработку, должна быть возращена в сроки, указанные в письме.

Iо Статья, не рекомендованная рецензентами к публикации, к повторному рассмотрению не принимается и не рассматривается на заседании редколлегии. 
Сроки рецензирования в каждом отдельном случае определяются с учетом возможности максимально оперативной публикации статьи. Максимальный срок рецензирования статьи - 3 месяца.

I2 Статьи, успешно прошедшие процедуру рецензирования, рассматриваются на заседании редколлегии. После принятия редколлегией решения о допуске статьи автор получает письмо с краткой информацией о результатах рецензирования и примерных сроках публикации рукописи. I3 Оригиналы рецензий хранятся в архиве журнала «Studia Litterarum» в течение 5 лет.

I4 Статьи членов редакции, редколлегии и международного редакционного совета, имеющих право на приоритетную публикацию в журнале I (одной) статьи в год, подвергаются рецензированию и обсуждаются на заседании редколлегии в общем порядке. 


\section{PEER-REVIEW PROCESS}

It is mandatory that all manuscripts submitted to the journal Studia Litterarum are peer reviewed by experts in the field.

$2 \quad$ At the first stage of the reviewing process, the Editorial Department reviews manuscripts on the subject of their compliance with the journal's formal requirements.

3 Manuscripts that do not meet the formal requirements or the subject scope of the journal will not be considered or peer reviewed. The Editorial Board decides whether the essay shall not be considered or accepted for publication.

4 Manuscripts that meet the formal requirements or the subject scope of the journal are sent to two independent reviewers in the specific field of the submitted manuscript.

$5 \quad$ The essay undergoes a double "blind" review process, e.g. when any of the reviewers knows the author's name nor the author knows the names of the reviewers.

6 The invited reviewers may be members of the Editorial Board or any other highly qualified experts from IWL RAS and other institutions. Reviewers must follow the principles of Publishing Ethics accepted by the journal.

$7 \quad$ Reviews are written in a free form or according to the scheme developed by the Editorial Board.

8 The review is sent to the author on his or her request without indicating the reviewer's name, job title, and place of work. If the reviewer recommends that the author revises/makes minor revisions and resubmits the manuscript, he or she will be sent a partial text of the review with suggestions without indicating the reviewer's name, job title, and place of work. In case of rejection, the author will receive a motivated refusal.

9 The essay sent to the author for revision shall be returned by the time specified in the letter.

Io The essay rejected by reviewers shall not be resubmitted or considered at the Editorial Board meeting.

II The time period of the review is determined in each particular case considering the most rapid possible publication of the essay. It takes the maximum of three months to have the manuscript reviewed. 
I2 The manuscripts that have successfully undergone the peer review process will be considered at the Editorial Board meeting. After making a decision about the essay's acceptance, the author will receive a letter briefly informing him or her about the results of the review and the possible date of publication.

I3 The original copies of reviews are kept in the archive of the journal Studia Litterarum for 5 years.

I4 Members of the Editorial Board, international Editorial Board, and the Editorial Department have the right for the priority publication of one (I) article per year; these articles are reviewed and accepted for publication on a common basis. 


\section{STUDIA LITTERARUM}

Литературные исследования

Literary Studies

Научный журнал

Academic journal

Том 2, № 3

Vol. 2, no 3

Дизайн обложки и макет журнала В.А. Музыченко

Верстка А.З. Бернштейн

Корректор Е.Н. Сченснович

$16+$

Подписано в печать 07.09.2017

Формат 60×901/16

Усл.-печ. л. 25,0

Тираж 500 экз. Заказ №

Отпечатано в ППП «Типография “Наука”

І2І099, Москва, Шубинский пер., д. 6

Институт мировой литературы им. А. М. Горького

Российской академии наук

І2І069, Москва, ул. Поварская, д. 25 а

тел. (495) 69I-23-0I, 690-05-6I 